JOINT TRANSPORTATION RESEARCH PROGRAM

\author{
FHWA/IN/JTRP-2001/09
}

Final Report

VIRTUAL WEIGH STATION

John Green

Andrew Nichols

Ed Allen

Luke Nuber

Jose Thomaz

Darcy Bullock

Guy Boruff

Jay Wasson

Mark Newland

June 2002 
Final Report

FHWA/IN/JTRP-2001/09

\section{VIRTUAL WEIGH STATION}

By

John G. Green

Graduate Research Assistant

Andrew Nichols

Graduate Research Assistant

Ed Allen, Luke Nuber

Undergraduate Research Assistant

Jose Thomaz

Database Analyst

And

Darcy Bullock

Professor of Civil Engineering

School of Civil Engineering

Purdue University

And

Guy Boruff

Indiana State Police

And

Jay Wasson

Indiana Department of Transportation

And

Mark Newland

Indiana Department of Transportation

Joint Transportation Research Program

Project No. C-36-17GGG

File No. 8-4-60

SPR-2481

The contents of this report reflect the views of the authors, who are responsible for the facts and the accuracy of the data presented herein. The contents do not necessarily reflect the views or policies of the Indiana State Police and the Indiana Department of Transportation. This report does not constitute a standard, specification, or regulation.

Purdue University

West Lafayette, IN 47907

June 2002 
TECHNICAL REPORT STANDARD TITLE PAGE

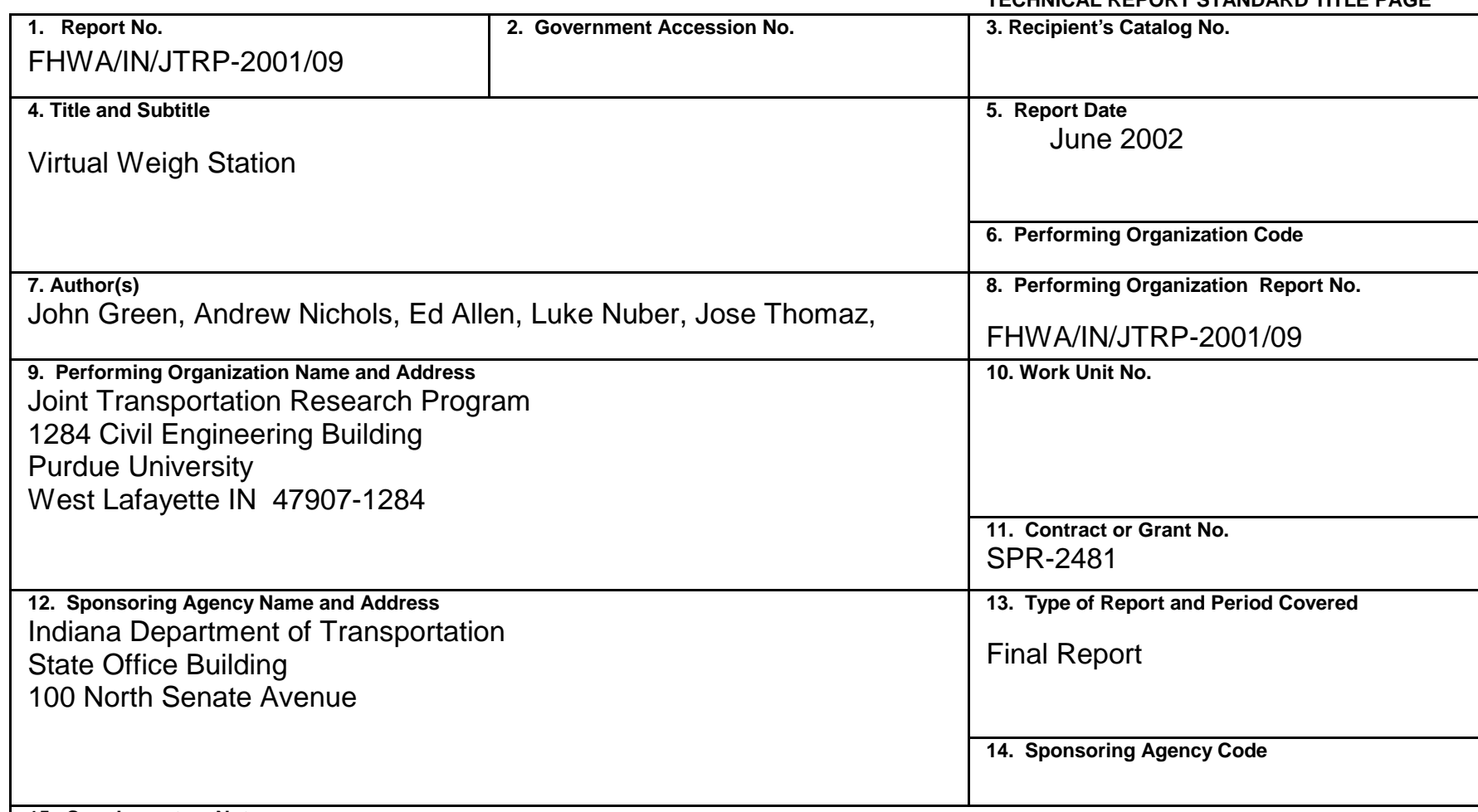

15. Supplementary Notes

Prepared in cooperation with the Indiana Department of Transportation and Federal Highway Administration.

16. Abstract

Overweight trucks shorten highway life and indirectly increase the costs of maintaining roads. Improved methods for enforcement of commercial vehicle weight laws may increase the number of overweight vehicles caught, thereby prolonging highway life. Improved enforcement may also reduce the number of illegally operating vehicles.

This report describes the concept of using existing INDOT Weigh-In-Motion equipment, a laptop computer, and wireless communication equipment, to develop a virtual weigh station screening tool. The Virtual Weigh Station screening tool developed in this project allows officers to read the weights of vehicles crossing WIM scales, in real time, in their patrol cars. Giving officers this information increases the chances that the vehicles selected for weighing on portable scales are indeed overweight. This report documents the accuracy and precision evaluation performed on all the candidate WIM sites as well as the new infrastructure required to implement the Virtual Weigh Station concept.

The report describes several cases where significantly overweight vehicles were identified and impounded. For example the procedures described in this report, resulted in the identifying the early morning hours as the best time for enforcement in Merrillville. As a result, on May 18, 2001 vehicles weighing 98,700 lbs and 100,600 lbs were stopped. Those vehicles were impounded and resulted in fines of $\$ 1,625.00$ and \$1,735.50, respectively. In February 2002, Commercial Vehicle Enforcement officers stopped ten trucks on US 24 near Fort Wayne using the virtual weigh station. Eight of the trucks were determined to be overweight and fined. The three heaviest trucks weighed 90,200 lbs, 90,900 lbs, and 91,100 lbs resulting in fines of \$1,099.50, \$1,169.50, and \$1,189.50, respectively. On April 12, 2002, another enforcement was conducted on I-65 near Merrillville. Three trucks were stopped based on the virtual weigh station data. One of the trucks weighed $87,400 \mathrm{lbs}$, resulting in a $\$ 529.50$ fine. The report concludes by making several recommendations designed to improve the quality of the WIM data and facilitate wide spread deployment by the Commercial Vehicle Enforcement Division.

\begin{tabular}{l|l} 
17. Key Words & 18. Distribution Statement
\end{tabular}

Commercial motor vehicle, weigh in motion, pavement damage

No restrictions. This document is available to the public through the National Technical Information Service, Springfield, VA 22161

\begin{tabular}{|l|l|l|l|}
\hline $\begin{array}{l}\text { 19. Security Classif. (of this report) } \\
\text { Unclassified }\end{array}$ & $\begin{array}{l}\text { 20. Security Classif. (of this page) } \\
\text { Unclassified }\end{array}$ & 22. Price of Pages \\
\hline
\end{tabular}




\section{TECHNICAL Summary}

Technology Transfer and Project Implementation Information

INDOT Research

TRB Subject Code 53-9 Weigh-In-Motion

Publication No.: FHWA/IN/JTRP-2001/09, SPR-2481

June 2002

Final Report

\section{VIRTUAL WEIGH STATION}

\section{Introduction}

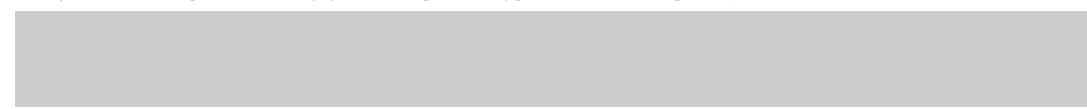

Overweight trucks shorten highway life and indirectly increase the costs of maintaining roads. A study for the Oregon Department of Transportation reported that a significant relationship exists between the rate of weight violations and a commercial carrier's accident rate. Improvement in methods for enforcement of commercial vehicle weight laws may increase the number of overweight vehicles caught, thereby prolonging highway life. Improved enforcement may also reduce the number of illegally operating vehicles.

In Indiana, officers of the Commercial Vehicle Enforcement Division carry out enforcement of laws regarding trucks. Officers from this branch of the Indiana State Police regulate any commercial vehicle weighing greater than $10,000 \mathrm{lbs}$. The two primary methods used to check that vehicles are in compliance with weight limit statutes and regulations are "Port-of-Entry" static scales and portable scale units.

As a truck approaches a static "Portof-Entry" scale on the highway, the operator is first directed whether the scale is "open" or "closed". If the scale is "closed" (not in operation), the vehicle may proceed on the highway, uninterrupted. If the scale is "open", then the truck enters the scale via an exit ramp and is weighed. Because the Portof-Entry permanent scales are located near Indiana's borders with other states, Indiana State Police deploy 46 portable scales to check the weights of vehicles in the interior of the state. Portable scale units are patrol cars usually equipped with four Haenni WL101 Wheel Load Scales.

While the portable scale measurements are accurate for the issuing of citations, officers must rely upon their own experience and intuition when choosing which vehicles to weigh. Because of the subjective nature of the current screening process, many legally loaded vehicles are weighed. More importantly, many overweight vehicles are not weighed because they do not usually exhibit characteristics that make it possible to identify them as being overweight.

\section{Findings}

The concept of using existing INDOT Weigh-In-Motion equipment, a laptop computer, and wireless communication equipment, to develop a virtual weigh station system was proposed for deployment in Indiana in 1998. The Virtual Weigh Station screening tool developed in this project allows officers to read the weights of vehicles crossing WIM scales, in real time, in their patrol cars. 
Giving officers this information increases the chances that the vehicles selected for weighing on portable scales are indeed overweight. This report documents the accuracy and precision evaluation performed on all the candidate WIM sites as well as the new infrastructure required to implement the Virtual Weigh Station concept.

\section{Implementation}

The report describes several cases where significantly overweight vehicles were identified and impounded. For example the procedures described in this report, resulted in the identifying the early morning hours as the best time for enforcement in Merrillville. As a result, on May 18, 2001 vehicles weighing 98,700 lbs and 100,600 lbs were stopped. Those vehicles were impounded and resulted in fines of $\$ 1,625.00$ and $\$ 1,735.50$, respectively. In February 2002, Commercial Vehicle Enforcement officers stopped ten trucks on US 24 near Fort Wayne using the virtual weigh station. Eight of the trucks were determined to be overweight and fined. The three heaviest trucks weighed 90,200 $\mathrm{lbs}, 90,900 \mathrm{lbs}$, and $91,100 \mathrm{lbs}$ resulting in fines of $\$ 1,099.50, \$ 1,169.50$, and $\$ 1,189.50$, respectively. On April 12, 2002, another enforcement was conducted on I-65 near Merrillville. Three trucks were stopped based on the virtual weigh station data. One of the trucks weighed $87,400 \mathrm{lbs}$, resulting in a $\$ 529.50$ fine.

The report concludes by making several recommendations designed to improve the quality of the WIM data and facilitate wide spread deployment by the Commercial Vehicle Enforcement Division.

\section{Contact}

For more information:

\author{
Prof. Darcy Bullock \\ Principal Investigator \\ School of Civil Engineering \\ Purdue University \\ West Lafayette IN 47907 \\ Phone: (765) 494-2226 \\ Fax: (765) 496-1105
}

\section{Indiana Department of Transportation}

Division of Research

1205 Montgomery Street

P.O. Box 2279

West Lafayette, IN 47906

Phone: (765) 463-1521

Fax: (765) 497-1665

\section{Purdue University}

Joint Transportation Research Program

School of Civil Engineering

West Lafayette, IN 47907-1284

Phone: (765) 494-9310

Fax: (765) 496-1105 


\section{Implementation Report}

There is a need for real time monitoring of Weigh In Motion sites around the state and reporting of summary statistics on the web. For example the procedures described in this report, resulted in the identifying the early morning hours as the best time for enforcement in Merrillville. As a result, on May 18, 2001 vehicles weighing 98,700 Ibs and 100,600 lbs were stopped. Those vehicles were impounded and resulted in fines of $\$ 1,625.00$ and $\$ 1,735.50$, respectively. In February 2002, Commercial Vehicle Enforcement officers stopped ten trucks on US 24 near Fort Wayne using the virtual weigh station. Eight of the trucks were determined to be overweight and fined. The three heaviest trucks weighed $90,200 \mathrm{lbs}, 90,900 \mathrm{lbs}$, and $91,100 \mathrm{lbs}$ resulting in fines of $\$ 1,099.50, \$ 1,169.50$, and $\$ 1,189.50$, respectively. On April 12, 2002, another enforcement was conducted on I-65 near Merrillville. Three trucks were stopped based on the virtual weigh station data. One of the trucks weighed $87,400 \mathrm{lbs}$, resulting in a $\$ 529.50$ fine.

In order to achieve a successful, wide scale deployment of the Virtual Weigh Station concept, on line data analysis procedures should be developed that permit rapid diagnosis of WIM calibration problems. This online diagnosis should have two components:

- Tabulation, by lane, of unclassified vehicles. The number of unclassified vehicles should not exceed $10 \%$ for any lane. The historical unclassified vehicle error rate should be presented in a format similar to that shown in Appendix E of this report. The memo in Appendix E identifies only 3 stations providing this level of accuracy in October 2000. Those stations were 4250, 5260, and 6260. All of those stations had only a WIM in a single lane.

- A crude evaluation of the accuracy and precision of a WIM can be estimated by looking at the distribution of the front axle weights. The thresholds shown in Appendix $\mathrm{H}$ provide a starting point for implementing a rigorous quality control program.

The following amendments to the INDOT WIM specification are suggested:

- "... documentation shall be furnished that completed installation confirms the ASTM pavement smoothness specification defined in the ASTM WIM standard E1318-94 at time of acceptance and possibly warranty smoothness for 2 years." This amendment is proposed because some of the recently completed WIM installations do not appear to conform to the required smoothness specification. Actually verifying conformance would require a lane closure. 
- “. . . a vehicle used for calibrating a WIM shall travel across the WIM at the average speed of Class 9 trucks. Documentation of the average speed of Class 9 trucks shall be provided by WIM records for Class 9 trucks during a weekday from 9am to $4 \mathrm{pm}$." This amendment is proposed because one of the sources of calibration error was thought to be that calibration trucks were not always traveling at the prevailing speed of Class 9 trucks. In Merrillville that difference was about $10 \mathrm{mph}$.

- ". . . a vehicle used for calibration shall not be in violation of any Indiana laws." This amendment is proposed because the truck used to calibrate the Merrillville WIM had a tandem load of 43,400 lbs. Subsequent discussion with IRD indicated this might cause calibration problems for lower axle weight vehicles.

- ". . . a WIM shall not be accepted by INDOT until telephone service has been operational for 30 consecutive days and the log files uploaded." This amendment is proposed because it is very difficult to determine if a site is operating properly unless a month or so of data files, including rainy days, are uploaded and IRD error reports are run on the uploaded data.

- " . . . the panel shown in Figure $\mathrm{J}-1$ with components, shown Figure $\mathrm{J}-2$, shall be furnished and installed as part of WIM system." This amendment is proposed so that all new WIMs will be accessible as a virtual scale as soon as they are turned on.

Regarding the use of WIMs for data collection purposes:

- Based upon the sensitivity analysis performed in Chapter 2, we believe a WIM should provide accurate axle weights within 6\% (ASTM Type III) in order to effectively estimate ESALs used to compute pavement life. Based upon observations at new single load cell installations (4410 and 5130), it is not clear whether any of the current installed systems are calibrated to this accuracy. A detailed evaluation at all Single Load Cell Sites $(4130,4150,4410,4420,5110,5120$, and 5130) should be conducted with Summer 2001 data, and field checks performed with Indiana Commercial Vehicle Enforcement Officers.

- Several of the older WIMs using Piezo technology are experiencing severe pavement distress and have likely reached the end their useful life. Those stations would be of little value to a virtual weigh station concept and are likely of little value for data collection. Consideration should be given to abandoning all Piezo WIM sites and perhaps all Bending Plate sites and devoting those additional resources to improved maintenance on the remaining sites.

- The WIMs that are most promising for the Virtual Weigh Station concept are the relatively new Single Load Cell installations. WIM 5110 on I-70 appears to hold some promise as a next Virtual Weigh Station site. However, some calibration and tuning will likely be required to eliminate some of the classification errors documented in this report. 


\section{Acknowledgements}

This project was the idea of Dan Shamo, Jay Wasson, and Guy Boruff.

This study could not have been conducted without the close participation of the Indiana State

Police. The efforts of Officers Deb Burkhart, Scott Fleming, Brian Nagle, Henry Davis, Gerald Young, Monty Buffum, Steve Baumgart, Jeff Ligget, and Sharon Branam were instrumental in the field verification and testing of the virtual weigh station concept.

Throughout this study Donn Klepinger, Larry Torrence, Phil Zurawski, and Scott MacCarthur provided field support and data archives necessary for several of the appendices. The figures in Appendix A are based upon Larry Torrence's files. The "Klepinger Scale" data in Appendix A was obtained from Donn Klepinger's qualitative site survey.

Finally, Rod Klashinsky from International Road Dynamics (IRD) provided the material for Appendix D as well as coordinated the field calibration and maintenance by Fred Kiesig. 


\section{Table of Contents}

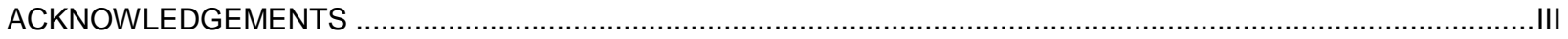

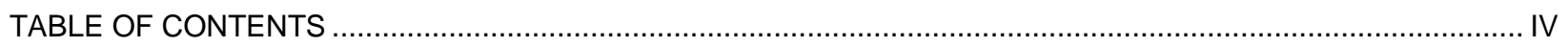

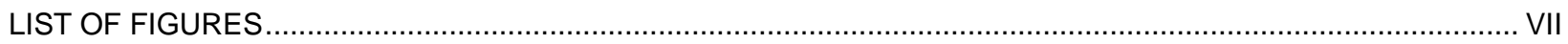

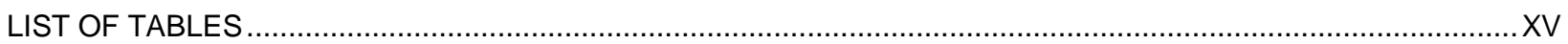

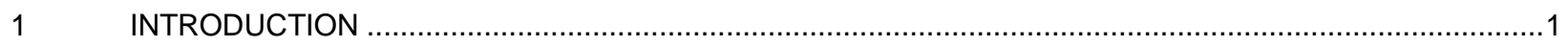

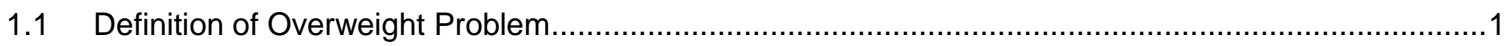

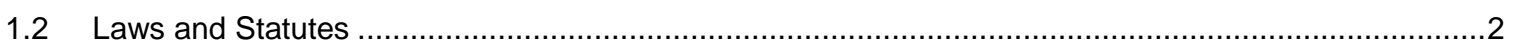

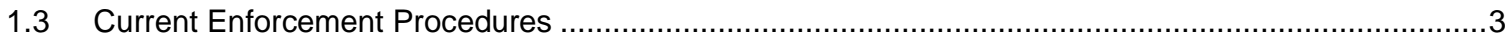

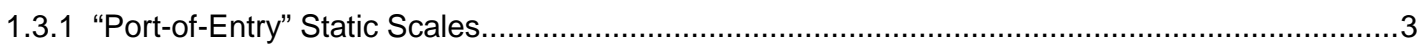

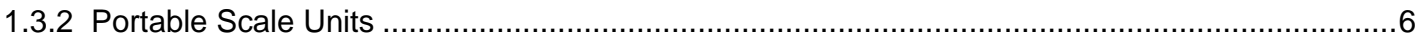

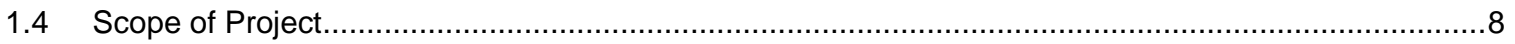

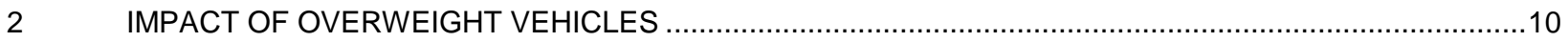

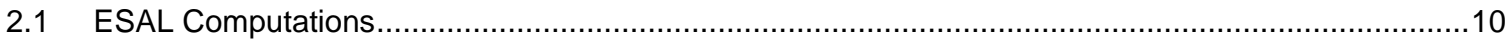

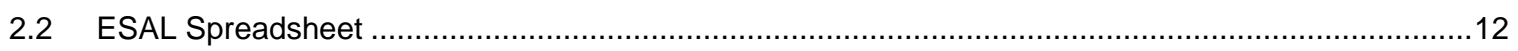

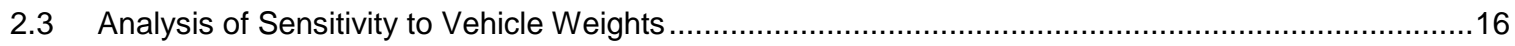

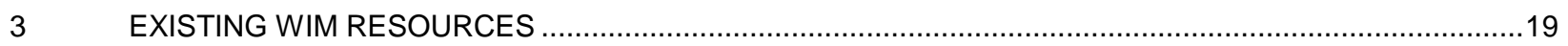

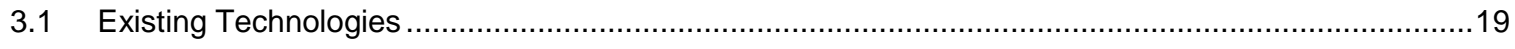

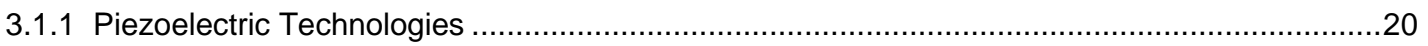

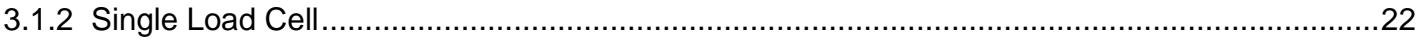

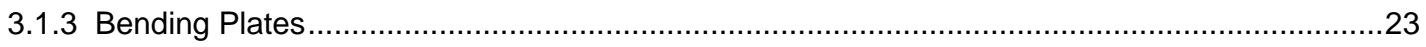

3.2 Suitability of Existing WIM Scales in Indiana for use with the Virtual Weigh Station .........................25

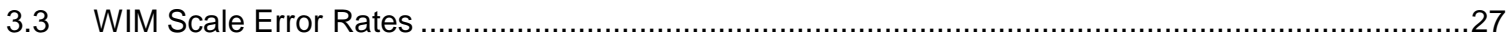

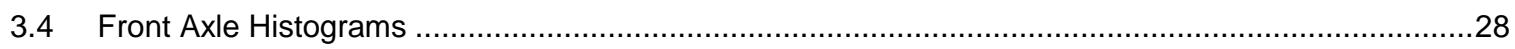

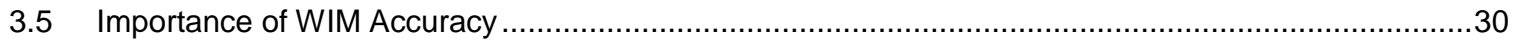

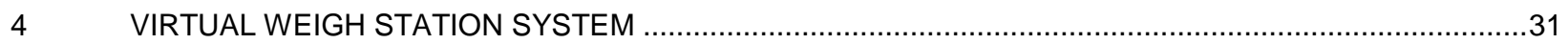

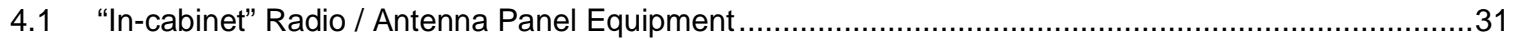




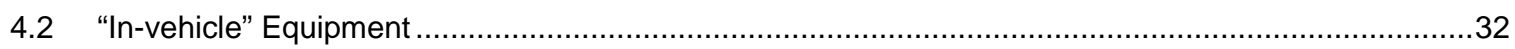

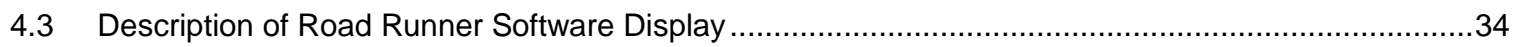

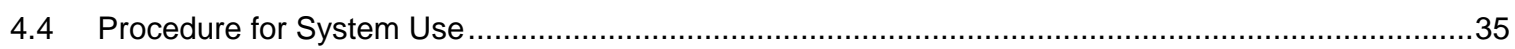

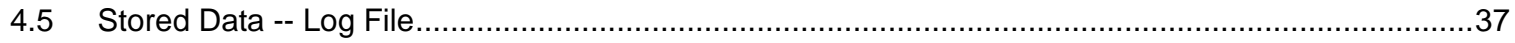

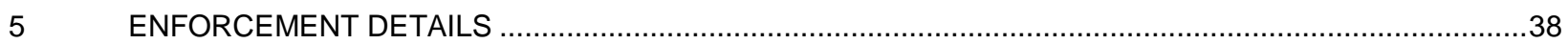

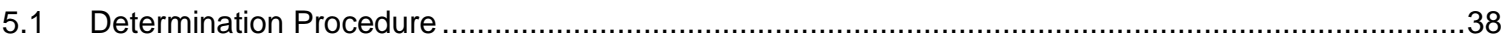

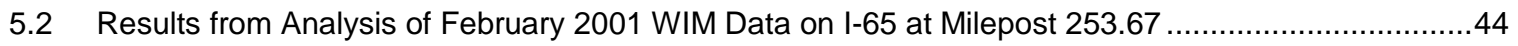

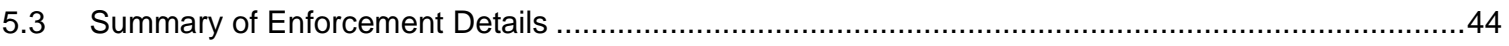

5.3.1 Summary of $8-10-00$ Tests on I-65, near Lafayette, IN ..........................................45

5.3.2 Summary of the 1-04-01 Tests on I-74, near Covington, IN ..........................................45

5.3.3 Summary of the Enforcement Details on I-65, near Merrillville, IN ...................................46

5.3.4 Summary of the Enforcement Details on US 24, near Fort Wayne, IN ...............................50

5.3.5 Summary of the Enforcement Details on I-65, near Merrillville, IN ...................................50

6

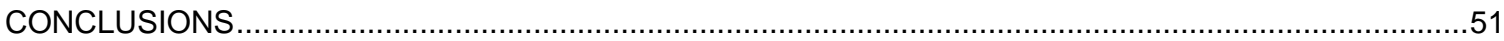

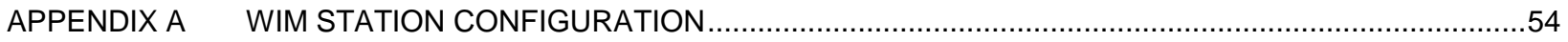

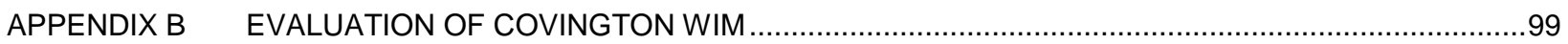

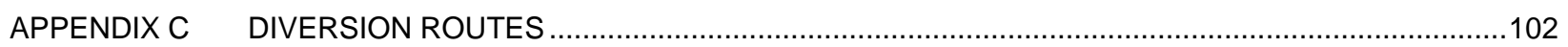

APPENDIX D INTERNATIONAL ROAD DYNAMICS COST SUMMARY MEMO $\quad$ IN....................................105

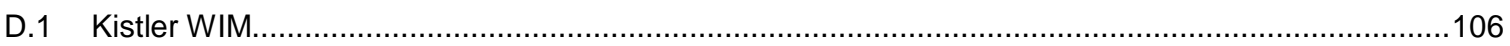

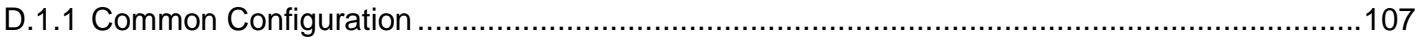

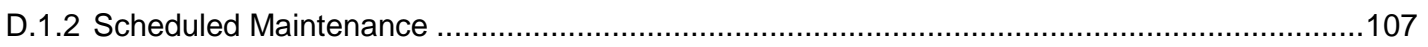

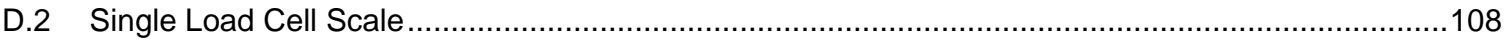

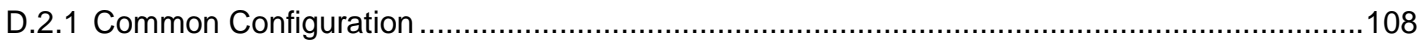

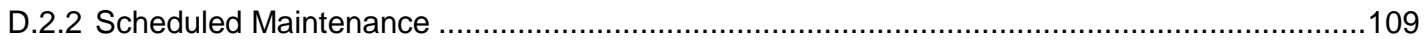

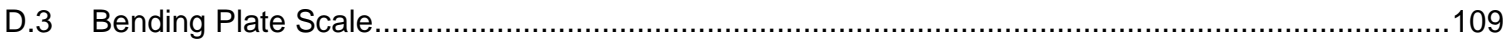

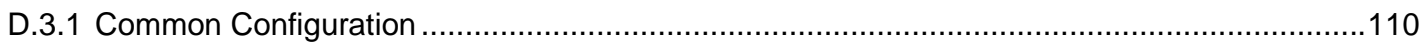

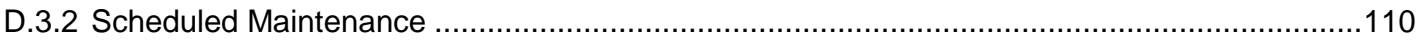

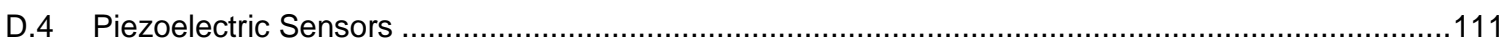


D.4.1 Common Configuration 112

D.4.2 Scheduled Maintenance .112

D.5 Comparison of WIM Technology Accuracies and Costs 113

D.6 Maintenance/Performance Monitoring Approach 115

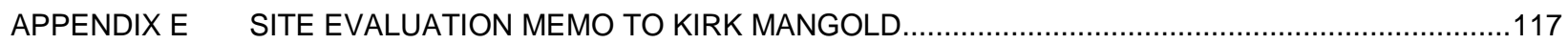

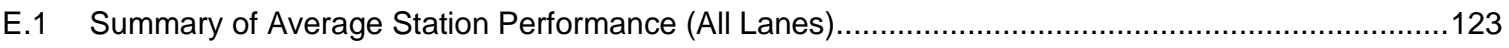

E.2 Summary of Average Station Performance (Individual Lanes) ............................................129

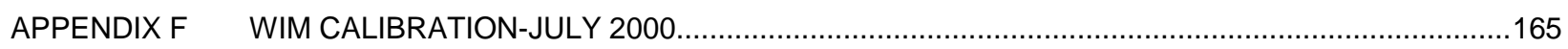

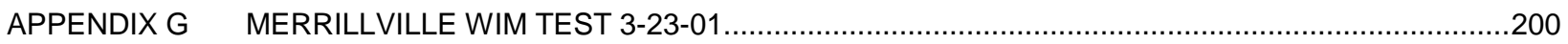

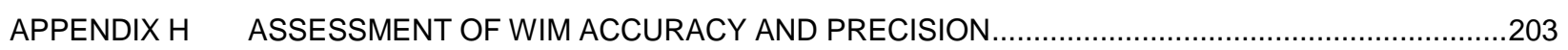

APPENDIX I SUMMARY OF MERRILLVILLE ENFORCEMENT DETAIL $\quad$ S.................................................227

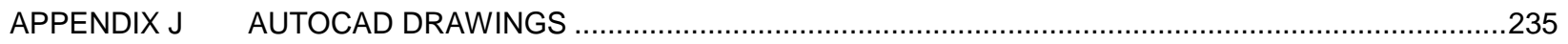

APPENDIX K SUMMARY OF SR 1 DATA (MARCH - MAY 2001) MEMO...........................................238

APPENDIX L SUMMARY OF SR 1 DATA (MARCH - JULY 2001) MEMO...........................................249

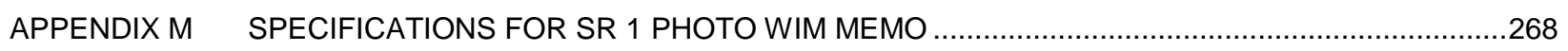

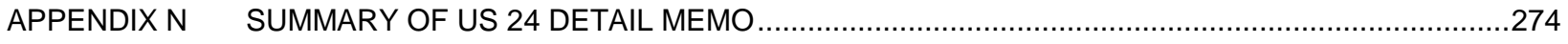

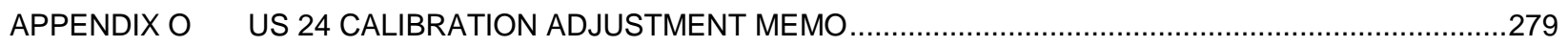

APPENDIX P SUMMARY OF US 24 DATA (MARCH 2002) MEMO $\quad$ S...................................................282

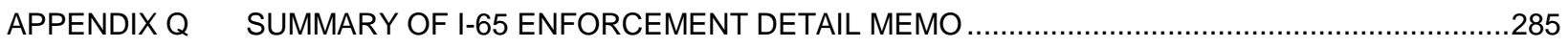

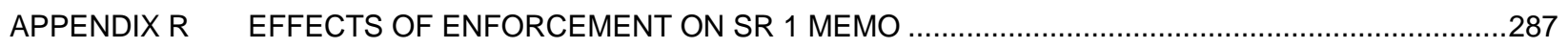

APPENDIX S SUMMARY OF BORMAN DATA (JANUARY-MARCH 2002) MEMO $\quad$ S..................................289

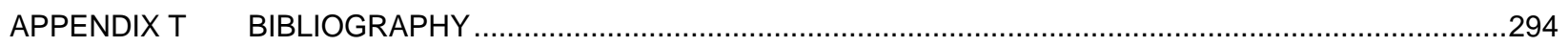




\section{List of Figures}

Figure 1-1: Indiana State Police Commercial Vehicle Enforcement Division Officers Ligget, Boruff, and Buffum with

INDOT official Jay Wasson in front of an illegally loaded (111,350-Lb) steel hauler, caught August 10, 2000 ..... 2

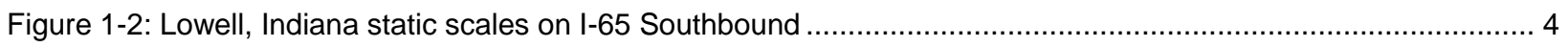

Figure 1-3: Truck being weighed on Lowell static scales ……....................................................................... 5

Figure 1-4: Indiana State Police Motor Carrier Officer Monty Buffum records vehicle weights at the Lowell Scales.... 5

Figure 1-5: Lowell scale weight display panel ........................................................................................ 6

Figure 1-6: Haenni WL 101 (portable) Wheel Load Scale ……............................................................................. 7

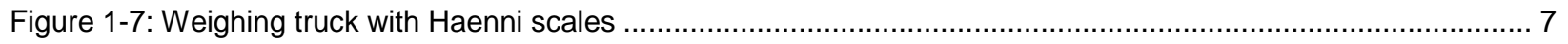

Figure 2-1: ESAL v. Axle Weights for Single and Tandem Axles ................................................................... 11

Figure 2-2: Screen capture of Microsoft EXCEL Spreadsheet, set up for calculation of Pavement Life.................... 13

Figure 2-3: Screen Capture of Class 9 Vehicle ESAL sheet ……....................................................................... 14

Figure 2-4: Expected Life of Pavement for Various WIM Errors ....................................................................... 17

Figure 2-5: Pavement Life Expectancy with $14 \%$ of vehicles $1.2{ }^{*}$ Legal Limit...................................................... 18

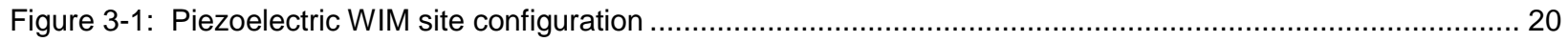

Figure 3-2: Piezo-electric WIM in pavement on I-65 NB, near Lafayette, IN ..................................................... 21

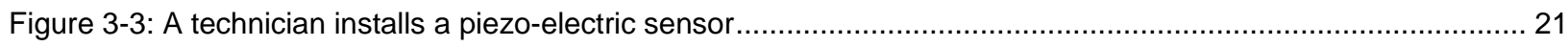

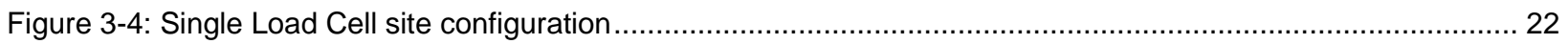

Figure 3-5: Single load cells in each lane, I-74 WB, near Covington, IN ......................................................... 23

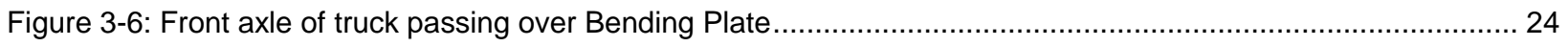

Figure 3-7: Failed Bending Plate Installation at WIM 5450 Filled with Asphalt ........................................................ 24

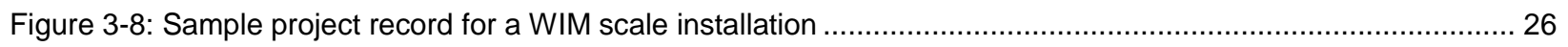

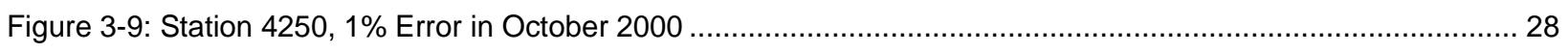

Figure 3-10: Scatter plot for Front Axle loads by lane distribution for station 4110, July 2000 ................................ 29

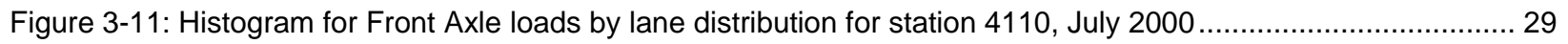

Figure 4-1: Sample WIM "in-cabinet” computer output screen ....................................................................... 31

Figure 4-2: Virtual Weigh Station System Hardware ......................................................................................... 33

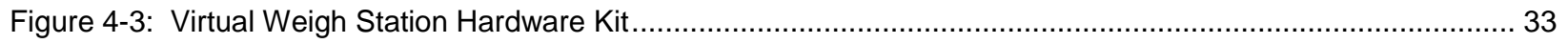

Figure 4-4: Screen Capture of latest version of Road Runner software ............................................................ 35

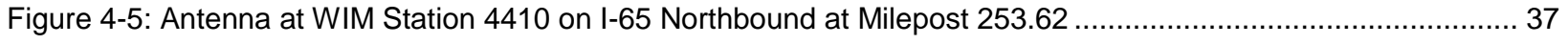

Figure 5-1: Overweight Northbound Lane 1, Class 9 Vehicles............................................................................ 43 
Figure 5-2: Overweight Southbound Lane 1, Class 9 Vehicles

Figure 5-3: Driver Vehicle Inspection Report of Vehicle Impounded by ISP Officer Henry Davis on May 18, 2001, caught using the "In-vehicle" system - GVW was 98,700 Lbs (compared to 80,000 Lbs allowable) ......

Figure 5-4: Driver Vehicle Inspection Report of vehicle impounded by ISP Officer Henry Davis on June 01, 2001,

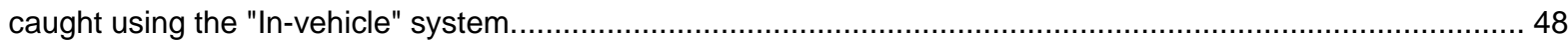

Figure 5-5: Graphical Comparison of Combined WIM to Scale Weight..................................................... 49

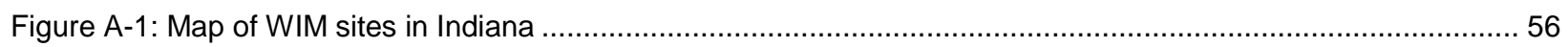

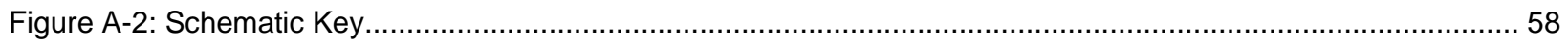

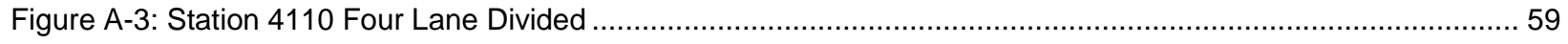

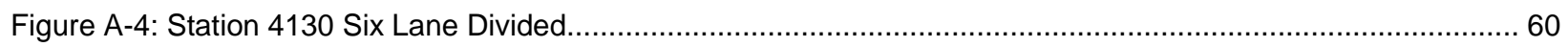

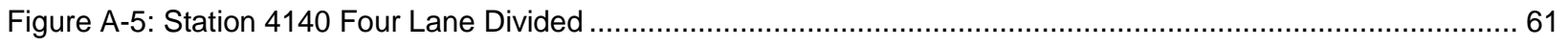

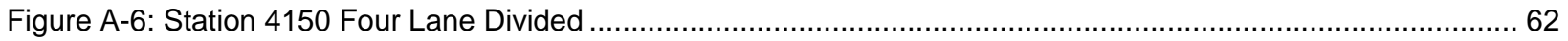

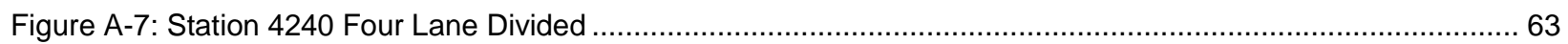

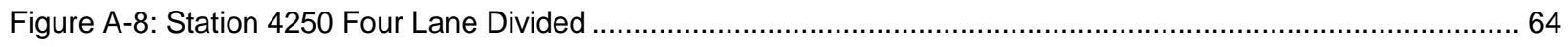

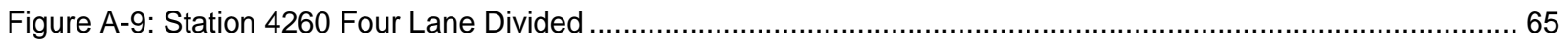

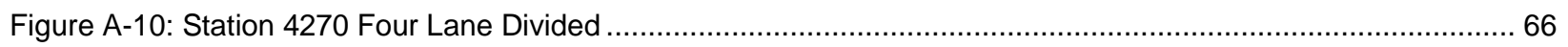

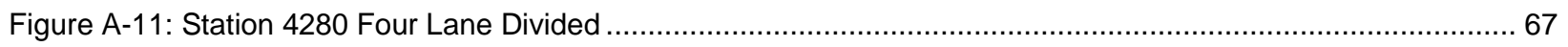

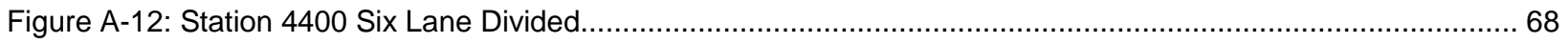

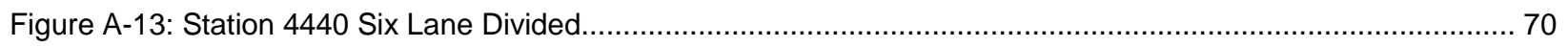

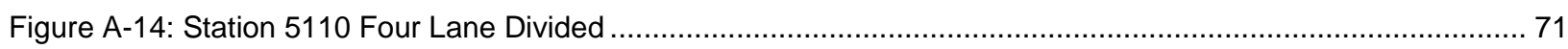

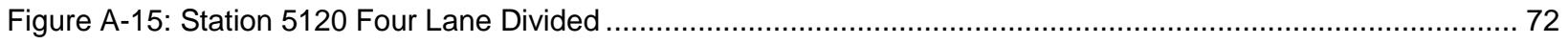

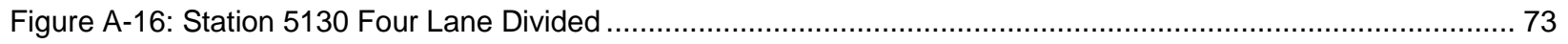

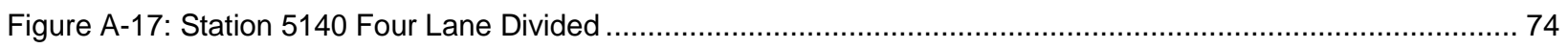

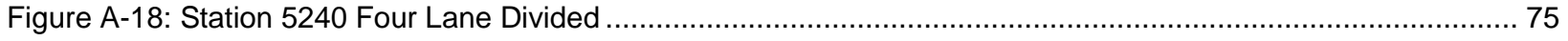

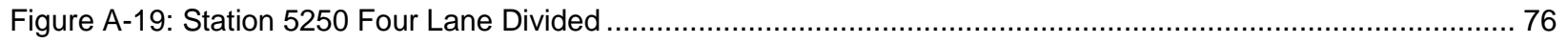

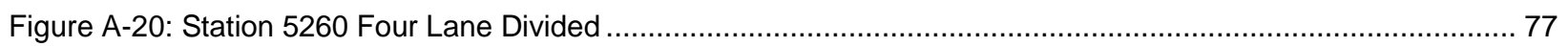

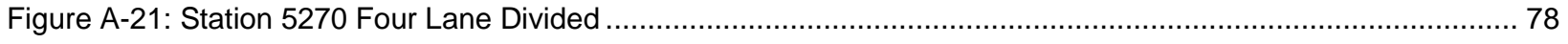

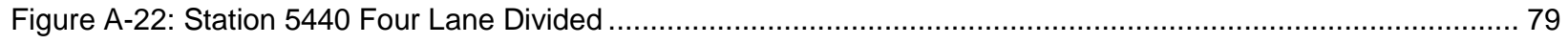

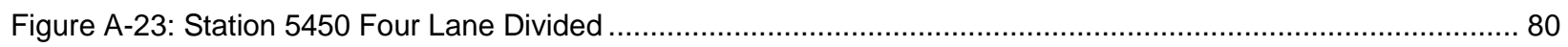

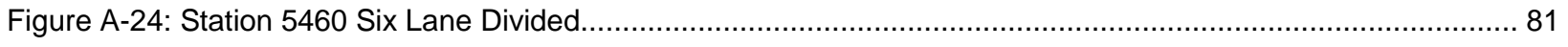

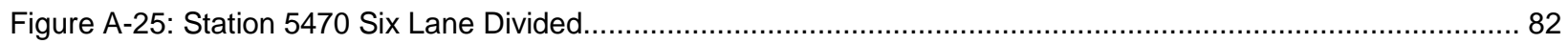




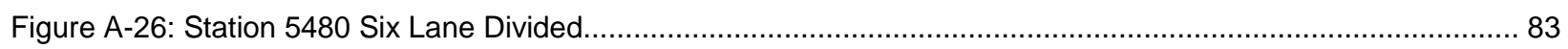

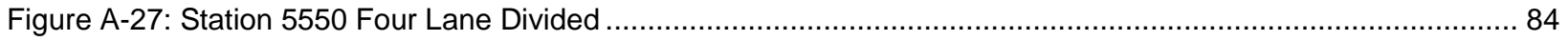

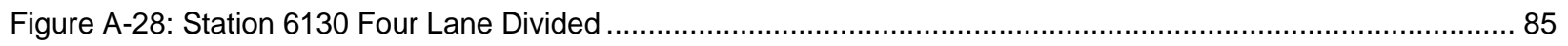

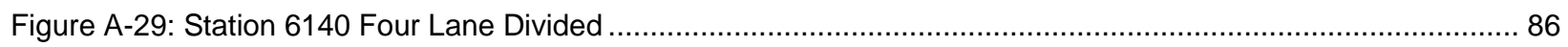

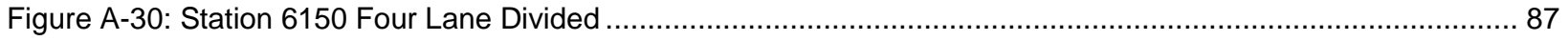

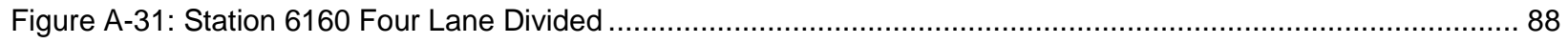

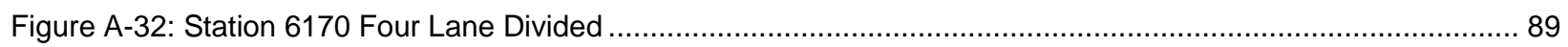

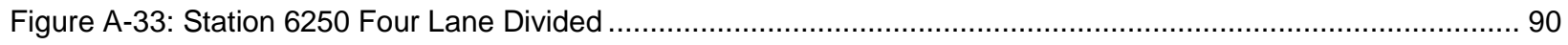

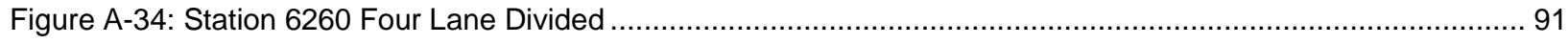

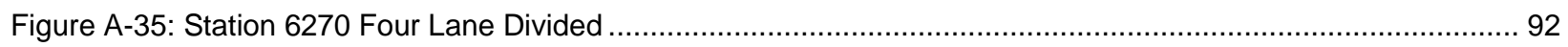

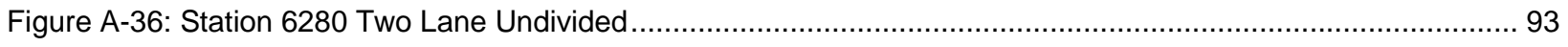

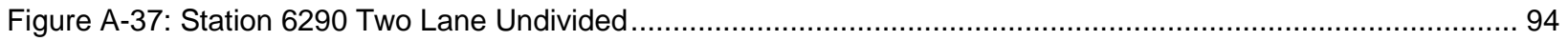

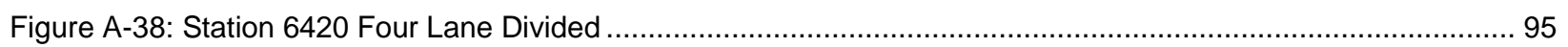

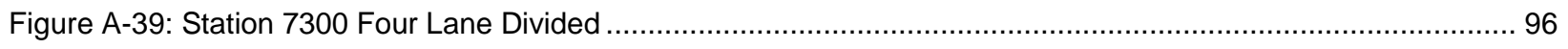

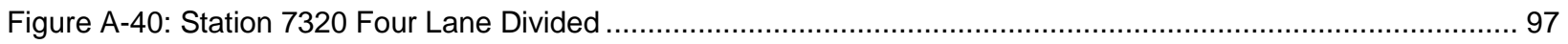

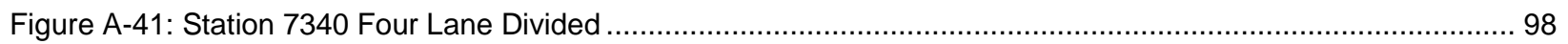

Figure B-1: Comparison of Test Weights 01-04-01 at Covington WIM 5130 ................................................... 101

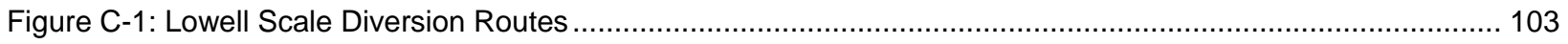

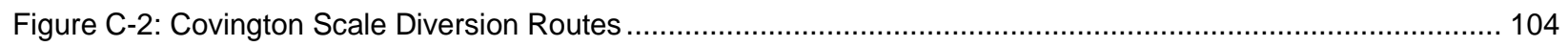

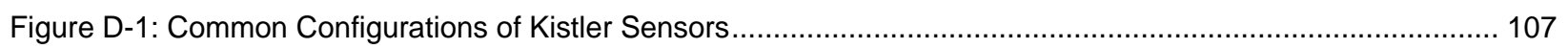

Figure D-2: Common Configuration of Single Load Cell Scale.......................................................................... 108

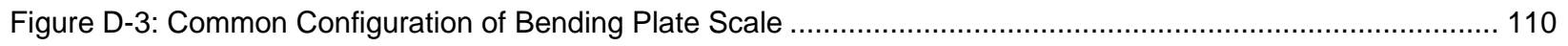

Figure D-4: Common Configuration of Piezoelectric Sensor ........................................................................ 112

Figure E-1: Error Rate at Station 4110

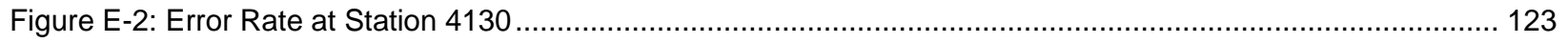

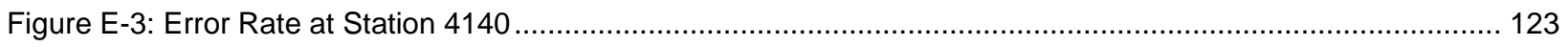

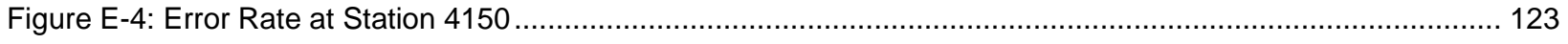

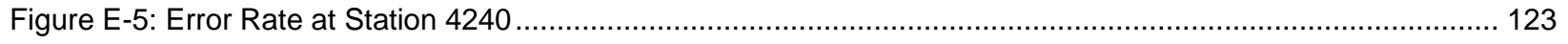

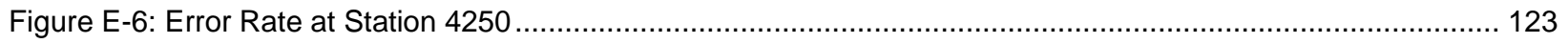

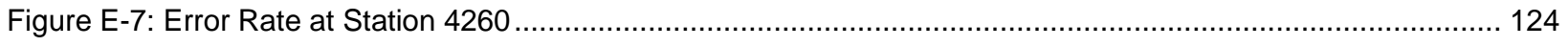

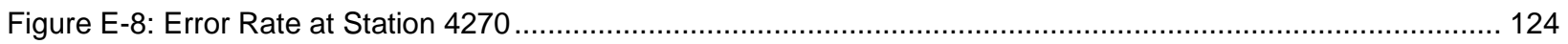




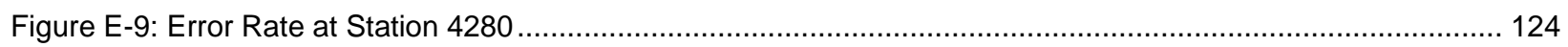

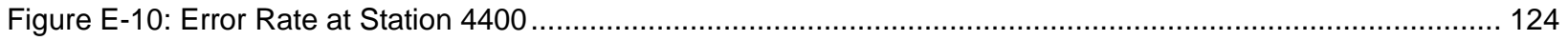

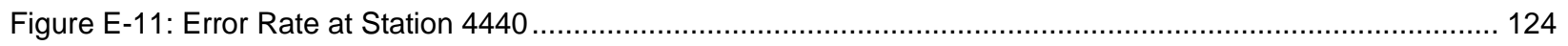

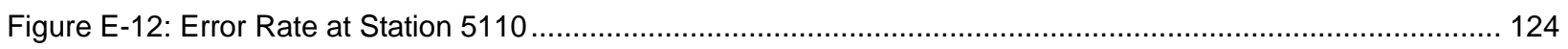

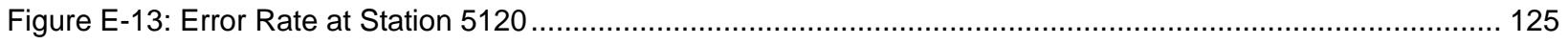

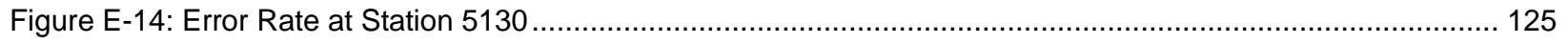

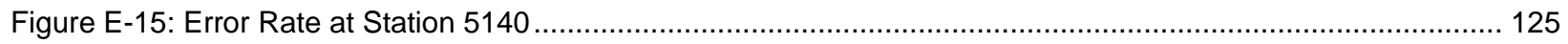

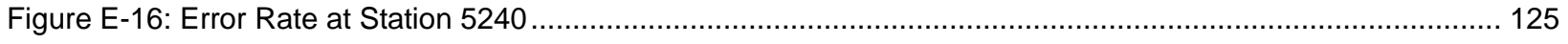

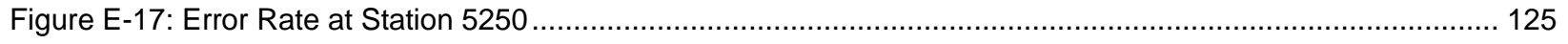

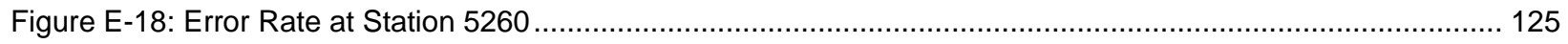

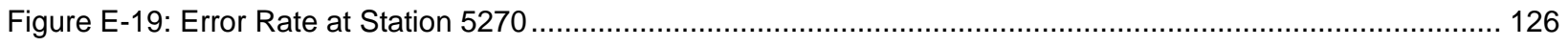

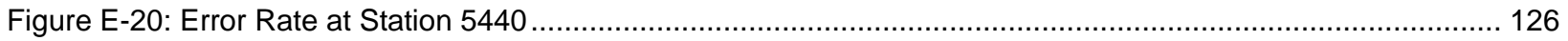

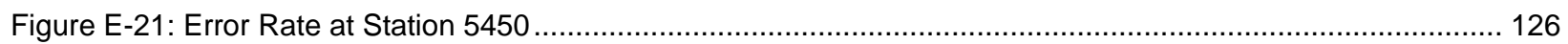

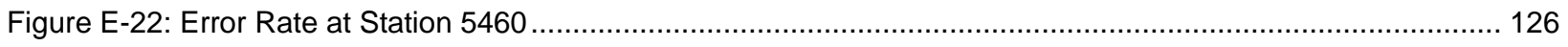

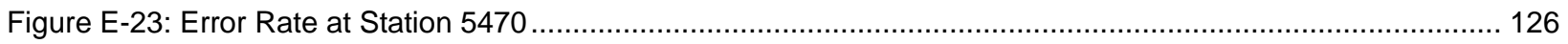

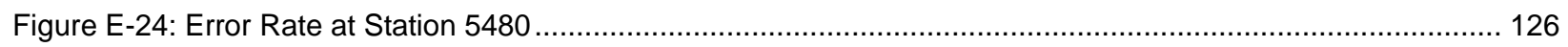

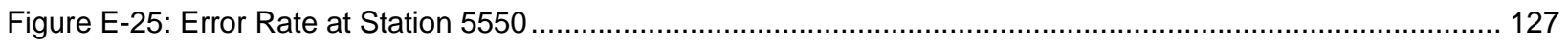

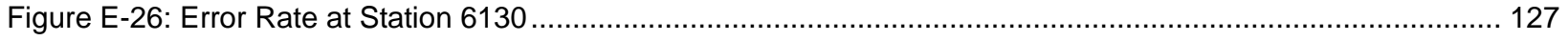

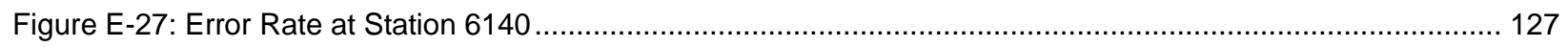

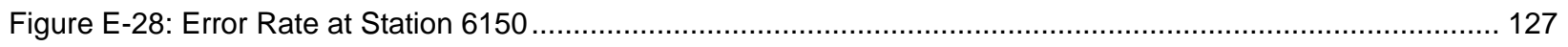

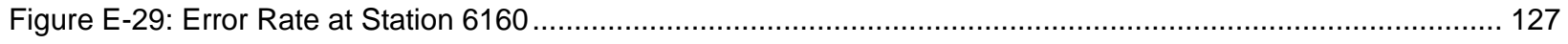

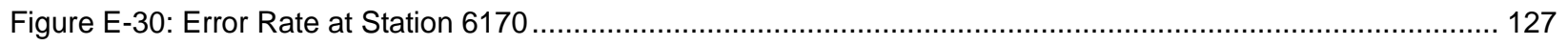

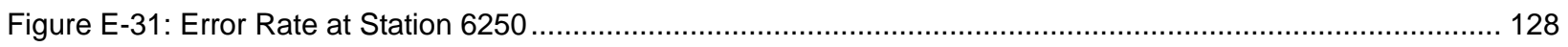

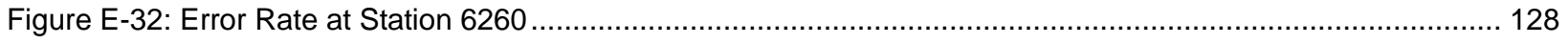

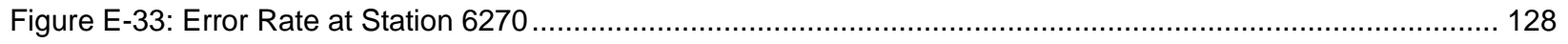

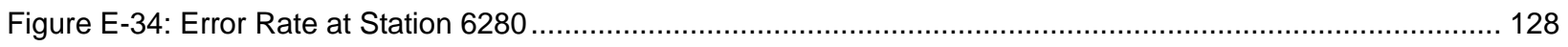

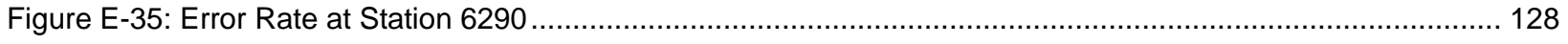

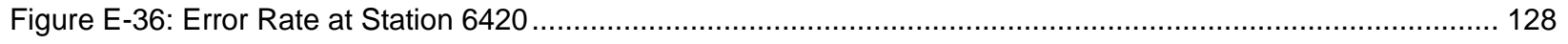

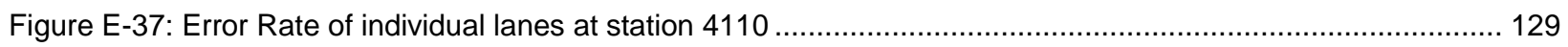

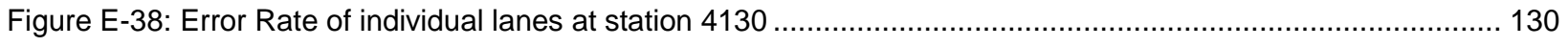

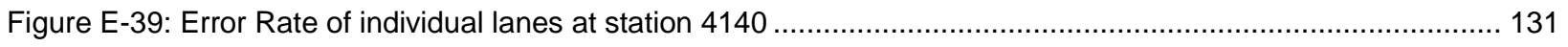




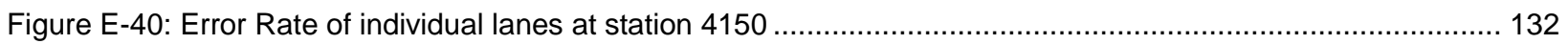

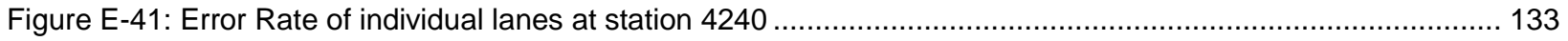

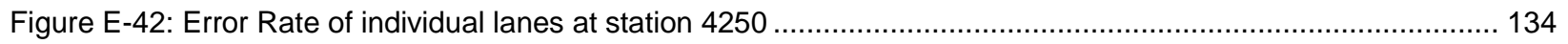

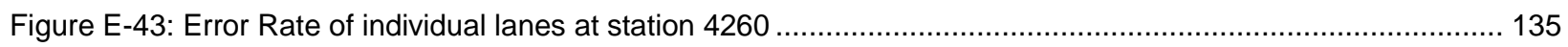

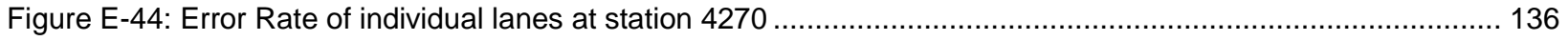

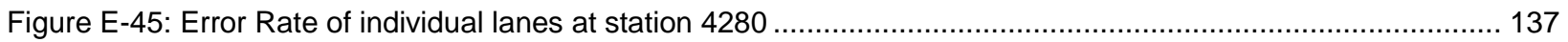

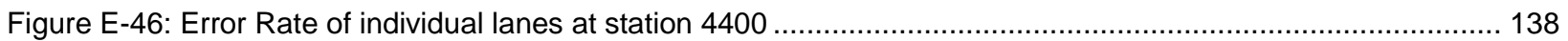

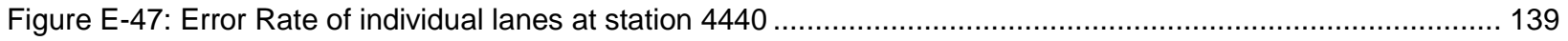

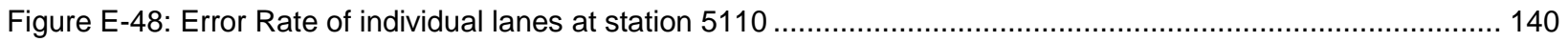

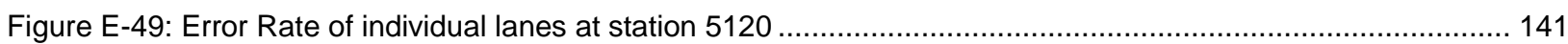

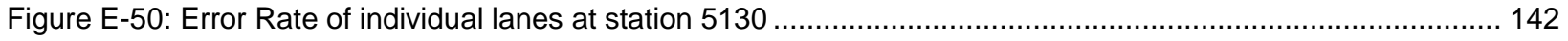

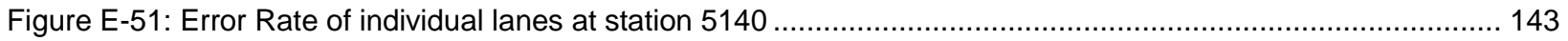

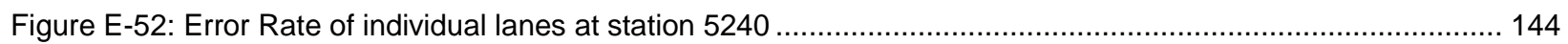

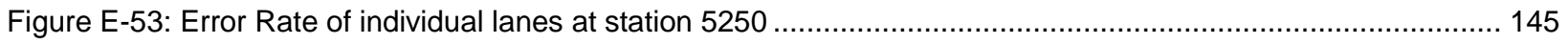

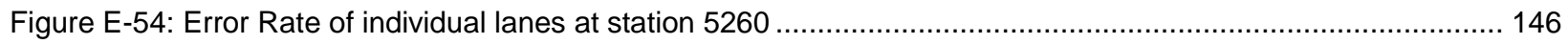

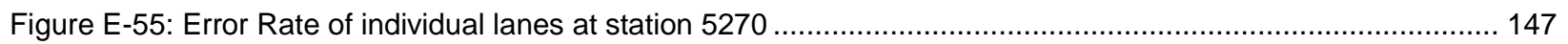

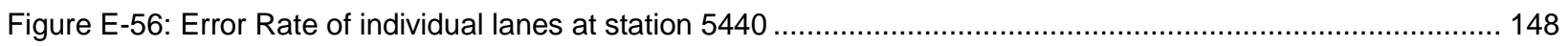

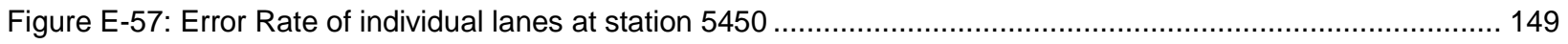

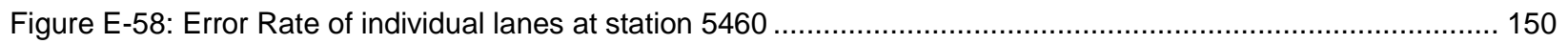

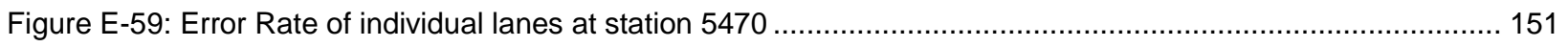

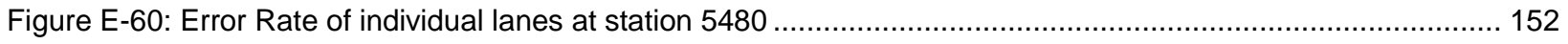

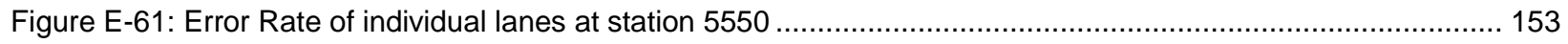

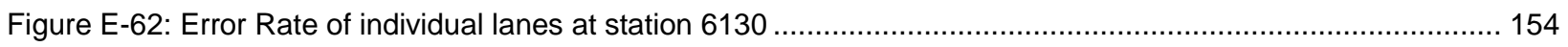

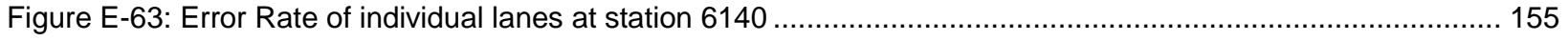

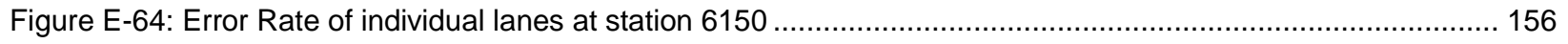

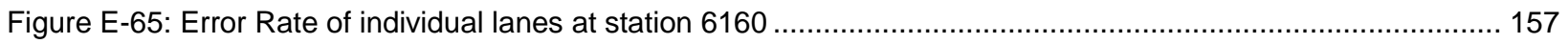

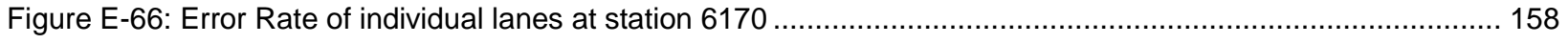

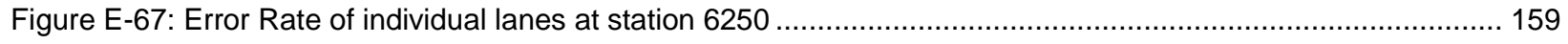

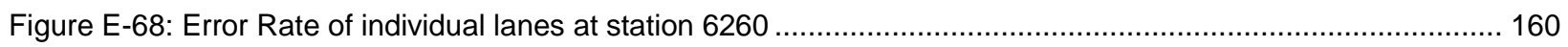

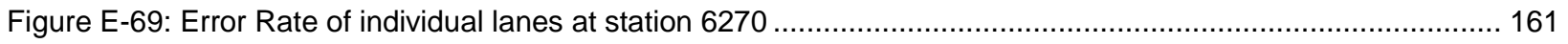

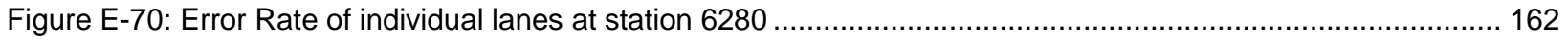




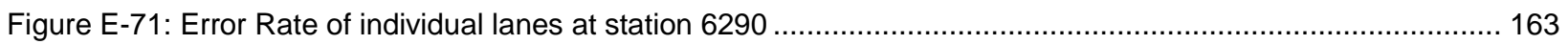

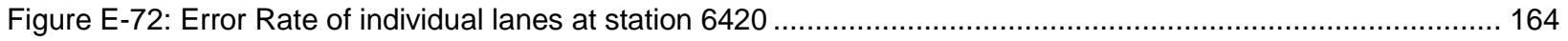

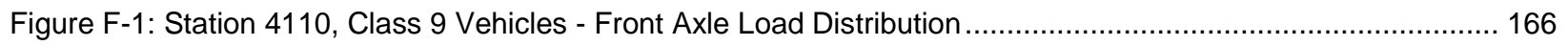

Figure F-2: Station 4110, Class 9 Vehicles - Gross Vehicle Weight vs. Front Axle ............................................. 166

Figure F-3: Station 4130, Class 9 Vehicles - Front Axle Load Distribution .......................................................... 167

Figure F-4: Station 4130, Class 9 Vehicles - Gross Vehicle Weight vs. Front Axle ................................................ 167

Figure F-5: Station 4140, Class 9 Vehicles - Front Axle Load Distribution ........................................................ 168

Figure F-6: Station 4140, Class 9 Vehicles - Gross Vehicle Weight vs. Front Axle ................................................ 168

Figure F-7: Station 4160, Class 9 Vehicles - Front Axle Load Distribution ........................................................... 169

Figure F-8: Station 4160, Class 9 Vehicles - Gross Vehicle Weight vs. Front Axle .............................................. 169

Figure F-9: Station 4240, Class 9 Vehicles - Front Axle Load Distribution ......................................................... 170

Figure F-10: Station 4240, Class 9 Vehicles - Gross Vehicle Weight vs. Front Axle ............................................. 170

Figure F-11: Station 4250, Class 9 Vehicles - Front Axle Load Distribution ...................................................... 171

Figure F-12: Station 4250, Class 9 Vehicles - Gross Vehicle Weight vs. Front Axle .............................................. 171

Figure F-13: Station 4260, Class 9 Vehicles - Front Axle Load Distribution ....................................................... 172

Figure F-14: Station 4260, Class 9 Vehicles - Gross Vehicle Weight vs. Front Axle ............................................ 172

Figure F-15: Station 4270, Class 9 Vehicles - Front Axle Load Distribution ...................................................... 173

Figure F-16: Station 4270, Class 9 Vehicles - Gross Vehicle Weight vs. Front Axle ............................................. 173

Figure F-17: Station 4280, Class 9 Vehicles - Front Axle Load Distribution ........................................................ 174

Figure F-18: Station 4280, Class 9 Vehicles - Gross Vehicle Weight vs. Front Axle ............................................. 174

Figure F-19: Station 4440, Class 9 Vehicles - Front Axle Load Distribution ......................................................... 175

Figure F-20: Station 4440, Class 9 Vehicles - Gross Vehicle Weight vs. Front Axle .............................................. 175

Figure F-21: Station 5110, Class 9 Vehicles - Front Axle Load Distribution ....................................................... 176

Figure F-22: Station 5110, Class 9 Vehicles - Gross Vehicle Weight vs. Front Axle ............................................. 176

Figure F-23: Station 5120, Class 9 Vehicles - Front Axle Load Distribution ......................................................... 177

Figure F-24: Station 5120, Class 9 Vehicles - Gross Vehicle Weight vs. Front Axle ........................................... 177

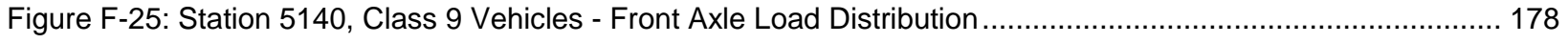

Figure F-26: Station 5140, Class 9 Vehicles - Gross Vehicle Weight vs. Front Axle ............................................. 178

Figure F-27: Station 5240, Class 9 Vehicles - Front Axle Load Distribution ...................................................... 179

Figure F-28: Station 5240, Class 9 Vehicles - Gross Vehicle Weight vs. Front Axle ............................................... 179

Figure F-29: Station 5250, Class 9 Vehicles - Front Axle Load Distribution ......................................................... 180 
Figure F-30: Station 5250, Class 9 Vehicles - Gross Vehicle Weight vs. Front Axle ............................................. 180

Figure F-31: Station 5260, Class 9 Vehicles - Front Axle Load Distribution ........................................................ 181

Figure F-32: Station 5260, Class 9 Vehicles - Gross Vehicle Weight vs. Front Axle ........................................... 181

Figure F-33: Station 5270, Class 9 Vehicles - Front Axle Load Distribution ...................................................... 182

Figure F-34: Station 5270, Class 9 Vehicles - Gross Vehicle Weight vs. Front Axle ............................................ 182

Figure F-35: Station 5440, Class 9 Vehicles - Front Axle Load Distribution ......................................................... 183

Figure F-36: Station 5440, Class 9 Vehicles - Gross Vehicle Weight vs. Front Axle ............................................ 183

Figure F-37: Station 5440, Class 9 Vehicles - Front Axle Load Distribution ......................................................... 184

Figure F-38: Station 5450, Class 9 Vehicles - Gross Vehicle Weight vs. Front Axle ............................................. 184

Figure F-39: Station 5460, Class 9 Vehicles - Front Axle Load Distribution ...................................................... 185

Figure F-40: Station 5460, Class 9 Vehicles - Gross Vehicle Weight vs. Front Axle ............................................. 185

Figure F-41: Station 5470, Class 9 Vehicles - Front Axle Load Distribution ........................................................ 186

Figure F-42: Station 5470, Class 9 Vehicles - Gross Vehicle Weight vs. Front Axle ............................................. 186

Figure F-43: Station 5480, Class 9 Vehicles - Front Axle Load Distribution ........................................................ 187

Figure F-44: Station 5480, Class 9 Vehicles - Gross Vehicle Weight vs. Front Axle ............................................ 187

Figure F-45: Station 5550, Class 9 Vehicles - Front Axle Load Distribution ....................................................... 188

Figure F-46: Station 5550, Class 9 Vehicles - Gross Vehicle Weight vs. Front Axle ............................................. 188

Figure F-47: Station 6130, Class 9 Vehicles - Front Axle Load Distribution ........................................................ 189

Figure F-48: Station 6130, Class 9 Vehicles - Gross Vehicle Weight vs. Front Axle ............................................. 189

Figure F-49: Station 6140, Class 9 Vehicles - Front Axle Load Distribution ........................................................ 190

Figure F-50: Station 6140, Class 9 Vehicles - Gross Vehicle Weight vs. Front Axle ............................................. 190

Figure F-51: Station 6150, Class 9 Vehicles - Front Axle Load Distribution ......................................................... 191

Figure F-52: Station 6150, Class 9 Vehicles - Gross Vehicle Weight vs. Front Axle …........................................ 191

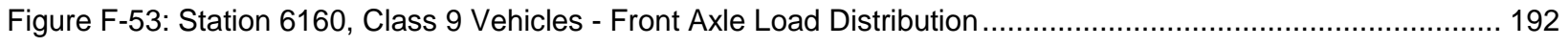

Figure F-54: Station 6160, Class 9 Vehicles - Gross Vehicle Weight vs. Front Axle .............................................. 192

Figure F-55: Station 6170, Class 9 Vehicles - Front Axle Load Distribution ...................................................... 193

Figure F-56: Station 6170, Class 9 Vehicles - Gross Vehicle Weight vs. Front Axle .......................................... 193

Figure F-57: Station 6250, Class 9 Vehicles - Front Axle Load Distribution ......................................................... 194

Figure F-58: Station 6250, Class 9 Vehicles - Gross Vehicle Weight vs. Front Axle ............................................. 194

Figure F-59: Station 6260, Class 9 Vehicles - Front Axle Load Distribution ……….......................................... 195

Figure F-60: Station 6260, Class 9 Vehicles - Gross Vehicle Weight vs. Front Axle .............................................. 195 
Figure F-61: Station 6270, Class 9 Vehicles - Front Axle Load Distribution ........................................................ 196

Figure F-62: Station 6270, Class 9 Vehicles - Gross Vehicle Weight vs. Front Axle ............................................. 196

Figure F-63: Station 6280, Class 9 Vehicles - Front Axle Load Distribution ........................................................ 197

Figure F-64: Station 6280, Class 9 Vehicles - Gross Vehicle Weight vs. Front Axle ............................................ 197

Figure F-65: Station 6290, Class 9 Vehicles - Front Axle Load Distribution ........................................................ 198

Figure F-66: Station 6290, Class 9 Vehicles - Gross Vehicle Weight vs. Front Axle ............................................. 198

Figure F-67: Station 6420, Class 9 Vehicles - Front Axle Load Distribution ....................................................... 199

Figure F-68: Station 6420, Class 9 Vehicles - Gross Vehicle Weight vs. Front Axle .............................................. 199

Figure G-1: WIM \#4410 Comparison to Portable Scales Test Results, 3-23-01 .................................................. 202

Figure H-1: Average Class 9 Front Axle Weight for All WIM Lanes .............................................................. 208

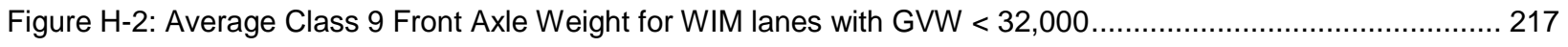

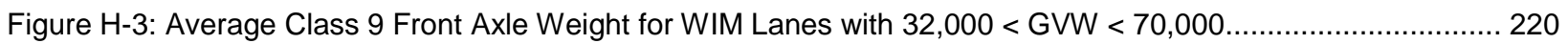

Figure H-4: Average Class 9 Front Axle Weight for WIM lanes with GVW > 70,000 ............................................ 223

Figure I-1: March 29, 2001 - Merrillville Scale Detail (WIM 4410) - WIM v. Static graph ...................................... 228

Figure I-2: May 8, 2001 - Merrillville Scale Detail (WIM 4410) - WIM v. Static graph ......................................... 229

Figure I-3: May 15, 2001 - Merrillville Scale Detail (WIM 4410) - WIM v. Static graph.......................................... 230

Figure I-4: May 18, 2001 - Merrillville Scale Detail (WIM 4410) - WIM v. Static graph.......................................... 231

Figure I-5: May 21, 2001 - Merrillville Scale Detail (WIM 4410) - WIM v. Static graph.......................................... 232

Figure I-6: May 23, 2001 - Merrillville Scale Detail (WIM 4410) - WIM v. Static graph .......................................... 233

Figure I-7: May 31, 2001 - Merrillville Scale Detail (WIM 4410) - WIM v. Static graph ........................................... 234

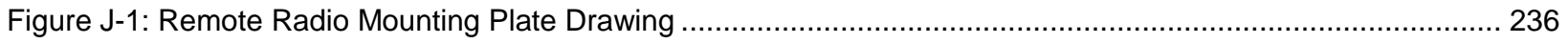

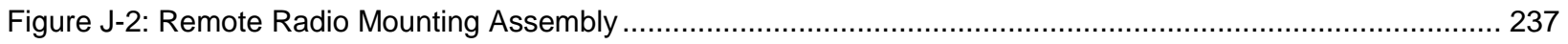




\section{List of Tables}

Table 2-1: Load Equivalency Factors for various Single Axle and Tandem Weights .......................................... 10

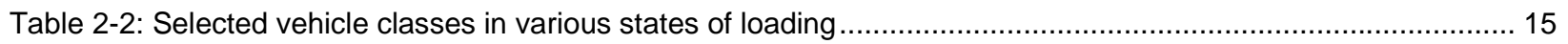

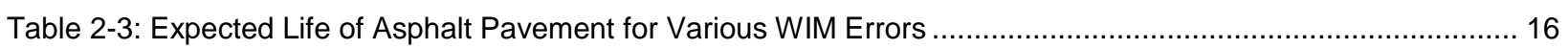

Table 3-1: Summary of ASTM 1318-94 Type Code and Accuracy for Common WIM Technology ............................ 19

Table 5-1: Class 9 Vehicles, Feb 01 00:00:00 2001 TO Thu Mar 01 00:00:00 2001 - Station 4410, Northbound........ 39

Table 5-2: Class 9 Vehicles, Feb 01 00:00:00 2001 TO Thu Mar 01 00:00:00 2001 - Station 4420, Southbound ...... 39

Table 5-3: February 2001, Northbound, Lane 1, Class 9 Vehicles exceeding 90,000lbs......................................... 40

Table 5-4: February 2001, Northbound, Lane 2, Class 9 Vehicles exceeding 90,000 Lbs....................................... 40

Table 5-5: February 2001, Northbound, Lane 3, Class 9 Vehicles exceeding 90,000 Lbs..................................... 41

Table 5-6: February 2001, Southbound, Lane 1, Class 9 Vehicles exceeding 90,000 Lbs. ..................................... 41

Table 5-7: February 2001, Southbound, Lane 2, Class 9 Vehicles exceeding 90,000 Lbs. .................................... 42

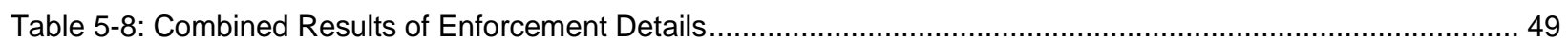

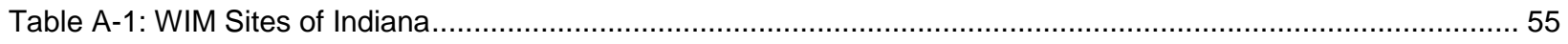

Table A-2: List of Automatic Traffic Recording Sites in Indiana....................................................................... 57

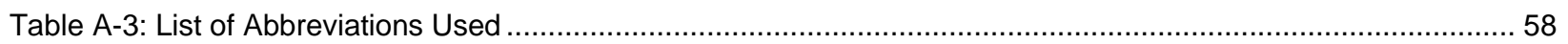

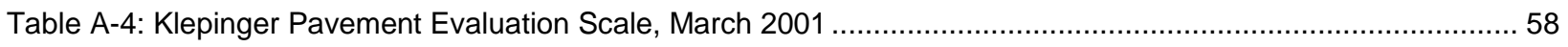

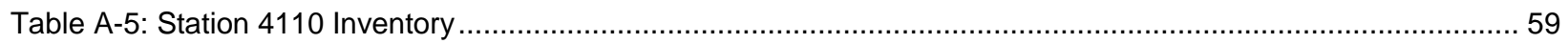

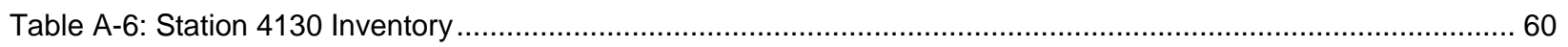

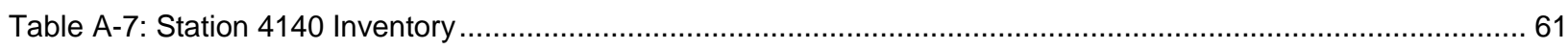

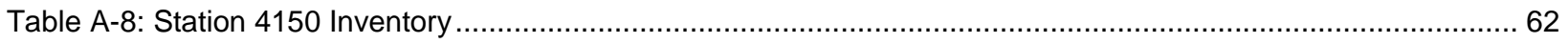

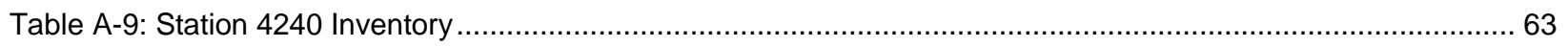

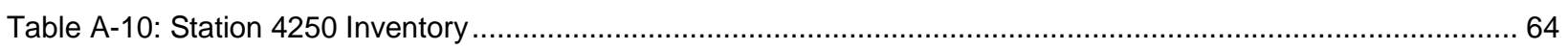

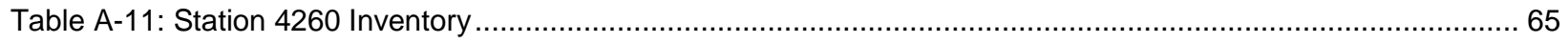

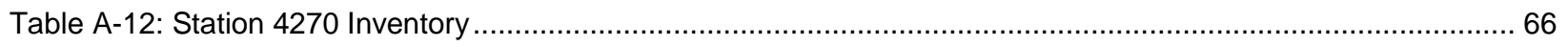

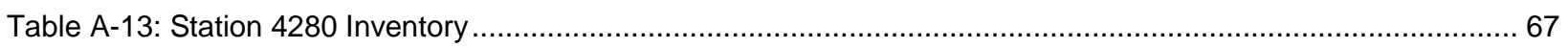

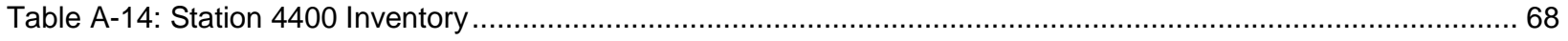

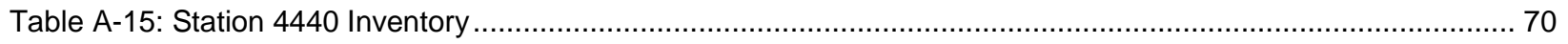

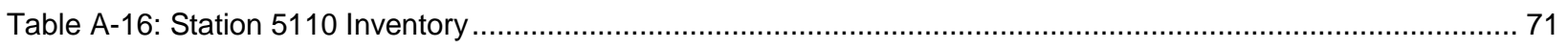

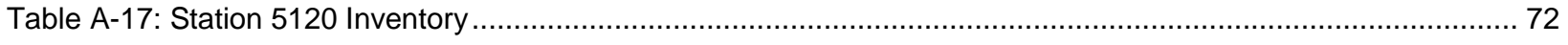

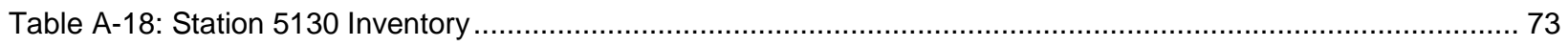




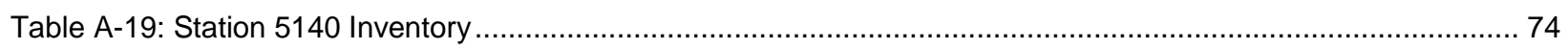

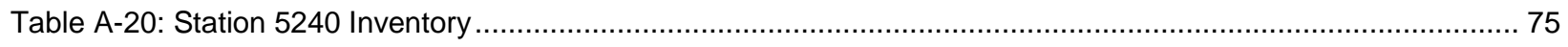

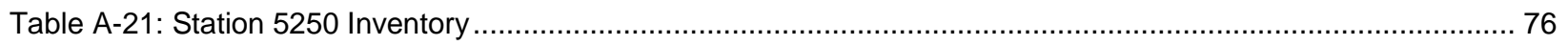

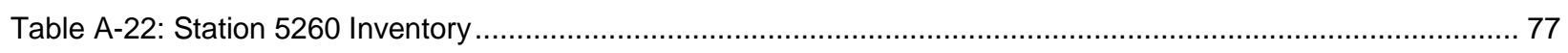

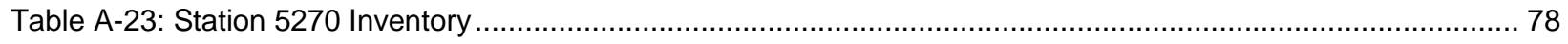

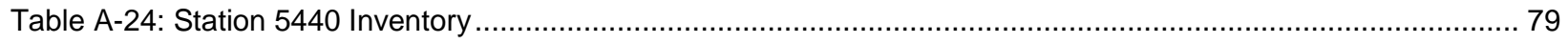

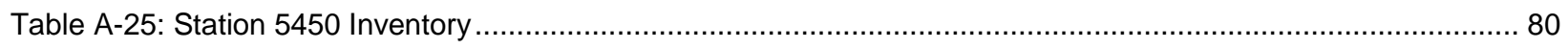

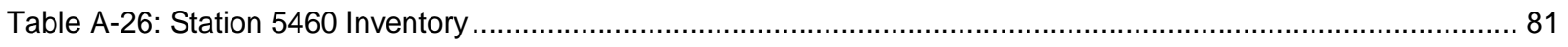

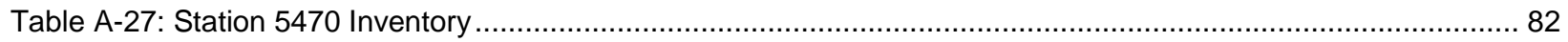

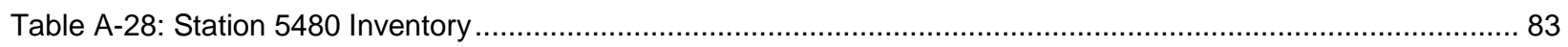

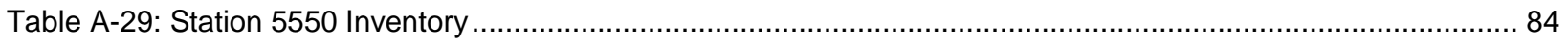

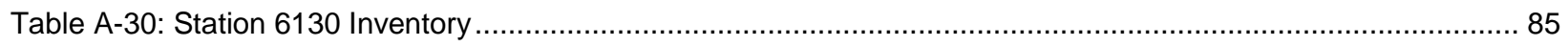

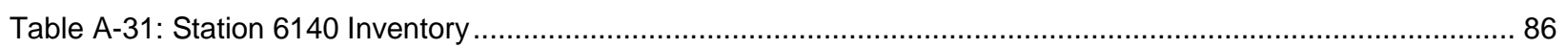

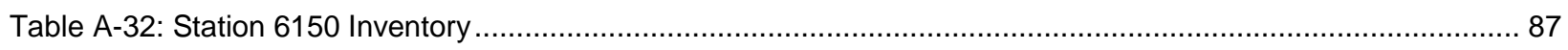

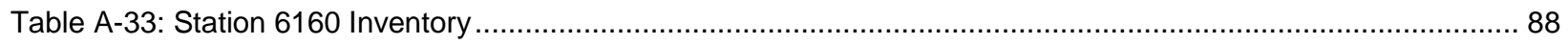

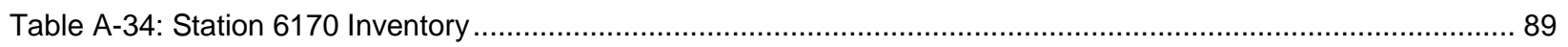

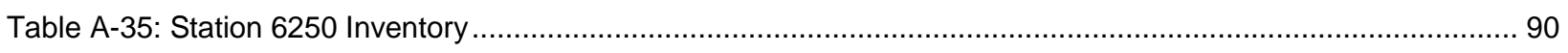

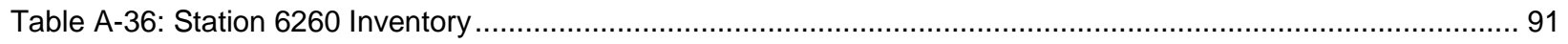

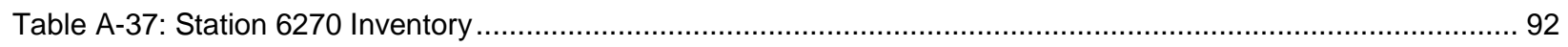

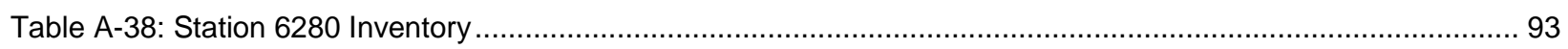

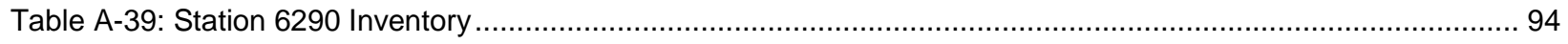

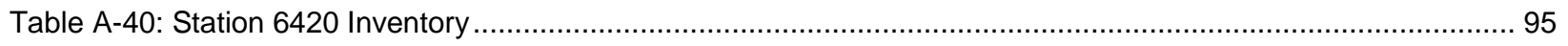

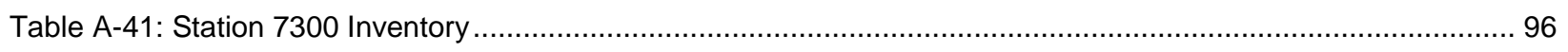

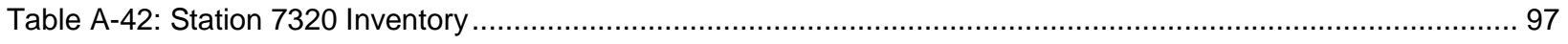

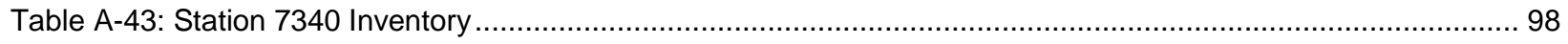

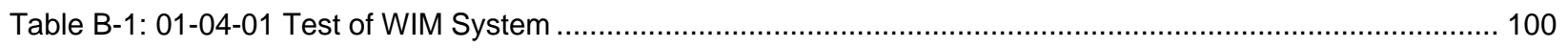

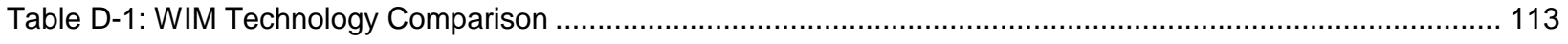

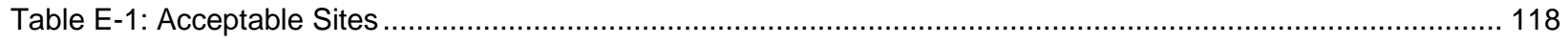

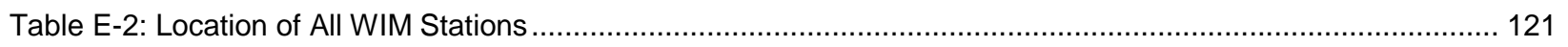

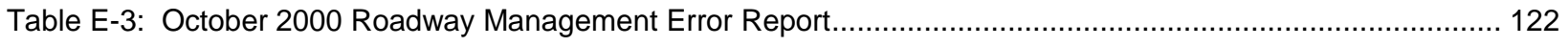

Table G-1: WIM \#4410 Comparison to Portable Scales Test Results, 3-23-01 .................................................... 201 
Table H-1: Average Class 9 Front Axle Weight for All WIM Lanes, Sorted by Front Axle Weight $(33,689-10,398) \ldots 204$

Table H-2: Average Class 9 Front Axle Weight for All WIM Lanes, Sorted by Front Axle Weight $(10,285-7,200) \ldots . .205$

Table H-3: Average Class 9 Axle Weight for All WIM Lanes, Sorted by Front Axle Weight $(6,310-1,001) \ldots \ldots \ldots \ldots \ldots . . .206$

Table H-4: Average Class 9 Axle Weight for All WIM Lanes, Sorted by Front Axle Weight (986-308) .................... 207

Table H-5: Average Class 9 Front Axle Weight for All WIM Lanes, Sorted by Number and Lane (4110-4280) ........ 209

Table H-6: Average Class 9 Front Axle Weight for All WIM Lanes, Sorted by Number and Lane (4400-5460) ........ 210

Table H-7: Average Class 9 Front Axle Weight for All WIM Lanes, Sorted by Number and Lane (5470-6250) ........ 211

Table H-8: Average Class 9 Front Axle Weight for All WIM Lanes, Sorted by Number and Lane (6270-7340) ........ 212

Table H-9: Average Class 9 Front Axle Weight for WIM lanes with GVW<32,000, Sorted by Site Number (4110-4400)

Table H-10: Average Class 9 Front Axle Weight for WIM lanes with GVW<32,000, Sorted by Site Number (51105470) 214

Table H-11: Average Class 9 Front Axle Weight for WIM lanes with GVW<32,000, Sorted by Site Number (5480$6250)$

Table H-12: Average Class 9 Front Axle Weight for WIM lanes with GVW<32,000, Sorted by Site Number (62707340) 216

Table H-13: Average Class 9 Front Axle Weight for WIM lanes with 32,000<GVW<70,000, Sorted by Site Number (4110-5450) 218

Table H-14: Average Class 9 Front Axle Weight for WIM lanes with $32,000<\mathrm{GVW}<70,000$, Sorted by Site Number (5470-7340)

Table H-15: Average Class 9 Front Axle Weight for WIM lanes with GVW>70,000, Sorted by Site Number (41105470) 221

Table H-16: Average Class 9 Front Axle Weight for WIM lanes with GVW>70,000, Sorted by Site Number (54807340) 222

Table H-17: Acceptable Ranges for Front Axle Mean \& Standard Deviation for Table H-18 and Table H-19.......... 224

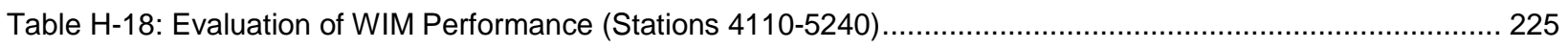

Table H-19: Evaluation of WIM Performance (Stations 5250-7340) .................................................................. 226

Table I-1: March 29, 2001 - Merrillville Scale Detail (WIM 4410) - WIM v. Static.................................................. 228

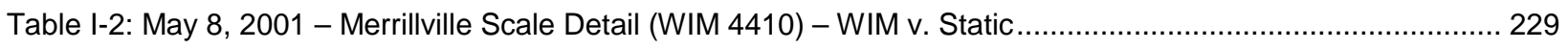

Table I-3: May 15, 2001 - Merrillville Scale Detail (WIM 4410) - WIM v. Static................................................... 230

Table I-4: May 18, 2001 - Merrillville Scale Detail (WIM 4410) - WIM v. Static ...................................................... 231 
Table I-5: May 21, 2001 - Merrillville Scale Detail (WIM 4410) - WIM v. Static .................................................. 232

Table I-6: May 23, 2001 - Merrillville Scale Detail (WIM 4410) - WIM v. Static ...................................................... 233

Table I-7: May 31, 2001 - Merrillville Scale Detail (WIM 4410) - WIM v. Static.................................................. 234 


\section{Introduction}

Overweight trucks shorten highway life and indirectly increase the costs of maintaining roads. Additionally, a study for the Oregon Department of Transportation found that a significant relationship exists between the rate of weight violations and a commercial carrier's accident rate [Eubanks, 1997]. Improvement in methods for enforcement of commercial vehicle weight laws may increase the number of overweight vehicles caught, thereby prolonging highway life. Improved enforcement may also reduce the number of illegally operating vehicles.

\subsection{Definition of Overweight Problem}

A highway is built to serve its function for a period of several years. This is called the road's design life. While transportation officials do plan and budget funds in the reference frame of time, the roads are actually designed according to a number of Equivalent Single Axle Loads, or ESAL, that can traverse the roadway before repairs or replacement is needed.

Problems arise when truck operators overload their vehicles. The amount of pavement life, measured in ESALs, consumed by the passage of a single truck increases dramatically as Gross Vehicular Weight (GVW) rises above the legal limits [IDOT, 1998]. To prevent the shortening of the roads' lifespans, the Indiana State Police enforces weight limits through the use of fixed-installation static scales and portable static scales.

By law, all commercial truck drivers must submit their vehicles for weighing if they traverse a section of roadway within which a static scale installation is located. Because there are a relatively small number of these expensive, permanent installations located in Indiana, Indiana State Police rely heavily upon the mobile scale units. Unfortunately, officers equipped with these portable scales currently have no tools to help them choose which trucks to weigh. While knowledge of truck driver behavior and accumulated experience help officers to choose vehicles for

inspection, understandably, many of the trucks that officers select and weigh are within legal weight limits. Since the inspections take roughly 45 minutes to perform, this research is intended to increase the likelihood that a stopped vehicle is in fact overweight. 


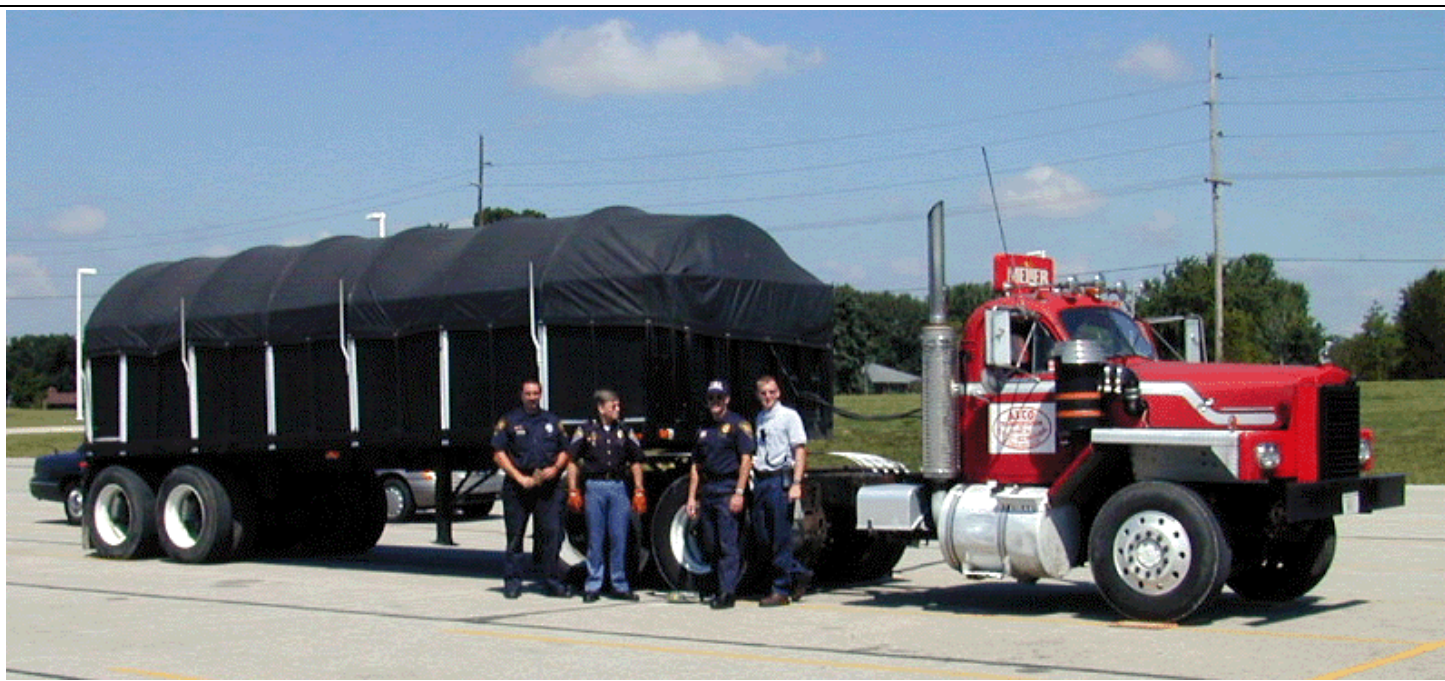

Figure 1-1: Indiana State Police Commercial Vehicle Enforcement Division Officers Ligget, Boruff, and Buffum with INDOT official Jay Wasson in front of an illegally loaded (111,350-Lb) steel hauler, caught August 10, 2000.

\subsection{Laws and Statutes}

While federal, state and local laws regulate commercial vehicles, the statutes pertaining to weight limits and loading configurations are primarily state laws. These weight laws are listed in Indiana Code 9-20-4. The Gross Vehicular Weight limit is described in IC 9-20-4-1.

"Sec. 1. (a) Except as provided in subsections (b) and (c), a person may not operate or cause to be operated upon an Indiana highway a vehicle or combination of vehicles having weight in excess of one (1) or more of the following limitations:

(1) The total gross weight, with load, in pounds of any vehicle or combination of vehicles may not exceed an overall gross weight on a group of two (2) or more consecutive axles produced by application of the following formula:

$$
W=500\{[(L N) \cdot(N-1)]+12 N+36\}
$$

where $\mathrm{W}$ equals the overall gross weight on any group of two (2) or more consecutive axles to the nearest five hundred (500) pounds, $L$ equals the distance in feet between the extreme of any group of two (2) or more consecutive axles, and $\mathrm{N}$ equals the number of axles in the group under consideration, except that two (2) consecutive sets of tandem axles may carry a gross load of thirty-four thousand $(34,000)$ pounds each, providing the overall distance between the first and last axles of the consecutive sets of tandem axles is thirty-six (36) feet or more. 
The overall gross weight limit, calculated under this subdivision, may not exceed eighty thousand $(80,000)$ pounds."

Individual axle group (tandem) limits are stated in this section as well.

"(2) The weight concentrated on the roadway surface from any tandem axle group may not exceed the following:

(A) Thirty-four thousand $(34,000)$ pounds total weight.

(B) Twenty thousand $(20,000)$ pounds on an individual axle in a tandem group," [Access Indiana, 2000].

\subsection{Current Enforcement Procedures}

In Indiana, officers of the Commercial Vehicle Enforcement Division carry out enforcement of laws regarding trucks. More specifically, officers from this branch of the Indiana State Police regulate any commercial vehicle weighing greater than $10,000 \mathrm{lbs}$. The two primary methods used to check that vehicles are in compliance with weight limit statutes and regulations are "Port-of-Entry" static scales and portable scale units.

\subsection{1 "Port-of-Entry" Static Scales}

Following Federal policy suggestions, "Ports-of-Entry", the first method that Indiana uses, is the operation of permanent, static scale installations. The Port-of-Entry concept directs that permanent scales be placed near state borders on high traffic volume routes, and only weigh trucks that have just entered the state. The idea is that if two neighboring states only operate installations weighing incoming vehicles, then redundancy will be avoided.

As a truck approaches a static scale installation from the highway, the operator is first directed whether the scale is "open" or "closed". If the scale is "closed" (not in operation), the vehicle may proceed on the highway, uninterrupted. If the scale is "open", then the truck enters the scale via an exit ramp.

At a modern station, such as the Lowell Scale on I-65, a Weigh-In-Motion (WIM) system along the ramp screens the trucks by weight, instructing the lighter weight vehicles to enter a scale bypass lane that sends the trucks back onto the highway. The trucks weighing close to their legally allowed limits (roughly within 10\%) are directed to enter a lane that proceeds to the scales.

When a truck reaches the proper position on the scales, the Commercial Vehicle Enforcement Officer operating the installation inside the scale house flips a switch that changes the traffic signal controlling the scale lane to red (Figure 1-2). When the truck stops, if it is improperly positioned for a proper scale reading, the Commercial 
Vehicle Enforcement Officer instructs the truck operator to adjust the position of his/her vehicle accordingly. When the vehicle is properly positioned, a weight reading is recorded.

If a vehicle is found to be overweight, either through exceeding the allowed gross vehicular weight or by surpassing the weight limit per axle tandem (or tridem), the truck operator is instructed to drive the truck to a detention lot. If laws were broken, citations may be issued. If the weight problem involves an overloaded axle, the driver may attempt to adjust the loading of the vehicle to become legal, and proceed back to the highway. However, if the truck exceeds GVW limits by a large enough margin (5000 Lbs for class 9 vehicles), the vehicle is impounded until part (or all) of the load is removed to make the vehicle legal.

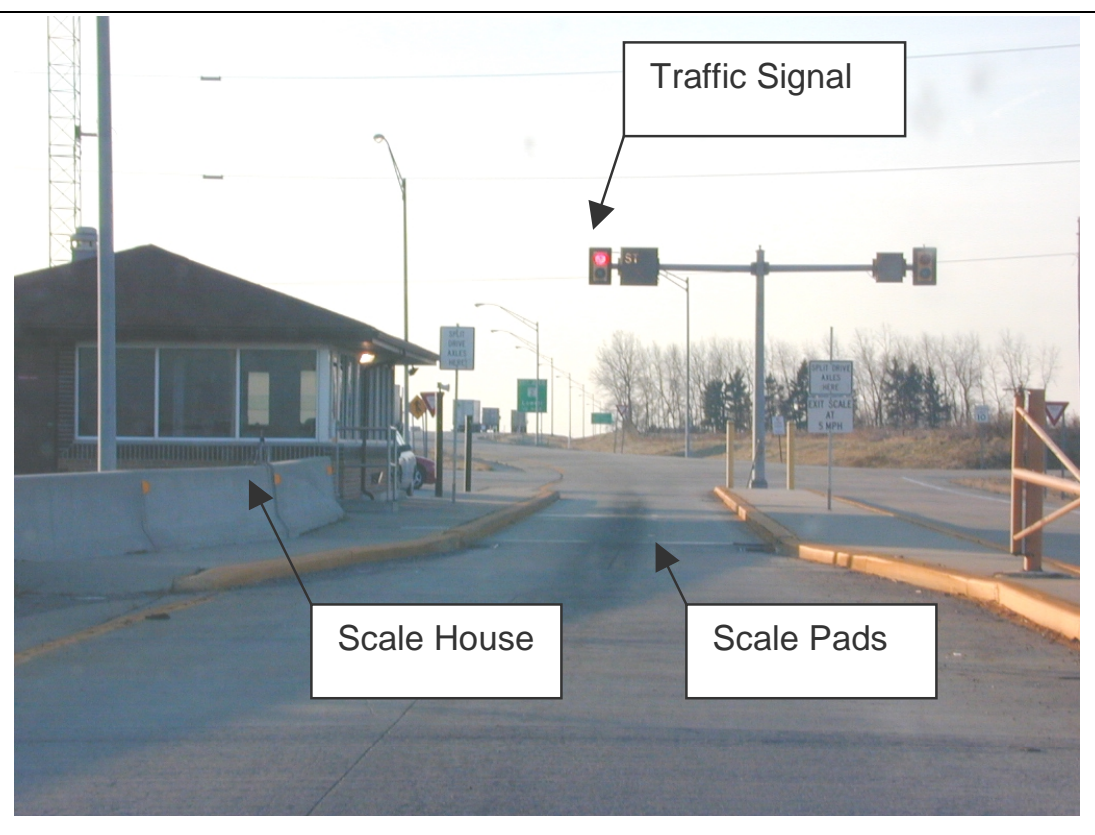

Figure 1-2: Lowell, Indiana static scales on I-65 Southbound 


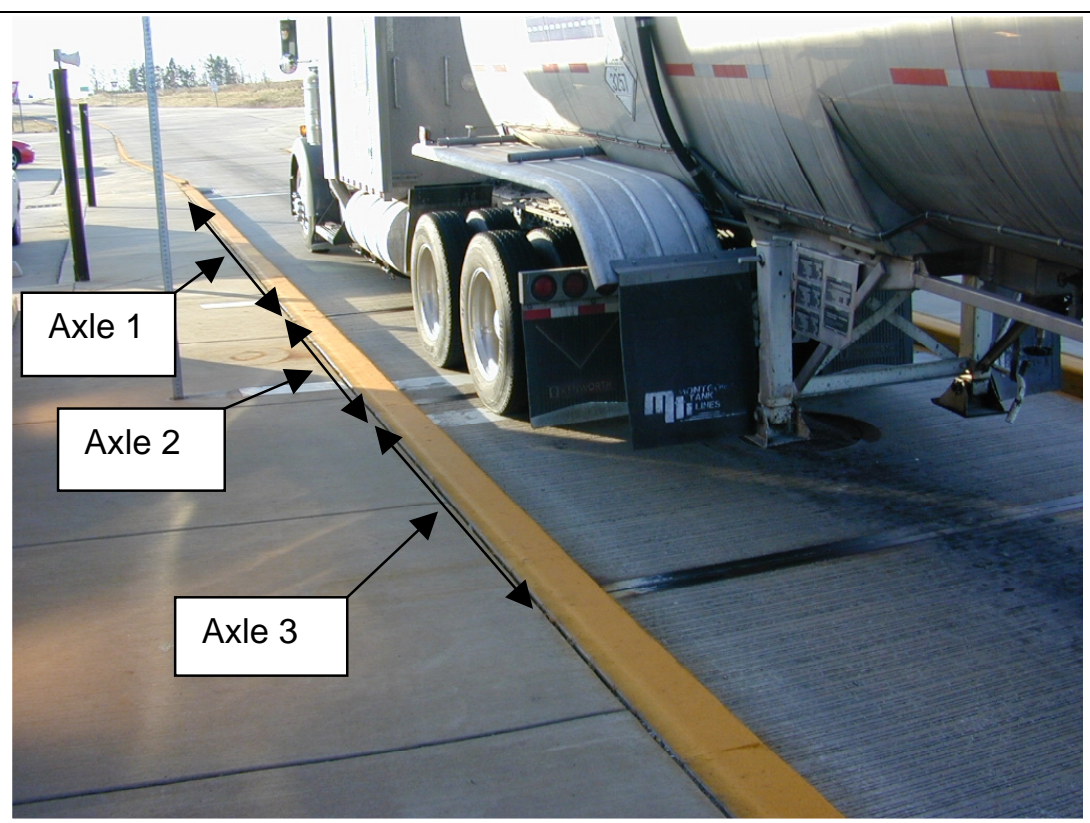

Figure 1-3: Truck being weighed on Lowell static scales

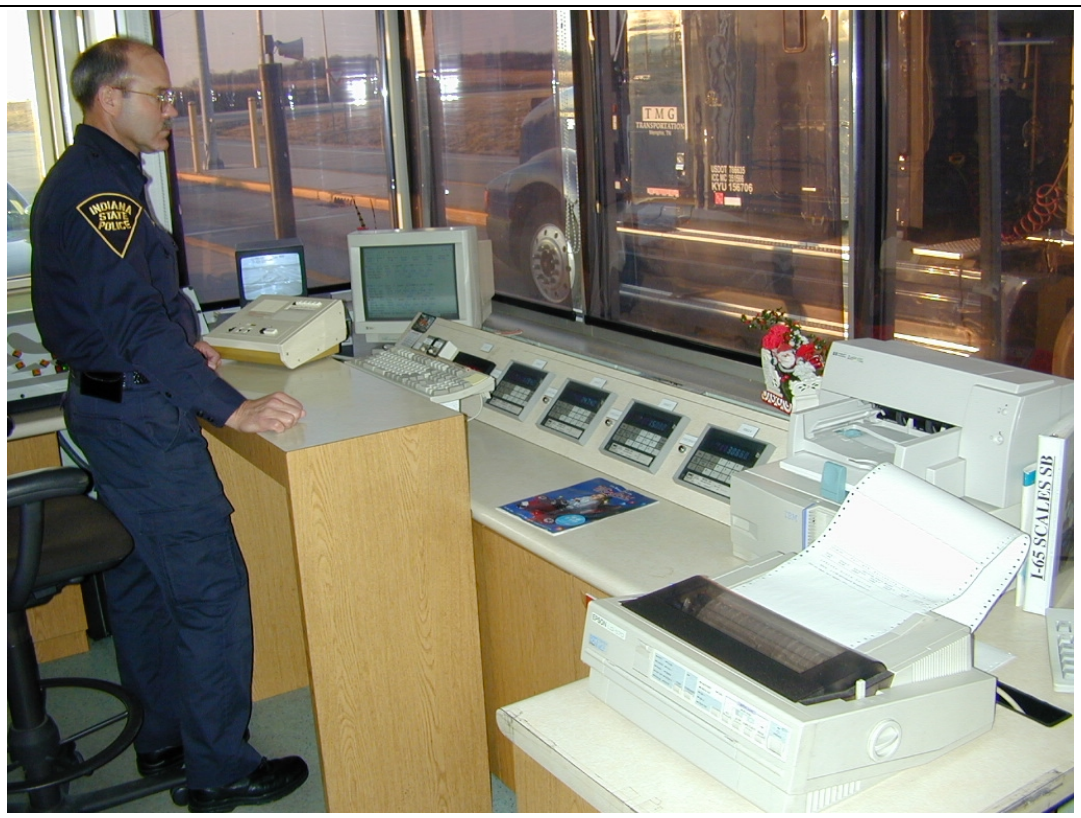

Figure 1-4: Indiana State Police Motor Carrier Officer Monty Buffum records vehicle weights at the Lowell Scales 


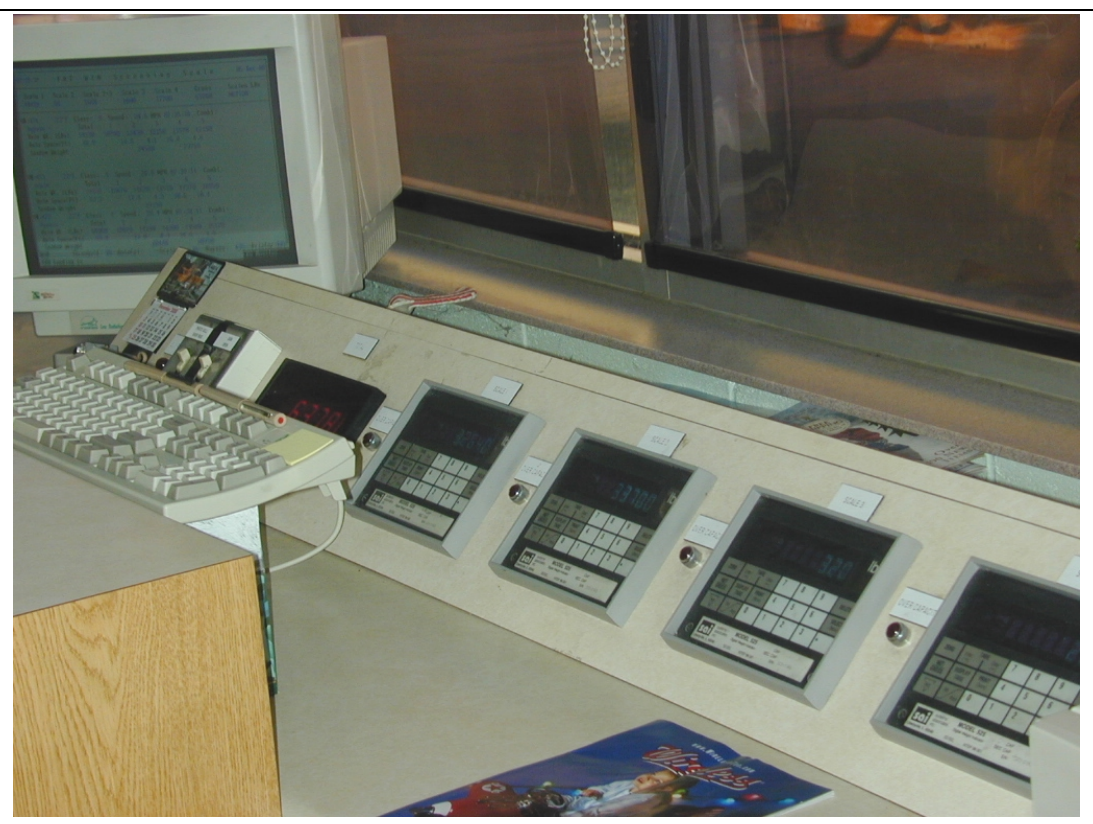

Figure 1-5: Lowell scale weight display panel

\subsubsection{Portable Scale Units}

Because the Port-of-Entry permanent scales are located near Indiana's borders with other states, Indiana State Police deploy 46 portable scale crews to check the weights of vehicles in the interior of the state [FHWA, 2000]. Portable scale units are patrol cars usually equipped with four or six Haenni WL101 Wheel Load Scales (Figure 1-6).

The procedure for weighing trucks with portable scales is as follows. Officers observe traffic, select a suspected vehicle, and then lead it to a safe area for weighing. Individual axle weights are first determined by placing scales beneath a pair of wheels on the same axle of a vehicle. The measurements are added and recorded. Sheets of plywood, the same thickness as the scales, are placed under the wheels that are not currently being weighed to maintain the same cross-level and avoid shifting of the load. The truck is moved slightly, the scales are placed under the remaining wheels, and weights are recorded. When all of the axles have been weighed, the axle weights are summed to determine Drive Tandem Weight, trailer Tandem Weight, and Gross Vehicular Weight. If the vehicle is found to be out of compliance with weight laws, the drivers are either issued warnings or citations. If the vehicle is significantly overweight, the overloaded vehicle may be impounded until the weight is made legal through load repositioning (tandem axle weight violation) or offloading (GVW violation). 

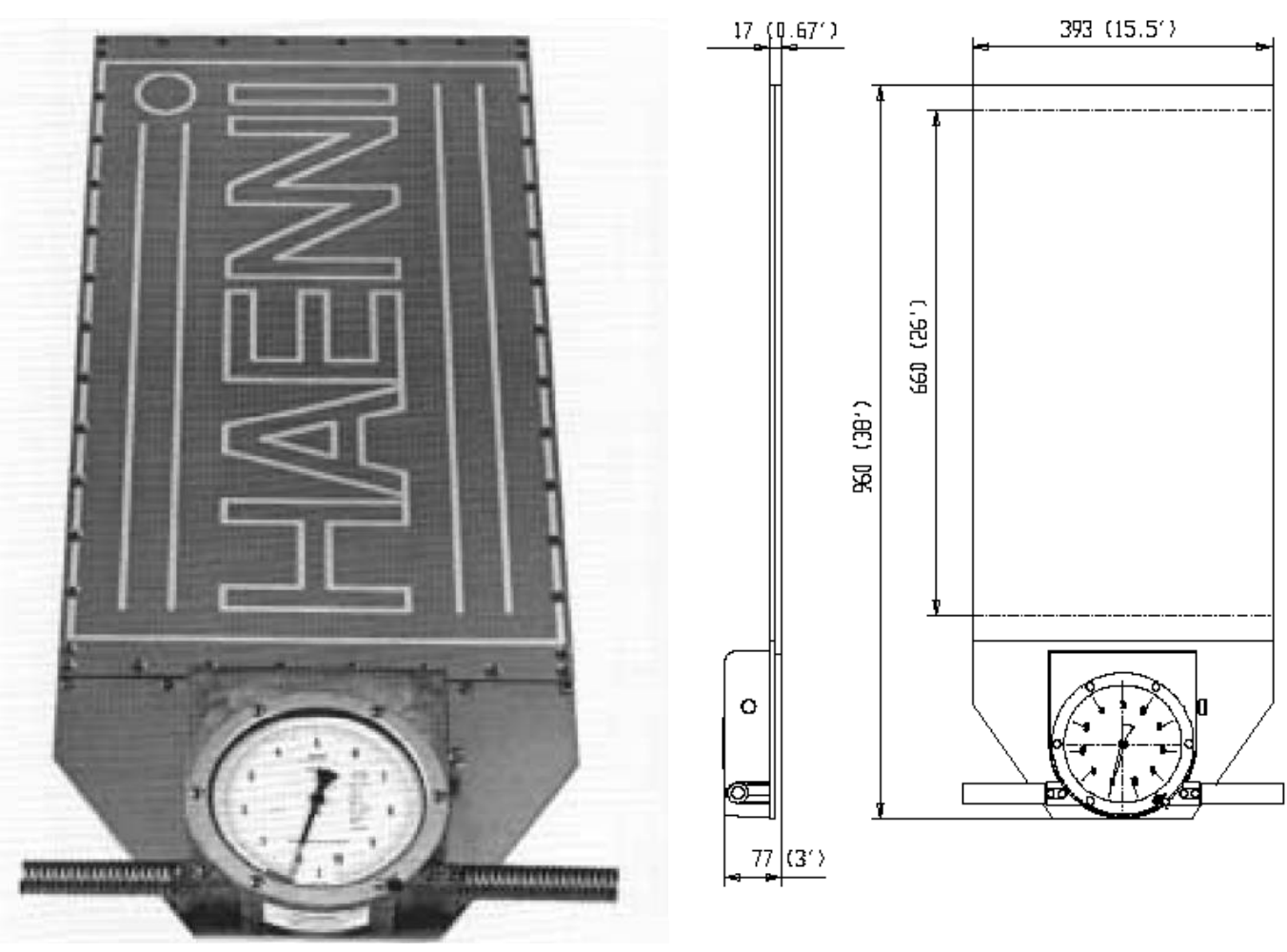

Figure 1-6: Haenni WL 101 (portable) Wheel Load Scale

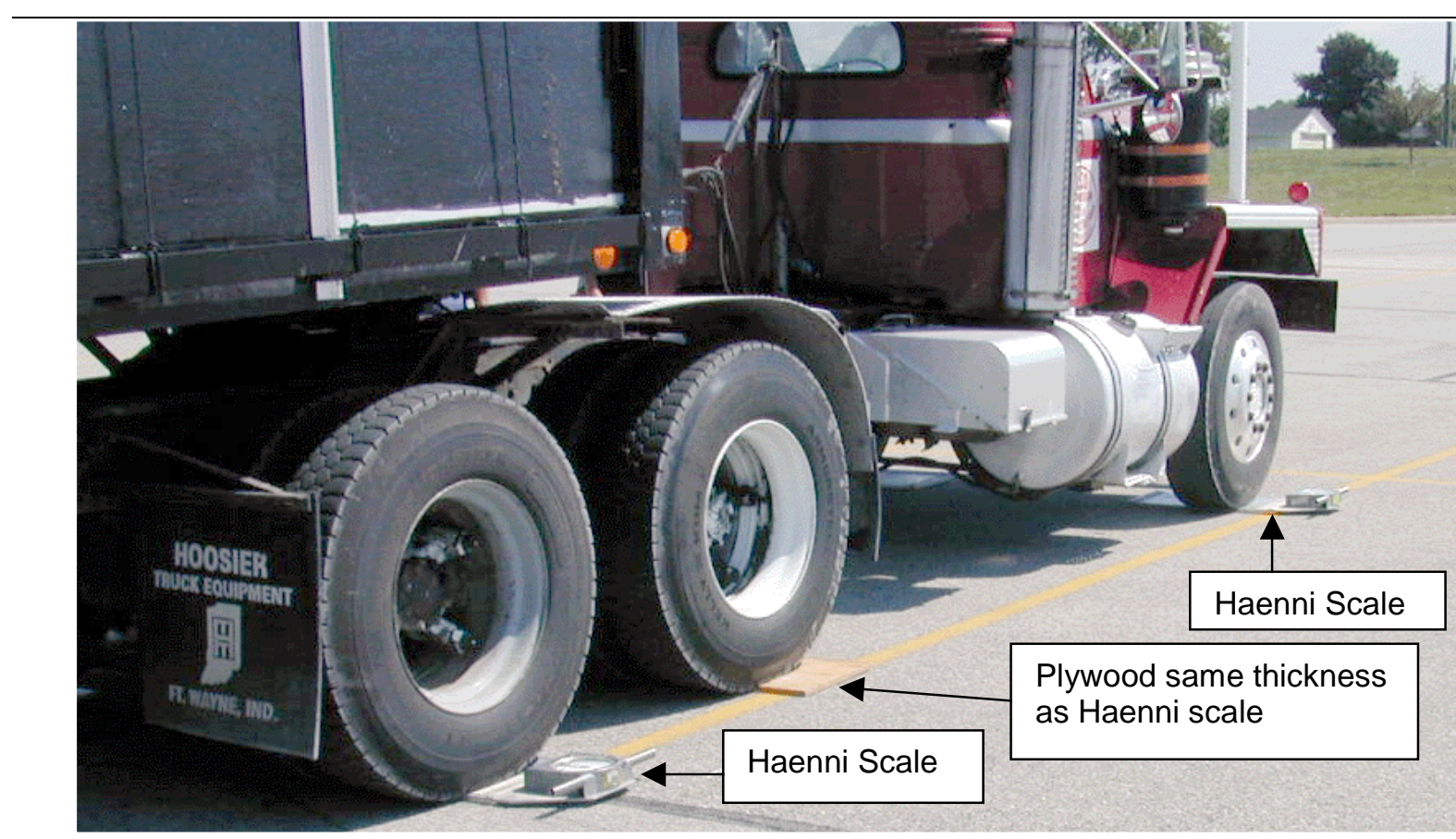

Figure 1-7: Weighing truck with Haenni scales 
While the measurements obtained have been determined to be accurate enough for the issuing of citations, officers must rely upon their own intuition when choosing which vehicles to weigh. Because of the subjective nature of the current screening process, many legally loaded vehicles are weighed. More importantly, many overweight vehicles are not weighed because they do not usually exhibit characteristics that make it possible to identify them as being overweight.

\subsection{Scope of Project}

This project had five objectives:

1) To quantify impact of overweight vehicles. Chapter 2 discusses the spreadsheet model developed for this purpose.

2) To identify which of Indiana's existing WIM sites are currently operating accurately enough to be used with the "in-vehicle" laptop system (and which sites need repairs) and to demonstrate the importance of WIM accuracy in determining accumulated ESALs. Chapter 3 discusses these data analysis procedures.

3) To develop prototype "in-cabinet" and "in-vehicle" WIM screening equipment to improve enforcement efficiency. Chapter 4 describes the necessary WIM cabinet components and the virtual weigh station software run in the vehicle called Road Runner.

4) To develop procedures to determine the best times for ISP to schedule enforcement details so that scarce resources are used as efficiently as possible. Chapter 5 shows some tabulations illustrating peak times for enforcement.

5) To document the impact of the virtual WIM on enforcement. Chapter 5 describes several details. Chapter 6 proposes several items that should be pursued to deploy the virtual weigh station concept in a manner that will maximize impact.

In addition, this report contains the following Appendices:

Appendix A: Tables and figures describing the location and features of existing WIMs. Because WIMs are constantly being upgraded, the reader is cautioned that this appendix is only a snapshot of the current WIM system statewide.

Appendix B: Tables and graphs from Covington WIM \#5130 evaluation. Subsequent analysis by Donn Klepinger found system did not meet INDOT specifications and the vendor was contacted. 
Appendix C: Diversion routes envisioned for trucks diverting around WIMs on I-65 and I-74. Locations of Scale Houses are also shown.

Appendix D: Cost summary information provided by International Road Dynamics.

Appendix E: Site evaluation memo sent to Kirk Mangold based upon classification error rates.

Appendix F: Tabulation of front axle loads from July 2000 used to screen for scale accuracy.

Appendix G: Summary of Merrillville WIM test.

Appendix $\mathrm{H}$ : Summary table and graph of front axle data from Appendix $\mathrm{F}$.

Appendix I: Summary sheets from Merrillville enforcement details.

Appendix J: Drawings of panels to be installed in INDOT cabinets to enable the Virtual Weigh Station Concept.

Appendix K: Memo summarizing the data obtained from the SR 1 WIM for March - May 2001.

Appendix L: Memo summarizing the data obtained from the SR 1 WIM for March - July 2001.

Appendix M: Memo summarizing the specifications for the video aspect of the SR 1 WIM.

Appendix N: Memo summarizing the enforcement details conducted on US 24 in February 2002.

Appendix O: Memo summarizing the calibration adjustment for the US 24 WIM.

Appendix P: Memo summarizing the data obtained from the US 24 WIM for March 2002.

Appendix Q: Memo summarizing the enforcement detail conducted on I-65 near Merrillville in April 2002.

Appendix R: Memo summarizing the effects of the SR 1 WIM installation on truck volumes.

Appendix S: Memo summarizing the data obtained from the I-80/I-94 WIM for January - March 2002.

Appendix T: List of references in this research. 


\section{Impact of Overweight Vehicles}

Overweight vehicles have a significant effect on pavement life. Because the relationship between vehicular weight and pavement life consumption is non-linear, one significantly overweight truck can do as much damage as all of the automobiles that traverse the same section of road in a day. Improperly distributed loads can also cause more damage to a roadway than a similar vehicle with the same load properly distributed. Therefore, to more accurately describe the effects of vehicles on pavement life, consumption is described in terms of Equivalent Single Axle Loads (ESALs), rather than Gross Vehicular Weight.

\subsection{ESAL Computations}

Design by ESALs is a straightforward concept, but needs to be explained. While vehicles that travel over Interstate Highways vary widely in appearance and operating capabilities, at least one property remains the same across all makes and classes - they all have pairs of wheels, connected by an axle, that transfer loads to the roadway running surface.

The standard weight for a single-axle ESAL is assumed to be 18,000 Lbs., and roads are designed to accept the loading cycles of a set number of ESALs before the road fails due to fatigue. For Interstate highways like I-65 in Indiana, an average design number of ESAL is around 50,000,000. Table 2-1 shows ESALs for various axle weights. Figure 2-1 illustrates the ESALs for both single axle and tandem weights [Huang, 1997].

\begin{tabular}{|c|c|c|c|c|c|c|c|c|}
\hline $\begin{array}{l}\text { Weight } \\
\text { (Lbs) }\end{array}$ & $\begin{array}{l}\text { Single Axle } \\
\text { ESAL Factor }\end{array}$ & $\begin{array}{c}\text { Tandem } \\
\text { ESAL Factor }\end{array}$ & $\begin{array}{c}\text { Weight } \\
\text { (Lbs) }\end{array}$ & $\begin{array}{l}\text { Single Axle } \\
\text { ESAL Factor }\end{array}$ & $\begin{array}{c}\text { Tandern } \\
\text { ESAL Factor }\end{array}$ & $\begin{array}{c}\text { Weight } \\
\text { (Lbs) }\end{array}$ & $\begin{array}{l}\text { Single Axle } \\
\text { ESAL Factor }\end{array}$ & $\begin{array}{c}\text { Tandem } \\
\text { ESAL Factor }\end{array}$ \\
\hline 1000 & 0.00002 & & 18000 & 1.00 & 0.07730 & 35000 & 12.50 & 1.23 \\
\hline 2000 & 0.00018 & & 19000 & 1.24 & 0.09710 & 36000 & 13.93 & 1.38 \\
\hline 3000 & 0.00072 & & 20000 & 1.51 & 0.12060 & 37000 & 15.50 & 1.53 \\
\hline 4000 & 0.00209 & & 21000 & 1.83 & 0.14800 & 38000 & 17.20 & 1.70 \\
\hline 5000 & 0.00500 & & 22000 & 2.18 & 0.180 & 39000 & 19.06 & 1.89 \\
\hline 6000 & 0.01043 & & 23000 & 2.58 & 0.217 & 40000 & 21.08 & 2.08 \\
\hline 7000 & 0.01960 & . & 24000 & 3.03 & 0.260 & 41000 & 23.27 & 2.29 \\
\hline 8000 & 0.03430 & & 25000 & 3.53 & 0.308 & 42000 & 25.64 & 2.51 \\
\hline 9000 & 0.05620 & & 26000 & 4.09 & 0.364 & 43000 & 28.22 & 2.75 \\
\hline 10000 & 0.08770 & 0.00688 & 27000 & 4.71 & 0.426 & 44000 & 31.00 & 3.00 \\
\hline 11000 & 0.13110 & 0.01008 & 28000 & 5.39 & 0.495 & 45000 & 34.00 & 3.27 \\
\hline 12000 & 0.189 & 0.01440 & 29000 & 6.14 & 0.572 & 46000 & 37.24 & 3.55 \\
\hline 13000 & 0.264 & 0.01990 & 30000 & 6.97 & 0.658 & 47000 & 40.74 & 3.85 \\
\hline 14000 & 0.360 & 0.02700 & 31000 & 7.88 & 0.753 & 48000 & 44.50 & 4.17 \\
\hline 15000 & 0.478 & 0.03600 & 32000 & 8.88 & 0.857 & 49000 & 48.54 & 4.51 \\
\hline 16000 & 0.623 & 0.04720 & 33000 & 9.98 & 0.971 & 50000 & 52.88 & 4.86 \\
\hline 17000 & 0.796 & 0.06080 & 34000 & 11.18 & 1.095 & & & \\
\hline
\end{tabular}

Table 2-1: Load Equivalency Factors for various Single Axle and Tandem Weights 


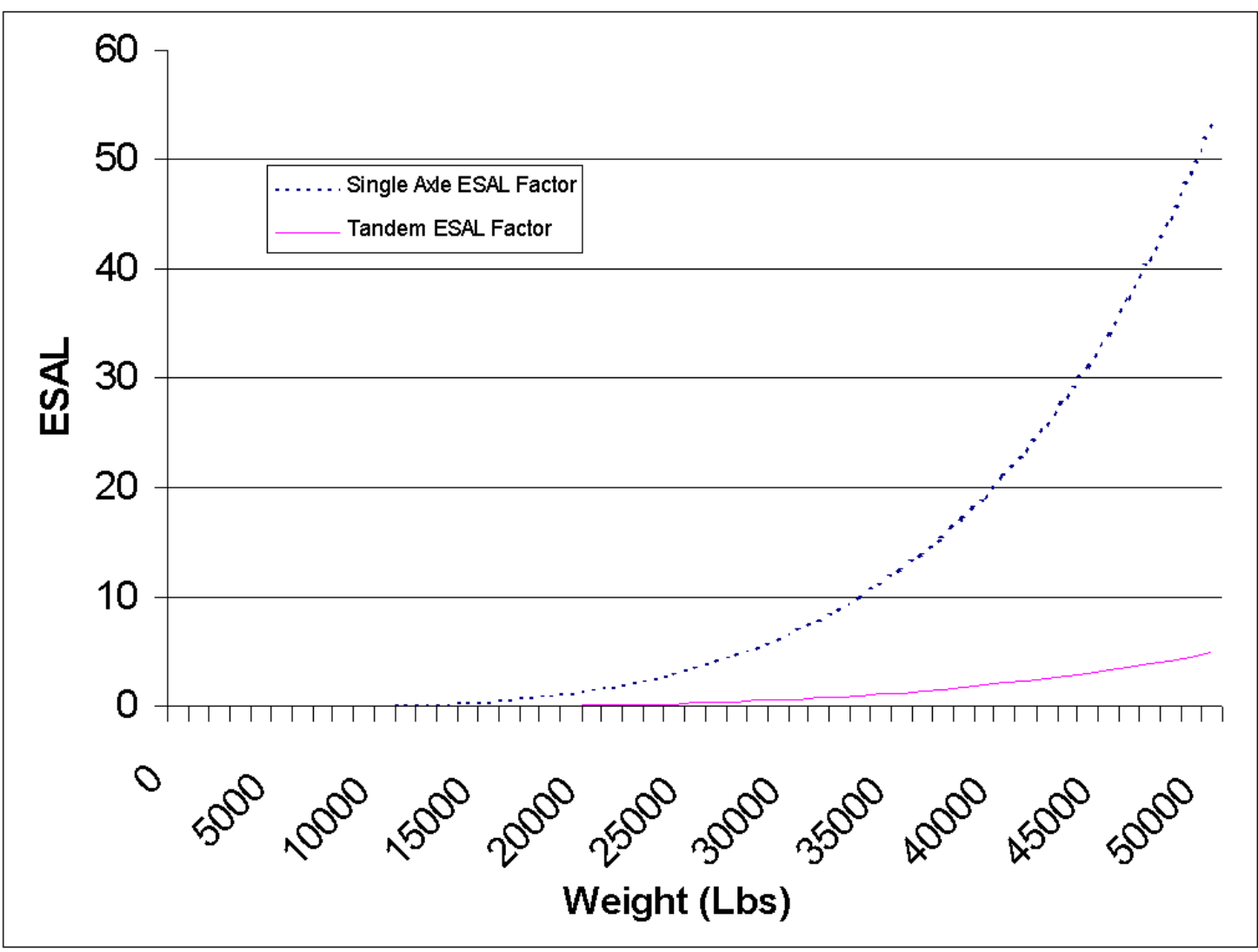

Figure 2-1: ESAL v. Axle Weights for Single and Tandem Axles

The formula used by many engineers for designing asphalt highway pavements was developed by the Asphalt Institute [Huang, 1997]. It is,

$E S A L=f_{d} \times G_{j t} \times A A D T_{i} \times 365 \times N_{i} \times F_{e i}$

Where

$E S A L=$ Equivalent Single Axle Loads

$\mathrm{f}_{\mathrm{d}}=$ design lane factor

$\mathrm{G}_{\mathrm{jt}}=$ growth factor for a given growth rate "j", and design period "t"

$\mathrm{AADT}_{\mathrm{i}}=$ first year annual average daily traffic for axle category "i"

$\mathrm{N}_{\mathrm{i}}$ = number of axles on each vehicle in category "i"

$F_{\text {ei }}=$ load equivalency factor for axle category "i"

The following sets of example calculations illustrate the procedure for applying this formula. The example assumes the following data: 


$\begin{array}{ll}\text { Passenger Cars (1000 Lb per axle) } & =50 \% \\ \text { 2-axle Single-unit Trucks (5000 Lb per axle) } & =30 \% \\ \text { 3-axle Single Unit Trucks (7500 Lb per axle) } & =20 \% \\ \text { AADT } & =12,000 \\ \text { Design Period } & =20 \text { years } \\ \% \text { Truck volume on design lane } & =45 \%\end{array}$

Solution:

$E S A L=f_{d} \times G_{j t} \times A A D T \times 365 \times N_{i} \times F_{e i}$

Growth factor $=29.78 \quad$ (Compound growth rate for 20 years at $4 \%$ growth) Load equivalency factors per axle:

$\begin{array}{lll}\text { Passenger cars } & =0.00002 & (\text { Table 2-1 }) \\ \text { 2-axle Single-unit Trucks } & =0.00500 & (\text { Table 2-1 }) \\ \text { 3-axle Single Unit Trucks } & =0.01960 & (\text { Table 2-1 })\end{array}$

Number of accumulated ESAL in the design lane:

Passenger cars $=0.45 \times 29.78 \times 12,000 \times 0.50 \times 365 \times 2 \times 0.00002=1174$

2-axle Single-unit Trucks $=0.45 \times 29.78 \times 12,000 \times 0.30 \times 365 \times 2 \times 0.005=176,089$

3-axle Single Unit Trucks $=0.45 \times 29.78 \times 12,000 \times 0.20 \times 365 \times 3 \times 0.0196=690,269$

Total $=866,358 \mathrm{ESAL}$

\section{$2.2 \quad$ ESAL Spreadsheet}

Performing ESAL calculations can be quite cumbersome when many highway alternatives are considered. This is especially true when the complete number of vehicle classes defined by the State of Indiana is considered in the calculations. Spreadsheet computer applications, such as Microsoft's EXCEL, can simplify the task, and reduce the amount of time necessary by considerable amounts.

Figure 2-2 is a screen-capture of an EXCEL spreadsheet configured to account for vehicle classes two through thirteen (accounting for the majority of traffic traversing I-65). Each class of vehicle is represented by several 
states of loading that may be expected in a random sampling of vehicles. Indiana State Police Commercial Vehicle Enforcement Division Officers Monty Buffum and Steve Baumgart have provided data for approximate Gross Vehicular Weights (GVW) and individual axles of each class.

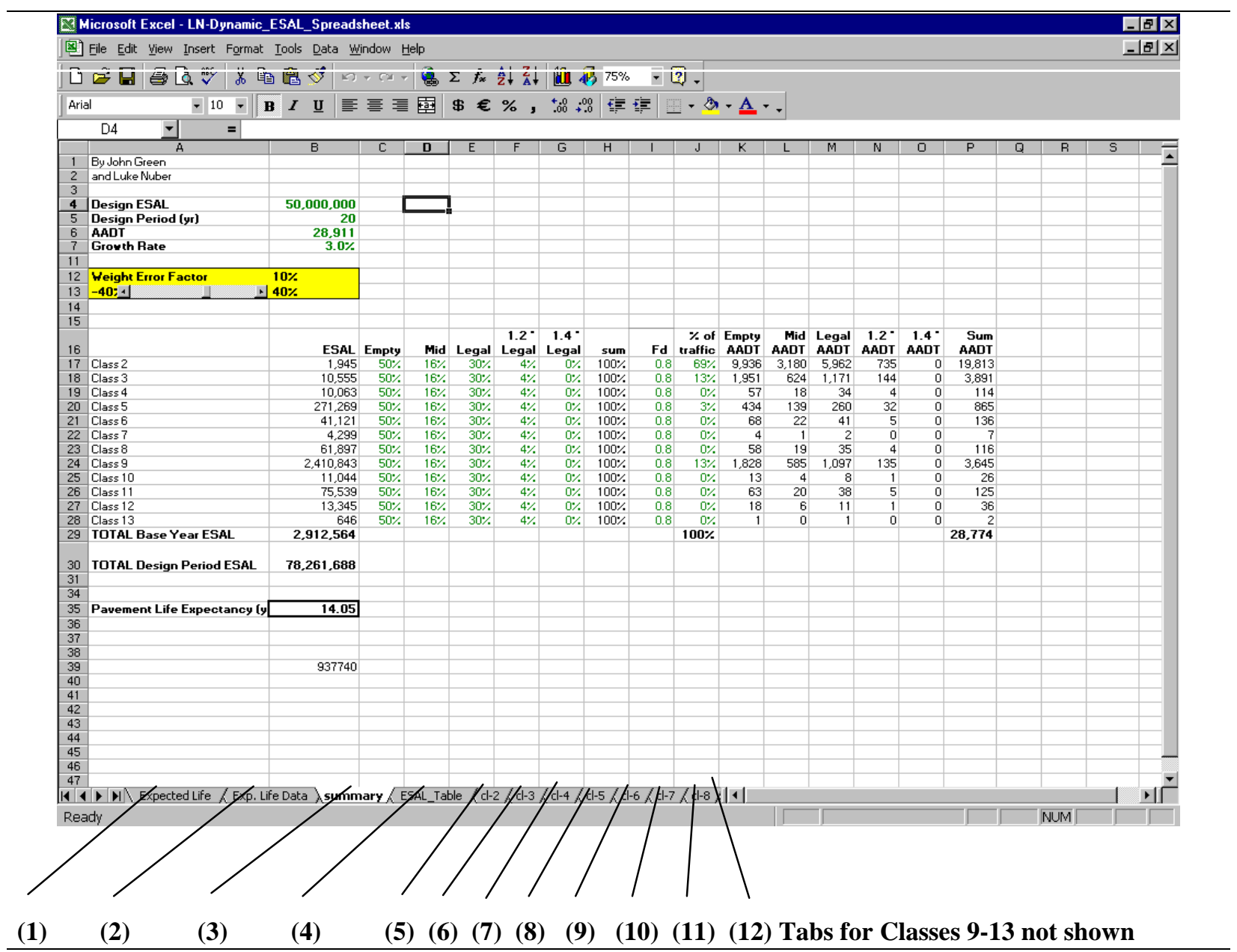

Figure 2-2: Screen capture of Microsoft EXCEL Spreadsheet, set up for calculation of Pavement Life

The first page (Figure 2-2, item 1), Expected Life, of the spreadsheet shows a graph comparing the pavement life versus the Weight Error Factor (Figure 2-4). The resulting curve produced by connecting the data points shows that a logarithmic relationship exists between the two. From the graph, it can be determined that, for a particular traffic scenario, a small error of $10 \%$ in calculation of accumulated ESALs may cause the pavement life estimate to be off by more than $25 \%$.

The second page (Figure 2-2, item 2), Expected Life Data, lists in tabular form results of pavement life expectancy produced by iterations of the spreadsheet program. Examining only the range varying from $80 \%$ to $120 \%$ of actual GVW, iterations show that pavement life varies accordingly from 39 to 10 years. 
The third page (Figure 2-2, item 3), Summary, summarizes the information calculated by the spreadsheet, contains areas for designers to input information regarding Design ESAL, Design Period (in years), AADT, and Growth Rate. Additionally, information in other areas, which are shown in light gray, can be altered to represent the actual mix of traffic if precise data is available. At the bottom of the Summary page results reporting the Total Base Year ESAL, Total Design Period ESAL, and Pavement Life Expectancy (in years), are shown.

The fourth page (Figure 2-2, item 4), ESAL Table, is a data table that the summary sheet calculations refer to for individual axle ESAL factors. This table was taken from Traffic and Highway Engineering by Garber \& Hoel [Garber, 1988]. The remaining pages in the spreadsheet contain information unique to each individual class of vehicles (Figure 2-2, items 5-12). Once again, the summary sheet is where the calculations are performed and the unique class sheets are only used for formula reference.

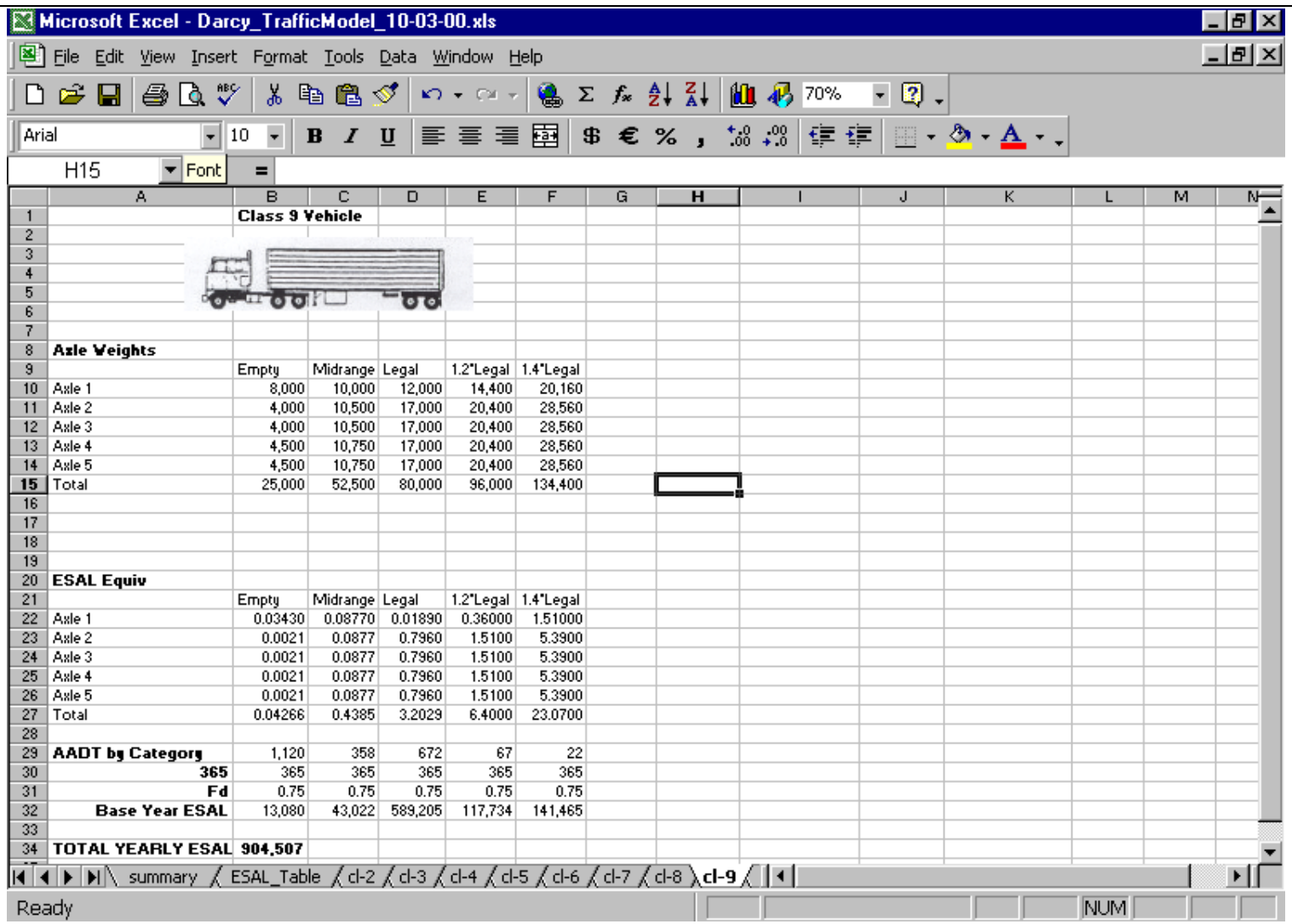

Figure 2-3: Screen Capture of Class 9 Vehicle ESAL sheet

What the ESAL spreadsheet illustrates is that increasing the weights of vehicles to overweight levels, especially for classes nine and greater, significantly reduces pavement life. The relationship for increasing weights 
and ESAL is not a linear function. As use of the ESAL spreadsheet shows, increasing the weights of all nonautomobiles (trucks) by $25 \%$ more than doubles the ESALs consumed.

\begin{tabular}{|c|c|c|c|c|c|c|c|}
\hline & \begin{tabular}{|c} 
Vehicle \\
Class
\end{tabular} & & Empty & Midrange & Legal & $1.2^{\star}$ Legal & $1.4^{\star}$ Legal \\
\hline \multirow{2}{*}{ a $=0$} & \multirow[b]{2}{*}{2} & Weight (Ibs) & 2,000 & 3,000 & 4,000 & 4,800 & 6,720 \\
\hline & & ESAL & 0.000 & 0.000 & 0.000 & 0.000 & 0.001 \\
\hline \multirow{2}{*}{ क्षण } & \multirow[b]{2}{*}{3} & Weight (Ibs) & 5,000 & 8,000 & 11,000 & 13,200 & 18,480 \\
\hline & & ESAL & 0.001 & 0.003 & 0.015 & 0.030 & 0.122 \\
\hline \multirow{2}{*}{ 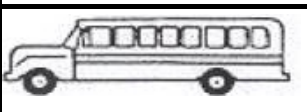 } & \multirow[b]{2}{*}{4} & Weight (Ibs) & 28,000 & 30,000 & 32,000 & 38,400 & 53,760 \\
\hline & & ESAL & 1.088 & 1.371 & 1.529 & 3.390 & 11.490 \\
\hline \multirow{2}{*}{$\frac{100}{0}$} & \multirow[b]{2}{*}{5} & Weight (Ibs) & 11,000 & 21,500 & 32,000 & 38,400 & 53,760 \\
\hline & & ESAL & 0.015 & 0.298 & 1.529 & 3.390 & 11.490 \\
\hline \multirow[b]{2}{*}{ (7) } & \multirow[b]{2}{*}{6} & Weight (Ibs) & 20,000 & 34,000 & 48,000 & 57,600 & 80,640 \\
\hline & & ESAL & 0.050 & 0.094 & 2.019 & 4.020 & 15.450 \\
\hline & \multirow[b]{2}{*}{7} & Weight (Ibs) & 27,000 & 47,500 & 68,000 & 81,600 & 95,200 \\
\hline & & ESAL & 0.131 & 1.414 & 5.860 & 11.290 & 20.790 \\
\hline \multirow[b]{2}{*}{ and } & \multirow[b]{2}{*}{8} & Weight (Ibs) & 26,000 & 47,000 & 68,000 & 81,600 & 114,240 \\
\hline & & ESAL & 0.066 & 0.454 & 3.529 & 7.050 & 25.430 \\
\hline \multirow{2}{*}{ तy } & \multirow[b]{2}{*}{9} & Weight (Ibs) & 25,000 & 52,500 & 80,000 & 96,000 & 134,400 \\
\hline & & ESAL & 0.043 & 0.439 & 3.203 & 6.400 & 23.070 \\
\hline \multirow{2}{*}{$\frac{D^{4}}{0=0.000}$} & \multirow[b]{2}{*}{10} & Weight (Ibs) & 35,000 & 57,500 & 80,000 & 96,000 & 134,400 \\
\hline & & ESAL & 0.070 & 0.453 & 1.892 & 4.268 & 15.800 \\
\hline \multirow{2}{*}{ क्ष बण } & \multirow[b]{2}{*}{11} & Weight (Ibs) & 36,000 & 58,000 & 80,000 & 96,000 & 134,400 \\
\hline & & ESAL & 0.124 & 0.244 & 3.203 & 6.400 & 23.070 \\
\hline \multirow{2}{*}{ 倍 } & \multirow[b]{2}{*}{12} & Weight (Ibs) & 42,000 & 61,000 & 80,000 & 96,000 & 134,400 \\
\hline & & ESAL & 0.134 & 0.538 & 1.627 & 3.185 & 12.910 \\
\hline \multirow[b]{2}{*}{ 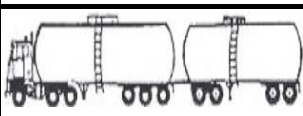 } & \multirow[b]{2}{*}{13} & Weight (Ibs) & 50,000 & 65,000 & 80,000 & 96,000 & 134,400 \\
\hline & & ESAL & 0.168 & 0.393 & 0.581 & 2.136 & 8.530 \\
\hline
\end{tabular}

Table 2-2: Selected vehicle classes in various states of loading 


\subsection{Analysis of Sensitivity to Vehicle Weights}

One of the most powerful uses of this spreadsheet is to evaluate the impact variations in WIM accuracy or vehicle mix have on estimated pavement life. For the example in Table 2-3, when the expected life is 20 years, we see that a WIM that overestimates the axle weight by $5 \%$ overestimates the life expectancy of the pavement by 3.1 years. Similarly, a WIM that underestimates the axle weight by $5 \%$ underestimates the life expectancy of the pavement by almost 4 years.

\begin{tabular}{|c|c|c|c|c|c|c|c|}
\hline $\begin{array}{l}\text { Weight } \\
\text { Error } \\
\text { Factor }\end{array}$ & $\begin{array}{l}\text { Expected } \\
\text { Life }\end{array}$ & $\begin{array}{l}\text { Weight } \\
\text { Error } \\
\text { Factor }\end{array}$ & $\begin{array}{l}\text { Expected } \\
\text { Life }\end{array}$ & $\begin{array}{l}\text { Weight } \\
\text { Error } \\
\text { Factor }\end{array}$ & $\begin{array}{l}\text { Expected } \\
\text { Life }\end{array}$ & $\begin{array}{l}\text { Weight } \\
\text { Error } \\
\text { Factor }\end{array}$ & $\begin{array}{l}\text { Expected } \\
\text { Life }\end{array}$ \\
\hline$-40 \%$ & 72.95 & $-20 \%$ & 39.36 & $1 \%$ & 19.49 & $21 \%$ & 9.59 \\
\hline$-39 \%$ & 71.6 & $-19 \%$ & 38.58 & $2 \%$ & 18.81 & $22 \%$ & 9.26 \\
\hline$-38 \%$ & 69.4 & $-18 \%$ & 37.27 & $3 \%$ & 18.15 & $23 \%$ & 8.92 \\
\hline$-37 \%$ & 67.39 & $-17 \%$ & 36.06 & $4 \%$ & 17.72 & $24 \%$ & 8.68 \\
\hline$-36 \%$ & 66.01 & $-16 \%$ & 35.18 & $5 \%$ & 16.9 & $25 \%$ & 8.3 \\
\hline$-35 \%$ & 63.5 & $-15 \%$ & 33.57 & $\overline{6 \%}$ & $1 \overline{6.34}$ & $26 \%$ & 7.98 \\
\hline$-34 \%$ & 61.52 & $-14 \%$ & 32.49 & $7 \%$ & 15.9 & $27 \%$ & 7.75 \\
\hline$-33 \%$ & 60.2 & $-13 \%$ & 31.71 & $8 \%$ & 15.34 & $28 \%$ & 7.47 \\
\hline$-32 \%$ & 58.27 & $-12 \%$ & 30.69 & $9 \%$ & 14.47 & $29 \%$ & 7.27 \\
\hline$-31 \%$ & 56.47 & $-11 \%$ & 29.6 & $10 \%$ & 14.05 & $30 \%$ & 6.91 \\
\hline$-30 \%$ & 54.19 & $-10 \%$ & 28.25 & $11 \%$ & 13.72 & $31 \%$ & 6.69 \\
\hline$-29 \%$ & 53.18 & $-9 \%$ & 27.61 & $12 \%$ & 13.25 & $32 \%$ & 6.46 \\
\hline$-28 \%$ & 51.37 & $-8 \%$ & 26.59 & $13 \%$ & 12.75 & $33 \%$ & 6.23 \\
\hline$-27 \%$ & 49.68 & $-7 \%$ & 25.69 & $14 \%$ & 12.4 & $34 \%$ & 6.03 \\
\hline$-26 \%$ & 48.62 & $-6 \%$ & 25.08 & $15 \%$ & 11.9 & $35 \%$ & 5.79 \\
\hline$-25 \%$ & 46.53 & $-5 \%$ & 23.98 & $16 \%$ & 11.44 & $36 \%$ & 5.57 \\
\hline$-24 \%$ & 45.15 & $-4 \%$ & 23.1 & $17 \%$ & 11.41 & $37 \%$ & 5.4 \\
\hline$-23 \%$ & 44.22 & $-3 \%$ & 22.57 & $18 \%$ & 10.73 & $38 \%$ & 5.21 \\
\hline$-22 \%$ & 42.68 & $-2 \%$ & 21.75 & $19 \%$ & 10.35 & $39 \%$ & 5.02 \\
\hline$-21 \%$ & 41.25 & $-1 \%$ & 21.04 & $20 \%$ & 9.86 & $40 \%$ & 4.84 \\
\hline
\end{tabular}

Table 2-3: Expected Life of Asphalt Pavement for Various WIM Errors 


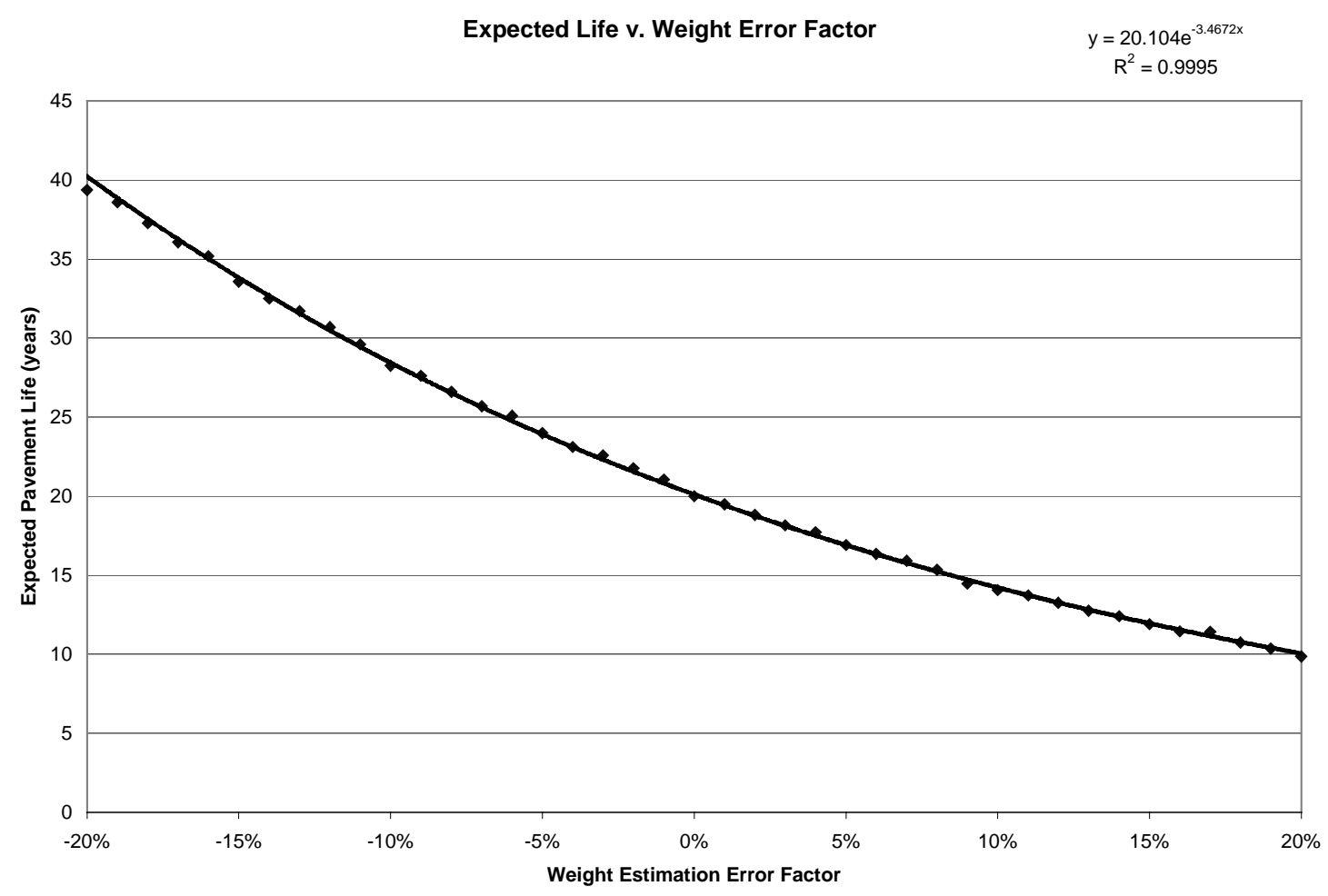

Figure 2-4: Expected Life of Pavement for Various WIM Errors

Since a typical section of interstate rehabilitation can cost roughly $\$ 1,000,000$ to $\$ 4,000,000$ / lane / mile, it is very important to obtain as accurate axle weight estimates as possible so that maintenance activities can be efficiently programmed.

Also, to estimate the impact overweight vehicles have on the life expectancy of pavement, consider the example from Figure 2-5. If the percentage of overweight vehicles is increased to $14 \%$, the pavement life expectancy decreases from 20 years to 16.6 years. 


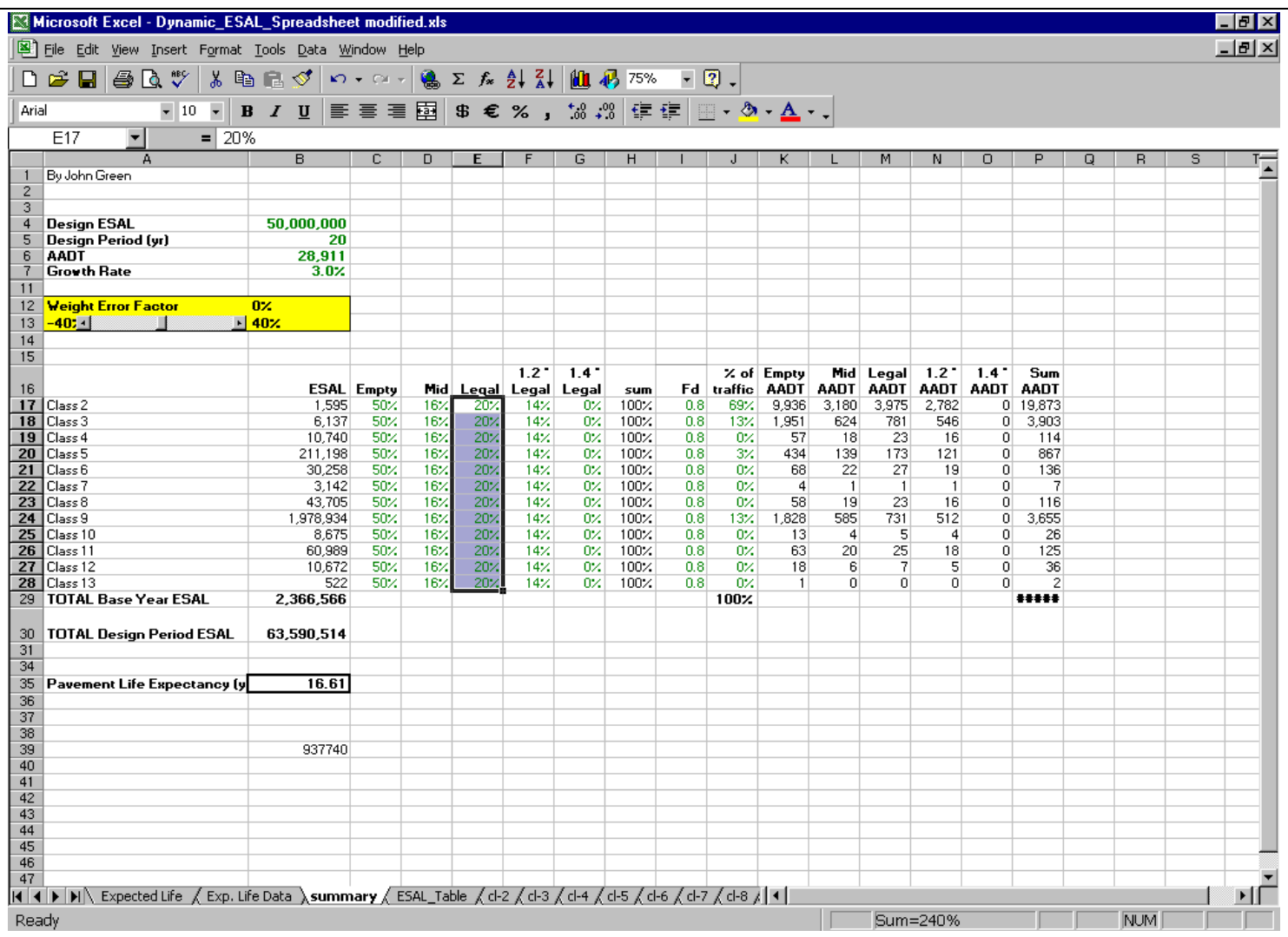

Figure 2-5: Pavement Life Expectancy with 14\% of vehicles 1.2* Legal Limit 


\section{Existing WIM Resources}

Indiana has employed WIM scales for data collection purposes for over 10 years. The goal of this project is to determine if these existing devices could be used to screen overweight trucks. This chapter reviews the technology used by WIMs and their relative accuracy levels.

\subsection{Existing Technologies}

There are currently 3 different Weigh-In-Motion technologies commonly employed in the pavements of Indiana's highways. They are Piezo-electric sensors, Single Load Cells, and Bending Plate scales. The Kistler technology is not currently used in Indiana, but is used in Illinois. Of these three WIM scale types, Piezo-electric sensors cost the least, but unfortunately, also produce the least accurate results. The error rates that can be expected for each of the technologies are shown in Table 3-1. [Bushman, 1998]. Appendix D was provided by Rod Klashinsky of IRD and summarizes the estimated costs and perceived accuracies of the available technologies.

\begin{tabular}{|c|c|c|}
\hline Technology & ASTM Type & GVW Accuracy \\
\hline Piezo & 2 & $15 \%$ \\
\hline Bending Plate, Kistler & 1 & $10 \%$ \\
\hline Load Cell & 3 & $6 \%$ \\
\hline
\end{tabular}

Table 3-1: Summary of ASTM 1318-94 Type Code and Accuracy for Common WIM Technology 


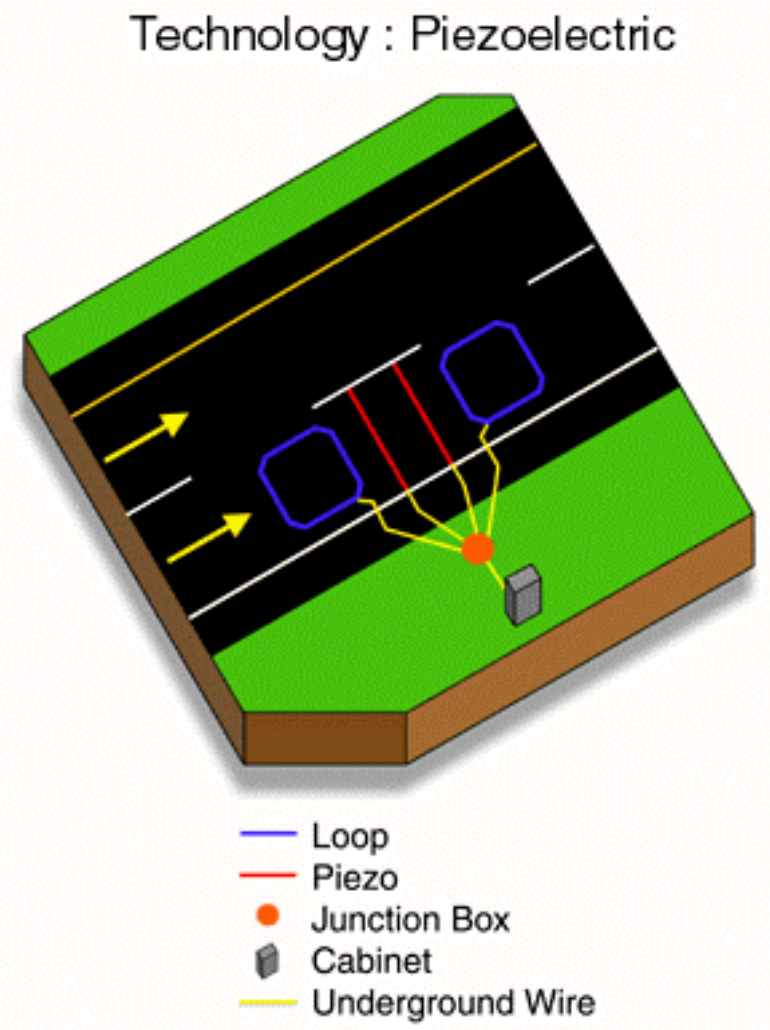

Figure 3-1: Piezoelectric WIM site configuration

\subsubsection{Piezoelectric Technologies}

At the heart of a piezoelectric sensor is a copper wire, surrounded by a piezoelectric material. When a vehicle passes over the sensor, the wire deforms slightly, and an electric charge is produced. The degree and characteristics of the electric charge are then analyzed to determine the weight of the vehicle.

Figure 3-1 shows the typical sensor configuration for a Piezo installation. Figure 3-2 shows a photograph of a failed Piezo installation in the northbound lane of I-65 at WIM site 5450. Figure 3-3 shows a photograph of a technician installing a Piezo sensor. 

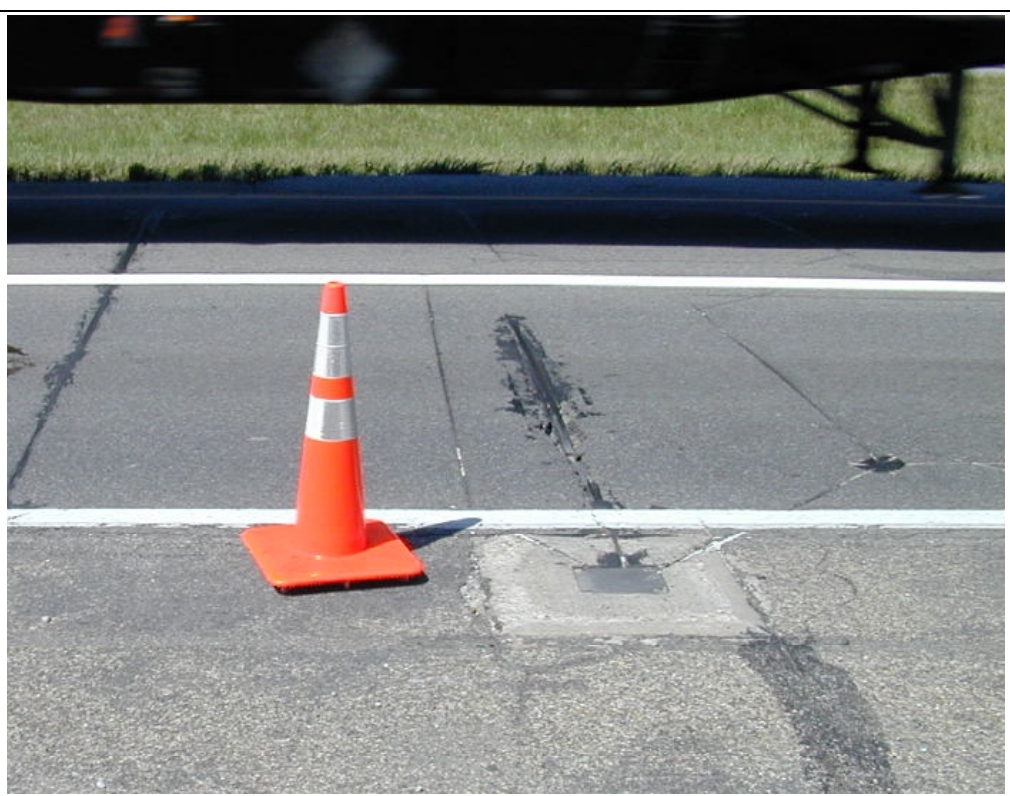

Figure 3-2: Piezo-electric WIM in pavement on I-65 NB, near Lafayette, IN

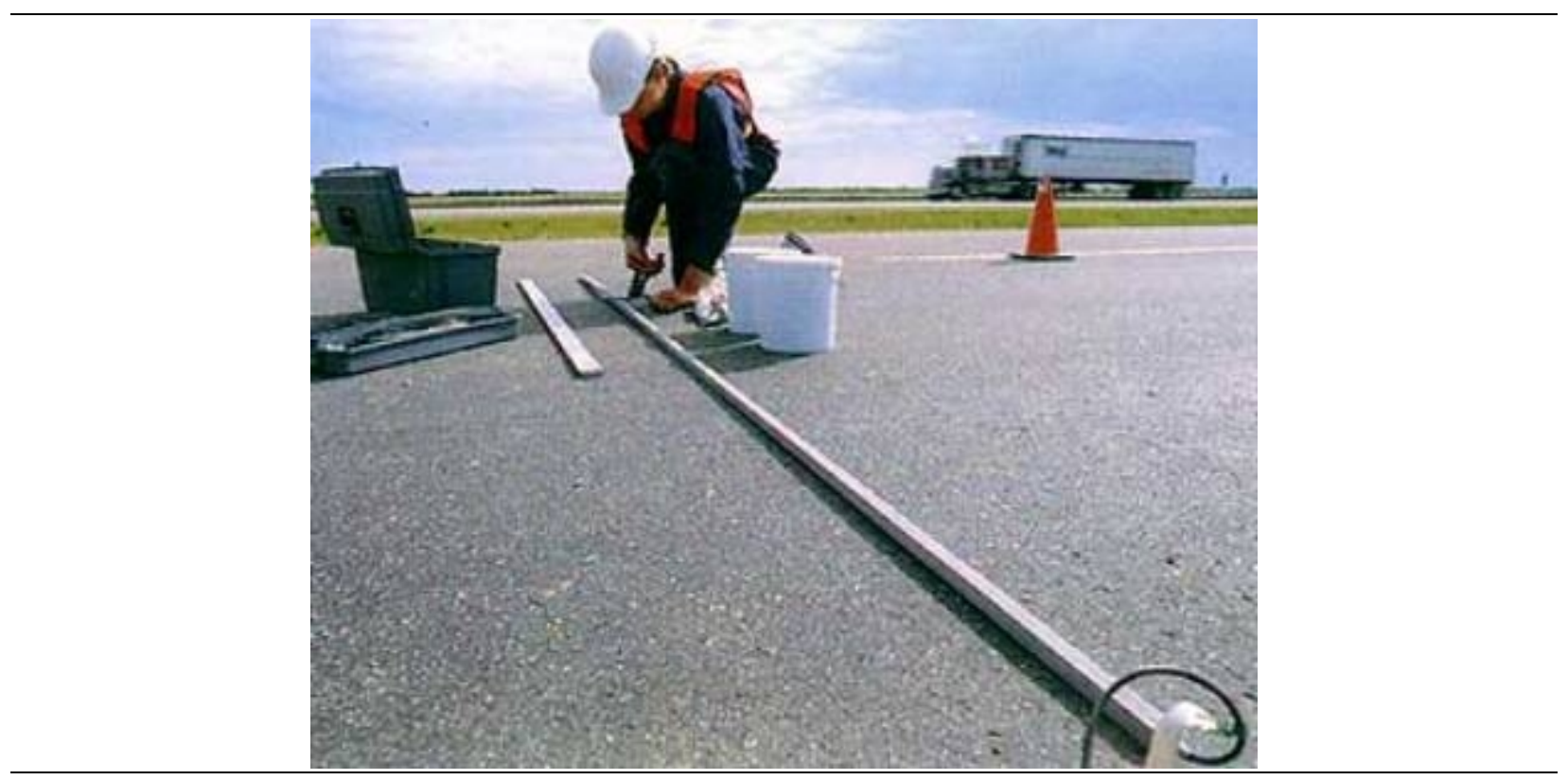

Figure 3-3: A technician installs a piezo-electric sensor 


\section{Technology : Single Load Cell}

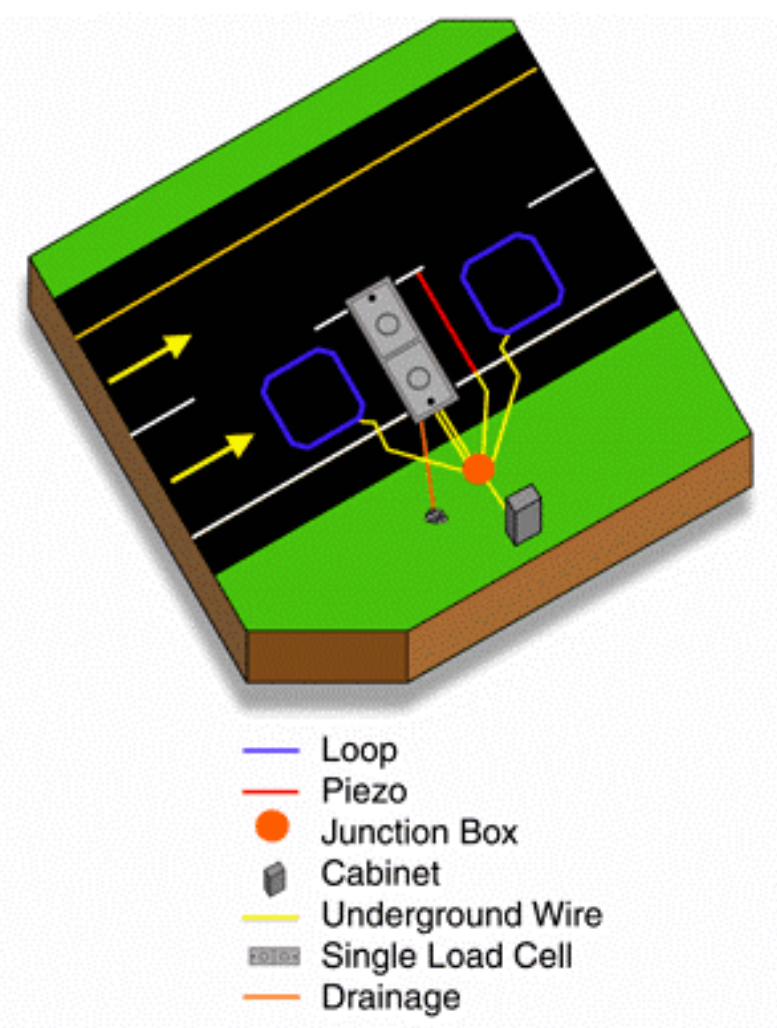

Figure 3-4: Single Load Cell site configuration

\subsubsection{Single Load Cell}

The Single Load Cell technology is believed to be the most accurate WIM weighing technology currently used in Indiana. It is also perhaps the most expensive of the technologies on a per site basis. Figure 3-4 shows the sensor configuration of a single load cell installation. Figure 3-5 shows a photograph of an installation on I-74 in the eastbound direction at station 5130 .

The Single Load Cell (WIM) Scale consists of two interconnected weighing platforms, situated side-by-side, covering one lane of traffic. Each platform has one hydraulic load cell inside it that measures half the weight of a vehicle passing over it. Weights recorded by each weighing platform are then combined to produce axle weights and ultimately GVW. 


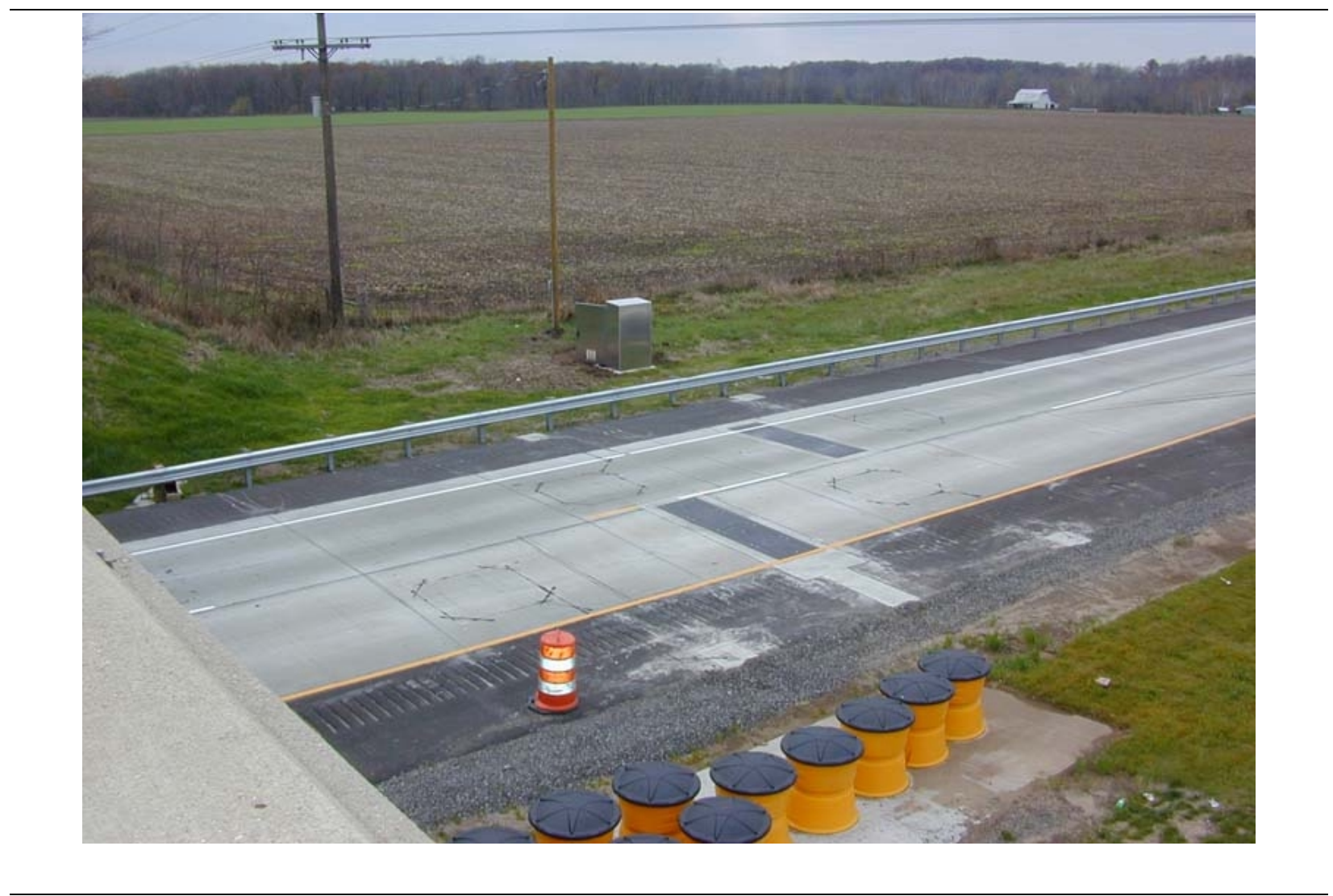

Figure 3-5: Single load cells in each lane, I-74 WB, near Covington, IN

\subsubsection{Bending Plates}

A Bending Plate Scale consists of two steel platforms placed next to each other, covering an entire lane of traffic. When a vehicle moves across the steel plates, strain gauges attached to the plates determine the amount that they deform. The strains of each steel platform are then analyzed to determine the weight of the vehicle.

Bending Plates have been in use for a long time in Indiana. However, the cost of a Bending Plate installation is comparable with a Single Load Cell site, while the accuracy is almost as poor as experienced with Piezo sensors (Table 3-1). Figure 3-6 shows a photograph of a bending plate installation. Figure 3-7 shows a photograph of a failed bending plate installation at station 5450 filled in with asphalt. 


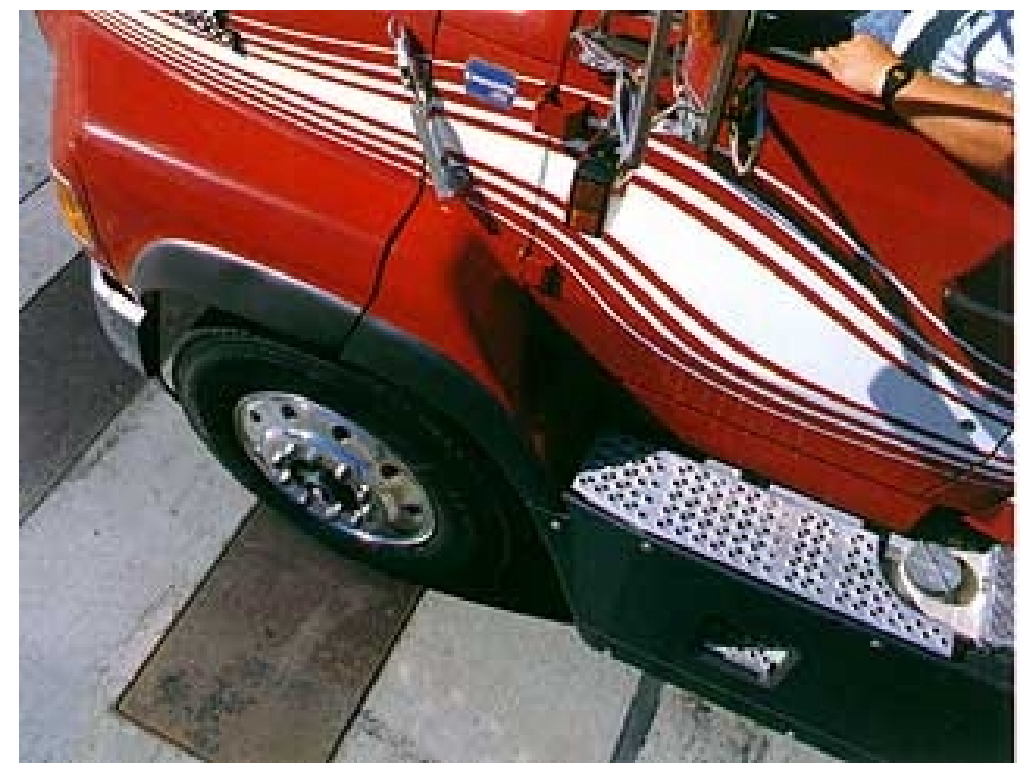

Figure 3-6: Front axle of truck passing over Bending Plate

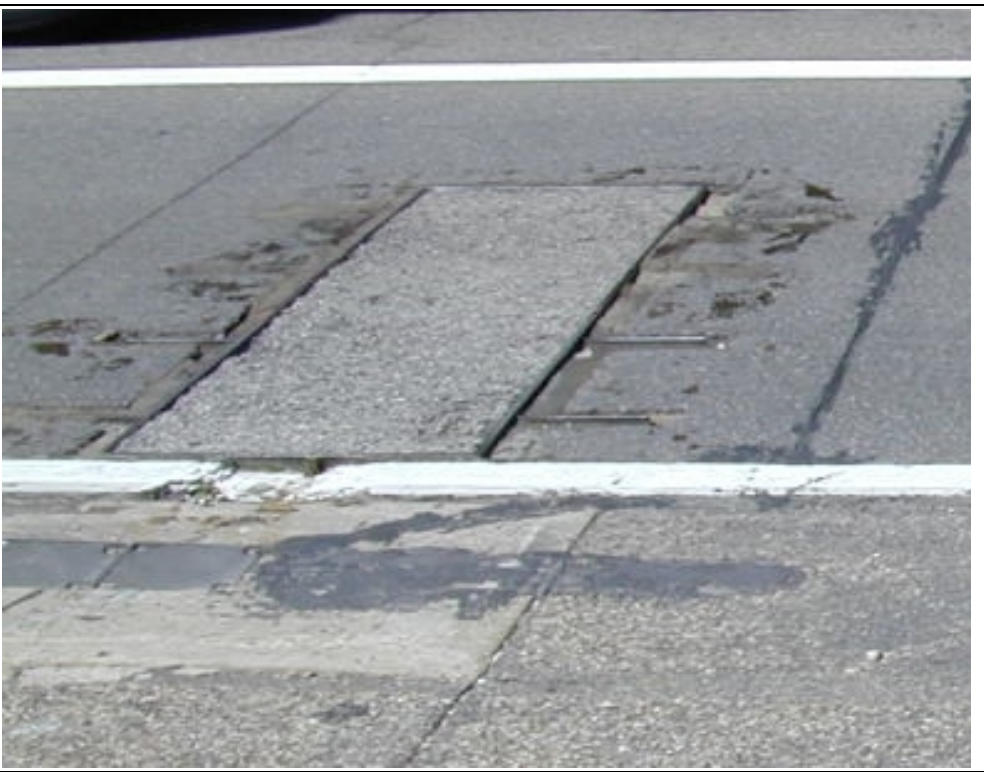

Figure 3-7: Failed Bending Plate Installation at WIM 5450 Filled with Asphalt 


\subsection{Suitability of Existing WIM Scales in Indiana for use with the Virtual Weigh Station}

Appendix A contains records for each WIM scale site in Indiana. Figure 3-8 is a sample record for a multilane scale installation in operation in Indiana on an interstate highway (I-65). There are two parts to each record -- a figure on the top of the page showing the physical lane configuration, and a table at the bottom of each page detailing the equipment in each lane, the suitability for Virtual Weigh Station operations, and the date (if known) of the last scale calibration. The July 2000 and October 2000 suitability dates provide the following information:

- $\quad$ October 2000 - Suitability is based upon classification error data provided in Appendix E and Section 3.3.

- July 2000 - Suitability is based upon front axle accuracy data provided in Appendices F, H, Section 3.4, and summarized in Table $\mathrm{H}-18$ and Table $\mathrm{H}-19$.

The following section details the data that supports these entries. The last row of the table is a numerical evaluation of the site performance by Donn Klepinger in the winter of 2001 . This is documented in Table A-4 and is referred to in this report as the Klepinger scale. 


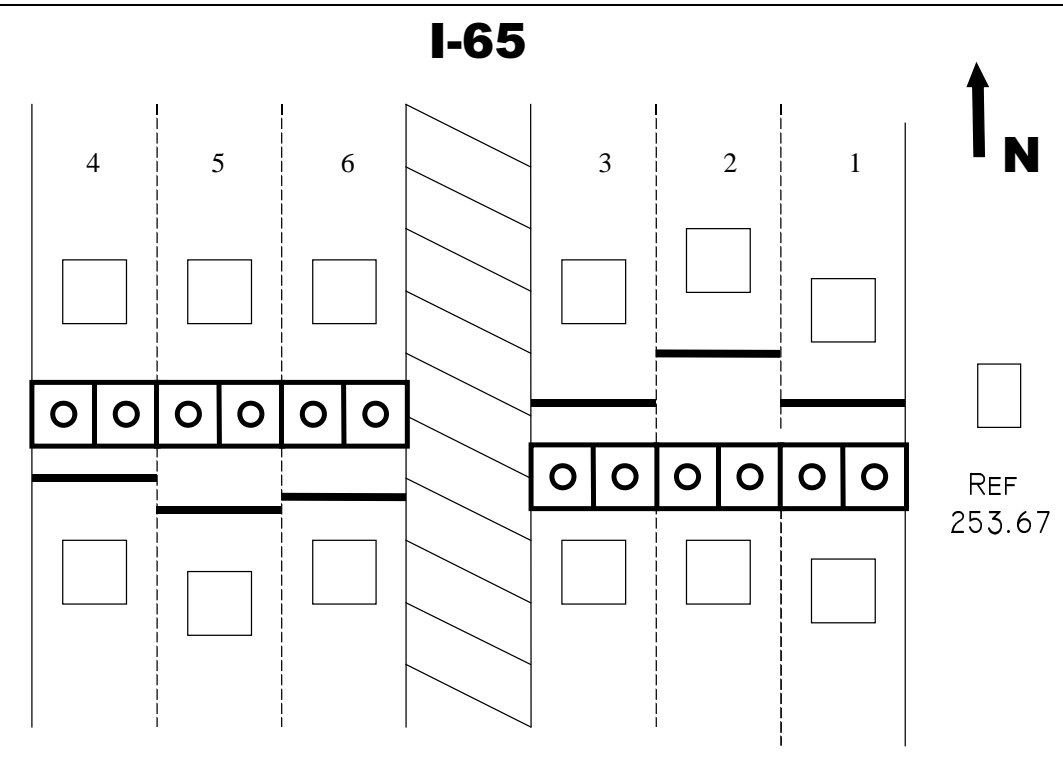

Figure A-13: Stations 4410 \& 4420 Six Lane Divided

\begin{tabular}{|c|c|c|c|c|c|c|}
\hline & Lane 1 & Lane 2 & Lane 3 & Lane 4 & Lane 5 & Lane 6 \\
\hline WIM & $\mathrm{X}$ & $\mathrm{X}$ & $\mathrm{X}$ & $\mathrm{X}$ & $\mathrm{X}$ & $\mathrm{X}$ \\
\hline Classification & & & & & & \\
\hline Sensor & SLC & SLC & SLC & SLC & SLC & SLC \\
\hline Pavement & C & C & C & C & C & C \\
\hline $\begin{array}{c}\text { Suitable for } \\
\text { VWS 7/00 }\end{array}$ & NO & DA & NO & NO & NO & NO \\
DATA & DATA & DATA & DATA & DATA \\
\hline $\begin{array}{c}\text { Suitable for } \\
\text { VWS 10/00 }\end{array}$ & NO & NO & NO & NO & NO & NO \\
\hline $\begin{array}{c}\text { Suitable for } \\
\text { VWS 2/01 }\end{array}$ & DATA & DATA & DATA & DATA & DATA \\
\hline $\begin{array}{c}\text { Klepinger Scale } \\
\text { Calibration } \\
\text { Dates }\end{array}$ & $6-$ & $6-$ & $6-$ & $6-$ & $6-$ & $6-$ \\
\hline
\end{tabular}

Table A-15: Stations 4410 and 4420 Inventory

Figure 3-8: Sample project record for a WIM scale installation 


\subsection{WIM Scale Error Rates}

WIM accuracy is dependent upon three factors: pavement smoothness, vehicle dynamics, and the integrity of the WIM system [Bergen, 1997]. Errors due to vehicle dynamics are typically isolated to liquid loads, vehicles changing lanes, and peculiar loads. Pavement condition and WIM systematic errors are a much bigger concern.

Since INDOT has approximately 40 stations, an early decision in the project was to select several potential sites at which the Virtual Weigh Station system would be tested. The normal procedure that Indiana uses to test and calibrate its WIM scales involves running a standard vehicle of known weight (determined by weighing on the closest static scale installation) over the same WIM scale many times. With each passage of the known-weight vehicle, the WIM produced weight is recorded, and a technician adjusts a factor in the "In-cabinet" computer controlling the WIM scale. When the technician feels that the WIM readings are sufficiently accurate, 10 passes are made with the same truck to verify the repeatability of the system. Once this is verified, the procedure is ended and the WIM scale is considered calibrated. Because the standard procedure is time intensive, for this project it was decided that an alternative method needed to be developed to determine the level of accuracy at which the WIM scales operate.

In consultation with IRD, the vendor decided that to properly test the Virtual Weigh Station system it would be desirable to use WIM scales operating with less than $10 \%$ of the vehicle records unclassified. As a starting point, it was decided to examine the error rates for all stations during a week. The team was able to obtain reports produced between January 1998 and October 2000 that list the "best" weekly error rates for all the stations (composite error rate calculated over all lanes and for individual lanes). Figure 3-9 shows an example graph of the historical classification error rate of station 4250. Based upon analysis of this data (which is found in Appendix E) as of October 2000, 8 stations were reporting all lanes within the proposed tolerance level of $10 \%$ or less error. Appendix E summarizes this information in a memo and Figure E-1 through Figure E-36.

Further analysis of these stations was performed on a lane-by-lane basis. In that analysis, individual lanes were analyzed and only three stations $(4250,5260,6260)$ had all lanes operating with less than $10 \%$ classification error. 


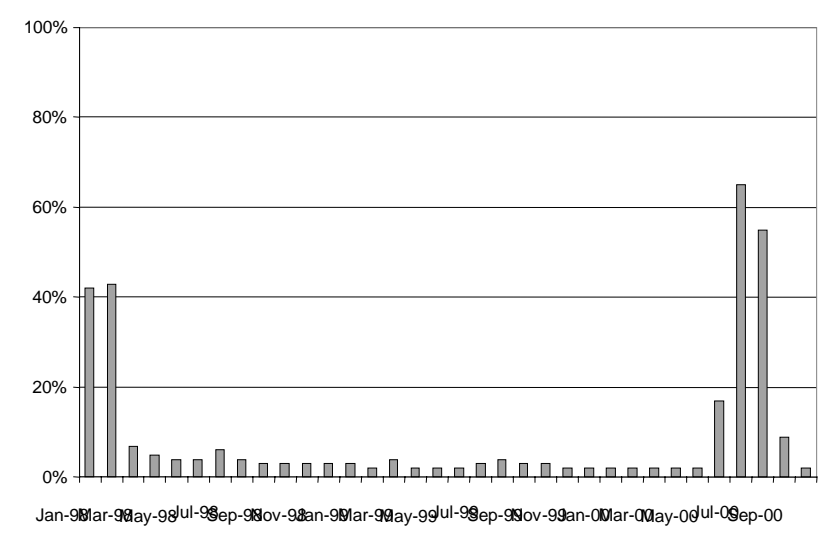

Figure 3-9: Station 4250, $1 \%$ Error in October 2000

\subsection{Front Axle Histograms}

The previous section discussed a screening procedure based on classification errors, but did not consider the accuracy of the axle weights. To evaluate the WIM scales' axle weight error, the front axle weights of all class 9 trucks on all WIM scales during July 2000 were tabulated [Dahlin, 1992]. The weights and configurations of commercial vehicles vary widely. Most of this variation can be attributed to the trailer and load. Previous researchers have reported that front axle weights are relatively uniform for class 9 trucks.

In light of this similarity, one would expect that if a scale were operating correctly, the front axles of most trucks crossing a weigh station would fall within this $9,000-\mathrm{Lb}$ to $12,000-\mathrm{Lb}$ range. This method was applied to the data gathered in July 2000 from the WIM sites in the state of Indiana. For each WIM site two graphs were plotted -a scatter plot of each valid (non-error) front axle weight record for the month, and a histogram constructed with 1500-lb intervals. The graphs were then subjectively judged for data "closeness of fit" to the predicted averages. This is how the "Suitability for VWS 7/00" row in each station record in Appendix A was determined. For example, Figure 3-10 and Figure 3-11 illustrate that the front axle data for lane 3 is clustered around 28,000 lbs. Such data indicate that weight data for lane 3 are probably not valid. In contrast, the data for lane 1 is clustered around a more believable $10,000 \mathrm{lbs}$, but appear to have too much dispersion. 


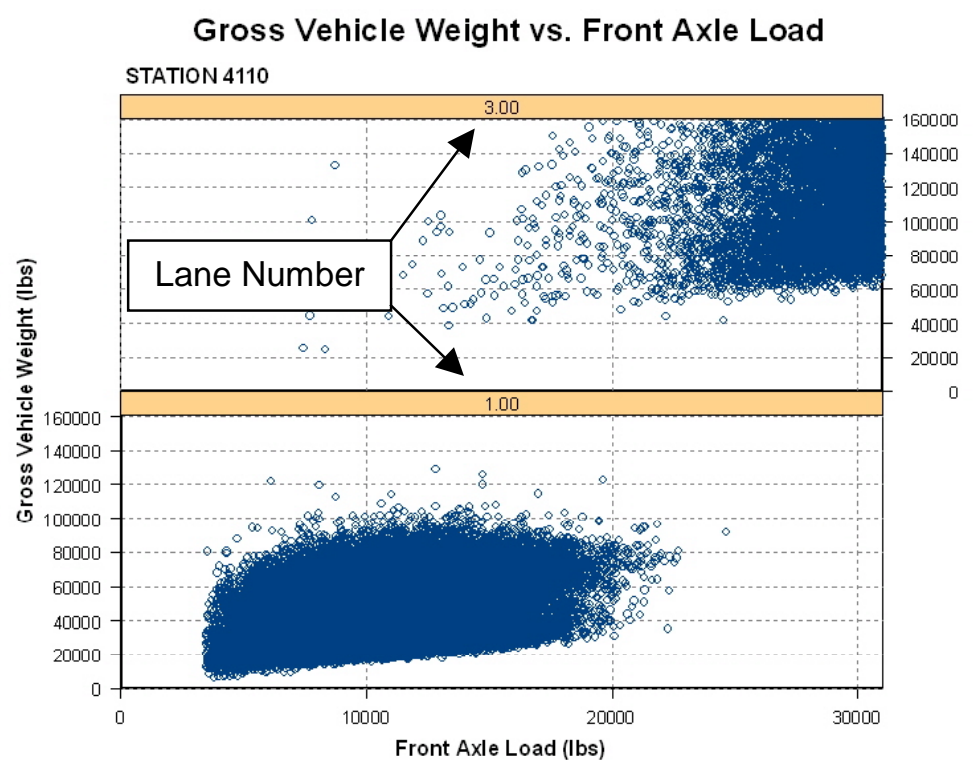

Figure 3-10: Scatter plot for Front Axle loads by lane distribution for station 4110, July 2000

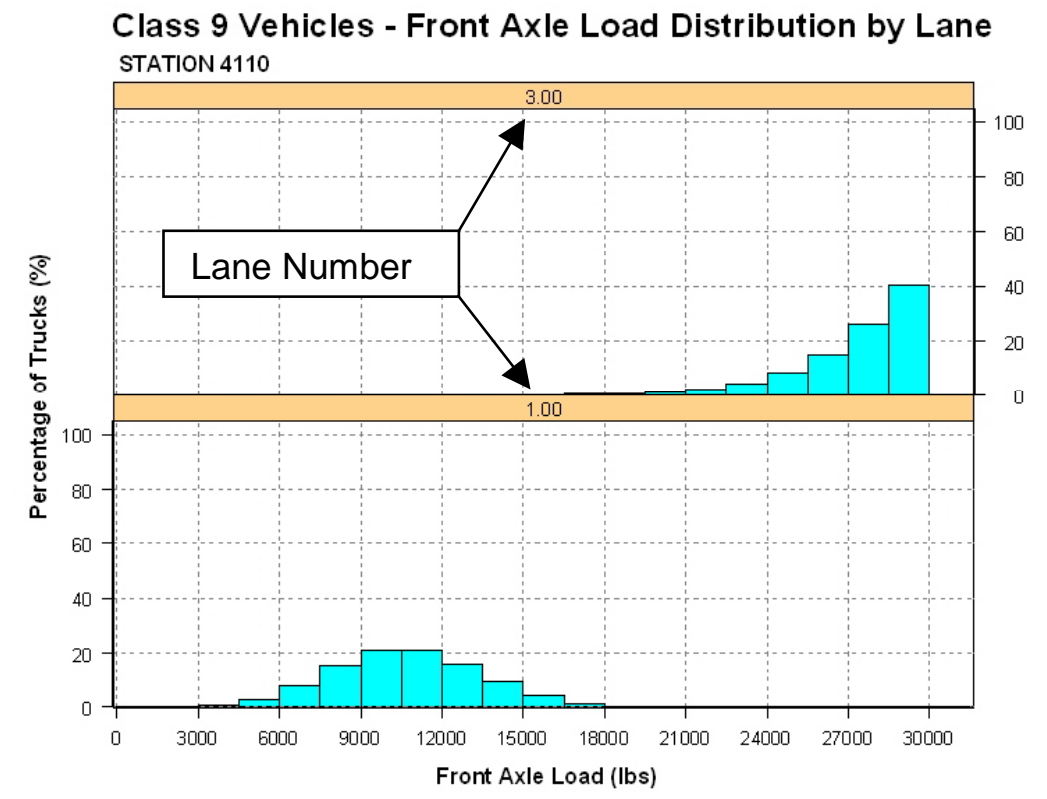

Figure 3-11: Histogram for Front Axle loads by lane distribution for station 4110, July 2000 


\subsection{Importance of WIM Accuracy}

The importance of accurate WIM measurements for planning and design purposes cannot be understated. As demonstrated in chapter two, error rates of a relatively small $10 \%$ can cause pavement life estimates to be in error by almost $50 \%$. When a pavement designed to last 20 years needs to be reconstructed in 14 years, both budgetary and political questions may arise. Therefore it is in the best interests of agencies operating WIMs to ensure that WIM scales produce highly accurate data. This is accomplished through preventative maintenance and calibration on a regular basis.

Resources expended to keep WIM sites operating at levels of high accuracy would serve the additional purpose of increasing the utility of the virtual WIM system. Accurate WIM data would increase the likelihood that vehicles chosen for weighing by portable scale by Commercial Vehicle Enforcement officers are in fact overweight. This would increase the effectiveness of scale enforcement research and serve to reduce the number of overweight trucks that lead to premature pavement failure. 


\section{Virtual Weigh Station System}

The concept of using existing INDOT Weigh-In-Motion equipment, a laptop computer, and wireless communication equipment, to develop a virtual weigh station system was proposed for deployment in Indiana by Guy Boruff, Dan Shamo, and Jay Wasson in 1998. This project provided a mechanism for developing and testing the concept. The Virtual Weigh Station screening tool allows officers to read the weights of vehicles crossing WIM scales, in real time, in their patrol cars. Giving officers this information increases the chances that the vehicles selected for weighing on portable scales are indeed overweight.

\section{1 “In-cabinet” Radio / Antenna Panel Equipment}

Potentially, all of the existing WIM sites providing accurate weight data in Indiana can be used for weight enforcement details with the virtual weigh station system. For one of the existing WIM sites to be utilized, a radio modem needs to be installed in the WIM scale cabinet, and an antenna installed nearby. Close proximity is necessary because "line-of-sight" radios were employed. A listing of the current WIM sites in Indiana and a map of the sites are included in Appendix A (Table A-1 and Figure A-1).

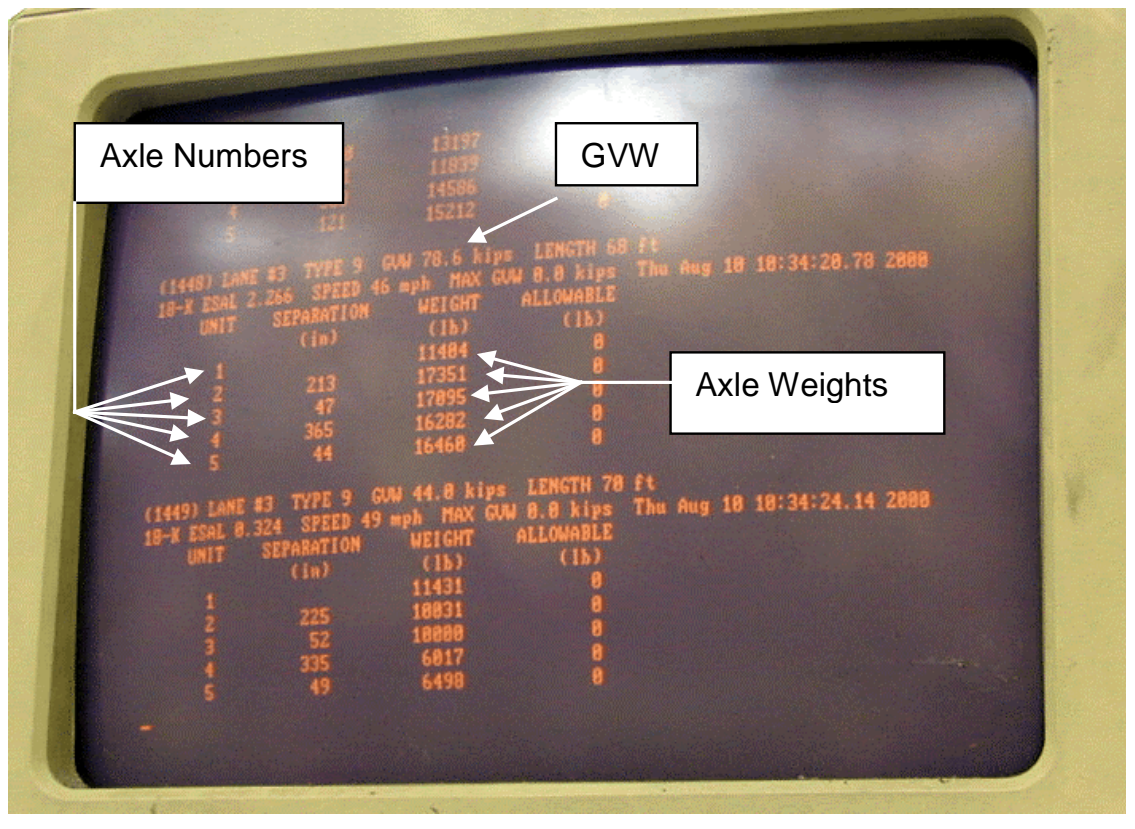

Figure 4-1: Sample WIM “in-cabinet” computer output screen 
Located in Appendix $\mathrm{J}$ are two AutoCAD drawings. Figure $\mathrm{J}-1$ depicts the dimensions of a metal plate needed to attach the Radio Modem to the inside of the WIM cabinet. Figure J-2 shows the modem and equipment used to provide the wireless connection in the WIM controller cabinets. This panel provides a wireless link to a laptop so that the information available at the cabinet WIM (Figure 4-1) is available to the Commercial Vehicle Enforcement Officer in their vehicle.

\section{$4.2 \quad$ "In-vehicle" Equipment}

The "in-vehicle" equipment needed for operation with the virtual weigh station system consists of a laptop computer (on which the Road Runner software is installed) connected to a Gina radio modem. The prototype equipment developed for this project is depicted in Figure 4-2. The prototype materials are portable - note the magnetic antenna and cushioned briefcase. After the Road Runner software was completely debugged, it was installed on all of the laptops located in the Indiana State Police Commercial Vehicle Enforcement Division patrol cars. Three hardware kits were assembled and given to CVE to use to connect to the WIM stations. A hardware kit is shown in Figure 4-3. The kit contains a radio modem, magnet-mount antenna, power cable, antenna cable, and serial cable. All of the equipment fits into a durable case and can be closed while being transferred between vehicles. 


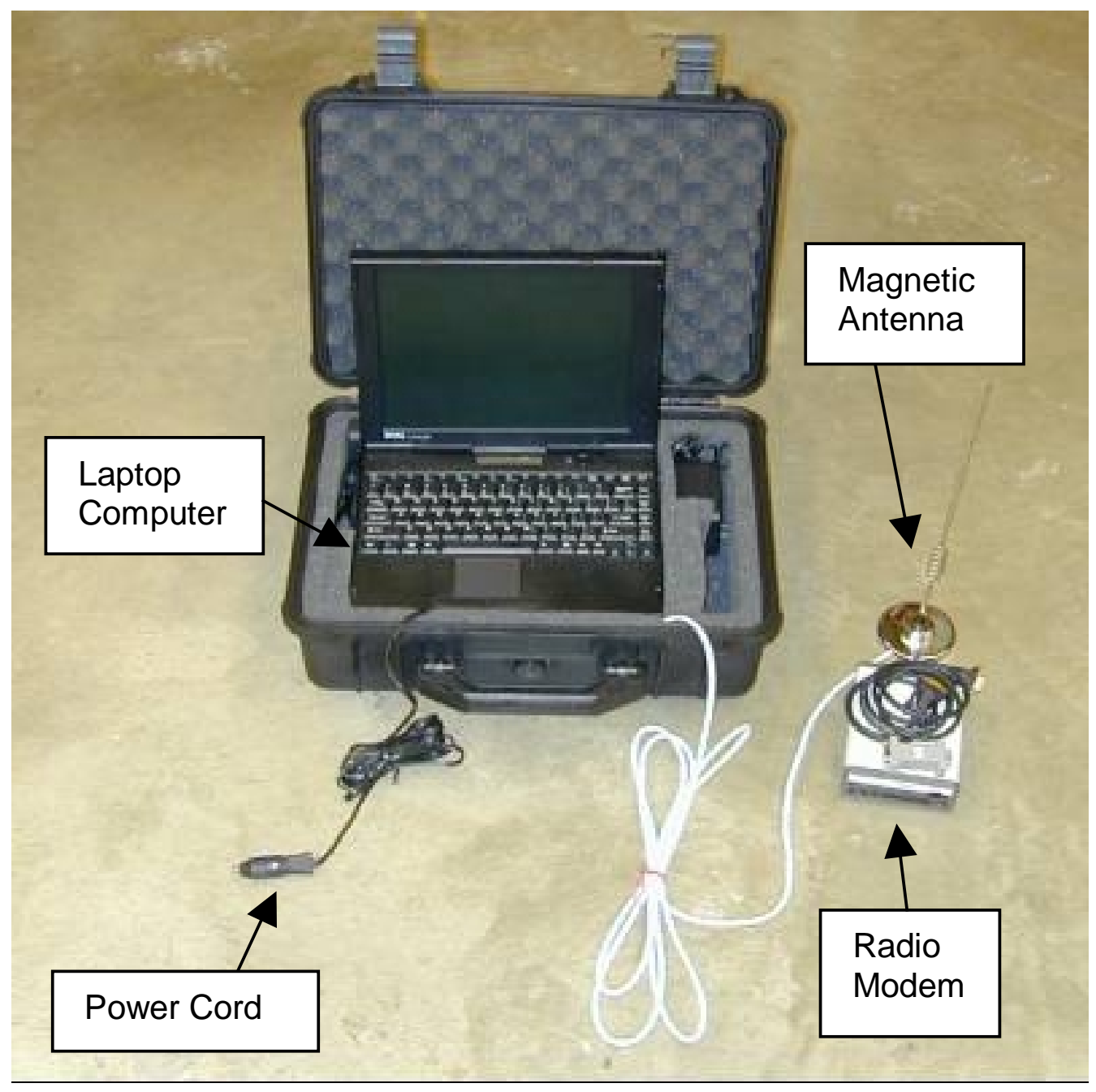

Figure 4-2: Virtual Weigh Station System Hardware

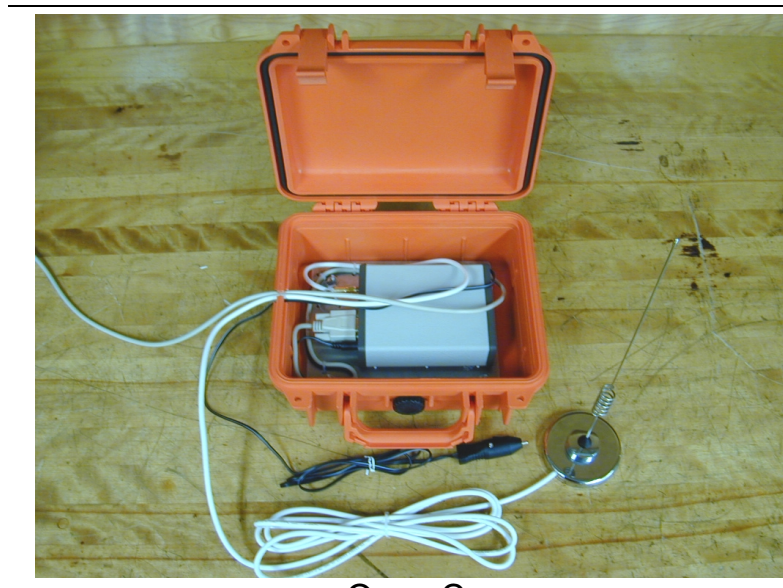

a. Open Case

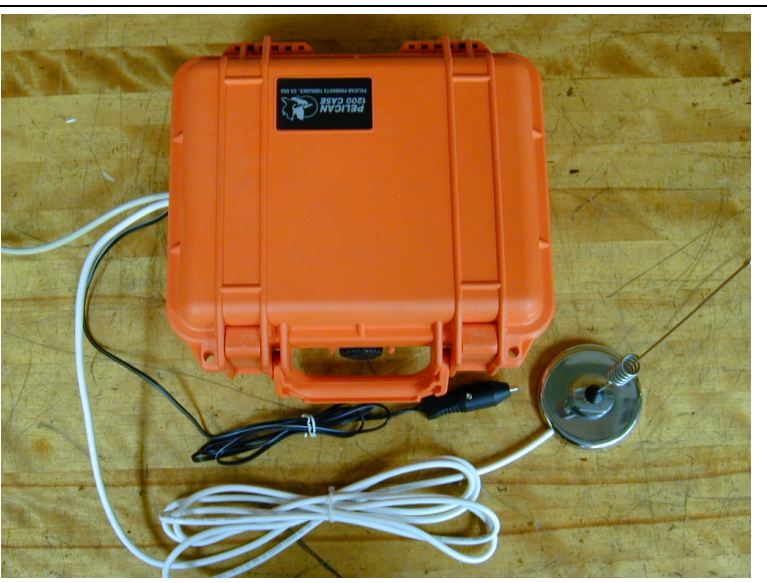

b. Closed Case

Figure 4-3: Virtual Weigh Station Hardware Kit 


\subsection{Description of Road Runner Software Display}

Figure 4-4 shows a screen-capture of the current configuration of the Road Runner software. The menus located at the top of the window allow the system user to connect to the WIM station and clear the screen. Within the communications menu, the user can choose a method of connection to the WIM station - either through a direction connection with wireless link, or through a dialup modem, ostensibly to check status of the system from an offsite location. The communication port to be used can also be selected. The "disconnect" button in this menu terminates the connection between the laptop and WIM. The "clear screen" menu button resets the output window that occupies the bottom half of the screen.

The first column from the left lists properties of the current vehicular record. "Date" and "time" are selfexplanatory. "Record" lists the record number assigned by the WIM station so that individual vehicle information may be referenced later. "Lane" tells in which traffic lane the vehicle is traveling. "Axles" gives the number of axles that a vehicle has. "Class", "Length", "Speed", and "GVW" also are self-explanatory.

The second column lists the individual axle weights for the current vehicle. If the vehicle has fewer axles than axle boxes, surplus axle boxes contain zeroes.

In the top right region of the window, the user can set the GVW limit threshold and enable and disable lanes and vehicle classes to view in the window. Since the primary intended use for the Road Runner system is as a tool for enforcement of commercial vehicle weight laws, the available class choices are limited to classes 7,8 , and 9 . Additionally, the user has the option to select and view "All Classes" of vehicles. This option is not recommended for high volume traffic areas, because in high volume conditions the system may experience slight delays in listing vehicle records. When the threshold is exceeded, the computer running the software beeps and displays the weight in red text on a black background. The vehicle record, class, lane, and GVW are then logged in the "Violators" list in the middle right side of the window.

The bottom half of the screen logs the vehicle records obtained while the software is running. Fields shown in the bottom half include Date, Time, Record, Lane, Class, and GVW. In heavy traffic, a vehicle record may appear for only a second before the next record replaces it. The bottom half is intended to allow the user to examine any record data that he or she may have missed in its listing in the "current" position. 


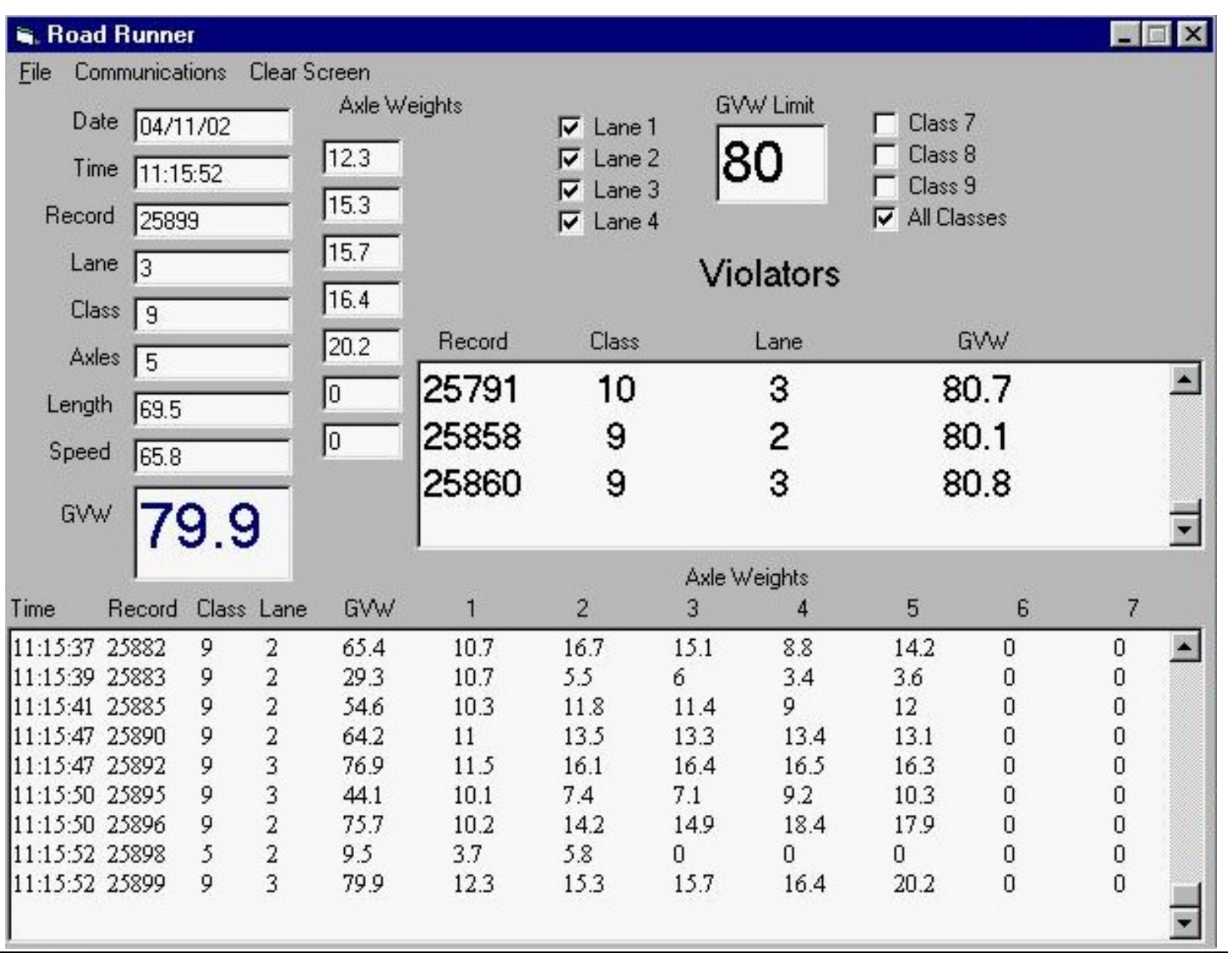

Figure 4-4: Screen Capture of latest version of Road Runner software

\subsection{Procedure for System Use}

A Commercial Vehicle Enforcement Division Officer in a vehicle equipped with the Road Runner wireless WIM system may use the existing WIM installation by locating his/her vehicle within an approximate one-mile radius of the antenna and within direct sight of the antenna. Figure 4-5 shows a picture of the antenna mounted at station 4410 on I-65 east. If the WIM installation covers traffic in two directions (for example, the Merrillville, Indiana WIMs $\# 4410$ and \#4420), the officer needs to set the direction of interest in the cabinet before operating the system. Once these conditions have been met, the officer turns on the system in the vehicle and runs the software program to start observing vehicular weights.

When the Roadrunner software starts up, the user needs to establish communication. This can be done through a serial or modem connection. 
Once a connection is established, the default threshold setting of 0.0 Kips will cause all vehicles crossing the WIM to register as overweight. To change the GVW limit threshold, the user must type in a higher number in the GVW limit box to set the overweight threshold to a higher weight, such as 80.0 kips $(80,000$ Lbs). While 80.0 kips is the legal GVW limit for class 9 vehicles, a higher or lower threshold may be more useful. Due to the dynamic nature of vehicles in motion - certain loads may cause vehicles to "bounce". Bouncing vehicles may register slightly higher (or lower) than actual weights as they cross the WIM scales.

Another default setting of the Road Runner software that can be easily changed is class of vehicle selected. When the program starts, records for all classes of vehicles will be shown on the display. In the current software version, users have the option to choose to view either all classes or any combination of vehicle classes 7,8 , and/or 9. To change this setting, the user only needs to pick clearly labeled check boxes for the desired classes.

When a vehicle crosses the WIM whose GVW is greater than the current threshold, a warning tone is sounded and the box displaying the GVW increases in size and the GVW of the vehicle is shown in red numbers on a black background. If the officer chooses to chase the vehicle, due to the physical distances involved in catching the suspected vehicle, radio contact will probably be lost between the WIM cabinet and the "in-vehicle" system. After the officer inspects and weighs the vehicle with portable scales, radio contact needs to be reestablished. This is accomplished by closing the program and restarting it when the officer is back in position near the WIM. Once in position, with the system running again, the officer can again observe vehicular weights. 


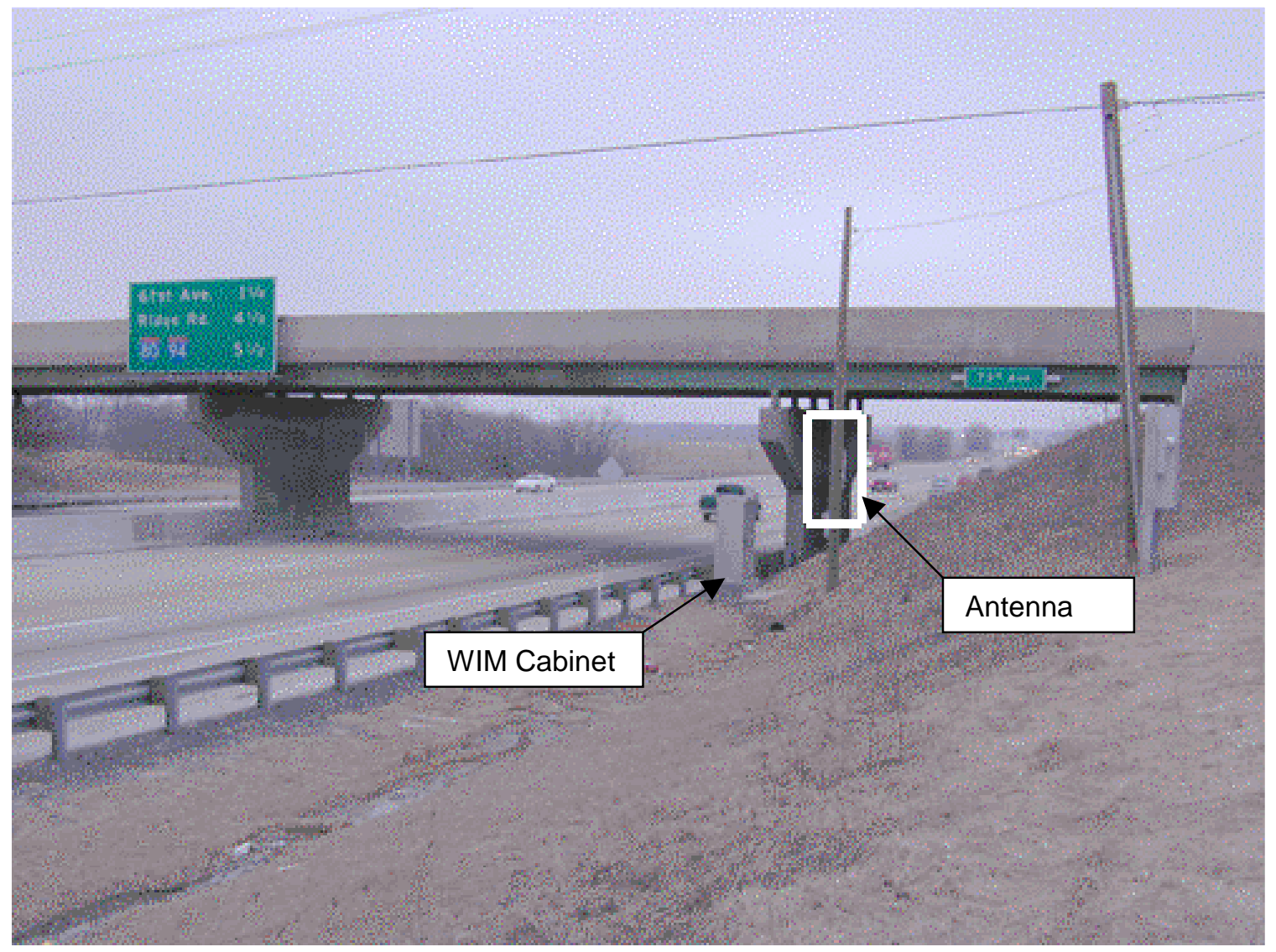

Figure 4-5: Antenna at WIM Station 4410 on I-65 Northbound at Milepost 253.62

\subsection{Stored Data -- Log File}

As an additional feature, the Road Runner software produces log files. Every vehicle record that the "invehicle" system receives from the WIM scale is stored in a log file, named according to the date that the system is in use. These log files are text files which can be analyzed easily with common spreadsheet software programs later. These files are in addition to the data that is continually logged in the WIM cabinet. 


\section{Enforcement Details}

An important question for management of any organization is how to best employ scarce resources. This is especially true for the Commercial Vehicle Enforcement Division of the Indiana State Police. A goal of this project was to develop a quick method to determine when the greatest numbers of overweight vehicles operate. Presumably, if given this information, coordinators could schedule work shifts to produce the greatest impact on overweight vehicle interception operations. In a study of enforcement operations in several states, it was determined that in areas where enforcement is visible and regular, GVW violations can be lower than 1\% [Taylor et al., 1999].

\subsection{Determination Procedure}

The times when Indiana State Police Commercial Vehicle Enforcement officers can be the most effective were determined by analyzing data already collected by the WIM sites and used for maintenance and planning purposes. Some states, such as California, already use WIM data to schedule enforcement hours [Bergen, 1998]. The assumption was made that Indiana State Police Commercial Vehicle Enforcement officers would have the highest probability of catching overweight vehicles when the greatest numbers of these overweight vehicles were operating. Therefore, enforcement details should be scheduled at these times to have the greatest impact.

Computer data files for an individual WIM site, covering the four weeks of February 2001, were analyzed.

Table 5-1 and Table 5-2 show a portion of the traffic count results reported for the entire month of February 2001 for the WIM Stations 4410 (Northbound) and 4420 (Southbound), at Milepost 253.67 on I-65. While the February data was selected, the same procedure can be applied to any 4-week period. Table 5-1 and Table 5-2 show the overweight violations reported by the IRD software in a strict axle and GVW threshold. However, since there were some calibration problems at that site in February, to be conservative, only Class 9 vehicles that exceeded 90,000 lbs were considered "overweight". The number of trucks that weighed more than 90,000 lbs was calculated using a spreadsheet and the occurrences of the violations are tabulated in Table 5-3 through Table 5-7. 


\begin{tabular}{|l|c|c|c|c|c|c|c|c|}
\hline & \multicolumn{10}{|c|}{ Lane Number } \\
\hline Status & 1 & 1 & 2 & 2 & 3 & 3 & All & All \\
\hline & Count & $\%$ & Count & $\%$ & Count & $\%$ & Count & $\%$ \\
\hline Legal & 52,793 & 70.9 & 38,118 & 87.8 & 567 & 78 & 91,478 & 77.2 \\
\hline Overweight & 21,425 & 28.8 & 5,077 & 11.7 & 151 & 20.8 & 26,653 & 22.5 \\
\hline
\end{tabular}

Table 5-1: Class 9 Vehicles, Feb 01 00:00:00 2001 TO Thu Mar 01 00:00:00 2001 - Station 4410, Northbound

\begin{tabular}{|l|c|c|c|c|c|c|c|c|}
\hline & \multicolumn{1}{|c|}{ Lane Number } \\
\hline Status & 1 & 1 & 2 & 2 & 3 & 3 & All & All \\
\hline & Count & $\%$ & Count & $\%$ & Count & $\%$ & Count & $\%$ \\
\hline Legal & 66,967 & 89.5 & 39,529 & 80.5 & 376 & 92.6 & 106,872 & 77.2 \\
\hline Overweight & 7,733 & 10.3 & 9,437 & 19.2 & 25 & 6.2 & 17,195 & 13.8 \\
\hline
\end{tabular}

Table 5-2: Class 9 Vehicles, Feb 01 00:00:00 2001 TO Thu Mar 01 00:00:00 2001 - Station 4420, Southbound

Counting overweight records and comparing the total amounts listed in each hourly group revealed the times when the most overweight vehicles operated. Table 5-3 through Table 5-7, Figure 5-1 and Figure 5-2 were constructed using this data. As was expected, most of the overweight vehicles were in Lane 1. Table 5-3, Table 5-4, and Table 5-5 show the number of Class 9 vehicles that exceeded 90,000 lbs, sorted by hour and day of week for lanes 1, 2, and 3 in the northbound direction. The Northbound lane 1 data is shown graphically in Figure 5-1.

Similarly, Table 5-6 and Table 5-7 show the number of Class 9 vehicles that exceeded 90,000 lbs, sorted by hour and day of week for the Southbound direction (a negligible amount were observed in Lane 3), while Figure 5-2 shows the Southbound lane 1 data graphically. 


\begin{tabular}{|c|c|c|c|c|c|c|c|}
\hline Hour & Sunday & Monday & Tuesday & Wednesday & Thursday & Friday & Saturday \\
\hline 0 & 2 & 25 & 20 & 13 & 31 & 24 & 6 \\
\hline 1 & 4 & 31 & 26 & 19 & 27 & 35 & 3 \\
\hline 2 & 4 & 28 & 25 & 20 & 40 & 42 & 8 \\
\hline 3 & 2 & 39 & 23 & 25 & 41 & 46 & 9 \\
\hline 4 & 8 & 34 & 33 & 42 & 37 & 47 & 6 \\
\hline 5 & 0 & 33 & 26 & 24 & 26 & 45 & 9 \\
\hline 6 & 6 & 29 & 21 & 19 & 25 & 30 & 8 \\
\hline 7 & 8 & 35 & 14 & 24 & 17 & 16 & 14 \\
\hline 8 & 13 & 36 & 29 & 27 & 33 & 39 & 14 \\
\hline 9 & 5 & 29 & 29 & 19 & 28 & 34 & 5 \\
\hline 10 & 8 & 28 & 36 & 34 & 29 & 35 & 9 \\
\hline 11 & 9 & 31 & 29 & 18 & 16 & 23 & 14 \\
\hline 12 & 13 & 33 & 23 & 26 & 28 & 22 & 19 \\
\hline 13 & 13 & 29 & 22 & 23 & 23 & 20 & 7 \\
\hline 14 & 9 & 26 & 22 & 34 & 22 & 15 & 9 \\
\hline 15 & 10 & 18 & 19 & 15 & 20 & 10 & 6 \\
\hline 16 & 10 & 18 & 18 & 22 & 17 & 7 & 8 \\
\hline 17 & 12 & 16 & 14 & 13 & 14 & 6 & 8 \\
\hline 18 & 8 & 18 & 23 & 9 & 19 & 5 & 7 \\
\hline 19 & 18 & 20 & 19 & 18 & 24 & 9 & 2 \\
\hline 20 & 21 & 23 & 19 & 16 & 33 & 9 & 1 \\
\hline 21 & 16 & 29 & 18 & 13 & 32 & 10 & 8 \\
\hline 22 & 23 & 27 & 18 & 21 & 33 & 8 & 7 \\
\hline 23 & 30 & 22 & 22 & 18 & 27 & 4 & 1 \\
\hline Total & $\mathbf{2 5 2}$ & $\mathbf{6 5 7}$ & $\mathbf{5 4 8}$ & $\mathbf{5 1 2}$ & $\mathbf{6 4 2}$ & $\mathbf{5 4 1}$ & $\mathbf{1 8 8}$ \\
\hline & & & & & & & \\
\hline 13 & & & & & & & \\
\hline
\end{tabular}

Table 5-3: February 2001, Northbound, Lane 1, Class 9 Vehicles exceeding 90,000lbs.

\begin{tabular}{|c|c|c|c|c|c|c|c|}
\hline Hour & Sunday & Monday & Tuesday & Wednesday & Thursday & Friday & Saturday \\
\hline 0 & 0 & 0 & 2 & 1 & 0 & 1 & 0 \\
\hline 1 & 0 & 1 & 0 & 0 & 0 & 0 & 0 \\
\hline 2 & 0 & 0 & 0 & 0 & 0 & 1 & 1 \\
\hline 3 & 0 & 0 & 0 & 0 & 0 & 0 & 0 \\
\hline 4 & 0 & 0 & 1 & 0 & 2 & 2 & 0 \\
\hline 5 & 0 & 0 & 1 & 0 & 1 & 1 & 0 \\
\hline 6 & 0 & 1 & 1 & 0 & 0 & 0 & 0 \\
\hline 7 & 0 & 0 & 0 & 0 & 1 & 1 & 0 \\
\hline 8 & 0 & 0 & 0 & 1 & 2 & 0 & 1 \\
\hline 9 & 0 & 0 & 0 & 2 & 3 & 1 & 1 \\
\hline 10 & 0 & 0 & 0 & 0 & 2 & 0 & 2 \\
\hline 11 & 0 & 1 & 1 & 0 & 2 & 0 & 3 \\
\hline 12 & 2 & 1 & 0 & 0 & 1 & 0 & 1 \\
\hline 13 & 1 & 0 & 0 & 1 & 1 & 1 & 1 \\
\hline 14 & 0 & 0 & 0 & 0 & 0 & 2 & 2 \\
\hline 15 & 0 & 0 & 0 & 1 & 4 & 0 & 1 \\
\hline 16 & 0 & 1 & 1 & 0 & 1 & 0 & 0 \\
\hline 17 & 0 & 0 & 0 & 0 & 0 & 0 & 0 \\
\hline 18 & 0 & 0 & 0 & 1 & 0 & 0 & 0 \\
\hline 19 & 0 & 0 & 1 & 0 & 0 & 0 & 0 \\
\hline 20 & 0 & 0 & 0 & 0 & 0 & 1 & 0 \\
\hline 21 & 1 & 0 & 0 & 0 & 0 & 0 & 0 \\
\hline 22 & 1 & 0 & 0 & 0 & 0 & 1 & 0 \\
\hline 23 & 0 & 1 & 0 & 0 & 0 & 0 & 0 \\
\hline Total & $\mathbf{5}$ & $\mathbf{6}$ & $\mathbf{8}$ & $\mathbf{7}$ & $\mathbf{2 0}$ & $\mathbf{1 2}$ & $\mathbf{1 3}$ \\
\hline
\end{tabular}

Table 5-4: February 2001, Northbound, Lane 2, Class 9 Vehicles exceeding 90,000 Lbs. 


\begin{tabular}{|c|c|c|c|c|c|c|c|}
\hline Hour & Sunday & Monday & Tuesday & Wednesday & Thursday & Friday & Saturday \\
\hline 0 & 0 & 0 & 0 & 0 & 0 & 0 & 0 \\
\hline 1 & 0 & 0 & 0 & 0 & 0 & 0 & 0 \\
\hline 2 & 0 & 0 & 0 & 0 & 0 & 0 & 0 \\
\hline 3 & 0 & 0 & 0 & 0 & 0 & 0 & 0 \\
\hline 4 & 0 & 0 & 0 & 1 & 0 & 0 & 0 \\
\hline 5 & 0 & 0 & 0 & 0 & 0 & 0 & 0 \\
\hline 6 & 0 & 0 & 0 & 0 & 0 & 0 & 0 \\
\hline 7 & 0 & 0 & 0 & 0 & 0 & 0 & 0 \\
\hline 8 & 0 & 0 & 0 & 0 & 0 & 0 & 0 \\
\hline 9 & 0 & 0 & 0 & 0 & 0 & 0 & 0 \\
\hline 10 & 0 & 0 & 0 & 0 & 0 & 0 & 0 \\
\hline 11 & 0 & 0 & 0 & 0 & 0 & 0 & 0 \\
\hline 12 & 0 & 0 & 0 & 0 & 1 & 0 & 0 \\
\hline 13 & 0 & 0 & 0 & 0 & 0 & 0 & 0 \\
\hline 14 & 0 & 0 & 0 & 0 & 0 & 0 & 0 \\
\hline 15 & 0 & 0 & 0 & 0 & 0 & 0 & 0 \\
\hline 16 & 0 & 0 & 0 & 0 & 0 & 0 & 0 \\
\hline 17 & 0 & 0 & 0 & 0 & 0 & 0 & 0 \\
\hline 18 & 0 & 0 & 0 & 0 & 0 & 0 & 0 \\
\hline 19 & 0 & 0 & 0 & 0 & 0 & 0 & 0 \\
\hline 20 & 0 & 0 & 0 & 0 & 0 & 0 & 0 \\
\hline 21 & 0 & 0 & 0 & 0 & 0 & 0 & 0 \\
\hline 22 & 1 & 0 & 0 & 0 & 0 & 0 & 0 \\
\hline 23 & 0 & 0 & 0 & 0 & 0 & 0 & 0 \\
\hline Total & $\mathbf{1}$ & $\mathbf{0}$ & $\mathbf{0}$ & $\mathbf{1}$ & $\mathbf{1}$ & $\mathbf{0}$ & $\mathbf{0}$ \\
\hline
\end{tabular}

Table 5-5: February 2001, Northbound, Lane 3, Class 9 Vehicles exceeding 90,000 Lbs.

\begin{tabular}{|c|c|c|c|c|c|c|c|}
\hline Hour & Sunday & Monday & Tuesday & Wednesday & Thursday & Friday & Saturday \\
\hline 0 & 0 & 0 & 0 & 0 & 2 & 2 & 0 \\
\hline 1 & 0 & 0 & 0 & 1 & 1 & 0 & 0 \\
\hline 2 & 0 & 0 & 0 & 0 & 1 & 0 & 1 \\
\hline 3 & 1 & 0 & 1 & 0 & 1 & 0 & 0 \\
\hline 4 & 0 & 2 & 1 & 2 & 0 & 0 & 0 \\
\hline 5 & 0 & 4 & 3 & 1 & 3 & 1 & 2 \\
\hline 6 & 1 & 0 & 0 & 1 & 1 & 1 & 0 \\
\hline 7 & 0 & 1 & 1 & 1 & 1 & 0 & 0 \\
\hline 8 & 0 & 3 & 2 & 0 & 0 & 1 & 0 \\
\hline 9 & 0 & 1 & 0 & 0 & 2 & 2 & 0 \\
\hline 10 & 1 & 0 & 0 & 1 & 0 & 0 & 1 \\
\hline 11 & 0 & 1 & 3 & 0 & 1 & 0 & 0 \\
\hline 12 & 0 & 1 & 2 & 1 & 0 & 1 & 0 \\
\hline 13 & 0 & 0 & 0 & 3 & 1 & 1 & 2 \\
\hline 14 & 0 & 1 & 0 & 2 & 0 & 1 & 1 \\
\hline 15 & 0 & 0 & 1 & 0 & 2 & 0 & 0 \\
\hline 16 & 0 & 0 & 0 & 1 & 3 & 1 & 1 \\
\hline 17 & 0 & 0 & 0 & 0 & 0 & 2 & 2 \\
\hline 18 & 0 & 0 & 0 & 1 & 2 & 0 & 3 \\
\hline 19 & 1 & 2 & 0 & 1 & 1 & 0 & 1 \\
\hline 20 & 2 & 0 & 3 & 0 & 0 & 0 & 0 \\
\hline 21 & 3 & 2 & 1 & 0 & 0 & 0 & 1 \\
\hline 22 & 2 & 2 & 1 & 5 & 0 & 7 & 1 \\
\hline 23 & 0 & 0 & 1 & 0 & 0 & 4 & 2 \\
\hline Total & $\mathbf{1 1}$ & $\mathbf{2 0}$ & $\mathbf{2 0}$ & $\mathbf{2 1}$ & $\mathbf{2 2}$ & $\mathbf{2 4}$ & $\mathbf{1 8}$ \\
\hline
\end{tabular}

Table 5-6: February 2001, Southbound, Lane 1, Class 9 Vehicles exceeding 90,000 Lbs. 


\begin{tabular}{|c|c|c|c|c|c|c|c|}
\hline Hour & Sunday & Monday & Tuesday & Wednesday & Thursday & Friday & Saturday \\
\hline 0 & 2 & 0 & 1 & 1 & 1 & 0 & 0 \\
\hline 1 & 0 & 1 & 2 & 1 & 0 & 0 & 0 \\
\hline 2 & 0 & 0 & 0 & 1 & 0 & 0 & 0 \\
\hline 3 & 0 & 0 & 0 & 0 & 0 & 0 & 0 \\
\hline 4 & 0 & 0 & 0 & 0 & 1 & 0 & 0 \\
\hline 5 & 0 & 1 & 1 & 1 & 0 & 0 & 1 \\
\hline 6 & 0 & 0 & 0 & 0 & 0 & 0 & 0 \\
\hline 7 & 1 & 0 & 0 & 0 & 0 & 0 & 0 \\
\hline 8 & 0 & 0 & 0 & 0 & 1 & 0 & 0 \\
\hline 9 & 0 & 1 & 0 & 0 & 0 & 0 & 0 \\
\hline 10 & 0 & 0 & 0 & 0 & 0 & 0 & 0 \\
\hline 11 & 0 & 0 & 1 & 1 & 0 & 0 & 0 \\
\hline 12 & 1 & 0 & 1 & 0 & 1 & 1 & 0 \\
\hline 13 & 0 & 2 & 2 & 0 & 0 & 1 & 3 \\
\hline 14 & 0 & 0 & 2 & 1 & 0 & 0 & 2 \\
\hline 15 & 0 & 0 & 0 & 0 & 0 & 0 & 2 \\
\hline 16 & 1 & 1 & 1 & 0 & 0 & 0 & 1 \\
\hline 17 & 0 & 0 & 1 & 2 & 0 & 0 & 0 \\
\hline 18 & 1 & 1 & 1 & 2 & 2 & 0 & 0 \\
\hline 19 & 0 & 0 & 1 & 0 & 0 & 2 & 0 \\
\hline 20 & 0 & 1 & 1 & 0 & 0 & 3 & 0 \\
\hline 21 & 0 & 0 & 2 & 0 & 0 & 1 & 1 \\
\hline 22 & 0 & 1 & 1 & 1 & 0 & 3 & 0 \\
\hline 23 & 0 & 1 & 1 & 0 & 1 & 0 & 0 \\
\hline Total & $\mathbf{6}$ & $\mathbf{1 0}$ & $\mathbf{1 9}$ & $\mathbf{1 1}$ & $\mathbf{7}$ & $\mathbf{1 1}$ & $\mathbf{1 0}$ \\
\hline & & & & & & & \\
\hline
\end{tabular}

Table 5-7: February 2001, Southbound, Lane 2, Class 9 Vehicles exceeding 90,000 Lbs. 


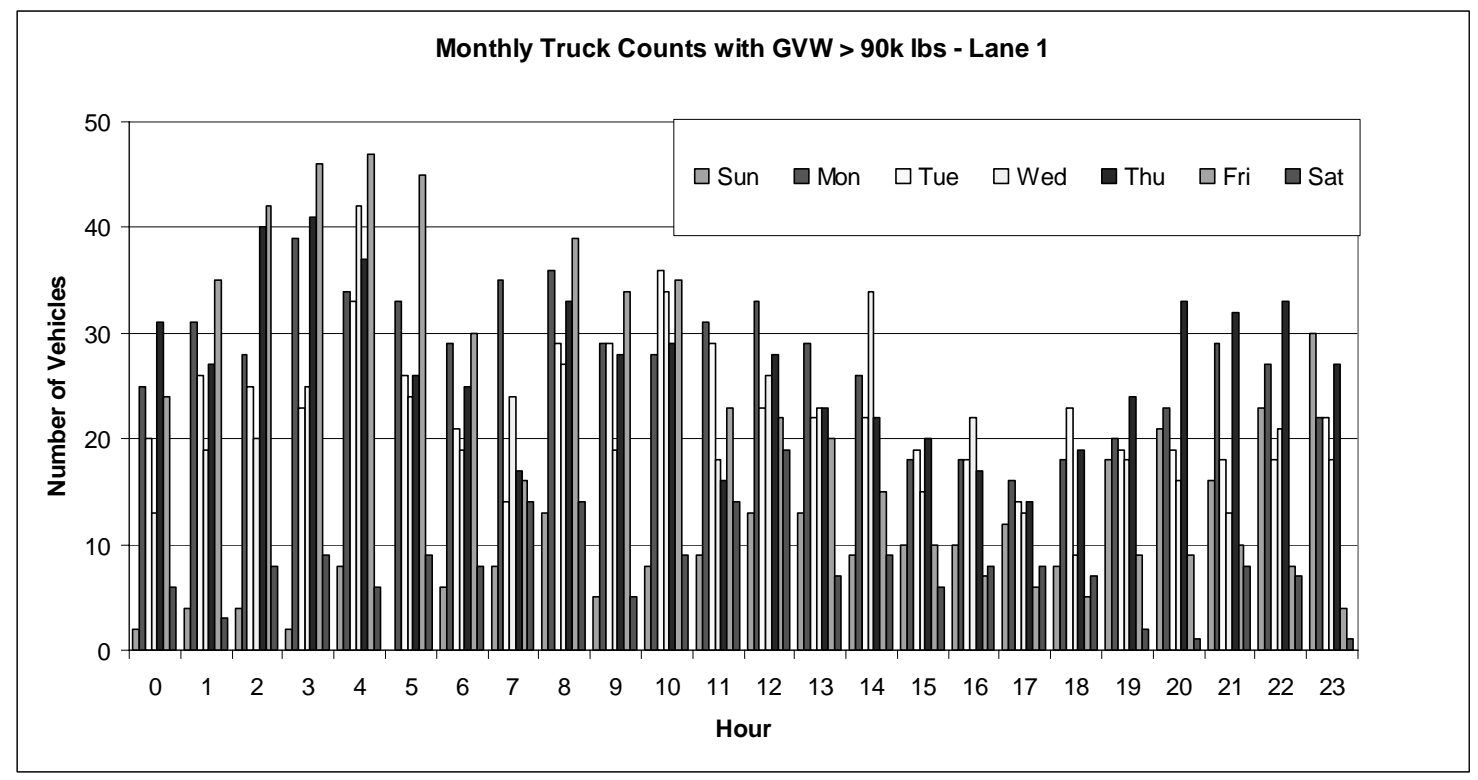

Figure 5-1: Overweight Northbound Lane 1, Class 9 Vehicles

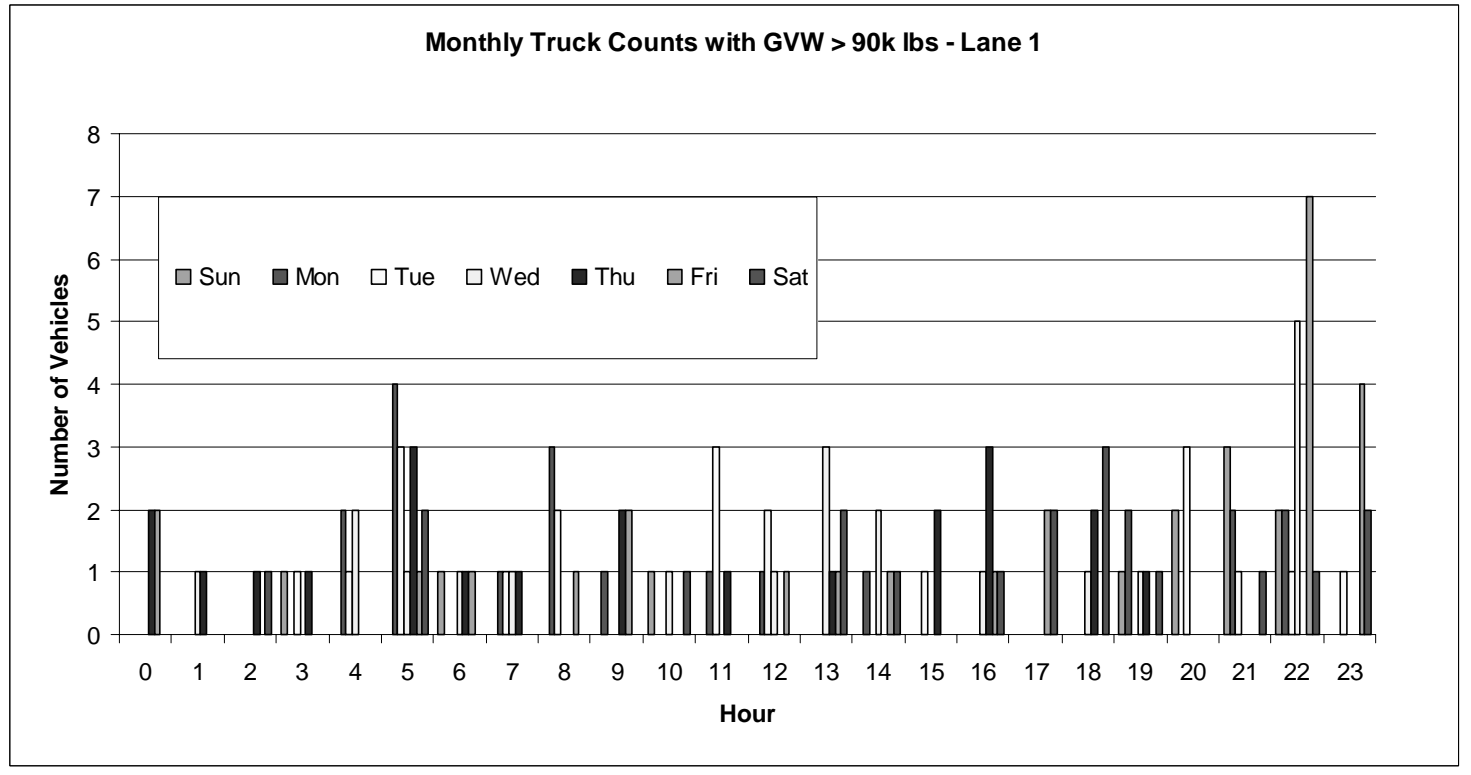

Figure 5-2: Overweight Southbound Lane 1, Class 9 Vehicles 


\subsection{Results from Analysis of February 2001 WIM Data on I-65 at Milepost 253.67}

Careful examination of the tables produces several conclusions about February 2001 traffic:

- Overall, $22.5 \%$ of the Northbound and $13.8 \%$ of the Southbound Class 9 traffic was considered overweight.

- A total of 3414 out of $91,478(3.7 \%)$ Class 9 vehicles exceeded $90,000 \mathrm{lbs}$ in the northbound direction during February 2001.

- A total of 210 out of $106,872(0.2 \%)$ Class 9 vehicles exceeded 90,000 lbs in the southbound direction during February 2001.

- The morning Friday hours in the Northbound direction, say from 2am to 6am, appear to be when most 90,000lb+ vehicles pass the WIM (see Table 5-3). Since there were 4 weeks in this reporting period, during those periods about 10-11 trucks per hour were over 90,000 lbs.

- Mondays and Thursdays are when the largest number of northbound $90,000 \mathrm{lb}+$ vehicles pass the WIM.

Similar analyses were performed for the WIMs on SR 1, US 24, and I-80/I-94. The results are summarized in the memos in Appendix K, Appendix L, Appendix P, and Appendix S.

It is widely recognized that overweight violation rate is inversely related to enforcement visibility [Taylor et al., 2000]. Therefore, the effectiveness of specific detail times and locations should decrease over time as commercial vehicle operators become aware of scheduled operations. When portable-scale detail effectiveness lessens noticeably (or sooner), current WIM traffic data should be gathered and analyzed. In this way, enforcement officers are likely to be in the areas where and when they may intercept the most overweight vehicles.

\subsection{Summary of Enforcement Details}

Several field studies were conducted with the virtual WIM equipment throughout its development. A first test was performed on August 10, 2000 on I-65 at WIM 5450 to test the theory that overweight vehicles could be identified in moderate traffic conditions as they passed over a WIM scale. On January 04, 2001 tests were conducted on I-74 near Covington, Indiana to determine if the prototype "in-vehicle" equipment and Road Runner software were working properly, and to learn if the discrepancies between WIM-recorded GVW and actual (weigh station static-scalerecorded) GVW would be prohibitive for virtual WIM system use. Once the prototype virtual WIM system was 
complete, it was tested under actual field enforcement conditions on March 23, May 08, May 15, May 18, May 21, and May 23 of 2001. The following text summarizes those details.

\subsubsection{Summary of 8-10-00 Tests on I-65, near Lafayette, IN}

INDOT Official Jay Wasson, and Indiana State Police Officers Guy Boruff, Monty Buffum, and Jeff Ligget performed the first Weigh-In-Motion detail on August 19, 2000. This detail was run at WIM scale \#5450 to determine if overweight vehicles could be identified in moderate traffic conditions as they passed over a WIM scale.

The procedure employed was straightforward. Weights were observed on the monitor in the WIM computer cabinet (Figure 4-1). When overweight vehicles crossed the WIM scales the information was communicated to Indiana State Police Commercial Vehicle Enforcement Officers in patrol cars. The selected vehicles were chased, escorted out of traffic, and weighed using Haenni WL101 portable static scales. The WIM data weights were compared to the actual, static scale weights, and it was determined that the vehicles selected for weighing were indeed the trucks selected using the WIM. It was during this detail that the 111,350-Lb, overweight vehicle in Figure 1-1 was caught.

\subsubsection{Summary of the 1-04-01 Tests on I-74, near Covington, IN}

Tests were performed on January 04, 2001 primarily to test the performance of the prototype virtual WIM equipment, and secondarily to test the accuracy of the WIM scale \#5130 on I-74, which is approximately 10 miles West of the Covington, IN static scale installation. Indiana State Police Officers Monty Buffum, Steve Baumgart, Jeff Ligget, and Sharon Branam, and Purdue University researchers John Green and Ed Allen performed the study.

With the prototype "in-vehicle" equipment inside, a patrol car was positioned near WIM scale \#5130 to select and record the weights of vehicles from eastbound traffic. After weights for the vehicle were recorded, a physical description of the vehicle was then radioed to the group members inside the Covington Scale house. When a vehicle matching a description forwarded by the detail near the WIM scale was weighed by the static scales, its individual axle weights and GVW were recorded. Later the data was compared and analyzed to determine accuracy.

The weights of 24 vehicles were compared using the WIM and Covington Weigh Station static scales, representing classes of vehicles 7 through 10 (classes of commonly overweight vehicles). The data collected is shown in Table B-1. A scatter plot graph comparing WIM weights to actual (Covington Scale) weights is shown in Figure B-1. After that detail was completed, it was found that it did not meet INDOT accuracy specifications. Subsequent work by the vendor involved closing a lane to repair a splice and adding additional filtering to get rid of noise. Because a very high level of compliance was observed here, no further details were scheduled. 


\subsubsection{Summary of the Enforcement Details on I-65, near Merrillville, IN}

The completed prototype virtual WIM system was tested to determine its effectiveness in actual enforcement conditions on March 23, May 08, May 15, May 18, May 21, May 23, and May 31 of 2001. The procedure employed for each day of testing was the same. All of the details were performed on I-65 (Northbound) near Merrillville, IN to test the accuracy of WIM site \#4410 and identifying overweight vehicles. The detail teams variously involved Indiana State Police Officers Deb Burkhart, Henry Davis, Scott Fleming, Scott Nagle, and Gerald Young, and Purdue University Researchers John Green and Ed Allen.

The procedure involved observing the weights of vehicles until one registered as overweight on the Road Runner software (on the "in-vehicle" computer) as it crossed the WIM scale heading north. The patrol car using the virtual WIM system then chased the suspected overweight vehicle and escorted it off of the Interstate.

Once off the Interstate, the vehicle was led to a safe location where it was weighed with Haenni static scales. After the individual axle weight and GVW measurements were obtained, appropriate enforcement actions were taken. In the cases of legally operating vehicles, the truck drivers were allowed to leave unhindered. Drivers of those vehicles found to be in violation of one or more Federal and/or State law were given either warnings or issued citations, depending on the severity of their violations. In several cases, the vehicles were found to be so grossly overweight that the vehicles were impounded with the appropriate local authorities. A copy of the report issued to one such vehicle is shown in Figure 5-3.

The actual individual axle weights and GVW of the vehicle were then recorded and compared to determine WIM accuracy. This information was then relayed to a WIM technician from International Road Dynamics, who adjusted factors within the "in-cabinet" WIM system software in an attempt to better calibrate the WIM scale. The combined results of each test are shown in Table 5-8 and in Figure 5-4. Additionally, the results of each enforcement detail are located in Appendix I. When the calibration adjustments were made, the patrol returned to a spot on the shoulder of I-65 to observe and await the next suspected overweight vehicle. As you can see from Figure 5-4, there is a large scatter in the data for this station. Subsequent investigation by IRD has indicated that there is a bad load cell in lane 1. Both load cells in lane 1 were replaced on May 31, 2001. 


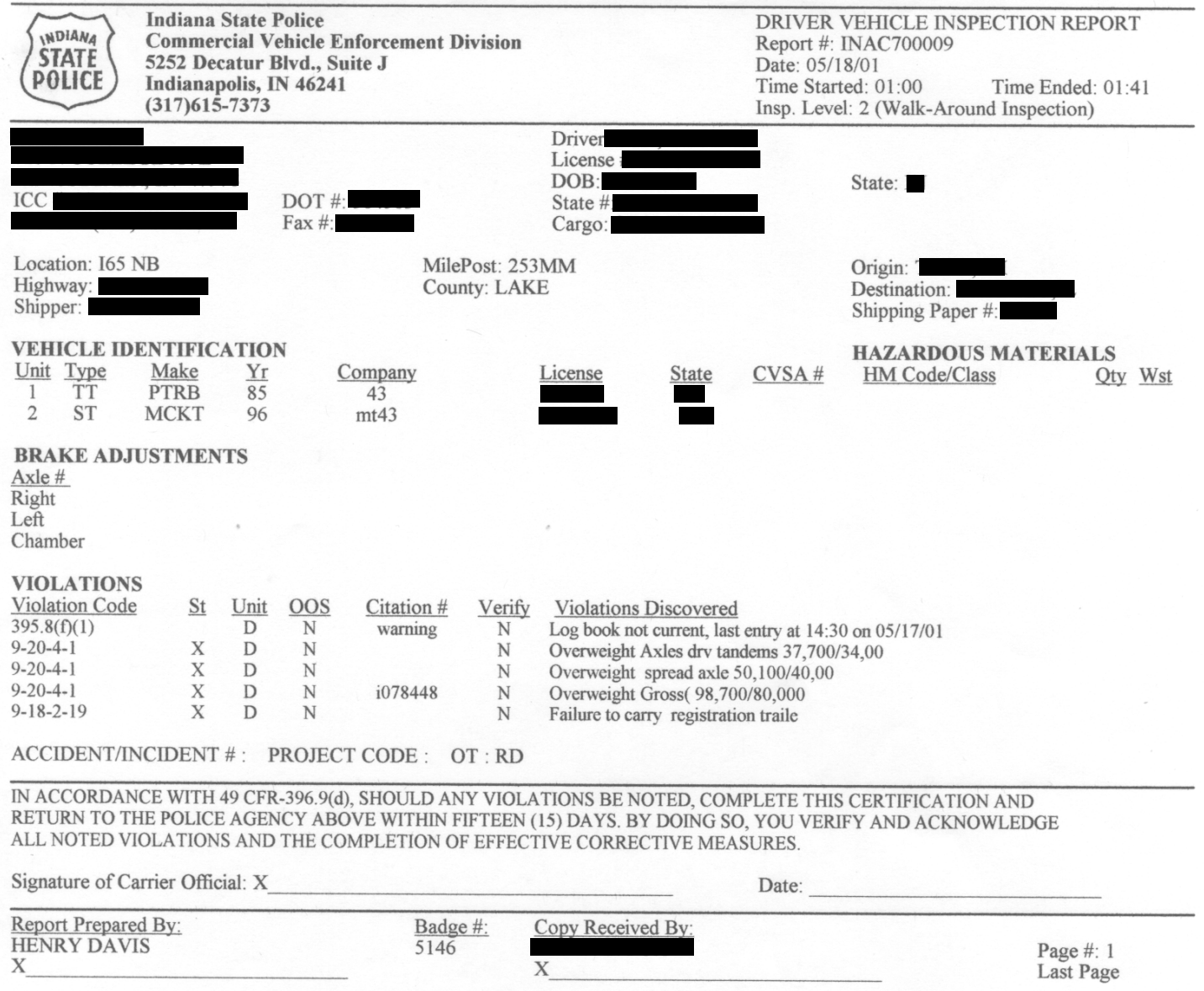

Figure 5-3: Driver Vehicle Inspection Report of Vehicle Impounded by ISP Officer Henry Davis on May 18, 2001, caught using the "In-vehicle" system - GVW was 98,700 Lbs (compared to 80,000 Lbs allowable) 


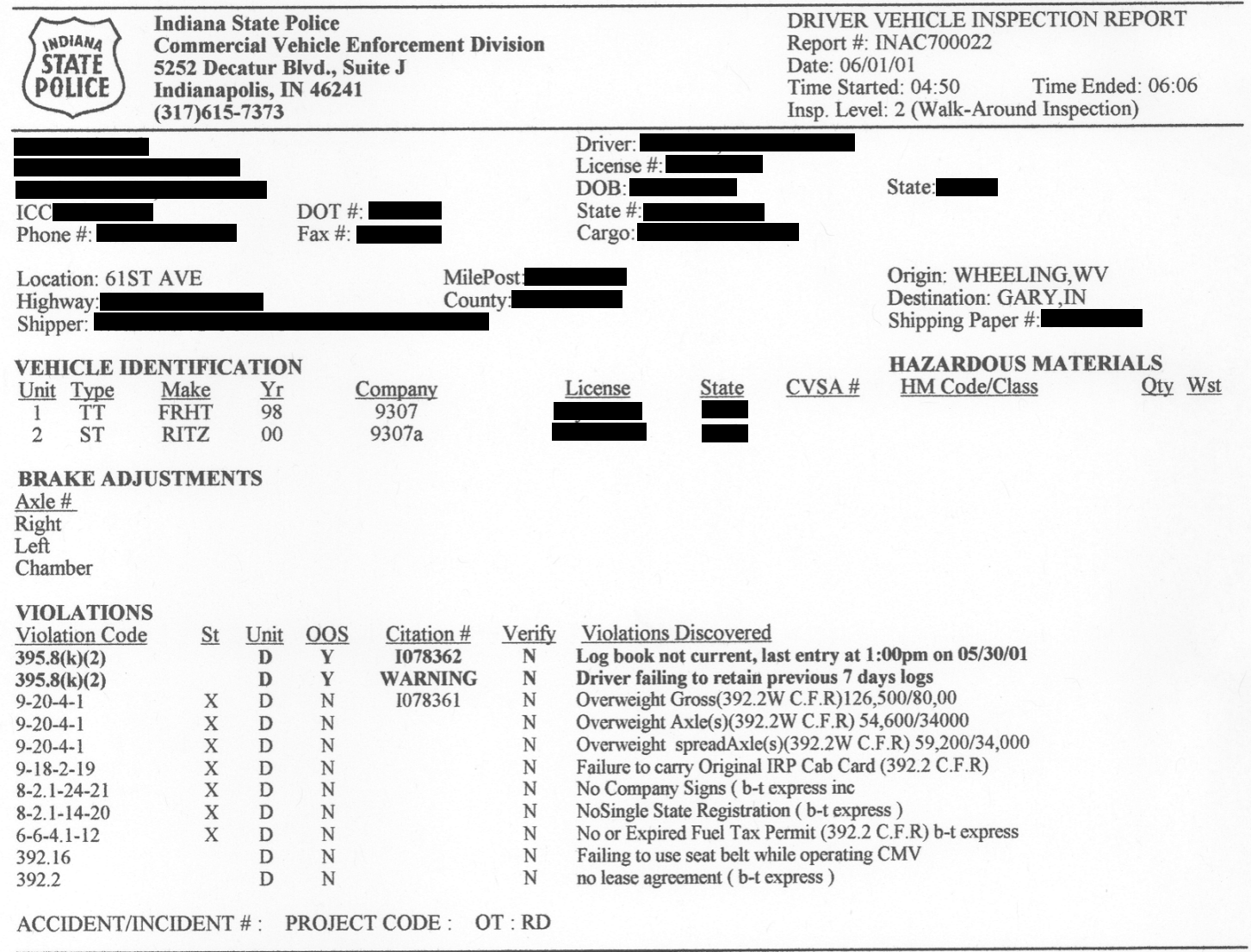

Pursuant to title 49 CFR-395.13(c) and (d)_ is considered OOS until 2:00 PM 06/01/01. No motor carrier shall require or permit a driver, nor shall any driver placed OOS drive any CMV until all terms of the OOS order has been fulfilled. OOS at: $\square$

IN ACCORDANCE WITH 49 CFR-396.9(d), SHOULD ANY VIOLATIONS BE NOTED, COMPLETE THIS CERTIFICATION AND RETURN TO THE POLICE AGENCY ABOVE WITHIN FIFTEEN (15) DAYS. BY DOING SO, YOU VERIFY AND ACKNOWLEDGE ALL NOTED VIOLATIONS AND THE COMPLETION OF EFFECTIVE CORRECTIVE MEASURES

Signature of Carrier Official: $\mathrm{X}$

Date:

\begin{tabular}{|c|c|c|}
\hline $\begin{array}{l}\text { Report Prepared By: } \\
\text { HENRY DAVIS } \\
\text { X }\end{array}$ & $\frac{\text { Badge \#: }}{5146} \quad$ Copy Received By: & $\begin{array}{l}\text { Page \#: } 1 \\
\text { Last Page }\end{array}$ \\
\hline
\end{tabular}

Figure 5-4: Driver Vehicle Inspection Report of vehicle impounded by ISP Officer Henry Davis on June 01, 2001, caught using the "In-vehicle" system. 


\begin{tabular}{|c|c|c|c|c|c|c|c|c|c|c|c|}
\hline Description & Record \# & $\begin{array}{c}\text { Axle } 1 \\
\text { WIM }\end{array}$ & $\begin{array}{l}\text { Axle } 1 \\
\text { Scale }\end{array}$ & $\begin{array}{c}\text { Tandem } 1 \\
\text { WIM }\end{array}$ & $\begin{array}{c}\text { Tandem } 1 \\
\text { Scale }\end{array}$ & $\begin{array}{c}\text { Tandem } 2 \\
\text { WIM }\end{array}$ & $\begin{array}{c}\text { Tandem } 2 \\
\text { Scale }\end{array}$ & GVW WIM & GVW Scale & Error & $\%$ Err \\
\hline CL9/L2 & 008679 & 11,200 & 11,600 & 28,300 & 30,000 & 31,700 & 30,900 & 71,200 & 72,500 & $-1,300$ & $-2 \%$ \\
\hline CL9/L1 & 010093 & 11,800 & 11,900 & 33,200 & 32,800 & 30,400 & 31,300 & 75,400 & 76,000 & -600 & $-1 \%$ \\
\hline CL9/L1 & 011130 & 11,100 & 10,200 & 33,700 & 33,100 & 36,000 & 32,900 & 80,800 & 76,200 & 4,600 & $6 \%$ \\
\hline CL9/L1 & 012132 & 12,500 & 12,200 & 33,100 & 32,200 & 32,200 & 31,000 & 77,800 & 75,400 & 2,400 & $3 \%$ \\
\hline CL9/L1 & 013522 & 12,500 & 12,700 & 31,100 & 32,100 & 35,600 & 32,400 & 79,200 & 77,200 & 2,000 & $3 \%$ \\
\hline CL9/L3 & 015038 & 12,600 & 12,200 & 33,500 & 32,800 & 33,400 & 32,400 & 79,600 & 77,300 & 2,300 & $3 \%$ \\
\hline CL9/L1 & 016548 & 10,400 & 11,100 & 35,000 & 29,000 & 38,700 & 35,400 & 84,000 & 75,400 & 8,600 & $11 \%$ \\
\hline CL9/L2 & 017419 & 11,100 & 11,500 & 31,100 & 32,400 & 33,400 & 34,200 & 75,700 & 78,100 & $-2,400$ & $-3 \%$ \\
\hline CL9/L1 & 018261 & 9,200 & 9,000 & 46,400 & 38,700 & 41,600 & 37,200 & 97,200 & 84,800 & 12,400 & $15 \%$ \\
\hline CL9/L1 - Freight Box & 021143 & 11,500 & 11,750 & 33,500 & 32,400 & 35,500 & 32,800 & 82,600 & 76,950 & 5,650 & $7 \%$ \\
\hline CL9/L1 - Freight Box & 022494 & 10,800 & 10,700 & 34,100 & 35,300 & 36,900 & 32,800 & 81,800 & 78,800 & 3,000 & $4 \%$ \\
\hline CL9/L2 - Grain & 026191 & 11,600 & 12,700 & 34,400 & 39,800 & 37,400 & 41,300 & 83,400 & 93,800 & $-10,400$ & $-11 \%$ \\
\hline CL9/L1 - Steel Coil & 003003 & 10,900 & 11,400 & 44,300 & 32,500 & 29,200 & 32,400 & 84,500 & 76,300 & 8,200 & $11 \%$ \\
\hline CL9/L1 - Container & 005352 & 11,000 & 11,400 & 34,100 & 34,900 & 33,700 & 32,800 & 78,800 & 79,100 & -300 & $0 \%$ \\
\hline CL9/L1 - Freight Box & 005360 & 11,600 & 12,500 & 32,700 & 35,200 & 33,000 & 31,700 & 77,300 & 79,400 & $-2,100$ & $-3 \%$ \\
\hline 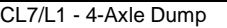 & 004050 & 19,100 & 19,100 & $75500^{*}$ & $50100^{*}$ & 0 & 0 & 93,400 & 69,200 & 24,200 & $35 \%$ \\
\hline CL9/L1 - Short Dump & 009810 & 9,400 & 10,200 & 36,300 & 27,900 & 45,500 & 35,100 & 91,200 & 73,200 & 18,000 & $25 \%$ \\
\hline CL9/L1 - Short Dump & 011336 & 9,400 & 10,400 & 33,000 & 31,100 & 43,300 & 39,300 & 85,700 & 80,800 & 4,900 & $6 \%$ \\
\hline CL9/L2 - Spread Axle & 000500 & 9,800 & 10,900 & 32,500 & 37,700 & 48,000 & 50,100 & 90,400 & 98,700 & $-8,300$ & $-8 \%$ \\
\hline CL9/L2 - Spread Axle & 001244 & 10,900 & 11,800 & 34,400 & 38,600 & 46,300 & 50,200 & 91,500 & 100,600 & $-9,100$ & $-9 \%$ \\
\hline CL9/L1 - Freight Box & 001844 & 11,100 & 12,200 & 37,300 & 35,300 & 35,200 & 33,100 & 83,600 & 80,600 & 3,000 & $4 \%$ \\
\hline CL9/L1 - Freight Box & 002984 & 9,700 & 11,200 & 37,900 & 36,600 & 36,100 & 31,300 & 83,700 & 79,100 & 4,600 & $6 \%$ \\
\hline 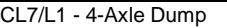 & 009184 & 11,100 & 13,650 & 60,700 & $50,100^{\star}$ & 0 & 0 & 71,900 & 63,750 & 8,150 & $13 \%$ \\
\hline CL9/L1 - Short Dump & 010944 & 8,800 & 9,650 & 31,000 & 25,800 & 35,400 & 32,450 & 75,300 & 67,900 & 7,400 & $11 \%$ \\
\hline CL9/L1 - Short Dump & 012501 & 8,600 & 9,950 & 31,800 & 27,350 & 39,000 & 31,600 & 79,400 & 68,900 & 10,500 & $15 \%$ \\
\hline CL9/L1 - Grain Hauler & 013812 & 9,300 & 10,650 & 38,000 & 40,200 & 38,300 & 38,750 & 85,500 & 89,600 & $-4,100$ & $-5 \%$ \\
\hline CL9/L1 - Steel Hauler & 015951 & 8,300 & 8,450 & 33,500 & 33,250 & 38,900 & 34,000 & 80,800 & 75,700 & 5,100 & $7 \%$ \\
\hline CL9/L1 - Tanker & 010490 & 11,000 & 11,750 & 34,300 & 31,900 & 35,500 & 33,100 & 80,700 & 76,750 & 3,950 & $5 \%$ \\
\hline CL9/L1 - Steel Hauler & 000493 & 10,500 & 9,700 & 38,000 & 36,600 & 32,700 & 37,100 & 81,200 & 83,400 & $-2,200$ & $-3 \%$ \\
\hline CL9/L1 - Timber Hauler & 001301 & 12,500 & 11,800 & 36,800 & 40,700 & 36,700 & 34,100 & 86,200 & 86,600 & -400 & $0 \%$ \\
\hline CL9/L1 - Steel Hauler & 002706 & 13,800 & 12,700 & 47,700 & 54,600 & 51,600 & 59,200 & 113,200 & 126,500 & $-13,300$ & $-11 \%$ \\
\hline
\end{tabular}

Table 5-8: Combined Results of Enforcement Details

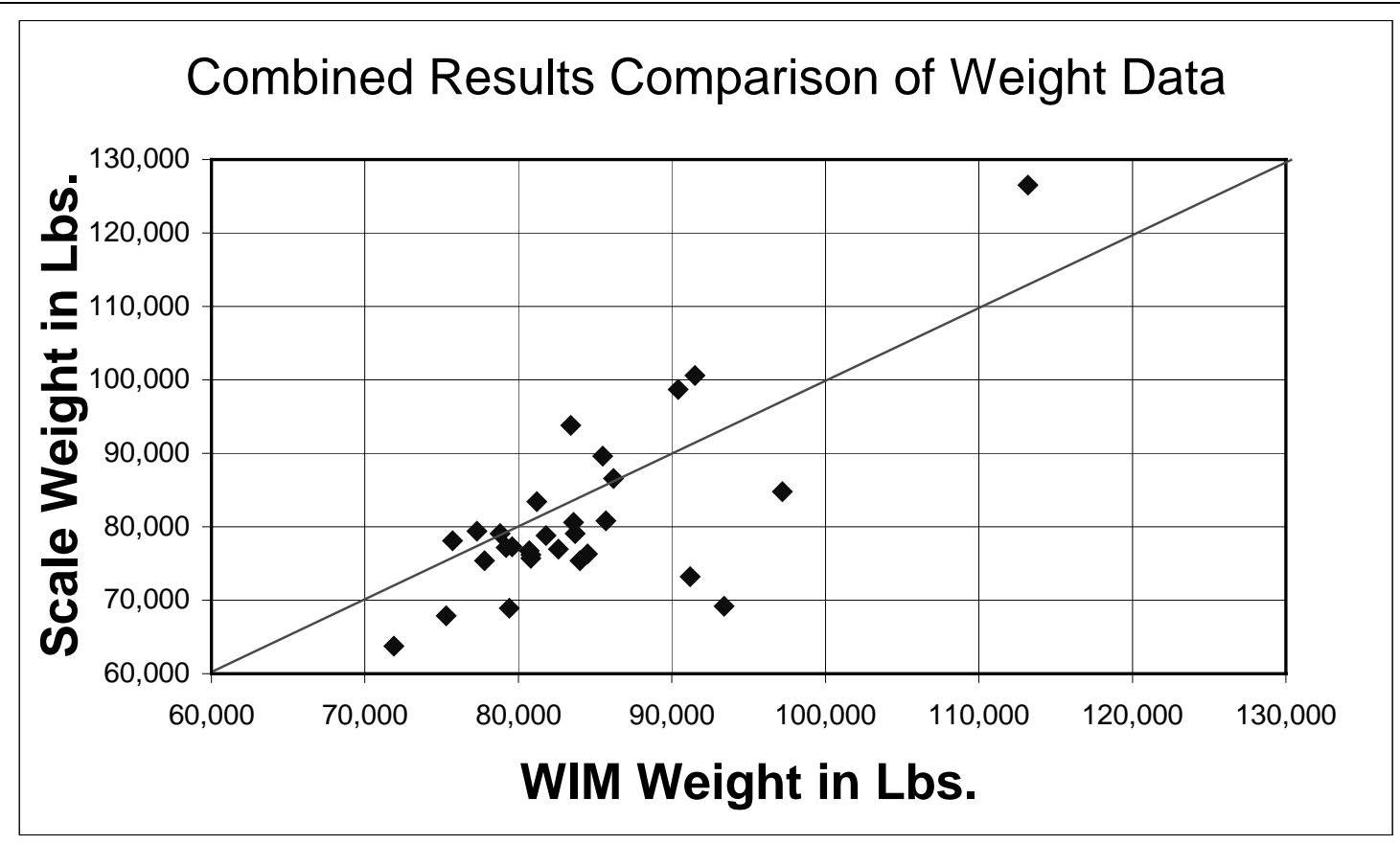

Figure 5-5: Graphical Comparison of Combined WIM to Scale Weight 
5.3.4 Summary of the Enforcement Details on US 24, near Fort Wayne, IN

On September 18, 2001, an enforcement was conducted at the WIM on US 24. Six trucks were stopped and weighed on the pulloff areas located to the east and west of the WIM. One truck was found to be overweight and was placed out of service because of a fuel leak. A summary of this detail can be found in the memo in Appendix $\mathrm{N}$.

After the software was installed on the CVE laptops and the hardware kits provided, the CVE officers conducted enforcement details at their own discretion. CVE officers periodically monitored the US 24 WIM beginning in February 2002. During the month of February, ten trucks were pulled over and weighed. Seven of the ten trucks were found to be in violation of weight limit laws. Based on the data collected, the calibration factors in the WIM station were adjusted by $-7.7 \%$ in the eastbound direction and $+3.9 \%$ in the westbound direction. A summary of the enforcement detail and calibration adjustment can be found in the memo in Appendix $\mathrm{O}$.

\subsubsection{Summary of the Enforcement Details on I-65, near Merrillville, IN}

An enforcement detail was conducted at the WIM on I-65 near Merrillville on April 12, 2002. Three trucks were pulled over and weighed. All three were determined to be overweight and issued fines. A summary of the enforcement can be found in the memo in Appendix $Q$. 


\section{Conclusions}

There is a need for real-time monitoring of Weigh In Motion sites around the state and reporting of summary statistics on the web. For example, Table 5-3 through Table 5-5, Figure 5-1 and Figure 5-2 resulted in identifying the early morning hours as the best time for enforcement in Merrillville. As a result, on May 18, 2001 vehicles weighing $98,700 \mathrm{lbs}$ and 100,600 lbs were stopped. Those vehicles were impounded and resulted in fines of $\$ 1,625.00$ and $\$ 1735.00$ respectively. In February 2002, Commercial Vehicle Enforcement officers stopped ten trucks on US 24 near Fort Wayne using the virtual weigh station. Eight of the trucks were determined to be overweight and fined. The three heaviest trucks weighed $90,200 \mathrm{lbs}, 90,900 \mathrm{lbs}$, and $91,100 \mathrm{lbs}$ resulting in fines of $\$ 1,099.50, \$ 1,169.50$, and $\$ 1,189.50$, respectively. On April 12, 2002, another enforcement was conducted on I-65 near Merrillville. Three trucks were stopped based on the virtual weigh station data. One of the trucks weighed $87,400 \mathrm{lbs}$, resulting in a $\$ 529.50$ fine. There is an urgent need to perfect the tools and procedures of the Virtual Weigh Station concept so that these tools can be deployed statewide. To support that objective, the following points should be considered:

- Online data analysis procedures should be developed that permit rapid diagnosis of WIM calibration problems. This online diagnosis should have two components:

- Tabulation, by lane, of unclassified vehicles. The number of unclassified vehicles should not exceed $10 \%$ for any lane. The historical unclassified vehicle error rate should be presented in a format similar to Figure E-53. The memo in Appendix E identifies only 3 stations providing this level of accuracy in October 2000. Those stations were 4250, 5260, and 6260. All of those stations had only a WIM in a single lane.

- A crude evaluation of the accuracy and precision of a WIM can be estimated by looking at the distribution of the front-axle weights. The thresholds shown in Table $\mathrm{H}-17$ provide a starting point for constructing tables similar to Table $\mathrm{H}-18$ and Table $\mathrm{H}-19$.

- A relative comparison of all front axles means should be performed on a monthly basis using a plot similar to Figure $\mathrm{H}-1$ constructed for data in Table $\mathrm{H}-1$ through Table $\mathrm{H}-4$.

- The wireless communication link is reasonably reliable with the radios shown in Appendix J. However, in the Merrillville area occasional interference will interrupt communications for up to 30 seconds. Some considerations may be given to using more sophisticated radios with a frequency hopping scheme. One radio system that might be considered is manufactured by California Microwave. It is currently used by INDOT in closed loop traffic signal systems.

- At larger WIM installations where more than 4 lanes are being monitored, the IRD system uses separate processing units. As a result, not all lanes can be connected simultaneously via a single radio link. The 
current procedure is to manually move the cable between systems. Some further study of the most appropriate procedure for handling this should be performed.

The following amendments to the INDOT WIM specification are suggested:

- “. . . documentation shall be furnished that completed installation confirms the ASTM pavement smoothness specification defined in the ASTM WIM standard E1318-94 at time of acceptance and possibly warrant smoothness for 2 years." This amendment is proposed because some of the recently completed WIM installations do not appear to confirm to the required smoothness specifications. Actually verifying conformance would require a lane closure.

- “. . . a vehicle used for calibrating a WIM shall travel across the WIM at the average speed of Class 9 trucks. Documentation of the average speed of Class 9 trucks shall be provided by WIM records for Class 9 trucks during a weekday from 9am to 4pm." This amendment is proposed because one of the sources of calibration error was thought to be that calibration trucks were not always traveling at the prevailing speed of Class 9 trucks. In Merrillville that difference was about $10 \mathrm{mph}$.

- ". . . a vehicle used for calibration shall not be in violation of any Indiana laws." This amendment is proposed because the truck used to calibrate the Merrillville WIM had a tandem load of $43,400 \mathrm{lbs}$. Subsequent discussion with IRD indicated this might have caused calibration problems for lower axle weight vehicles.

- “. . . a WIM shall not be accepted by INDOT until telephone service has been operational for 30 consecutive days and the log files uploaded." This amendment is proposed because it is very difficult to determine if a site is operating properly unless a month or so of data files, including rainy days, are uploaded and IRD error reports are run on the uploaded data.

- “. . . the panel shown in Figure J-1 with component, shown in Figure J-2, shall be furnished and installed as part of WIM system." This amendment is proposed so that all new WIMs will be accessible as a virtual scale as soon as they are turned on.

Regarding the use of WIMs for data collection purposes:

- $\quad$ Based upon the sensitivity analysis performed in Chapter 2 (Table 2-3 and Figure 2-4), we believe a WIM should provide accurate axle weights within 6\% (ASTM Type III) in order to effectively estimate ESALs used to compute pavement life. Based upon observations at new single load cell installations (4410 and 5130), it is not clear whether any of the current installed systems are calibrated to this accuracy. A detailed evaluation at all Single Load Cell Sites (4130, 4150, 4410, 4420, 5110, 5120, and 5130) should be 
conducted with Summer 2001 data, and field checks performed with Indiana Commercial Vehicle Enforcement Officers.

- Several of the older WIMs using Piezo technology are experiencing severe pavement distress and have likely reached the end of their useful life. Those stations would be of little value to a virtual weigh station concept and are likely of little value for data collection. Consideration should be given to abandoning all Piezo WIM sites and perhaps all Bending Plate sites and devoting those additional resources to improved maintenance on the remaining sites.

- The WIMs that are most promising for the Virtual Weigh Station concept are the relatively new Single Load Cell installations. For example, from Table H-18, WIM 5110 on I-70 appears to hold some promise. However, some calibration and tuning will likely be required to eliminate some of the classification errors shown in Figure E-48.

On a concluding note, the "online data analysis" procedure recommended needs to also include checks in the standard IRD report and be highly automated so they can be performed on a daily or weekly basis.

Finally, the diversion route study and the video capture portion of this project have not been performed to date. A revised work plan is currently being developed to address these proposed tasks. 
Appendix A WIM Station Configuration 


\begin{tabular}{|c|c|c|c|c|}
\hline Station & Type & Ref. Marker & Location & Side \\
\hline 4110 & WIM & 218.38 & ON I-65 3.64 MILES N OF SR 114 & NB \\
\hline 4130 & WIM & 038.03 & ON I-94 1.92 MILES W OF US 20/35 & EB \\
\hline 4140 & WIM & 068.26 & ON I-69 4.16 MILES N OF SR 18 & SB \\
\hline 4150 & WIM & 137.88 & ON I-69 2.53 MILES S OF SR 4 & SB \\
\hline 4240 & WIM & 035.30 & ON SR 491.58 MILES S OF US 6 & NB \\
\hline 4250 & WIM & 065.18 & ON SR 22.84 MILES W OF US 20 & WB \\
\hline 4260 & WIM & 216.98 & ON US 310.66 MILES S OF SR 10 & NB \\
\hline 4270 & WIM & 087.62 & ON US 244.49 MILES W OF SR 115 & WB \\
\hline 4280 & WIM & 100.16 & ON US 27/33 6.26 MILES S OF I-469 & SB \\
\hline 4400 & WIM & 013.40 & ON I-80/94 1.56 MILES E OF I-65 & WB \\
\hline 4410 & WIM & 253.67 & ON I-65 0.70 MI N OF US 30 (NB) & NB \\
\hline 4420 & WIM & 253.67 & ON I-65 0.70 MI N OF US 30 (SB) & NB \\
\hline 4440 & WIM & 005.96 & ON I-80/94 0.89 MILES E OF SR 912 (CLINE) & EB \\
\hline 4900 & WIM & 032.01 & ON I-80/90 0.97 MI E OF SR 49 & WB \\
\hline 4910 & WIM & 071.60 & ON I-80/90 0.49 MI W OF US 31 & WB \\
\hline 4920 & WIM & 079.42 & ON I-80/90 2.61 MI W OF SR 933 & WB \\
\hline 5110 & WIM & 107.98 & ON I-70 4.33 MILES E OF SR 9 & EB \\
\hline 5120 & WIM & 079.09 & ON I-65 1.00 MILES S OF SR 252 & SB \\
\hline 5130 & WIM & 004.84 & ON I-74 0.60 MILES E OF SR 63 & WB \\
\hline 5140 & WIM & 155.49 & ON I-70 0.52 MILES W OF US 40 & EB \\
\hline 5240 & WIM & 199.87 & ON US 411.27 MILES S OF SR 18 & SB \\
\hline 5250 & WIM & 096.70 & ON SR 372.84 MILES S OF SR 45 SB & SB \\
\hline 5260 & WIM & 172.25 & ON SR 371.18 MILES S OF SR 238 & SB \\
\hline 5270 & WIM & 000.54 & ON SR 332 0.54 MILES E OF I-69 & WB \\
\hline 5440 & WIM & 007.52 & ON I-70 0.68 MILES E OF US 41 & WB \\
\hline 5450 & WIM & 175.94 & ON I-65 0.78 MILES N OF SR 25 & NB \\
\hline 5460 & WIM & 010.02 & ON I-465 (W. SIDE) 0.70 MILES N OF I-70 & SB \\
\hline 5470 & WIM & 102.54 & ON I-65 0.65 MILES S OF Southport Rd. & NB \\
\hline 5480 & WIM & 042.41 & ON I-465 (E. SIDE) 0.97 MILES S OF US 36 & SB \\
\hline 5550 & WIM & 125.65 & ON US 312.27 MILES N OF I-465 & NB \\
\hline 6130 & WIM & 002.16 & ON I-164 0.75 MILES W OF Green River Rd. & WB \\
\hline 6140 & WIM & 027.92 & ON I-64 1.53 MILES W OF I-164 / SR 57 & EB \\
\hline 6150 & WIM & 054.82 & ON I-64 1.22 MILES E OF SR 161 & EB \\
\hline 6160 & WIM & 116.96 & ON I-64 0.98 MILES W OF SR 62/64 & EB \\
\hline 6170 & WIM & 169.77 & ON I-74 0.82 MILES E OF US 52 & EB \\
\hline 6250 & WIM & 012.51 & ON SR 622.58 MILES E OF SR 69 & WB \\
\hline 6260 & WIM & 018.72 & ON SR 660.97 MILES W OF SR 65 & EB \\
\hline 6270 & WIM & 047.65 & ON SR 662.97 MILES W OF SR 161 & WB \\
\hline 6280 & WIM & 024.11 & ON US 502.34 MILES E OF SR 257 & EB \\
\hline 6290 & WIM & 137.40 & ON US 501.08 MILES W OF US 421 NB & WB \\
\hline 6420 & WIM & 004.63 & ON I-65 0.89 MILES S OF I-265 & SB \\
\hline
\end{tabular}


Figure $A-1$

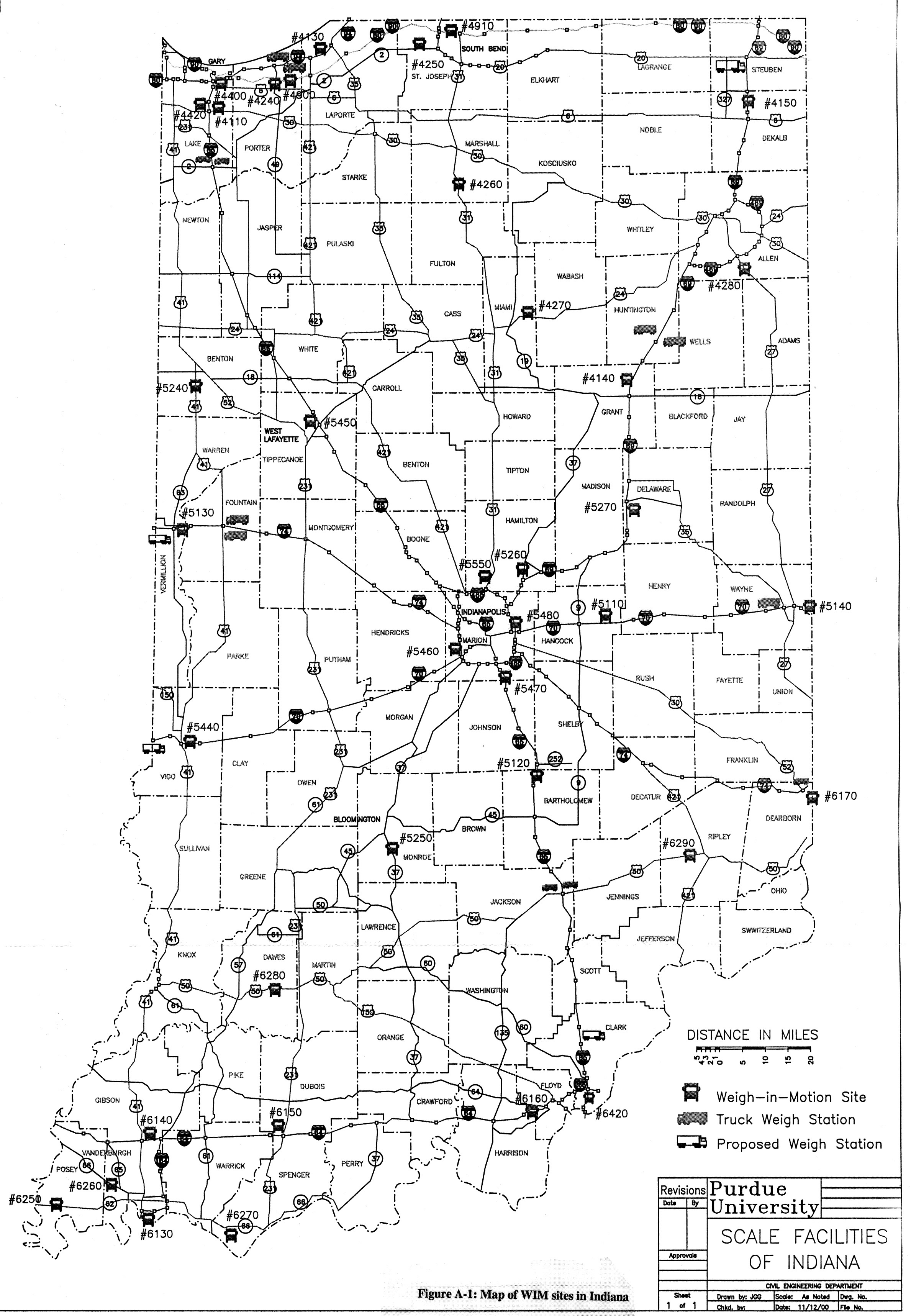




\begin{tabular}{|c|c|c|c|c|c|c|}
\hline $\begin{array}{l}\text { Station \#: } \\
0101\end{array}$ & $\begin{array}{l}\text { Route \#: } \\
\text { 052-US }\end{array}$ & $\begin{array}{l}\text { Location: } \\
\text { ON US 52/231 } 1.52 \text { MILES W OF US } 231 \text { SB }\end{array}$ & $\begin{array}{l}\text { Ref. Mkr.: } \\
041.67\end{array}$ & $\begin{array}{l}\text { County: } \\
\text { TIPPECANOE }\end{array}$ & $\begin{array}{l}\text { District: } \\
\text { CRAWFORDSVILLE }\end{array}$ & $\begin{array}{l}\text { Sub-district: } \\
\text { FOWLER }\end{array}$ \\
\hline 0102 & 231-US & ON US 2312.78 MILES N OF SR 28 & 196.03 & TIPPECANOE & CRAWFORDSVILLE & CRAWFORDSVILLE \\
\hline 0103 & 136-US & ON US 1364.23 MILES E OF SR 25 SB & 031.31 & MONTGOMERY & CRAWFORDSVILLE & CRAWFORDSVILLE \\
\hline 0104 & ו & ON I-65 1.46 MILES S OF SR 267 & 131.89 & BOONE & CRAWFORDSVILLE & FRANKFORT \\
\hline 0105 & 041-US & ON US 415.63 MILES S OF I-70 & 104.22 & VIGO & CRAWFORDSVILLE & TERRE HAUTE \\
\hline 0106 & - ו- & ON I-70 3.22 MILES E OF SR 59 & 025.80 & CLAY & CRAWFORDSVILLE & TERRE HAUTE \\
\hline 0107 & 042-SR & ON SR 420.81 MILES E OF SR 59 & 012.21 & CLAY & CRAWFORDSVILLE & TERRE HAUTE \\
\hline 0108 & $065-1$ & ON I-65 1.98 MILES S OF SR 18 & 185.95 & WHITE & CRAWFORDSVILLE & FOWLER \\
\hline 0109 & ו-074 & ON I-74 1.54 MILES W OF I-465 & 071.76 & MARION & CRAWFORDSVILLE & CRAWFORDSVILLE \\
\hline 0201 & 120-SR & ON SR 1200.92 MILES W OF SR 13 & 013.85 & ELKHART & FORT WAYNE & GOSHEN \\
\hline 0202 & 006-US & ON US 60.94 MILES W OF SR 15 & 093.56 & ELKHART & FORT WAYNE & GOSHEN \\
\hline 0203 & 015-SR & ON SR 150.88 MILES N OF US 30 & 060.03 & KOSCIUSKO & FORT WAYNE & WARSAW \\
\hline 0204 & 069-I & ON I-69 1.92 MILES N OF SR 14 & 107.19 & ALLEN & FORT WAYNE & FORT WAYNE \\
\hline 0205 & 930-SR & ON SR 9303.06 MILES W OF I-469 & 010.39 & ALLEN & FORT WAYNE & FORT WAYNE \\
\hline 0206 & 069-I & ON I-69 0.65 MILES N OF SR 5 & 078.18 & HUNTINGTON & FORT WAYNE & BLUFFTON \\
\hline 0207 & 124-SR & ON SR 1243.86 MILES E OF SR 3 & 041.01 & WELLS & FORT WAYNE & BLUFFTON \\
\hline 0208 & $101-S R$ & ON SR 1011.28 MILES S OF US 224 & 039.79 & ADAMS & FORT WAYNE & BLUFFTON \\
\hline 0209 & - I & ON I-69 2.52 MILES S OF SR 4 & 137.89 & DEKALB & FORT WAYNE & ANGOLA \\
\hline 0301 & 009-SR & ON SR 90.71 MILES N OF SR 32 EB & 073.07 & MADISON & GREENFIELD & GREENFIELD \\
\hline 0302 & 032-SR & ON SR 320.69 MILES E OF SR 9 & 107.69 & MADISON & GREENFIELD & GREENFIELD \\
\hline 0303 & 035-US & ON US 350.80 MILES N OF SR 32 & 044.51 & DELAWARE & GREENFIELD & ALBANY \\
\hline 0304 & 001-SR & ON SR 10.31 MILES S OF SR 32 EB & 084.53 & RANDOLPH & GREENFIELD & ALBANY \\
\hline 0305 & 037-SR & ON Old SR 371.96 MILES S OF I-465 & 161.93 & MARION & GREENFIELD & INDIANAPOLIS \\
\hline 0306 & $465-1$ & ON I-465 0.72 MILES N OF I-69 & 036.15 & MARION & GREENFIELD & INDIANAPOLIS \\
\hline 0307 & $465-1$ & ON I-465 0.60 MILES S OF US 40 EB & 046.26 & MARION & GREENFIELD & INDIANAPOLIS \\
\hline 0308 & 040-US & ON US 404.91 MILES E OF SR 9 & 103.27 & HANCOCK & GREENFIELD & GREENFIELD \\
\hline 0309 & 031-US & ON US 311.16 MILES S OF I-465 & 106.07 & MARION & GREENFIELD & INDIANAPOLIS \\
\hline 0310 & 044-SR & ON SR 444.32 MILES W OF SR 3 & 051.05 & RUSH & GREENFIELD & GREENFIELD \\
\hline 0311 & $065-1$ & S OF LAFAYETTE RD & 119.67 & MARION & GREENFIELD & INDIANAPOLIS \\
\hline 0312 & $465-1$ & ON I-465 0.85 MILES E OF I-65 & 052.39 & MARION & GREENFIELD & INDIANAPOLIS \\
\hline 0401 & ו ו-080 & ON I-80/94 1.55 MILES E OF I-65 & 013.39 & LAKE & LaPORTE & GARY \\
\hline 0402 & 020-US & ON US 200.12 MILES W OF SR 520 & 036.48 & PORTER & LaPORTE & LaPORTE \\
\hline
\end{tabular}

Table A-2: List of Automatic Traffic Recording Sites in Indiana 


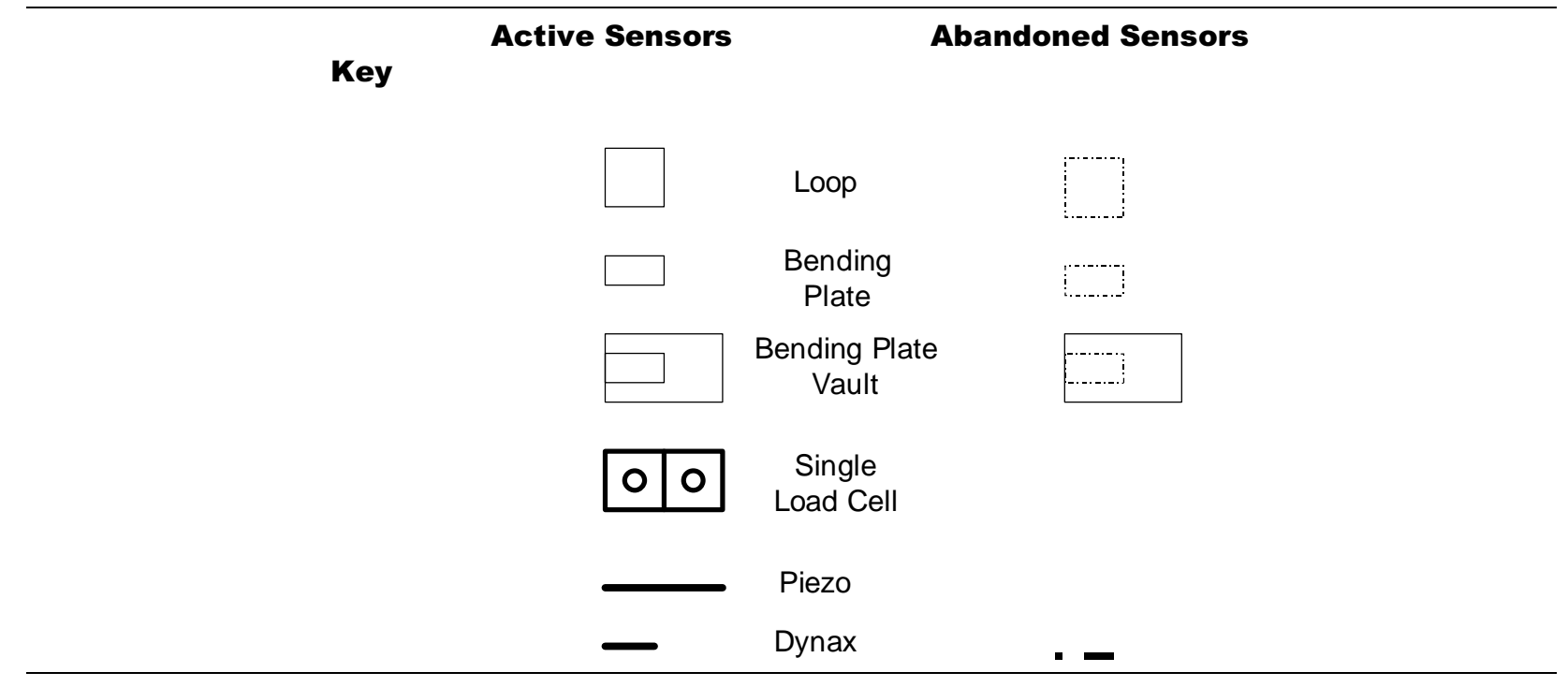

Figure A-2: Schematic Key

\begin{tabular}{|c|c|c|}
\hline Piezo & $=$ & Piezo-Electric Sensor \\
\hline SLC & $=$ & Single Load Cell \\
\hline CLS & $=$ & Classification Only \\
\hline BP & $=$ & Bending Plate \\
\hline BP-V & $=$ & Bending Plate Vault \\
\hline C & $=$ & Concrete Pavement \\
\hline A & $=$ & Asphalt Pavement \\
\hline
\end{tabular}

Table A-3: List of Abbreviations Used

\begin{tabular}{lll}
\hline 1 & $=$ & Road and Sensors Bad \\
2 & $=$ & Road Determination / Sensor Determination \\
3 & $=$ & Road Cracking \\
4 & $=$ & Sensors O.K. \\
5 & $=$ & Sensors in Road in Good Shape \\
6 & $=$ & Ideal Conditions \\
+ & $=$ & Slightly Higher \\
- & $=$ & Slightly Lower
\end{tabular}

Table A-4: Klepinger Pavement Evaluation Scale, March 2001 


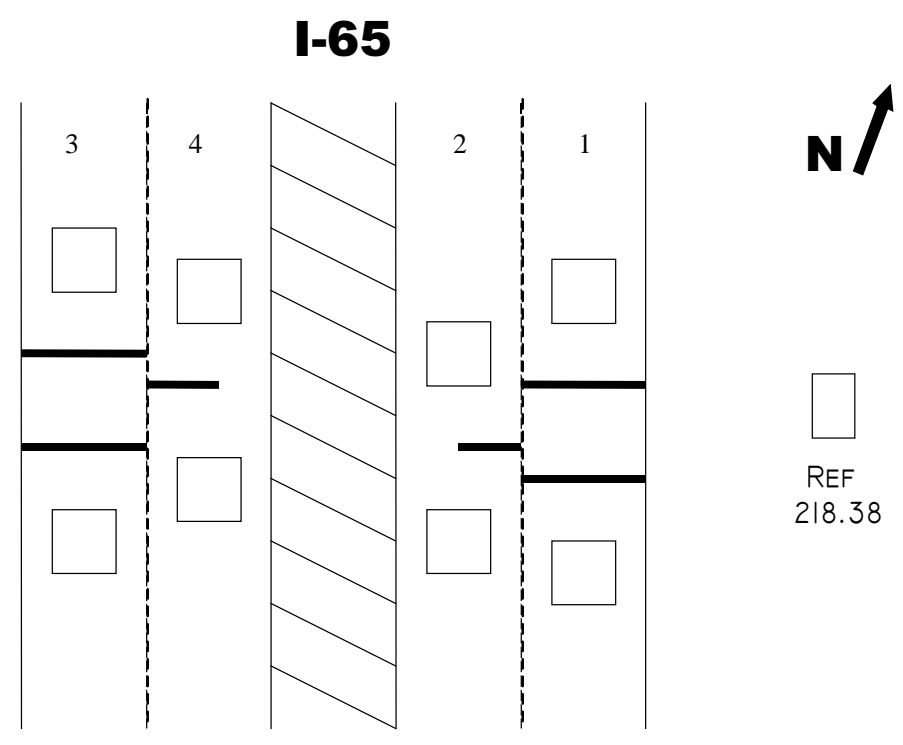

Figure A-3: Station 4110 Four Lane Divided

\begin{tabular}{|c|c|c|c|c|}
\hline & Lane 1 & Lane 2 & Lane 3 & Lane 4 \\
\hline WIM & $\mathrm{X}$ & & $\mathrm{X}$ & \\
\hline Classification & & $\mathrm{X}$ & & $\mathrm{X}$ \\
\hline Sensor & PIEZO & CLS & PIEZO & CLS \\
\hline Pavement & C & C & C & C \\
\hline $\begin{array}{c}\text { Suitable for VWS } \\
6 / 00 \text { (F. Axle) }\end{array}$ & YES & & NO & \\
\hline $\begin{array}{c}\text { Suitable for VWS } \\
10 / 00 \text { (Class.) }\end{array}$ & YES & & NO & \\
\hline $\begin{array}{c}\text { Suitable for VWS } \\
\text { 3/01 (F. Axle) }\end{array}$ & NO & & NO & \\
\hline Klepinger Scale & 4 & 4 & 4 & 4 \\
\hline Calibration Dates & \multicolumn{2}{|c|}{$3-22-99,8-12-99$} \\
\hline
\end{tabular}

Table A-5: Station 4110 Inventory 


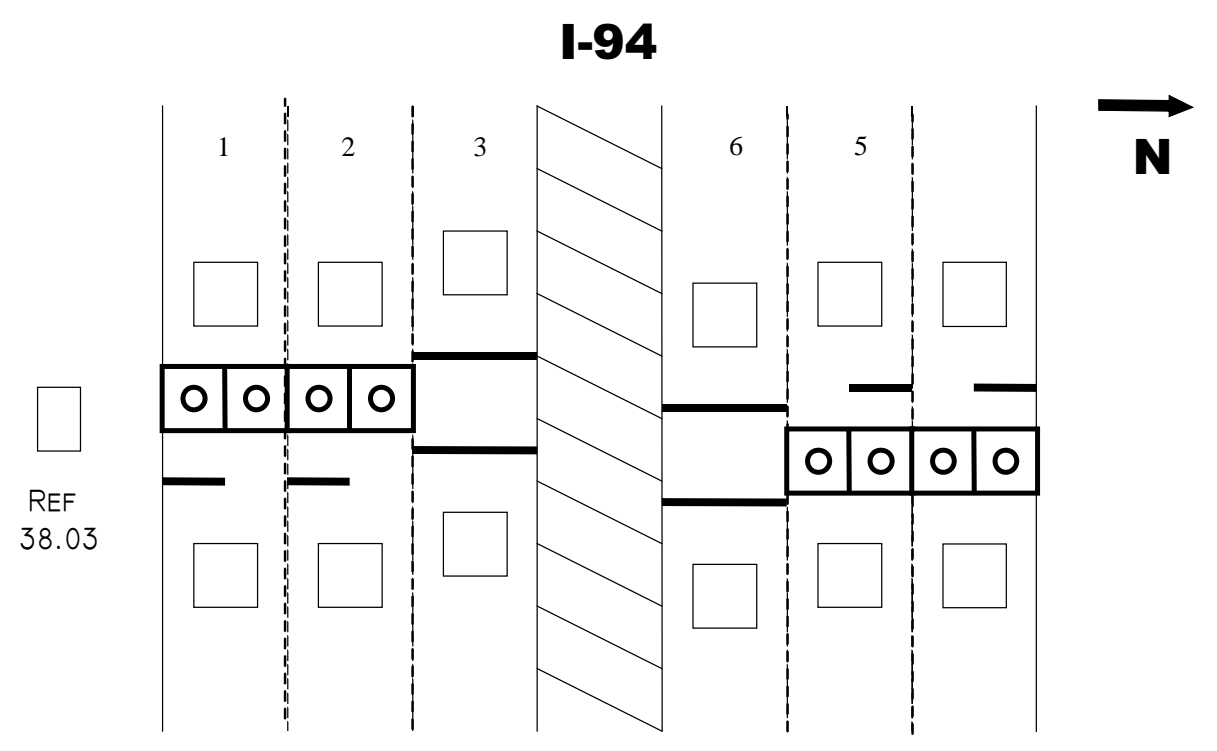

Figure A-4: Station 4130 Six Lane Divided

\begin{tabular}{|c|c|c|c|c|c|c|}
\hline & Lane 1 & Lane 2 & Lane 3 & Lane4 & Lane 5 & Lane 6 \\
\hline WIM & $\mathrm{X}$ & $\mathrm{X}$ & $\mathrm{X}$ & $\mathrm{X}$ & $\mathrm{X}$ & $\mathrm{X}$ \\
\hline Classification & & & & & & \\
\hline Sensor & SLC & SLC & PIEZO & SLC & SLC & PIEZO \\
\hline Pavement & $\mathrm{C}$ & $\mathrm{C}$ & $\mathrm{C}$ & $\mathrm{C}$ & $\mathrm{C}$ & $\mathrm{C}$ \\
\hline $\begin{array}{c}\text { Suitable for VWS } \\
6 / 00 \text { (F. Axle) }\end{array}$ & YES & YES & NO & NO & YES & NO \\
\hline $\begin{array}{c}\text { Suitable for VWS } \\
10 / 00 \text { (Class.) }\end{array}$ & NO & NO & YES & NO & NO & YES \\
\hline $\begin{array}{c}\text { Suitable for VWS } \\
3 / 01 \text { (F. Axle) }\end{array}$ & YES & YES & NO & NO & NO & NO \\
\hline Klepinger Scale & 5 & 5 & 5 & 5 & 5 & 5 \\
\hline Calibration Dates & & & & & & \\
\hline
\end{tabular}

Table A-6: Station 4130 Inventory 


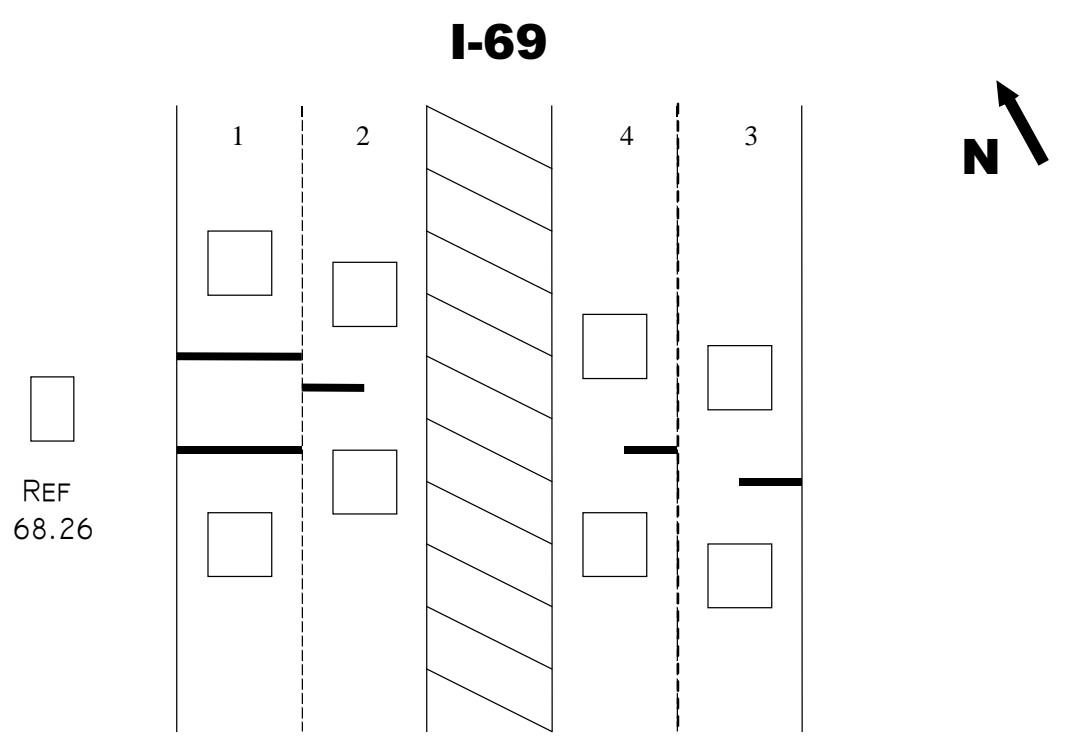

Figure A-5: Station 4140 Four Lane Divided

\begin{tabular}{|c|c|c|c|c|}
\hline & Lane 1 & Lane 2 & Lane 3 & Lane 4 \\
\hline WIM & $\mathrm{X}$ & & & \\
\hline Classification & & $\mathrm{X}$ & $\mathrm{X}$ & $\mathrm{X}$ \\
\hline Sensor & PIEZO & CLS & CLS & CLS \\
\hline Pavement & C & C & C & C \\
\hline $\begin{array}{c}\text { Suitable for VWS } \\
\text { 6/00 (F. Axle) }\end{array}$ & NO & & & \\
\hline $\begin{array}{c}\text { Suitable for VWS } \\
10 / 00 \text { (Class.) }\end{array}$ & NO & & & \\
\hline $\begin{array}{c}\text { Suitable for VWS } \\
\text { 3/01 (F. Axle) }\end{array}$ & YES & & & \\
\hline Klepinger Scale & 4 & 4 & $4-$ & $4-$ \\
\hline Calibration Dates & \multicolumn{2}{|c|}{$1-15-98,7-15-99,11-30-00$} \\
\hline
\end{tabular}

Table A-7: Station 4140 Inventory 


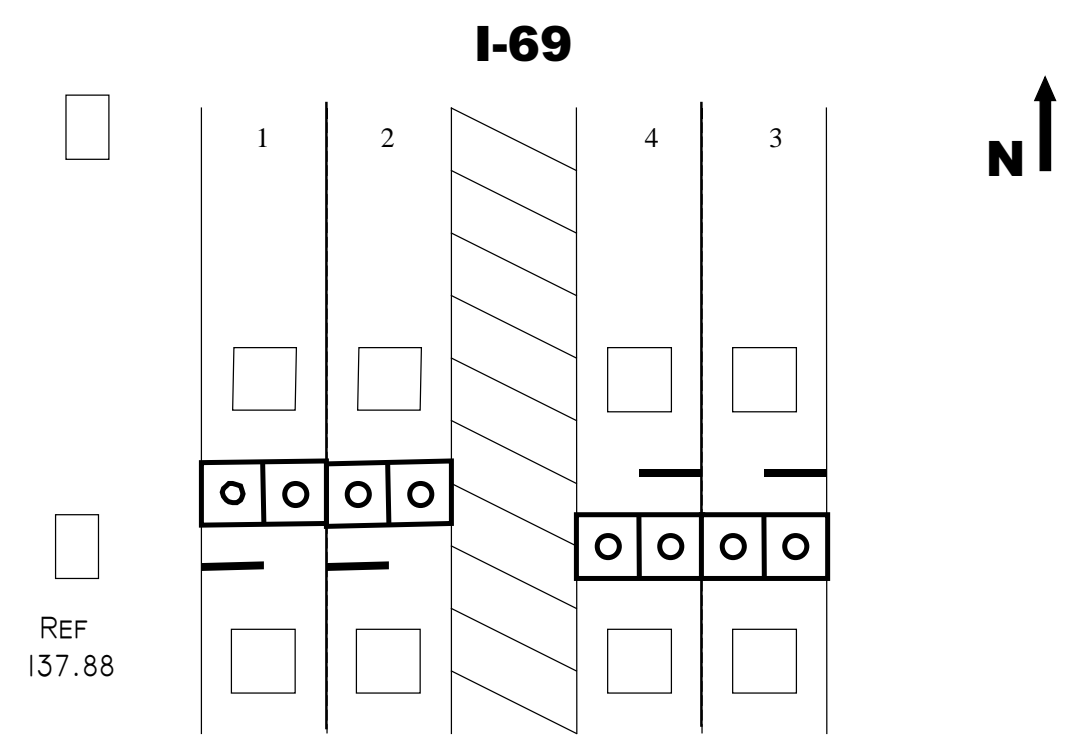

Figure A-6: Station 4150 Four Lane Divided

\begin{tabular}{|c|c|c|c|c|}
\hline & Lane 1 & Lane 2 & Lane 3 & Lane 4 \\
\hline WIM & $\mathrm{X}$ & $\mathrm{X}$ & $\mathrm{X}$ & $\mathrm{X}$ \\
\hline Classification & SLC & SLC & SLC & SLC \\
\hline Sensor & C & C & C & C \\
\hline Pavement & NO & YES & YES & NO \\
\hline $\begin{array}{c}\text { Suitable for VWS } \\
6 / 00 \text { (F. Axle) }\end{array}$ & YES & NO & YES & NO \\
\hline $\begin{array}{c}\text { Suitable for VWS } \\
10 / 00 \text { (Class.) }\end{array}$ & NO & NO & NO & NO \\
\hline $\begin{array}{c}\text { Suitable for VWS } \\
\text { 3/01 (F. Axle) }\end{array}$ & $4+$ & $5-$ & $5-$ & $5-$ \\
\hline Klepinger Scale & \multicolumn{4}{|c|}{$11-27-00$} \\
\hline $\begin{array}{c}\text { Calibration } \\
\text { Dates }\end{array}$ & \multicolumn{4}{|l}{} \\
\hline
\end{tabular}

Table A-8: Station 4150 Inventory 


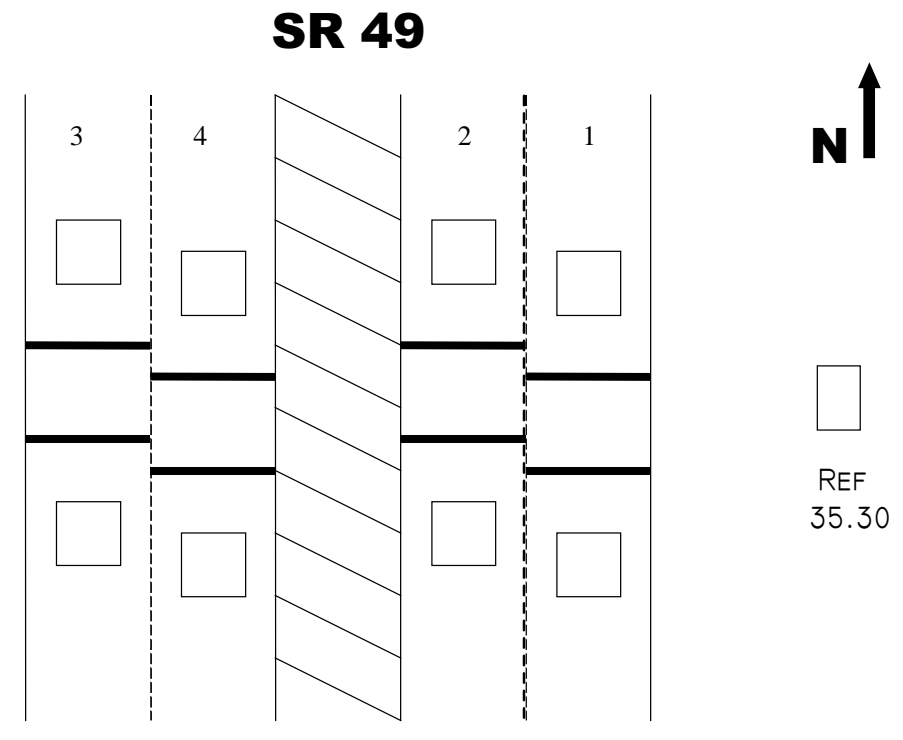

Figure A-7: Station 4240 Four Lane Divided

\begin{tabular}{|c|c|c|c|c|}
\hline & Lane 1 & Lane 2 & Lane 3 & Lane 4 \\
\hline WIM & $\mathrm{X}$ & $\bar{X}$ & $\mathrm{X}$ & $\mathrm{X}$ \\
\hline \multicolumn{5}{|l|}{ Classification } \\
\hline Sensor & PIEZO & PIEZO & PIEZO & PIEZO \\
\hline Pavement & $A$ & $\mathrm{~A}$ & $A$ & $A$ \\
\hline $\begin{array}{c}\text { Suitable for VWS } \\
6 / 00 \text { (F. Axle) }\end{array}$ & $\begin{array}{c}\text { NO } \\
\text { DATA }\end{array}$ & $\begin{array}{c}\text { NO } \\
\text { DATA }\end{array}$ & $\begin{array}{c}\text { NO } \\
\text { DATA }\end{array}$ & $\begin{array}{c}\text { NO } \\
\text { DATA }\end{array}$ \\
\hline $\begin{array}{l}\text { Suitable for VWS } \\
10 / 00 \text { (Class.) }\end{array}$ & $\begin{array}{c}\text { NO } \\
\text { DATA }\end{array}$ & $\begin{array}{c}\text { NO } \\
\text { DATA }\end{array}$ & $\begin{array}{c}\mathrm{NO} \\
\text { DATA }\end{array}$ & $\begin{array}{c}\text { NO } \\
\text { DATA }\end{array}$ \\
\hline $\begin{array}{c}\text { Suitable for VWS } \\
3 / 01 \text { (F. Axle) }\end{array}$ & $\begin{array}{c}\text { NO } \\
\text { DATA }\end{array}$ & $\begin{array}{c}\text { NO } \\
\text { DATA }\end{array}$ & $\begin{array}{c}\text { NO } \\
\text { DATA }\end{array}$ & $\begin{array}{l}\text { NO } \\
\text { DATA }\end{array}$ \\
\hline \multicolumn{5}{|l|}{ Klepinger Scale } \\
\hline Calibration Dates & & & & \\
\hline
\end{tabular}

Table A-9: Station 4240 Inventory 


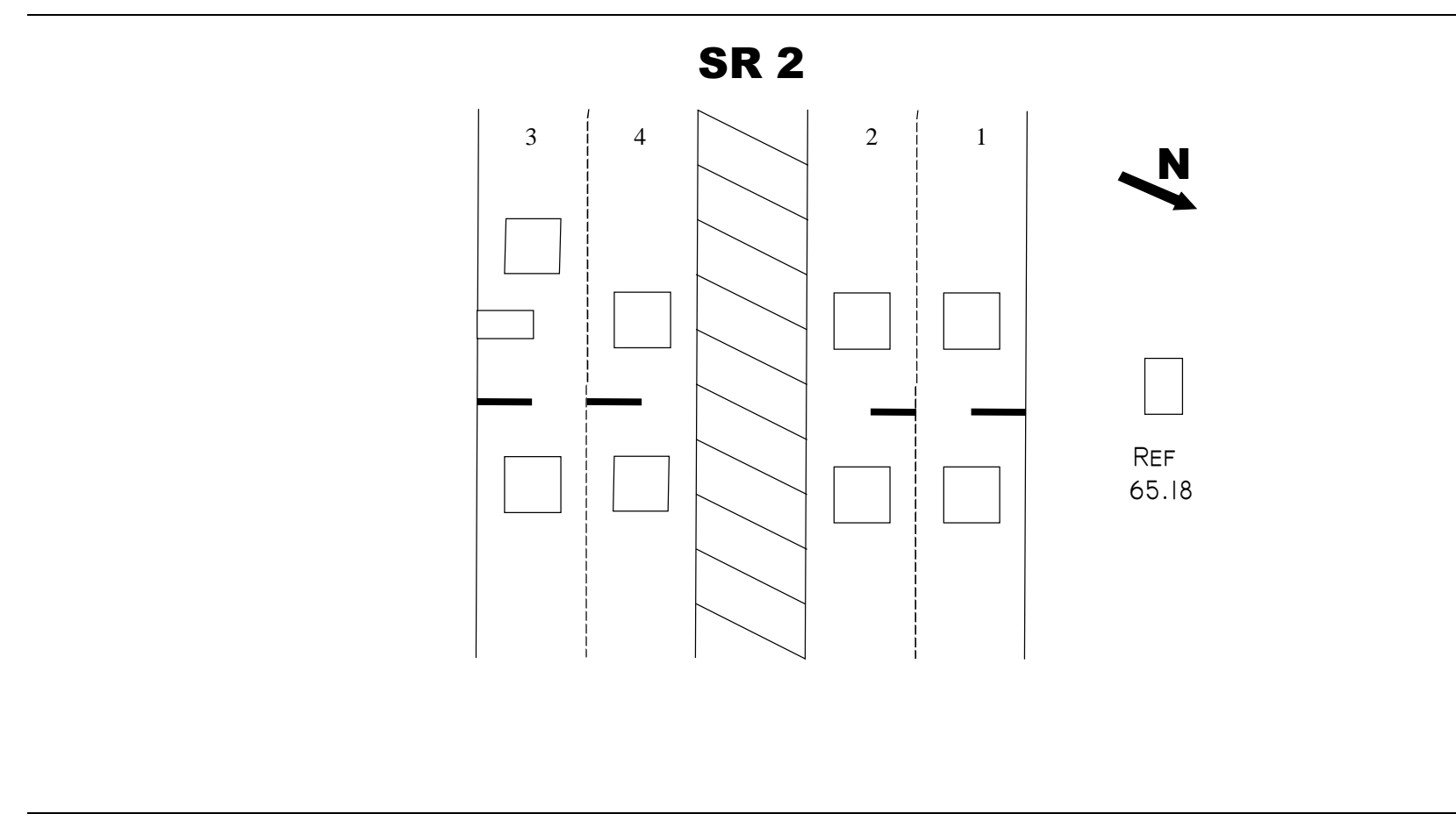

Figure A-8: Station 4250 Four Lane Divided

\begin{tabular}{|c|c|c|c|c|}
\hline & Lane 1 & Lane 2 & Lane 3 & Lane 4 \\
\hline WIM & & & $\mathrm{X}$ & \\
\hline Classification & $\mathrm{X}$ & $\mathrm{X}$ & & $\mathrm{X}$ \\
\hline Sensor & CLS & CLS & BP & CLS \\
\hline Pavement & A & A & A & A \\
\hline $\begin{array}{c}\text { Suitable for VWS } \\
6 / 00 \text { (F. Axle) }\end{array}$ & & NO & \\
\hline $\begin{array}{c}\text { Suitable for VWS } \\
10 / 00 \text { (Class.) }\end{array}$ & & YES & \\
\hline $\begin{array}{c}\text { Suitable for VWS } \\
\text { 3/01 (F. Axle) }\end{array}$ & & & NO & \\
\hline $\begin{array}{c}\text { Klepinger Scale } \\
\text { Calibration } \\
\text { Dates }\end{array}$ & $3+$ & $3-$ & $3+$ & $3-$ \\
\hline
\end{tabular}

Table A-10: Station 4250 Inventory 


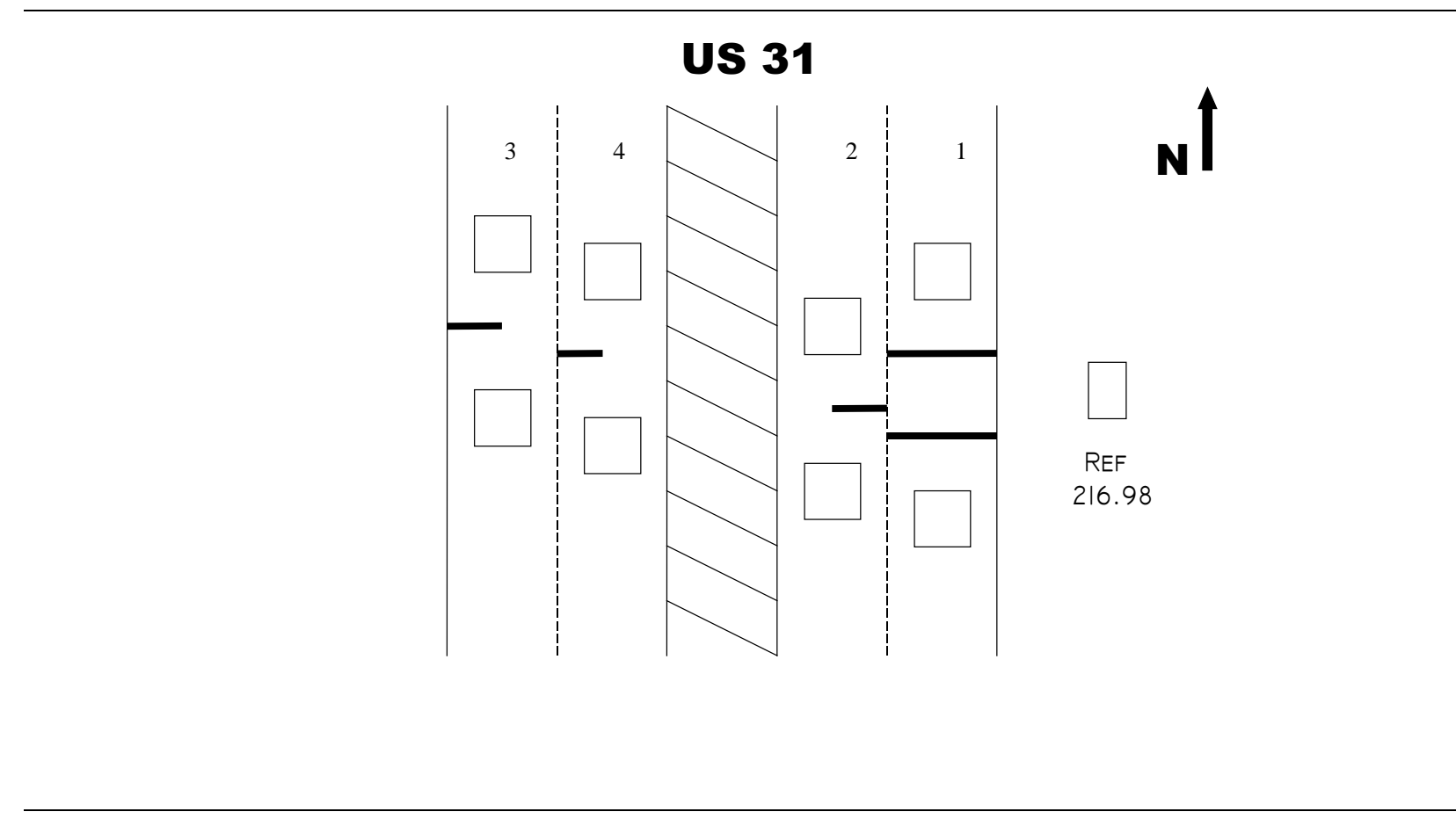

Figure A-9: Station 4260 Four Lane Divided

\begin{tabular}{|c|c|c|c|c|}
\hline & Lane 1 & Lane 2 & Lane 3 & Lane 4 \\
\hline WIM & $\mathrm{X}$ & & & \\
\hline Classification & & $\mathrm{X}$ & $\mathrm{X}$ & $\mathrm{X}$ \\
\hline Sensor & PIEZO & CLS & CLS & CLS \\
\hline Pavement & $\mathrm{A}$ & $\mathrm{A}$ & $\mathrm{A}$ & $\mathrm{A}$ \\
\hline $\begin{array}{c}\text { Suitable for VWS } \\
6 / 00 \text { (F. Axle) }\end{array}$ & NO & & & \\
\hline $\begin{array}{c}\text { Suitable for VWS } \\
10 / 00 \text { (Class.) }\end{array}$ & YES & & & \\
\hline $\begin{array}{c}\text { Suitable for VWS } \\
\text { 3/01 (F. Axle) }\end{array}$ & NO & & & \\
\hline Klepinger Scale & $2+$ & $3+$ & 3 & $3+$ \\
\hline Calibration Dates & \multicolumn{3}{|c|}{$3-23-99$} \\
\hline
\end{tabular}

Table A-11: Station 4260 Inventory 


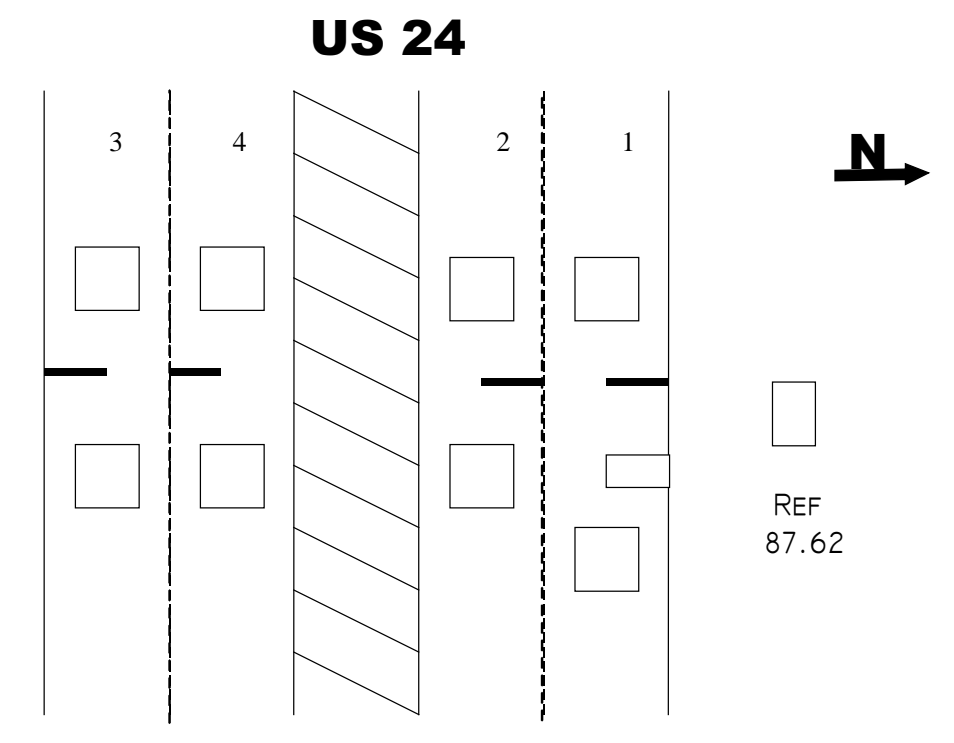

Figure A-10: Station 4270 Four Lane Divided

\begin{tabular}{|c|c|c|c|c|}
\hline & Lane 1 & Lane 2 & Lane 3 & Lane 4 \\
\hline WIM & $\mathrm{X}$ & & & \\
\hline Classification & & $\mathrm{X}$ & $\mathrm{X}$ & $\mathrm{X}$ \\
\hline Sensor & $\mathrm{BP}$ & CLS & CLS & CLS \\
\hline Pavement & A & $A$ & $A$ & A \\
\hline $\begin{array}{c}\text { Suitable for VWS } \\
6 / 00 \text { (F. Axle) }\end{array}$ & YES & & & \\
\hline $\begin{array}{l}\text { Suitable for VWS } \\
10 / 00 \text { (Class.) }\end{array}$ & $\mathrm{NO}$ & & & \\
\hline $\begin{array}{c}\text { Suitable for VWS } \\
3 / 01 \text { (F. Axle) }\end{array}$ & $\mathrm{NO}$ & & & \\
\hline Klepinger Scale & $3-$ & $2+$ & 4 & 4 \\
\hline $\begin{array}{l}\text { Calibration } \\
\text { Dates }\end{array}$ & \multicolumn{4}{|c|}{$6-01-98,4-08-99,11-29-00$} \\
\hline
\end{tabular}

Table A-12: Station 4270 Inventory 


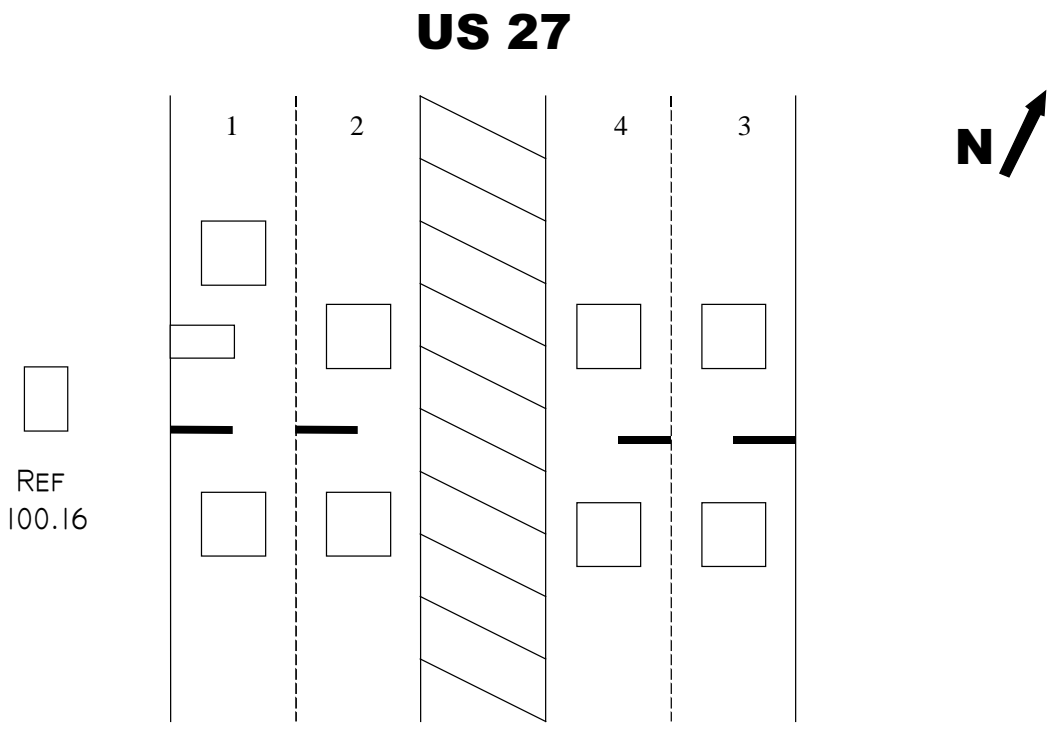

Figure A-11: Station 4280 Four Lane Divided

\begin{tabular}{|c|c|c|c|c|}
\hline & Lane 1 & Lane 2 & Lane 3 & Lane 4 \\
\hline WIM & X & & & \\
\hline Classification & & X & X & X \\
\hline Sensor & BP & CLS & CLS & CLS \\
\hline Pavement & A & A & A & A \\
\hline $\begin{array}{c}\text { Suitable for VWS } \\
6 / 00 \text { (F. Axle) }\end{array}$ & YES & & & \\
\hline $\begin{array}{c}\text { Suitable for VWS } \\
10 / 00 \text { (Class.) }\end{array}$ & NO & & & \\
\hline $\begin{array}{c}\text { Suitable for VWS } \\
\text { 3/01 (F. Axle) }\end{array}$ & YES & & & \\
\hline Klepinger Scale & $3+$ & $3+$ & 3 & 3 \\
\hline Calibration Dates & \multicolumn{3}{|c|}{$3-26-90,11-28-00$} \\
\hline
\end{tabular}

Table A-13: Station 4280 Inventory 


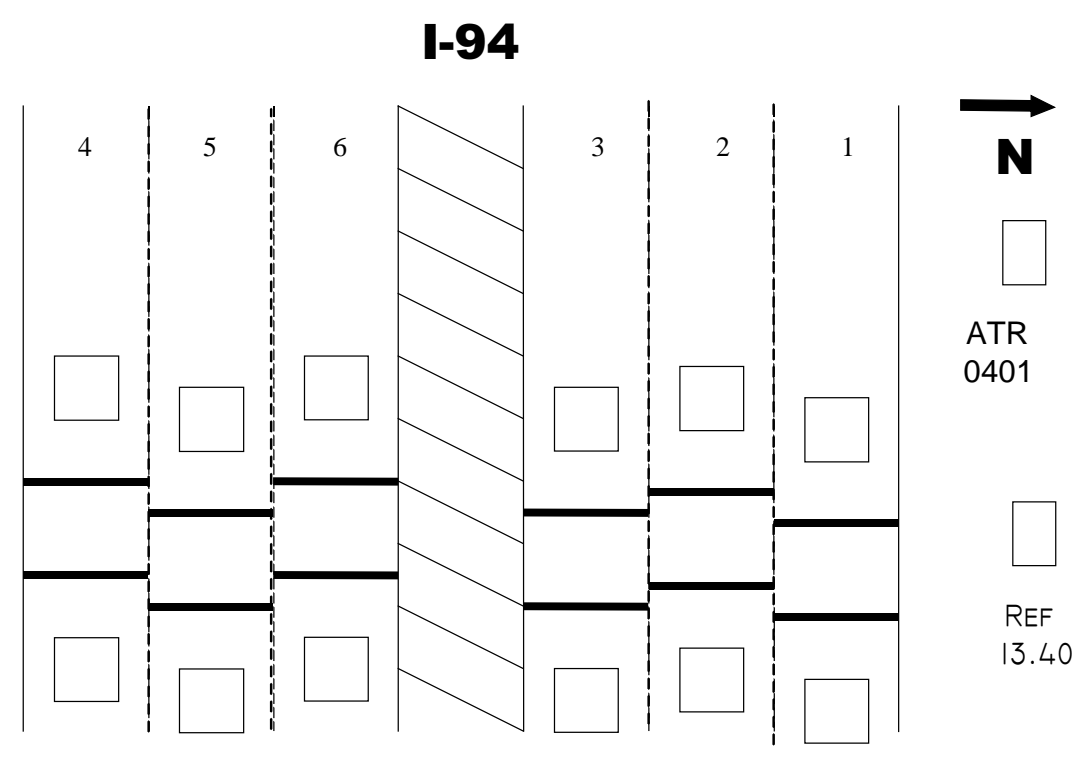

Figure A-12: Station 4400 Six Lane Divided

\begin{tabular}{|c|c|c|c|c|c|c|}
\hline & Lane 1 & Lane 2 & Lane 3 & Lane 4 & Lane 5 & Lane 6 \\
\hline WIM & $\mathrm{X}$ & $\mathrm{X}$ & $\mathrm{X}$ & $\bar{x}$ & $\mathrm{X}$ & $\bar{X}$ \\
\hline \multicolumn{7}{|l|}{ Classification } \\
\hline Sensor & PIEZO & PIEZO & PIEZO & PIEZO & PIEZO & PIEZO \\
\hline Pavement & $\mathrm{A}$ & $A$ & $\mathrm{~A}$ & $\mathrm{~A}$ & A & A \\
\hline $\begin{array}{c}\text { Suitable for VWS } \\
6 / 00(\mathrm{~F} . \text { Axle) }\end{array}$ & $\begin{array}{c}\text { NO } \\
\text { DATA }\end{array}$ & $\begin{array}{c}\text { NO } \\
\text { DATA }\end{array}$ & $\begin{array}{c}\text { NO } \\
\text { DATA }\end{array}$ & $\begin{array}{c}\text { NO } \\
\text { DATA }\end{array}$ & $\begin{array}{c}\text { NO } \\
\text { DATA }\end{array}$ & $\begin{array}{c}\text { NO } \\
\text { DATA }\end{array}$ \\
\hline $\begin{array}{c}\text { Suitable for VWS } \\
10 / 00 \text { (Class.) }\end{array}$ & YES & YES & $\mathrm{NO}$ & YES & YES & $\mathrm{NO}$ \\
\hline $\begin{array}{c}\text { Suitable for VWS } \\
\text { 3/01 (F. Axle) }\end{array}$ & NO & NO & NO & NO & YES & NO \\
\hline Klepinger Scale & 5 & 5 & 5 & 4- & 4 & $4+$ \\
\hline Calibration Dates & & & & & & \\
\hline
\end{tabular}

Table A-14: Station 4400 Inventory 


\section{$1-65$}

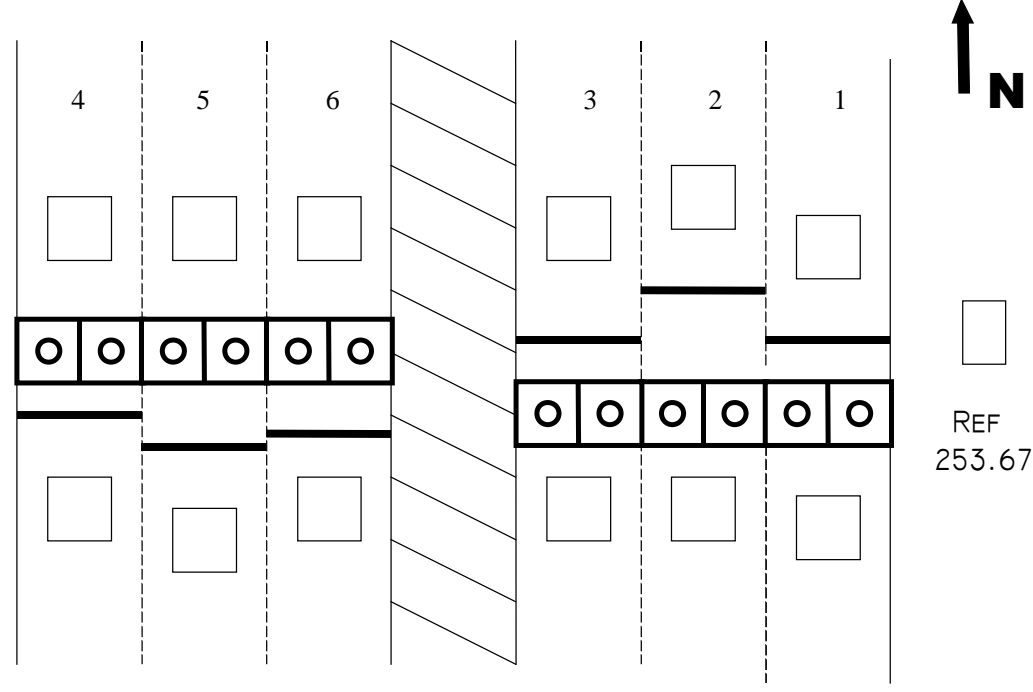

Figure A-13: Stations 4410 \& 4420 Six Lane Divided

\begin{tabular}{|c|c|c|c|c|c|c|}
\hline & Lane 1 & Lane 2 & Lane 3 & Lane 4 & Lane 5 & Lane 6 \\
\hline WIM & $\mathrm{X}$ & $\mathrm{X}$ & $\mathrm{X}$ & $\mathrm{X}$ & $\mathrm{X}$ & $\mathrm{X}$ \\
\hline \multicolumn{7}{|l|}{ Classification } \\
\hline Sensor & SLC & SLC & SLC & SLC & SLC & SLC \\
\hline Pavement & C & C & C & C & C & $\mathrm{C}$ \\
\hline $\begin{array}{c}\text { Suitable for VWS } \\
6 / 00 \text { (F. Axle) }\end{array}$ & $\begin{array}{c}\text { NO } \\
\text { DATA }\end{array}$ & $\begin{array}{c}\text { NO } \\
\text { DATA }\end{array}$ & $\begin{array}{c}\text { NO } \\
\text { DATA }\end{array}$ & $\begin{array}{c}\text { NO } \\
\text { DATA }\end{array}$ & $\begin{array}{c}\text { NO } \\
\text { DATA }\end{array}$ & $\begin{array}{c}\text { NO } \\
\text { DATA }\end{array}$ \\
\hline $\begin{array}{c}\text { Suitable for VWS } \\
10 / 00 \text { (Class.) }\end{array}$ & $\begin{array}{c}\text { NO } \\
\text { DATA }\end{array}$ & $\begin{array}{c}\text { NO } \\
\text { DATA }\end{array}$ & $\begin{array}{c}\text { NO } \\
\text { DATA }\end{array}$ & $\begin{array}{c}\text { NO } \\
\text { DATA }\end{array}$ & $\begin{array}{c}\text { NO } \\
\text { DATA }\end{array}$ & $\begin{array}{c}\text { NO } \\
\text { DATA }\end{array}$ \\
\hline $\begin{array}{c}\text { Suitable for VWS } \\
\text { 3/01 (F. Axle) }\end{array}$ & $\begin{array}{c}\text { NO } \\
\text { DATA }\end{array}$ & $\begin{array}{c}\text { NO } \\
\text { DATA }\end{array}$ & $\begin{array}{c}\text { NO } \\
\text { DATA }\end{array}$ & $\begin{array}{c}\text { NO } \\
\text { DATA }\end{array}$ & $\begin{array}{c}\text { NO } \\
\text { DATA }\end{array}$ & $\begin{array}{c}\text { NO } \\
\text { DATA }\end{array}$ \\
\hline Klepinger Scale & 6- & 6- & 6- & 6- & 6- & 6- \\
\hline $\begin{array}{c}\text { Calibration } \\
\text { Dates }\end{array}$ & & & & & & \\
\hline
\end{tabular}

Table A-15: Stations 4410 and 4420 Inventory 


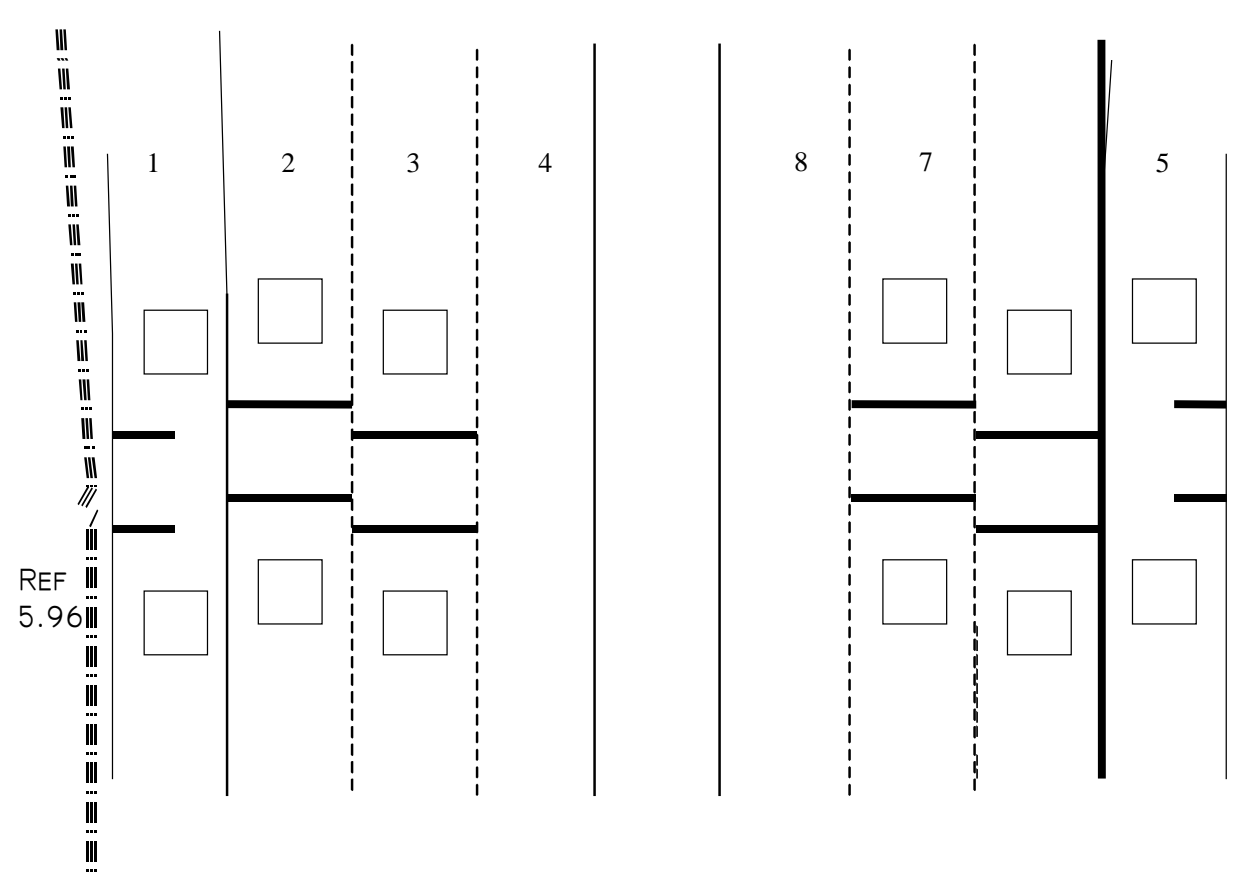

Figure A-13: Station 4440 Six Lane Divided

\begin{tabular}{|c|c|c|c|c|c|c|c|c|}
\hline & $\begin{array}{c}\text { Lane } \\
1\end{array}$ & $\begin{array}{c}\text { Lane } \\
2\end{array}$ & $\begin{array}{c}\text { Lane } \\
3\end{array}$ & $\begin{array}{c}\text { Lane } \\
4\end{array}$ & $\begin{array}{l}\text { Lane } \\
5\end{array}$ & $\begin{array}{c}\text { Lane } \\
6\end{array}$ & $\begin{array}{l}\text { Lane } \\
7\end{array}$ & $\begin{array}{c}\text { Lane } \\
8\end{array}$ \\
\hline WIM & & $\mathrm{X}$ & $X$ & $\mathrm{X}$ & & $\mathrm{X}$ & $X$ & $\mathrm{X}$ \\
\hline Classification & $\mathrm{X}$ & & & & $\mathrm{X}$ & & & \\
\hline Sensor & CLS & PIEZO & PIEZO & PIEZO & CLS & PIEZO & PIEZO & PIEZO \\
\hline Pavement & C & A & A & A & C & A & A & A \\
\hline $\begin{array}{c}\text { Suitable for } \\
\text { VWS } 6 / 00 \text { (F. } \\
\text { Axle) }\end{array}$ & & $\begin{array}{c}\text { NO } \\
\text { DATA }\end{array}$ & $\begin{array}{c}\text { NO } \\
\text { DATA }\end{array}$ & $\begin{array}{c}\text { NO } \\
\text { DATA }\end{array}$ & & $\begin{array}{c}\text { NO } \\
\text { DATA }\end{array}$ & $\begin{array}{c}\text { NO } \\
\text { DATA }\end{array}$ & $\begin{array}{c}\text { NO } \\
\text { DATA }\end{array}$ \\
\hline $\begin{array}{l}\text { Suitable for } \\
\text { VWS 10/00 } \\
\text { (Class.) }\end{array}$ & & $\begin{array}{c}\text { NO } \\
\text { DATA }\end{array}$ & $\begin{array}{c}\text { NO } \\
\text { DATA }\end{array}$ & $\begin{array}{c}\text { NO } \\
\text { DATA }\end{array}$ & & $\begin{array}{c}\text { NO } \\
\text { DATA }\end{array}$ & $\begin{array}{c}\text { NO } \\
\text { DATA }\end{array}$ & $\begin{array}{c}\text { NO } \\
\text { DATA }\end{array}$ \\
\hline $\begin{array}{c}\text { Suitable for } \\
\text { VWS 3/01 (F. } \\
\text { Axle) }\end{array}$ & & $\begin{array}{c}\text { NO } \\
\text { DATA }\end{array}$ & $\begin{array}{c}\text { NO } \\
\text { DATA }\end{array}$ & $\begin{array}{c}\text { NO } \\
\text { DATA }\end{array}$ & & $\begin{array}{c}\text { NO } \\
\text { DATA }\end{array}$ & $\begin{array}{c}\text { NO } \\
\text { DATA }\end{array}$ & $\begin{array}{c}\text { NO } \\
\text { DATA }\end{array}$ \\
\hline $\begin{array}{l}\text { Klepinger } \\
\text { Scale }\end{array}$ & 5 & 2 & 2 & 3 & 5 & $2+$ & 2 & 4 \\
\hline $\begin{array}{c}\text { Calibration } \\
\text { Dates }\end{array}$ & & & & & & & & \\
\hline
\end{tabular}

Table A-15: Station 4440 Inventory 


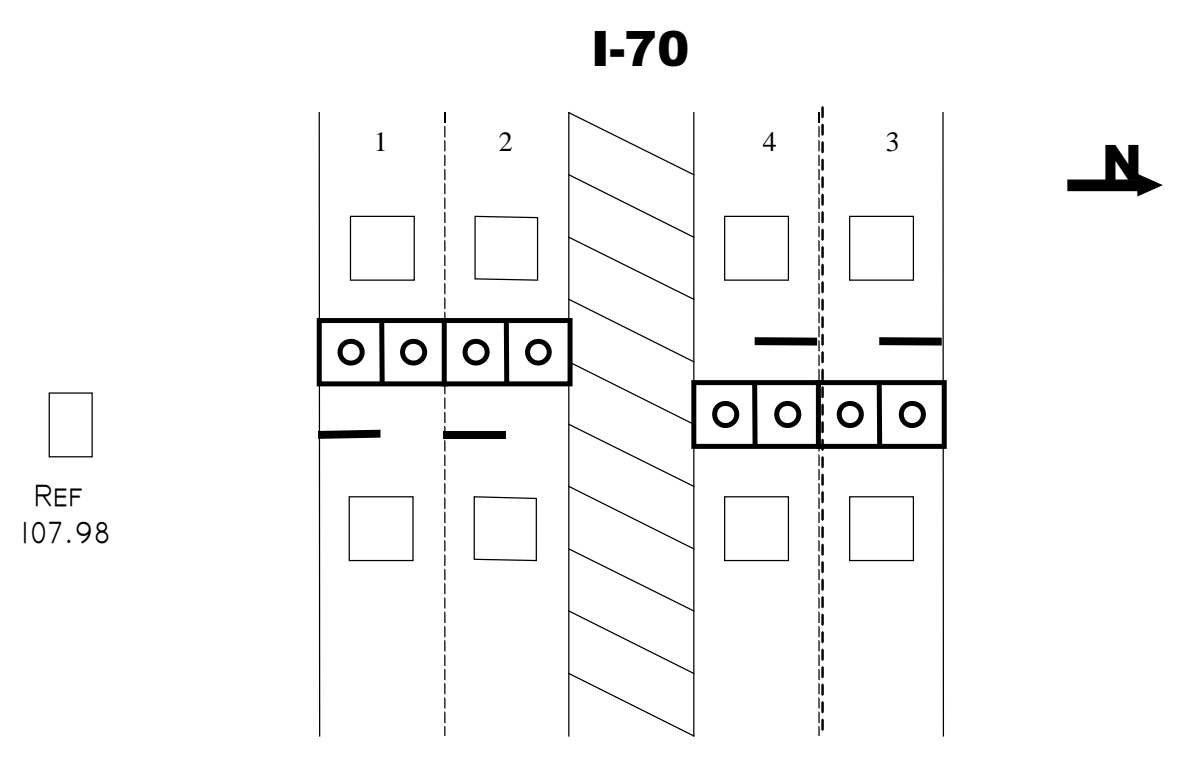

Figure A-14: Station 5110 Four Lane Divided

\begin{tabular}{|c|c|c|c|c|}
\hline WIM & Lane 1 & Lane 2 & Lane 3 & Lane 4 \\
\hline Classification & & $\mathrm{X}$ & $\mathrm{X}$ & $\mathrm{X}$ \\
\hline Sensor & SLC & SLC & SLC & SLC \\
\hline Pavement & $\mathrm{A}$ & $\mathrm{A}$ & $\mathrm{A}$ & $\mathrm{A}$ \\
\hline $\begin{array}{c}\text { Suitable for VWS } \\
6 / 00 \text { (F. Axle) }\end{array}$ & NO & YES & NO & NO \\
\hline $\begin{array}{c}\text { Suitable for VWS } \\
10 / 00 \text { (Class.) }\end{array}$ & YES & NO & YES & NO \\
\hline $\begin{array}{c}\text { Suitable for VWS } \\
\text { 3/01 (F. Axle) }\end{array}$ & YES & YES & YES & YES \\
\hline Klepinger Scale & 3 & 3 & $3+$ & $3+$ \\
\hline $\begin{array}{c}\text { Calibration } \\
\text { Dates }\end{array}$ & \multicolumn{3}{|c|}{$01-13-98$} & \\
\hline
\end{tabular}

Table A-16: Station 5110 Inventory 


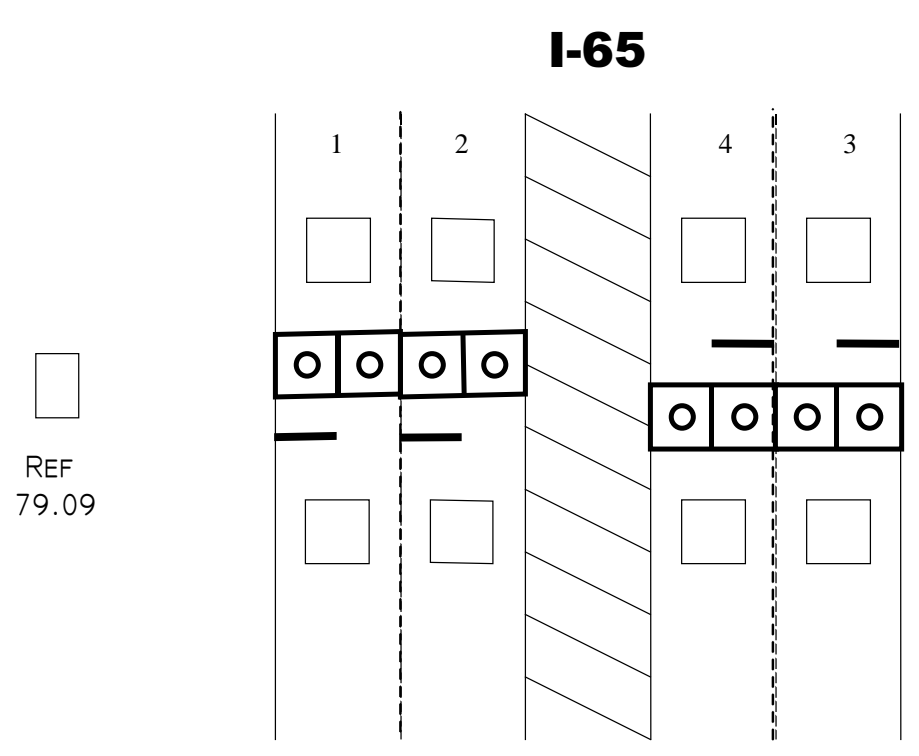

N1

Figure A-15: Station 5120 Four Lane Divided

\begin{tabular}{|c|c|c|c|c|}
\hline & Lane 1 & Lane 2 & Lane 3 & Lane 4 \\
\hline WIM & $\mathrm{X}$ & $\mathrm{X}$ & $\mathrm{X}$ & $\mathrm{X}$ \\
\hline Classification & & & & \\
\hline Sensor & SLC & SLC & SLC & SLC \\
\hline Pavement & A & A & A & A \\
\hline $\begin{array}{c}\text { Suitable for VWS } \\
6 / 00 \text { (F. Axle) }\end{array}$ & NO & NO & YES & NO \\
\hline $\begin{array}{c}\text { Suitable for VWS } \\
10 / 00 \text { (Class.) }\end{array}$ & NO & YES & NO & NO \\
\hline $\begin{array}{c}\text { Suitable for VWS } \\
\text { 3/01 (F. Axle) }\end{array}$ & NO & NO & NO & NO \\
\hline Klepinger Scale & 2 & $4-$ & $3+$ & $3+$ \\
\hline $\begin{array}{c}\text { Calibration } \\
\text { Dates }\end{array}$ & & & \\
\hline
\end{tabular}

Table A-17: Station 5120 Inventory 


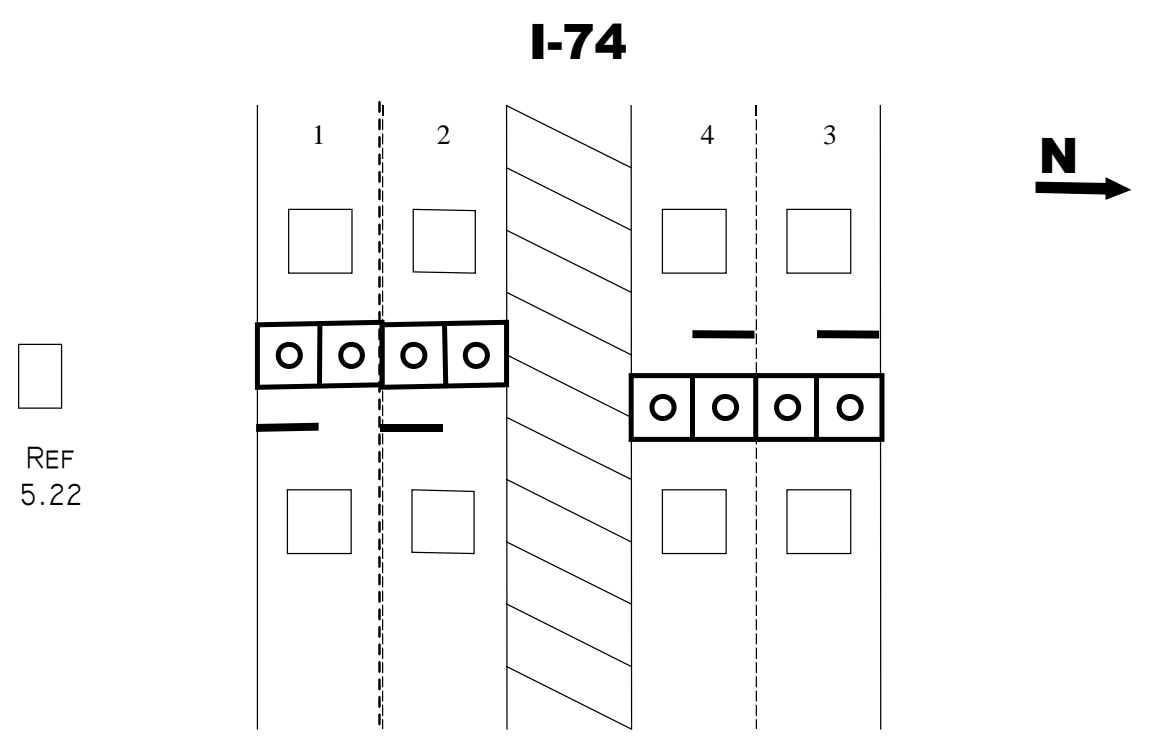

Figure A-16: Station 5130 Four Lane Divided

\begin{tabular}{|c|c|c|c|c|}
\hline & Lane 1 & Lane 2 & Lane 3 & Lane 4 \\
\hline WIM & $\mathrm{X}$ & $\mathrm{X}$ & $\mathrm{X}$ & $\mathrm{X}$ \\
\hline Classification & & & & \\
\hline Sensor & SLC & SLC & SLC & SLC \\
\hline Pavement & $\mathrm{C}$ & $\mathrm{C}$ & $\mathrm{C}$ & $\mathrm{C}$ \\
\hline $\begin{array}{c}\text { Suitable for VWS } \\
6 / 00 \text { (F. Axle) }\end{array}$ & NO & NA & NO & NO \\
DATA & DATA & DATA & DATA \\
\hline $\begin{array}{c}\text { Suitable for VWS } \\
10 / 00 \text { (Class.) }\end{array}$ & YES & NO & NO & NO \\
DATA
\end{tabular}

Table A-18: Station 5130 Inventory 


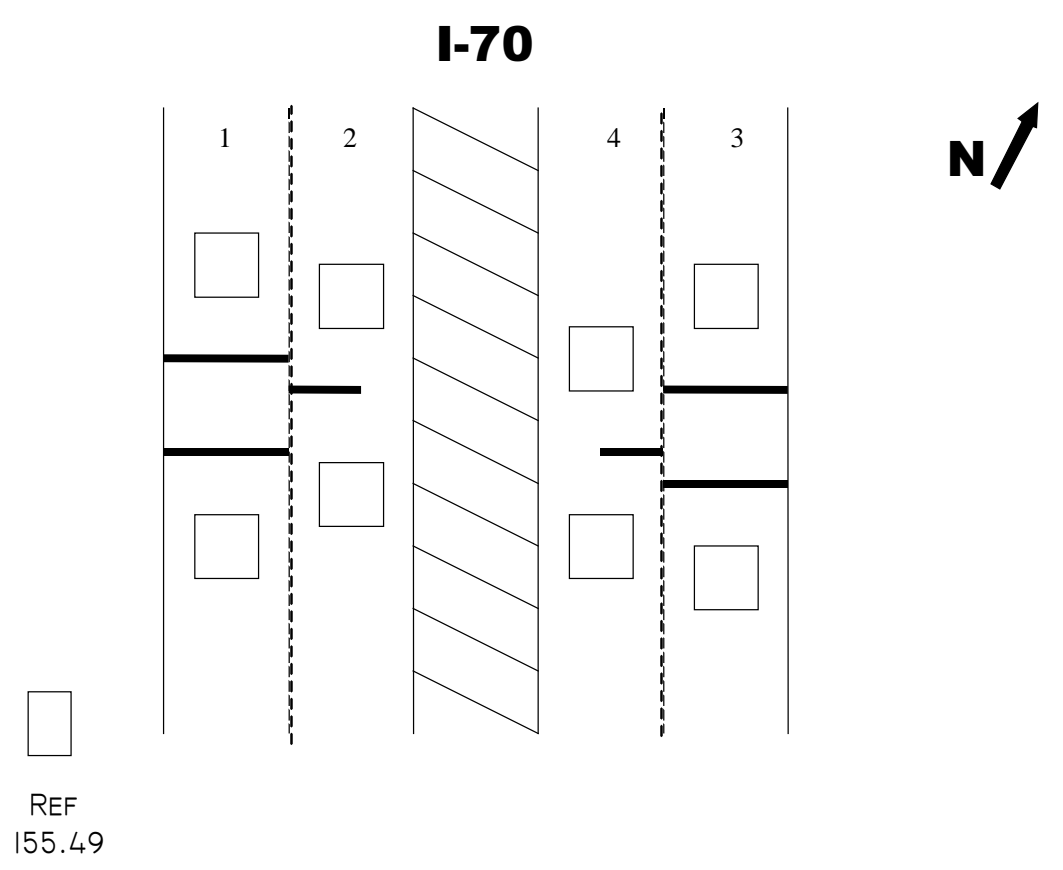

Figure A-17: Station 5140 Four Lane Divided

\begin{tabular}{|c|c|c|c|c|}
\hline & Lane 1 & Lane 2 & Lane 3 & Lane 4 \\
\hline WIM & $\mathrm{X}$ & & $\mathrm{X}$ & \\
\hline Classification & & $\mathrm{X}$ & & $\mathrm{X}$ \\
\hline Sensor & PIEZO & CLS & PIEZO & CLS \\
\hline Pavement & $\mathrm{A}$ & $\mathrm{A}$ & $\mathrm{A}$ & $\mathrm{A}$ \\
\hline $\begin{array}{c}\text { Suitable for VWS } \\
6 / 00 \text { (F. Axle) }\end{array}$ & NO & & NO & \\
\hline $\begin{array}{c}\text { Suitable for VWS } \\
10 / 00 \text { (Class.) }\end{array}$ & YES & & YES & \\
\hline $\begin{array}{c}\text { Suitable for VWS } \\
\text { 3/01 (F. Axle) }\end{array}$ & NO & & NO & \\
\hline Klepinger Scale & $3-$ & 3 & $2+$ & $3-$ \\
\hline Calibration Dates & \multicolumn{3}{|c|}{$02-26-99$} \\
\hline
\end{tabular}

Table A-19: Station 5140 Inventory 


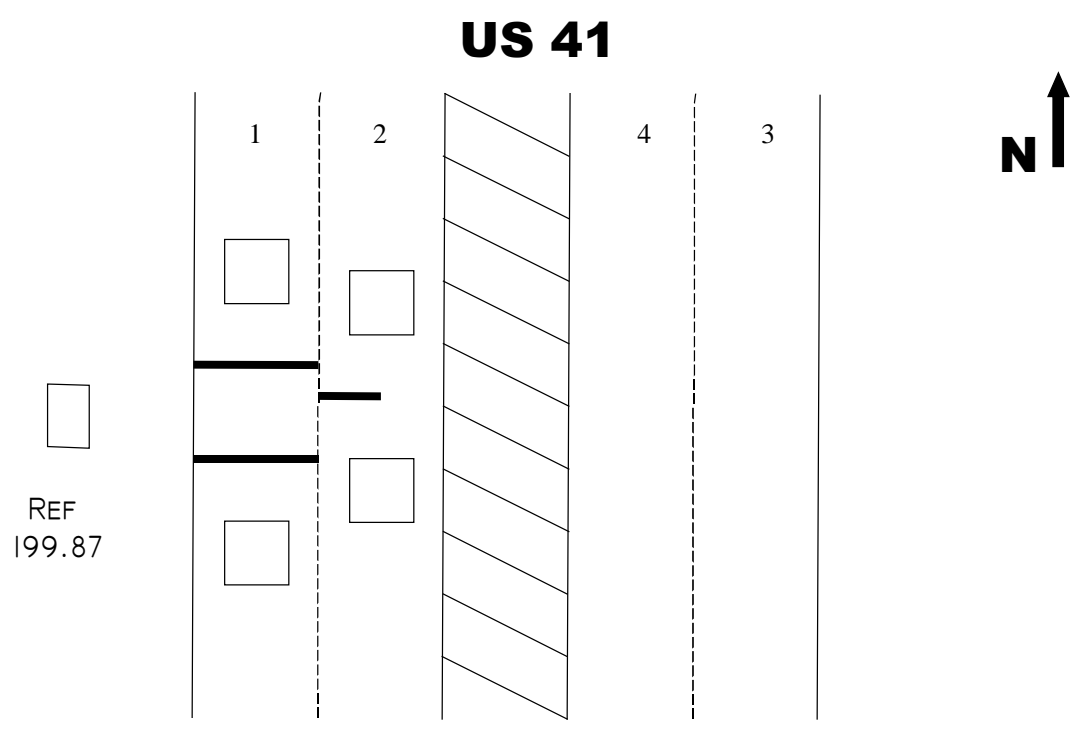

Figure A-18: Station 5240 Four Lane Divided

\begin{tabular}{|c|c|c|c|c|}
\hline & Lane 1 & Lane 2 & Lane 3 & Lane 4 \\
\hline WIM & $\mathrm{X}$ & & & \\
\hline Classification & & $\mathrm{X}$ & & \\
\hline Sensor & PIEZO & CLS & & \\
\hline Pavement & C & C & A & A \\
\hline $\begin{array}{c}\text { Suitable for VWS } \\
6 / 00 \text { (F. Axle) }\end{array}$ & NO & & NO & NO \\
\hline $\begin{array}{c}\text { Suitable for VWS } \\
10 / 00 \text { (Class.) }\end{array}$ & YES & & N/A & N/A \\
\hline $\begin{array}{c}\text { Suitable for VWS } \\
\text { 3/01 (F. Axle) }\end{array}$ & NO & & & \\
\hline Klepinger Scale & $3+$ & $4-$ & N/A & N/A \\
\hline Calibration Dates & & \multicolumn{3}{|l}{} \\
\hline
\end{tabular}

Table A-20: Station 5240 Inventory 


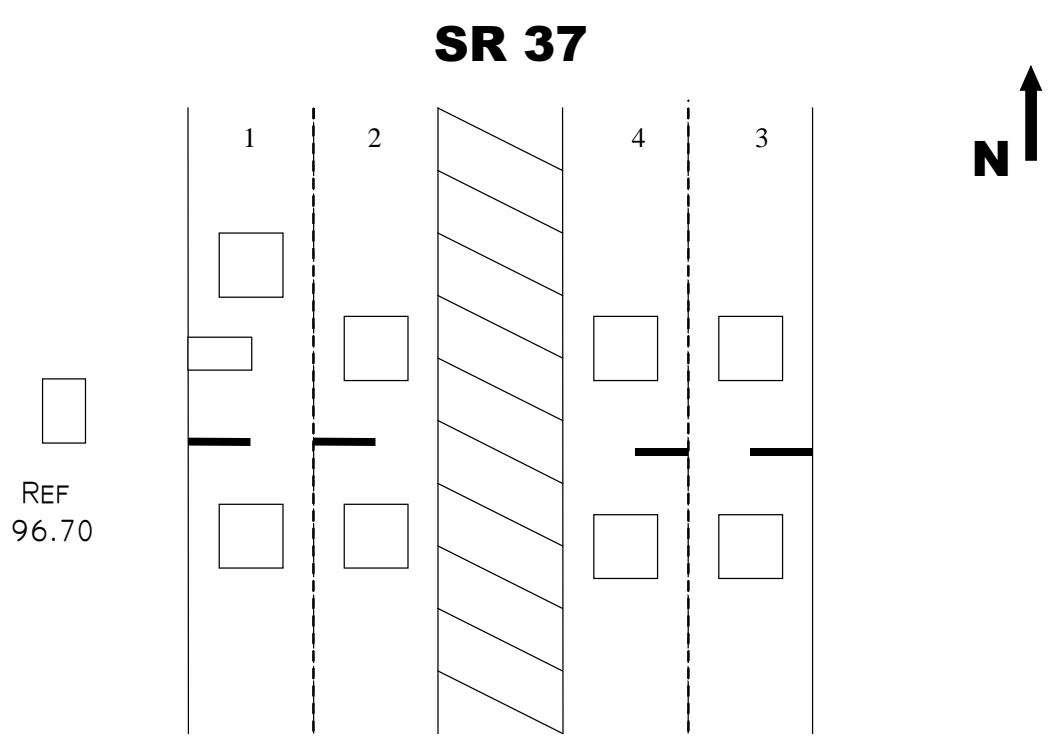

Figure A-19: Station 5250 Four Lane Divided

\begin{tabular}{|c|c|c|c|c|}
\hline & Lane 1 & Lane 2 & Lane 3 & Lane 4 \\
\hline WIM & X & & & \\
\hline Classification & & X & X & X \\
\hline Sensor & BP & CLS & CLS & CLS \\
\hline Pavement & C & C & C & C \\
\hline $\begin{array}{c}\text { Suitable for VWS } \\
\text { 6/00 (F. Axle) }\end{array}$ & NO & & & \\
\hline $\begin{array}{c}\text { Suitable for VWS } \\
\text { 10/00 (Class.) }\end{array}$ & NO & & & \\
\hline $\begin{array}{c}\text { Suitable for VWS } \\
\text { 3/01 (F. Axle) }\end{array}$ & YES & & & \\
\hline Klepinger Scale & $3+$ & $3+$ & $3+$ & $3+$ \\
\hline $\begin{array}{c}\text { Calibration } \\
\text { Dates }\end{array}$ & \multicolumn{3}{|c|}{$3-25-99$} \\
\hline
\end{tabular}

Table A-21: Station 5250 Inventory 


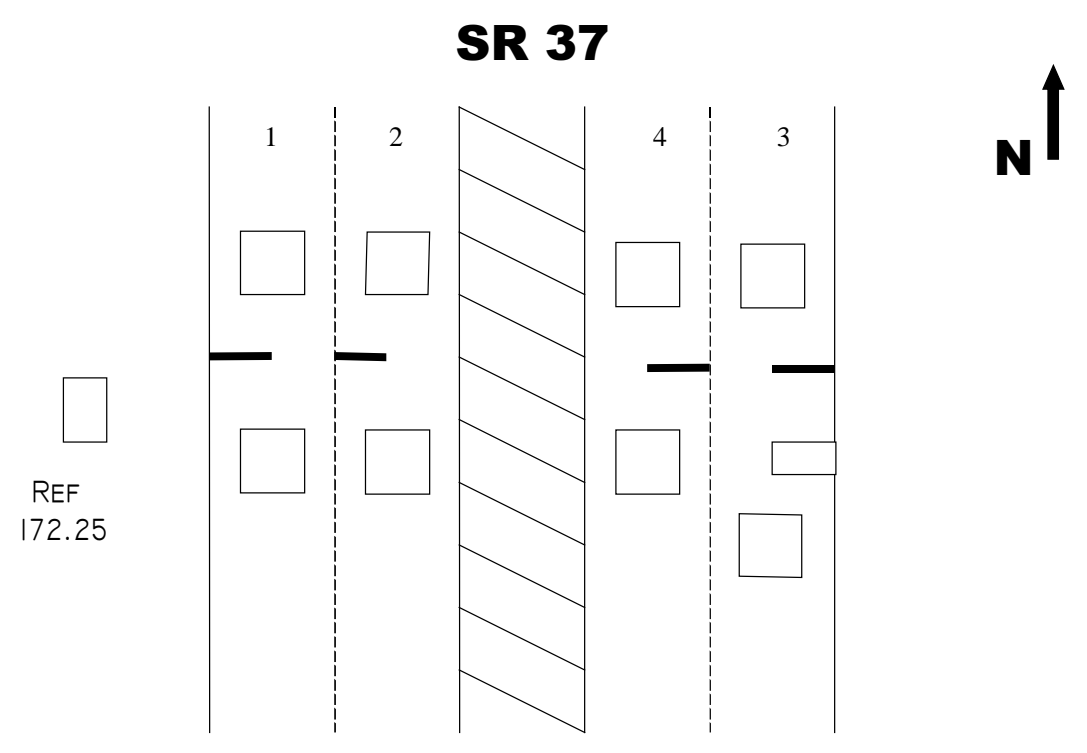

Figure A-20: Station 5260 Four Lane Divided

\begin{tabular}{|c|c|c|c|c|}
\hline & Lane 1 & Lane 2 & Lane 3 & Lane 4 \\
\hline WIM & & & $\mathrm{X}$ & \\
\hline Classification & $\mathrm{X}$ & $\mathrm{X}$ & & $\mathrm{X}$ \\
\hline Sensor & CLS & CLS & BP-V & CLS \\
\hline Pavement & $\mathrm{A}$ & $\mathrm{A}$ & $\mathrm{A}$ & $\mathrm{A}$ \\
\hline $\begin{array}{c}\text { Suitable for VWS } \\
\text { 6/00 (F. Axle) }\end{array}$ & & & NO & \\
\hline $\begin{array}{c}\text { Suitable for VWS } \\
\text { 10/00 (Class.) }\end{array}$ & & & YES & \\
\hline $\begin{array}{c}\text { Suitable for VWS } \\
\text { 3/01 (F. Axle) }\end{array}$ & & & NO & \\
\hline Klepinger Scale & $5-$ & $5-$ & 5 & 5 \\
\hline Calibration Dates & \multicolumn{4}{|c|}{$02-27-99,10-26-99$} \\
\hline
\end{tabular}

Table A-22: Station 5260 Inventory 
SR 332

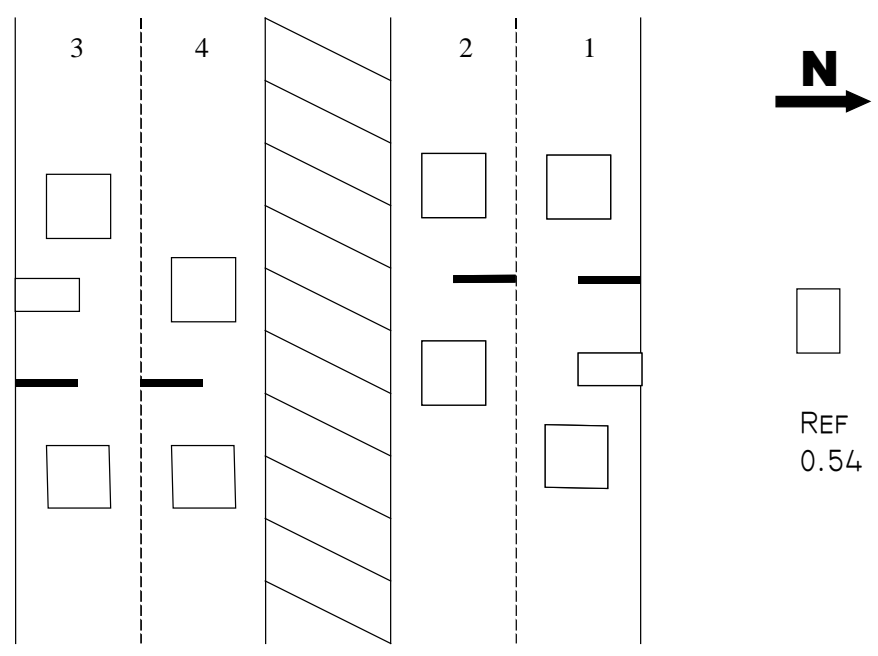

Figure A-21: Station 5270 Four Lane Divided

\begin{tabular}{|c|c|c|c|c|}
\hline & Lane 1 & Lane 2 & Lane 3 & Lane 4 \\
\hline WIM & $\mathrm{X}$ & & $\mathrm{X}$ & \\
\hline Classification & & $\mathrm{X}$ & & $\mathrm{X}$ \\
\hline Sensor & $\mathrm{BP}$ & $\mathrm{CLS}$ & $\mathrm{BP}$ & $\mathrm{CLS}$ \\
\hline Pavement & $\mathrm{C}$ & $\mathrm{C}$ & $\mathrm{C}$ & $\mathrm{C}$ \\
\hline $\begin{array}{c}\text { Suitable for VWS } \\
6 / 00 \text { (F. Axle) }\end{array}$ & NO & & NO & \\
\hline $\begin{array}{c}\text { Suitable for VWS } \\
10 / 00 \text { (Class.) }\end{array}$ & NO & & NO & \\
\hline $\begin{array}{c}\text { Suitable for VWS } \\
\text { 3/01 (F. Axle) }\end{array}$ & NO & & NO & \\
\hline Klepinger Scale & $3+$ & $3+$ & $4-$ & 4 \\
\hline Calibration Dates & \multicolumn{3}{|l}{} \\
\hline
\end{tabular}

Table A-23: Station 5270 Inventory 


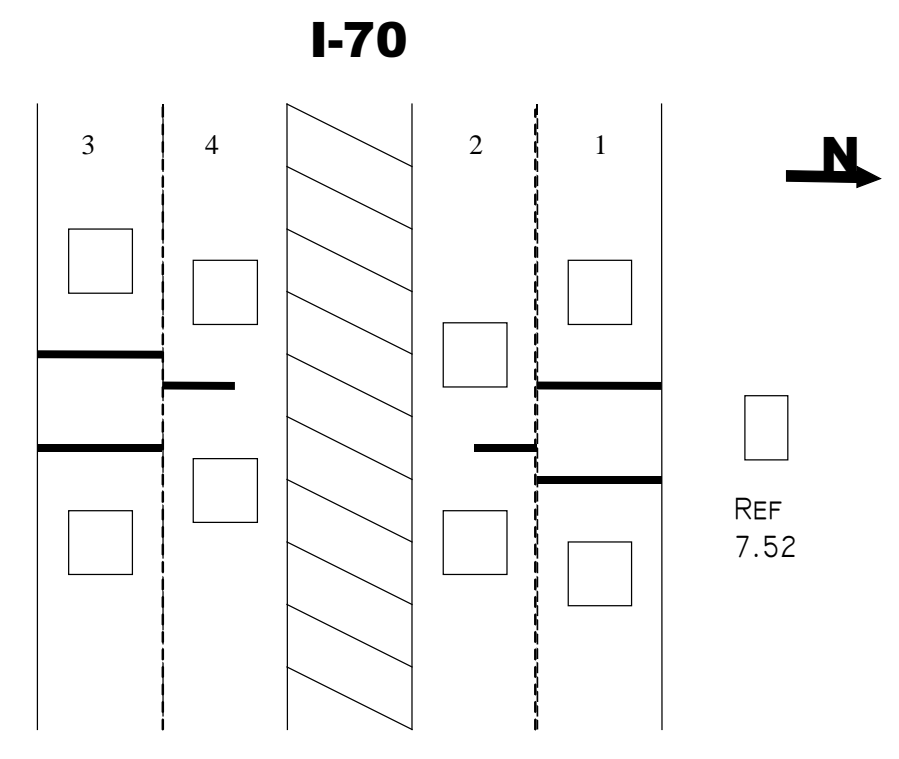

Figure A-22: Station 5440 Four Lane Divided

\begin{tabular}{|c|c|c|c|c|}
\hline & Lane 1 & Lane 2 & Lane 3 & Lane 4 \\
\hline WIM & $\mathrm{X}$ & & $\mathrm{X}$ & \\
\hline Classification & & $\mathrm{X}$ & & $\mathrm{X}$ \\
\hline Sensor & PIEZO & CLS & PIEZO & CLS \\
\hline Pavement & A & A & A & A \\
\hline $\begin{array}{c}\text { Suitable for VWS } \\
6 / 00 \text { (F. Axle) }\end{array}$ & $\begin{array}{c}\text { NO } \\
\text { DATA }\end{array}$ & & NO & \\
\hline $\begin{array}{c}\text { Suitable for VWS } \\
10 / 00 \text { (Class.) }\end{array}$ & YES & & NO & \\
\hline $\begin{array}{c}\text { Suitable for VWS } \\
\text { 3/01 (F. Axle) }\end{array}$ & $\begin{array}{c}\text { NO } \\
\text { DATA }\end{array}$ & & NO & \\
\hline Klepinger Scale & $2+$ & $3-$ & $3-$ & $2+$ \\
\hline Calibration Dates & \multicolumn{4}{|c|}{$3-18-99,11-29-00$} \\
\hline
\end{tabular}

Table A-24: Station 5440 Inventory 


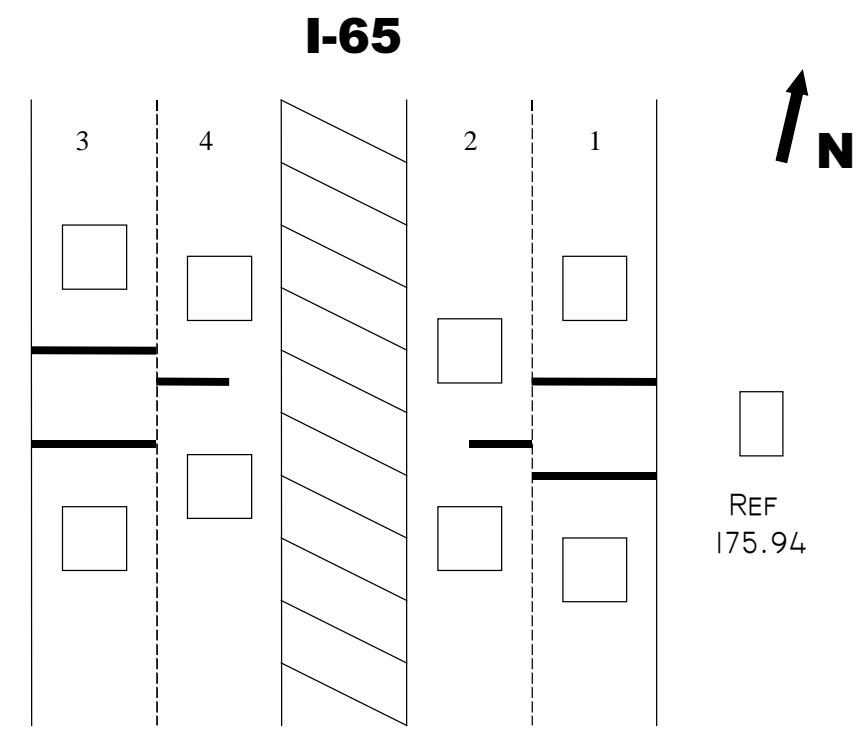

Figure A-23: Station 5450 Four Lane Divided

\begin{tabular}{|c|c|c|c|c|}
\hline & Lane 1 & Lane 2 & Lane 3 & Lane 4 \\
\hline WIM & $\mathrm{X}$ & & $\mathrm{X}$ & \\
\hline Classification & & $\mathrm{X}$ & & $\mathrm{X}$ \\
\hline Sensor & PIEZO & CLS & PIEZO & CLS \\
\hline Pavement & $\mathrm{A}$ & $\mathrm{A}$ & $\mathrm{A}$ & $\mathrm{A}$ \\
\hline $\begin{array}{c}\text { Suitable for VWS } \\
6 / 00 \text { (F. Axle) }\end{array}$ & NO & & NO & \\
\hline $\begin{array}{c}\text { Suitable for VWS } \\
10 / 00 \text { (Class.) }\end{array}$ & NO & & NO & \\
\hline $\begin{array}{c}\text { Suitable for VWS } \\
\text { 3/01 (F. Axle) }\end{array}$ & NO & & NO & \\
\hline Klepinger Scale & 1 & 3 & 3 & 3 \\
\hline Calibration Dates & \multicolumn{3}{|c|}{$3-19-99$} \\
\hline
\end{tabular}

Table A-25: Station 5450 Inventory 


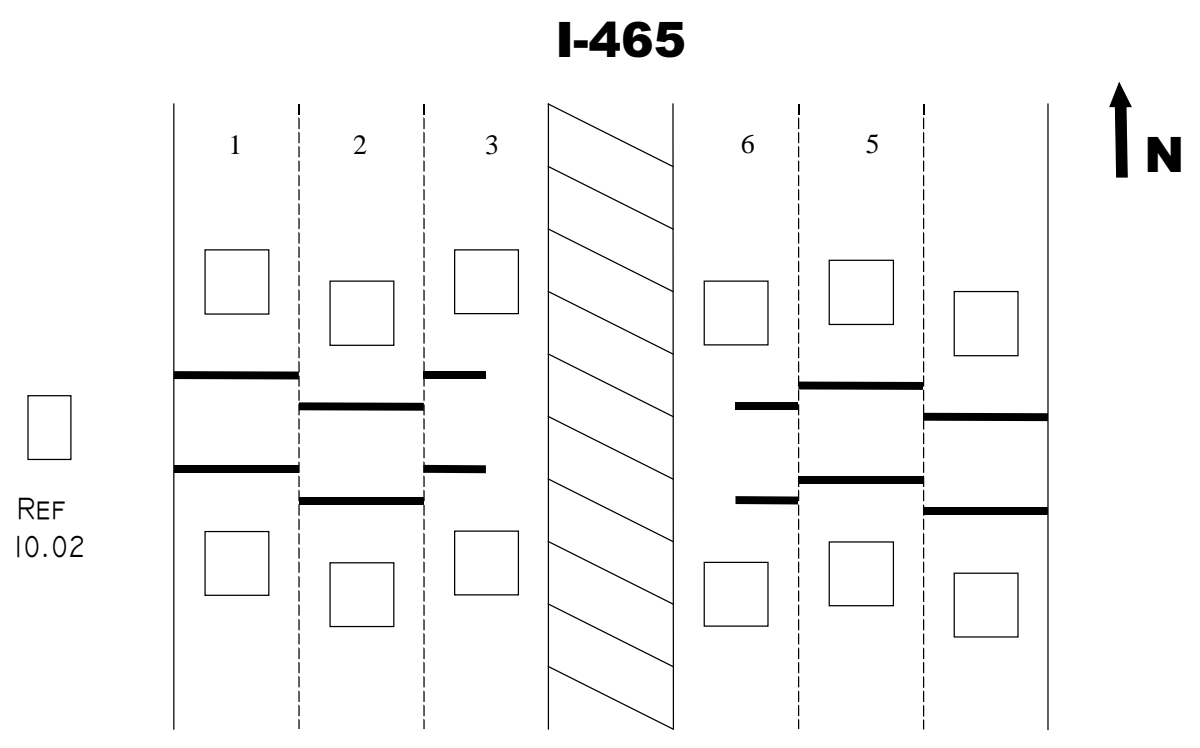

Figure A-24: Station 5460 Six Lane Divided

\begin{tabular}{|c|c|c|c|c|c|c|}
\hline & Lane 1 & Lane 2 & Lane 3 & Lane 4 & Lane 5 & Lane 6 \\
\hline WIM & $\bar{x}$ & $\mathrm{X}$ & & $\mathrm{X}$ & $\mathrm{X}$ & \\
\hline Classification & & & $\mathrm{X}$ & & & $\mathrm{X}$ \\
\hline Sensor & PIEZO & PIEZO & CLS & PIEZO & PIEZO & CLS \\
\hline Pavement & $A$ & $A$ & $A$ & $A$ & $A$ & $A$ \\
\hline $\begin{array}{c}\text { Suitable for VWS } \\
6 / 00 \text { (F. Axle) }\end{array}$ & NO & $\begin{array}{l}\text { NO } \\
\text { DATA }\end{array}$ & & $\begin{array}{l}\text { NO } \\
\text { DATA }\end{array}$ & $\begin{array}{l}\text { NO } \\
\text { DATA }\end{array}$ & \\
\hline $\begin{array}{l}\text { Suitable for VWS } \\
10 / 00 \text { (Class.) }\end{array}$ & $\mathrm{NO}$ & $\mathrm{NO}$ & & $\mathrm{NO}$ & $\mathrm{NO}$ & \\
\hline $\begin{array}{c}\text { Suitable for VWS } \\
3 / 01 \text { (F. Axle) }\end{array}$ & $\mathrm{NO}$ & $\begin{array}{l}\text { NO } \\
\text { DATA }\end{array}$ & & $\begin{array}{c}\text { NO } \\
\text { DATA }\end{array}$ & $\begin{array}{c}\text { NO } \\
\text { DATA }\end{array}$ & \\
\hline Klepinger Scale & 3- & 3- & $3+$ & 3 & 3 & $3+$ \\
\hline
\end{tabular}

Table A-26: Station 5460 Inventory 


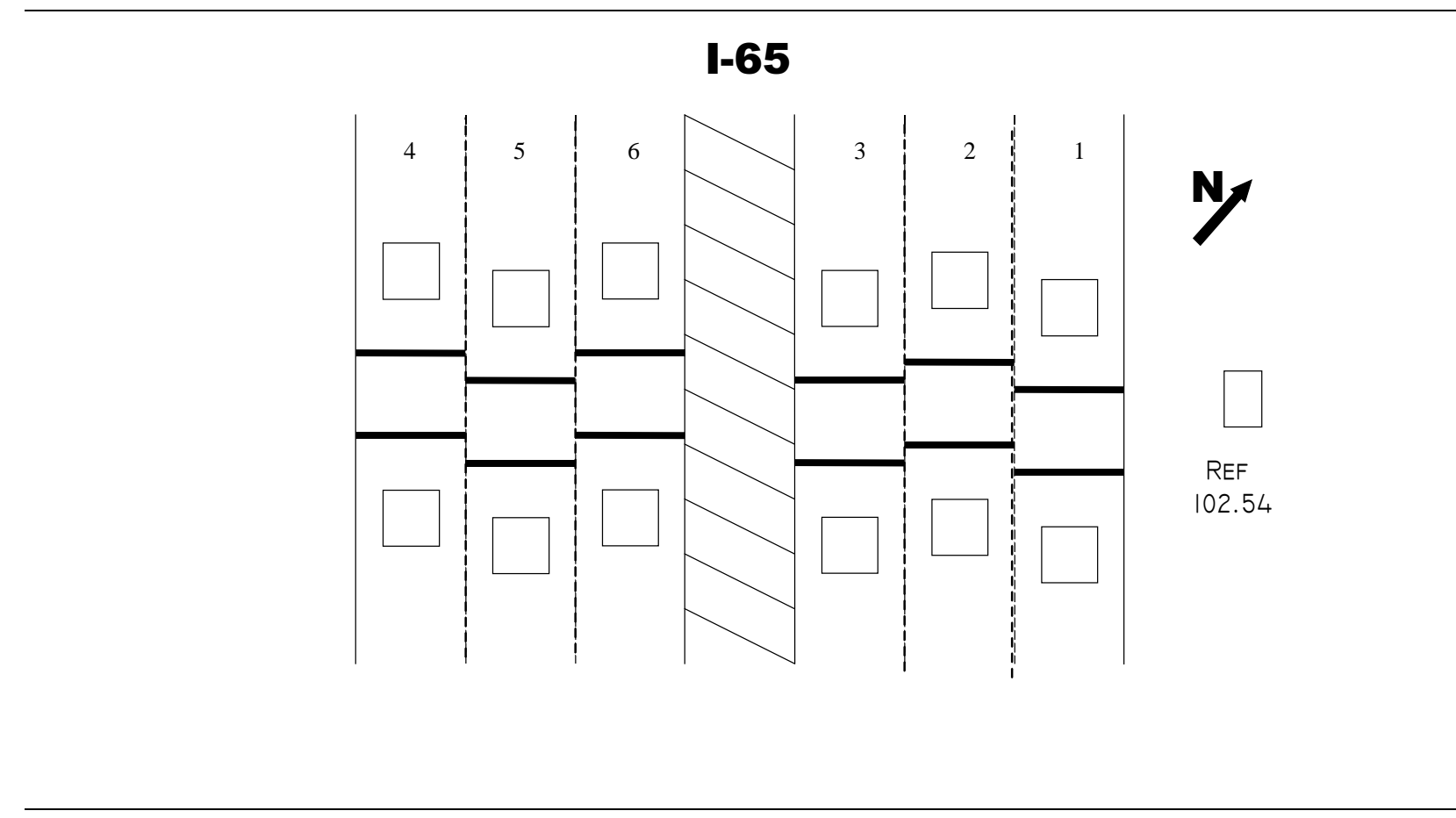

Figure A-25: Station 5470 Six Lane Divided

\begin{tabular}{|c|c|c|c|c|c|c|}
\hline & Lane 1 & Lane 2 & Lane 3 & Lane 4 & Lane 5 & Lane 6 \\
\hline WIM & $\mathrm{X}$ & $\mathrm{X}$ & $\mathrm{X}$ & $\mathrm{X}$ & $\mathrm{X}$ & $\mathrm{X}$ \\
\hline Classification & & & & & & \\
\hline Sensor & PIEZO & $\mathrm{PIEZO}$ & $\mathrm{PIEZO}$ & $\mathrm{PIEZO}$ & $\mathrm{PIEZO}$ & $\mathrm{PIEZO}$ \\
\hline Pavement & $\mathrm{A}$ & $\mathrm{A}$ & $\mathrm{A}$ & $\mathrm{A}$ & $\mathrm{A}$ & $\mathrm{A}$ \\
\hline $\begin{array}{c}\text { Suitable for VWS } \\
6 / 00 \text { (F. Axle) }\end{array}$ & $\mathrm{NO}$ & $\mathrm{NO}$ & $\mathrm{NO}$ & $\mathrm{NO}$ & $\mathrm{NO}$ & $\mathrm{NO}$ \\
\hline $\begin{array}{c}\text { Suitable for VWS } \\
10 / 00 \text { (Class.) }\end{array}$ & YES & YES & YES & NO & YES & YES \\
\hline $\begin{array}{c}\text { Suitable for VWS } \\
3 / 01 \text { (F. Axle) }\end{array}$ & NO & NO & NO & NO & NO & NO \\
\hline Klepinger Scale & $3+$ & $3+$ & $3+$ & $4-$ & $4-$ & $4-$ \\
\hline Calibration Dates & & & & & & \\
\hline
\end{tabular}

Table A-27: Station 5470 Inventory 


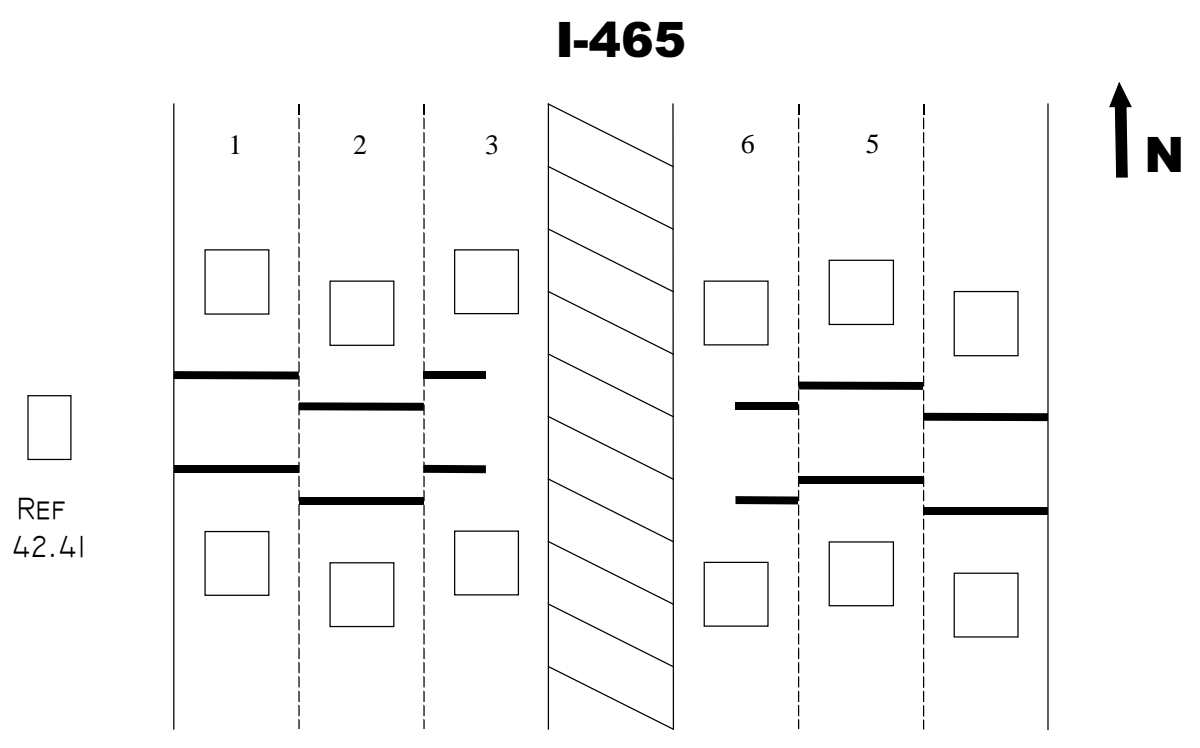

Figure A-26: Station 5480 Six Lane Divided

\begin{tabular}{|c|c|c|c|c|c|c|}
\hline & Lane 1 & Lane 2 & Lane 3 & Lane 4 & Lane 5 & Lane 6 \\
\hline WIM & $\bar{X}$ & $\mathrm{X}$ & & $\mathrm{X}$ & $\mathrm{X}$ & \\
\hline Classification & & & $\mathrm{X}$ & & & $\mathrm{X}$ \\
\hline Sensor & PIEZO & PIEZO & CLS & PIEZO & PIEZO & CLS \\
\hline Pavement & $\mathrm{C}$ & $\mathrm{C}$ & $\mathrm{C}$ & $\mathrm{C}$ & $\mathrm{C}$ & $\mathrm{C}$ \\
\hline $\begin{array}{c}\text { Suitable for VWS } \\
6 / 00 \text { (F. Axle) }\end{array}$ & NO & NO & & $\mathrm{NO}$ & NO & \\
\hline $\begin{array}{l}\text { Suitable for VWS } \\
10 / 00 \text { (Class.) }\end{array}$ & NO & $\mathrm{NO}$ & & $\mathrm{NO}$ & YES & \\
\hline $\begin{array}{c}\text { Suitable for VWS } \\
\text { 3/01 (F. Axle) }\end{array}$ & NO & $\mathrm{NO}$ & & $\mathrm{NO}$ & NO & \\
\hline Klepinger Scale & 2 & $3+$ & 5 & 2 & $3-$ & 5 \\
\hline
\end{tabular}

Table A-28: Station 5480 Inventory 


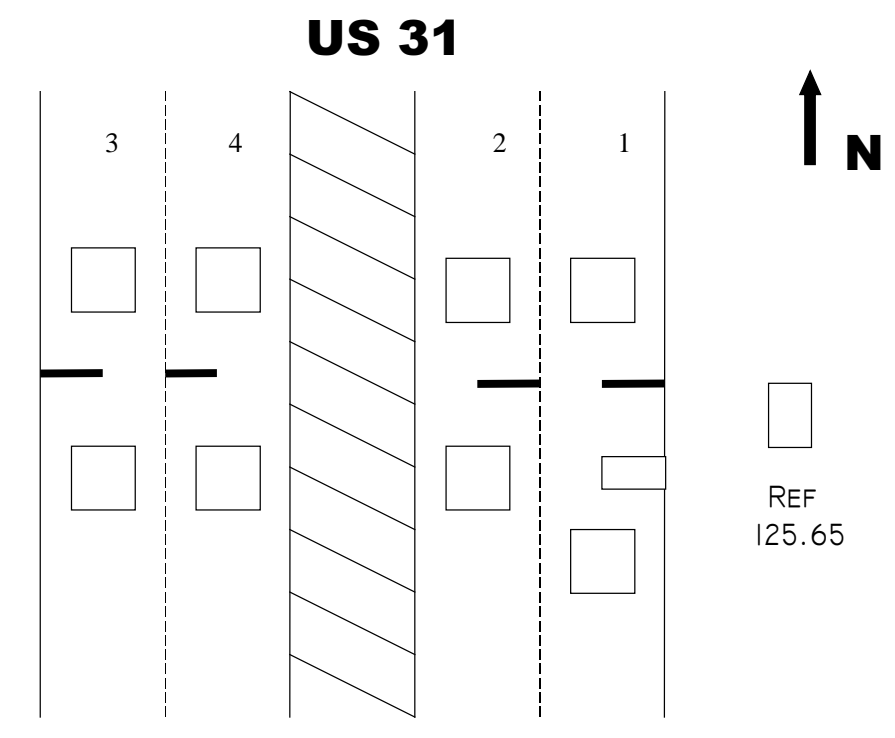

Figure A-27: Station 5550 Four Lane Divided

\begin{tabular}{|c|c|c|c|c|}
\hline & Lane 1 & Lane 2 & Lane 3 & Lane 4 \\
\hline WIM & $\mathrm{X}$ & $\mathrm{X}$ & $\mathrm{X}$ & $\mathrm{X}$ \\
\hline Classification & & & & \\
\hline Sensor & PIIEZO & PIEZO & PIEZO & PIEZO \\
\hline Pavement & $\mathrm{A}$ & $\mathrm{A}$ & $\mathrm{A}$ & $\mathrm{A}$ \\
\hline $\begin{array}{c}\text { Suitable for VWS } \\
6 / 00 \text { (F. Axle) }\end{array}$ & NO & NO & NO & NO \\
\hline $\begin{array}{c}\text { Suitable for VWS } \\
10 / 00 \text { (Class.) }\end{array}$ & NO & NO & NO & NO \\
\hline $\begin{array}{c}\text { Suitable for VWS } \\
\text { 3/01 (F. Axle) }\end{array}$ & NO & NO & NO & NO \\
\hline Klepinger Scale & 6 & 6 & 6 & 6 \\
\hline Calibration Dates & \multicolumn{4}{|c|}{$01-29-01,02-28-01$} \\
\hline
\end{tabular}

Table A-29: Station 5550 Inventory 


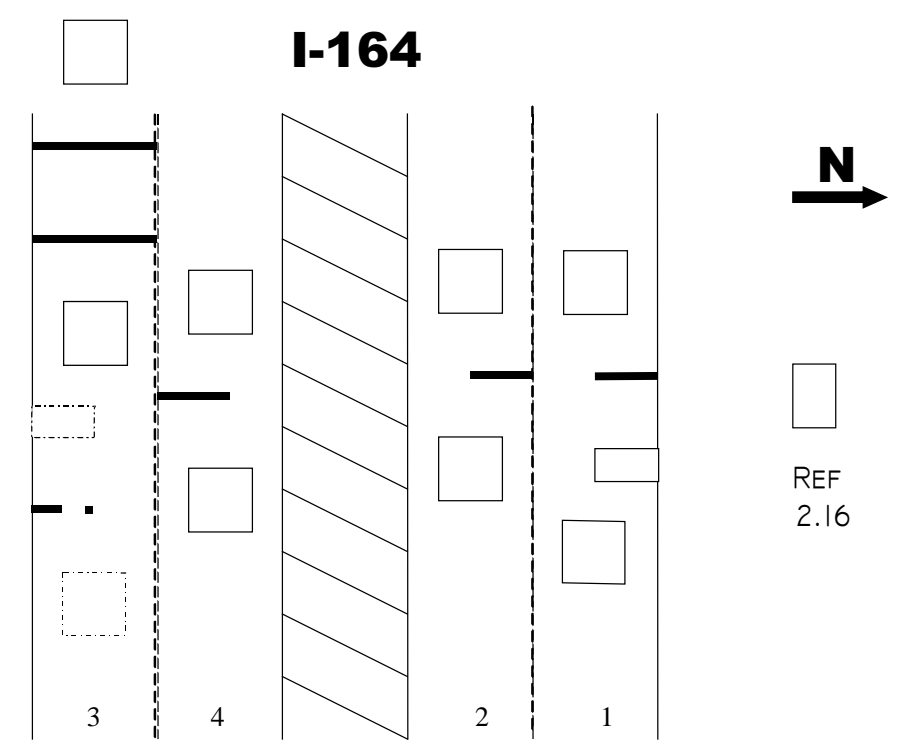

Figure A-28: Station 6130 Four Lane Divided

\begin{tabular}{|c|c|c|c|c|}
\hline & Lane 1 & Lane 2 & Lane 3 & Lane 4 \\
\hline WIM & $\mathrm{X}$ & & $\mathrm{X}$ & \\
\hline Classification & & $\mathrm{X}$ & & $\mathrm{X}$ \\
\hline Sensor & PIEZO & CLS & PIEZO & CLS \\
\hline Pavement & $\mathrm{A}$ & $\mathrm{A}$ & $\mathrm{A}$ & $\mathrm{A}$ \\
\hline $\begin{array}{c}\text { Suitable for VWS } \\
6 / 00 \text { (F. Axle) }\end{array}$ & $\mathrm{NO}$ & & NO & \\
\hline $\begin{array}{c}\text { Suitable for VWS } \\
10 / 00 \text { (Class.) }\end{array}$ & NO & & NO & \\
\hline $\begin{array}{c}\text { Suitable for VWS } \\
3 / 01 \text { (F. Axle) }\end{array}$ & NO & & NO & \\
\hline $\begin{array}{c}\text { Klepinger Scale } \\
\text { DATA }\end{array}$ & $4+$ & $4+$ & DATA & \\
\hline Calibration Dates & \multicolumn{3}{|l|}{$3-17-98,02-05-99$} & $4-$ \\
\hline
\end{tabular}

Table A-30: Station 6130 Inventory 


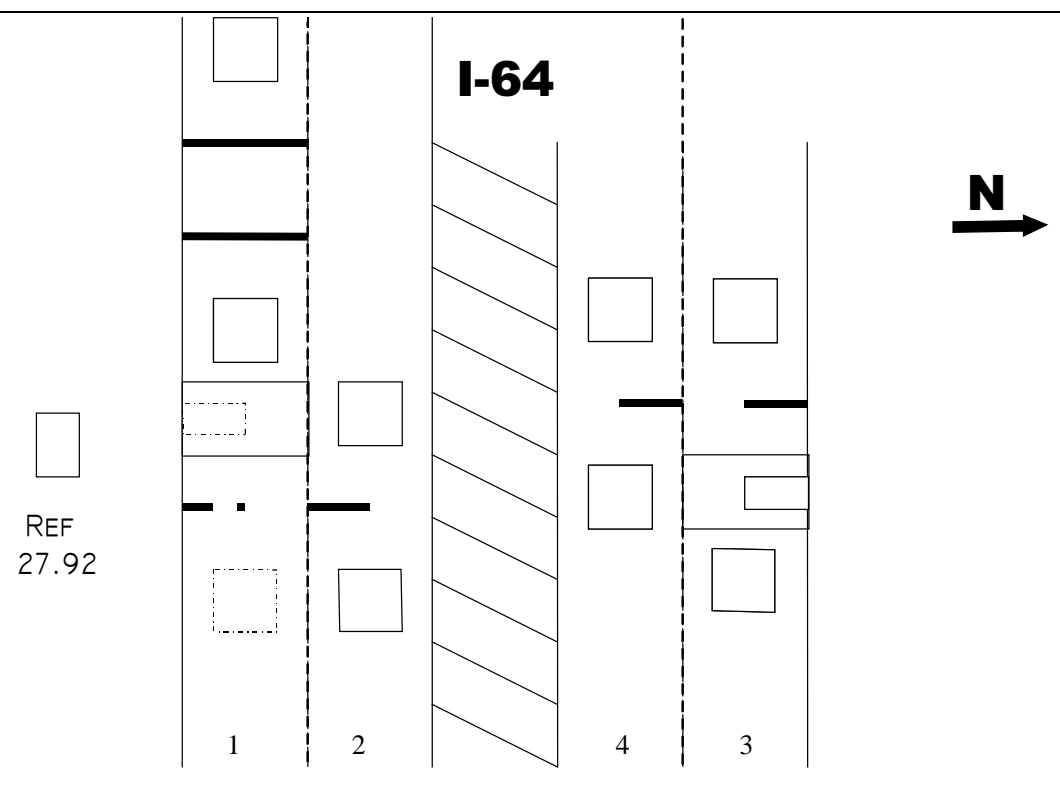

Figure A-29: Station 6140 Four Lane Divided

\begin{tabular}{|c|c|c|c|c|}
\hline & Lane 1 & Lane 2 & Lane 3 & Lane 4 \\
\hline WIM & $\mathrm{X}$ & & $\mathrm{X}$ & \\
\hline Classification & & $\mathrm{X}$ & & $\mathrm{X}$ \\
\hline Sensor & $\mathrm{PIEZO}$ & $\mathrm{CLS}$ & $\mathrm{BP}-\mathrm{V}$ & $\mathrm{CLS}$ \\
\hline Pavement & $\mathrm{A}$ & $\mathrm{A}$ & $\mathrm{A}$ & $\mathrm{A}$ \\
\hline $\begin{array}{c}\text { Suitable for VWS } \\
6 / 00 \text { (F. Axle) }\end{array}$ & $\mathrm{NO}$ & & $\mathrm{NO}$ & \\
\hline $\begin{array}{c}\text { Suitable for VWS } \\
10 / 00 \text { (Class.) }\end{array}$ & $\mathrm{NO}$ & & $\mathrm{NO}$ & \\
\hline $\begin{array}{c}\text { Suitable for VWS } \\
\text { 3/01 (F. Axle) }\end{array}$ & $\mathrm{NO}$ & & $\mathrm{NO}$ & \\
\hline Klepinger Scale & $4+$ & $4+$ & $4+$ & $4+$ \\
\hline Calibration Dates & \multicolumn{2}{|l}{} \\
\hline \multicolumn{2}{|l|}{}
\end{tabular}

Table A-31: Station 6140 Inventory 


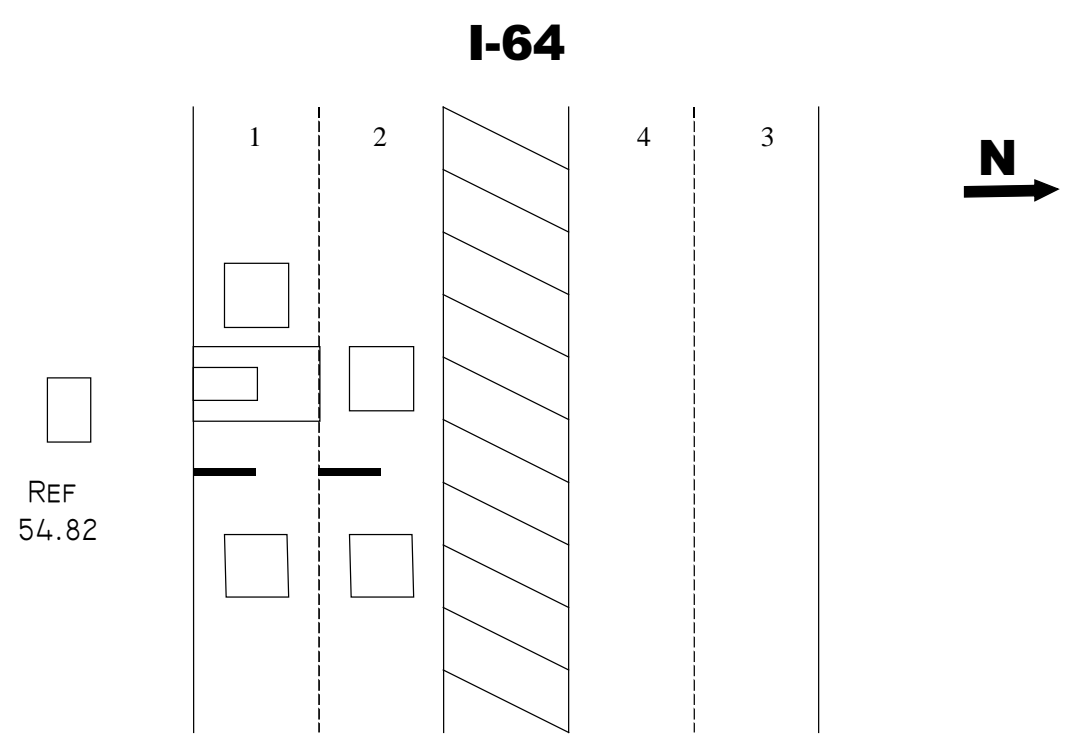

Figure A-30: Station 6150 Four Lane Divided

\begin{tabular}{|c|c|c|c|c|}
\hline & Lane 1 & Lane 2 & Lane 3 & Lane 4 \\
\hline WIM & $\mathrm{X}$ & & & \\
\hline Classification & & $\mathrm{X}$ & & \\
\hline Sensor & BP-V & CLS & & \\
\hline Pavement & $A$ & $A$ & $A$ & $A$ \\
\hline $\begin{array}{c}\text { Suitable for VWS } \\
6 / 00 \text { (F. Axle) }\end{array}$ & YES & & $\mathrm{N} / \mathrm{A}$ & $\mathrm{N} / \mathrm{A}$ \\
\hline $\begin{array}{c}\text { Suitable for VWS } \\
10 / 00 \text { (Class.) }\end{array}$ & $\mathrm{NO}$ & & $\mathrm{N} / \mathrm{A}$ & $\mathrm{N} / \mathrm{A}$ \\
\hline $\begin{array}{c}\text { Suitable for VWS } \\
\text { 3/01 (F. Axle) }\end{array}$ & NO & & $\mathrm{N} / \mathrm{A}$ & $\mathrm{N} / \mathrm{A}$ \\
\hline Klepinger Scale & $3+$ & $4+$ & $\mathrm{N} / \mathrm{A}$ & $\mathrm{N} / \mathrm{A}$ \\
\hline $\begin{array}{l}\text { Calibration } \\
\text { Dates }\end{array}$ & \multicolumn{4}{|c|}{$11-12-97,02-17-98,02-09-99$} \\
\hline
\end{tabular}

Table A-32: Station 6150 Inventory 


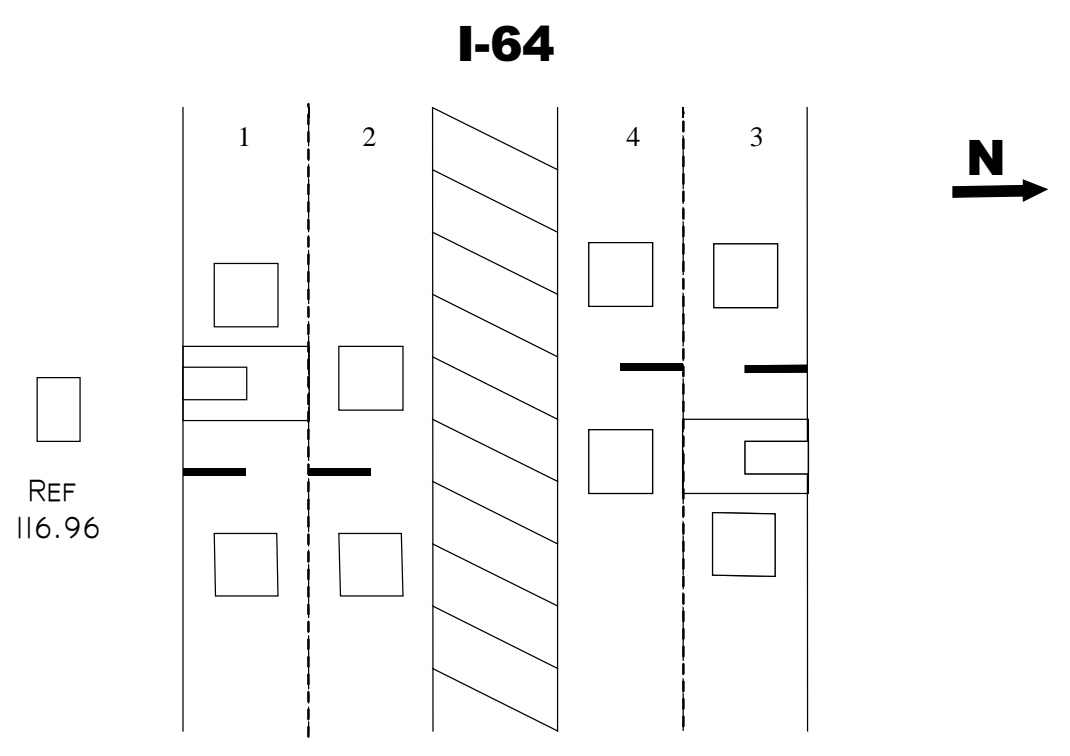

Figure A-31: Station 6160 Four Lane Divided

\begin{tabular}{|c|c|c|c|c|}
\hline & Lane 1 & Lane 2 & Lane 3 & Lane 4 \\
\hline WIM & $\mathrm{X}$ & & $\mathrm{X}$ & \\
\hline Classification & & $\mathrm{X}$ & & $\mathrm{X}$ \\
\hline Sensor & $\mathrm{BP}$ & $\mathrm{CLS}$ & $\mathrm{BP}$ & $\mathrm{CLS}$ \\
\hline Pavement & $\mathrm{C}$ & $\mathrm{C}$ & $\mathrm{C}$ & $\mathrm{C}$ \\
\hline $\begin{array}{c}\text { Suitable for VWS } \\
6 / 00 \text { (F. Axle) }\end{array}$ & $\mathrm{NO}$ & & $\mathrm{NO}$ & \\
\hline $\begin{array}{c}\text { Suitable for VWS } \\
10 / 00 \text { (Class.) }\end{array}$ & $\mathrm{NO}$ & & $\mathrm{NO}$ & \\
\hline $\begin{array}{c}\text { Suitable for VWS } \\
\text { 3/01 (F. Axle) }\end{array}$ & $\mathrm{NO}$ & & $\mathrm{NO}$ & \\
\hline $\begin{array}{c}\text { Klepinger Scale } \\
\text { Calibration } \\
\text { Dates }\end{array}$ & 2 & 3 & 1 & $2+$ \\
\hline
\end{tabular}

Table A-33: Station 6160 Inventory 


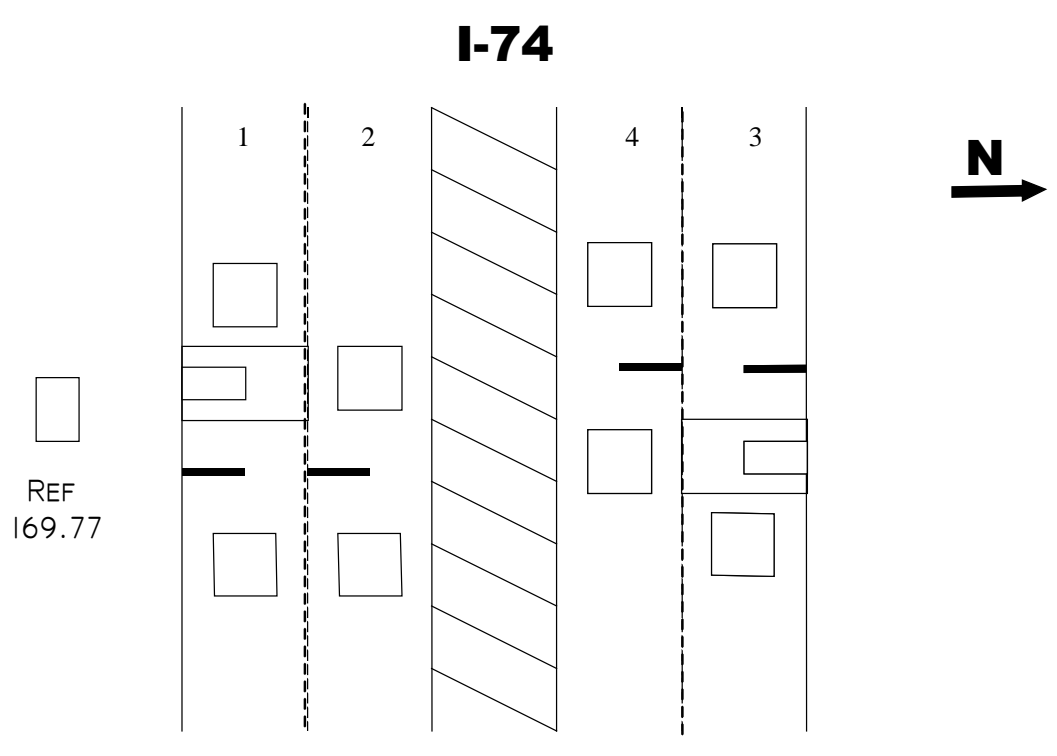

Figure A-32: Station 6170 Four Lane Divided

\begin{tabular}{|c|c|c|c|c|}
\hline & Lane 1 & Lane 2 & Lane 3 & Lane 4 \\
\hline WIM & $\mathrm{X}$ & & $\mathrm{X}$ & \\
\hline Classification & & $\mathrm{X}$ & & $\mathrm{X}$ \\
\hline Sensor & PIEZO & CLS & BP-V & CLS \\
\hline Pavement & $\mathrm{A}$ & $\mathrm{A}$ & $\mathrm{A}$ & $\mathrm{A}$ \\
\hline $\begin{array}{c}\text { Suitable for VWS } \\
6 / 00 \text { (F. Axle) }\end{array}$ & NO & & NO & \\
\hline $\begin{array}{c}\text { Suitable for VWS } \\
10 / 00 \text { (Class.) }\end{array}$ & YES & & NO & \\
\hline $\begin{array}{c}\text { Suitable for VWS } \\
\text { 3/01 (F. Axle) }\end{array}$ & NO & & YES & \\
\hline Klepinger Scale & 5 & $5+$ & 5 & $5+$ \\
\hline \begin{tabular}{c} 
Calibration Dates \\
\hline
\end{tabular} & $3-13-98,3-30-99$ \\
\hline
\end{tabular}

Table A-34: Station 6170 Inventory 


\section{SR 62}

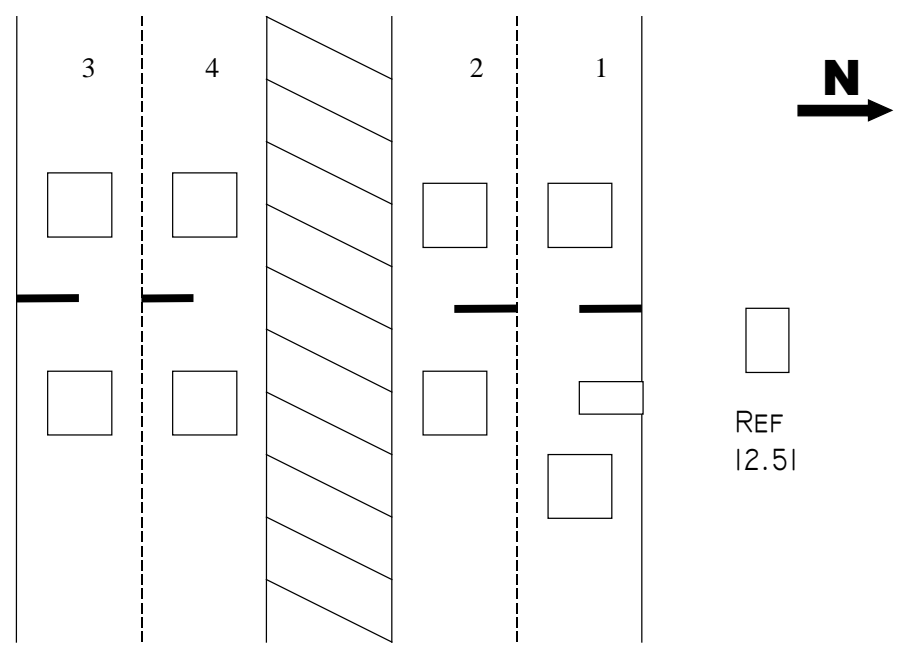

Figure A-33: Station 6250 Four Lane Divided

\begin{tabular}{|c|c|c|c|c|}
\hline & Lane 1 & Lane 2 & Lane 3 & Lane 4 \\
\hline WIM & $\mathrm{X}$ & & & \\
\hline Classification & & $\mathrm{X}$ & $\mathrm{X}$ & $\mathrm{X}$ \\
\hline Sensor & $\mathrm{BP}$ & CLS & CLS & CLS \\
\hline Pavement & C & C & C & C \\
\hline $\begin{array}{c}\text { Suitable for VWS } \\
6 / 00 \text { (F. Axle) }\end{array}$ & $\mathrm{NO}$ & & & \\
\hline $\begin{array}{l}\text { Suitable for VWS } \\
10 / 00 \text { (Class.) }\end{array}$ & $\mathrm{NO}$ & & & \\
\hline $\begin{array}{c}\text { Suitable for VWS } \\
3 / 01 \text { (F. Axle) }\end{array}$ & $\mathrm{NO}$ & & & \\
\hline Klepinger Scale & 5 & 5 & 5 & 5 \\
\hline $\begin{array}{l}\text { Calibration } \\
\text { Dates }\end{array}$ & & $3-15-c$ & $4-99$ & \\
\hline
\end{tabular}

Table A-35: Station 6250 Inventory 


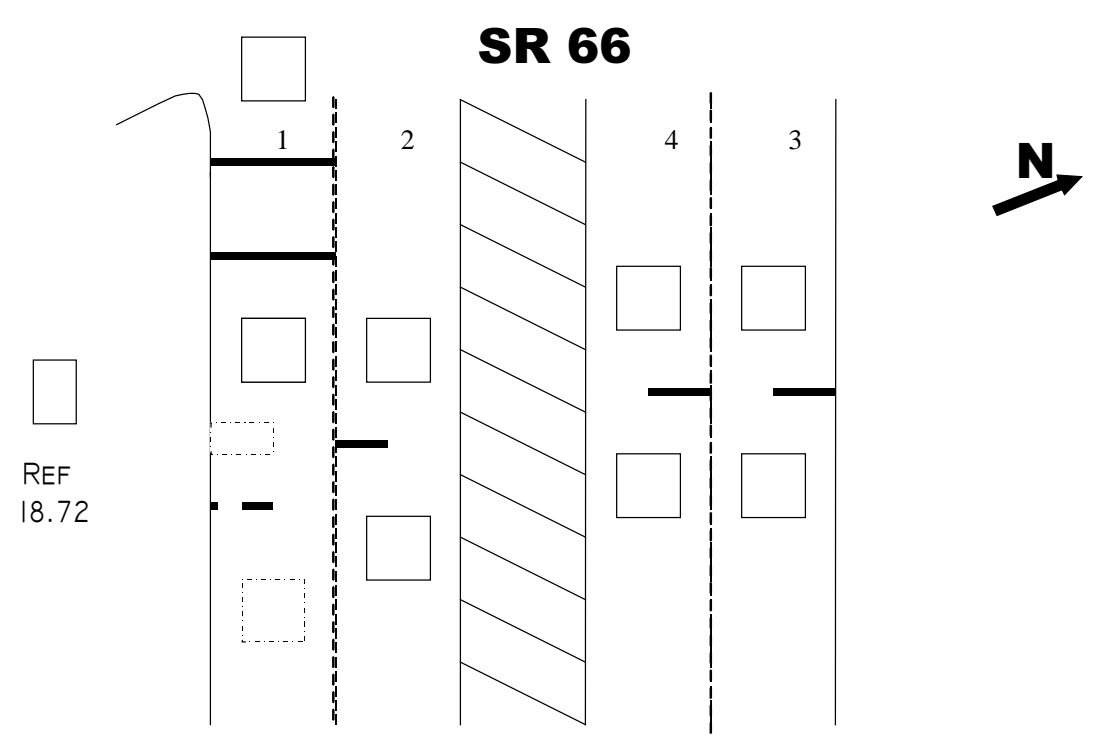

Figure A-34: Station 6260 Four Lane Divided

\begin{tabular}{|c|c|c|c|c|}
\hline & Lane 1 & Lane 2 & Lane 3 & Lane 4 \\
\hline WIM & $\mathrm{X}$ & & & \\
\hline Classification & & $\mathrm{X}$ & $\mathrm{X}$ & $\mathrm{X}$ \\
\hline Sensor & PIEZO & CLS & CLS & CLS \\
\hline Pavement & C & C & C & C \\
\hline $\begin{array}{c}\text { Suitable for VWS } \\
\text { 6/00 (F. Axle) }\end{array}$ & $\begin{array}{c}\text { NO } \\
\text { DATA }\end{array}$ & & & \\
\hline $\begin{array}{c}\text { Suitable for VWS } \\
10 / 00 \text { (Class.) }\end{array}$ & YES & & & \\
\hline $\begin{array}{c}\text { Suitable for VWS } \\
\text { 3/01 (F. Axle) }\end{array}$ & NO & & & \\
\hline DATA & & 3 & 3 & 3 \\
\hline $\begin{array}{c}\text { Calibinger Scale } \\
\text { Calion Dates }\end{array}$ & $3-$ & $3-19-98,01-04-99$ \\
\hline
\end{tabular}

Table A-36: Station 6260 Inventory 


\section{SR 66}

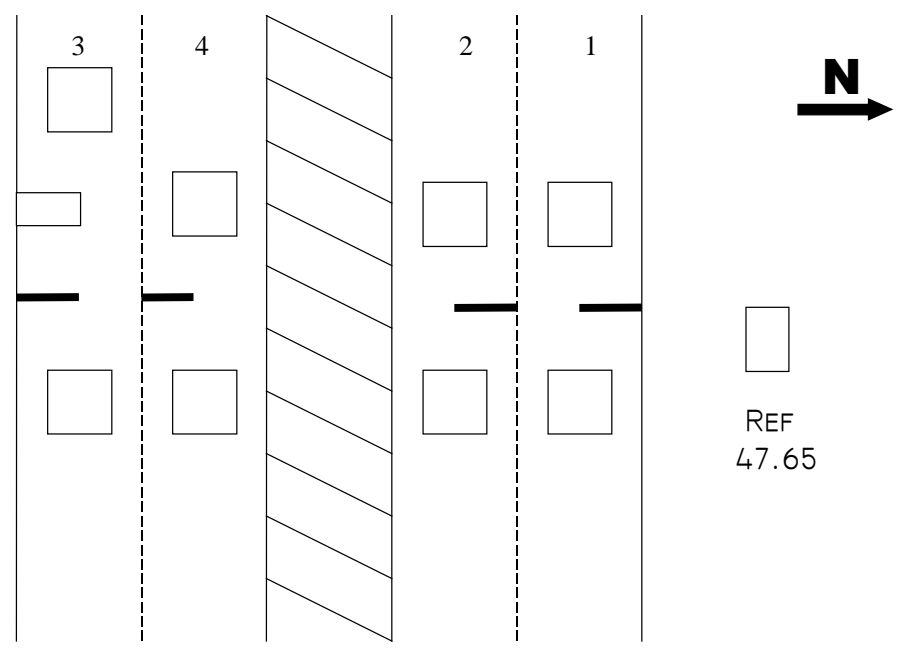

Figure A-35: Station 6270 Four Lane Divided

\begin{tabular}{|c|c|c|c|c|}
\hline & Lane 1 & Lane 2 & Lane 3 & Lane 4 \\
\hline WIM & & & X & \\
\hline Classification & X & X & & X \\
\hline Sensor & CLS & CLS & BP & CLS \\
\hline Pavement & A & A & A & A \\
\hline $\begin{array}{c}\text { Suitable for VWS } \\
\text { 6/00 (F. Axle) }\end{array}$ & & & NO & \\
\hline $\begin{array}{c}\text { Suitable for VWS } \\
\text { 10/00 (Class.) }\end{array}$ & & YES & \\
\hline $\begin{array}{c}\text { Suitable for VWS } \\
\text { 3/01 (F. Axle) }\end{array}$ & & & NO & \\
\hline Klepinger Scale & 3 & 3 & $3-$ & $2+$ \\
\hline Calibration Dates & $11-13-97,02-11-98,02-10-99$ \\
\hline
\end{tabular}

Table A-37: Station 6270 Inventory 


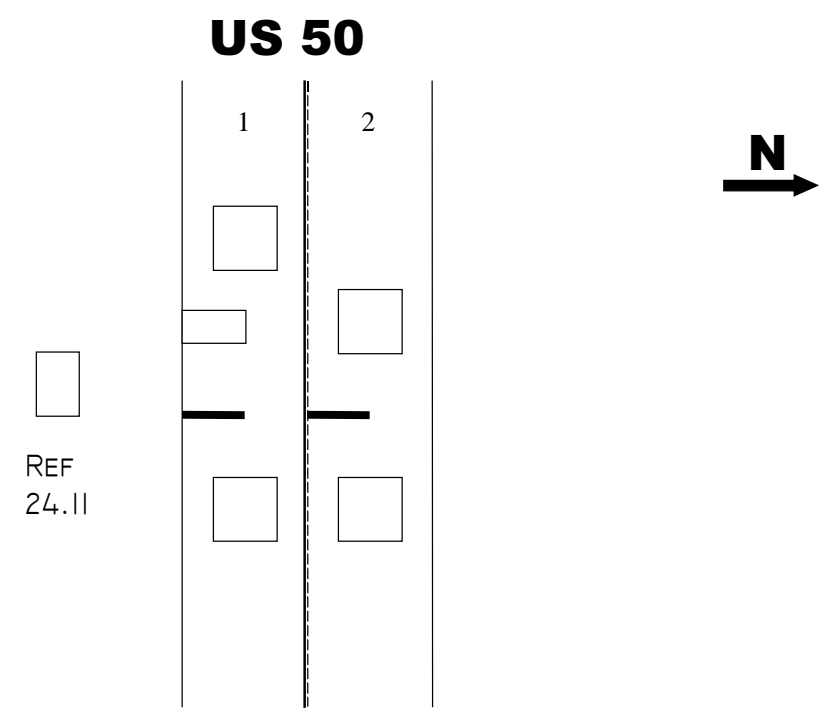

Figure A-36: Station 6280 Two Lane Undivided

\begin{tabular}{|c|c|c|}
\hline & Lane 1 & Lane 2 \\
\hline WIM & $\mathrm{X}$ & \\
\hline Classification & & $\mathrm{X}$ \\
\hline Sensor & $\mathrm{BP}$ & $\mathrm{CLS}$ \\
\hline Pavement & $\mathrm{A}$ & $\mathrm{A}$ \\
\hline $\begin{array}{c}\text { Suitable for VWS } \\
6 / 00 \text { (F. Axle) }\end{array}$ & $\mathrm{NO}$ & \\
\hline $\begin{array}{c}\text { Suitable for VWS } \\
10 / 00 \text { (Class.) }\end{array}$ & $\mathrm{NO}$ & \\
\hline $\begin{array}{c}\text { Suitable for VWS } \\
\text { 3/01 (F. Axle) }\end{array}$ & $\mathrm{NO}$ & \\
\hline Klepinger Scale & $2+$ & $2+$ \\
\hline Calibration Dates & $\begin{array}{c}10-08-97,3-26- \\
99,4-23-99\end{array}$ \\
\hline
\end{tabular}

Table A-38: Station 6280 Inventory 


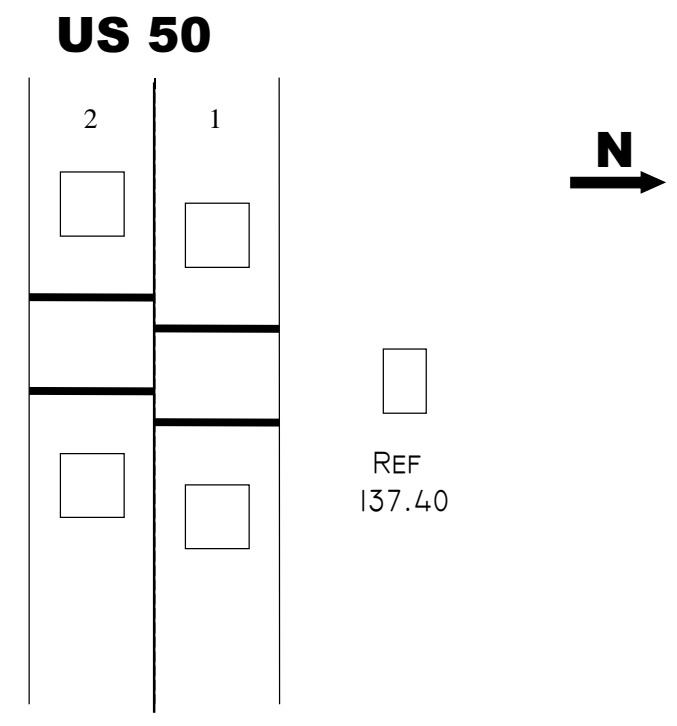

Figure A-37: Station 6290 Two Lane Undivided

\begin{tabular}{|c|c|c|}
\hline & Lane 1 & Lane 2 \\
\hline WIM & $\mathrm{X}$ & $\mathrm{X}$ \\
\hline Classification & & \\
\hline Sensor & PIEZO & PIEZO \\
\hline Pavement & $\mathrm{A}$ & $\mathrm{A}$ \\
\hline $\begin{array}{c}\text { Suitable for VWS } \\
6 / 00 \text { (F. Axle) }\end{array}$ & $\mathrm{NO}$ & $\mathrm{NO}$ \\
\hline $\begin{array}{c}\text { Suitable for VWS } \\
10 / 00 \text { (Class.) }\end{array}$ & $\mathrm{NO}$ & $\mathrm{NO}$ \\
\hline $\begin{array}{c}\text { Suitable for VWS } \\
\text { 3/01 (F. Axle) }\end{array}$ & $\mathrm{NO}$ & $\mathrm{NO}$ \\
\hline Klepinger Scale & 4 & $4-$ \\
\hline Calibration Dates & $01-16-98,3-04-99$ \\
\hline
\end{tabular}

Table A-39: Station 6290 Inventory 


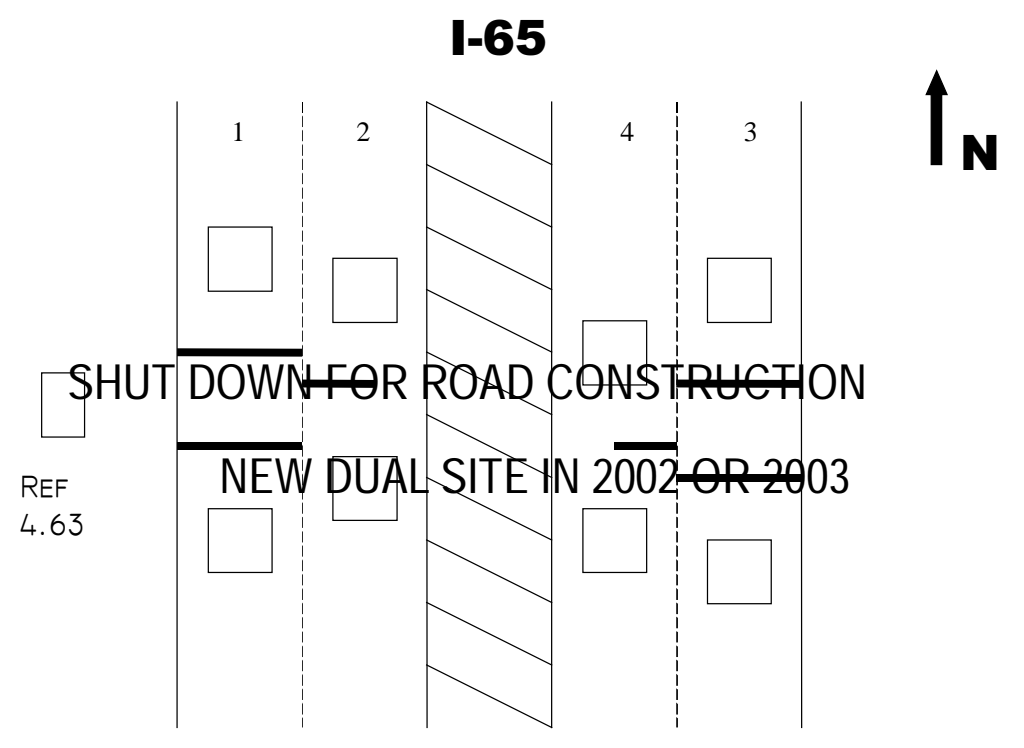

Figure A-38: Station 6420 Four Lane Divided

\begin{tabular}{|c|l|l|l|l|}
\hline & Lane 1 & Lane 2 & Lane 3 & Lane 4 \\
\hline WIM & & & & \\
\hline Classification & & & & \\
\hline Sensor & & & & \\
\hline Pavement & & & & \\
\hline Suitable for & & & & \\
VWS 7/00 & & & & \\
\hline Suitable for & & & & \\
VWS 10/00 & & & & \\
\hline Suitable for & & & & \\
VWS 2/01 & & & & \\
\hline Klepinger Scale & & & & \\
\hline Calibration & & & & \\
Dates & & & \\
\hline
\end{tabular}

Table A-40: Station 6420 Inventory 


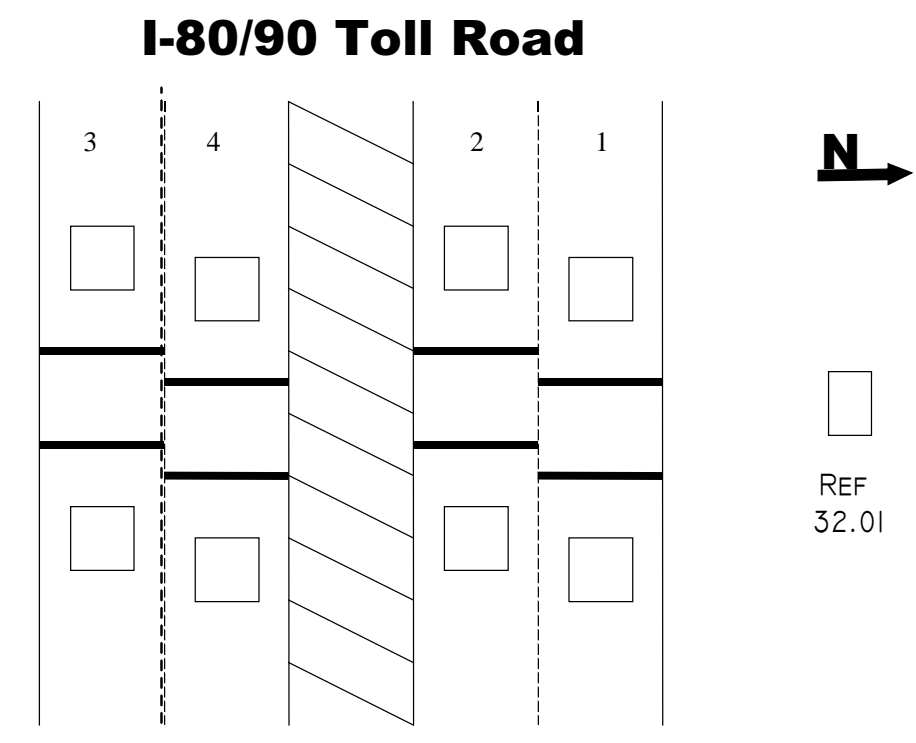

Figure A-39: Station 7300 Four Lane Divided

\begin{tabular}{|c|c|c|c|c|}
\hline & Lane 1 & Lane 2 & Lane 3 & Lane 4 \\
\hline WIM & $\mathrm{X}$ & $\mathrm{X}$ & $\mathrm{X}$ & $\mathrm{X}$ \\
\hline Classification & & & & \\
\hline Sensor & PIEZO & PIEZO & PIEZO & PIEZO \\
\hline Pavement & $\mathrm{C}$ & $\mathrm{C}$ & $\mathrm{C}$ & $\mathrm{C}$ \\
\hline $\begin{array}{c}\text { Suitable for VWS } \\
6 / 00 \text { (F. Axle) }\end{array}$ & NO & NO & NO & NO \\
DATA & DATA & DATA & DATA \\
\hline $\begin{array}{c}\text { Suitable for VWS } \\
10 / 00 \text { (Class.) }\end{array}$ & NO & NO & NO & NO \\
\hline $\begin{array}{c}\text { Suitable for VWS } \\
\text { 3/01 (F. Axle) }\end{array}$ & NO & NATA & DATA & DATA \\
\hline Klepinger Scale & & & YES & NO \\
\hline Calibration Dates & & & & \\
\hline
\end{tabular}

Table A-41: Station 7300 Inventory 
I-80/90 Toll Road

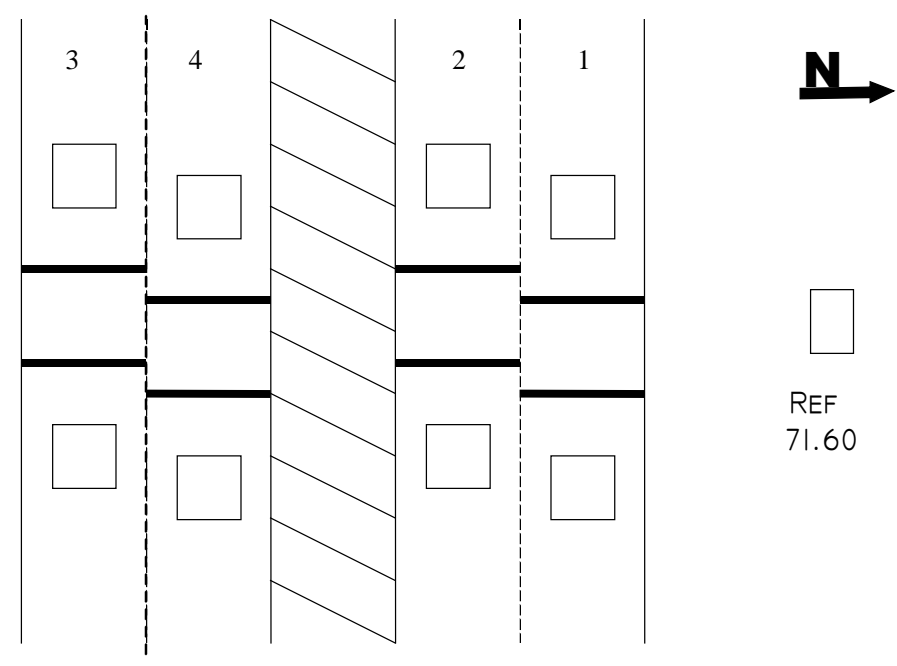

Figure A-40: Station 7320 Four Lane Divided

\begin{tabular}{|c|c|c|c|c|}
\hline & Lane 1 & Lane 2 & Lane 3 & Lane 4 \\
\hline WIM & $\mathrm{X}$ & $\mathrm{X}$ & $\mathrm{X}$ & $\mathrm{X}$ \\
\hline Classification & & & & \\
\hline Sensor & PIEZO & PIEZO & PIEZO & PIEZO \\
\hline Pavement & C & C & C & C \\
\hline $\begin{array}{c}\text { Suitable for VWS } \\
\text { 6/00 (F. Axle) }\end{array}$ & NO & NO & NO & NO \\
Suitable for VWS & NO & NATA & DATA & DATA \\
$10 / 00$ (Class.) & DATA & DATA & NO & NO \\
\hline $\begin{array}{c}\text { Suitable for VWS } \\
\text { 3/01 (F. Axle) }\end{array}$ & YES & YES & NO & DAT \\
\hline Klepinger Scale & & & & \\
\hline Calibration Dates & & & & \\
\hline
\end{tabular}

Table A-42: Station 7320 Inventory 
I-80/90 Toll Road

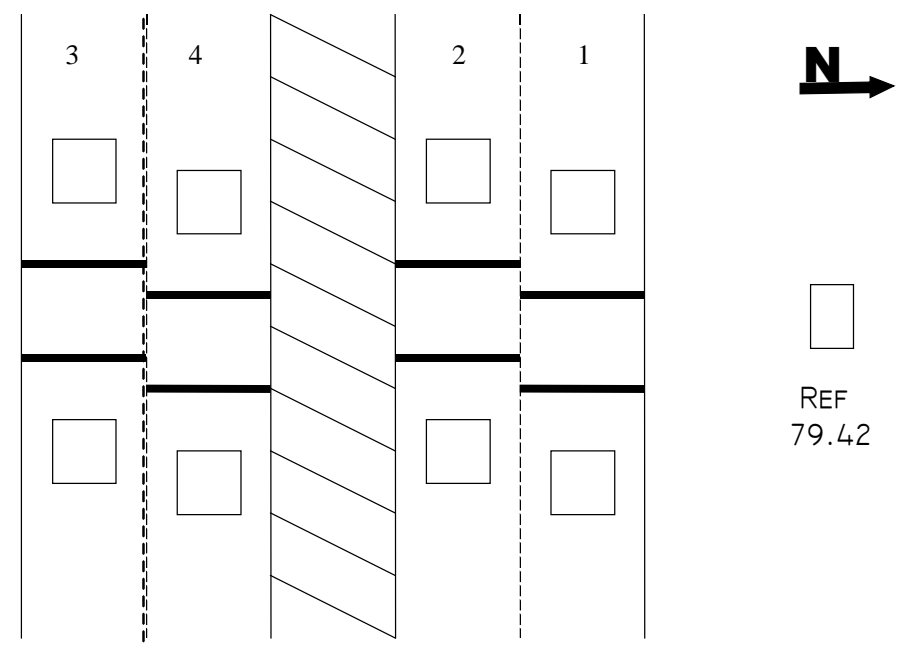

Figure A-41: Station 7340 Four Lane Divided

\begin{tabular}{|c|c|c|c|c|}
\hline & Lane 1 & Lane 2 & Lane 3 & Lane 4 \\
\hline WIM & $\mathrm{X}$ & $\mathrm{X}$ & $\mathrm{X}$ & $\mathrm{X}$ \\
\hline Classification & & & & \\
\hline Sensor & PIEZO & PIEZO & PIEZO & PIEZO \\
\hline Pavement & C & C & C & C \\
\hline $\begin{array}{c}\text { Suitable for VWS } \\
\text { 6/00 (F. Axle) }\end{array}$ & NO & NO & NO & NO \\
Suitable for VWS & NO & NATA & DATA & DATA \\
$10 / 00$ (Class.) & DATA & DATA & NO & NO \\
\hline $\begin{array}{c}\text { Suitable for VWS } \\
\text { 3/01 (F. Axle) }\end{array}$ & YES & NO & NO & DAT \\
\hline Klepinger Scale & & & & \\
\hline Calibration Dates & & & & \\
\hline
\end{tabular}

Table A-43: Station 7340 Inventory 
Appendix B Evaluation of Covington WIM 


$\begin{array}{ccccc}\begin{array}{c}\text { January } 4,2001 \\ \text { I-74 Scale }\end{array} & & & & \\ \text { WIM 5130 } & & & & \\ & \text { Ed Allen } & \text { John Green } & \text { Error } & \% \text { Error } \\ \text { Record \# } & \text { GVW WIM } & \text { GVW Scale } & & \\ 3221 & 81,800 & 79,360 & 2,440 & 3 \% \\ 3332 & 81,600 & 77,860 & 3,740 & 5 \% \\ 3355 & 50,700 & 50,640 & 60 & 0 \% \\ 3400 & 33,000 & 38,840 & -5,840 & -15 \% \\ 3452 & 70,200 & 74,520 & -4,320 & -6 \% \\ 3532 & 56,900 & 59,800 & -2,900 & -5 \% \\ 3579 & 46,700 & 48,080 & -1,380 & -3 \% \\ 3771 & 66,100 & 30,580 & 35,520 & 116 \% \\ 3810 & 80,900 & 77,660 & 3,240 & 4 \% \\ 3970 & 73,900 & 72,280 & 1,620 & 2 \% \\ 4030 & 51,700 & 58,780 & -7,080 & -12 \% \\ 4083 & 79,000 & 77,900 & 1,100 & 1 \% \\ 4205 & 28,100 & 33,980 & -5,880 & -17 \% \\ 4376 & 82,700 & 76,780 & 5,920 & 8 \% \\ 4409 & 75,500 & 74,720 & 780 & 1 \% \\ 4475 & 81,800 & 77,760 & 4,040 & 5 \% \\ 4521 & 80,700 & 76,320 & 4,380 & 6 \% \\ 4558 & 44,900 & 46,280 & -1,380 & -3 \% \\ 4595 & 80,700 & 78,560 & 2,140 & 3 \% \\ 4648 & 37,500 & 39,480 & -1,980 & -5 \% \\ 4707 & 31,000 & 33,680 & -2,680 & -8 \% \\ 4760 & 75,700 & 75,100 & 600 & 1 \% \\ 4804 & 78,600 & 78,420 & 180 & 0 \% \\ 4839 & 62,500 & 65,380 & -2,880 & -4 \%\end{array}$

Table B-1: 01-04-01 Test of WIM System 
Comparison of Weight Data

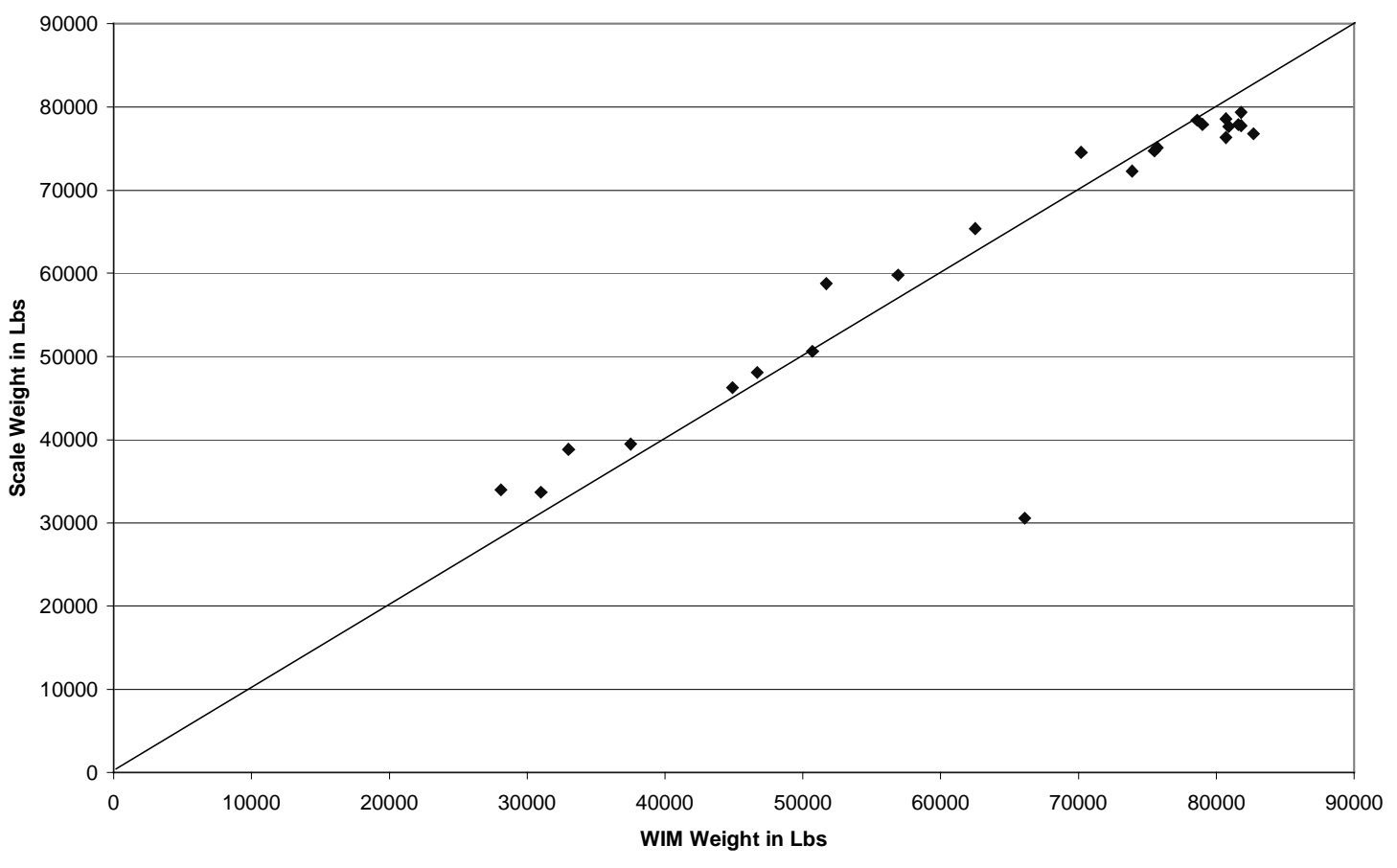

Figure B-1: Comparison of Test Weights 01-04-01 at Covington WIM 5130 
Appendix C Diversion Routes 


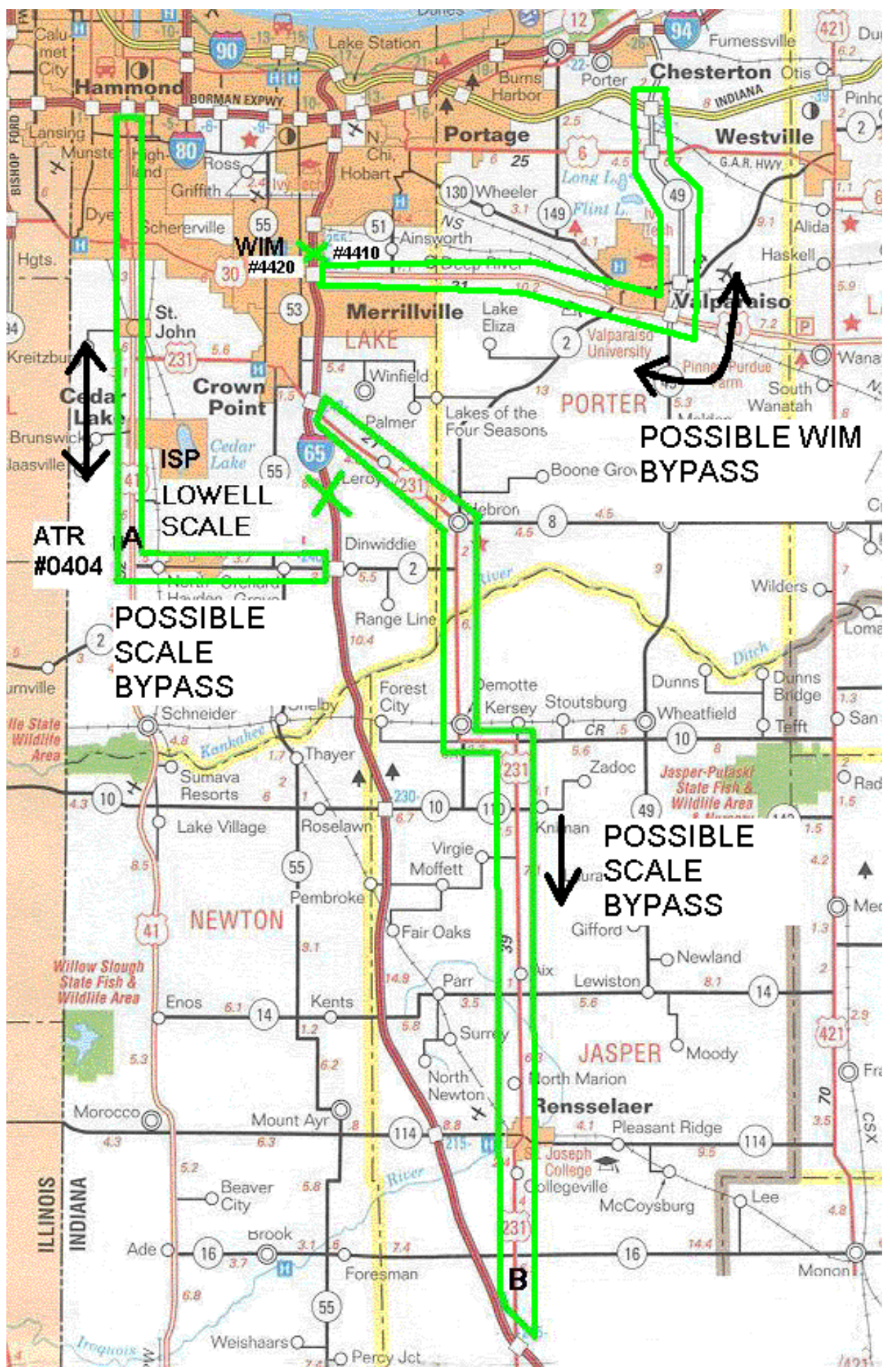

Figure C-1: Lowell Scale Diversion Routes 


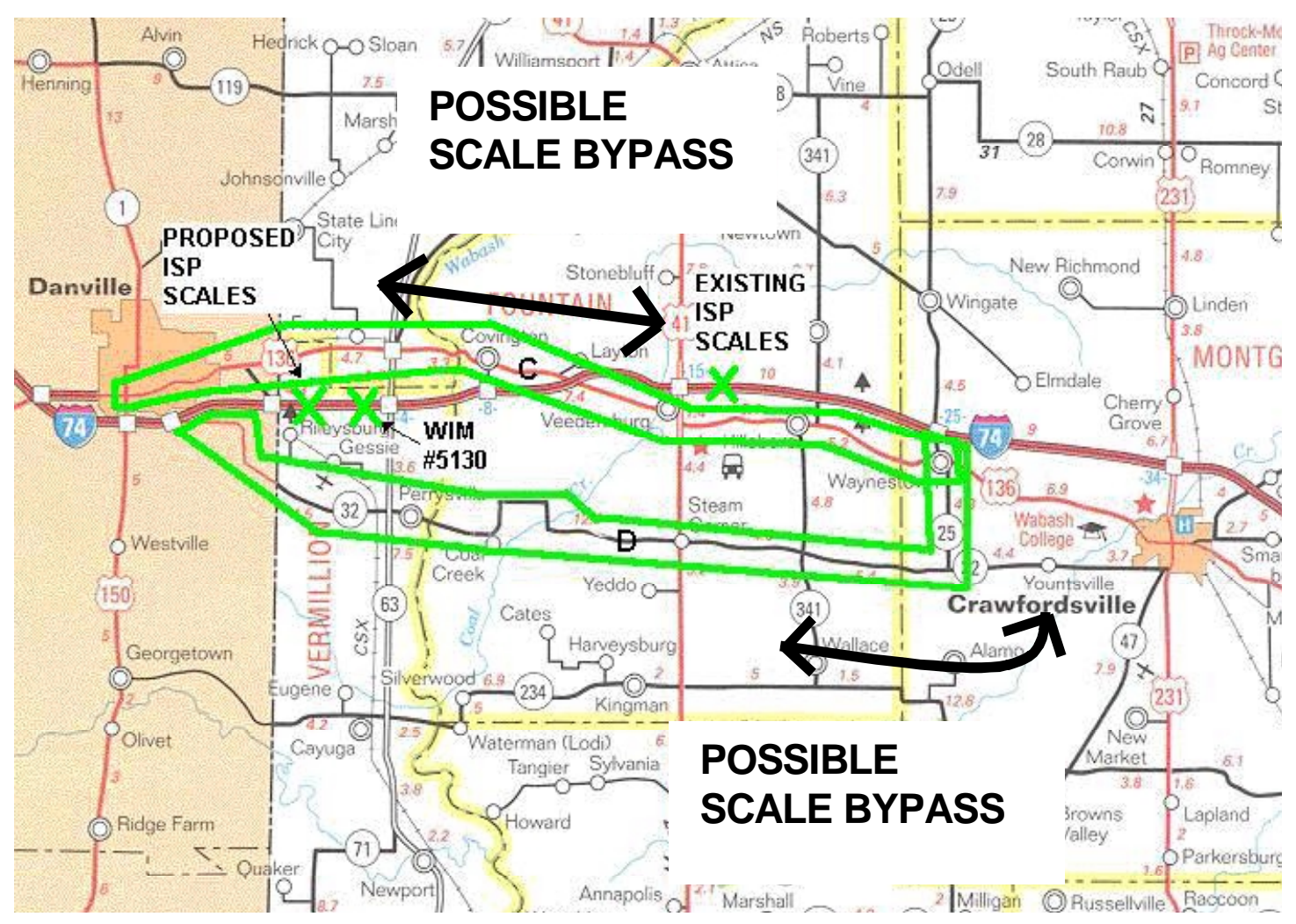

Figure C-2: Covington Scale Diversion Routes 
Appendix D International Road Dynamics Cost Summary Memo 


\section{D.1 Kistler WIM}

The Kistler WIM consists of a light metal profile in the middle of which quartz disks are fitted under preload. When force is applied to the sensor surface the quartz disks yield an electric charge proportional to the applied force through piezoelectric effect. This electric charge is converted by a charge amplifier into a proportional voltage that can then be further processed as required.

The sensors can be installed in combination with other traffic detectors like induction loops, switching cables, etc. Kistler WIM sensors are easy to install both individually and in groups for comprehensive recording over a wide roadway. Typically, four one-meter-long (39.4") sensors are required to cover one typical lane width of approximately 12 feet.

Installation begins by making a relatively small cut in the road into which the sensor will be installed. The size of the cut varies depending on the sensor being installed, but is generally 2.25" deep and 3" wide. The sensor is placed in the sawcut and secured in place by a fast curing grout.

A complete lane installation consisting of eight sensors and two loops can be accomplished in less than a day, including curing time.

When properly installed and calibrated, the Kistler WIM system should be expected to provide gross vehicle weights that are within $10 \%$ of the actual vehicle weight for $95 \%$ of the trucks measured. 


\section{D.1.1 Common Configuration}
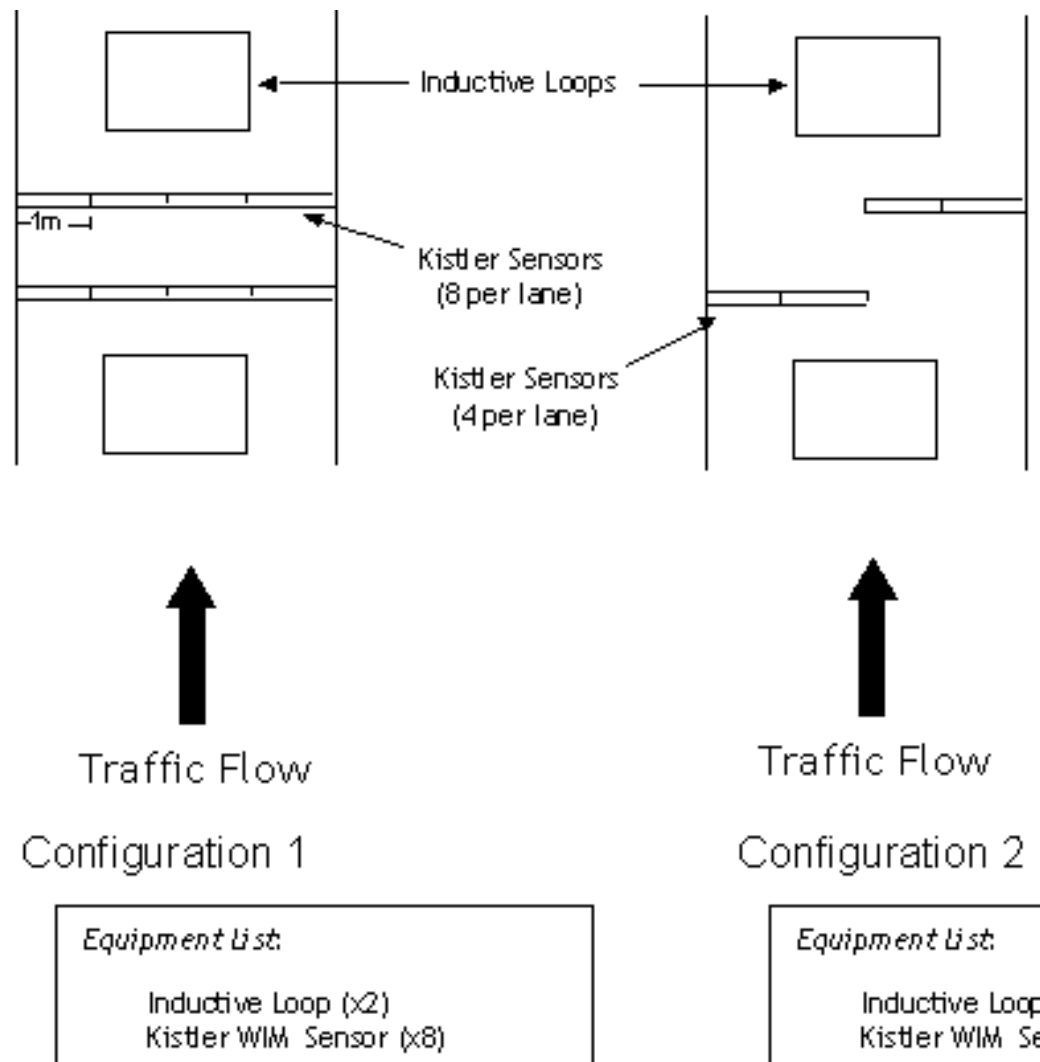

Configuration 2

Equipment List:

Inductive Loop ( $(2)$

Kistler wilk Sensor (x4)

Figure D-1: Common Configurations of Kistler Sensors

\section{D.1.2 Scheduled Maintenance}

At six (6) Month intervals the following Scheduled Maintenance should be performed to ensure continual sensor operation:

- Visually inspect the Kistler sensor installation.

- Ensure no cracks are forming in grout or surrounding pavement.

- Ensure seal between grout and pavement.

- Maintain the installation of the grout.

- Maintain all Kistler sensor cable splices as required.

- Visually inspect the BNC connector and replace if required.

- Measure the resistance and voltage output of the sensor. 


\section{D.2 Single Load Cell Scale}

The Single Load Cell Scale consists of two (2) weighing platforms with a surface size of 6' by 3'2", placed adjacent to each other to fully cover a normal 12 ' traffic lane. A single hydraulic load cell is installed at the center of each platform to measure the force applied to the scales. The load measurements are recorded and analyzed by the system electronics to determine the axle loads.

The installation of a single load cell scale requires the use of a concrete vault. The roadway is cut and excavated to form a pit. The frame is positioned in place and then is cast into the concrete to form a secure and durable foundation for the scale. The size of the vault required is slightly large, measuring 165 " by 58 " by 38 ".

The Single Load Cell scale is typically installed in a lane with two inductive loops and an axle sensor to provide vehicle length and axle spacing information. Installing a complete lane of scales, loops and axle sensor can be accomplished in 3 days.

When properly installed and calibrated, the Single Load Cell WIM system should be expected to provide gross vehicle weights that are within $6 \%$ of the actual vehicle weight for $95 \%$ of the trucks measured.

\section{D.2.1 Common Configuration}

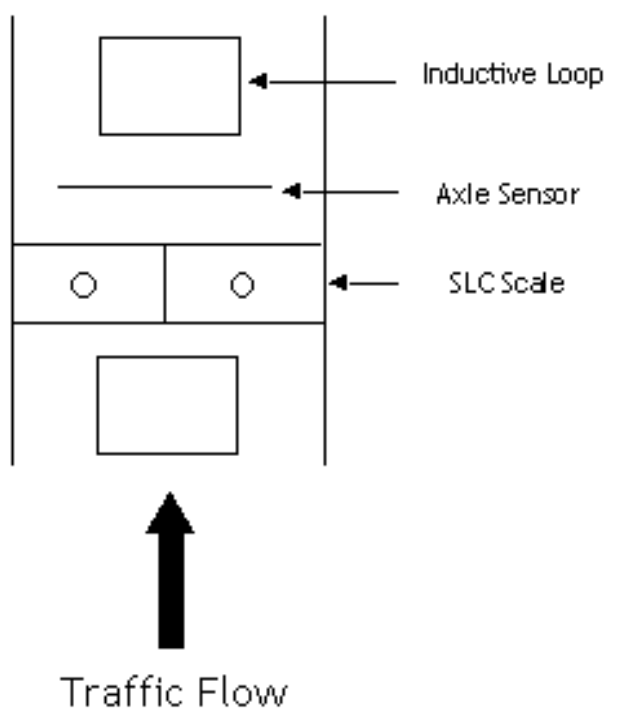

Equipment list:

Inductive Loop $(2)$

Single Load Cell Sca (1 Lane)

Axle Sensor ( $x 1$ )

Figure D-2: Common Configuration of Single Load Cell Scale 


\section{D.2.2 Scheduled Maintenance}

At six (6) month intervals the following scheduled maintenance should be performed to ensure continued scale operation:

- Visually inspect the scale installation.

- Maintain installation of the concrete vault.

- Maintain the slot between the concrete vault and the existing roadway with loop sealant.

- Remove the load cell from the load cell cavity, retorque the four (4) mounting bolts in the load cell cavity, check the splice, replace the antifreeze in the load cell cavity, replace the load cell, load cell hatch, secure and reseal load cell hatch.

- $\quad$ Retorque and/or replace the eight (8) mounting bolts as required.

- $\quad$ Replace all frost plugs as required.

- $\quad$ Maintain the installation of the silicon sealant between the scale and frame.

- Maintain all splices in junction boxes as required.

- $\quad$ Measure the signal cable resistance of the scale.

- Recalibrate the scale.

\section{D.3 Bending Plate Scale}

The Bending Plate scale consists of two steel platforms, which are each 2' by 6', placed adjacent to each other to cover a 12' lane. The steel plate is instrumented with strain gages at critical points to measure the strain in the plate as a tire or axle passes over. The measured strain is analyzed to determine the axle load. The Bending Plate scale is typically installed in a lane with two inductive loops and an axle sensor to provide vehicle length and axle spacing information.

There are two basic installation methods for a Bending Plate scale. In concrete roadways of sufficient depth, a shallow excavation is made in the surface of the road (Quick Installation). The scale frame is anchored into place using anchoring bars and epoxy. In asphalt roads or thin concrete roads, it is necessary to install a concrete foundation for support of the frame (Vault Installation). The roadway is cut and excavated to form a pit of 30 " deep by 4'10" wide by 13'10"long. The frame is positioned in place and then is cast into concrete to form a secure and durable foundation for the scale. 
Installing a complete lane of scales, loops and axle sensor can be accomplished in a day using the shallow excavation method and in 3 days using the concrete vault.

When properly installed and calibrated, the Bending Plate WIM system should be expected to provide gross vehicle weights that are within $10 \%$ of the actual vehicle weight for $95 \%$ of the trucks measured.

\section{D.3.1 Common Configuration}

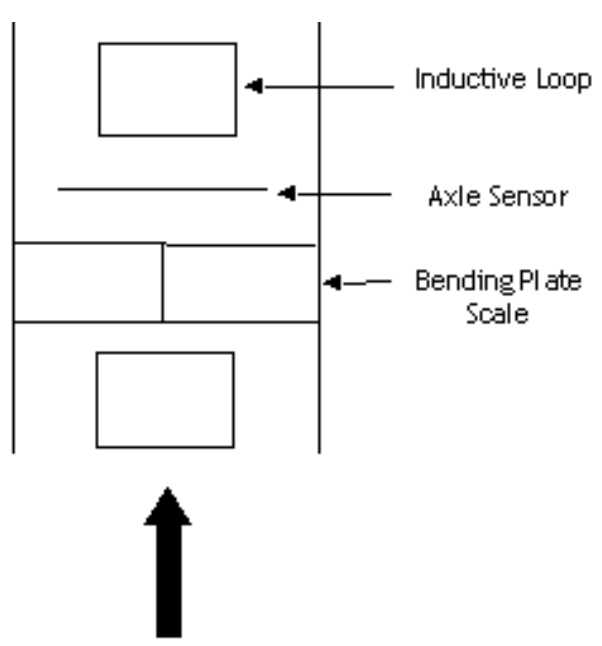

Equipment list:

Inductive Loop (x)

Bending Plate Scale (1 I ane)

Axle Sensor ( $x 1$ )

Traffic Flow

Figure D-3: Common Configuration of Bending Plate Scale

\section{D.3.2 Scheduled Maintenance}

\section{Quick Installation (No concrete vault)}

At six (6) month intervals the following scheduled maintenance should be performed to ensure continued scale operation:

- Visually inspect the scale installation.

- Maintain installation of the epoxy material

- Re-torque and/or replace stainless steel cap screws.

- Replace frost plugs as required.

- Maintain installation of the silicon seal.

- Maintain all splices in the junction boxes as required.

- Measure signal cable resistance of scale. 
- Recalibrate the scales.

\section{Vault Installation}

At six (6) month intervals the following scheduled maintenance should be performed to ensure continued scale operation:

- Visually inspect the scale installation.

- Maintain installation of the concrete vault.

- Maintain the slot between the concrete vault and the existing roadway with loop sealant.

- Re-Torque and/or replace stainless steel cap screws.

- Replace frost plugs as required.

- Maintain installation of the silicon seal.

- Maintain all splices in the junction boxes as required.

- Measure signal cable resistance of scale.

- Recalibrate the scales.

\section{D.4 Piezoelectric Sensors}

The basic construction of the typical sensor consists of a copper strand, surrounded by a piezoelectric material, which is covered by a copper sheath. When pressure is applied to the piezoelectric material an electrical charge is produced. The sensor is actually embedded in the pavement and the load is transferred through the pavement. The characteristics of the pavement will therefore affect the output signal. By measuring and analyzing the charge produced, the sensor can be used to measure the weight of a passing tire or axle group.

For a complete data collection system, it is common to install two inductive loops and two piezoelectric sensors in each lane, which is being monitored. Installation begins by making a relatively small cut in the road into which the sensor will be installed. The size of the cut varies depending on the sensor being installed, but is generally 1 " to 2" deep and 1" to 2" wide. The sensor is placed in the sawcut and secured in place by a fast curing grout.

A complete lane installation consisting of two sensors and two loops can be accomplished in less than a full day, including curing time.

When properly installed and calibrated, a piezoelectric WIM system should be expected to provide gross vehicle weights that are within $15 \%$ of the actual vehicle weight for $95 \%$ of the trucks measured. 


\section{D.4.1 Common Configuration}

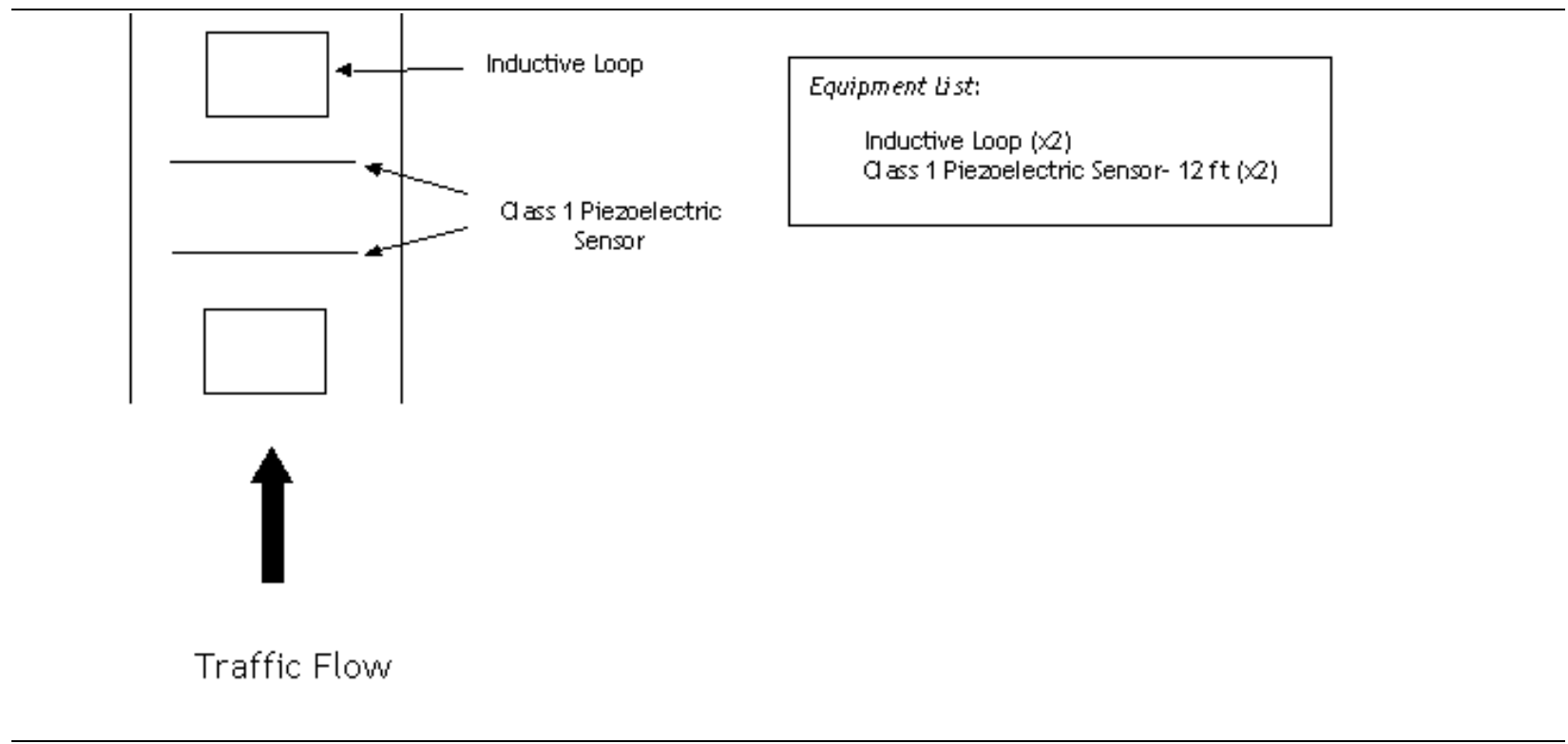

Figure D-4: Common Configuration of Piezoelectric Sensor

\section{D.4.2 Scheduled Maintenance}

At six (6) Month intervals the following Scheduled Maintenance should be performed to ensure continual sensor operation:

- Visually inspect the piezo installation.

- Maintain the installation of the grout.

- Maintain all piezo cable splices as required.

- Visually inspect the BNC connector and replace if required.

- Measure the resistance and voltage output of the sensor. 


\section{D.5 Comparison of WIM Technology Accuracies and Costs}

In order to evaluate which technology is most appropriate, the cost of each technology must also be considered. However, there are many factors to include in the cost of a WIM technology beyond equipment cost or the installation cost. Other factors to consider include the expected life, maintenance cost and replacement costs.

The life cycle costing was carried over a twelve-year period. For comparison, the equipment and installation costs will be for the in-road equipment only. The cost of the electronics, cabinet, power supply, telephone connection, and road preparation are assumed to be relatively constant, regardless of technology use and are not included in these estimates. The initial installation includes the equipment supply, installation by a local contractor, installation supervision and calibration by a vendor representative and traffic control during installation and curing. Installation costs are dependent on site conditions and local market rates.

The equipment included for each type of WIM technology is displayed in the individual configurations shown previously. The Quick installation (no vault) has been included for the Bending Plate scale comparison. The Kistler configuration included in the comparison is seen in Configuration 1, previously displayed.

\begin{tabular}{|c|c|c|c|c|}
\hline & Kistler & Single Load Cell & Bending Plate & Piezoelectric \\
\hline $\begin{array}{c}\text { Accuracy (GVW) } \\
(95 \% \text { confidence level) }\end{array}$ & $2 \sigma=10 \%$ & $2 \sigma=6 \%$ & $2 \sigma=10 \%$ & $2 \sigma=15 \%$ \\
\hline Service Life & 6 years & 20 years & 6 years & 4 years \\
\hline Initial Budgetary & $\$ 20,500$ & $\$ 39,000$ & $\$ 8,000$ & $\$ 2,500$ \\
Equipment Cost & $/$ lane & /lane & $/$ lane & $/$ lane \\
\hline Initial Budgetary & $\$ 12,000$ & $\$ 20,800$ & $\$ 13,500$ & $\$ 6,500$ \\
Installation Cost & $/$ lane & /lane & /lane & /lane \\
\hline Life Cycle Cost & $\$ 7,500$ & $\$ 6,200$ & $\$ 6,400$ & $\$ 4,750$ \\
(over 12 year period) & /year/lane & /year/lane & /year/lane & /year/lane \\
\hline
\end{tabular}

\section{Table D-1: WIM Technology Comparison}

Note:

* $\quad$ Prices shown are ESTIMATED only.

* $\quad$ All monetary values in USD.

* $\quad$ Life cycle costing carried out over a twelve-year period.

* Kistler Accuracy stated for Configuration 1.

* No Vault installation used in cost comparison of Bending Plate. 
* $\quad$ All accuracies stated at a 95\% confidence level.

* Initial Budgetary installation costs include materials to install and physical installation. 


\section{D.6 Maintenance/Performance Monitoring Approach}

The following are a number of suggested maintenance monitoring approaches, depending on the level of service desired.

- Current Method - Data collection group completes reports every one (1) to three (3) months. At this time they identify any errors, which indicates that maintenance.

- Scheduled Performance Monitoring by INDOT - INDOT would carry out daily, weekly or monthly maintenance checks and they would prepare summary reports. Within these reports, the client could look for irregularities in \% errors, \% un-classed vehicles, vehicle volume or \% of vehicle types.

- Scheduled Performance Monitoring by IRD - same as listed for INDOT in above item.

- Self-Diagnostics - Change system software, so software looks for high \% errors or vehicle volume irregularities. The system would phone out when problems detected.

\section{$\underline{\text { Standard IRD Maintenance Form }}$}

Customer Recommended Maintenance For IRD Weigh-In-Motion (WIM) Systems. Preventative Maintenance Service as identified below should be performed at six (6) month intervals. In-Road WIM Sensors:

- $\quad$ All WIM Sensors

- Test response levels, signal level and lead cables

- Verify sensor performance and reliability

- Adjust calibration factors as required

- $\quad$ Single Load Cell Scales

○ Maintain installation of concrete vault

- Maintain silicone seal around perimeter of the weigh pads

- Tighten or replace damaged hardware and frost plugs as required

- Remove and replace single load cell hatch and perform visual inspection of single load cell and lightning protection

- Add antifreeze to single load cell scale as required

- $\quad$ Bending Plates 
- Maintain installation of concrete vault or epoxy

- Maintain silicone seal around the perimeter of the weigh pads

- Tighten or replace damaged hardware and frost plugs as required

- Piezo Sensors

- Maintain installation of grout

- Kistler Sensors

- Maintain installation of grout

$\circ$ Maintain seal

Other In-Road Sensors:

- All In-Road Sensors

- Test response levels, signal level and lead cables

- Verify sensor performance and reliability

- Dynax Sensors

- Maintain installation of concrete vault or epoxy

- Tighten or replace damaged hardware and frost plugs as required

- Loops

- Maintain installation of loop sealant

Electronics Interface and System Computers:

- Clean interior and exterior of all components

- Remove, clean and inspect all printed circuit boards

- Maintain all electrical connectors, cables and components

- Test and verify control and sequence of operation of interface components 
Appendix E Site Evaluation Memo to Kirk Mangold 


\section{To: $\quad$ Kirk Mangold}

From: Darcy Bullock

Date: February 2, 2001

Subject: $\quad$ Weigh in Motion Data Analysis, Update III

As you are aware, Mark Newland requested that I supply him with information concerning the impact of overweight vehicles on Indiana roads. Since INDOT has approximately 40 stations, we mutually decided to initially examine only about $25 \%$ of the stations. The week of January 15,2001 , I forwarded Mark a list of selected stations (Table E-1) and requested data for those stations during July 2000. On January 17, 2001, Philip Zurawski forwarded me data for the July 9-16, 2000 period. Table E-1 summarized that data. Information obtained from Roy Czinku at IRD indicated that the error rate should be less $10 \%$. Preliminary review of that data showed that all stations exceeded that recommended standard (Table E-1).

\begin{tabular}{|c|c|c|c|c|c|}
\hline No. & M.P. & Location & Legal & Over & Error \\
\hline 4140 & 068.26 & I-69 4.16 MILES N OF SR 18 & 61.7 & 1.4 & 36.9 \\
\hline 4150 & 137.88 & I-69 2.53 MILES S OF SR 4 & 68.4 & 18.0 & 13.6 \\
\hline 4260 & 216.98 & US 31 0.66 MILES S OF SR 10 & 81.7 & 0.0 & 18.3 \\
\hline 5110 & 107.98 & I-70 4.33 MILES E OF SR 9 & 71.0 & 14.0 & 15.0 \\
\hline 5450 & 175.94 & I-65 0.78 MILES N OF SR 25 & 36.5 & 13.8 & 49.7 \\
\hline 5460 & 010.02 & I-465 (W. SIDE) 0.70 MILES N OF I-70 & 65.1 & 0.5 & 34.4 \\
\hline 5480 & 042.41 & I-465 (E. SIDE) 0.97 MILES S OF US & 67.6 & 3.7 & 28.7 \\
\hline 6160 & 116.96 & I-64 0.98 MILES W OF SR 62/64 & 14.1 & 3.6 & 82.3 \\
\hline 6280 & 024.11 & ON US 50 2.34 MILES E OF SR 257 & 60.8 & 0.0 & 39.2 \\
\hline 6290 & 137.40 & US 50 1.08 MILES W OF US 421 NB & 54.8 & 11.2 & 34.0 \\
\hline 6420 & 004.63 & I-65 0.89 MILES S OF I-265 & 74.6 & 7.7 & 17.7 \\
\hline
\end{tabular}

\section{Table E-1: Acceptable Sites}

On January 19, 2001, we decided to examine the error rates for all stations (Table E-2) during a week in July and week in November. Phil Zurawski provided some additional data for the entire months of July and November. However, because of limitations of the reporting program, some of the data sets were too large for the IRD reporting program to produce monthly reports. Instead, Phil had to produce daily reports for some of the more active sites (For Example Station 4150). Those reports were too voluminous to analyze quickly. 
On January 23, 2001, we visited Don Klepinger and Larry Torrance at Roadway Management and learned that some error reports were available from them. We were able to obtain reports produced between January 1998 and October 2000 that list the "best" weekly error rates for all the stations (composite error rate calculated over all lanes and for individual lanes). An example of that data is shown in Table E-3. Figure E-1 to Figure E-36 on the following pages graphically depict that data we obtained from Roadway Management that summarized the performance across all lanes.

A preliminary scan of the data suggests the following stations were running within the expected accuracy range as of October 2000:

- $\quad$ Station $4250,1 \%$ Error

- $\quad$ Station 4270, (borderline) $7 \%$ Error

- $\quad$ Station 5140, 5\% Error

- $\quad$ Station 5260, 2\% Error

- $\quad$ Station 5470, 5\% Error

- $\quad$ Station 6170, (borderline) 8\% Error

- $\quad$ Station 6260, 2\% Error

- $\quad$ Station 6270, 3\% Error

As we understand it, the source of these errors is the "best" week of a monthly report ${ }^{1}$. If that is the case, some of these borderline stations may not be performing acceptably during other weeks in the month. An example transient problem masked by this type of reporting would be a bad loop detector splice that performs fine during dry weather, but fails during wet weather.

After reviewing the data further, we determined that because the errors shown in Figure E-1 through Figure E-36 are the average across all lanes, there is the possibility of averaging out significant errors in individual lanes. On February 2, 2001 we prepared graphs shown in Figure E-37 through Figure E-72. After reviewing those graphs we have determined the following stations have individual lanes experiencing error rates higher than that proposed by Roy Czinku:

- $\quad$ Station 4270: Lane 1 errors (Figure E-44) have crept up to $13 \%$ as of October 2000.

- $\quad$ Station 5140: Lane 1 errors (Figure E-51) have crept up to 11\% as of October 2000.

\footnotetext{
${ }^{1}$ This fact needs to be checked to understand the exact procedure for producing these reports.
} 
- $\quad$ Station 5470: Lane 4 errors (Figure E-59) have crept up to $16 \%$ as of October 2000.

- $\quad$ Station 6170: Lane 3 errors (Figure E-66) have crept up to $12 \%$ as of October 2000.

- $\quad$ Station 6270: Lane 4 errors (Figure E-69) have declined some (Sept was 12\%), but are at $10 \%$.

Based upon this additional analysis, as of October 2000 (Table E-3), the following stations are the only ones reporting all lanes within the tolerance proposed by Roy Czinku

- Station 4250, 1\% Error. Reviewing the individual lane errors shown in Figure E-42, this station appears to have been very reliable since January 1998, except for a few isolated problems in past years.

- Station 5260, 2\% Error. Reviewing the individual lane errors shown in Figure E-54, this station appears to have been very reliable since November 1999 when long-term problems with Lane 3 appear to have been corrected. Unfortunately, this cabinet was recently hit by a car and is currently out of service.

- Station 6260, 2\% Error. Reviewing the individual lane errors shown in Figure E-68, this station has been reliable since September 1998, recently experienced very high errors rates this past summer, but September 2000 showed improvement and by October 2000 the errors rates were all below $5 \%$. Since October 2000 is our latest data, this station should probably be reexamined to see if it continues to stay within expected error tolerances. 


\begin{tabular}{|c|c|c|}
\hline Station & County & Location \\
\hline 4110 & Jasper & I65 NB MM 218.4 \\
\hline 4130 & LaPorte & 194 EB MM 38.0 \\
\hline 4140 & Grant & 169 SB MM 68.3 \\
\hline 4150 & Dekalb & I69 SB MM 137.9 \\
\hline 4240 & Porter & SR 49 NB RM 35.3 \\
\hline 4250 & LaPorte & SR 2 WB RM 65.2 \\
\hline 4260 & Marshall & US 31 NB RM 217.0 \\
\hline 4270 & Miami & US 24 WB RM 87.6 \\
\hline 4280 & Adams & US 27 SB RM 100.2 \\
\hline 4400 & Lake & I80 / I94 WB MM 13.3 \\
\hline 4410 & Lake & I65 NB MM 253.7 \\
\hline 4420 & Lake & 165 NB MM 253.7 \\
\hline 4440 & Lake & 180 / I94 EB MM 6.0 \\
\hline 5110 & Hancock & I70 EB MM 108.0 \\
\hline 5120 & Shelby & I65 SB MM 79.1 \\
\hline 5130 & Vermillion & I74 EB MM 4.8 \\
\hline 5140 & Wayne & I70 EB MM 155.5 \\
\hline 5240 & Benton & US 41 SB RM 199.9 \\
\hline 5250 & Monroe & SR 37 SB RM 96.7 \\
\hline 5260 & Hamilton & SR 37 SB RM 172.0 \\
\hline 5270 & Delaware & SR 332 WB RM 0.5 \\
\hline 5440 & Vigo & 170 WB MM 7.5 \\
\hline 5450 & Tippecanoe & I65 NB MM 175.9 \\
\hline 5460 & Marion & 1465 SB MM 10.0 \\
\hline 5470 & Marion & I65 NB MM 102.5 \\
\hline 5480 & Marion & I465 SB MM 42.4 \\
\hline 5550 & Hamilton & US 31 NB RM 125.6 \\
\hline 6130 & Vanderburgh & I164 WB MM 2.2 \\
\hline 6140 & Gibson & I64 EB MM 27.9 \\
\hline 6150 & Spencer & I64 EB MM 54.8 \\
\hline 6160 & Floyd & I64 EB MM 117.0 \\
\hline 6170 & Dearborn & I74 EB MM 169.8 \\
\hline 6250 & Posey & SR 62 WB RM 12.5 \\
\hline 6260 & Vanderburgh & SR 66 EB RM 18.7 \\
\hline 6270 & Spencer & SR 66 WB RM 47.6 \\
\hline 6280 & Daviess & US 50 EB RM 24.1 \\
\hline 6290 & Ripley & US 50 WB RM 137.4 \\
\hline 6420 & Clark & I65 SB MM 4.8 \\
\hline
\end{tabular}

Table E-2: Location of All WIM Stations 


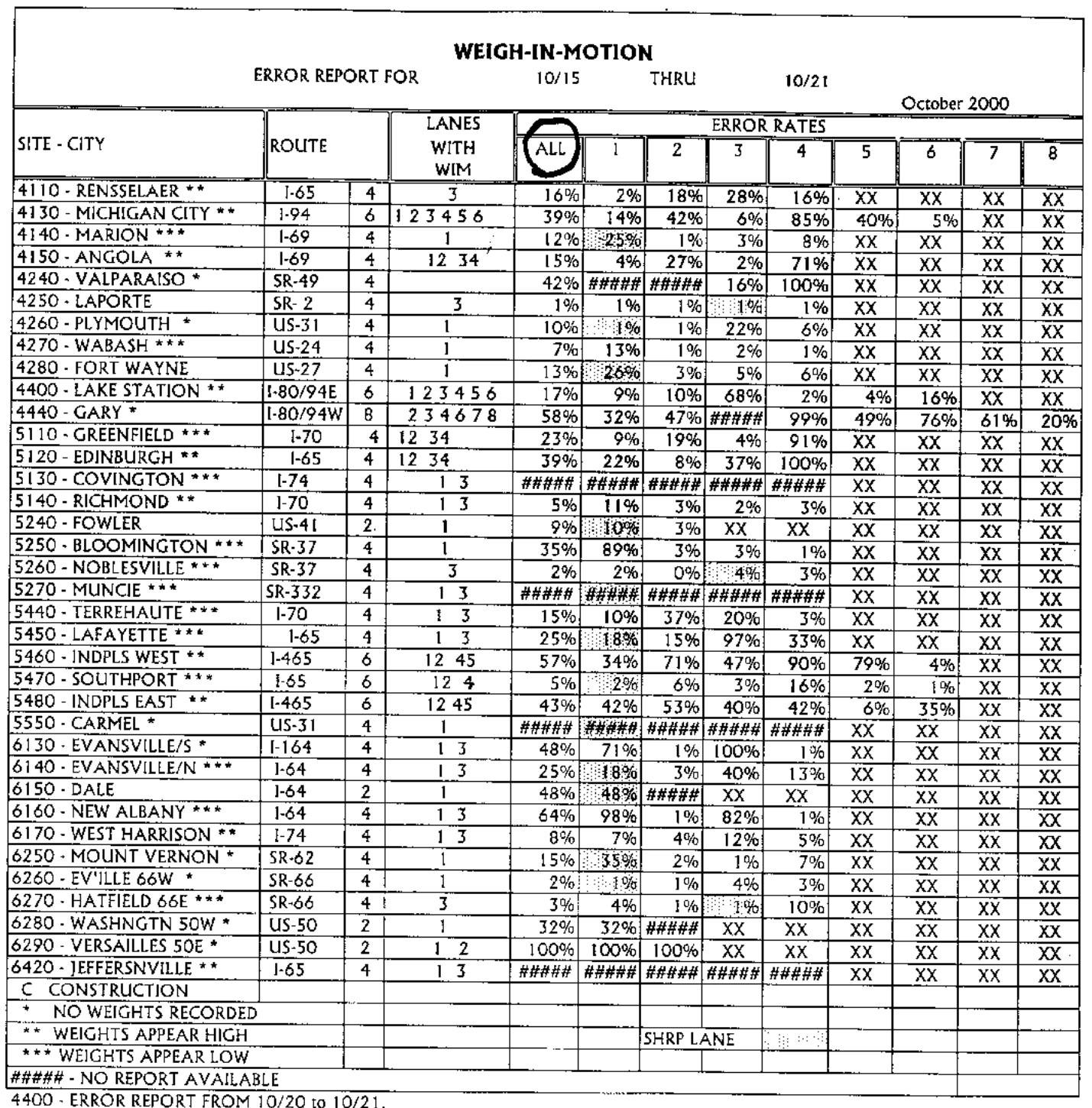

Table E-3: October 2000 Roadway Management Error Report 


\section{E.1 Summary of Average Station Performance (All Lanes)}

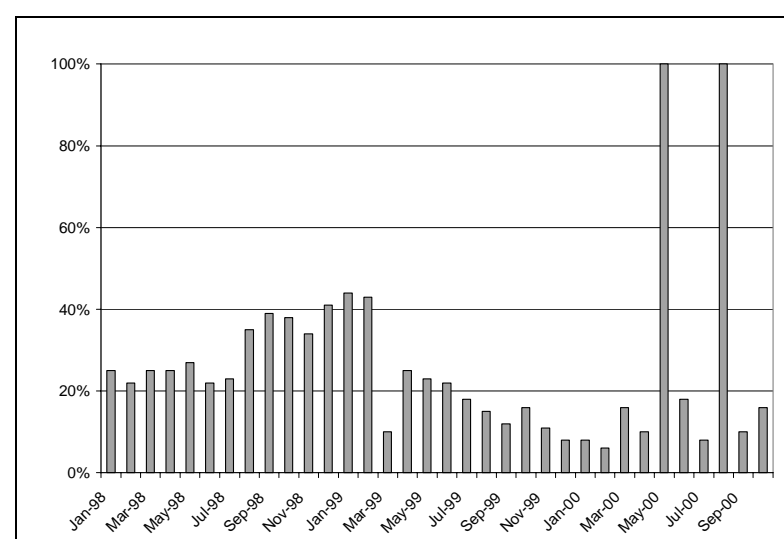

Figure E-1: Error Rate at Station 4110

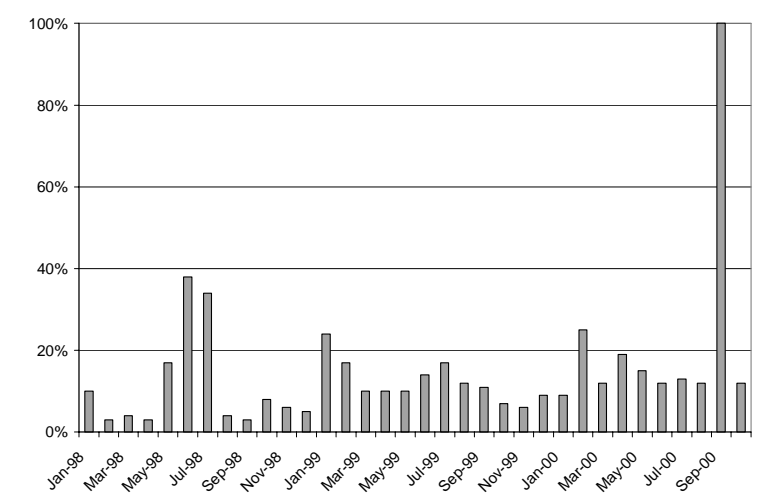

Figure E-3: Error Rate at Station 4140

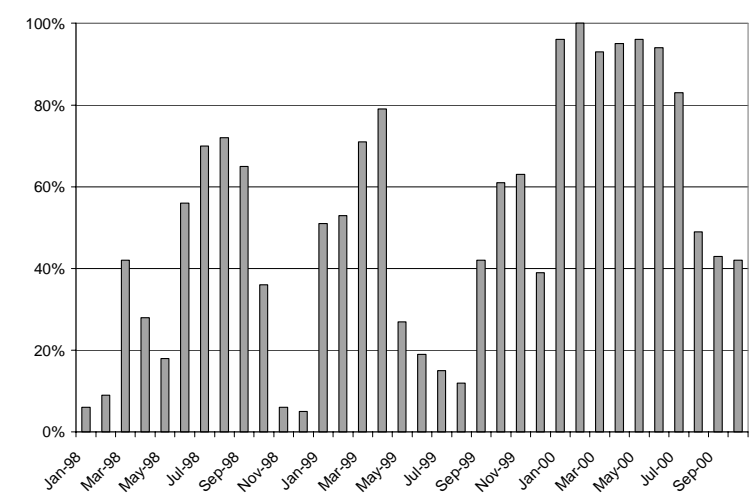

Figure E-5: Error Rate at Station 4240

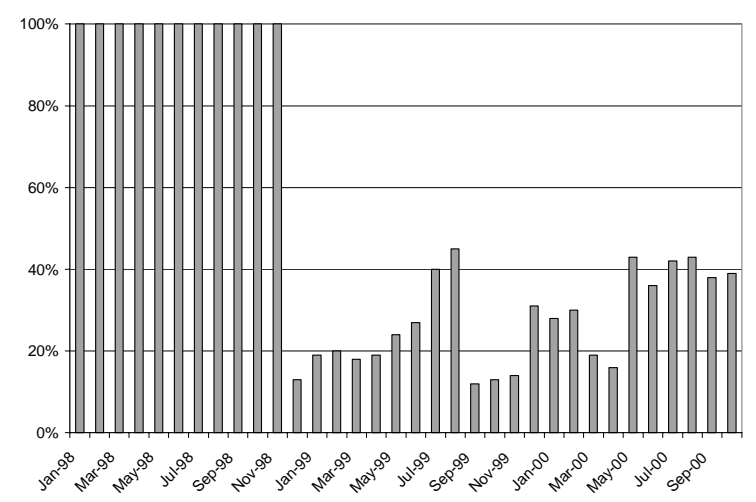

Figure E-2: Error Rate at Station 4130

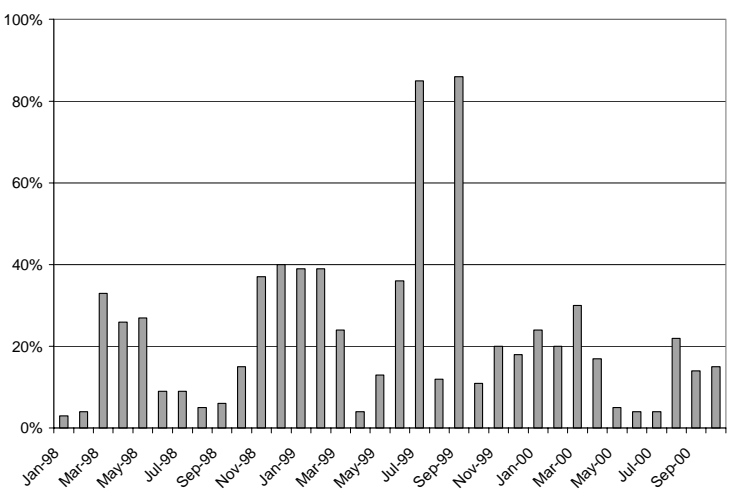

Figure E-4: Error Rate at Station 4150

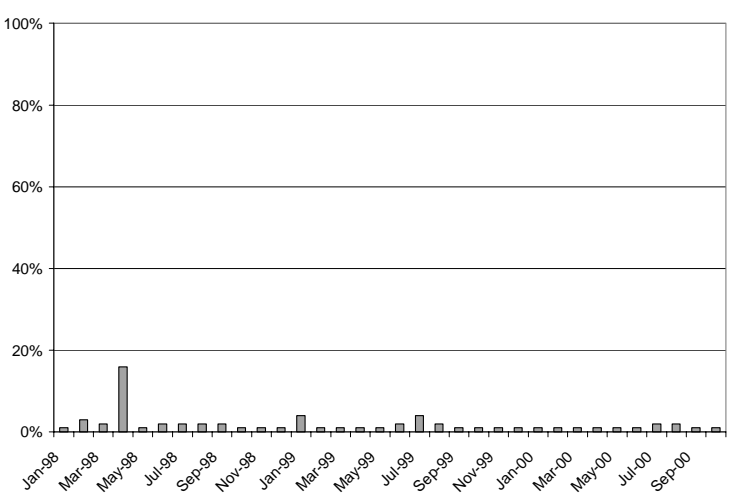

Figure E-6: Error Rate at Station 4250 

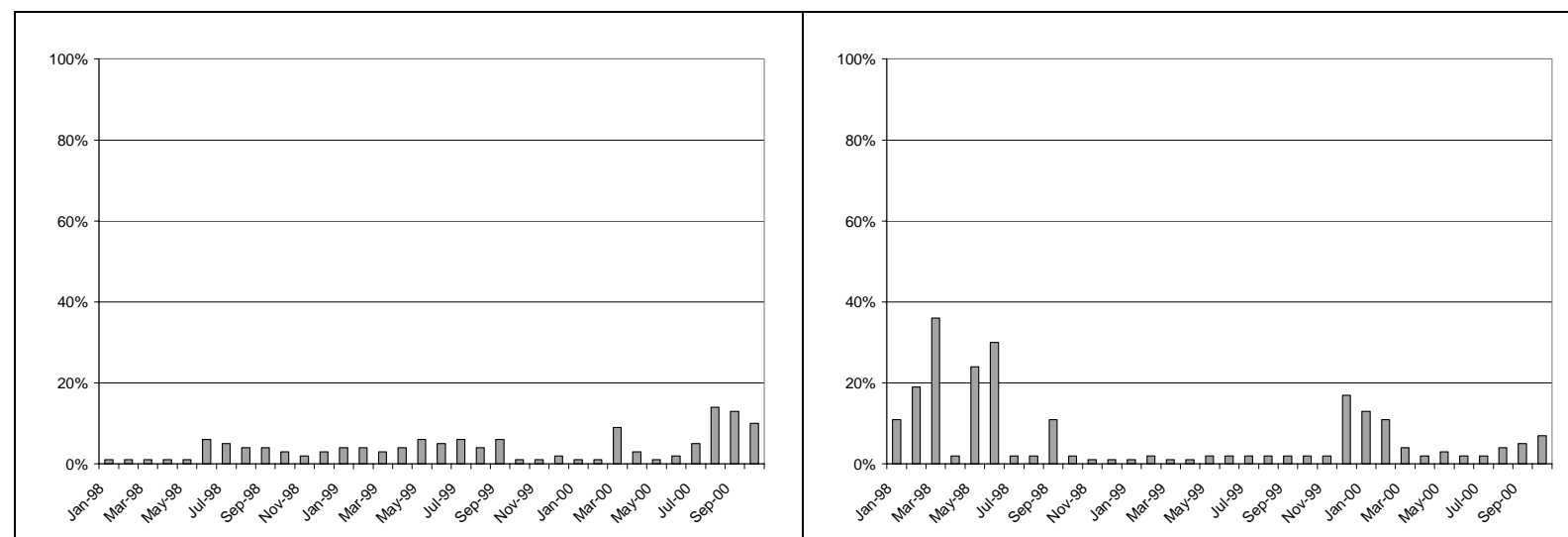

Figure E-7: Error Rate at Station 4260

Figure E-8: Error Rate at Station 4270

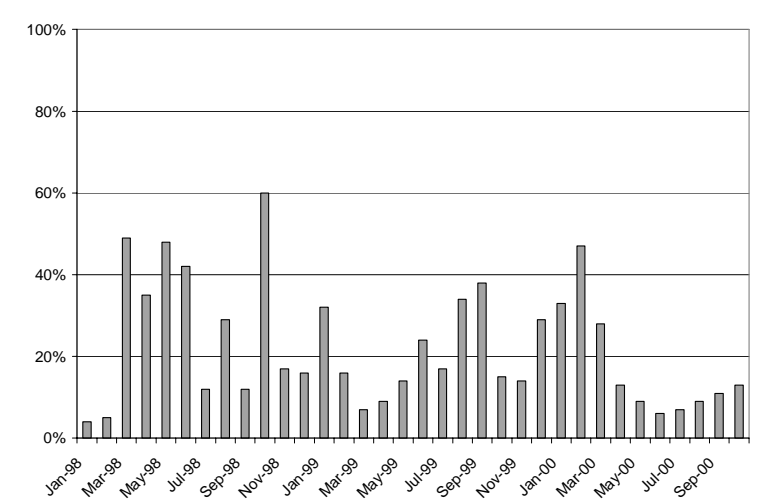

Figure E-9: Error Rate at Station 4280

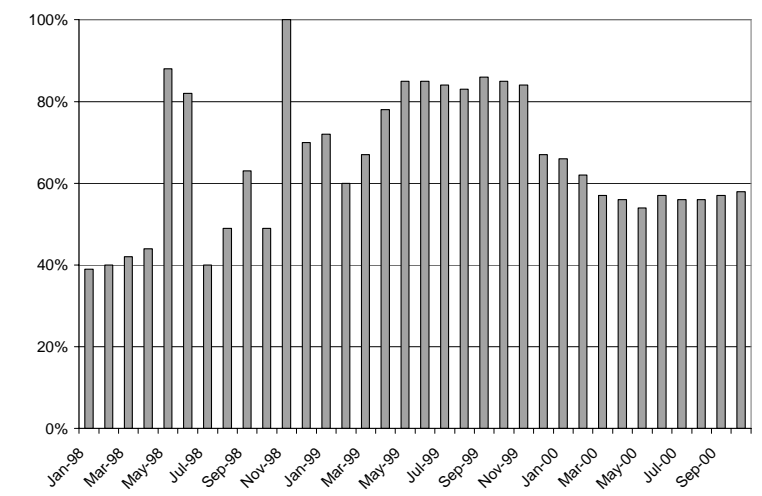

Figure E-11: Error Rate at Station 4440

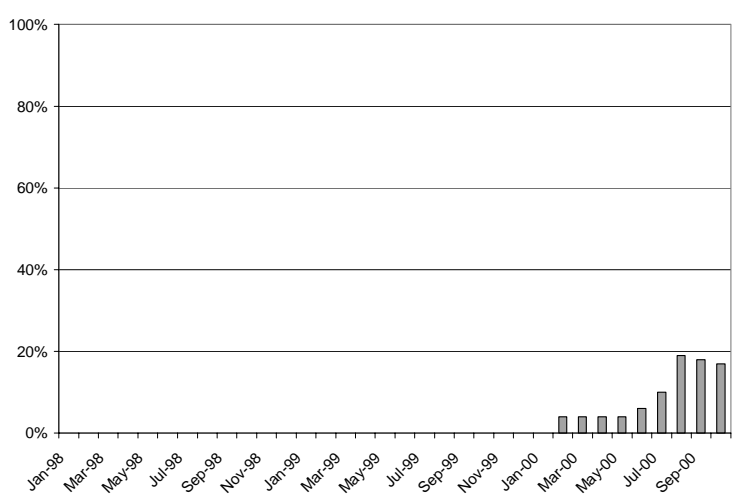

Figure E-10: Error Rate at Station 4400

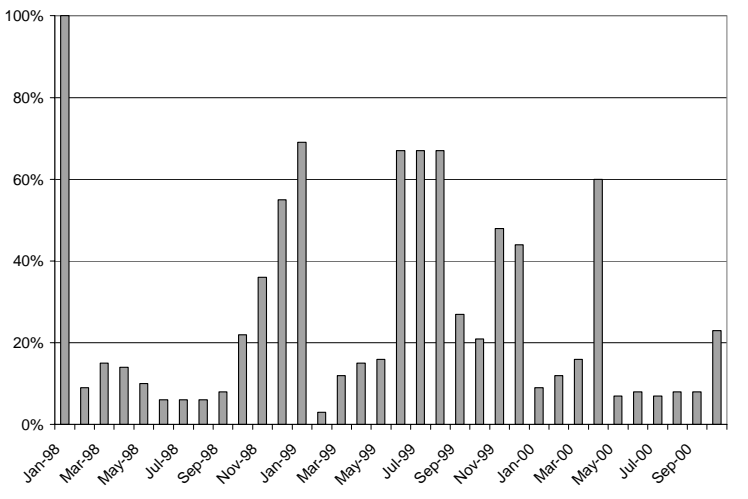

Figure E-12: Error Rate at Station 5110 


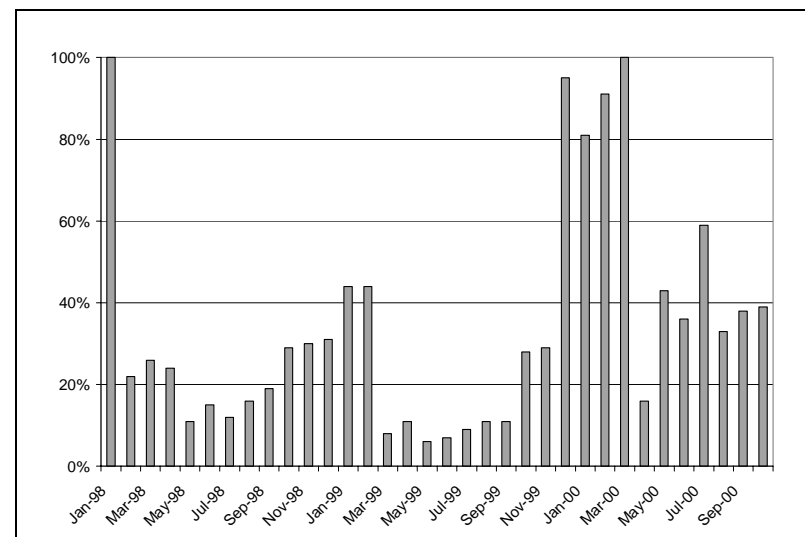

Figure E-13: Error Rate at Station 5120

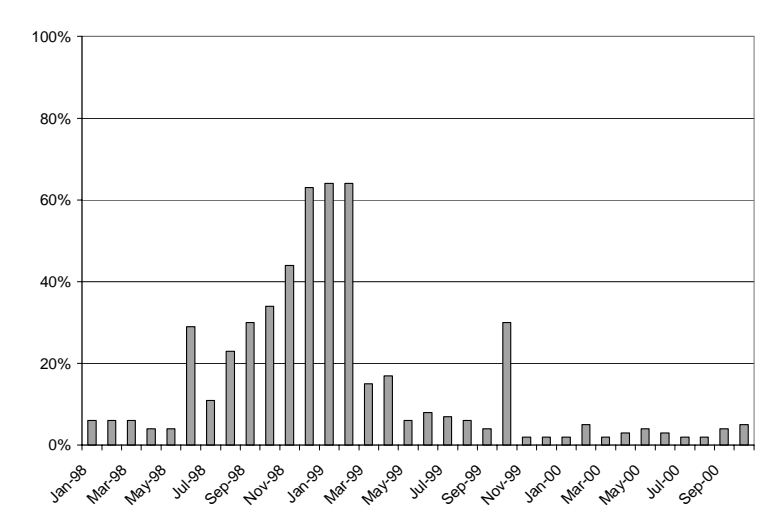

Figure E-15: Error Rate at Station 5140

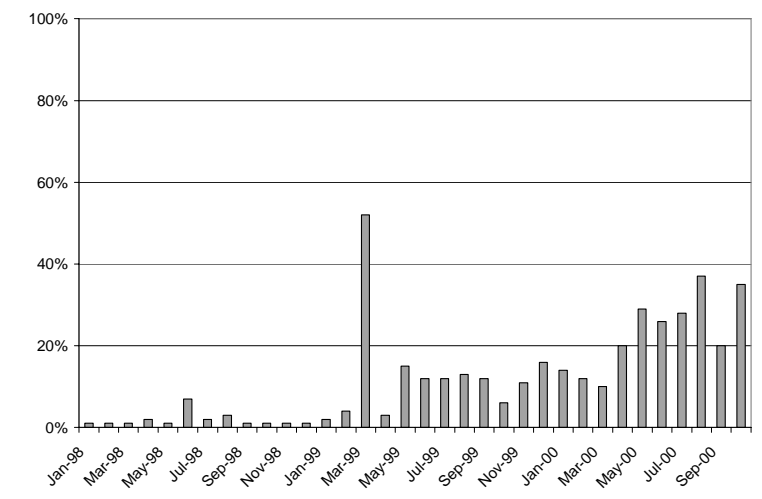

Figure E-17: Error Rate at Station 5250

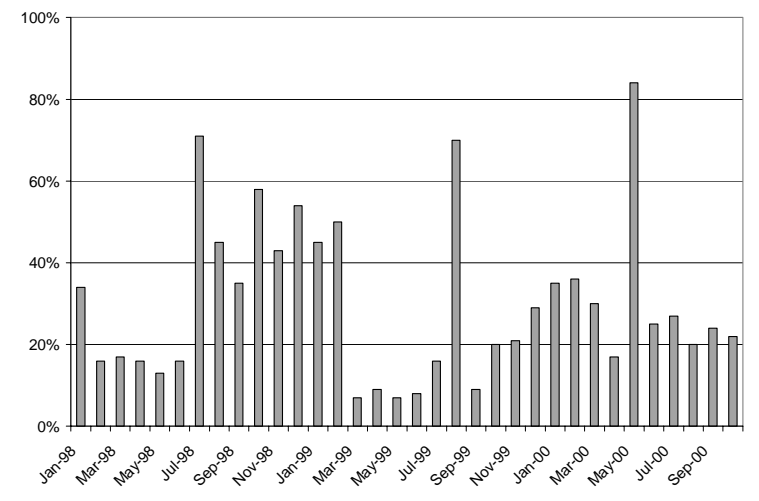

Figure E-14: Error Rate at Station 5130

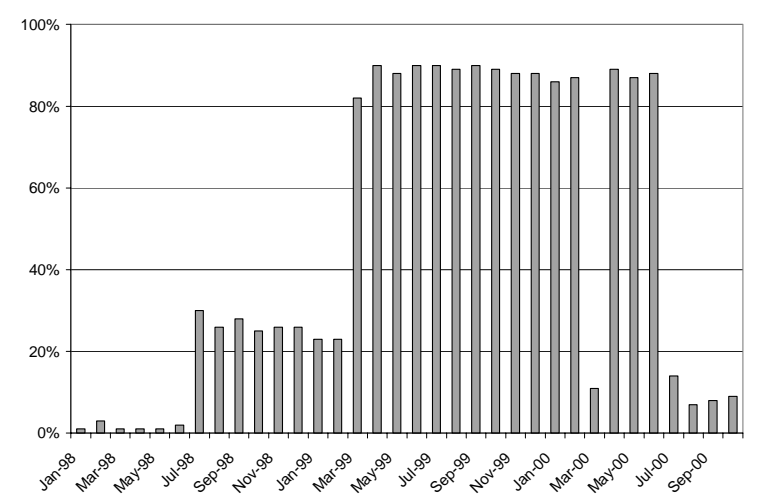

Figure E-16: Error Rate at Station 5240

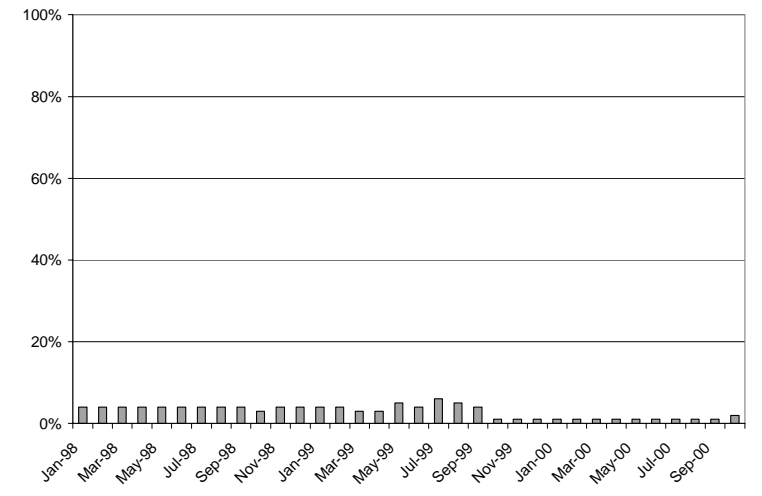

Figure E-18: Error Rate at Station 5260 


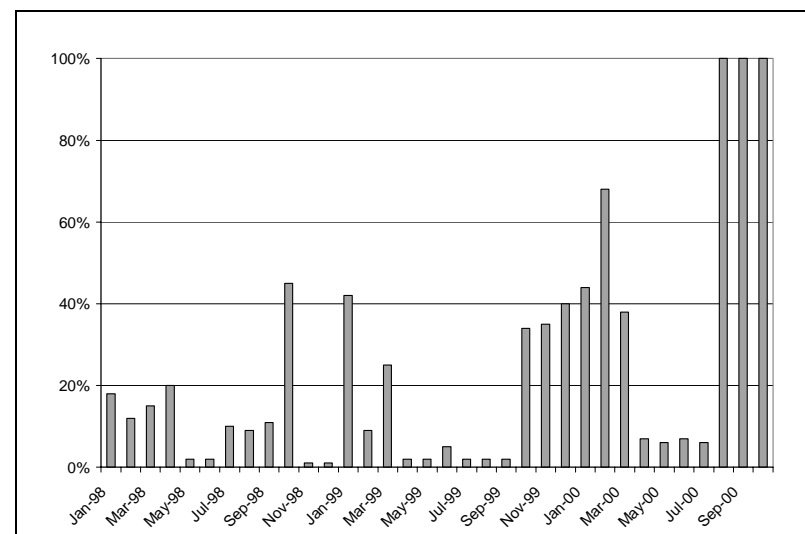

Figure E-19: Error Rate at Station 5270

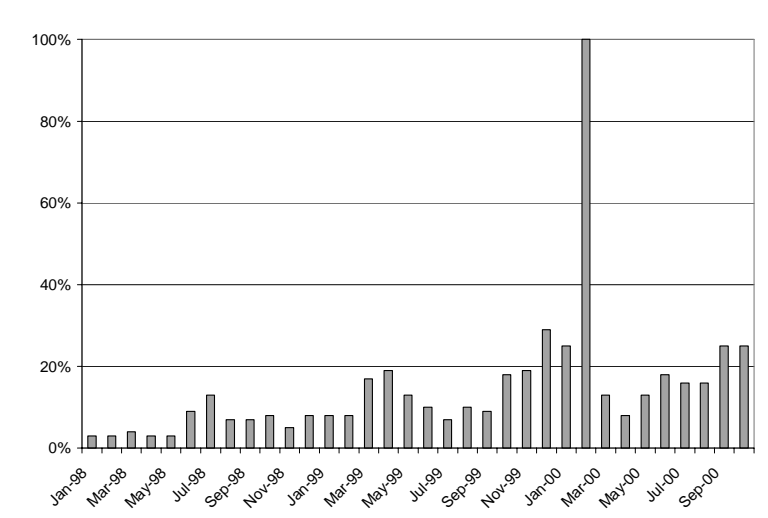

Figure E-21: Error Rate at Station 5450

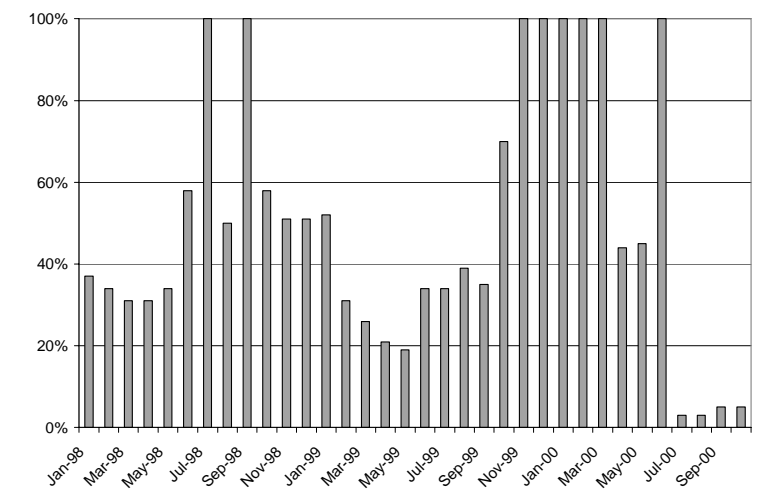

Figure E-23: Error Rate at Station 5470

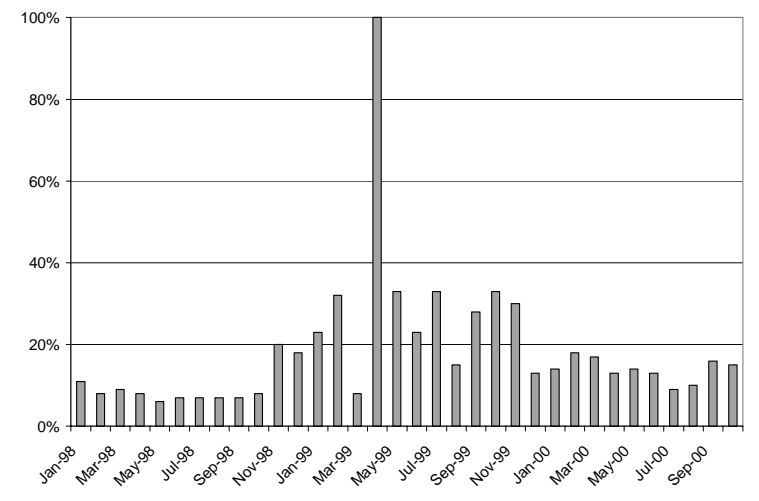

Figure E-20: Error Rate at Station 5440

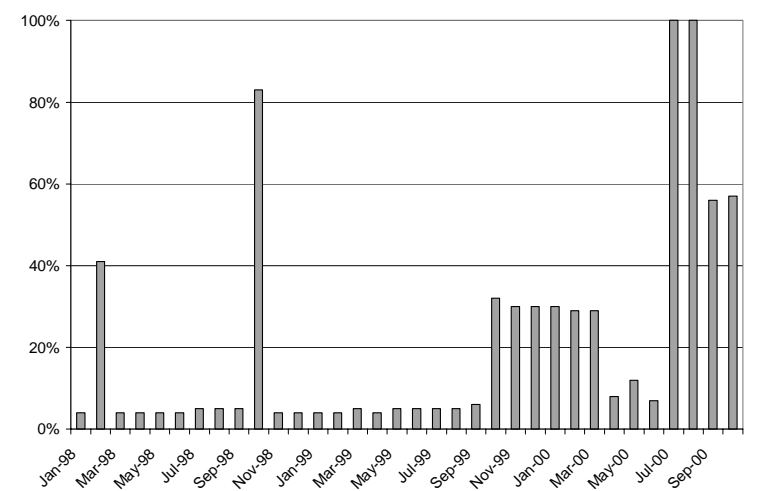

Figure E-22: Error Rate at Station 5460

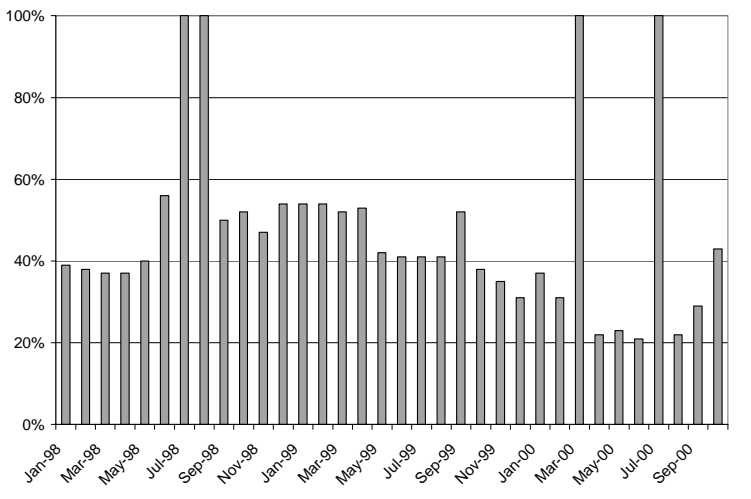

Figure E-24: Error Rate at Station 5480 


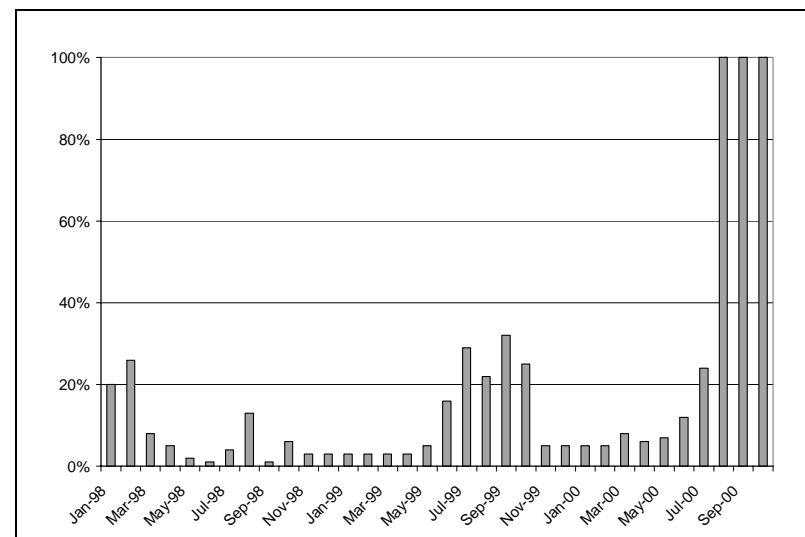

Figure E-25: Error Rate at Station 5550

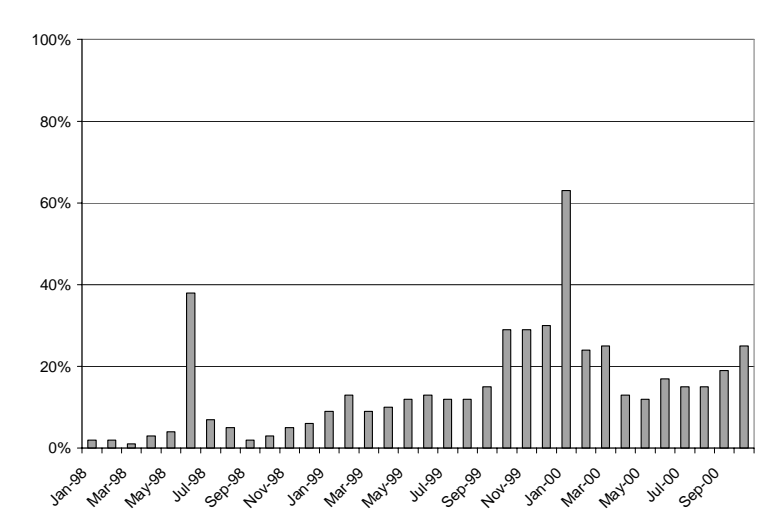

Figure E-27: Error Rate at Station 6140

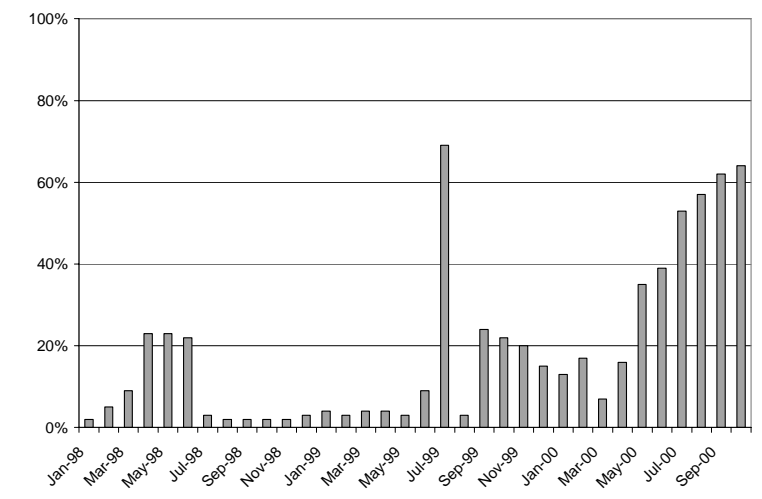

Figure E-29: Error Rate at Station 6160

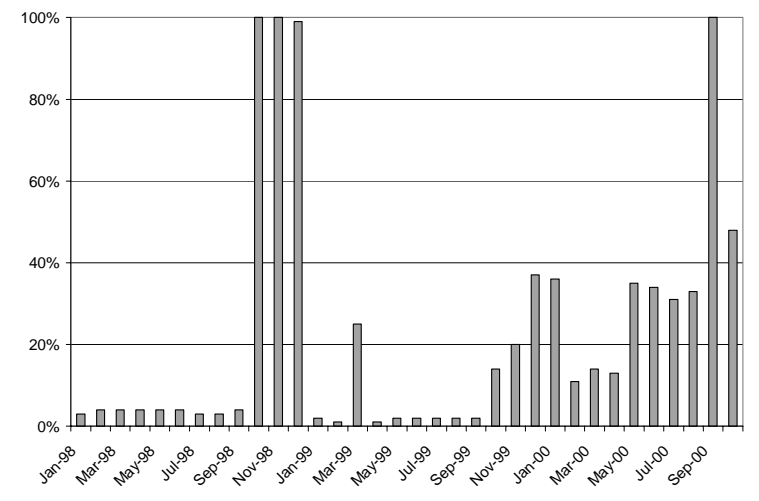

Figure E-26: Error Rate at Station 6130

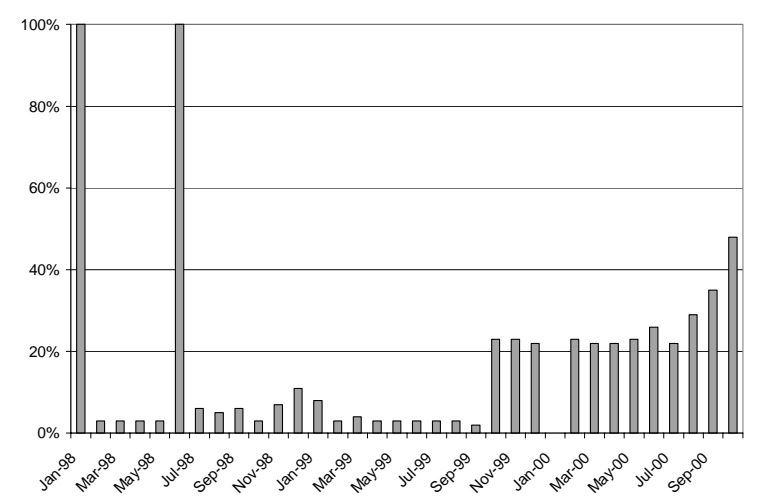

Figure E-28: Error Rate at Station 6150

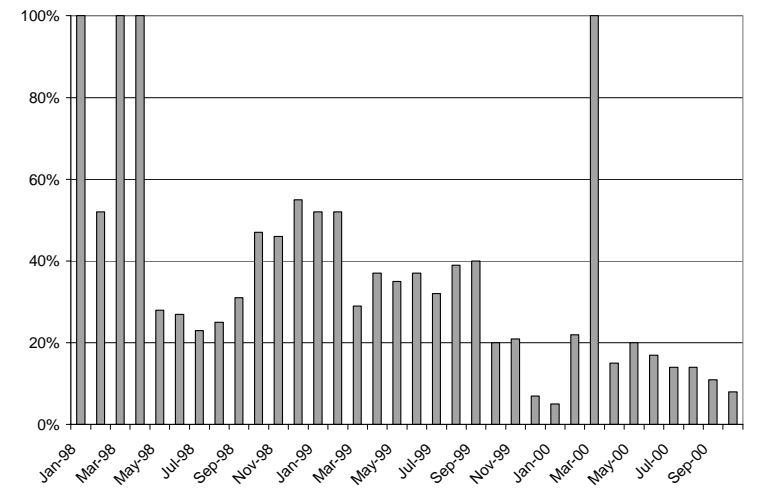

Figure E-30: Error Rate at Station 6170 


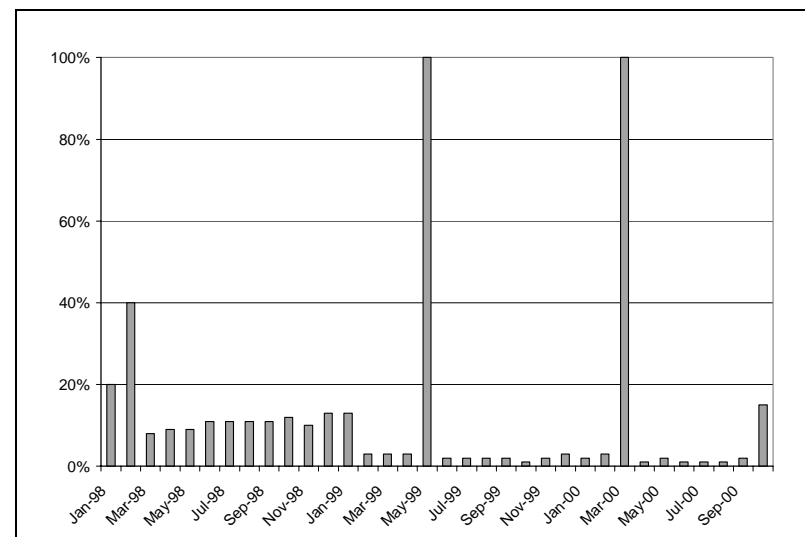

Figure E-31: Error Rate at Station 6250

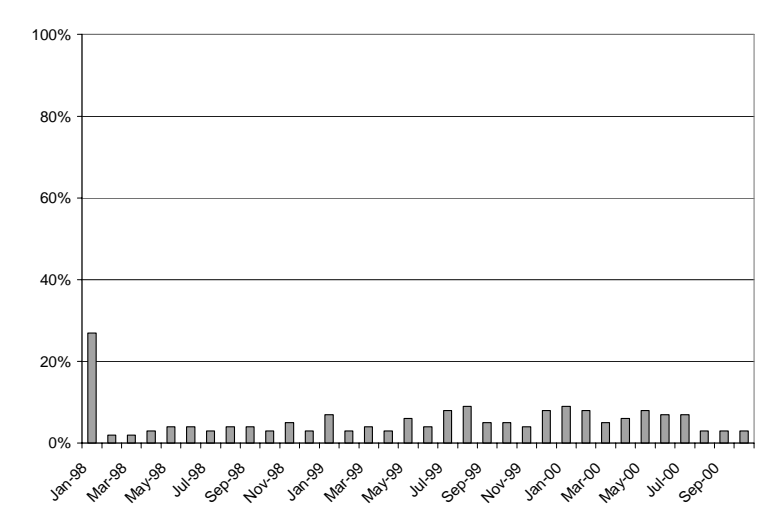

Figure E-33: Error Rate at Station 6270

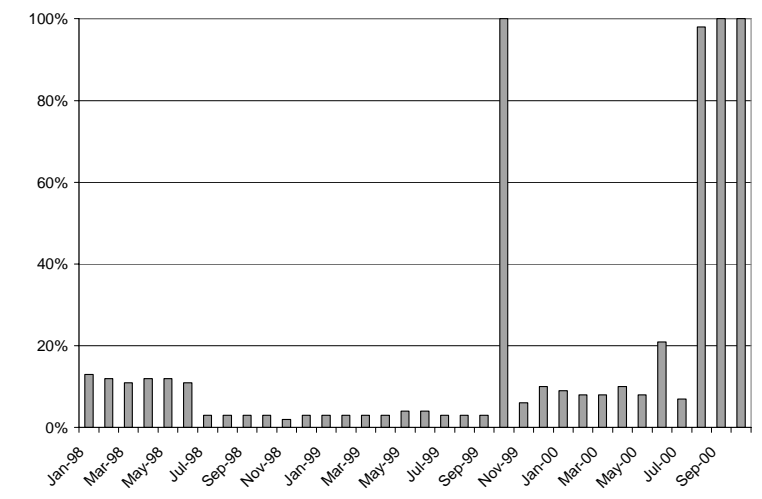

Figure E-35: Error Rate at Station 6290

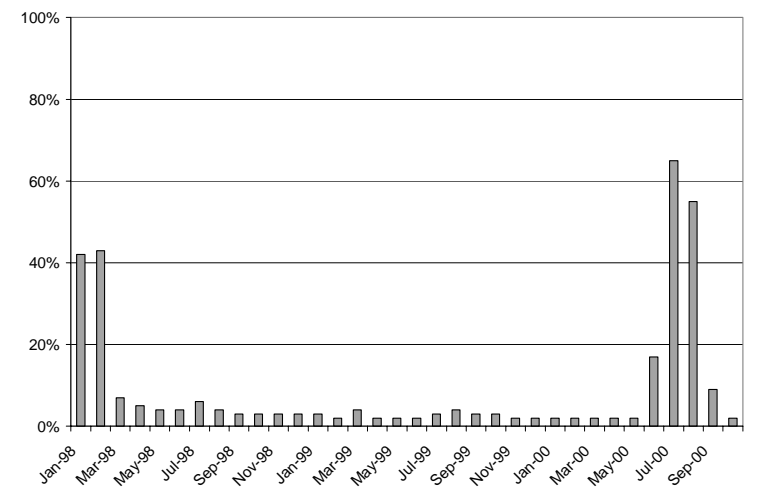

Figure E-32: Error Rate at Station 6260

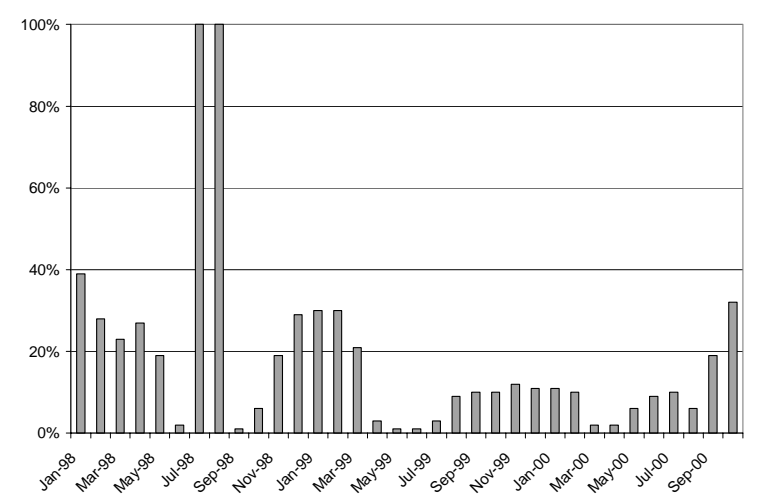

Figure E-34: Error Rate at Station 6280

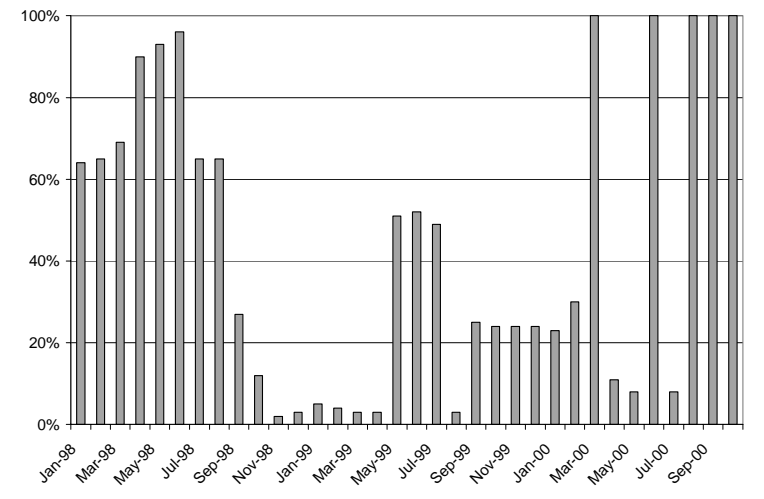

Figure E-36: Error Rate at Station 6420 


\section{E.2 Summary of Average Station Performance (Individual Lanes)}

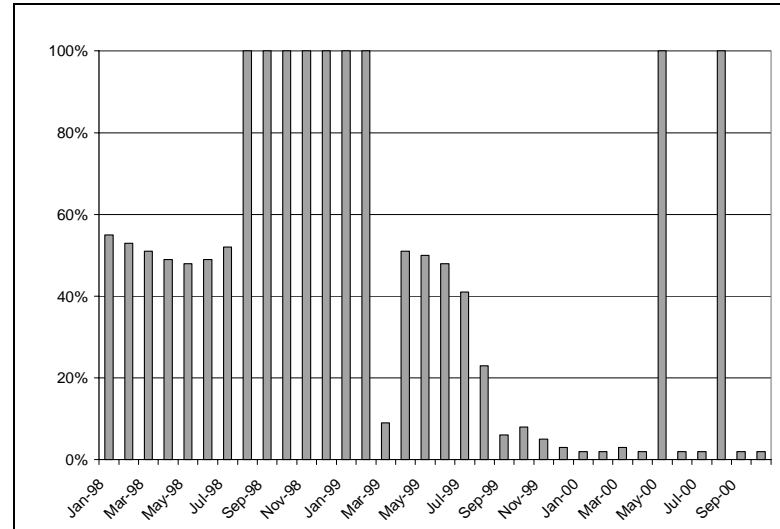

Station 4110 - Lane 1

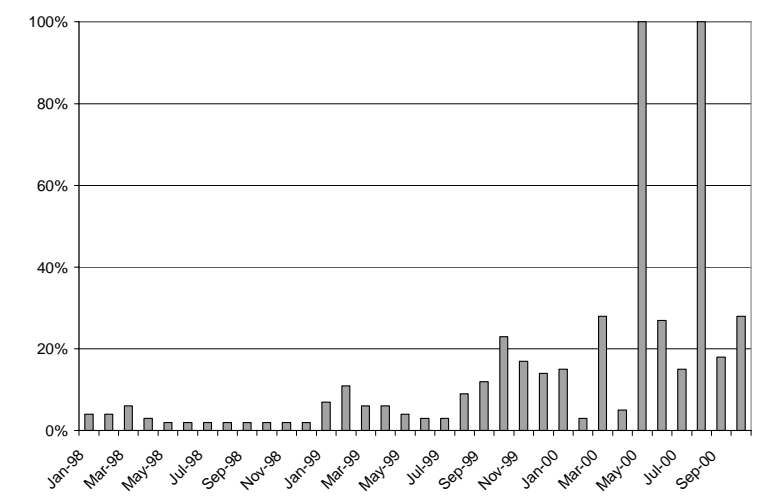

Station 4110 - Lane 3

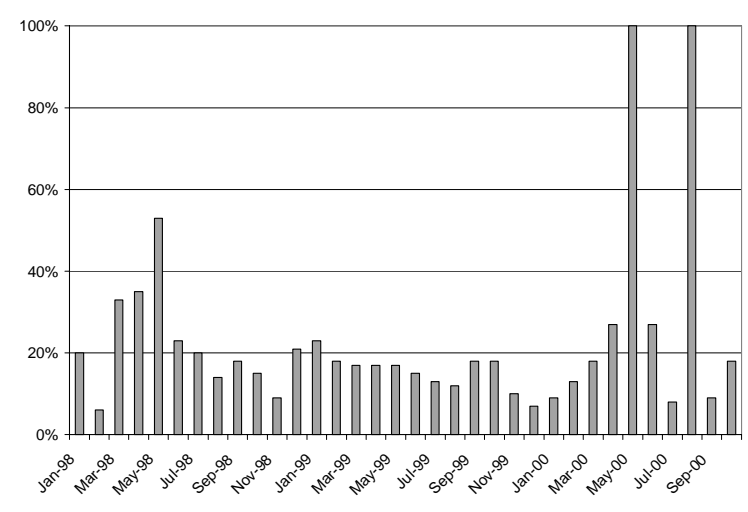

Station 4110 - Lane 2

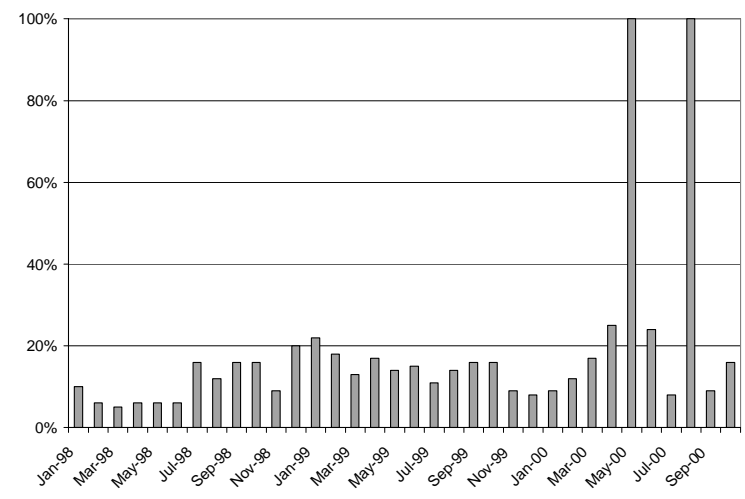

Station 4110 - Lane 4

Figure E-37: Error Rate of individual lanes at station 4110 


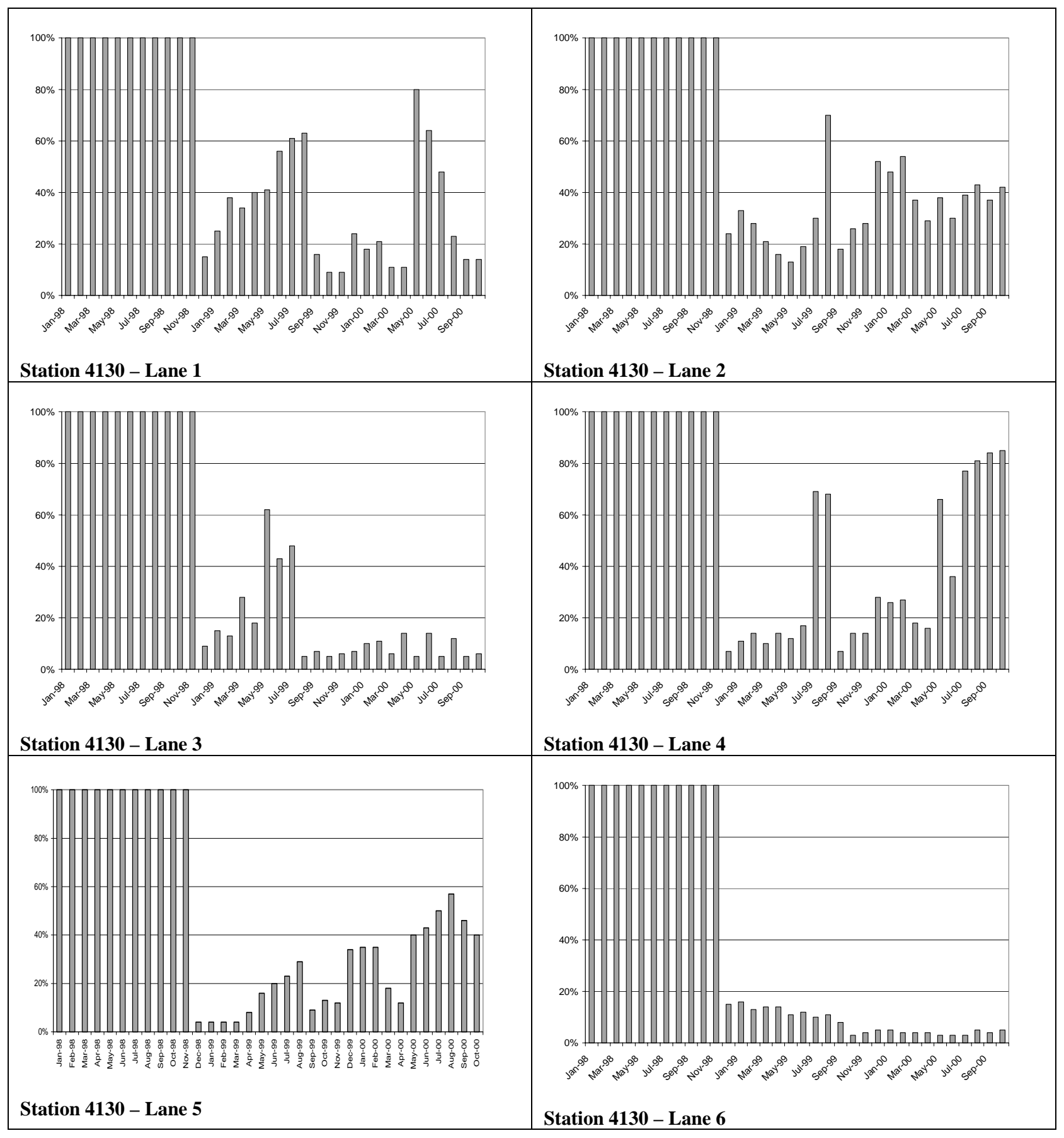

Figure E-38: Error Rate of individual lanes at station 4130 


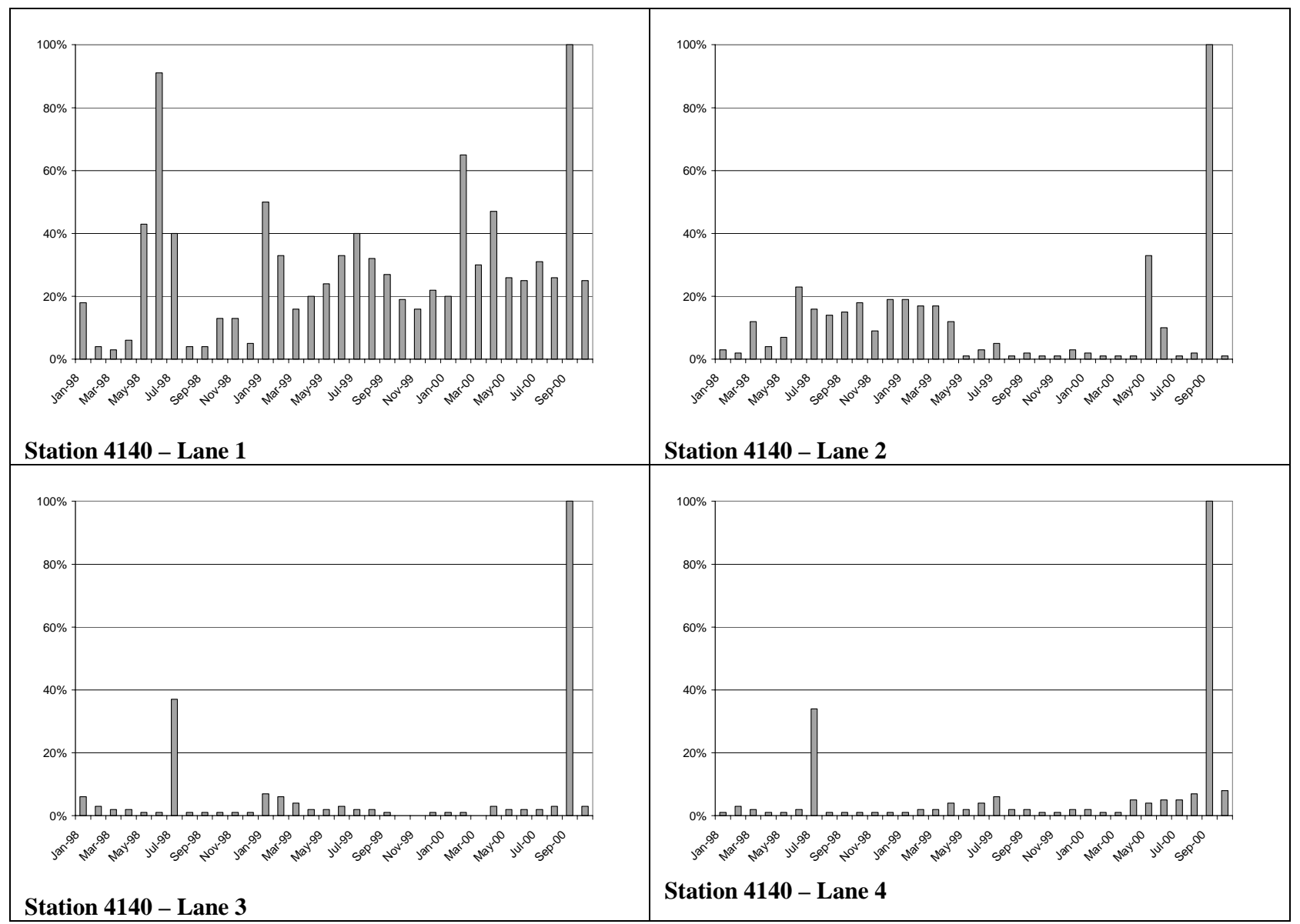

Figure E-39: Error Rate of individual lanes at station 4140 


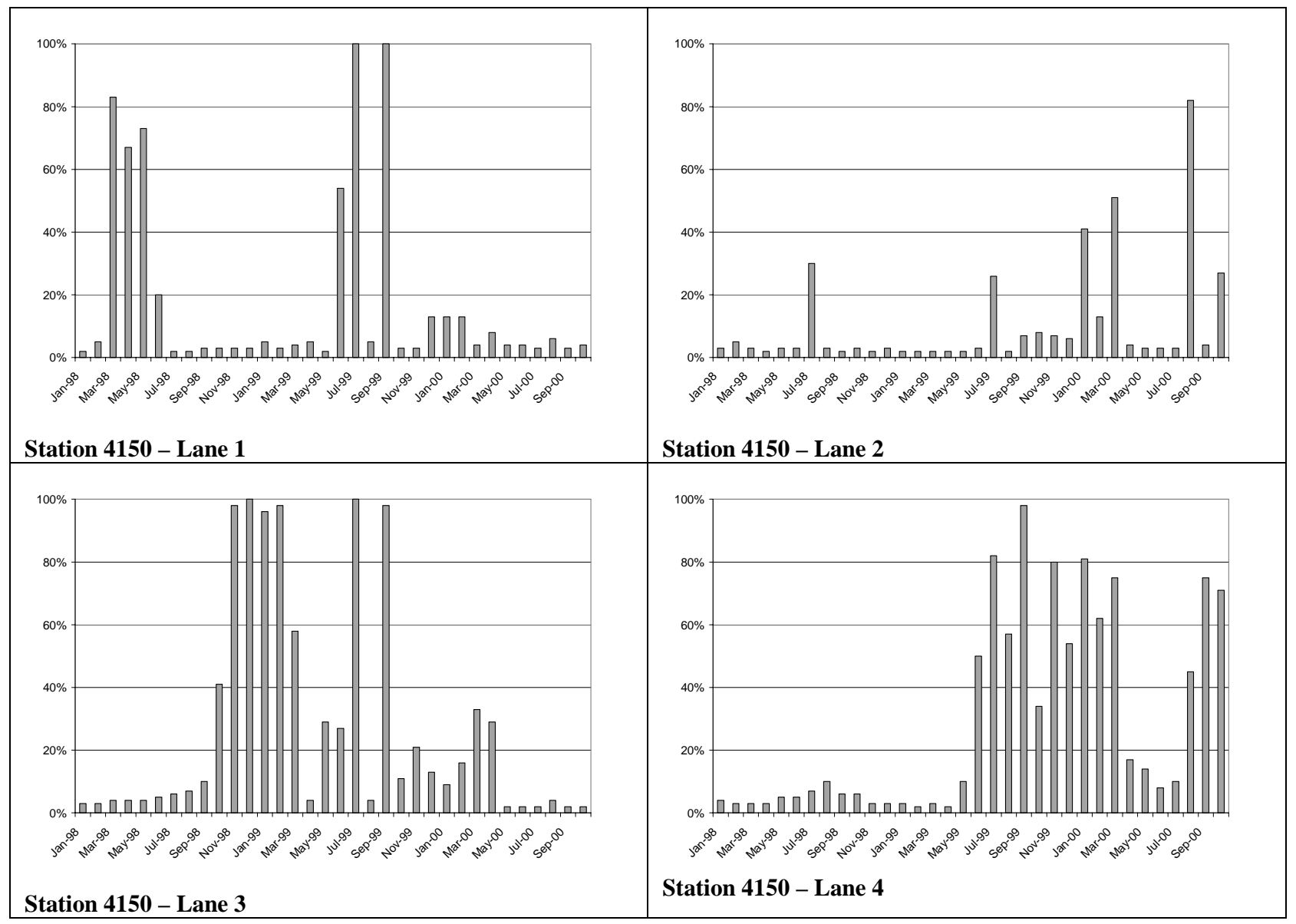

Figure E-40: Error Rate of individual lanes at station 4150 


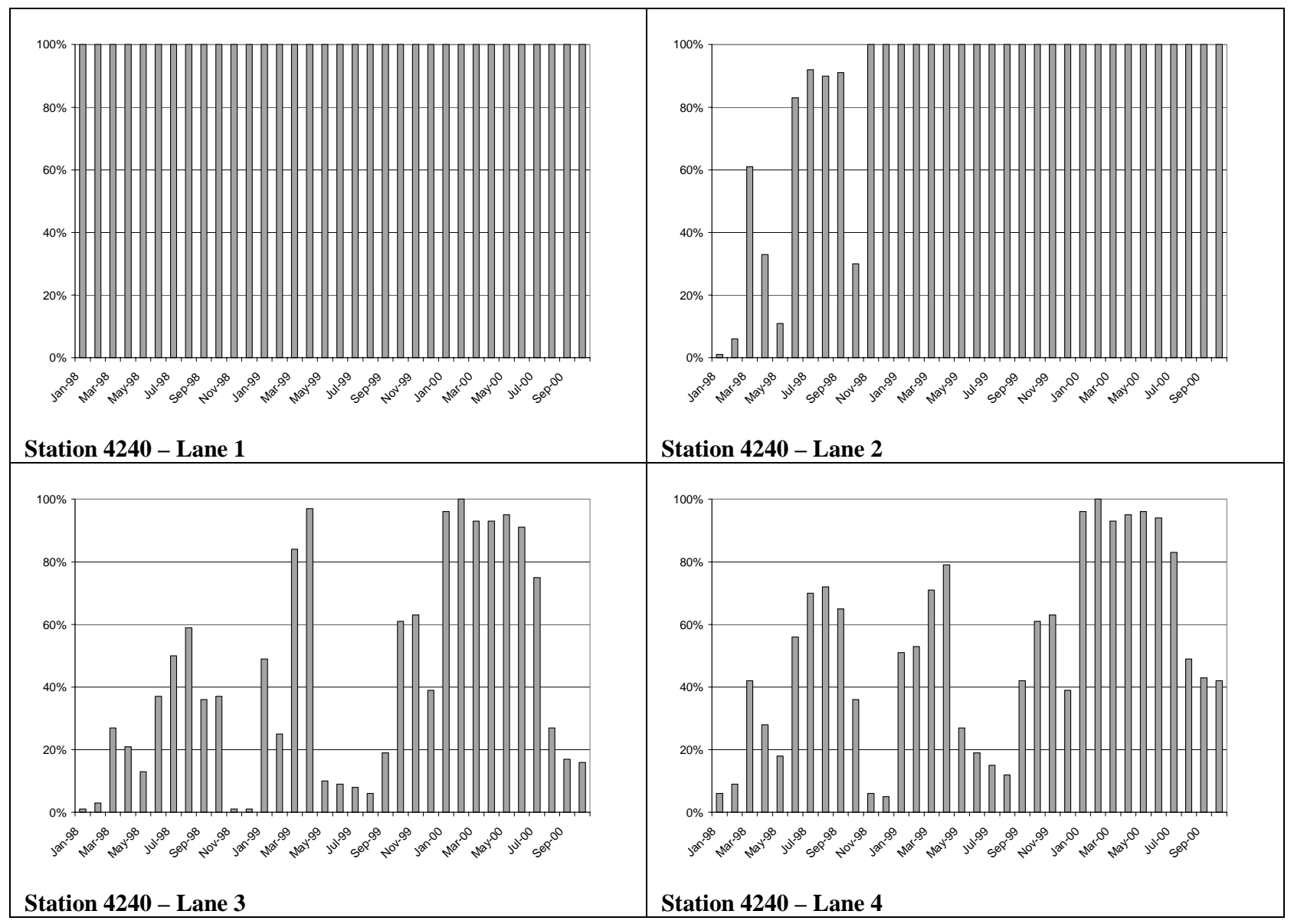

Figure E-41: Error Rate of individual lanes at station 4240 
134

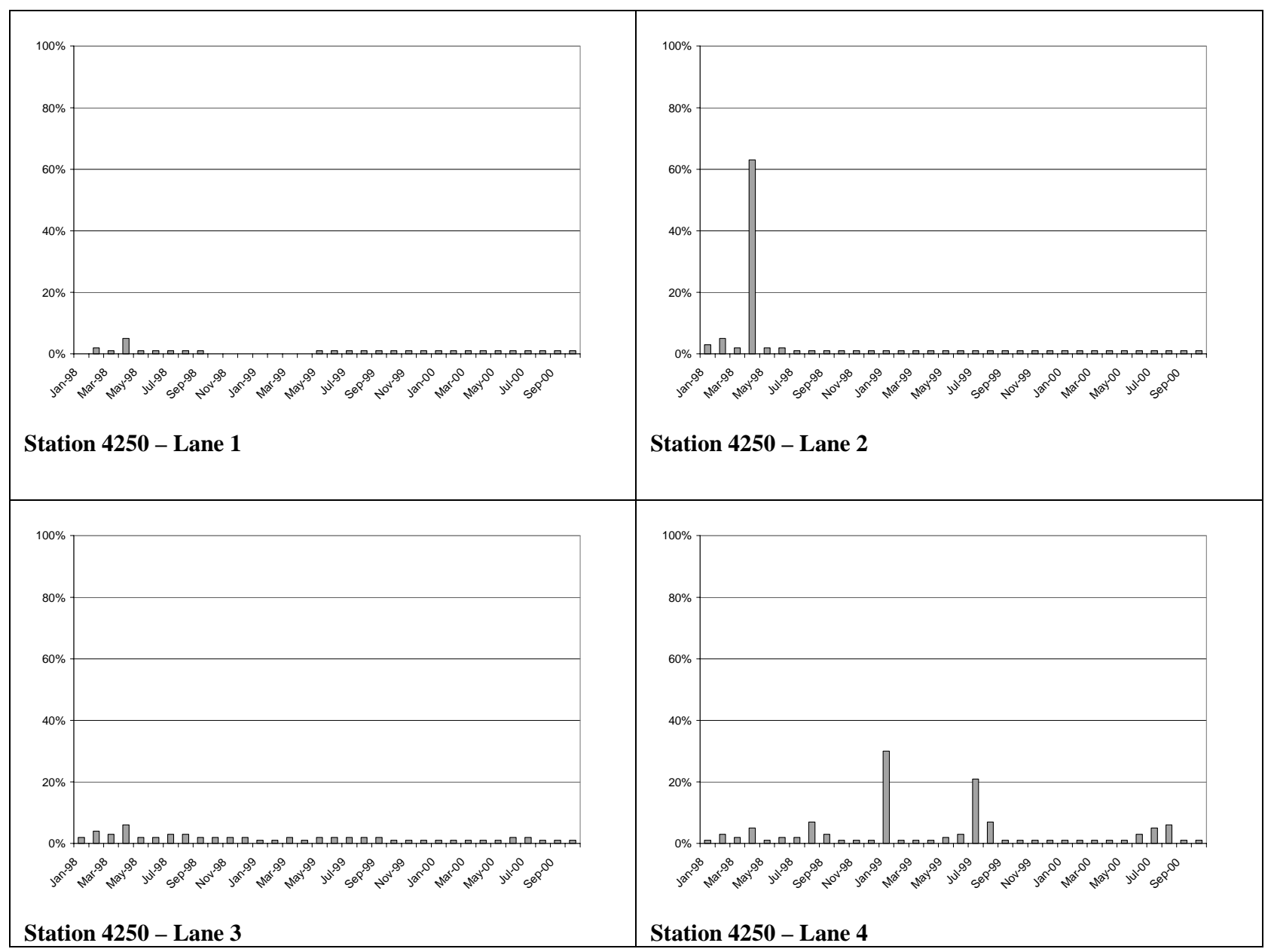

Figure E-42: Error Rate of individual lanes at station 4250 
135

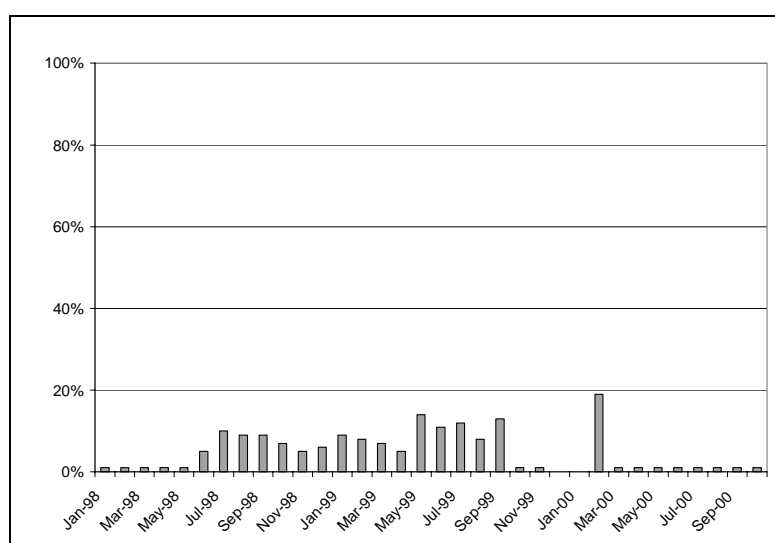

Station 4260 - Lane 1

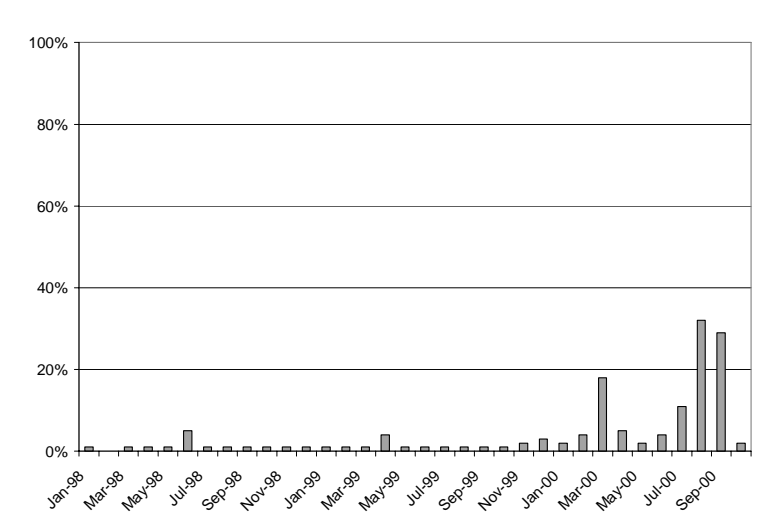

Station 4260 - Lane 3

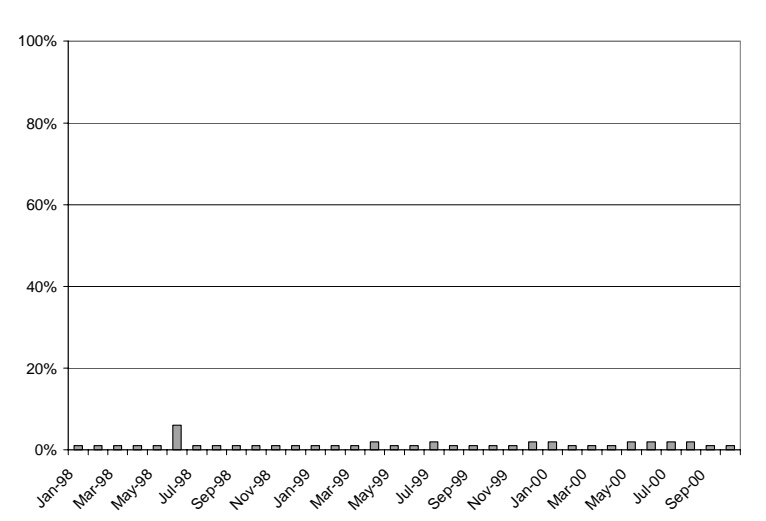

Station 4260 - Lane 2

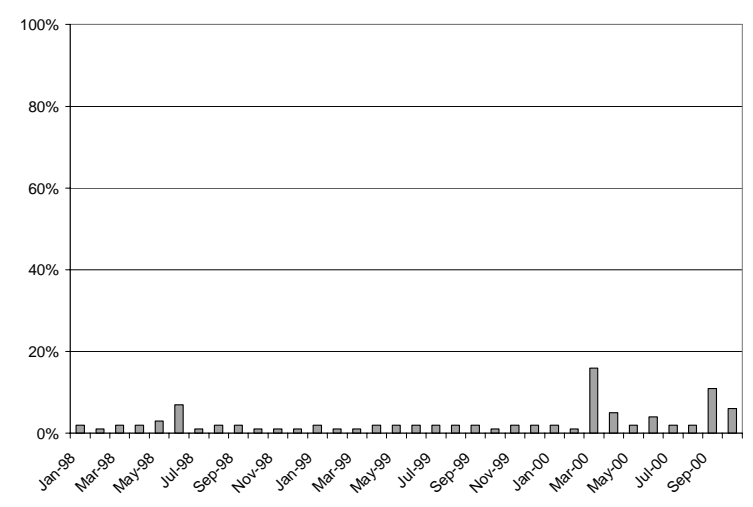

Station 4260 - Lane 4

Figure E-43: Error Rate of individual lanes at station 4260 
136

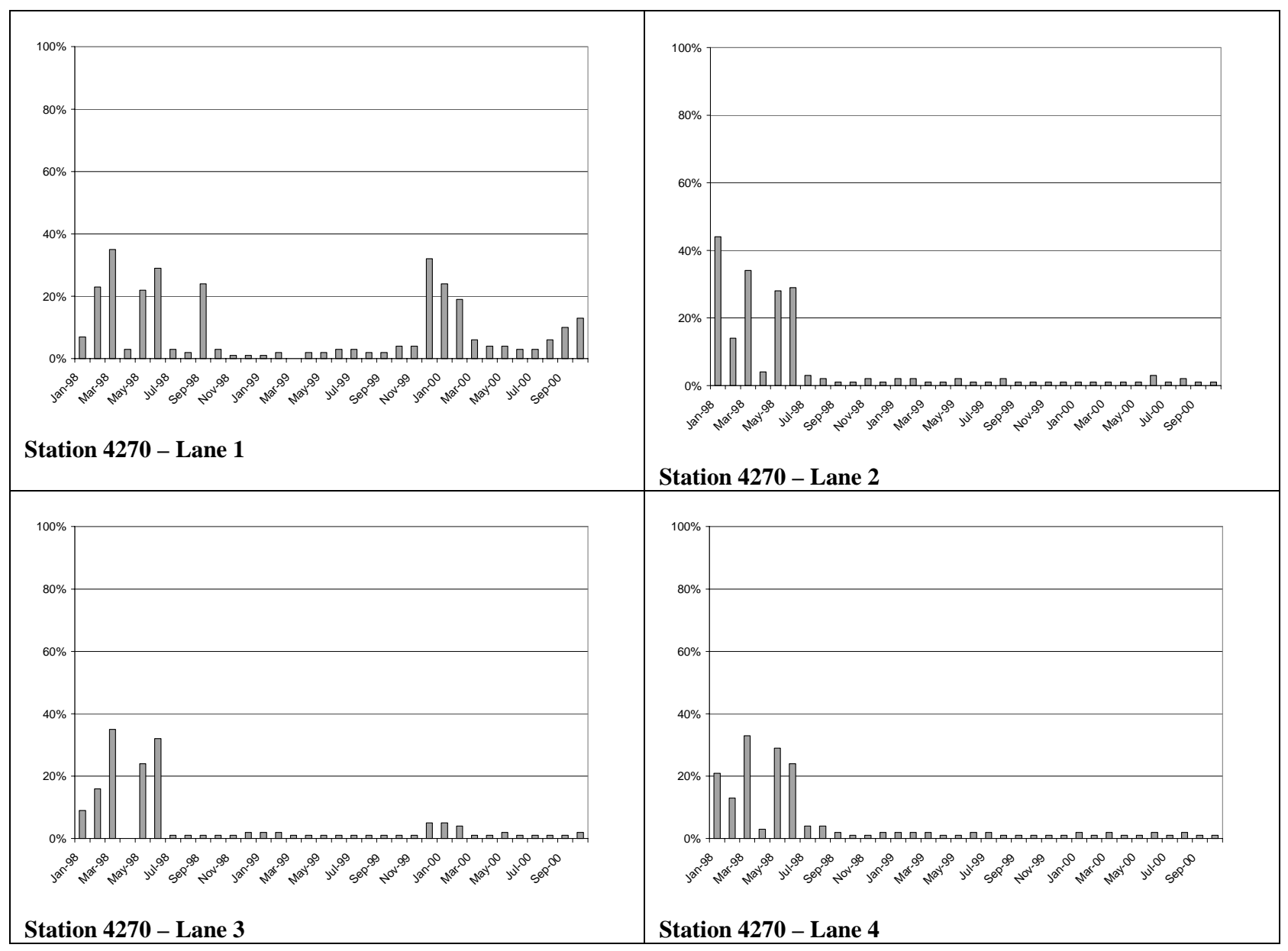

Figure E-44: Error Rate of individual lanes at station 4270 


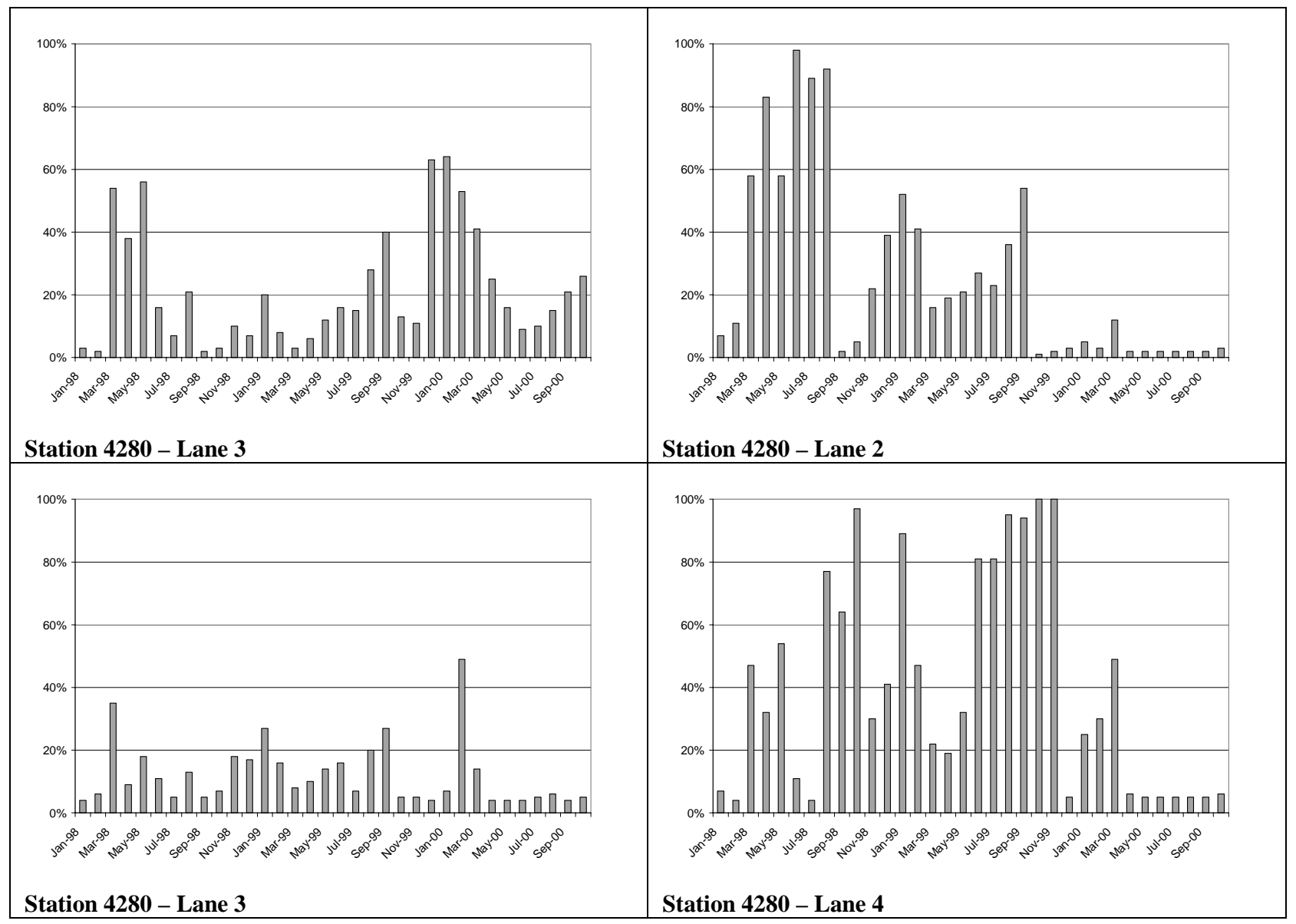

Figure E-45: Error Rate of individual lanes at station 4280 
138

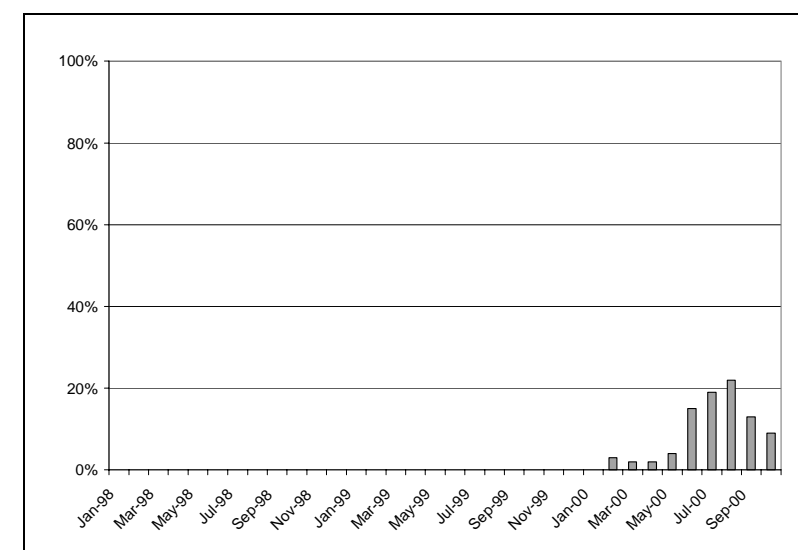

Station 4400 - Lane 1

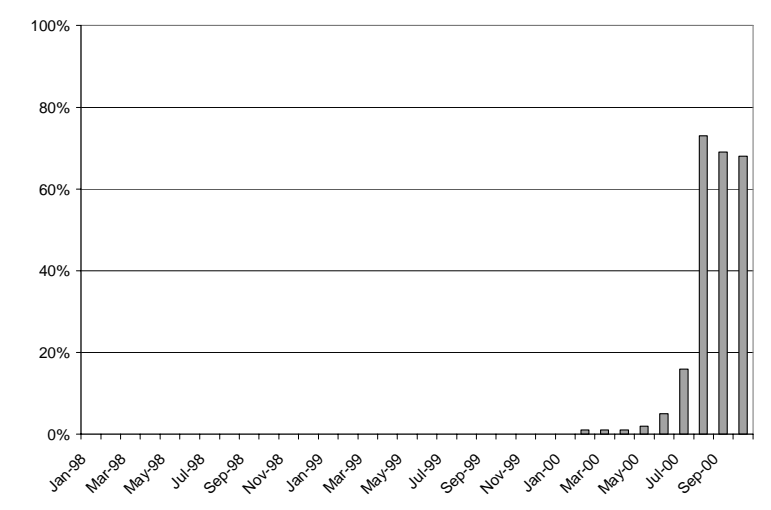

Station 4400 - Lane 3

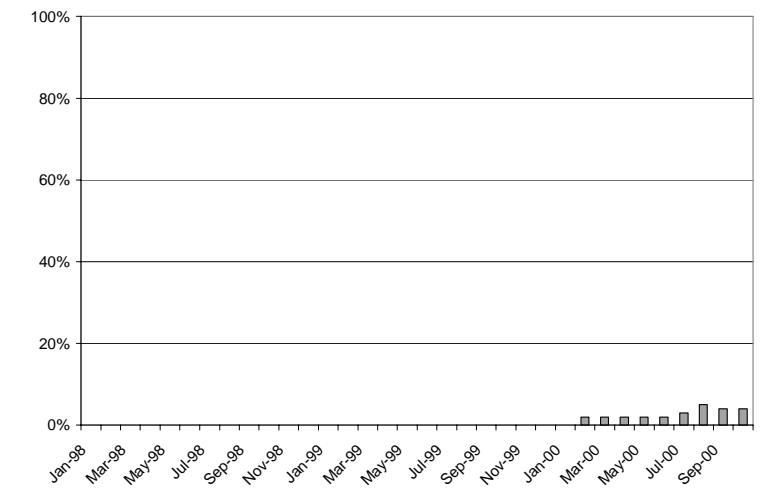

Station 4400 - Lane 5

Figure E-46: Error Rate of individual lanes at station 4400

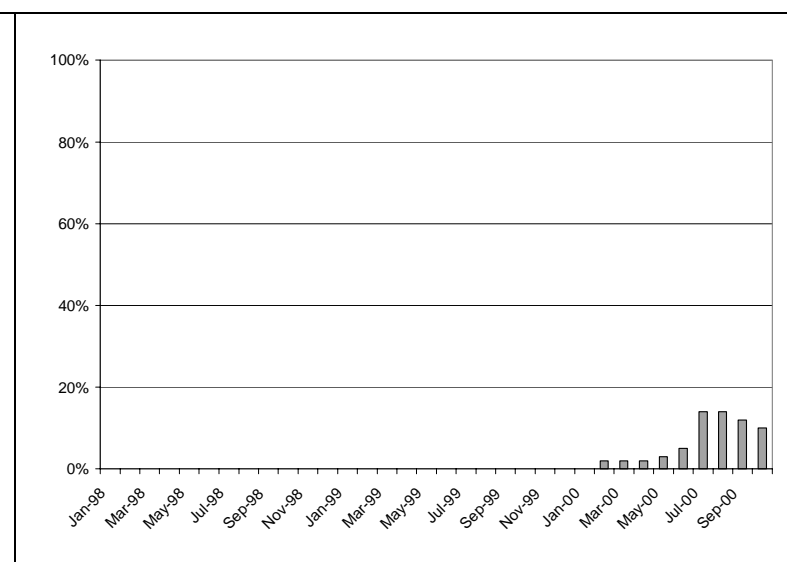

Station 4400 - Lane 2

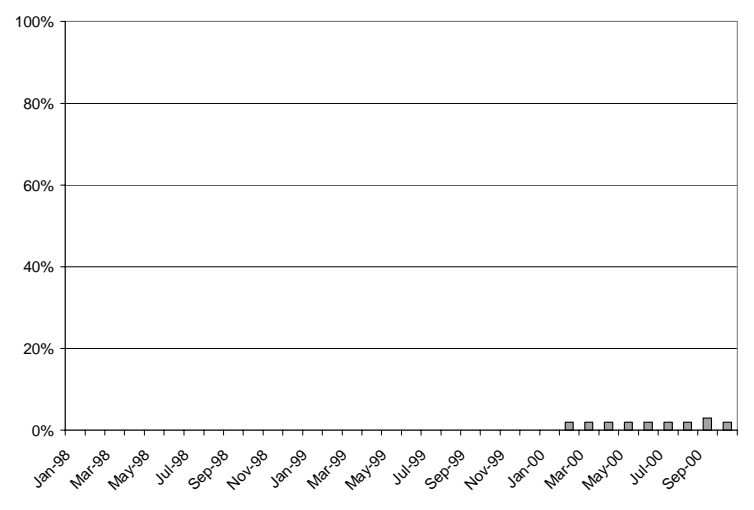

Station 4400 - Lane 4

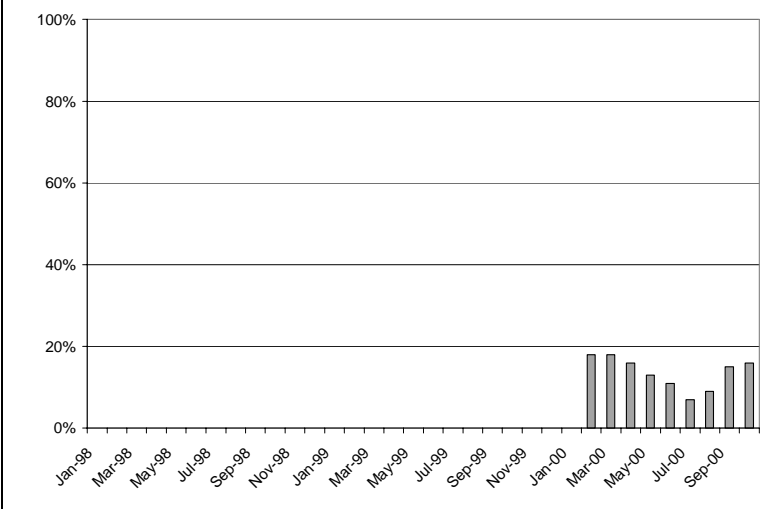

Station 4400 - Lane 6 


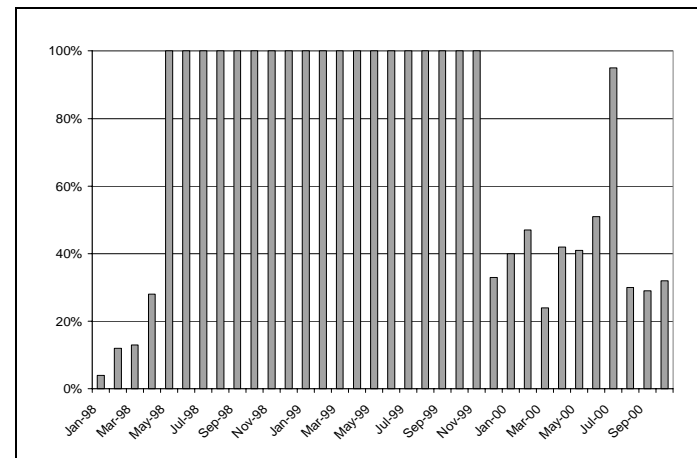

Station 4440 - Lane 1

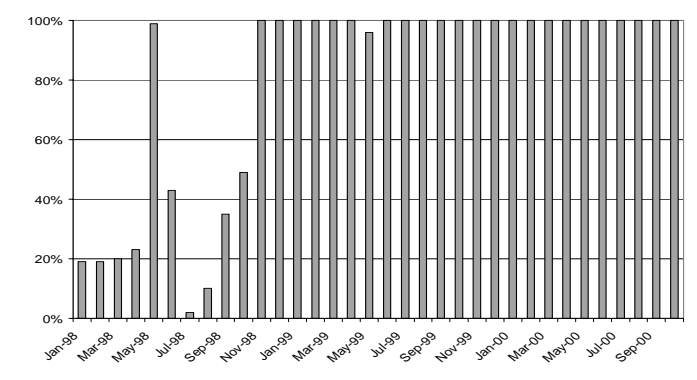

Station 4440 - Lane 3

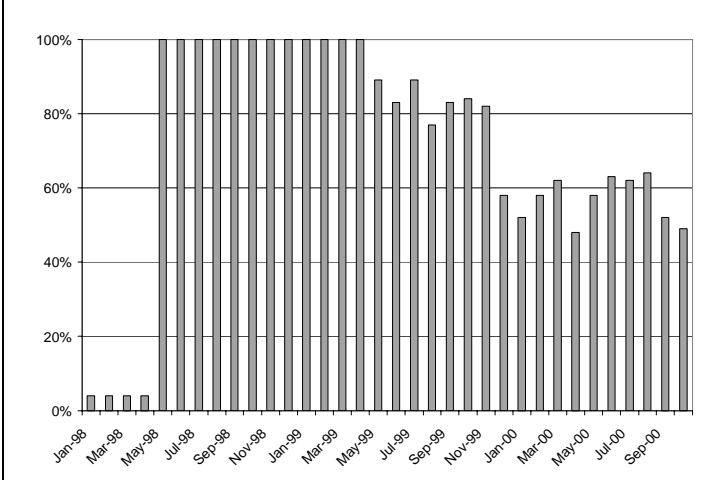

Station 4440 - Lane 5

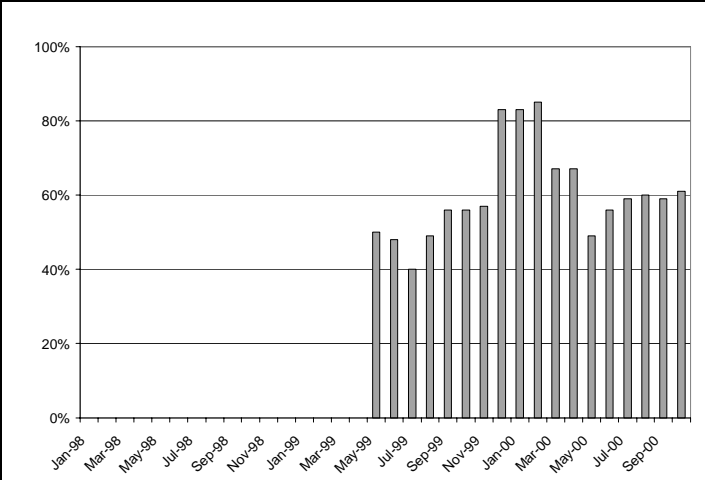

Station 4440 - Lane 7

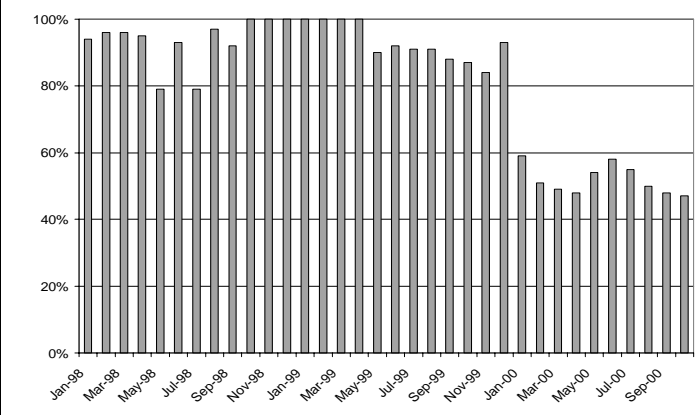

Station 4440 - Lane 2

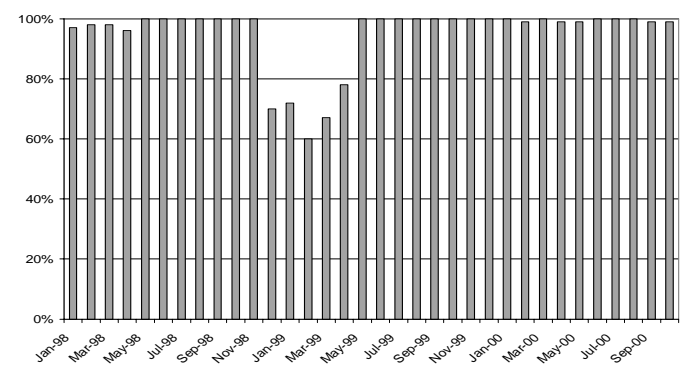

Station 4440 - Lane 4

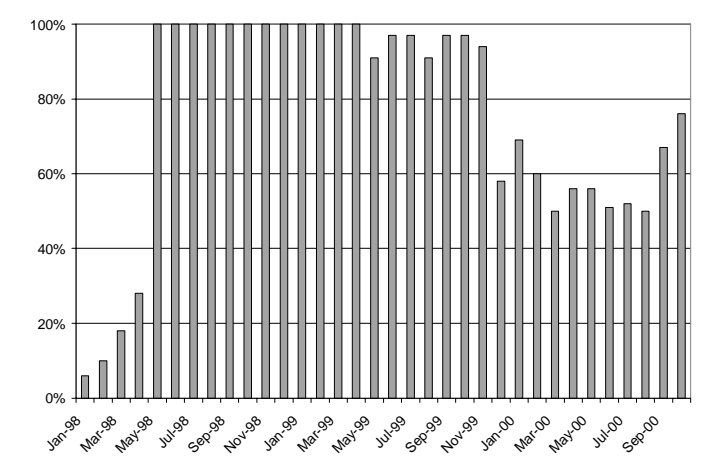

Station 4440 - Lane 6

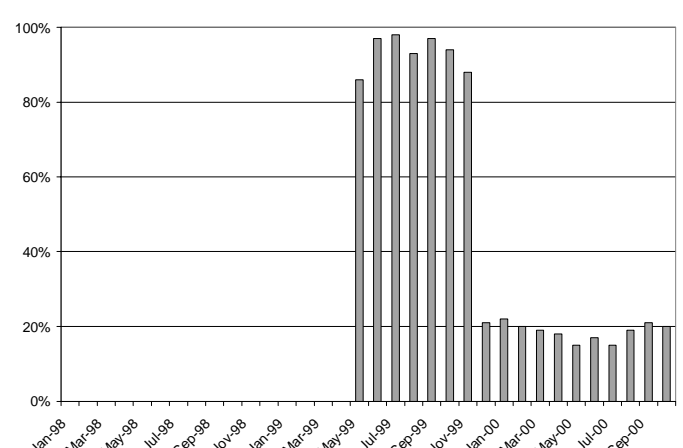

Station 4440 - Lane 8

Figure E-47: Error Rate of individual lanes at station 4440 


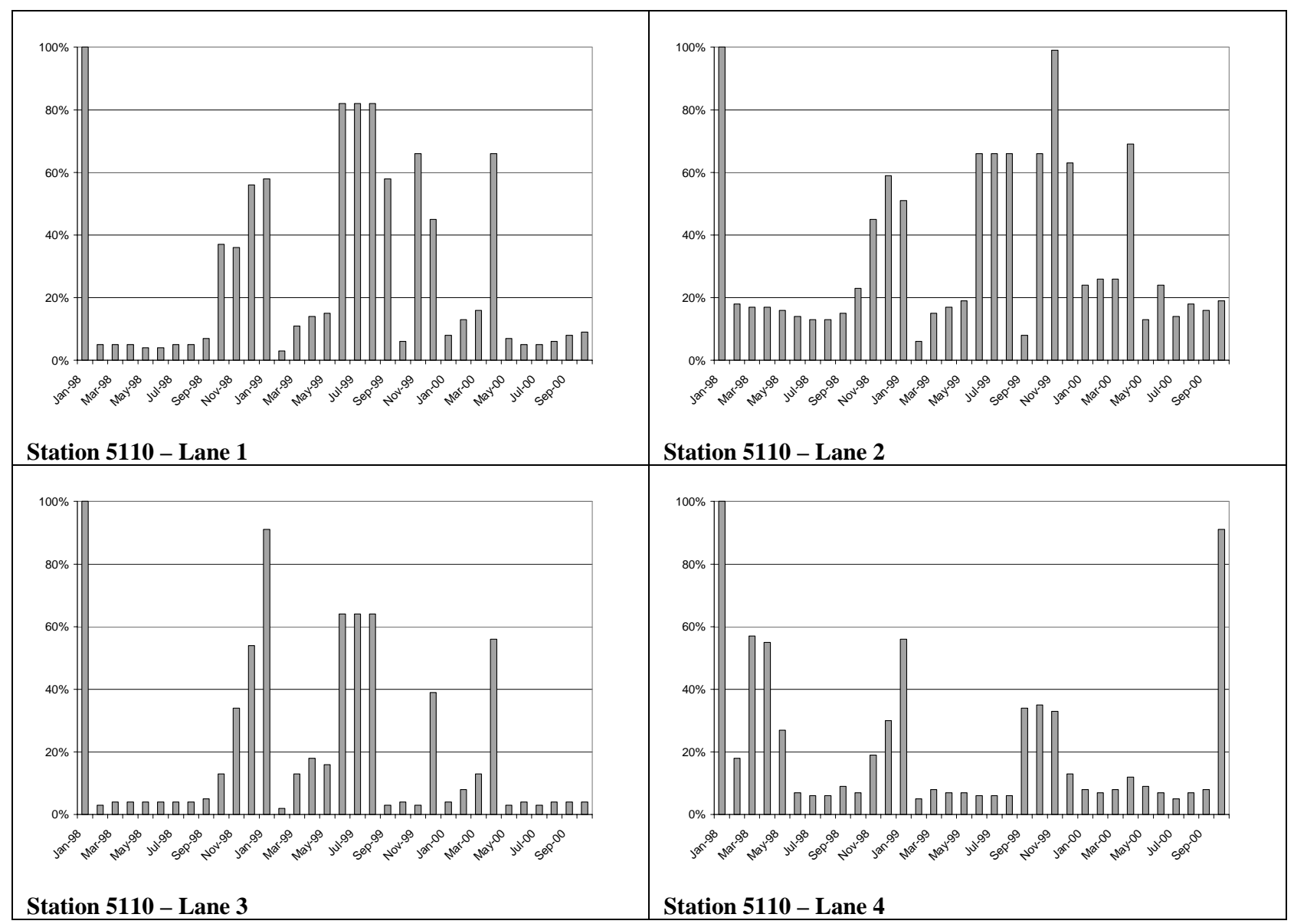

Figure E-48: Error Rate of individual lanes at station 5110 


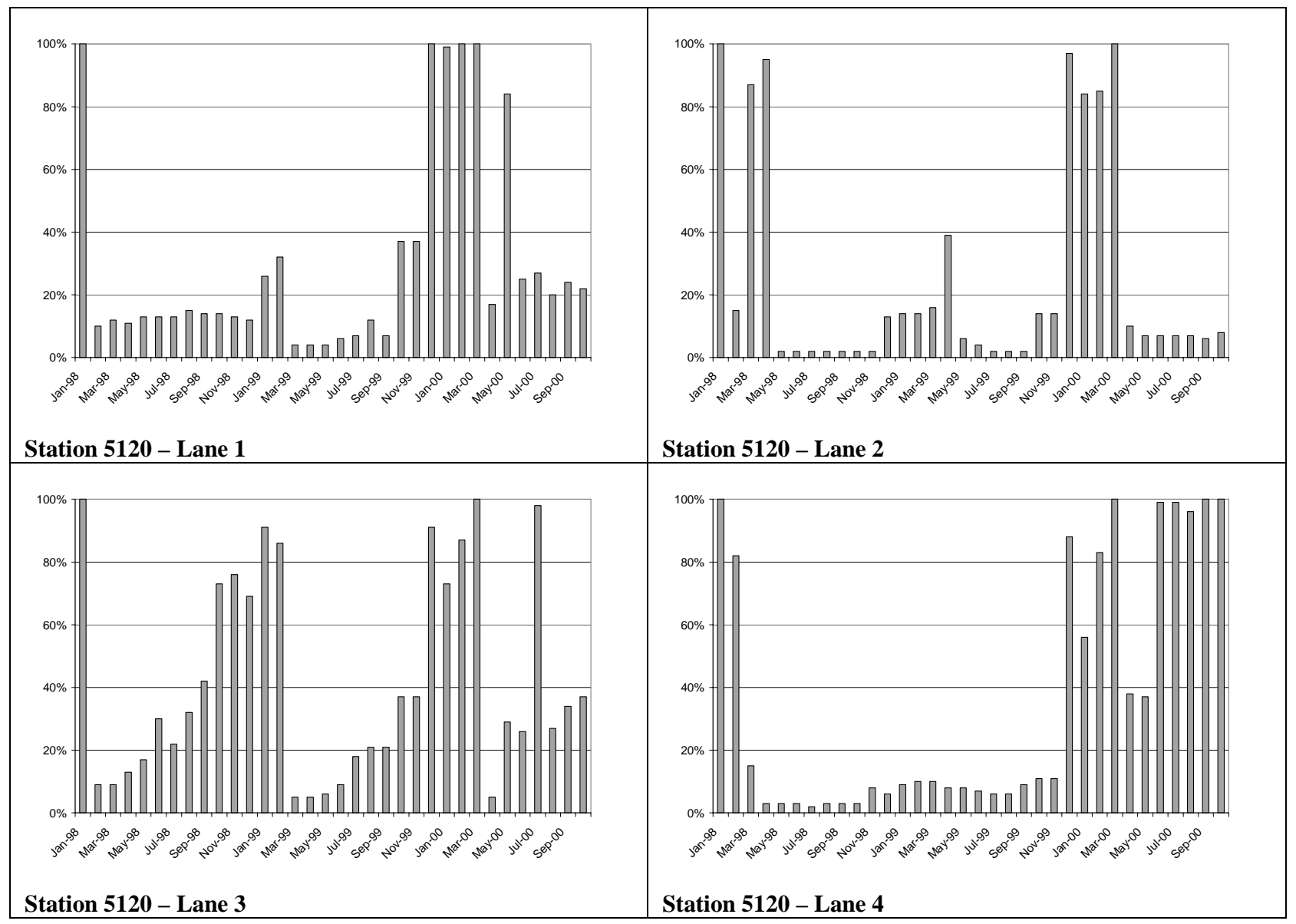

Figure E-49: Error Rate of individual lanes at station 5120 


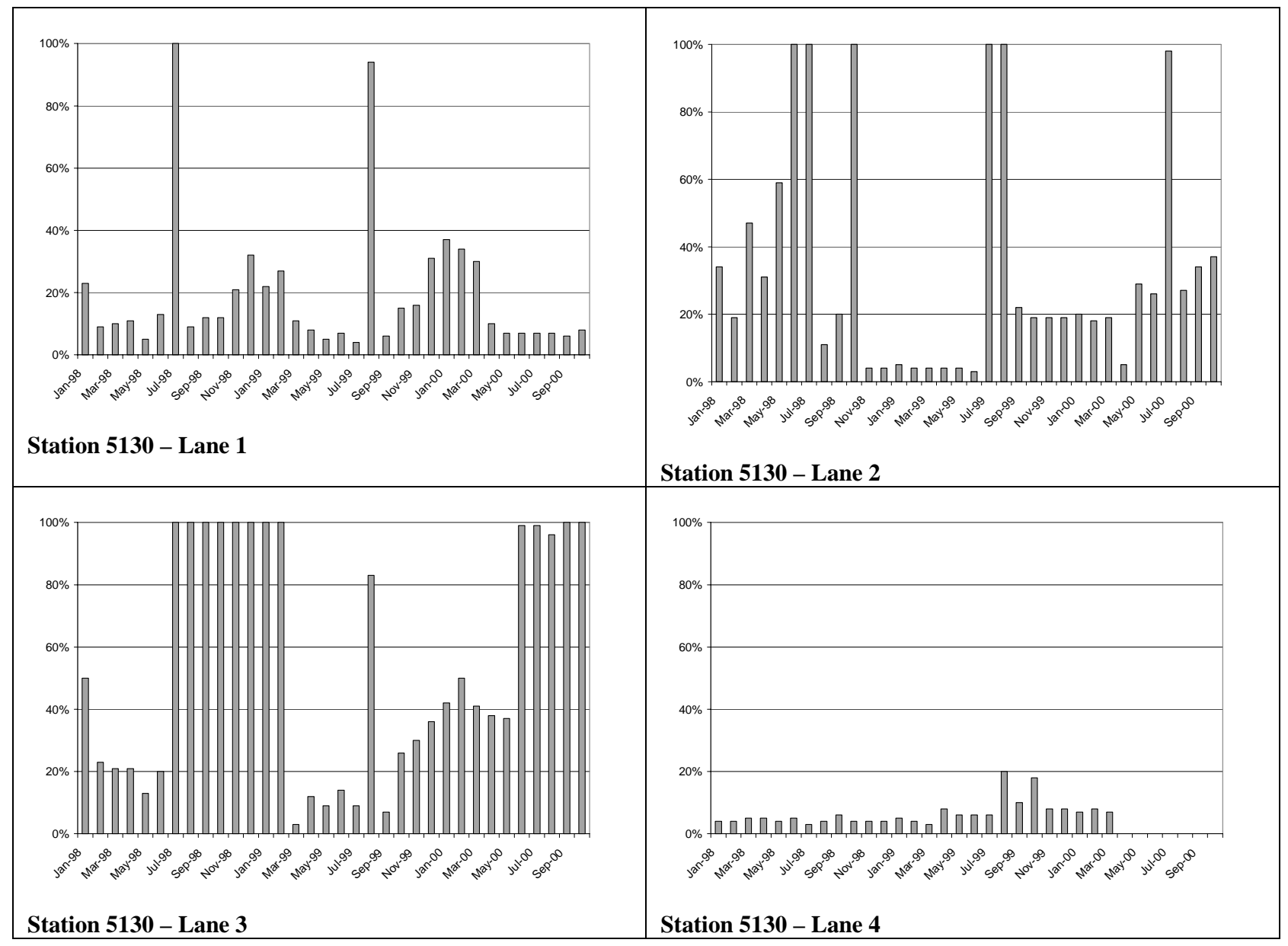

Figure E-50: Error Rate of individual lanes at station 5130 
143

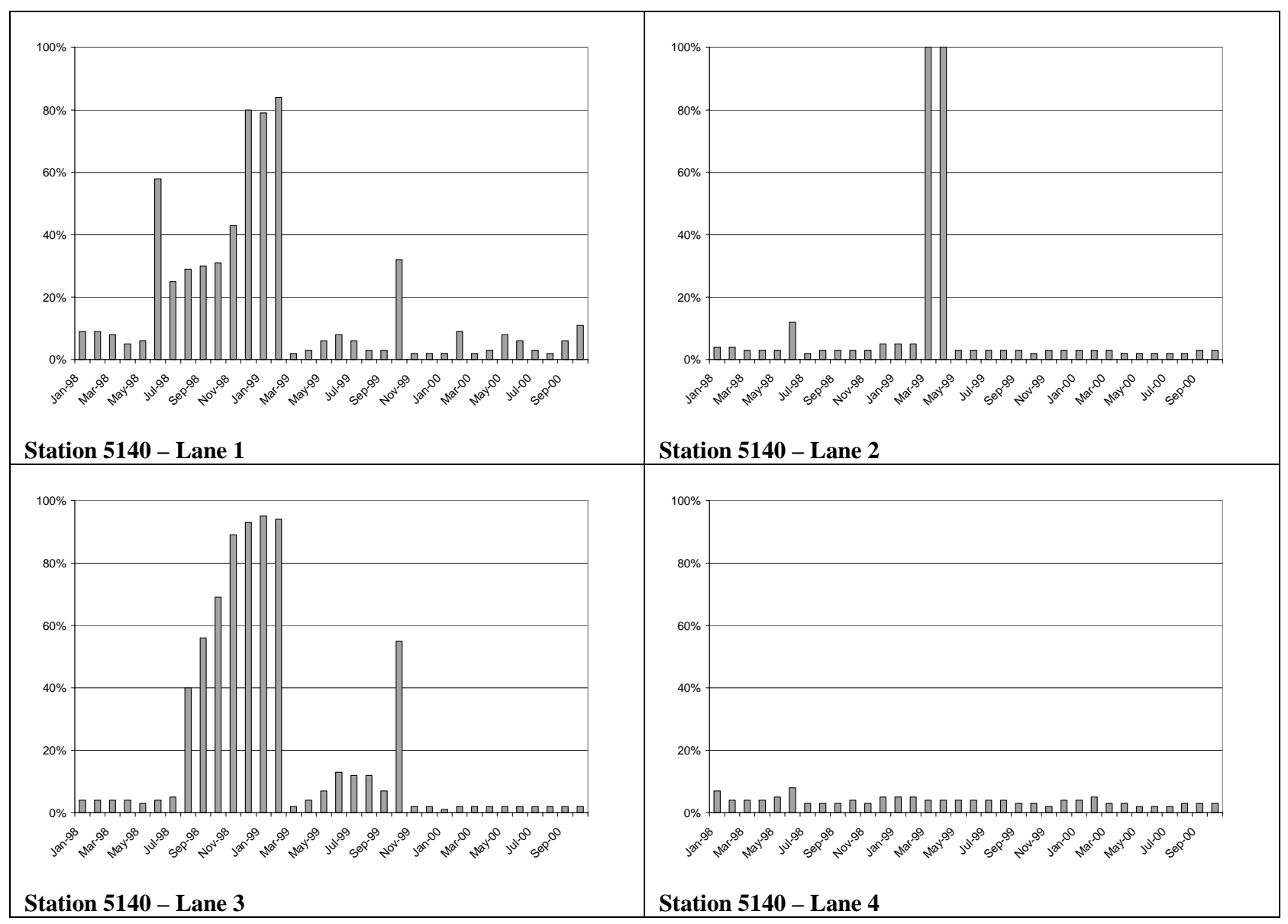

Figure E-51: Error Rate of individual lanes at station 5140 


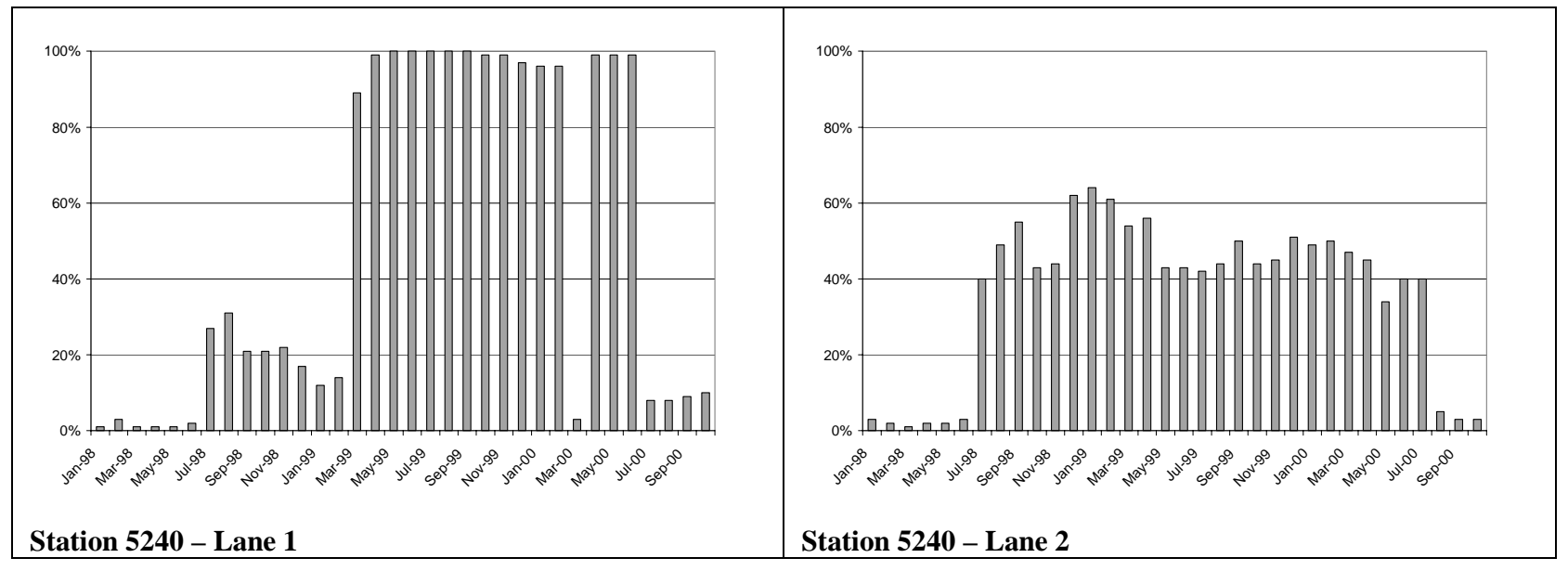

Figure E-52: Error Rate of individual lanes at station 5240 
145

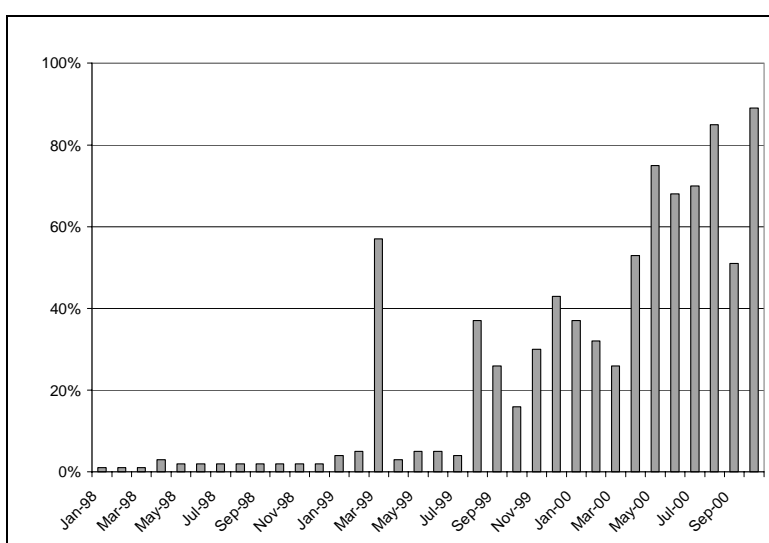

Station 5250 - Lane 1

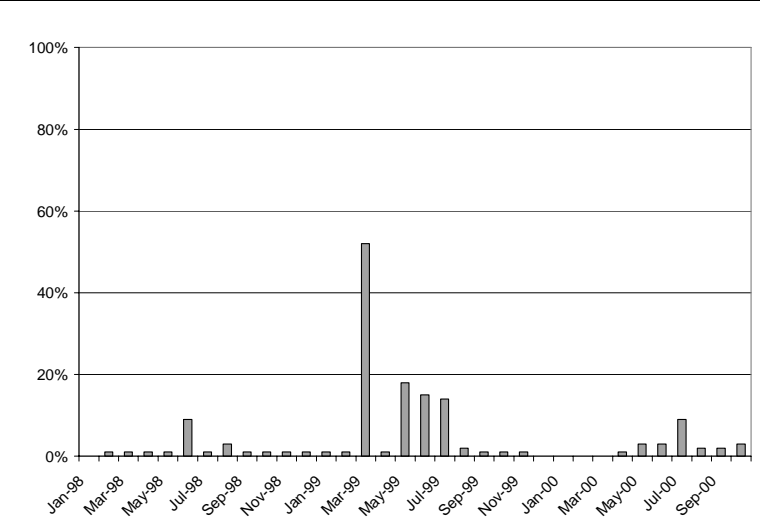

Station 5250 - Lane 3

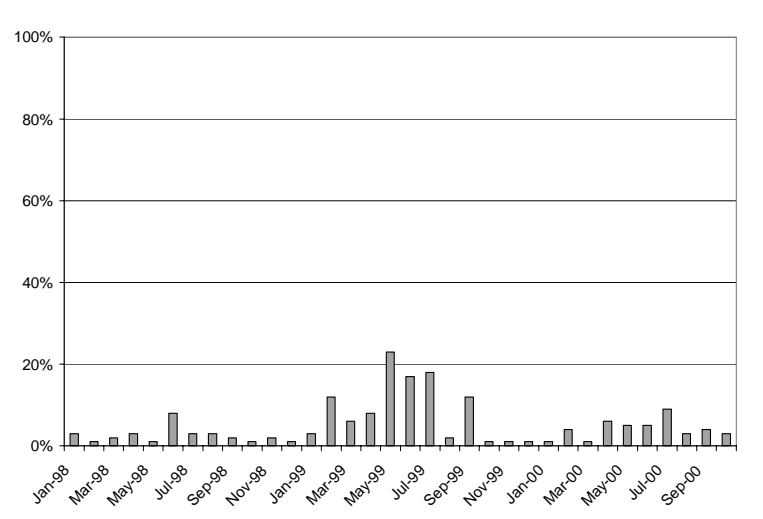

Station 5250 - Lane 2

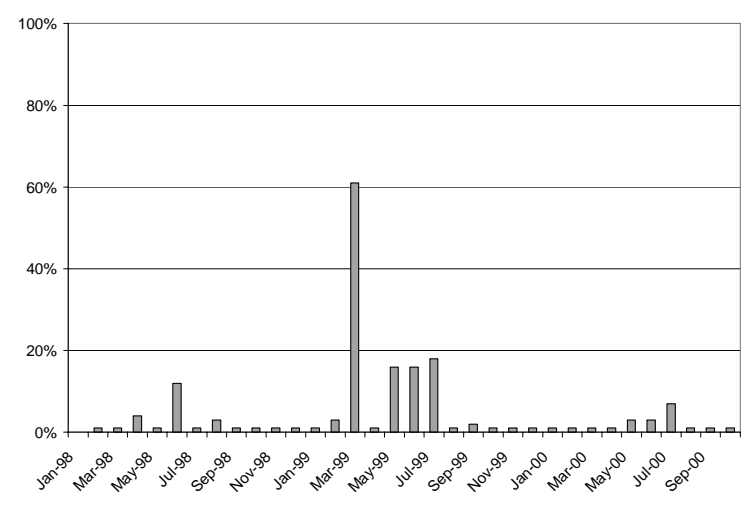

Station 5250 - Lane 4

Figure E-53: Error Rate of individual lanes at station 5250 
146
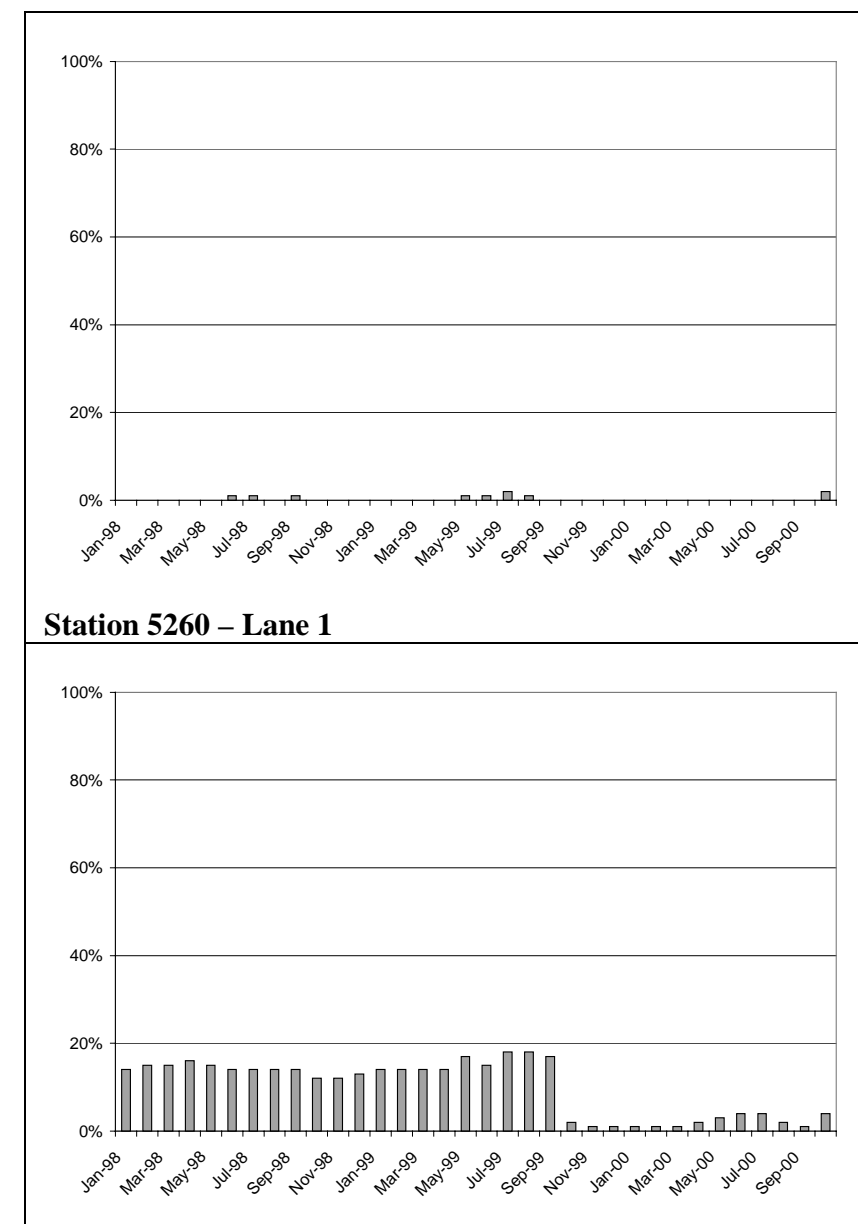

Station 5260 - Lane 3 Figure E-54: Error Rate of individual lanes at station 5260

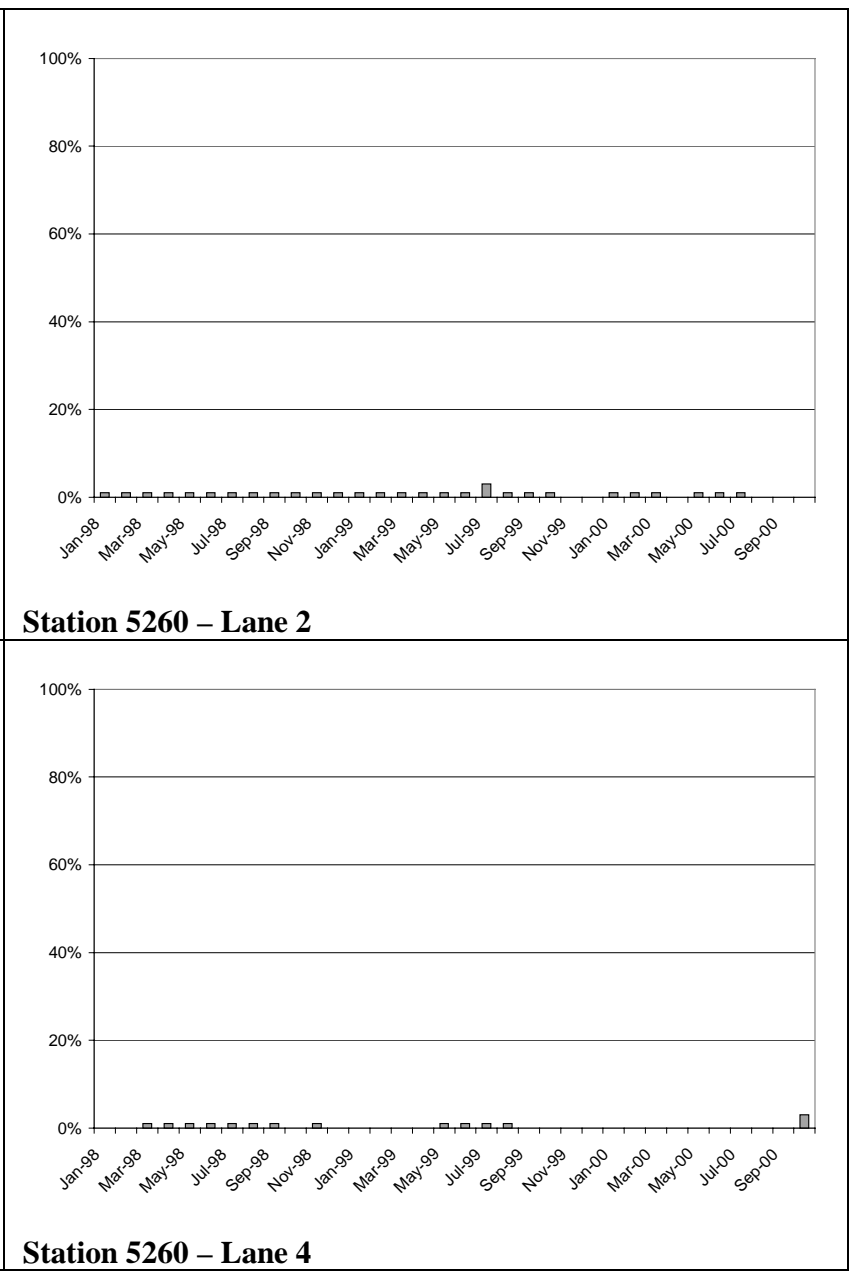

Station 5260 - Lane 4 


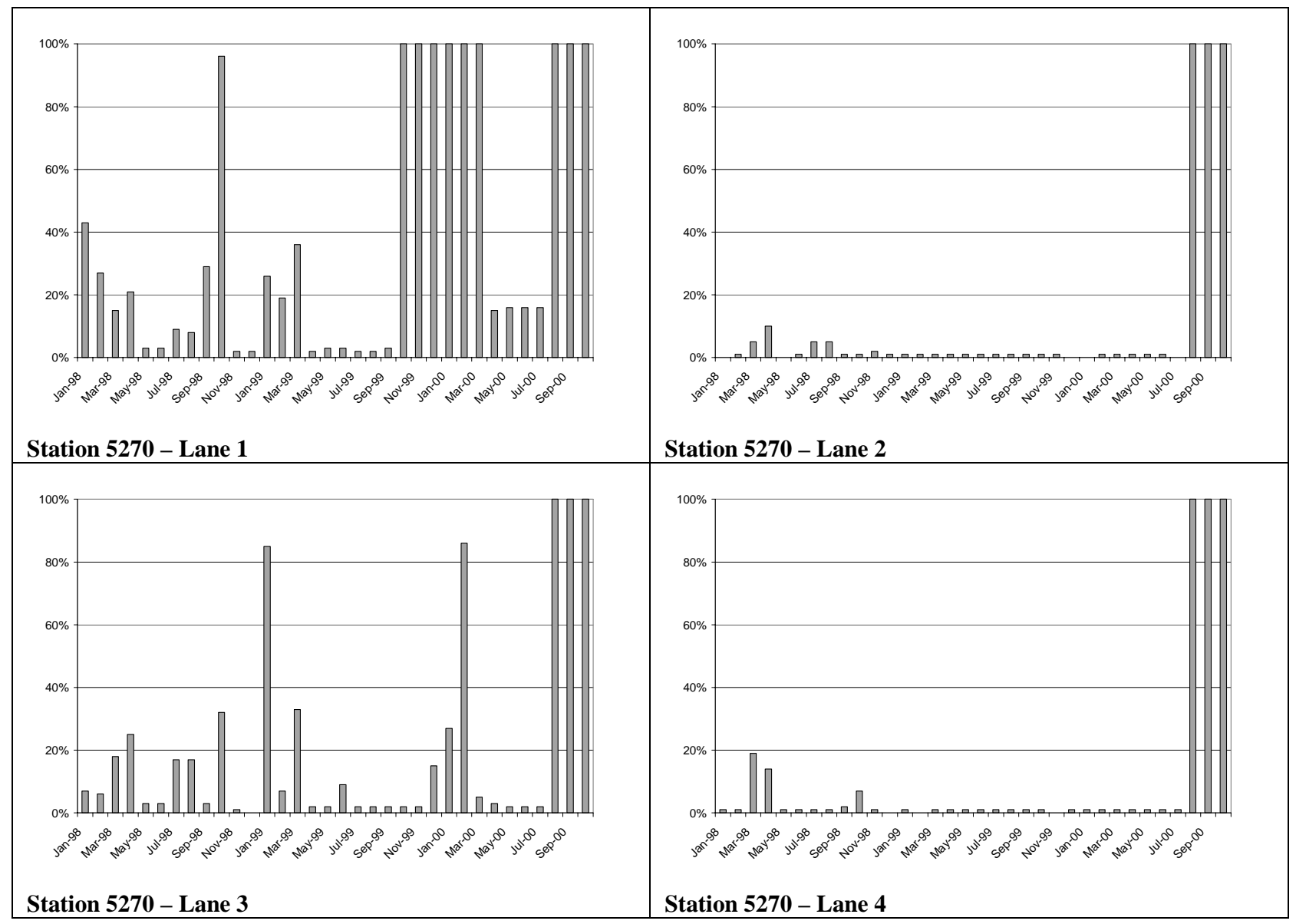

Figure E-55: Error Rate of individual lanes at station 5270 


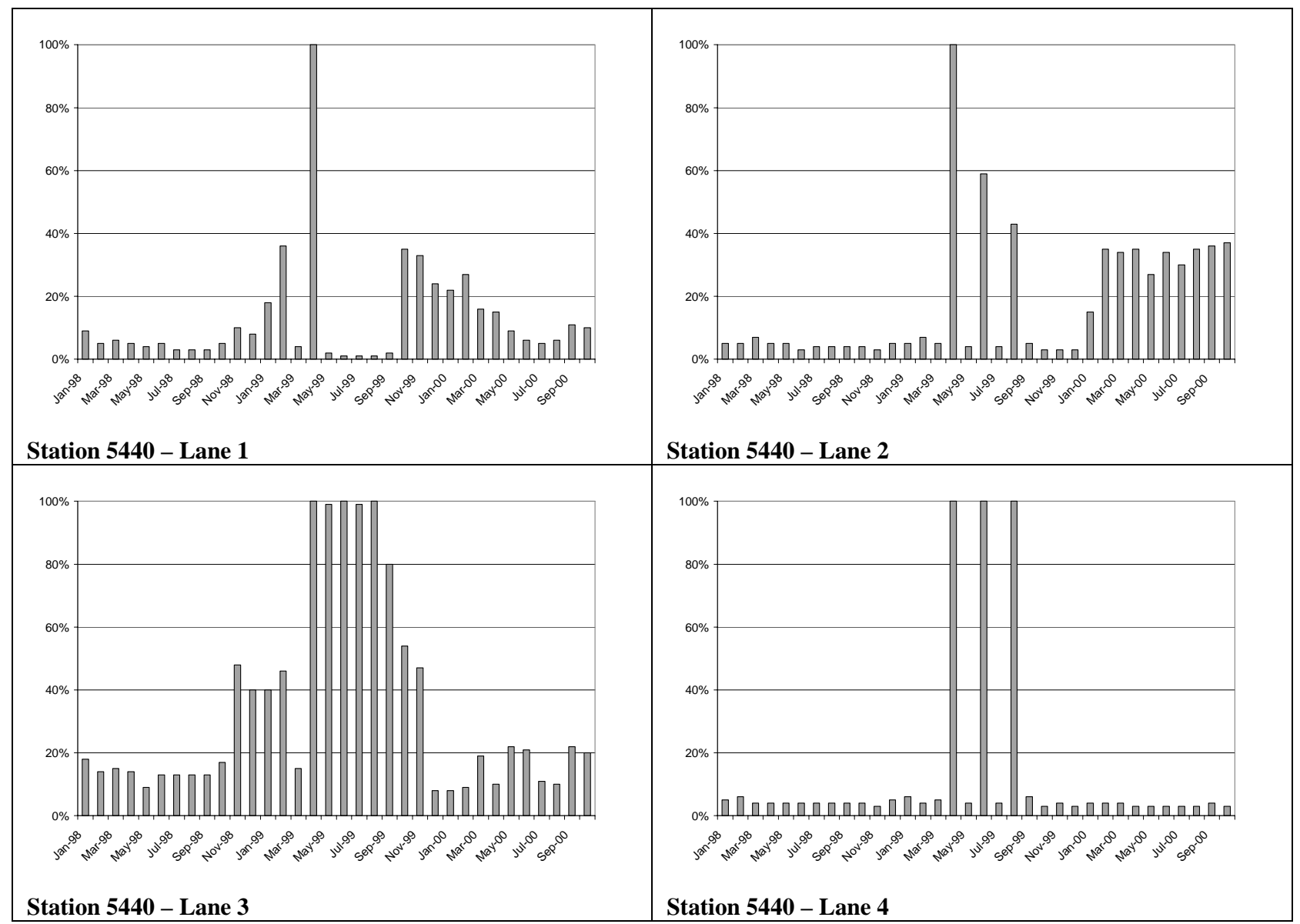

Figure E-56: Error Rate of individual lanes at station 5440 


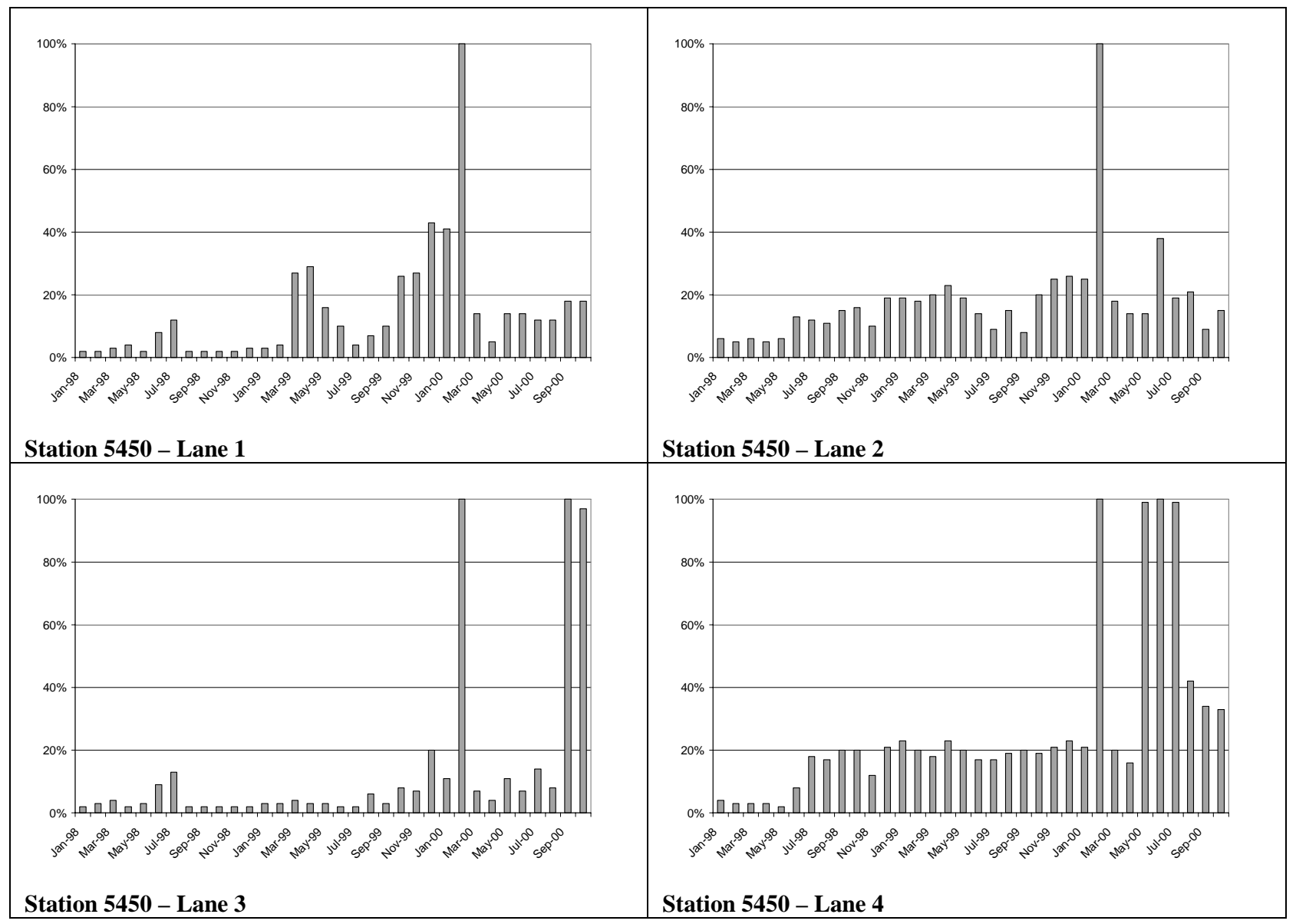

Figure E-57: Error Rate of individual lanes at station 5450 


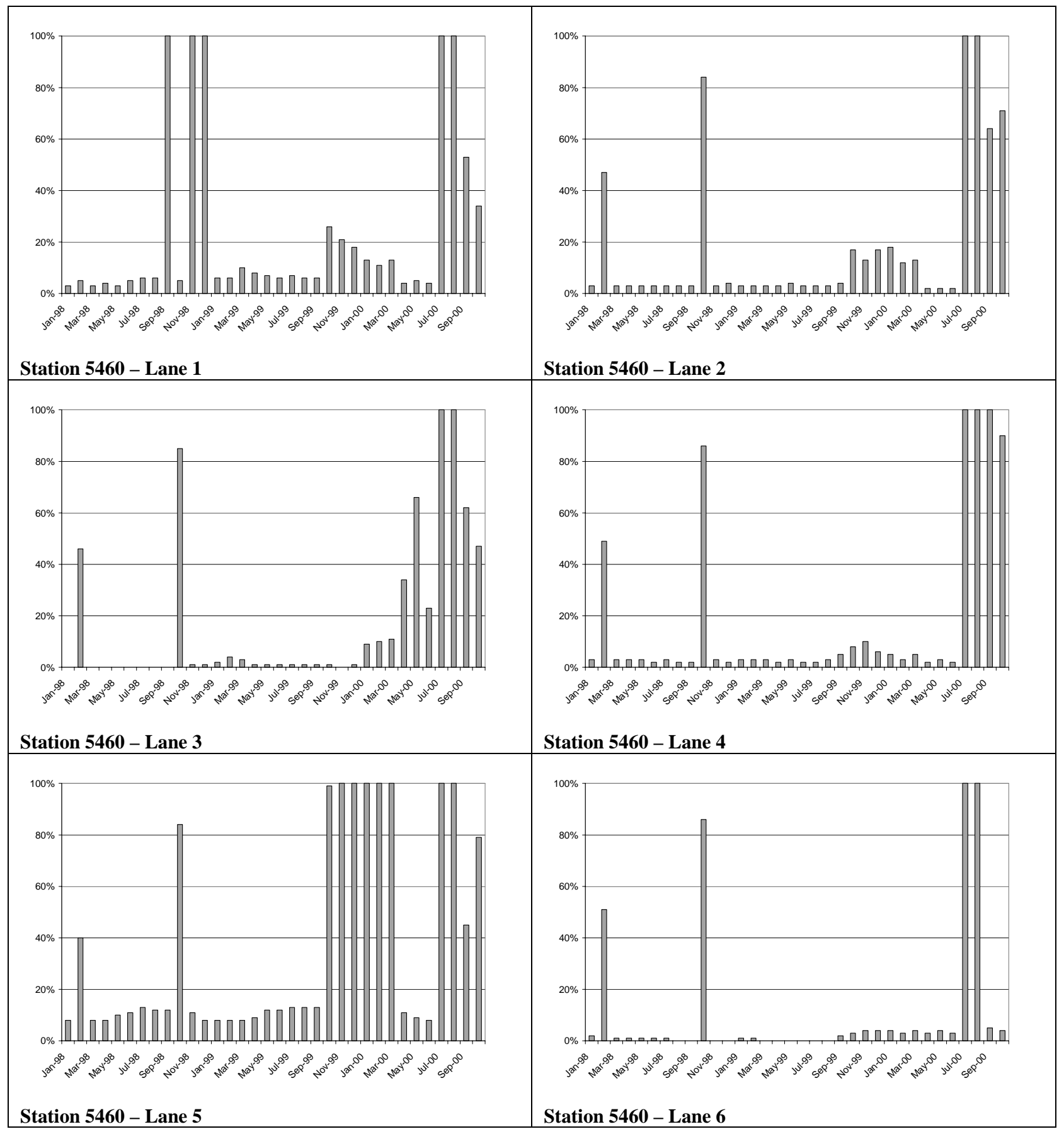

Figure E-58: Error Rate of individual lanes at station 5460 


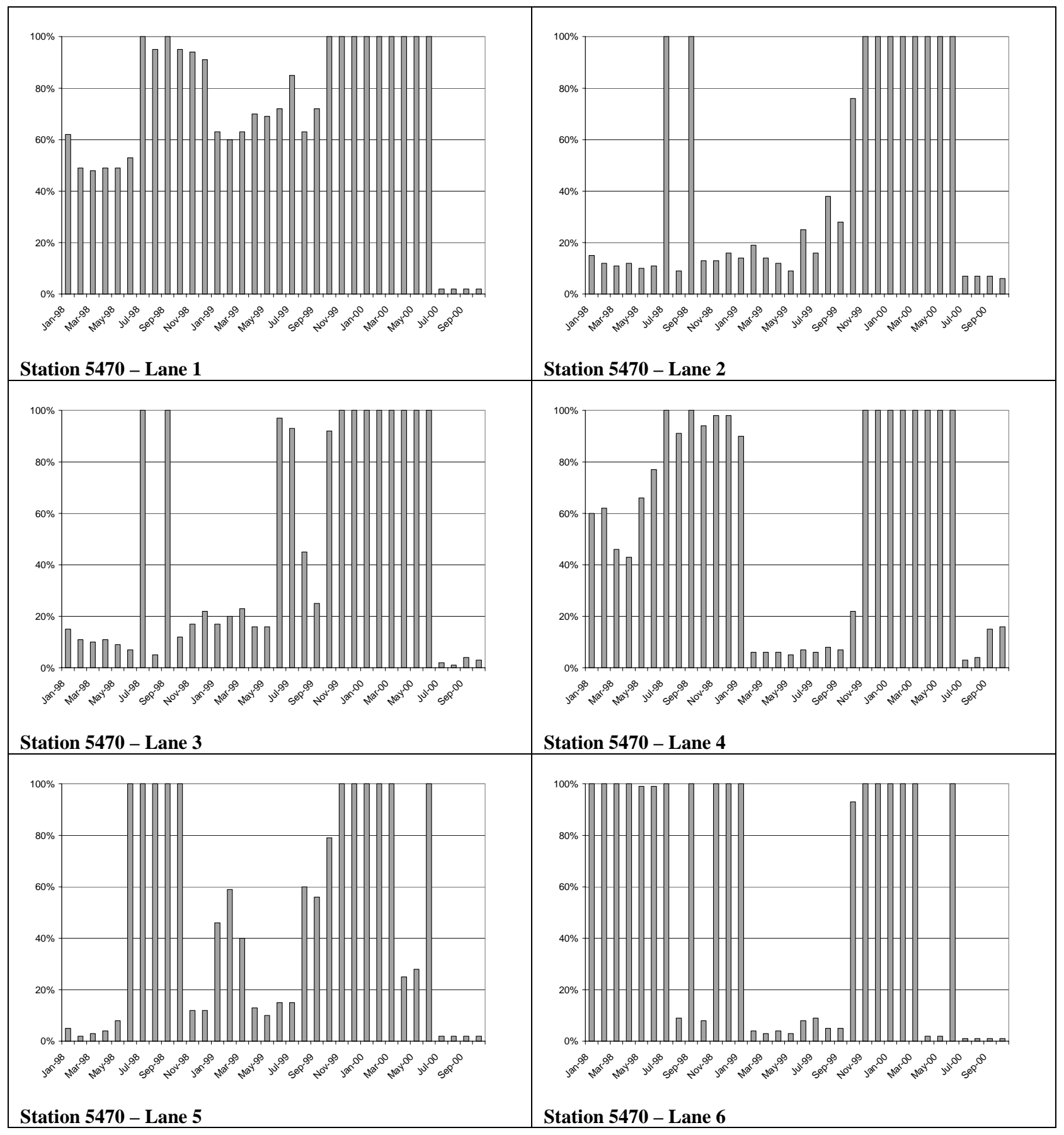

Figure E-59: Error Rate of individual lanes at station 5470 


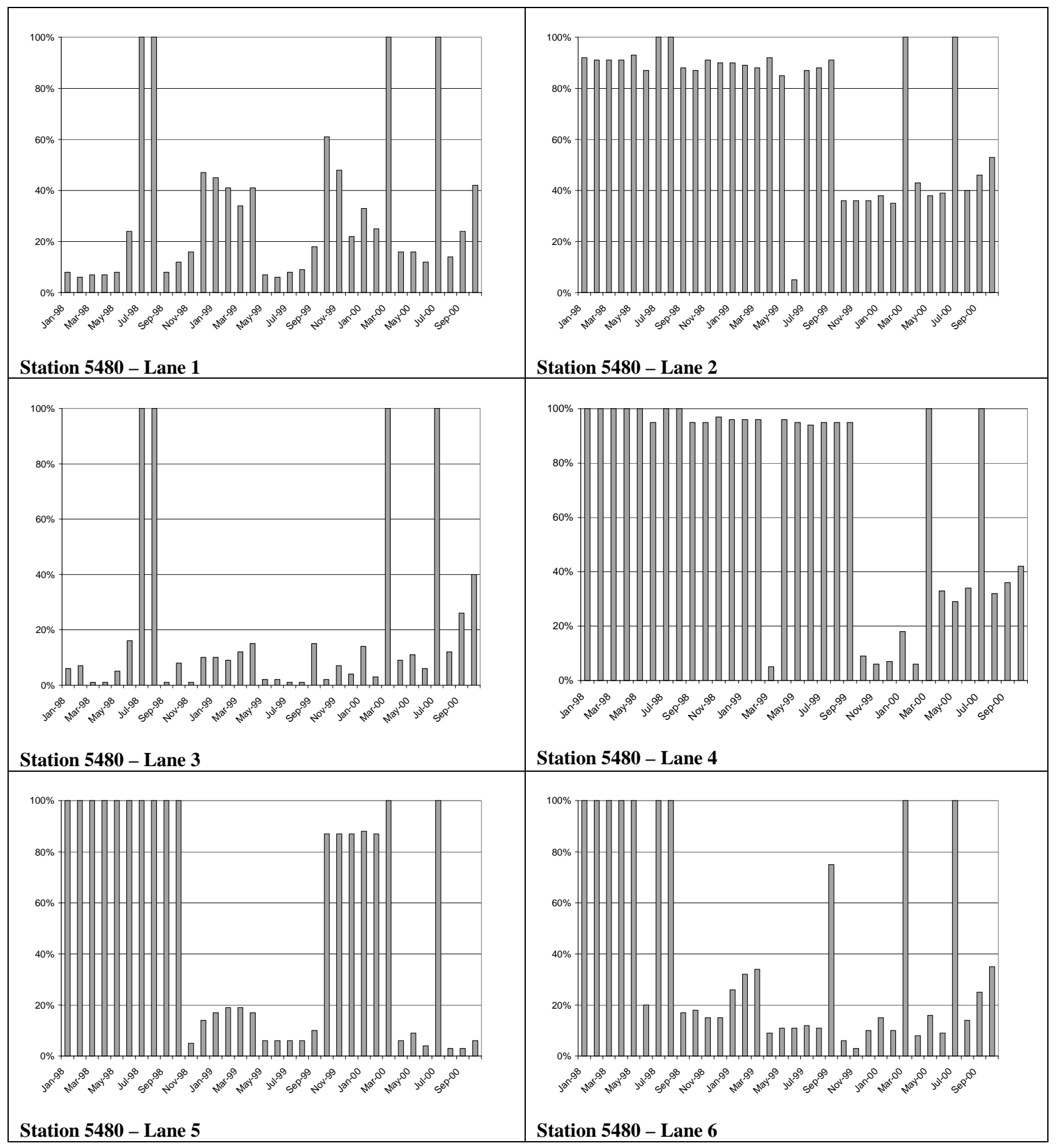

Figure E-60: Error Rate of individual lanes at station 5480 


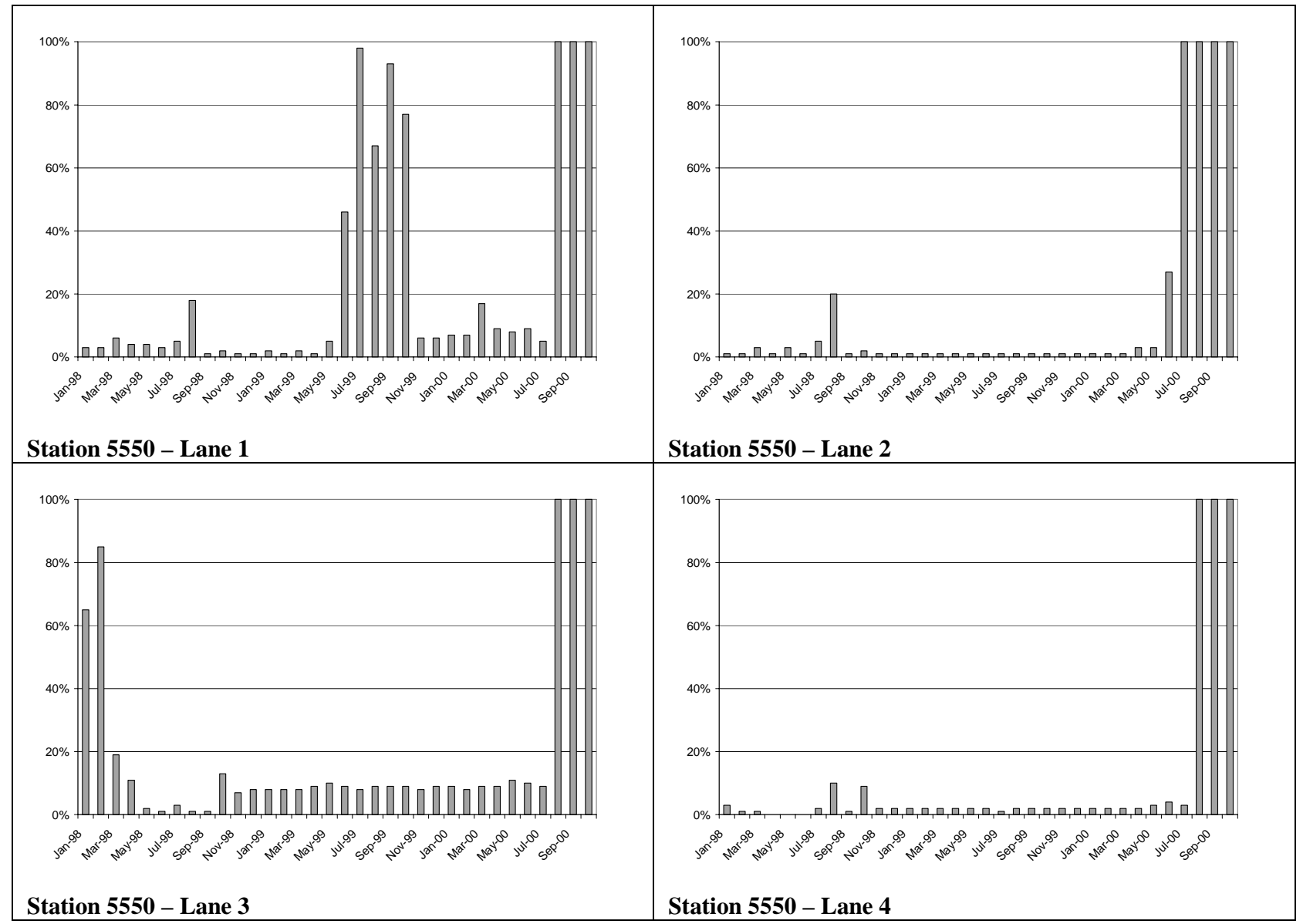

Figure E-61: Error Rate of individual lanes at station 5550 


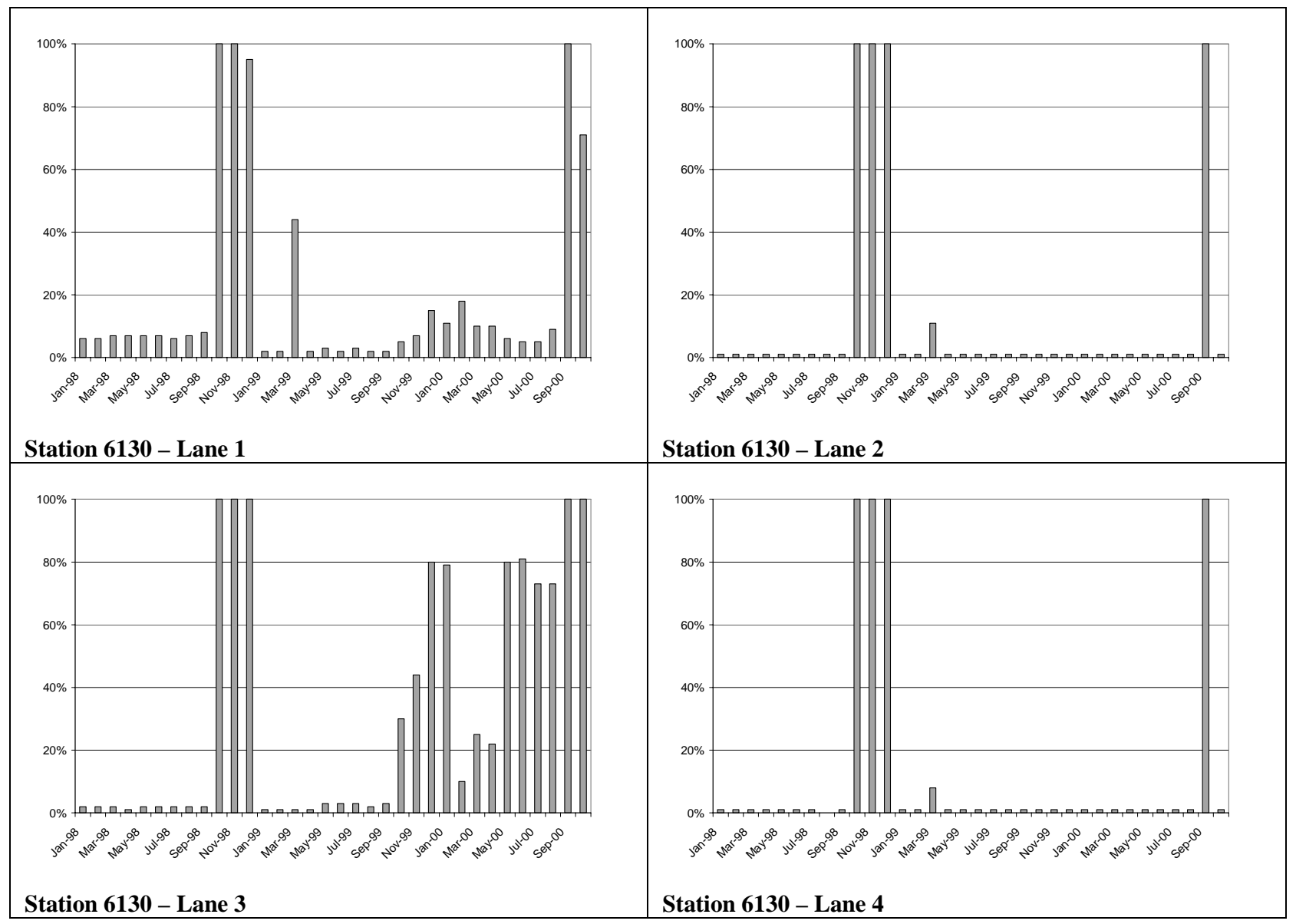

Figure E-62: Error Rate of individual lanes at station 6130 


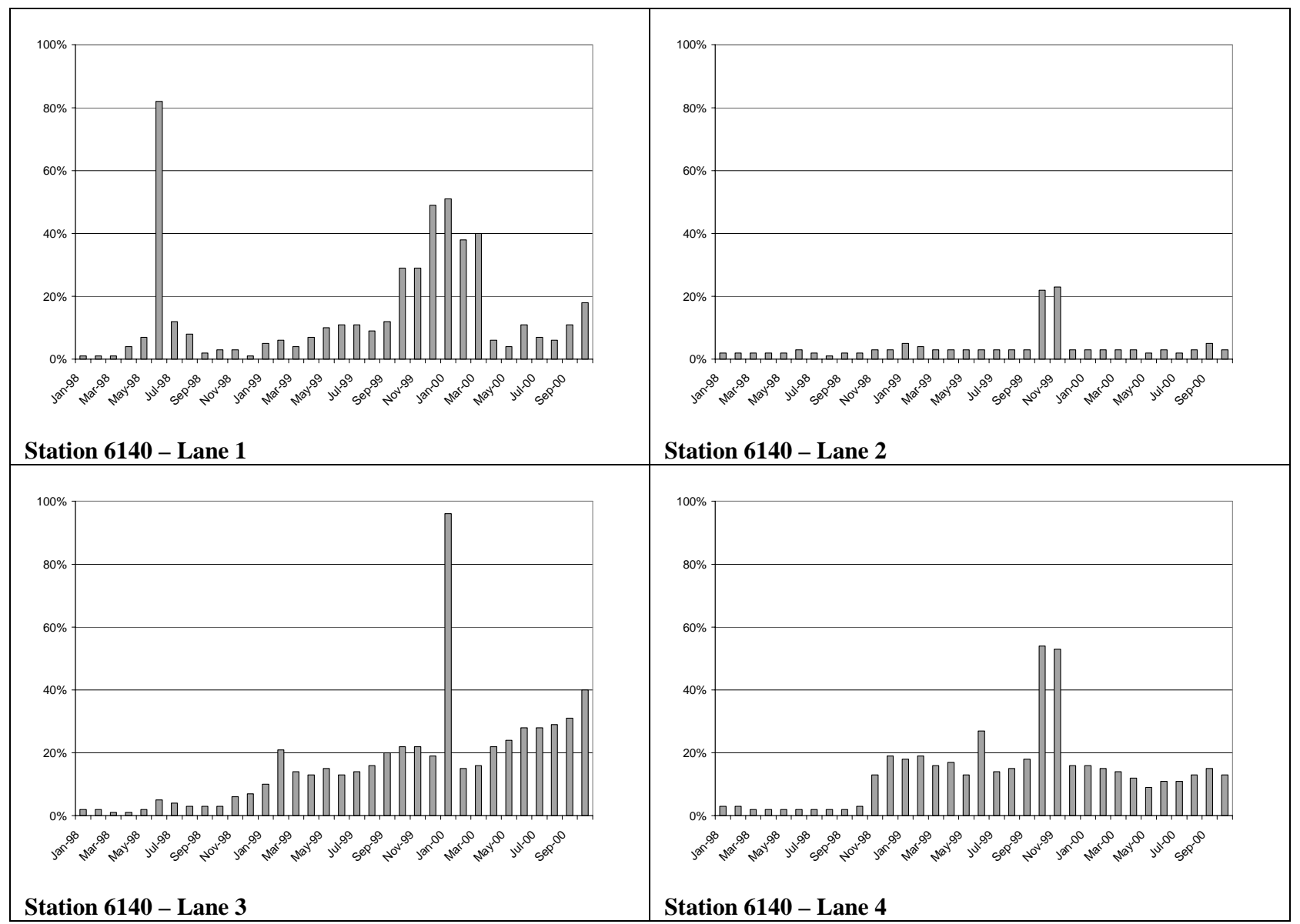

Figure E-63: Error Rate of individual lanes at station 6140 
156

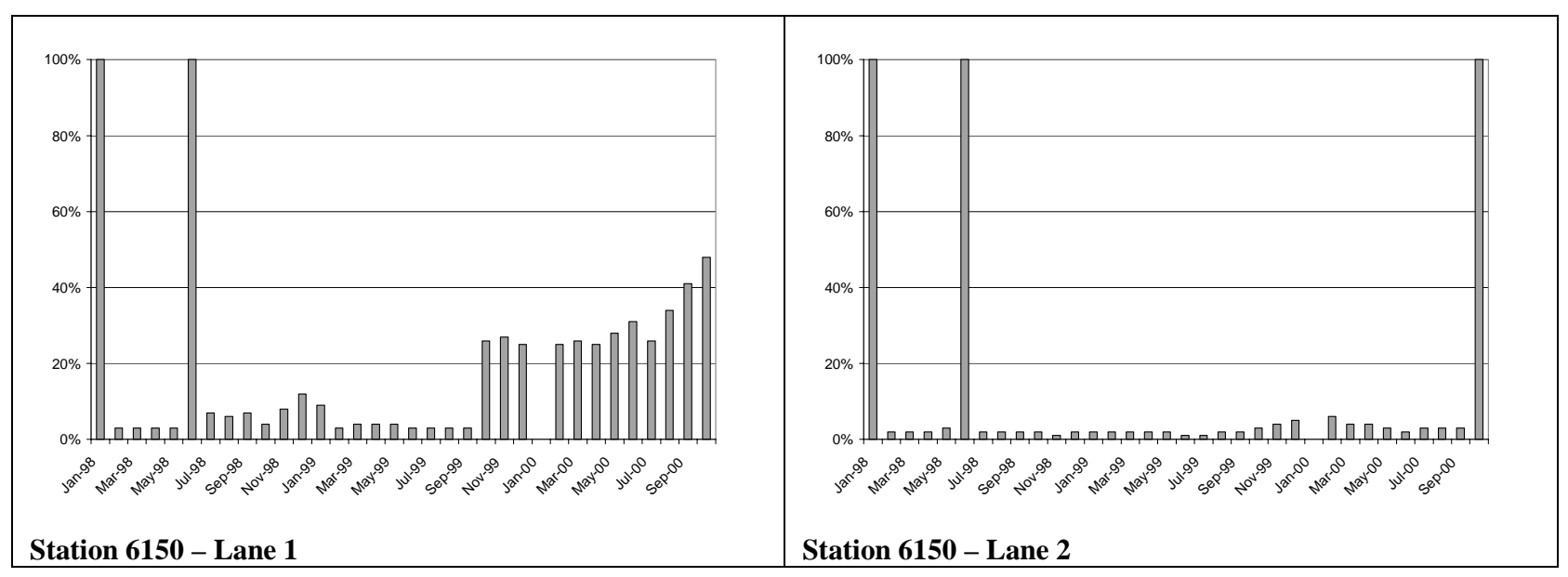

Figure E-64: Error Rate of individual lanes at station 6150 


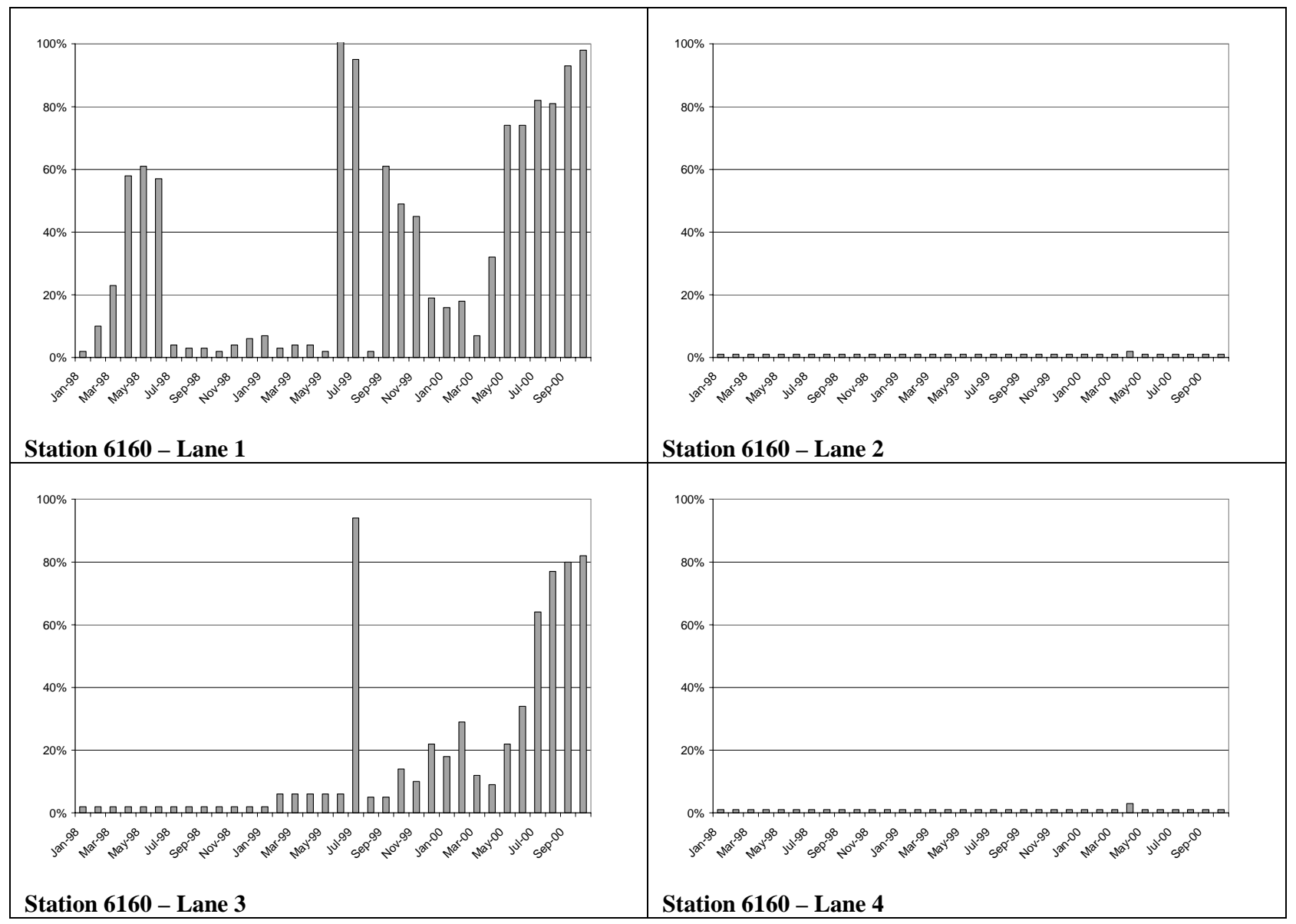

Figure E-65: Error Rate of individual lanes at station 6160 


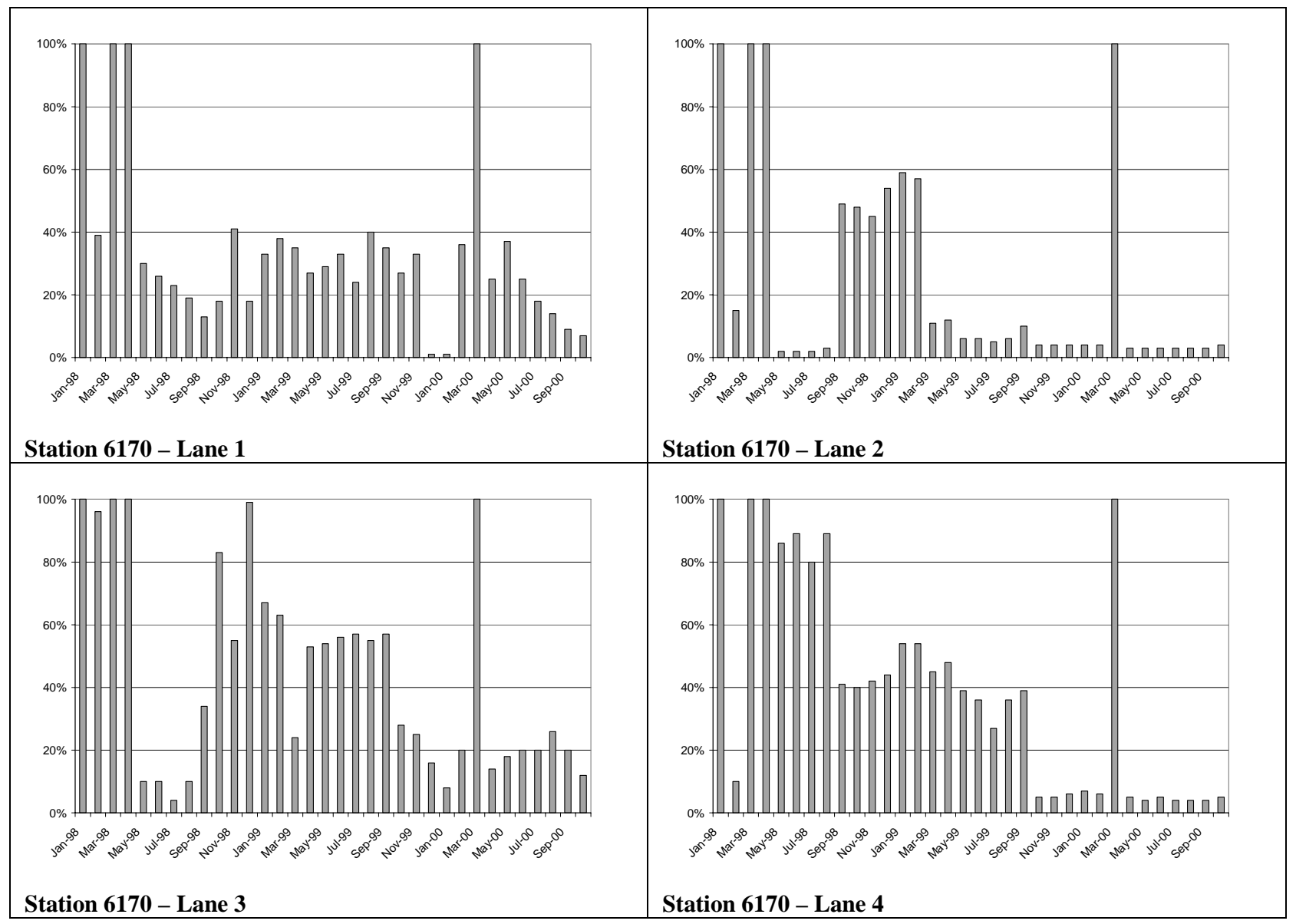

Figure E-66: Error Rate of individual lanes at station 6170 


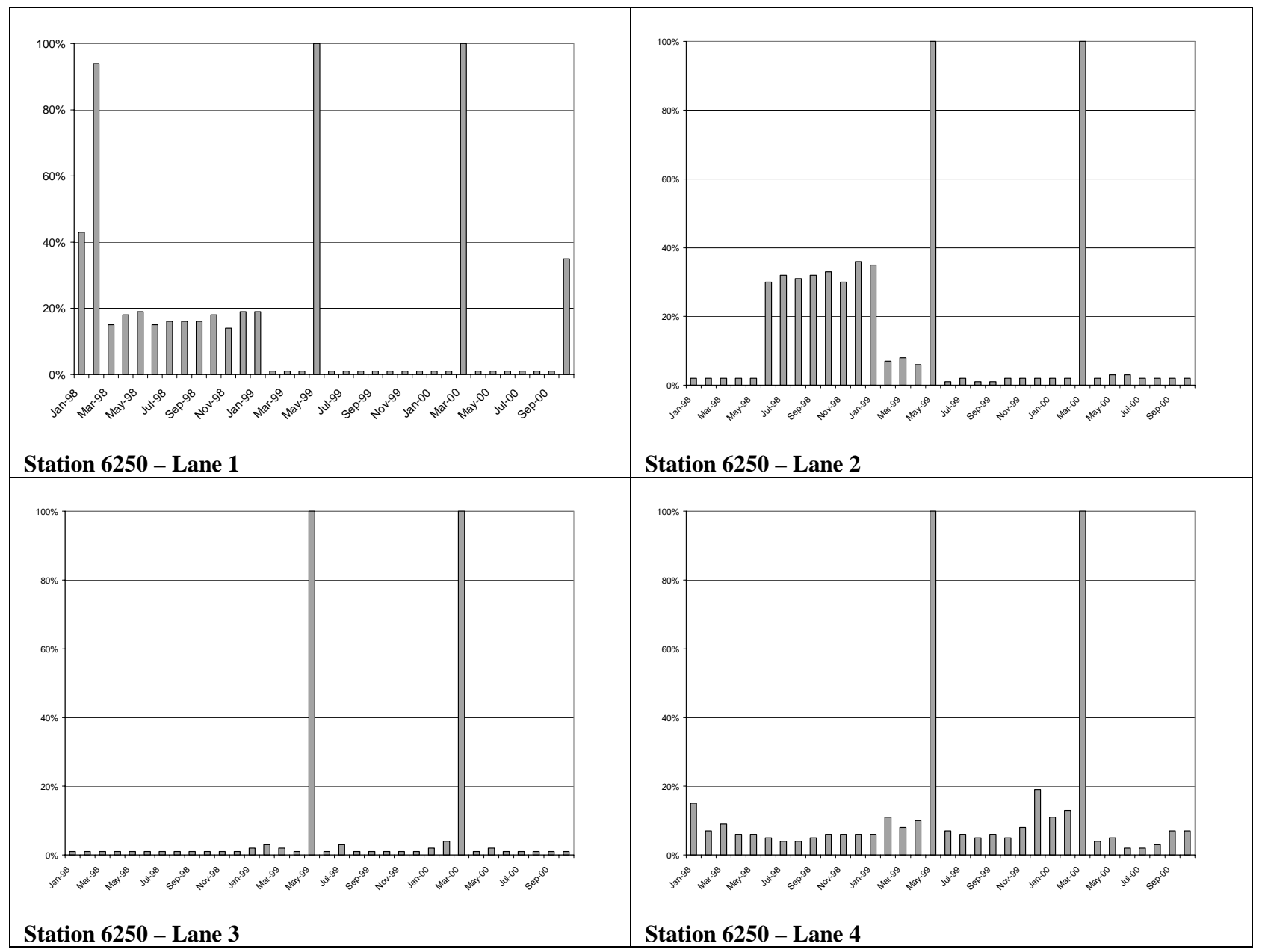

Figure E-67: Error Rate of individual lanes at station 6250 


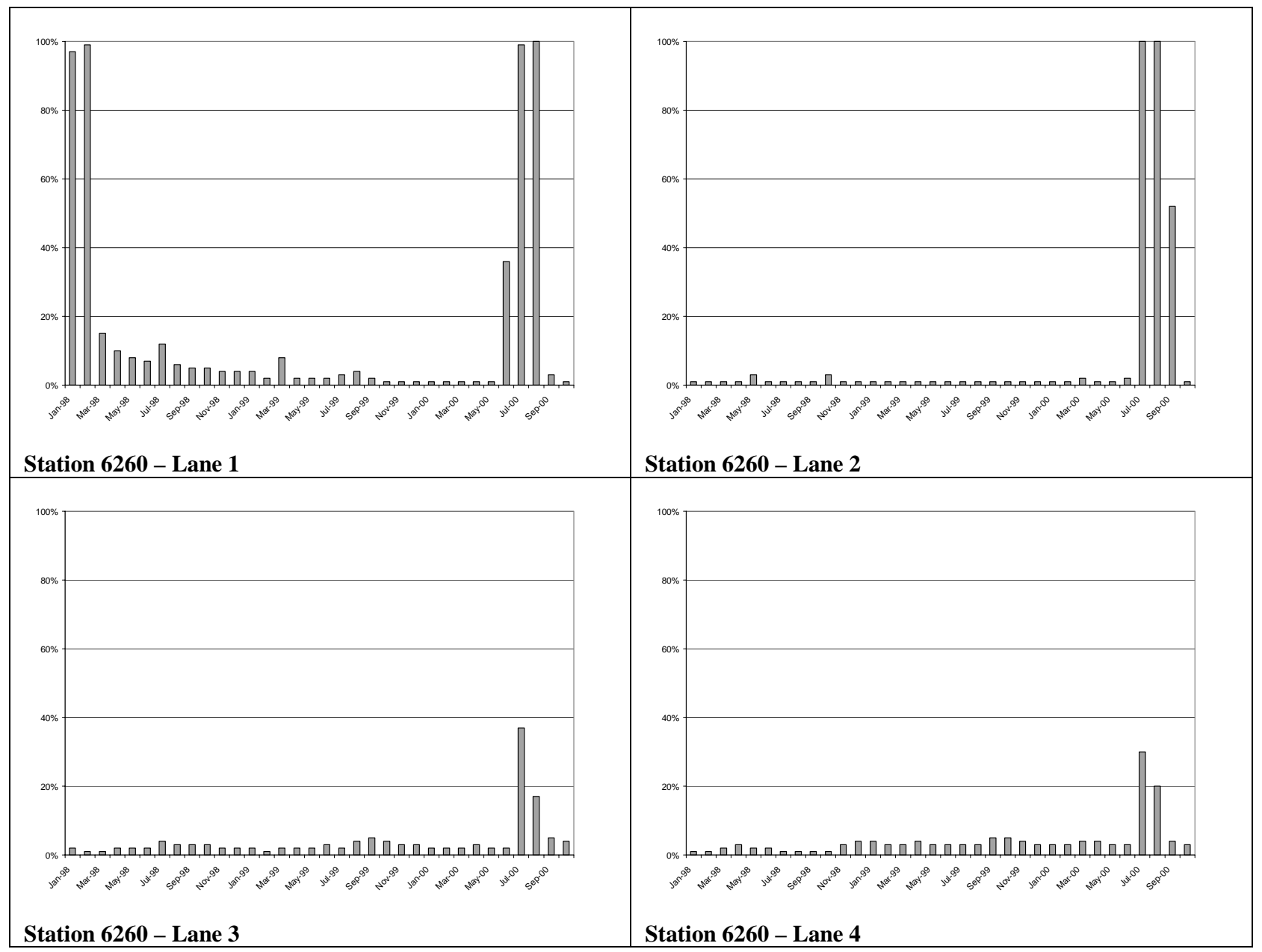

Figure E-68: Error Rate of individual lanes at station 6260 


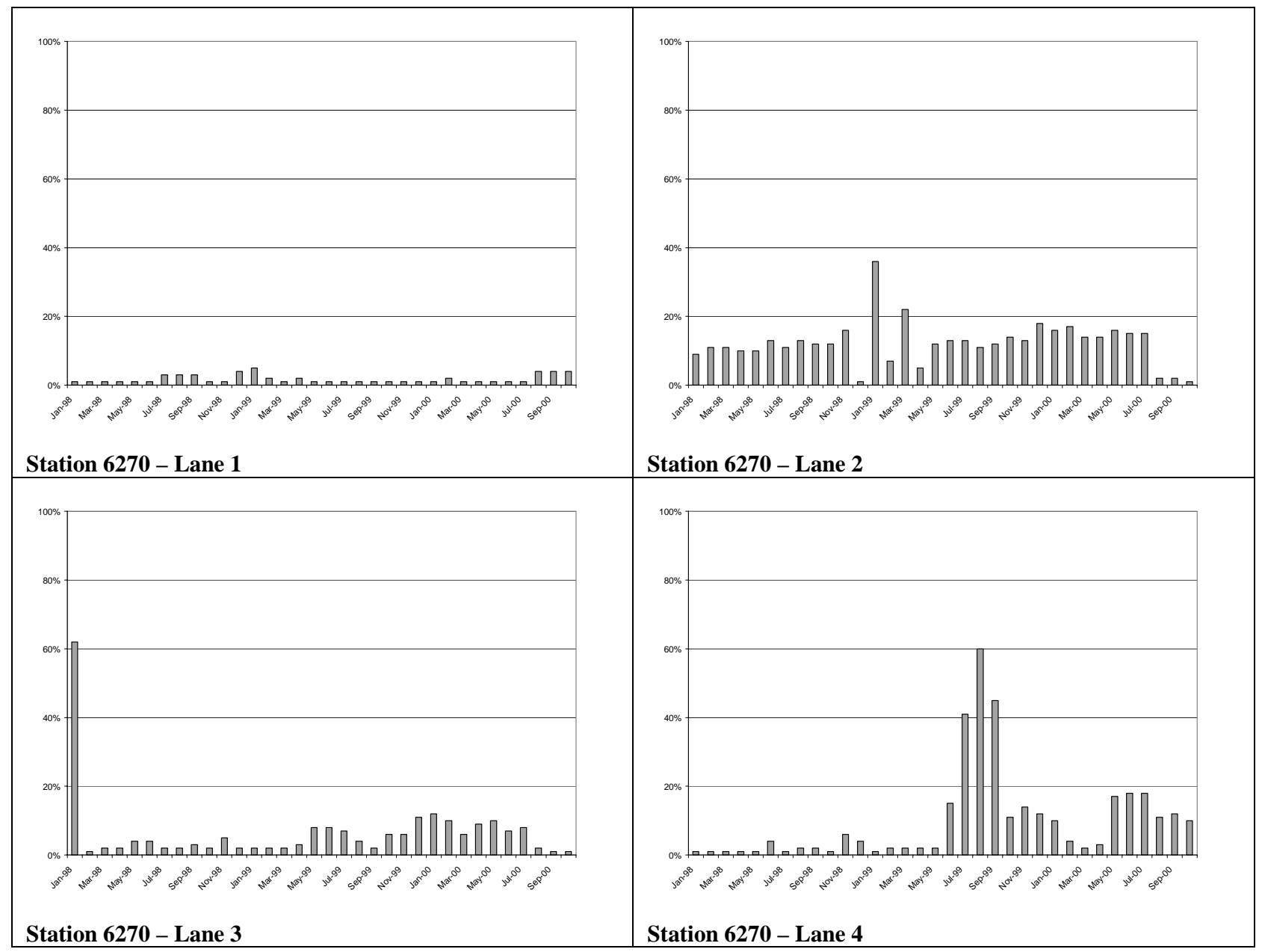

Figure E-69: Error Rate of individual lanes at station 6270 


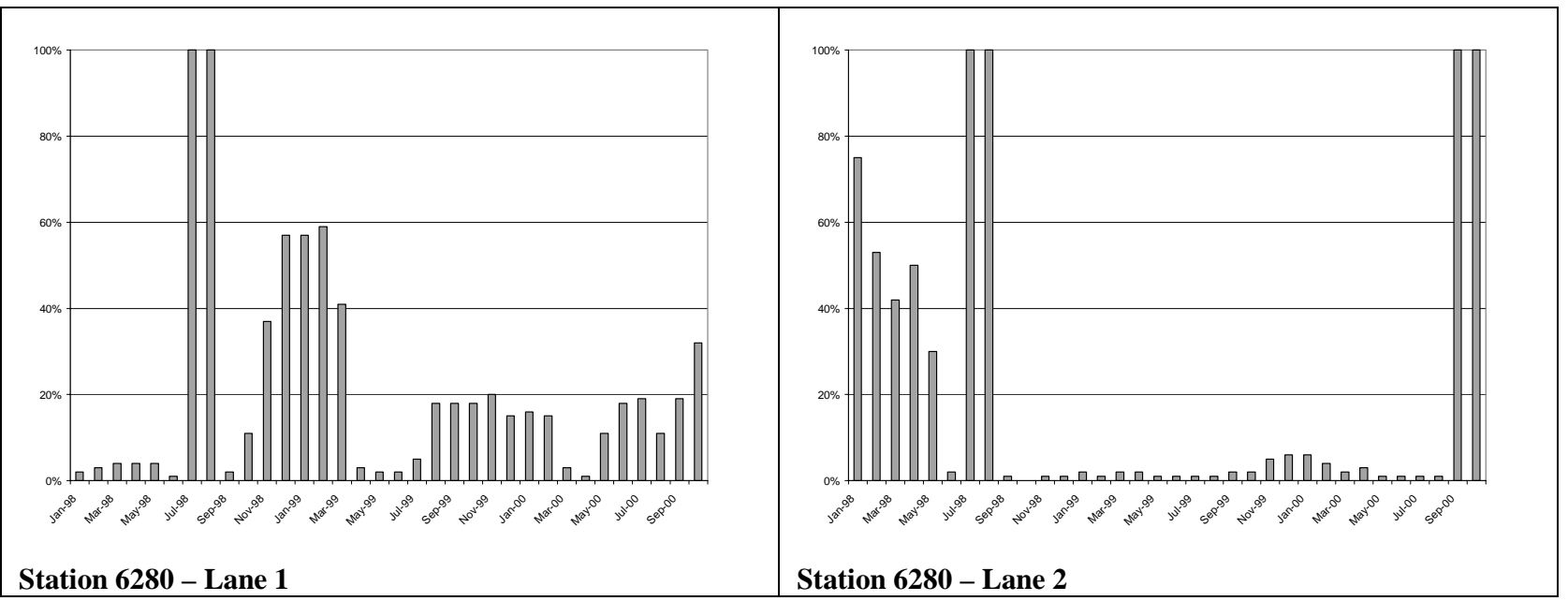

Figure E-70: Error Rate of individual lanes at station 6280 


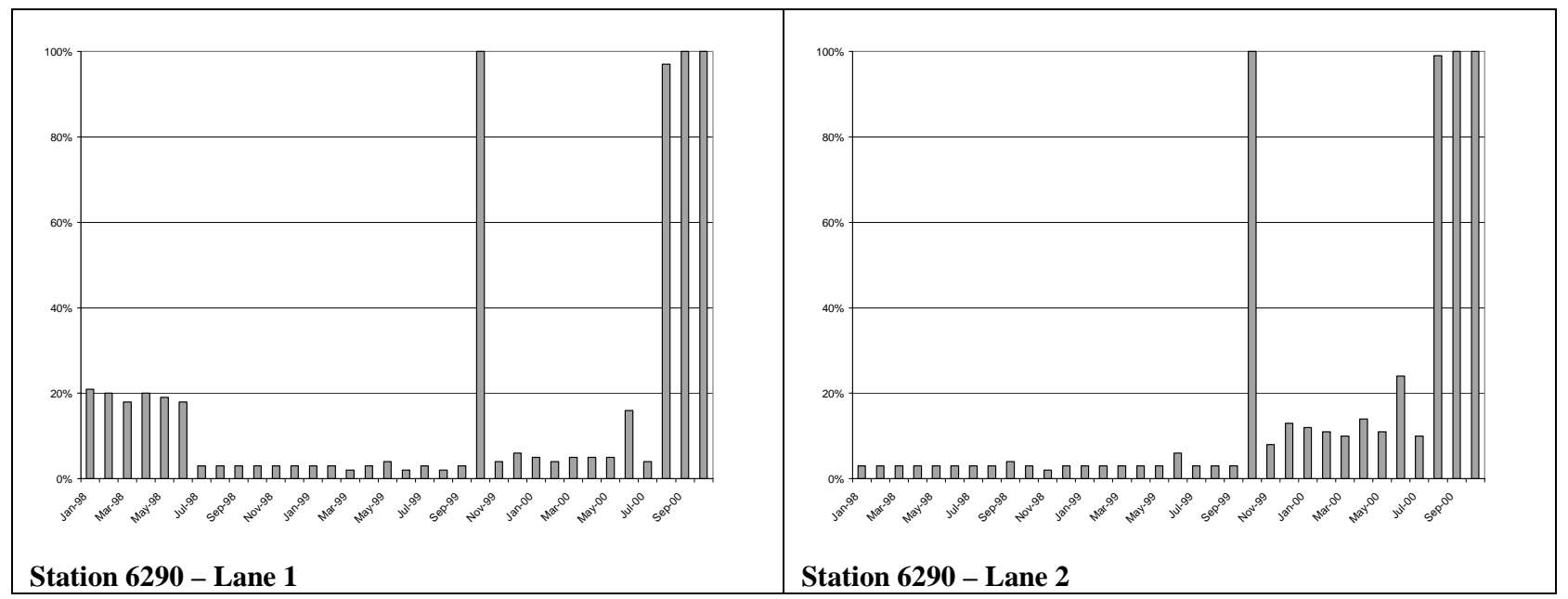

Figure E-71: Error Rate of individual lanes at station 6290 


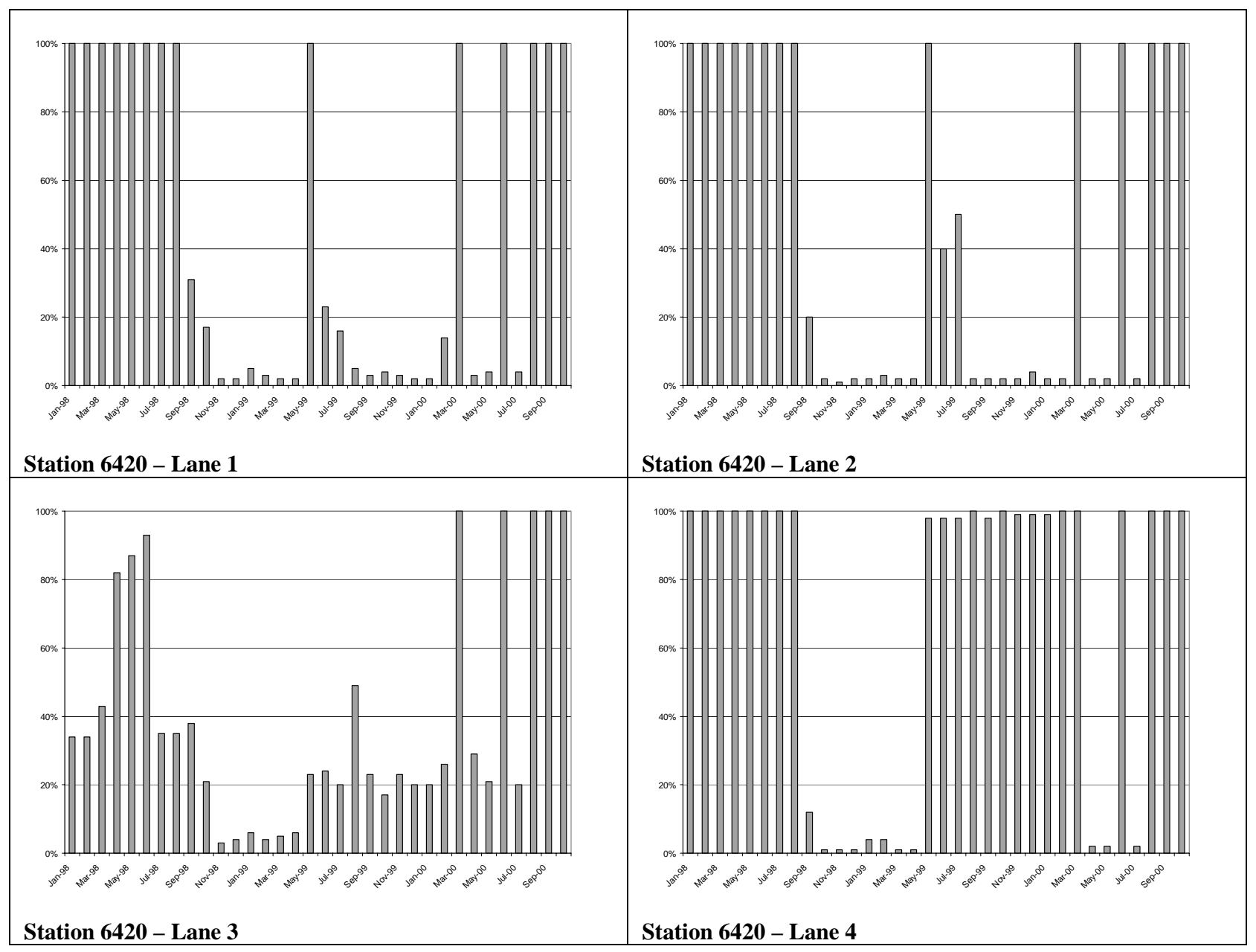

Figure E-72: Error Rate of individual lanes at station 6420 
Appendix F WIM Calibration-July 2000 


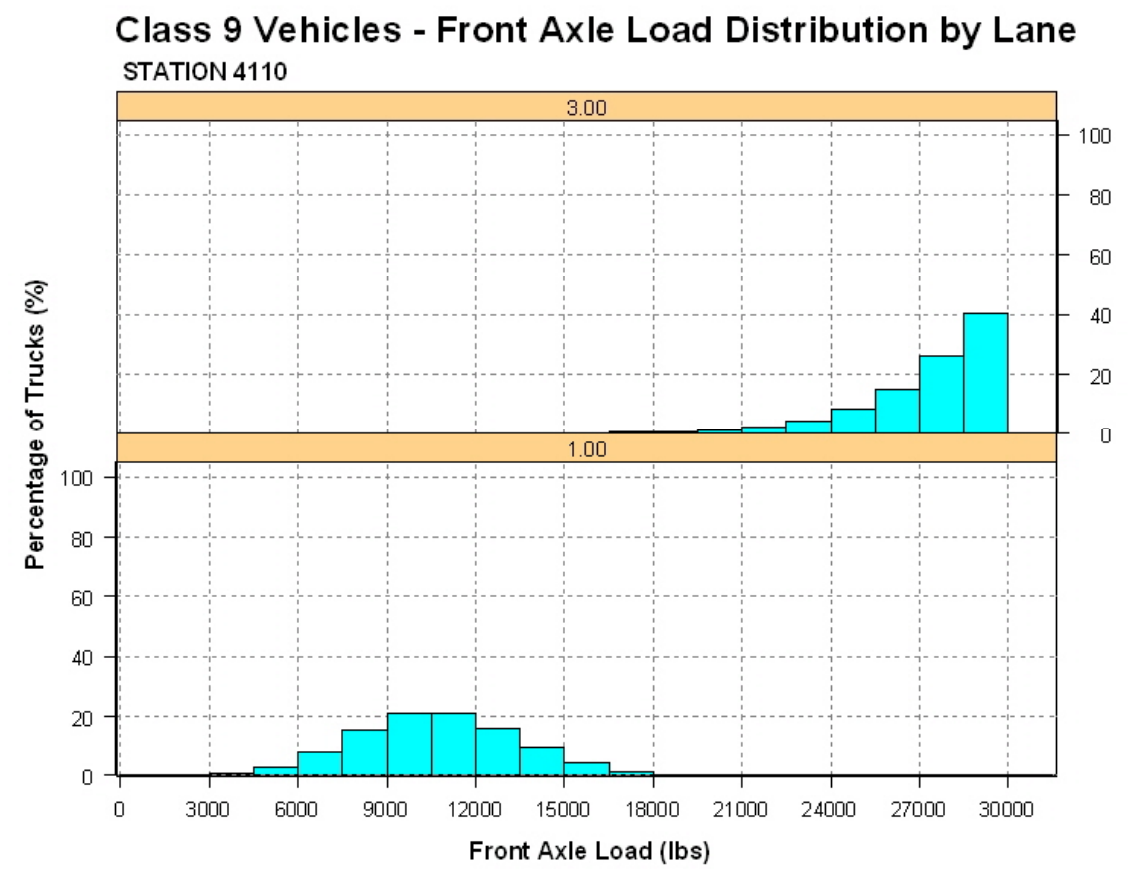

Figure F-1: Station 4110, Class 9 Vehicles - Front Axle Load Distribution

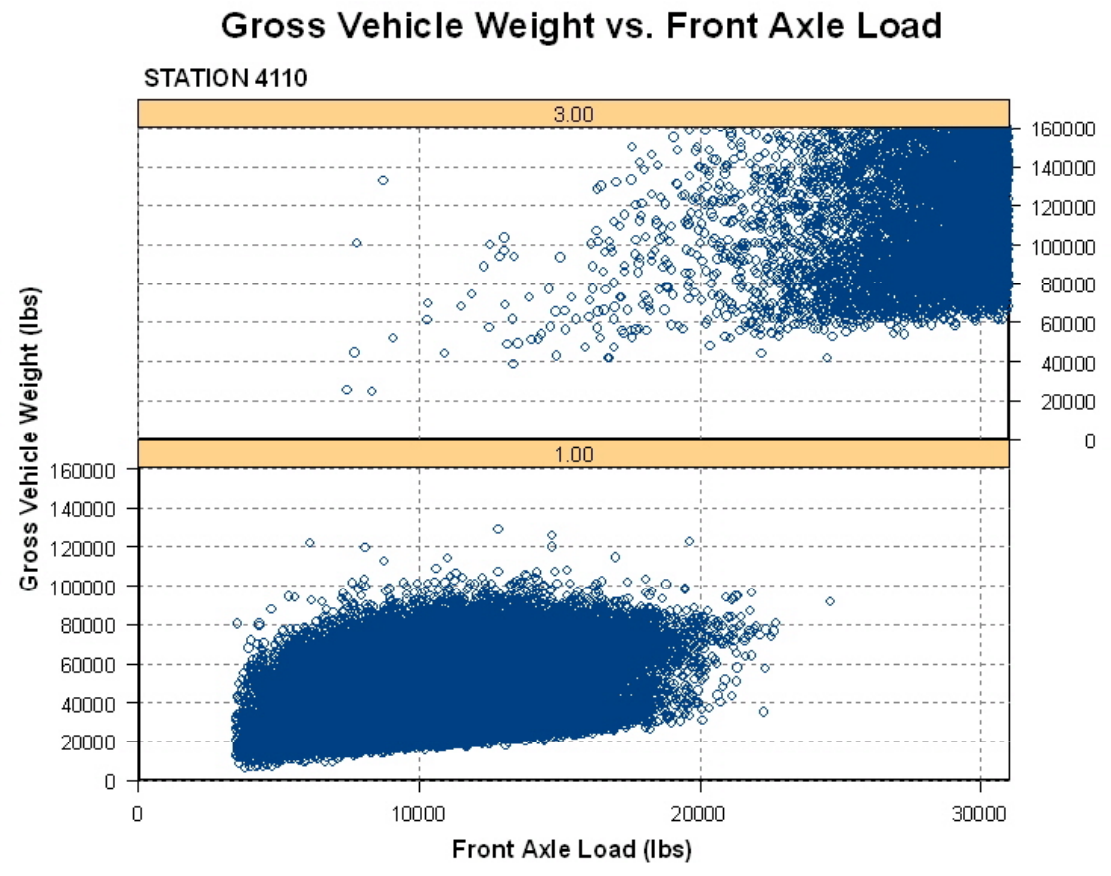

Figure F-2: Station 4110, Class 9 Vehicles - Gross Vehicle Weight vs. Front Axle 


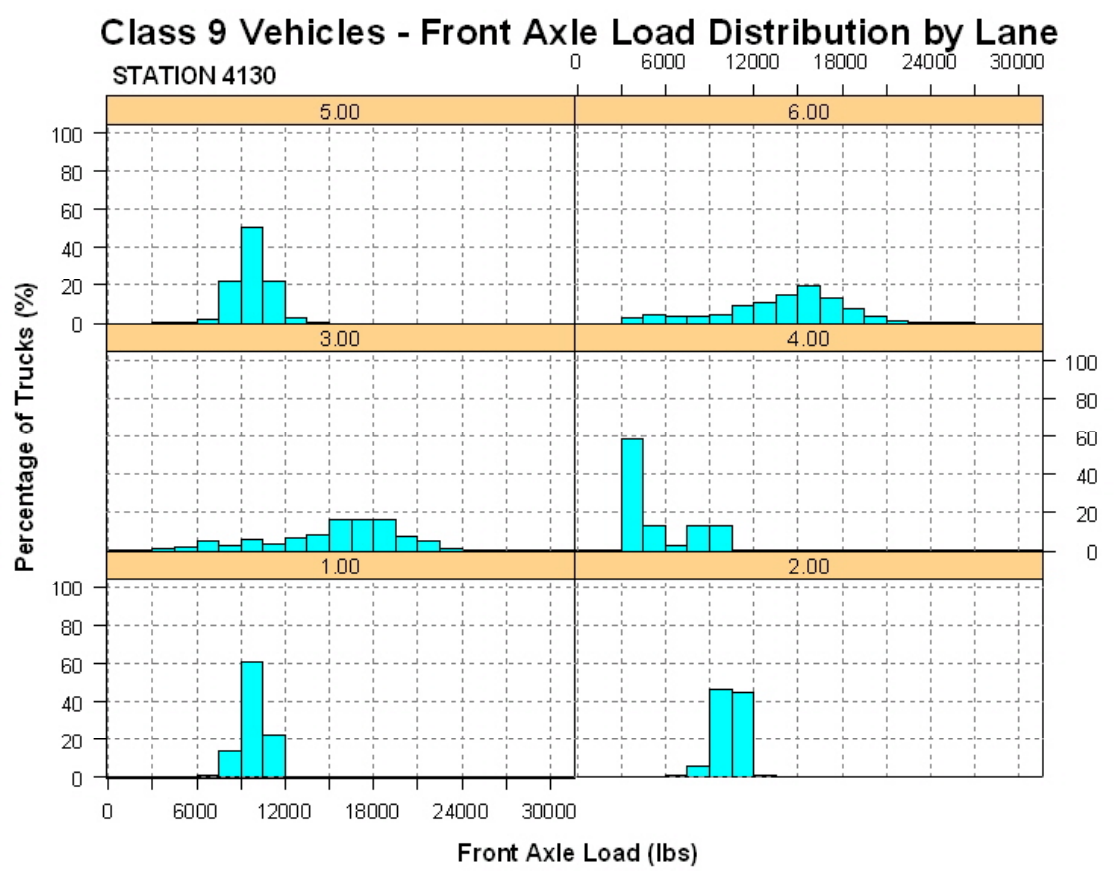

Figure F-3: Station 4130, Class 9 Vehicles - Front Axle Load Distribution

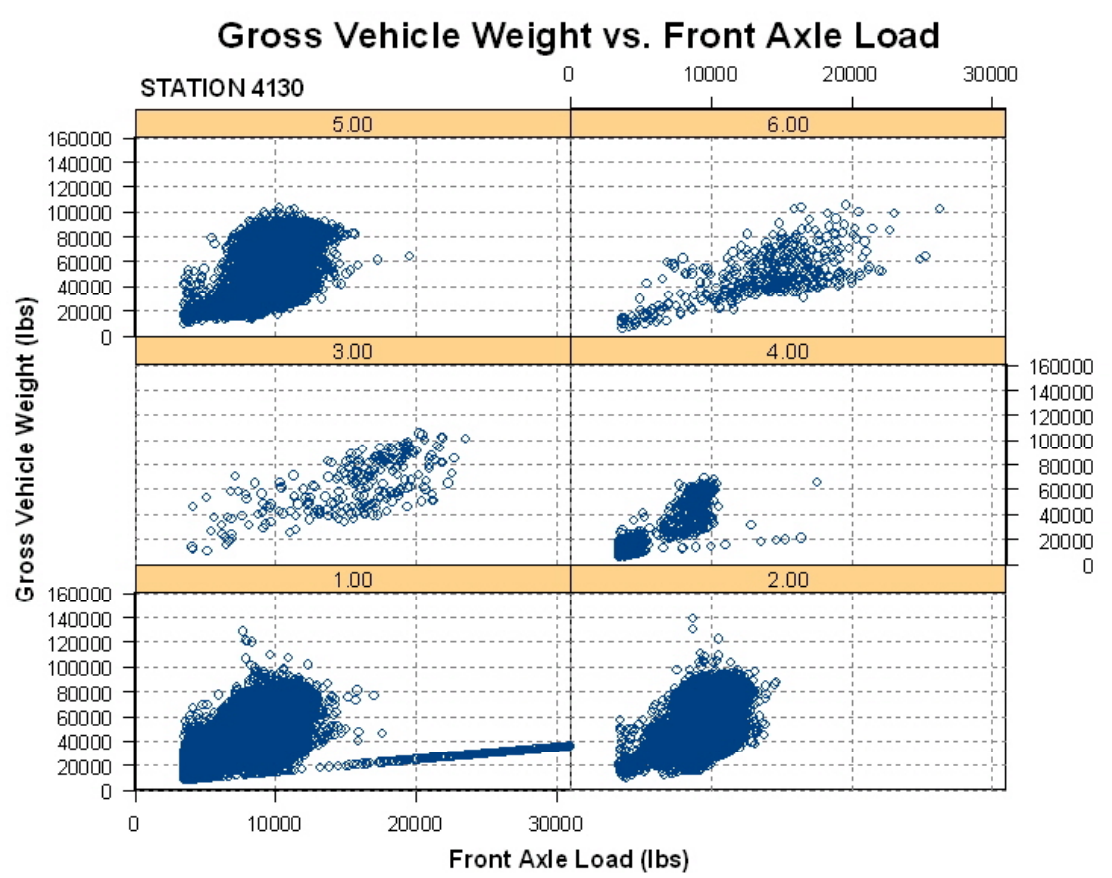

Figure F-4: Station 4130, Class 9 Vehicles - Gross Vehicle Weight vs. Front Axle 


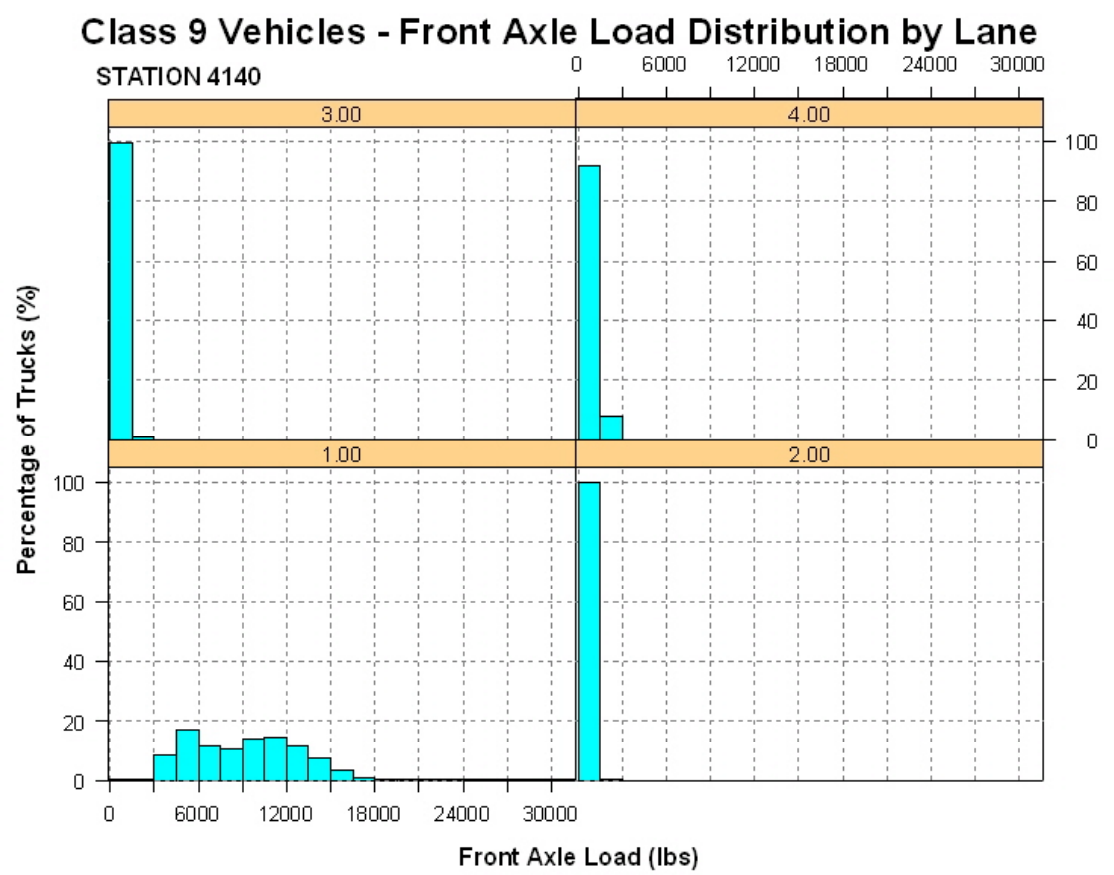

Figure F-5: Station 4140, Class 9 Vehicles - Front Axle Load Distribution

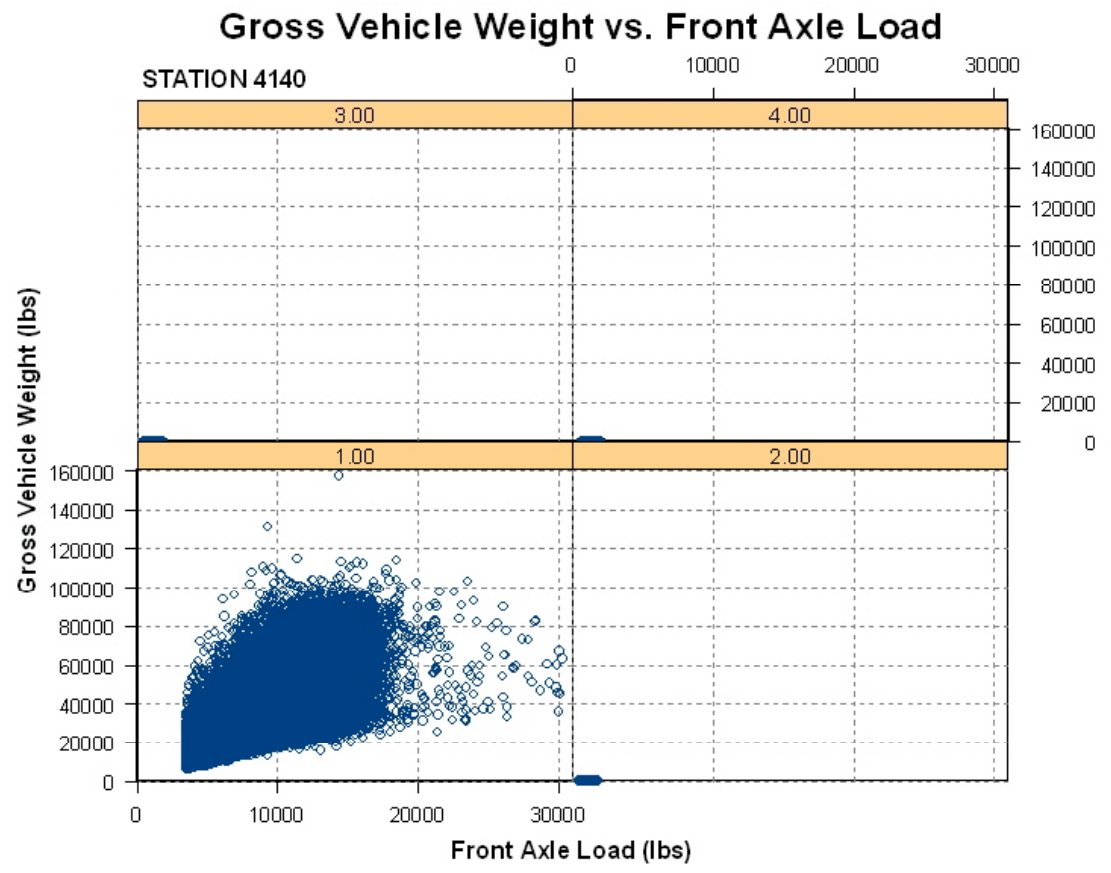

Figure F-6: Station 4140, Class 9 Vehicles - Gross Vehicle Weight vs. Front Axle 


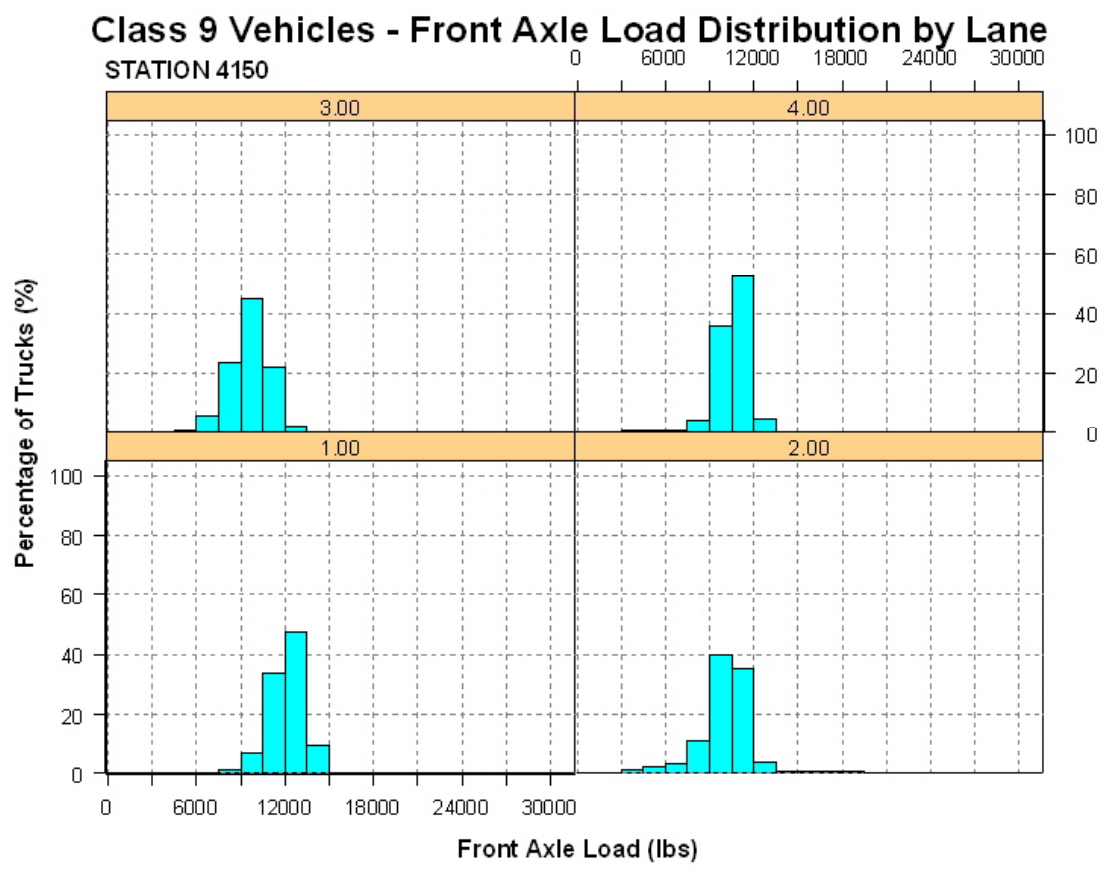

Figure F-7: Station 4160, Class 9 Vehicles - Front Axle Load Distribution

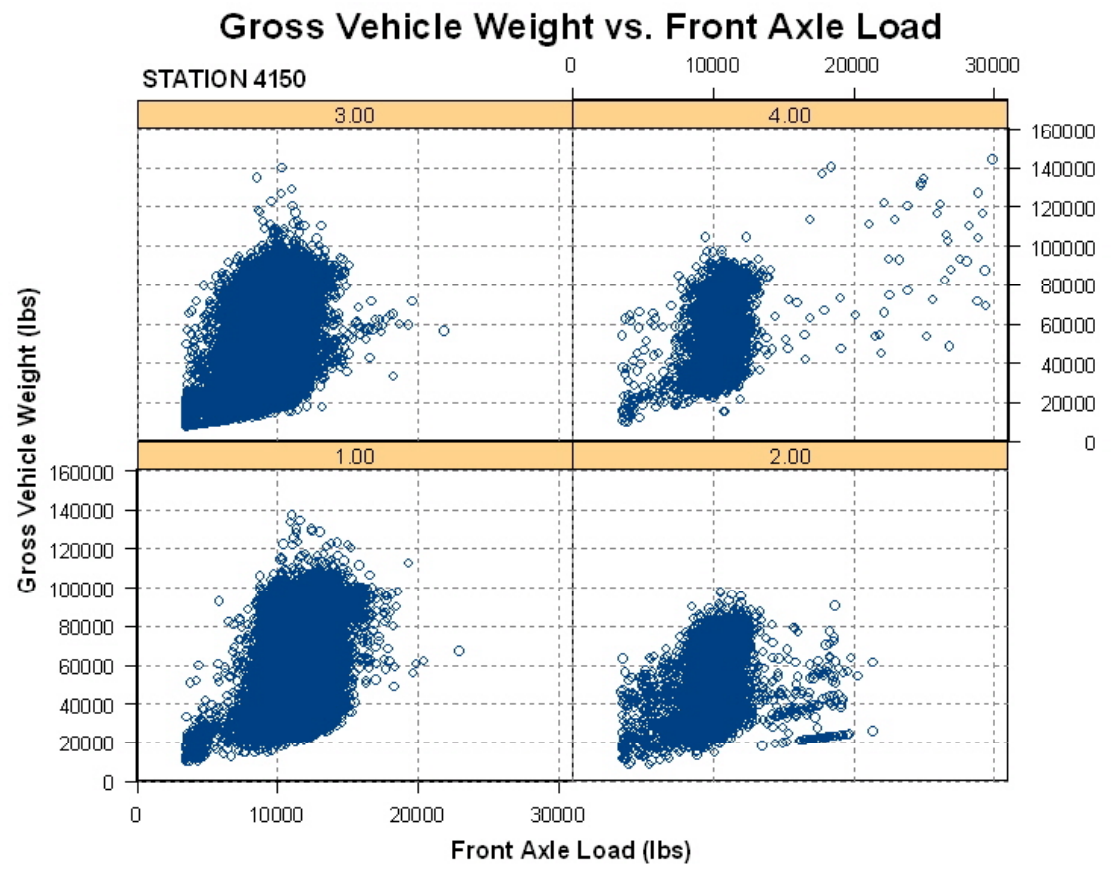

Figure F-8: Station 4160, Class 9 Vehicles - Gross Vehicle Weight vs. Front Axle 


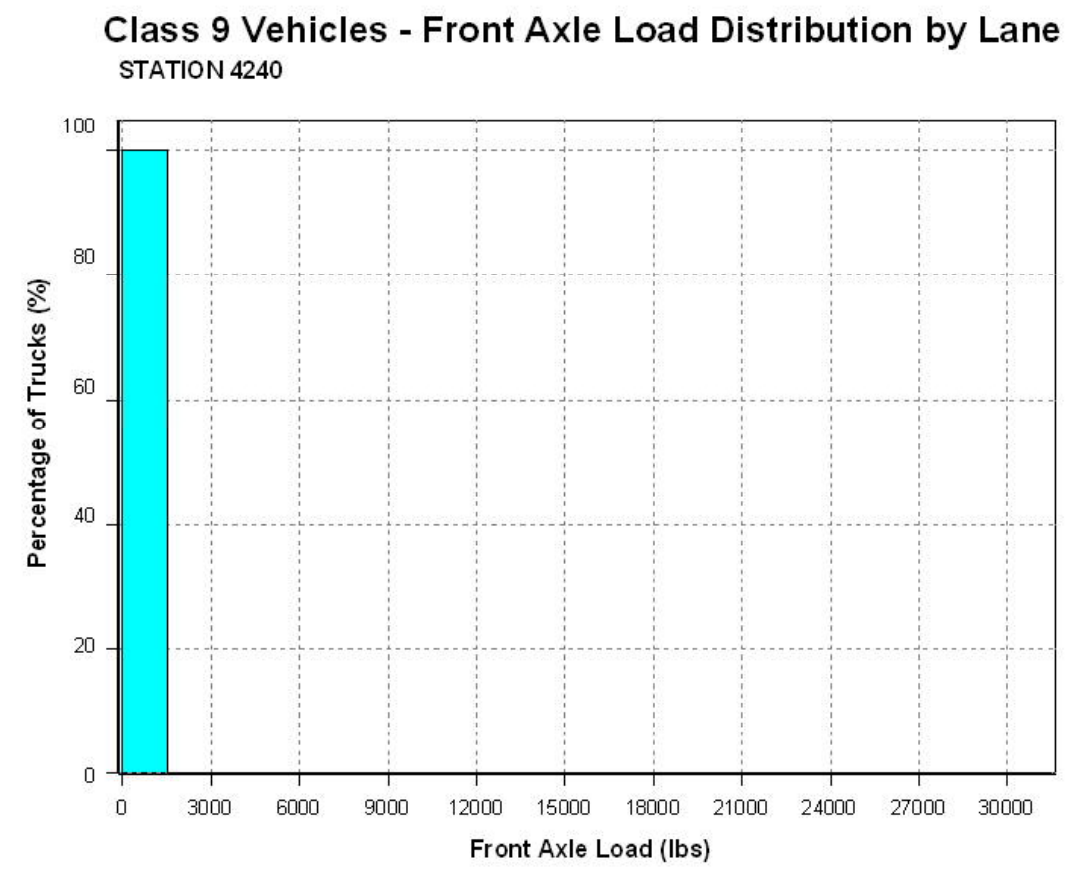

Figure F-9: Station 4240, Class 9 Vehicles - Front Axle Load Distribution

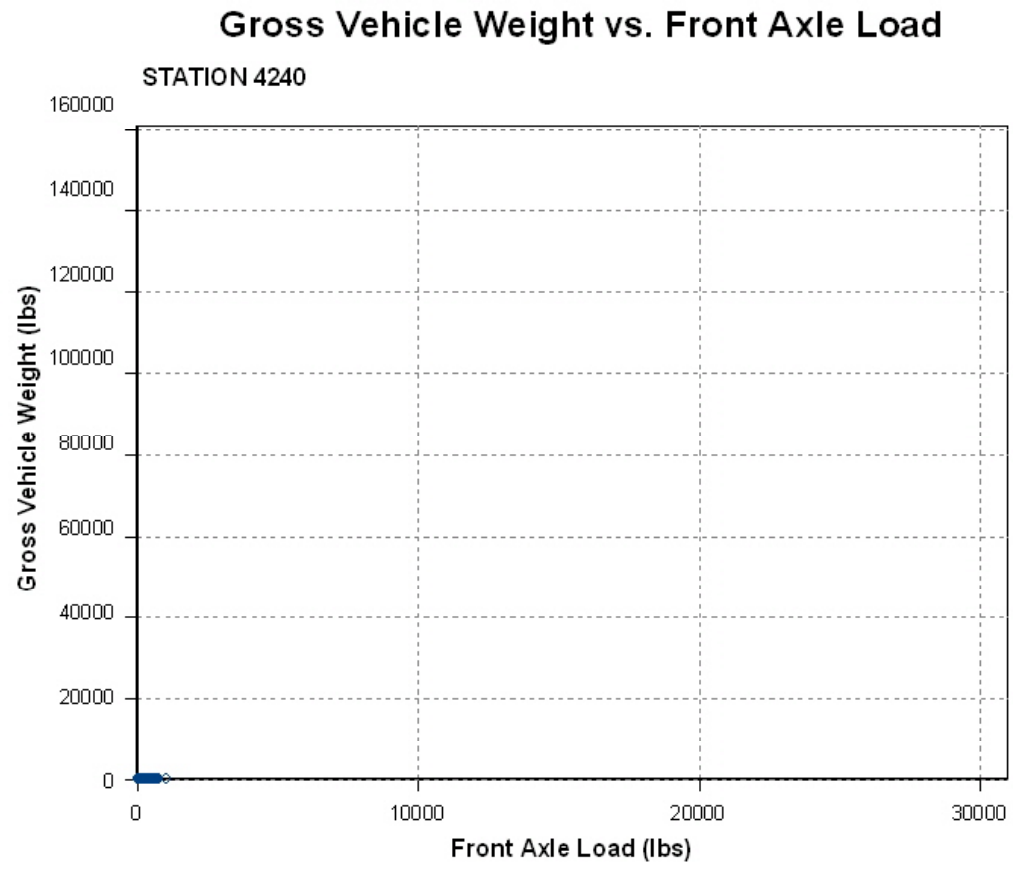

Figure F-10: Station 4240, Class 9 Vehicles - Gross Vehicle Weight vs. Front Axle 


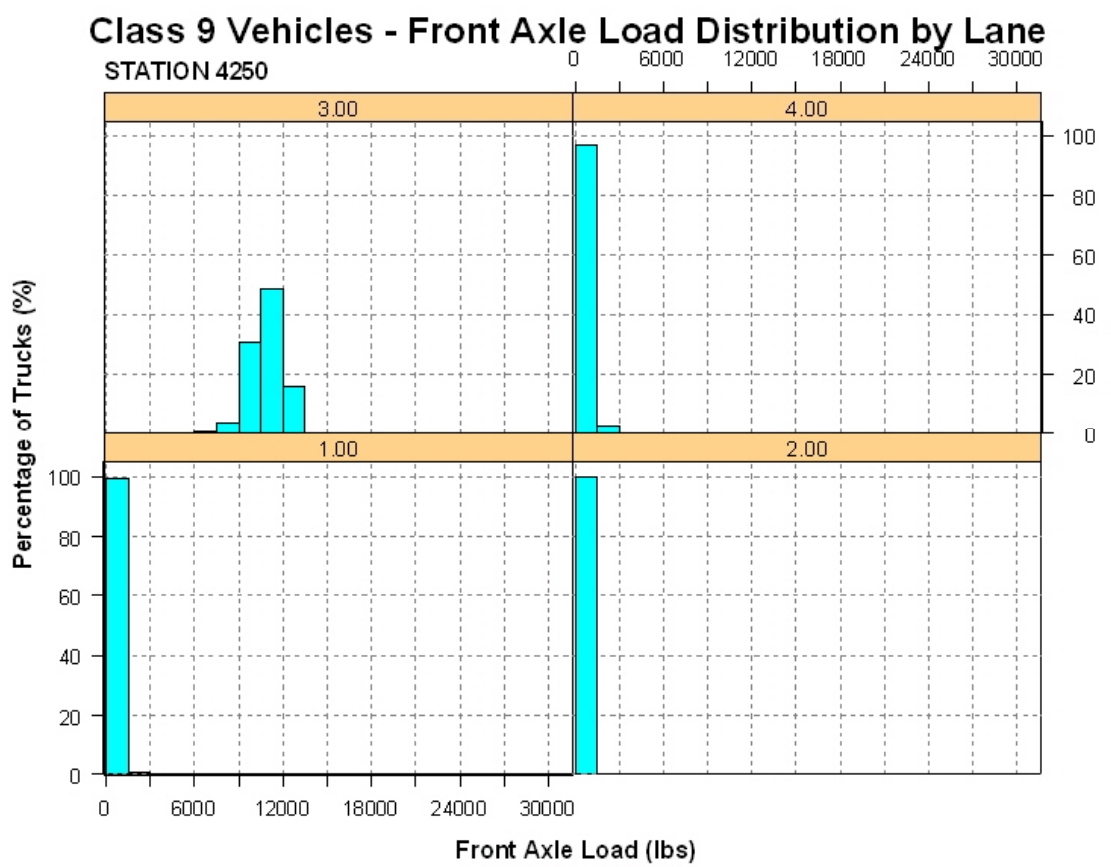

Figure F-11: Station 4250, Class 9 Vehicles - Front Axle Load Distribution

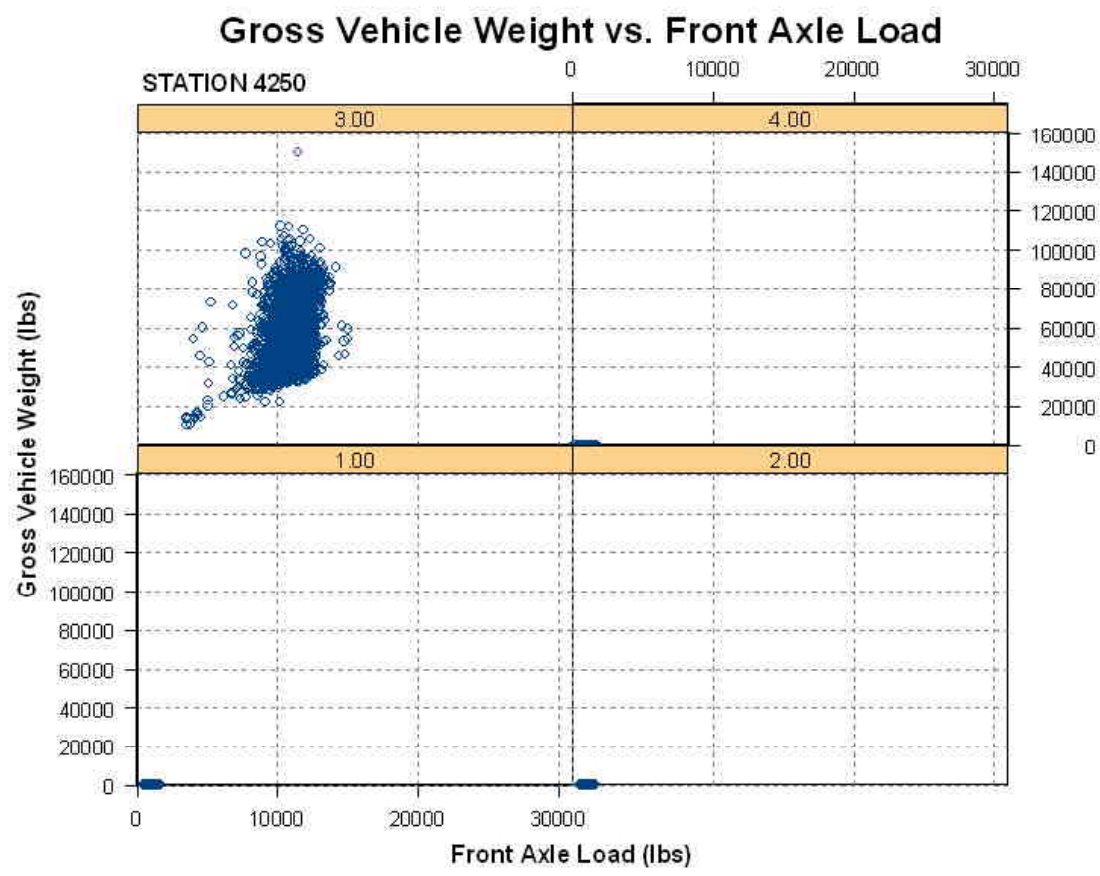

Figure F-12: Station 4250, Class 9 Vehicles - Gross Vehicle Weight vs. Front Axle 


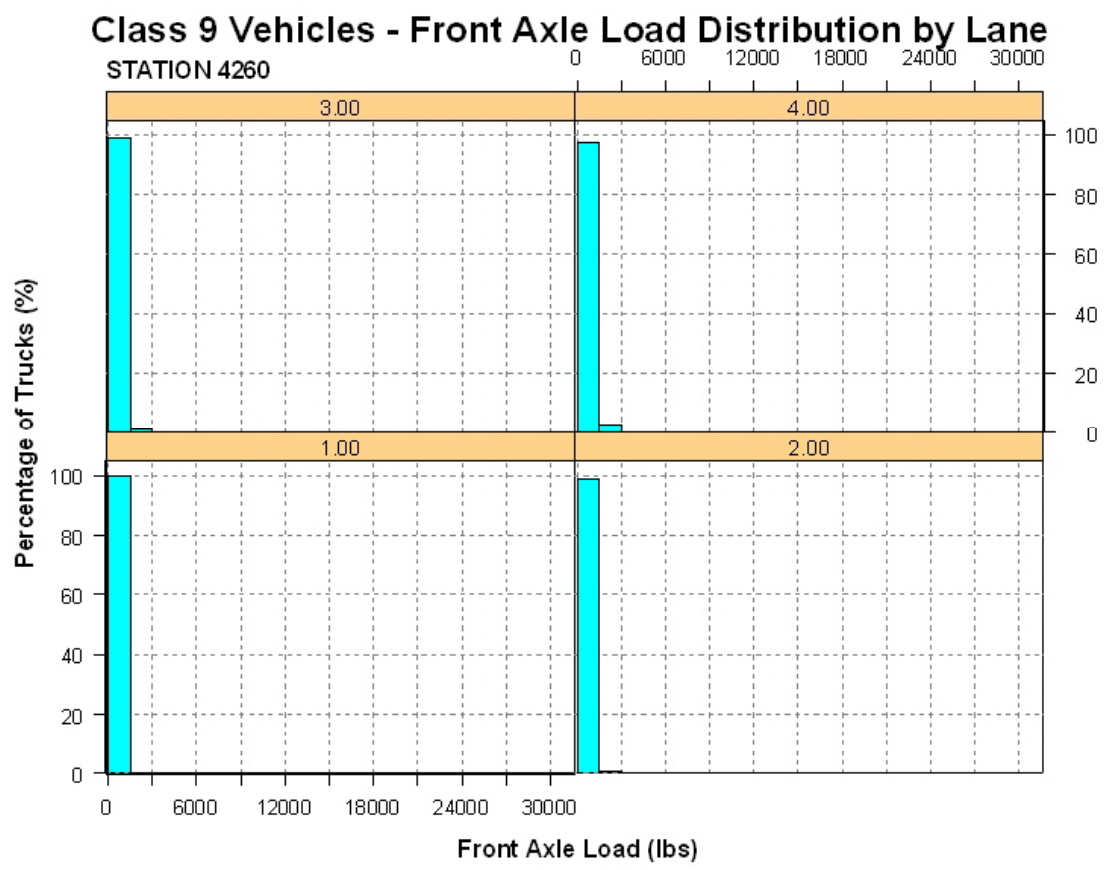

Figure F-13: Station 4260, Class 9 Vehicles - Front Axle Load Distribution

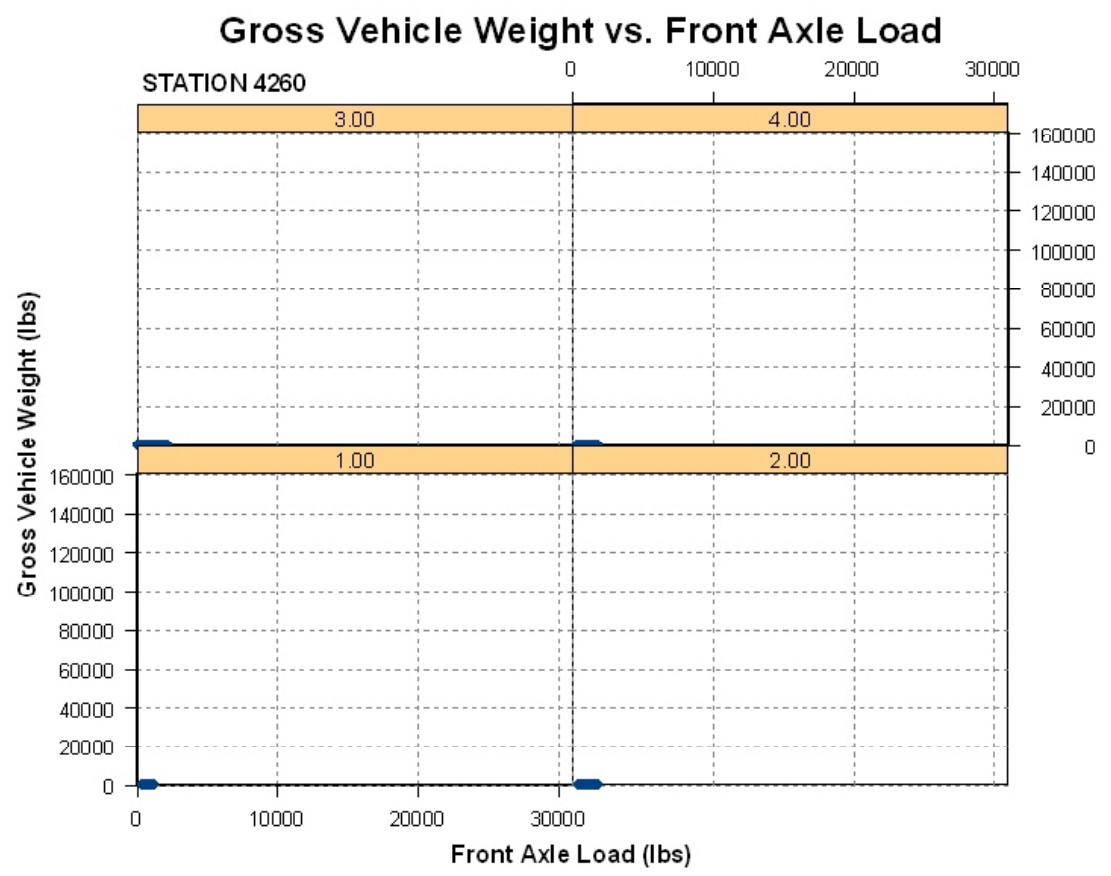

Figure F-14: Station 4260, Class 9 Vehicles - Gross Vehicle Weight vs. Front Axle 


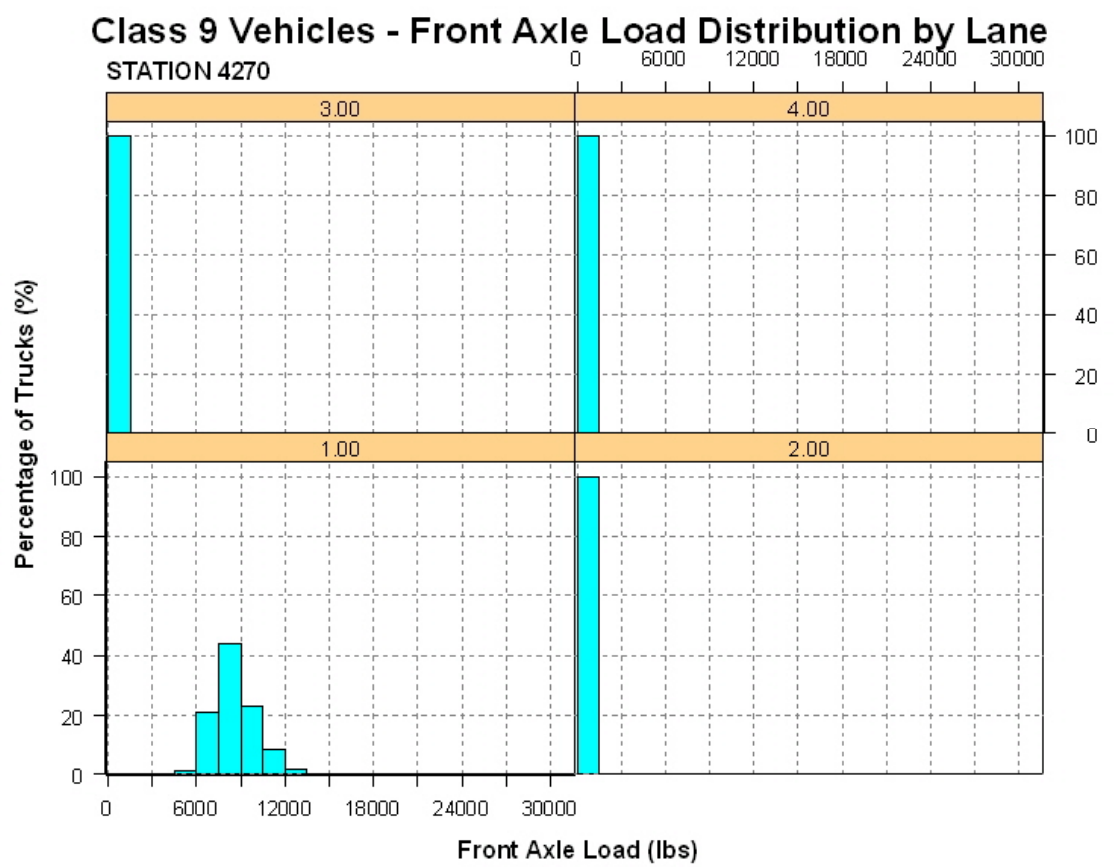

Figure F-15: Station 4270, Class 9 Vehicles - Front Axle Load Distribution

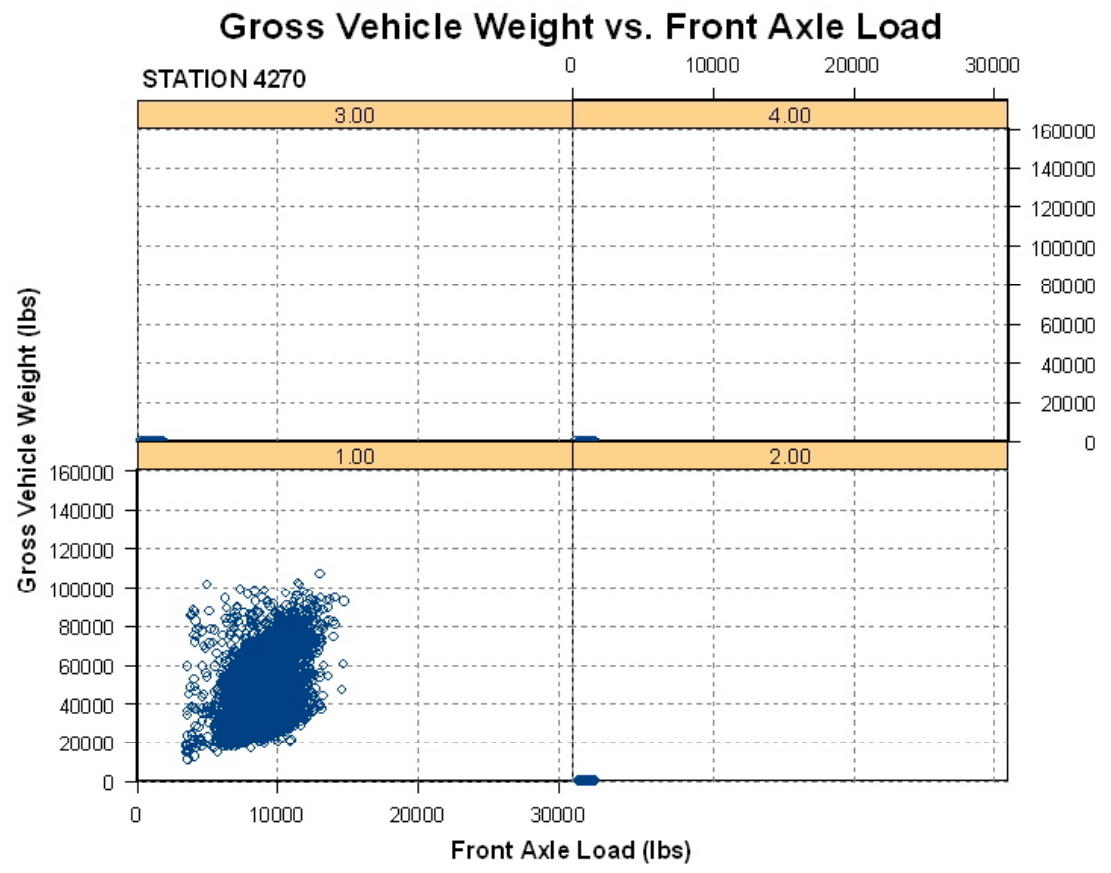

Figure F-16: Station 4270, Class 9 Vehicles - Gross Vehicle Weight vs. Front Axle 


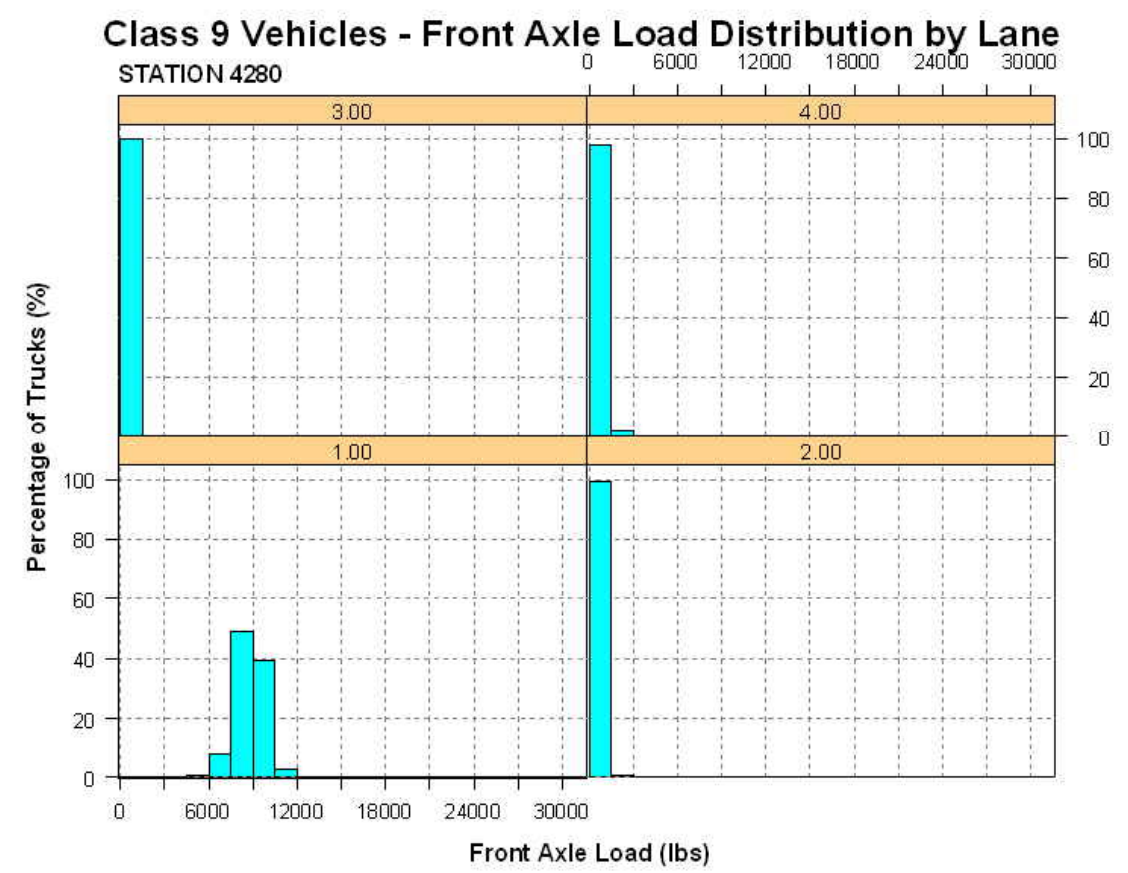

Figure F-17: Station 4280, Class 9 Vehicles - Front Axle Load Distribution

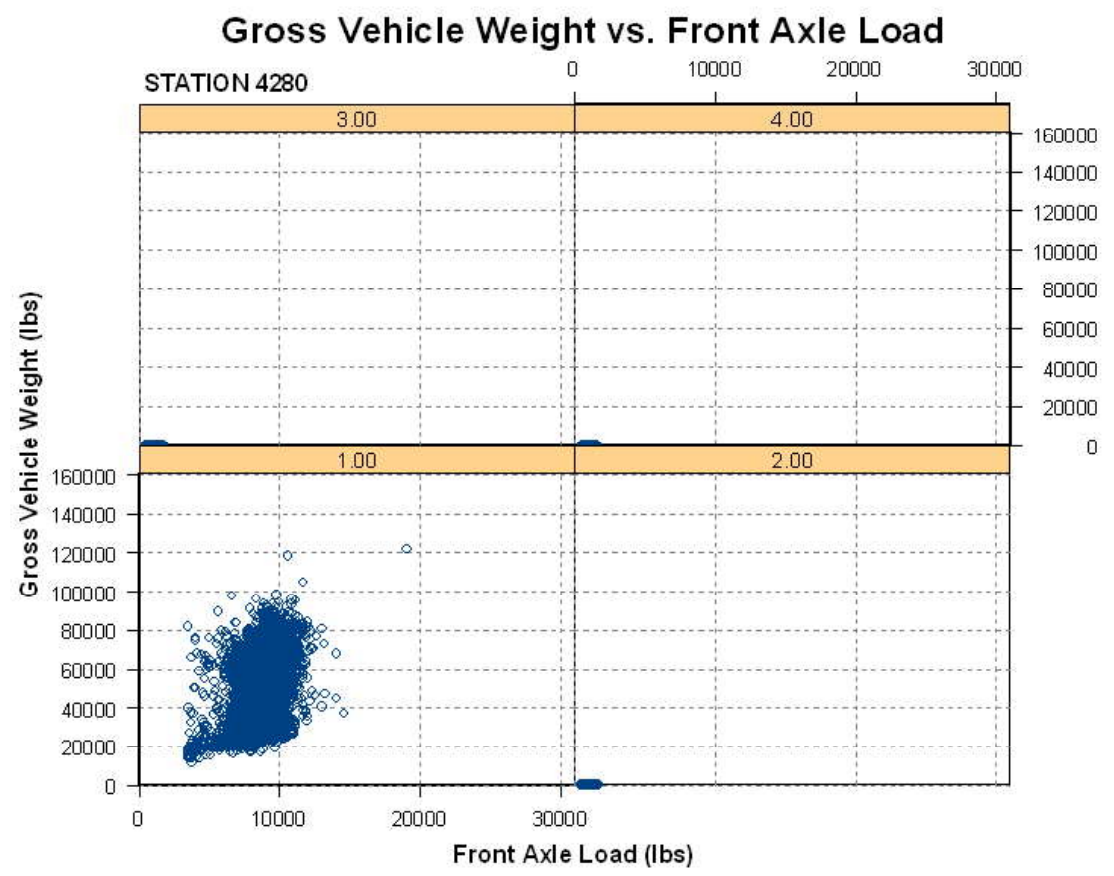

Figure F-18: Station 4280, Class 9 Vehicles - Gross Vehicle Weight vs. Front Axle 


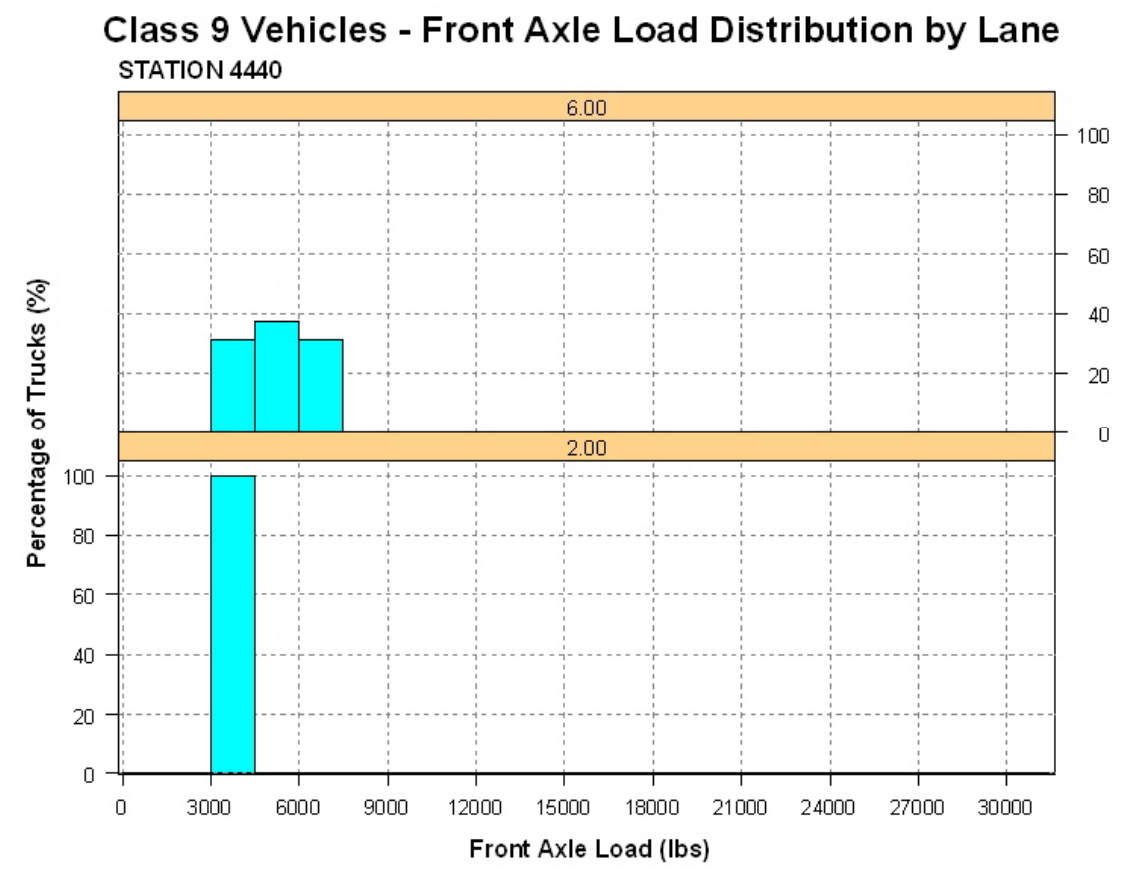

Figure F-19: Station 4440, Class 9 Vehicles - Front Axle Load Distribution

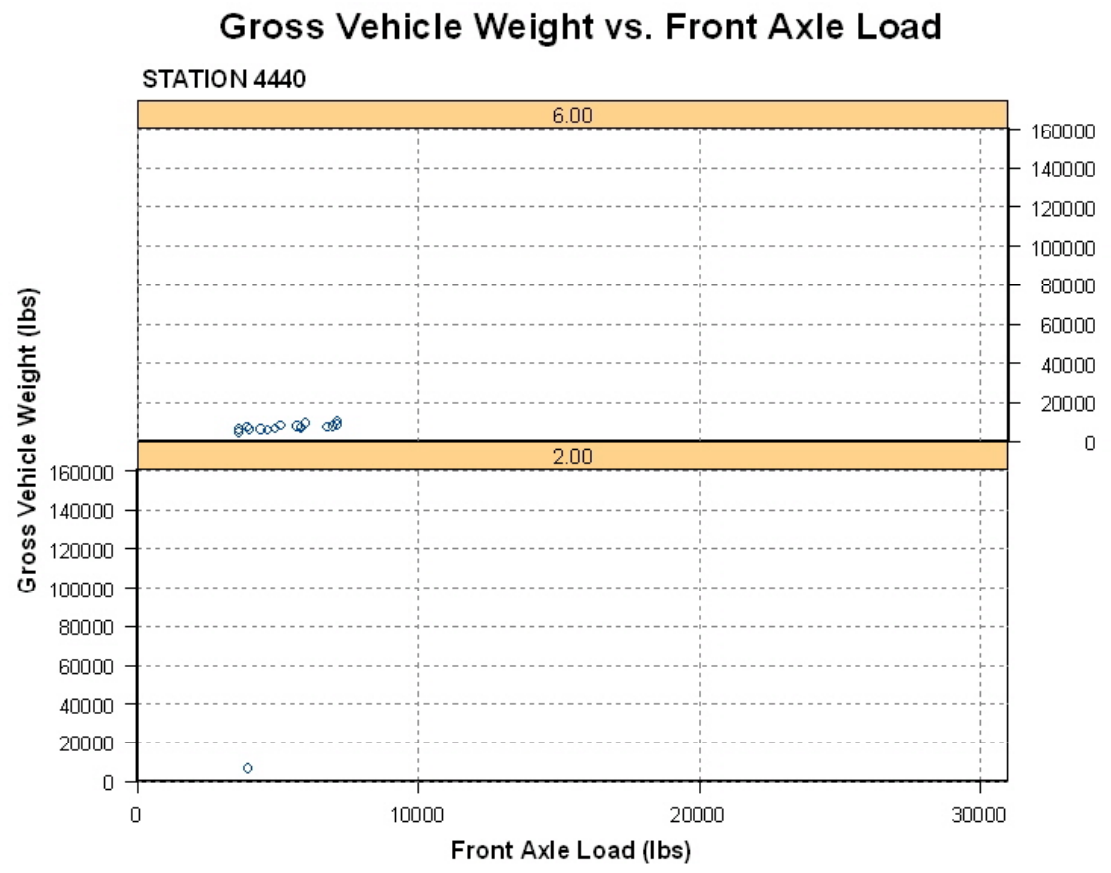

Figure F-20: Station 4440, Class 9 Vehicles - Gross Vehicle Weight vs. Front Axle 


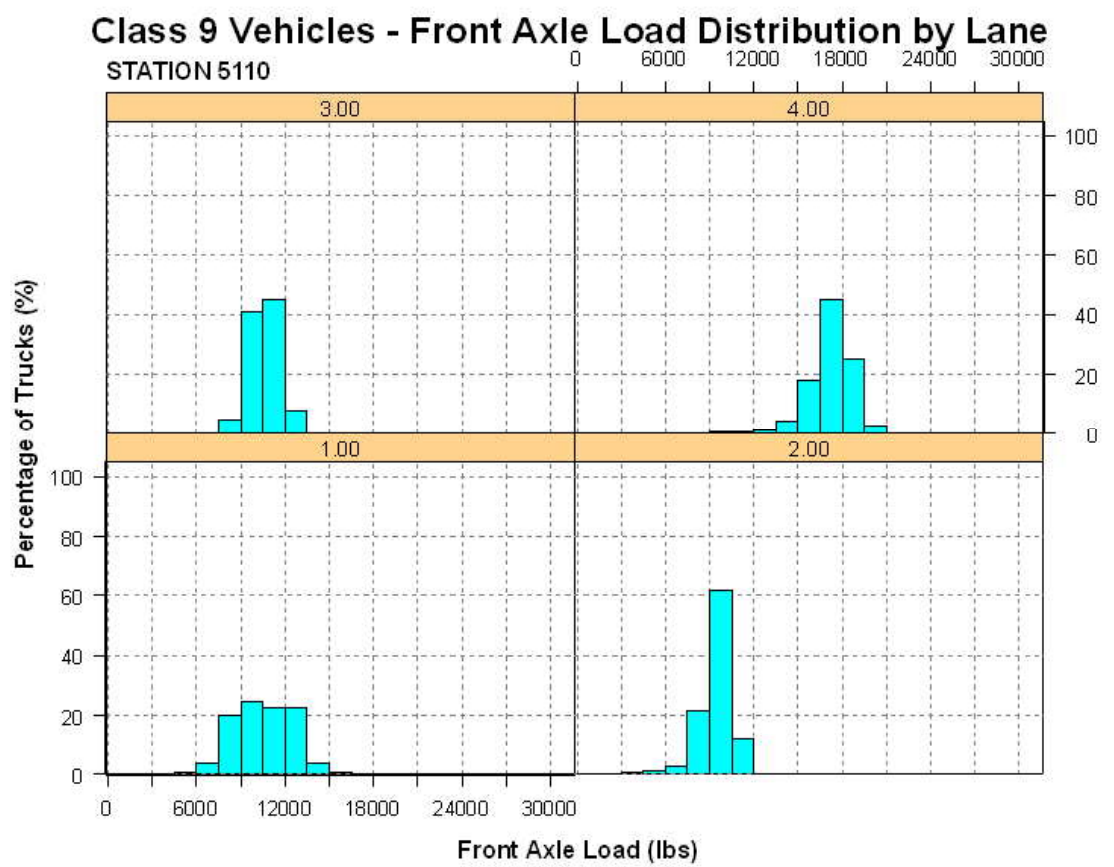

Figure F-21: Station 5110, Class 9 Vehicles - Front Axle Load Distribution

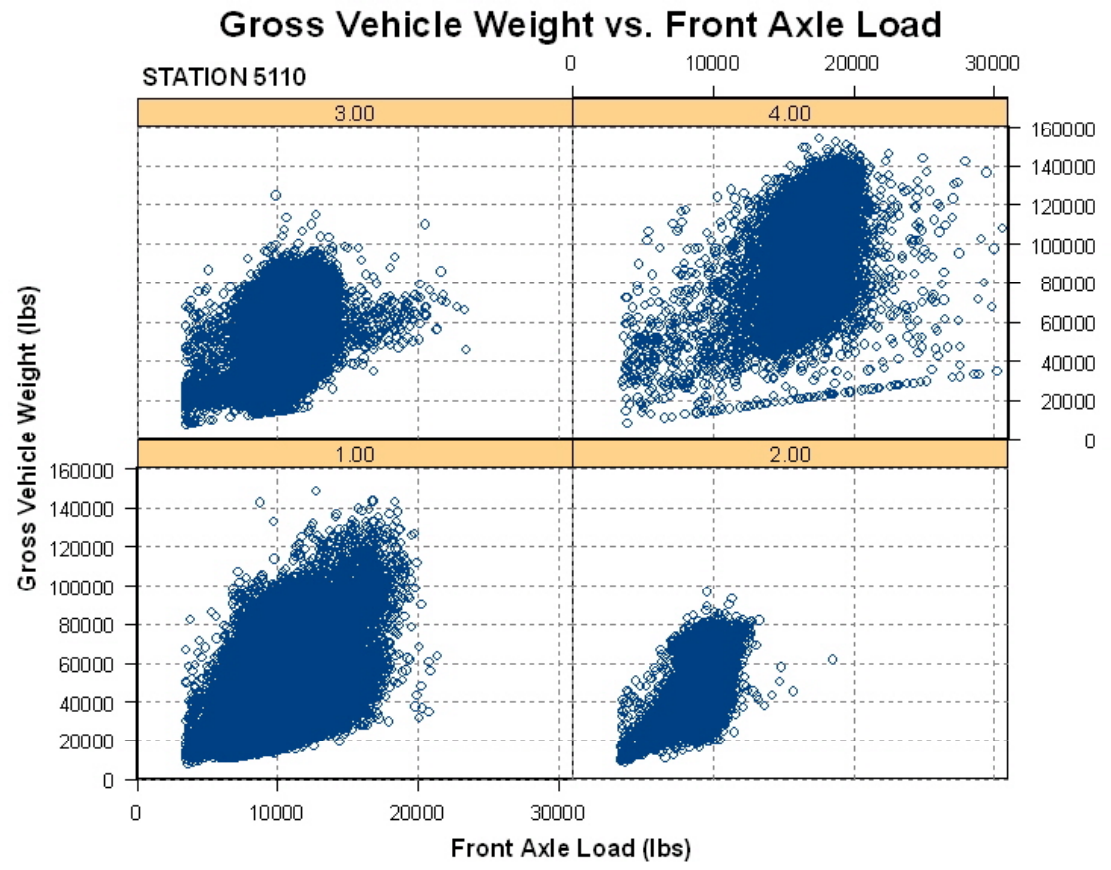

Figure F-22: Station 5110, Class 9 Vehicles - Gross Vehicle Weight vs. Front Axle 


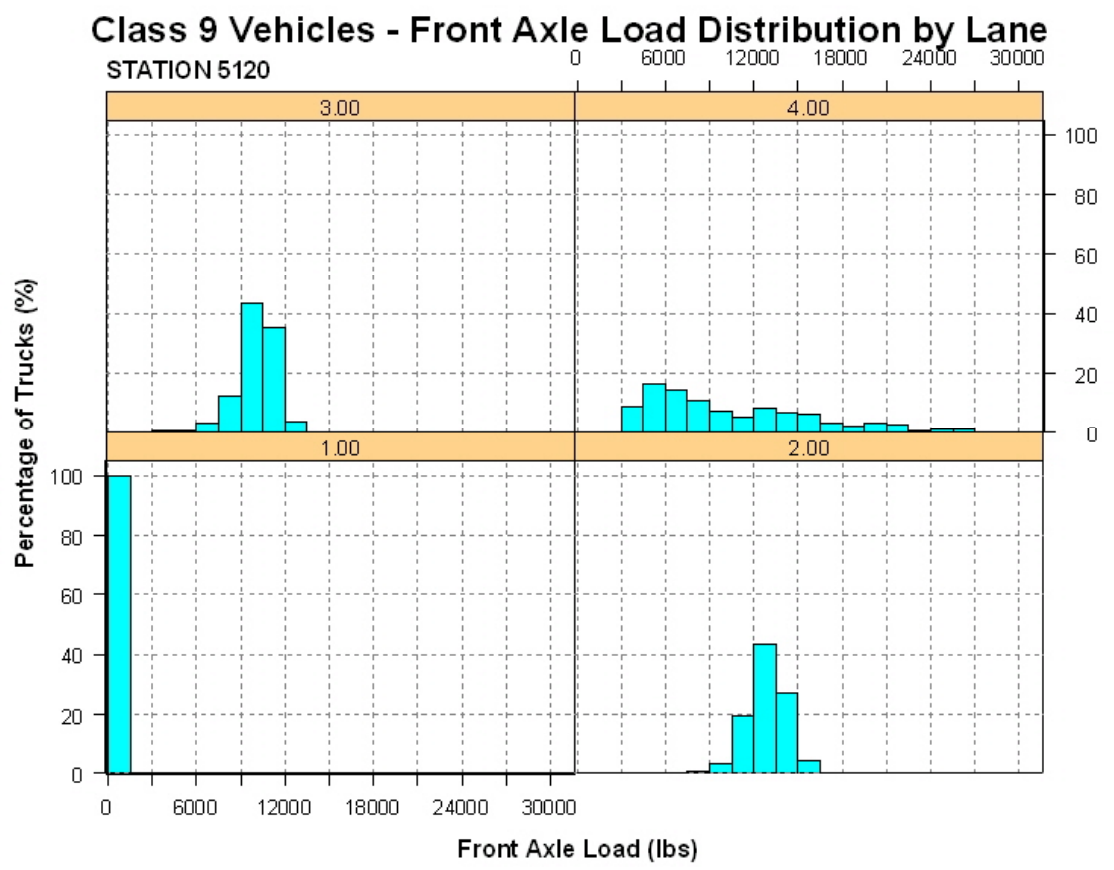

Figure F-23: Station 5120, Class 9 Vehicles - Front Axle Load Distribution

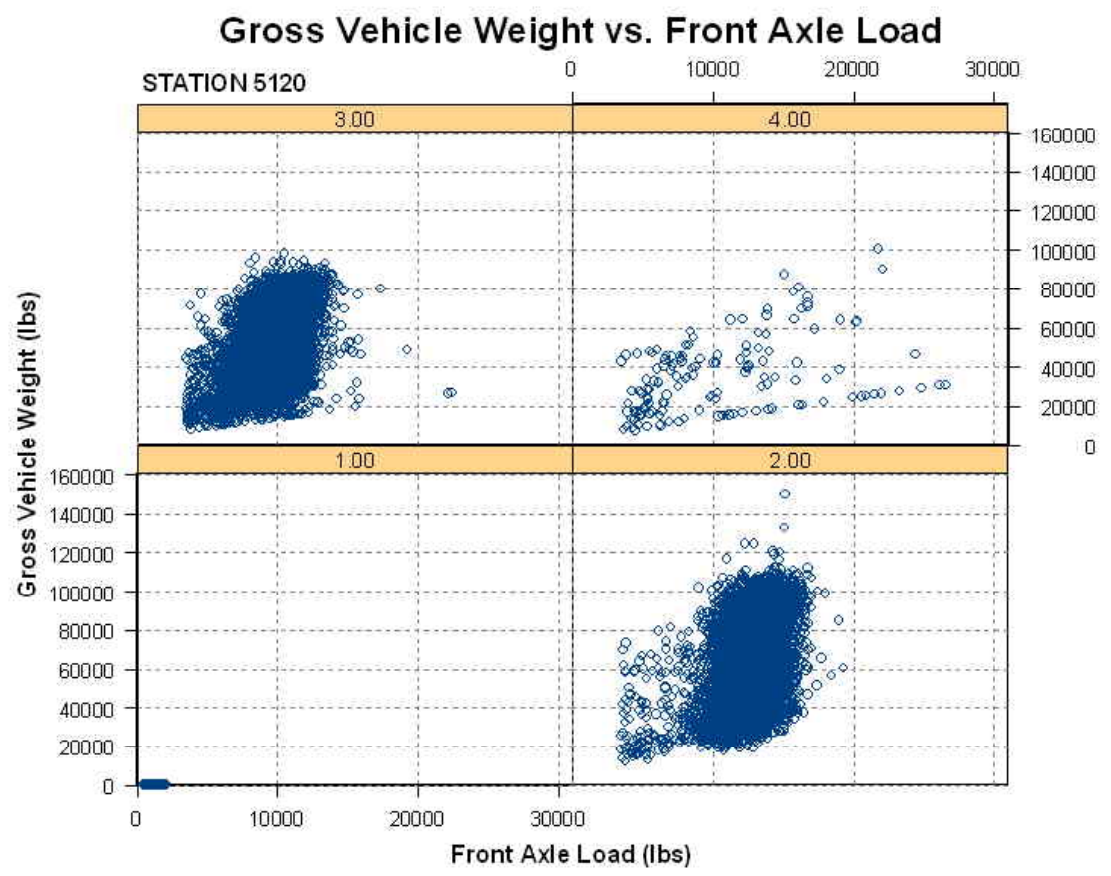

Figure F-24: Station 5120, Class 9 Vehicles - Gross Vehicle Weight vs. Front Axle 


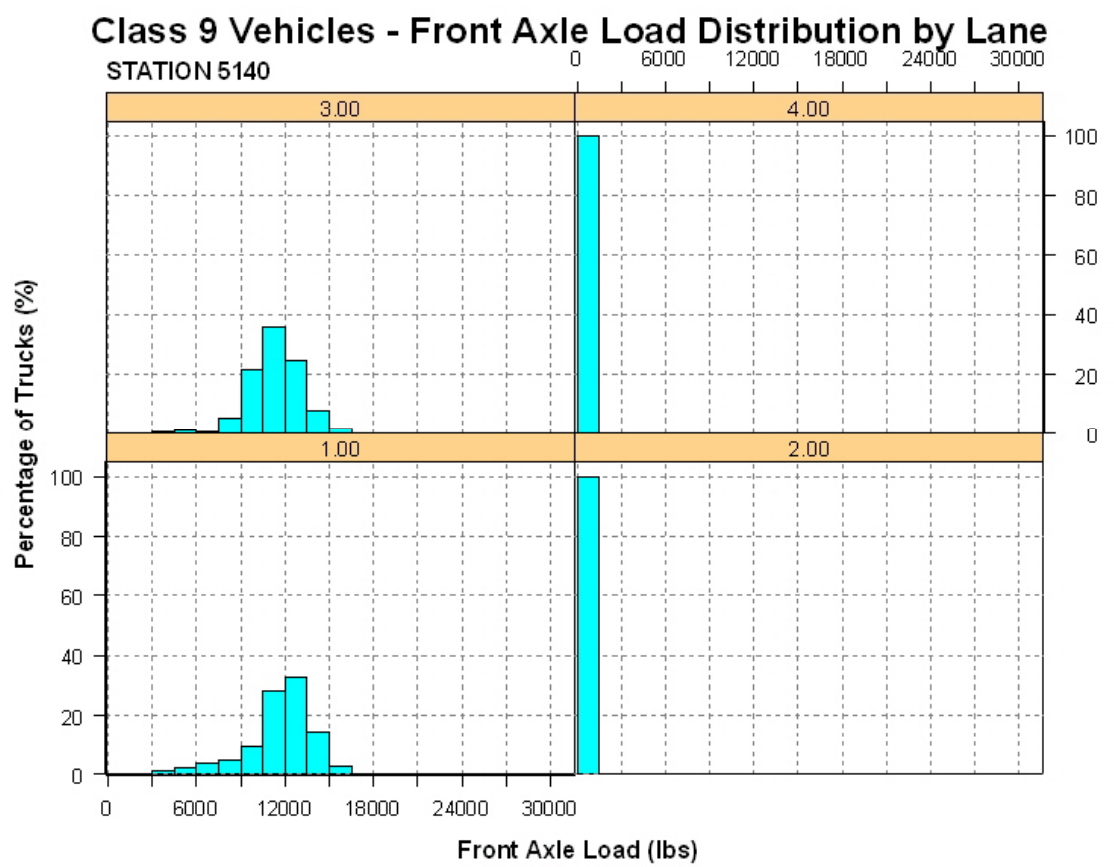

Figure F-25: Station 5140, Class 9 Vehicles - Front Axle Load Distribution

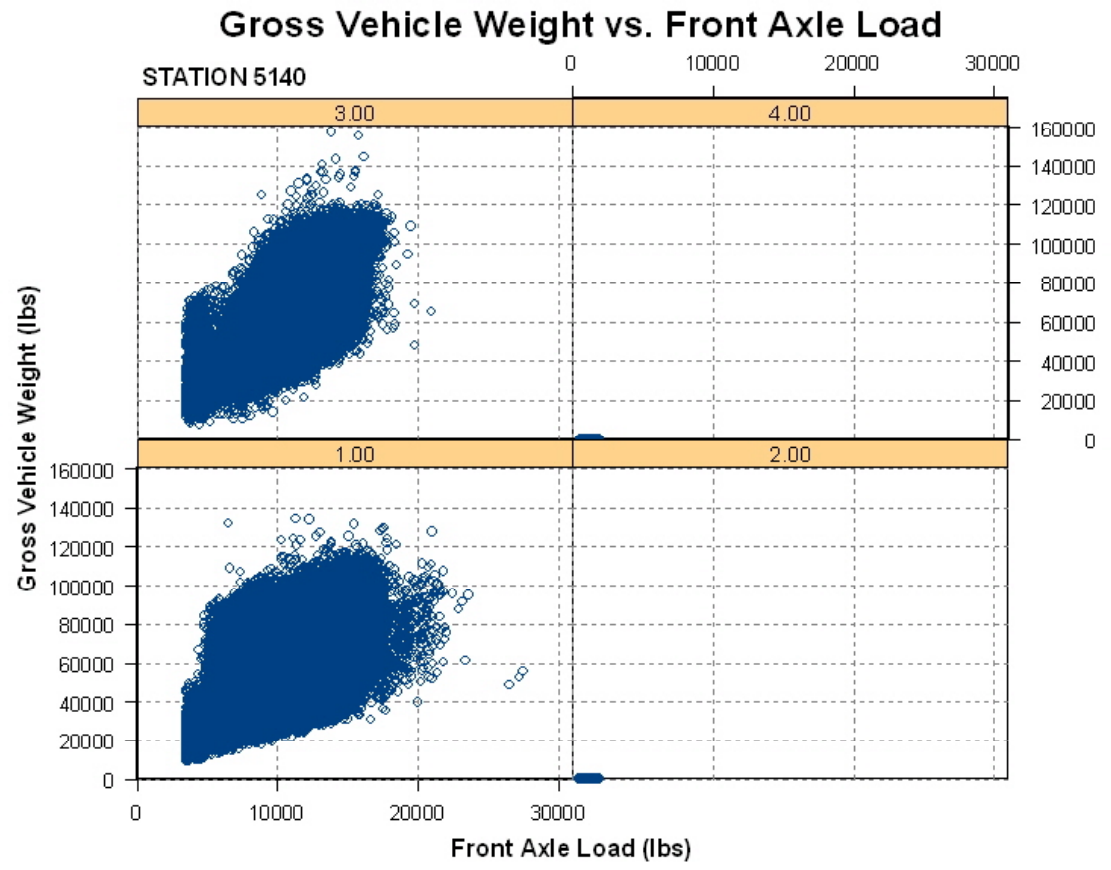

Figure F-26: Station 5140, Class 9 Vehicles - Gross Vehicle Weight vs. Front Axle 


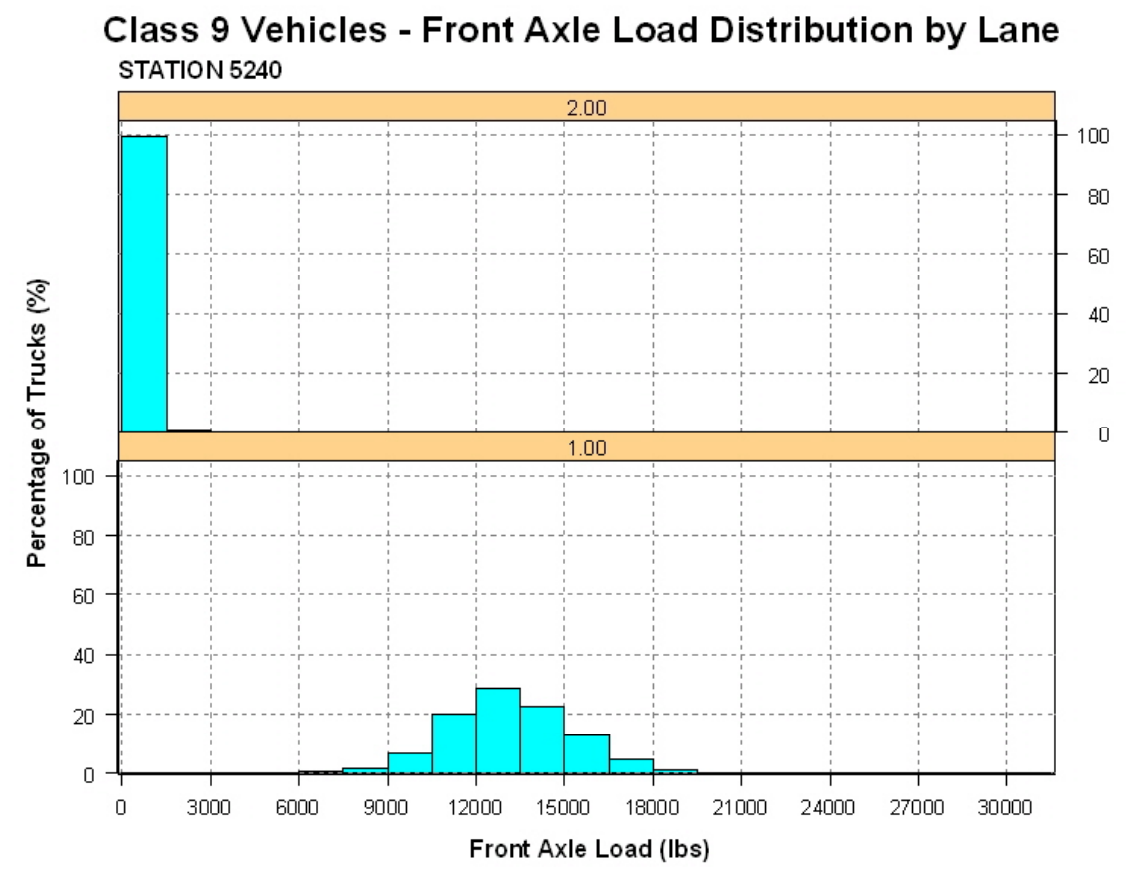

Figure F-27: Station 5240, Class 9 Vehicles - Front Axle Load Distribution

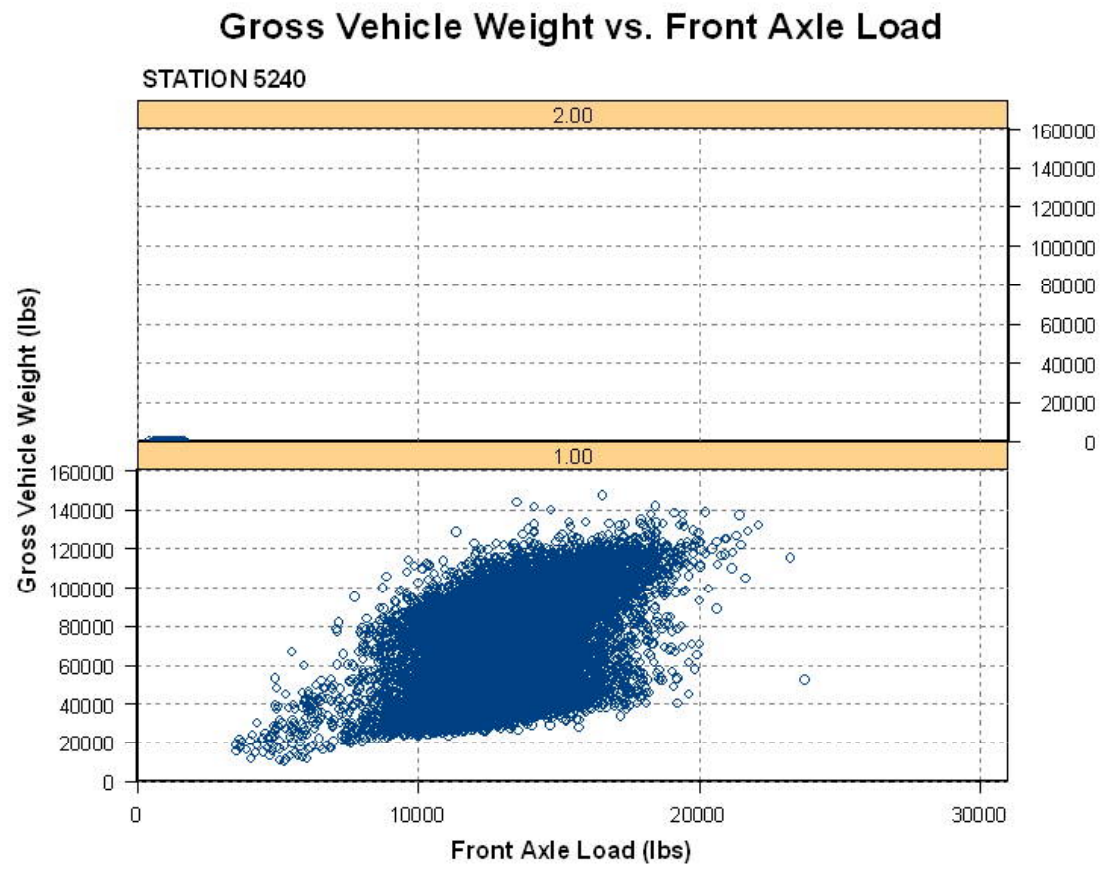

Figure F-28: Station 5240, Class 9 Vehicles - Gross Vehicle Weight vs. Front Axle 


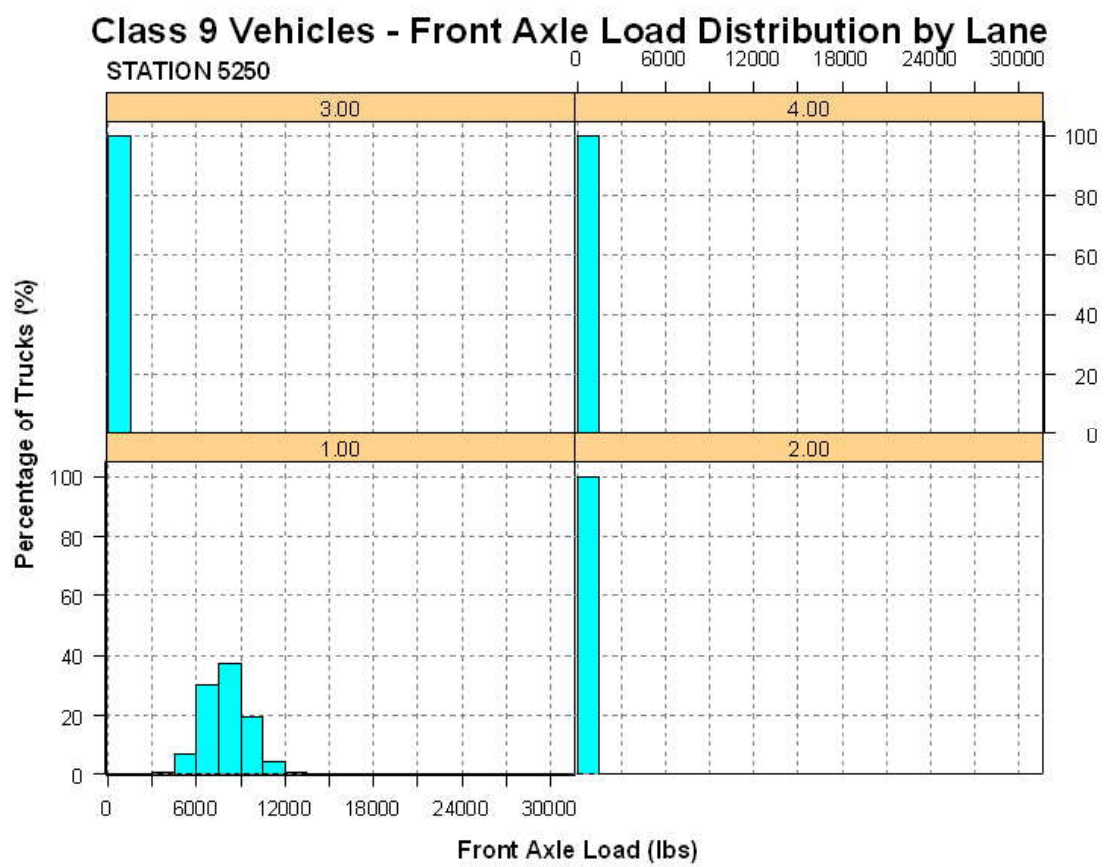

Figure F-29: Station 5250, Class 9 Vehicles - Front Axle Load Distribution

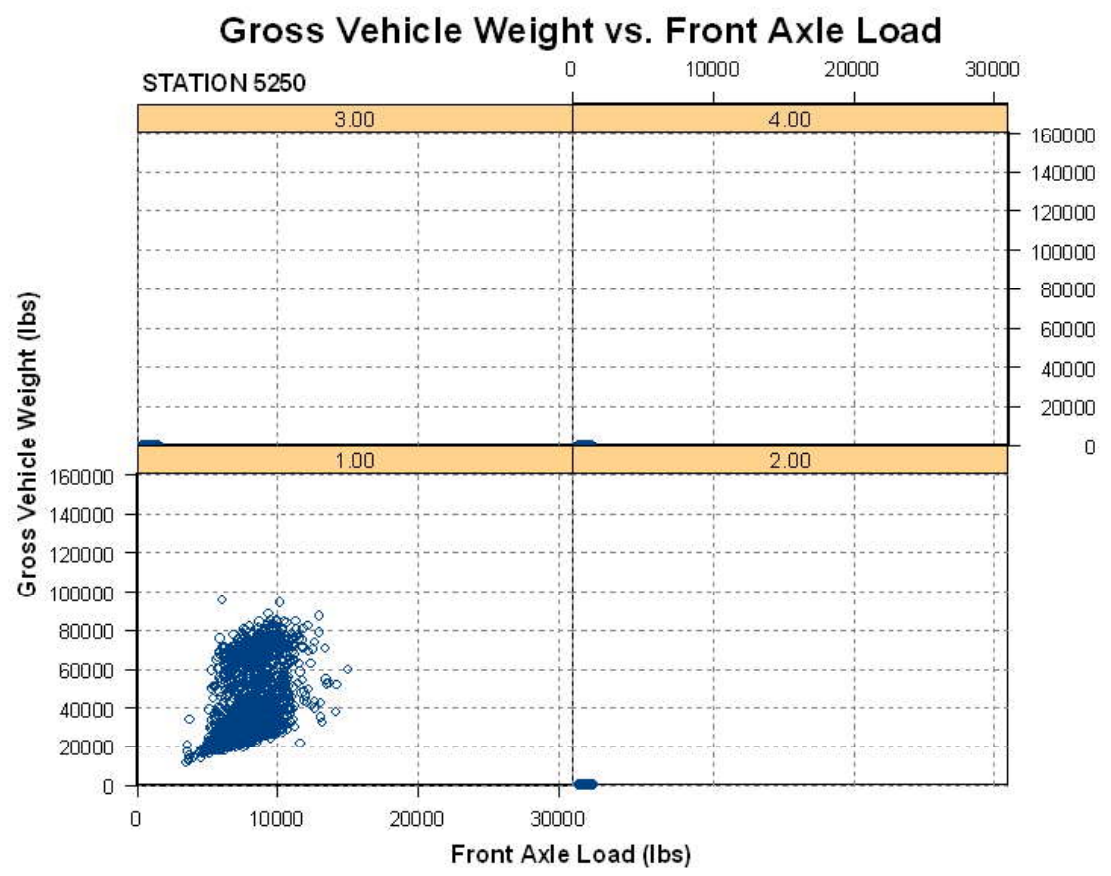

Figure F-30: Station 5250, Class 9 Vehicles - Gross Vehicle Weight vs. Front Axle 


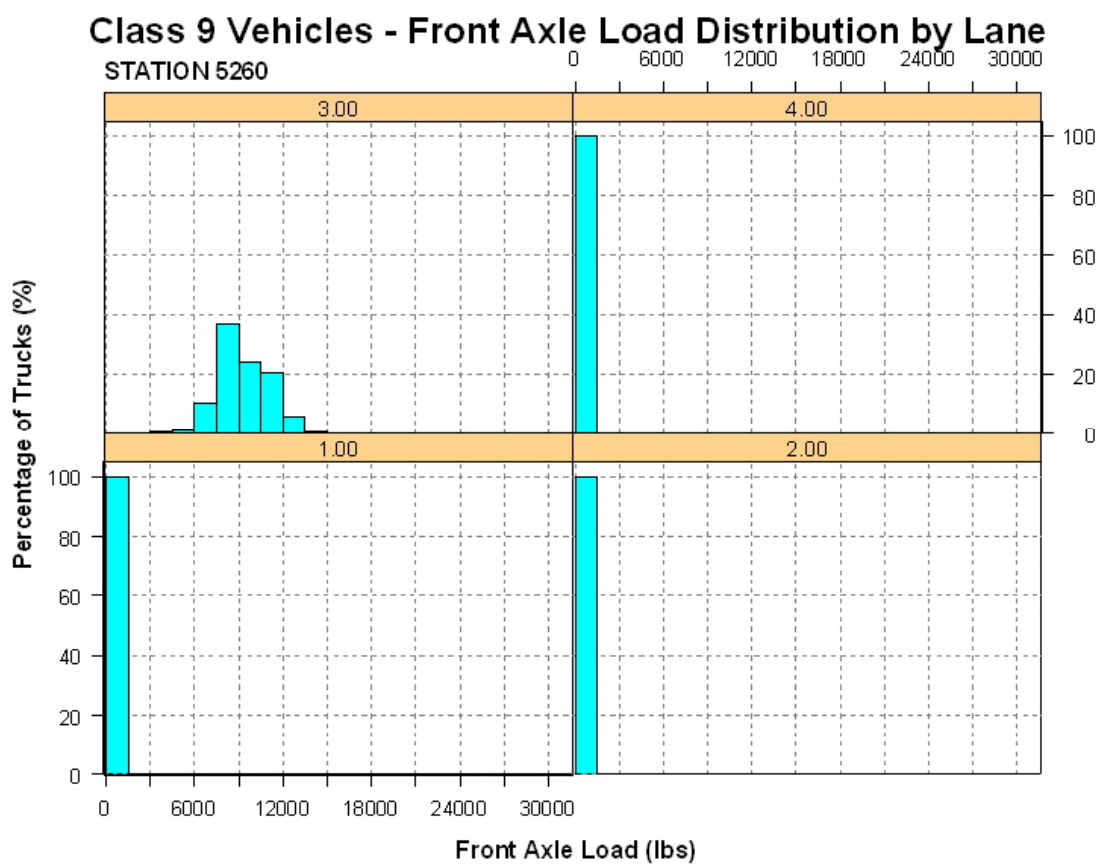

Figure F-31: Station 5260, Class 9 Vehicles - Front Axle Load Distribution

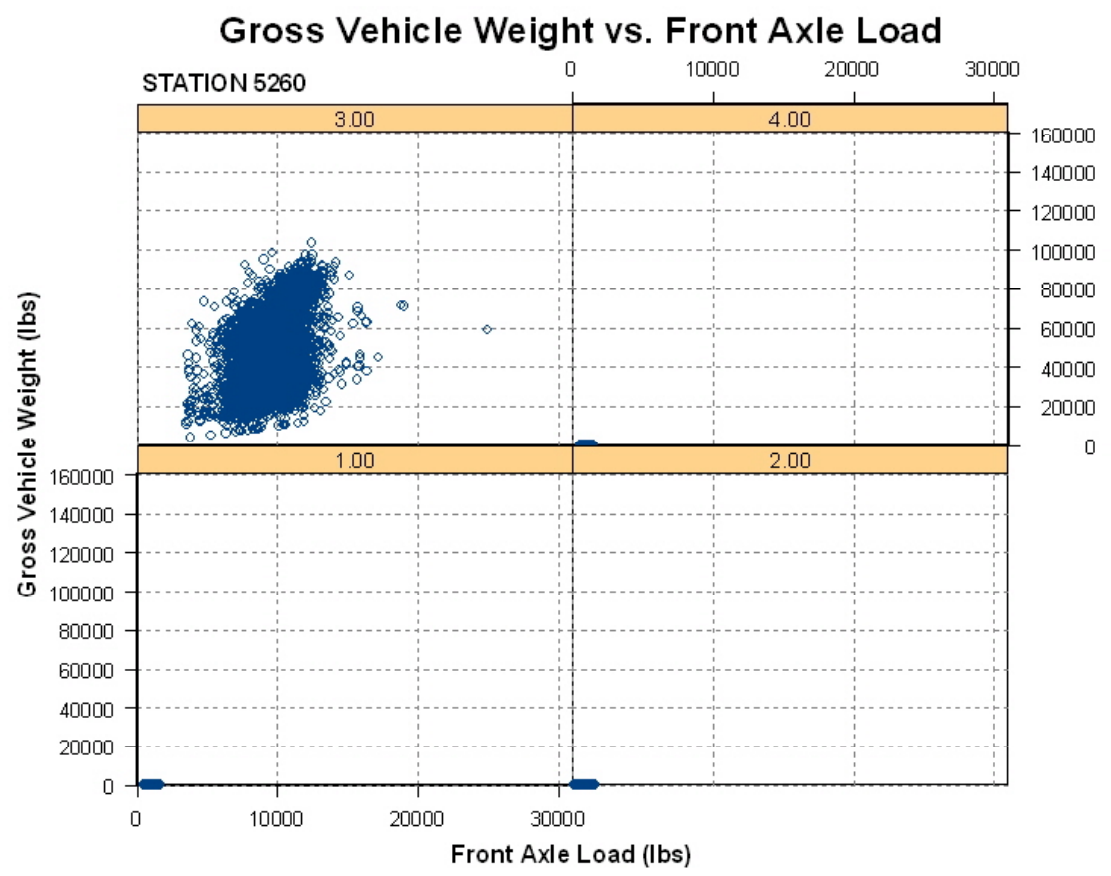

Figure F-32: Station 5260, Class 9 Vehicles - Gross Vehicle Weight vs. Front Axle 


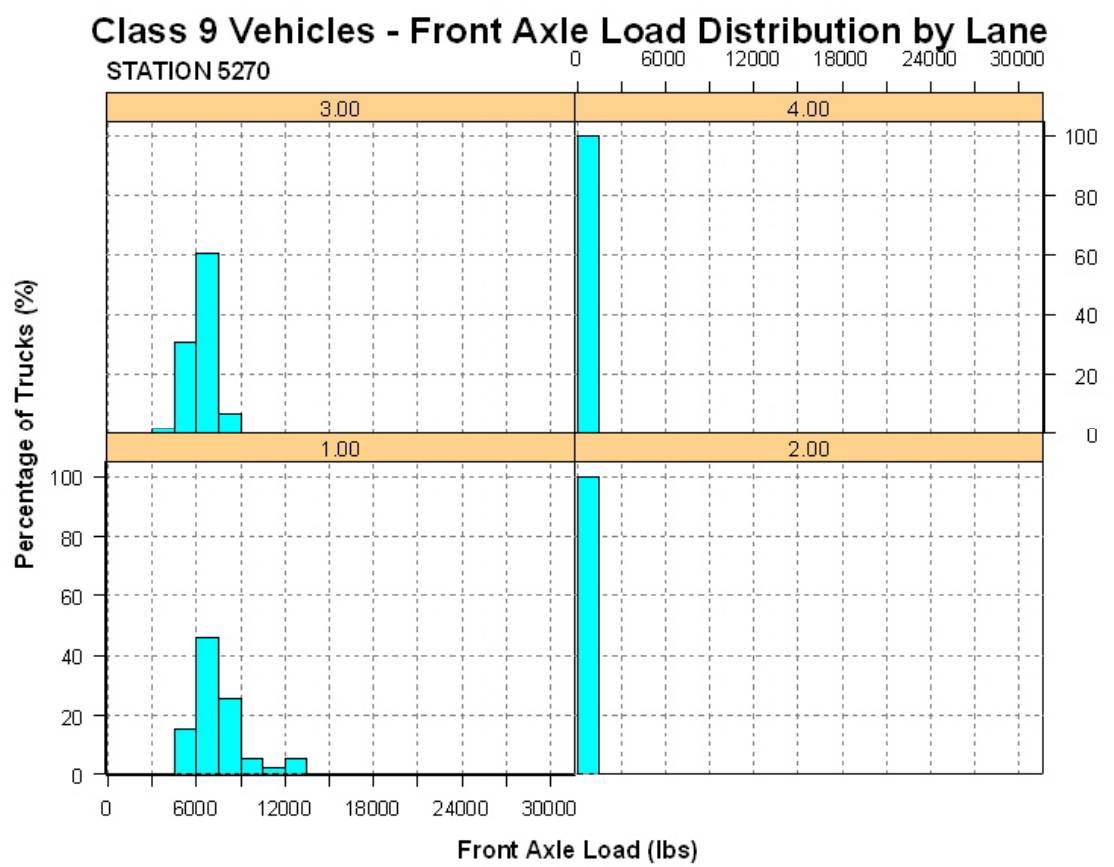

Figure F-33: Station 5270, Class 9 Vehicles - Front Axle Load Distribution

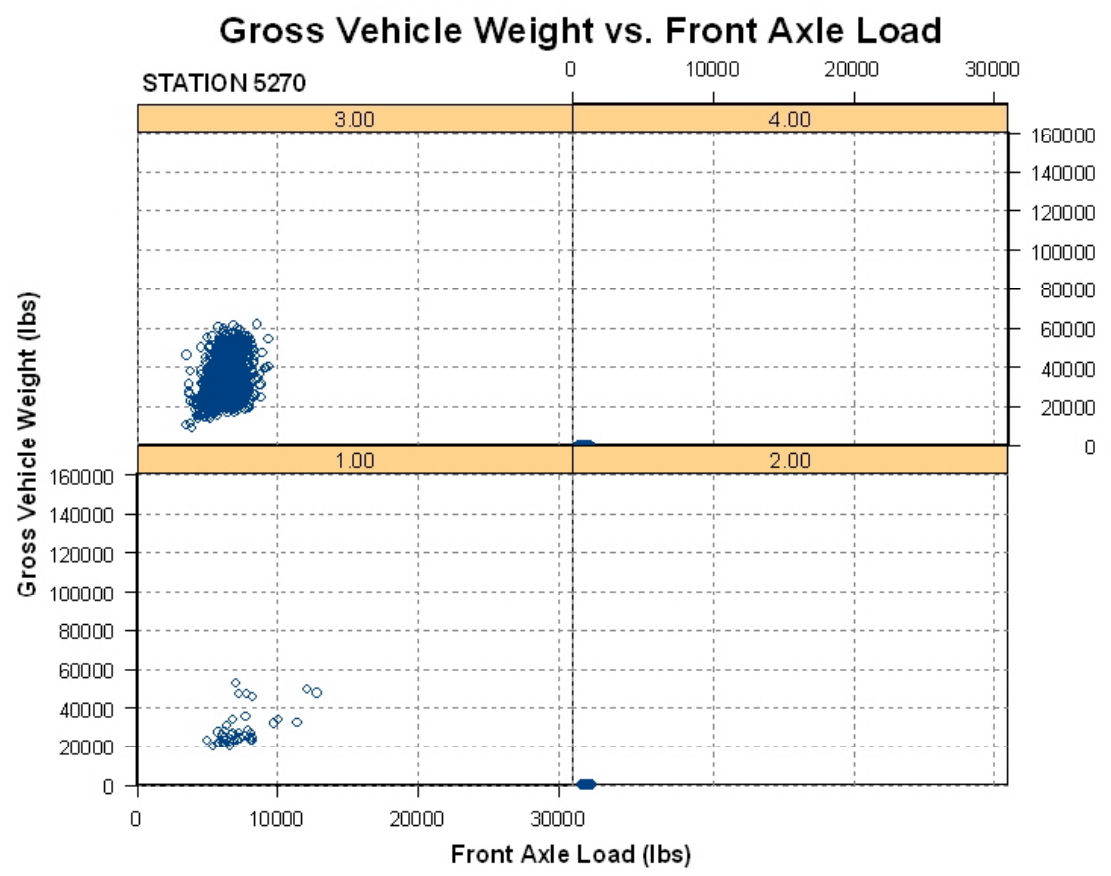

Figure F-34: Station 5270, Class 9 Vehicles - Gross Vehicle Weight vs. Front Axle 


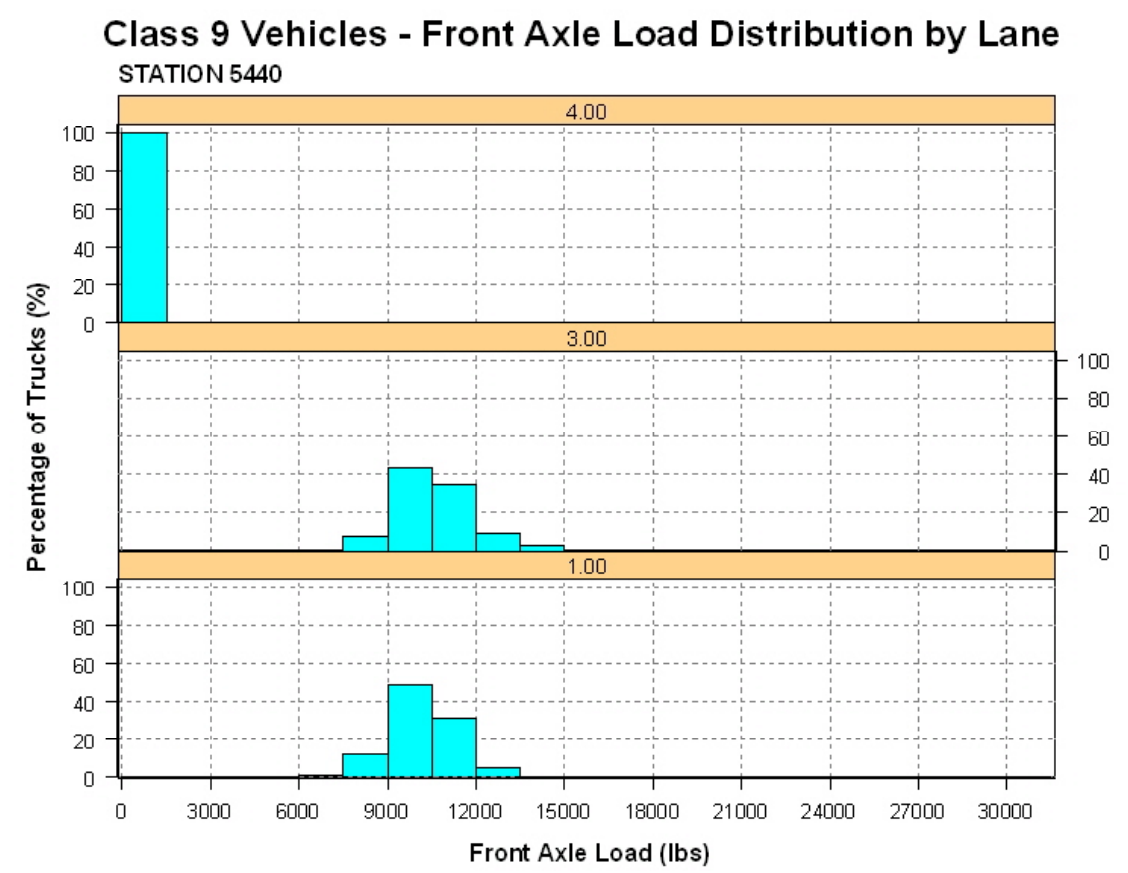

Figure F-35: Station 5440, Class 9 Vehicles - Front Axle Load Distribution

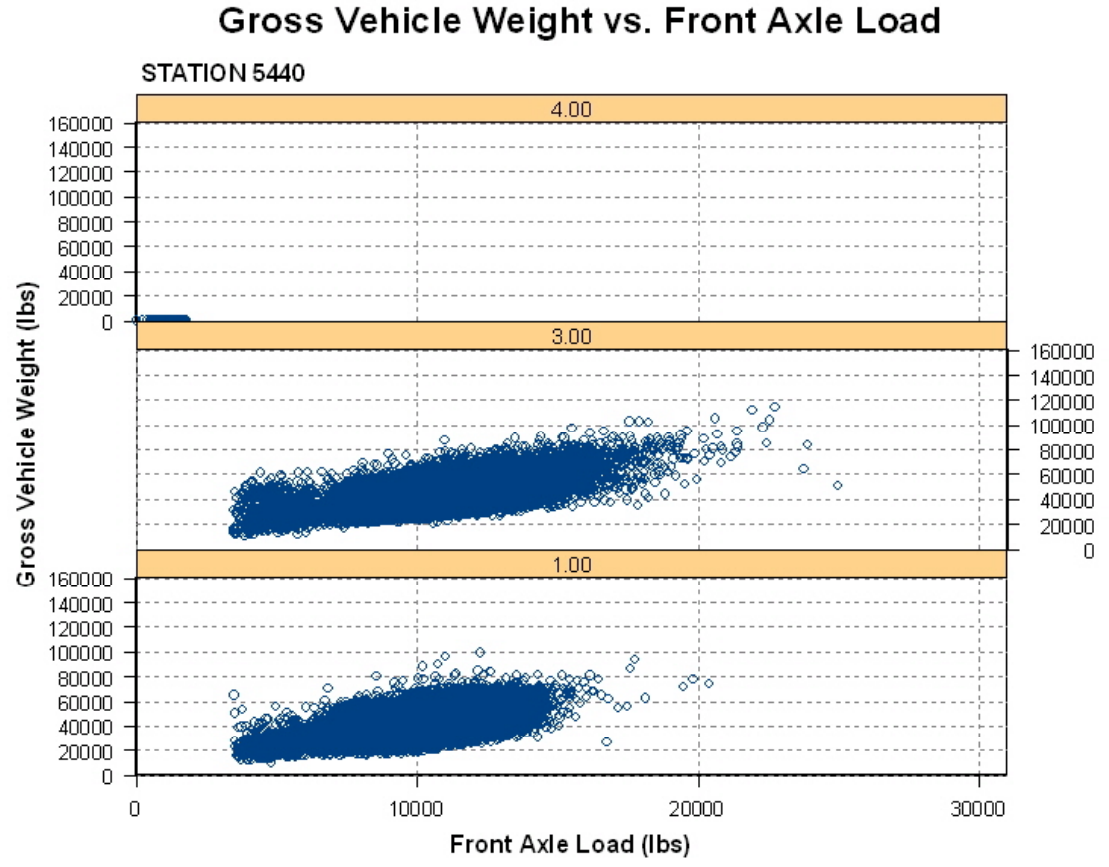

Figure F-36: Station 5440, Class 9 Vehicles - Gross Vehicle Weight vs. Front Axle 


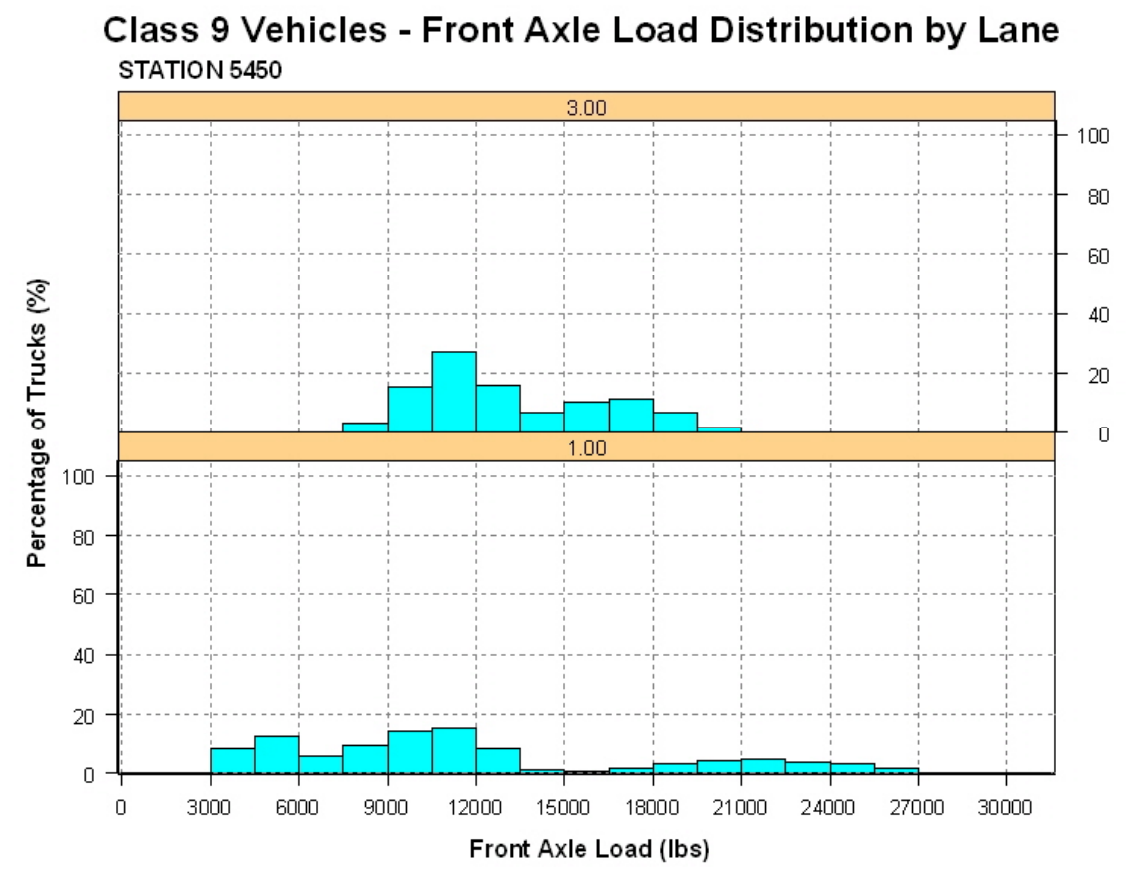

Figure F-37: Station 5440, Class 9 Vehicles - Front Axle Load Distribution

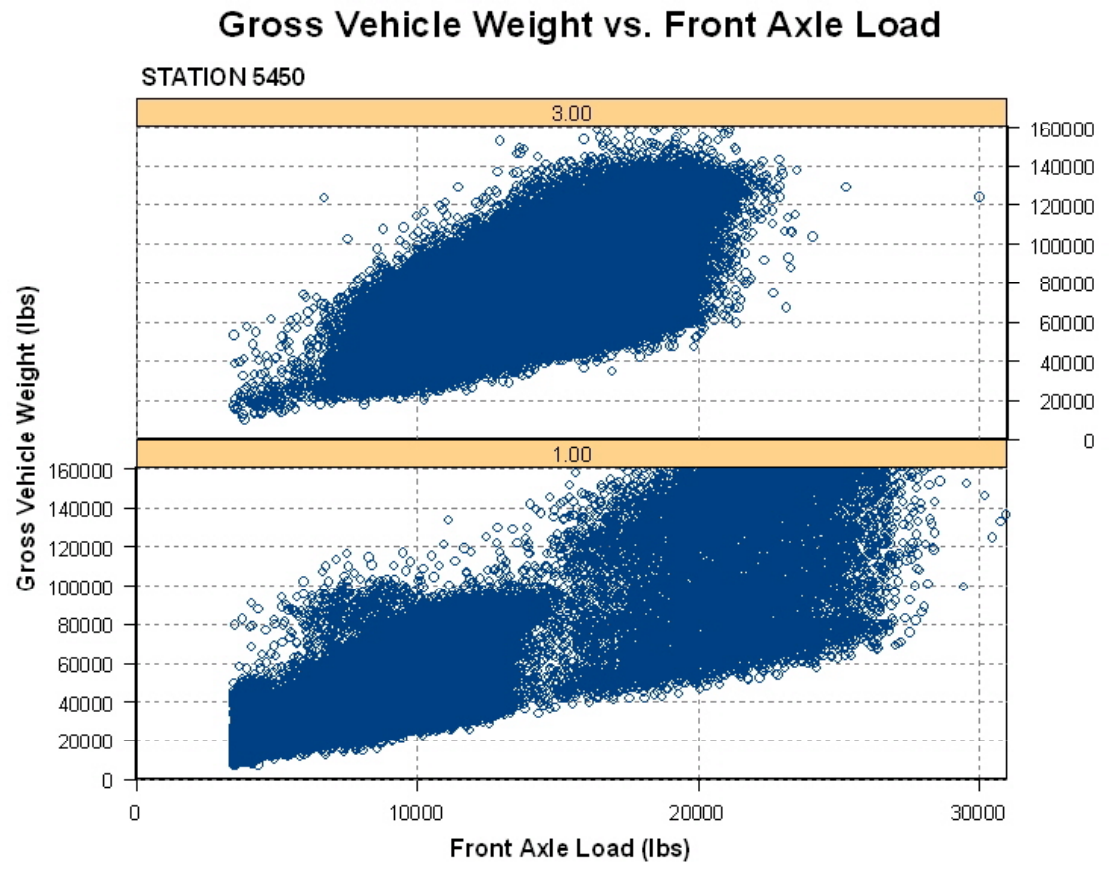

Figure F-38: Station 5450, Class 9 Vehicles - Gross Vehicle Weight vs. Front Axle 


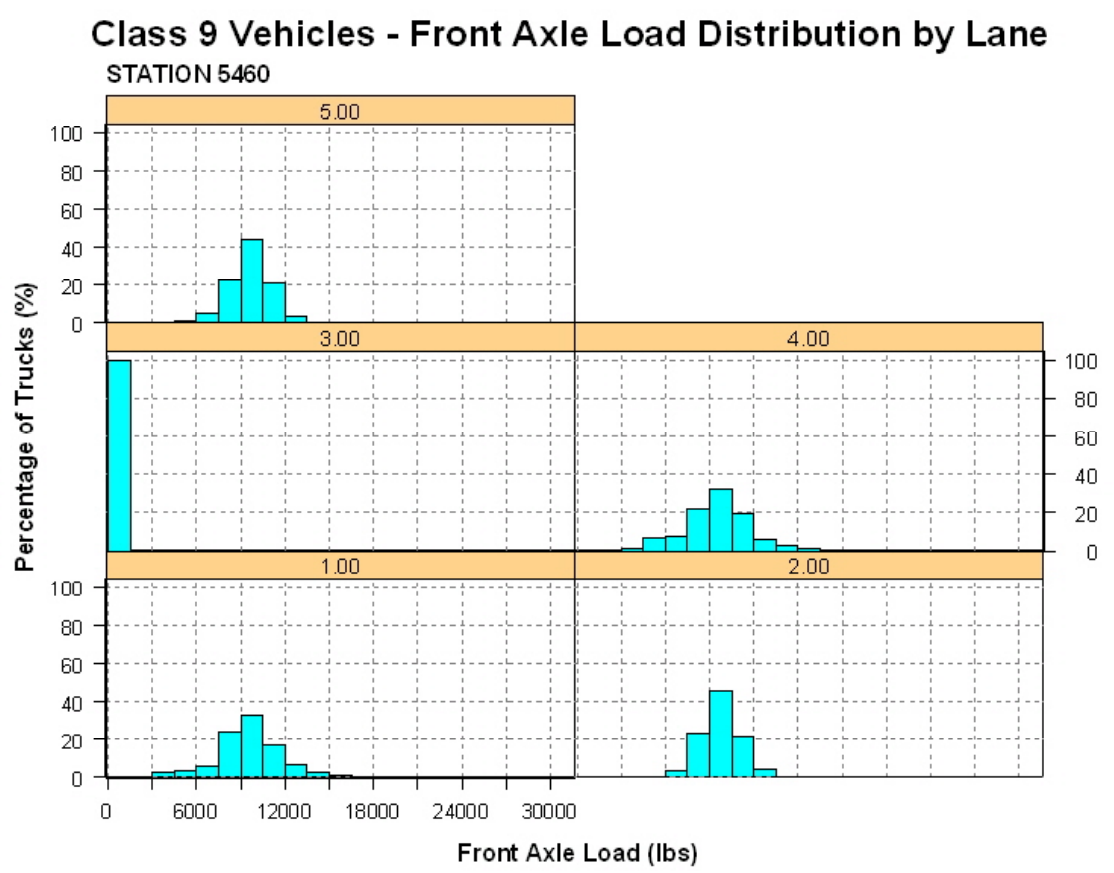

Figure F-39: Station 5460, Class 9 Vehicles - Front Axle Load Distribution

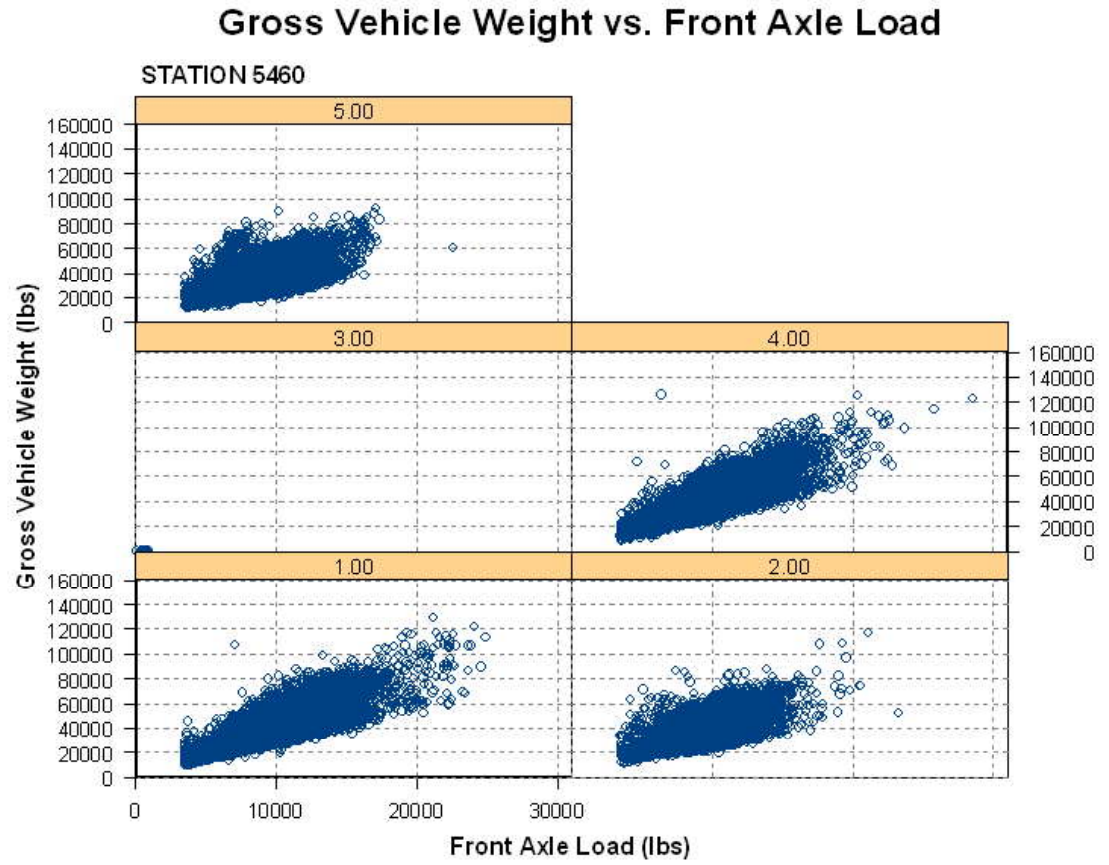

Figure F-40: Station 5460, Class 9 Vehicles - Gross Vehicle Weight vs. Front Axle 


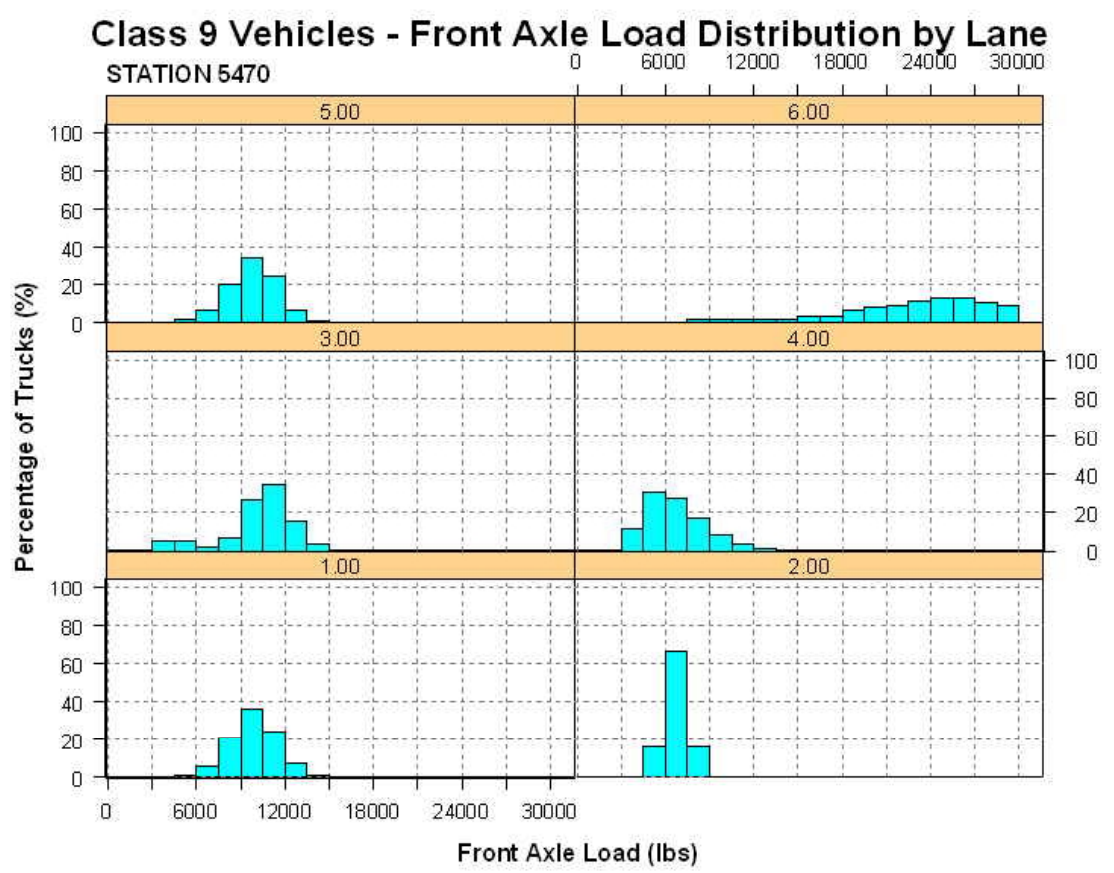

Figure F-41: Station 5470, Class 9 Vehicles - Front Axle Load Distribution

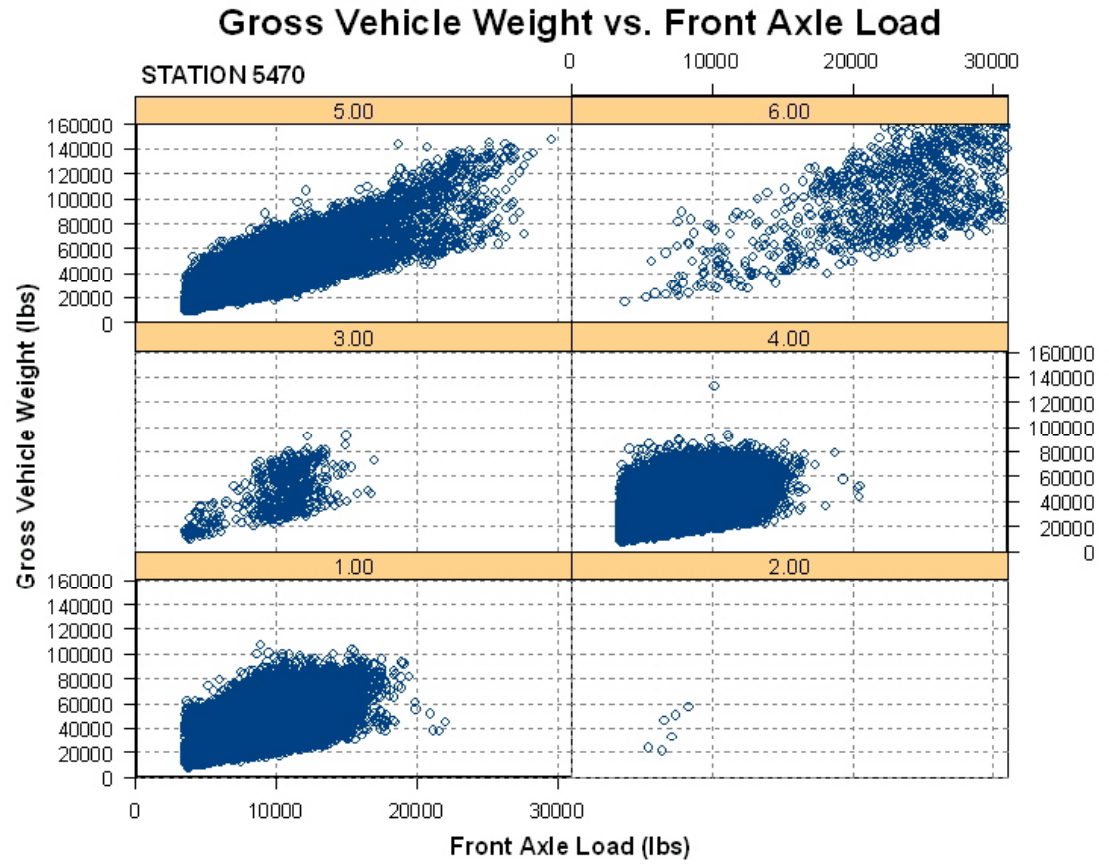

Figure F-42: Station 5470, Class 9 Vehicles - Gross Vehicle Weight vs. Front Axle 


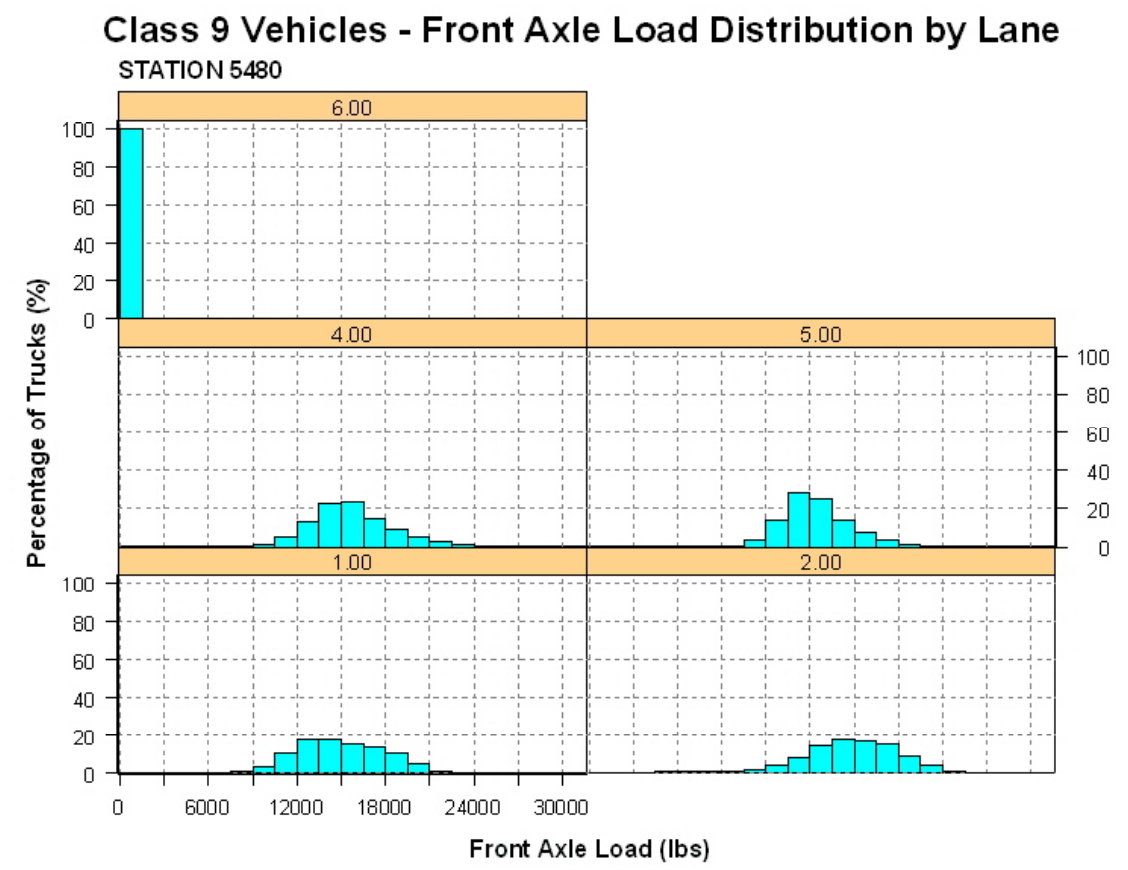

Figure F-43: Station 5480, Class 9 Vehicles - Front Axle Load Distribution

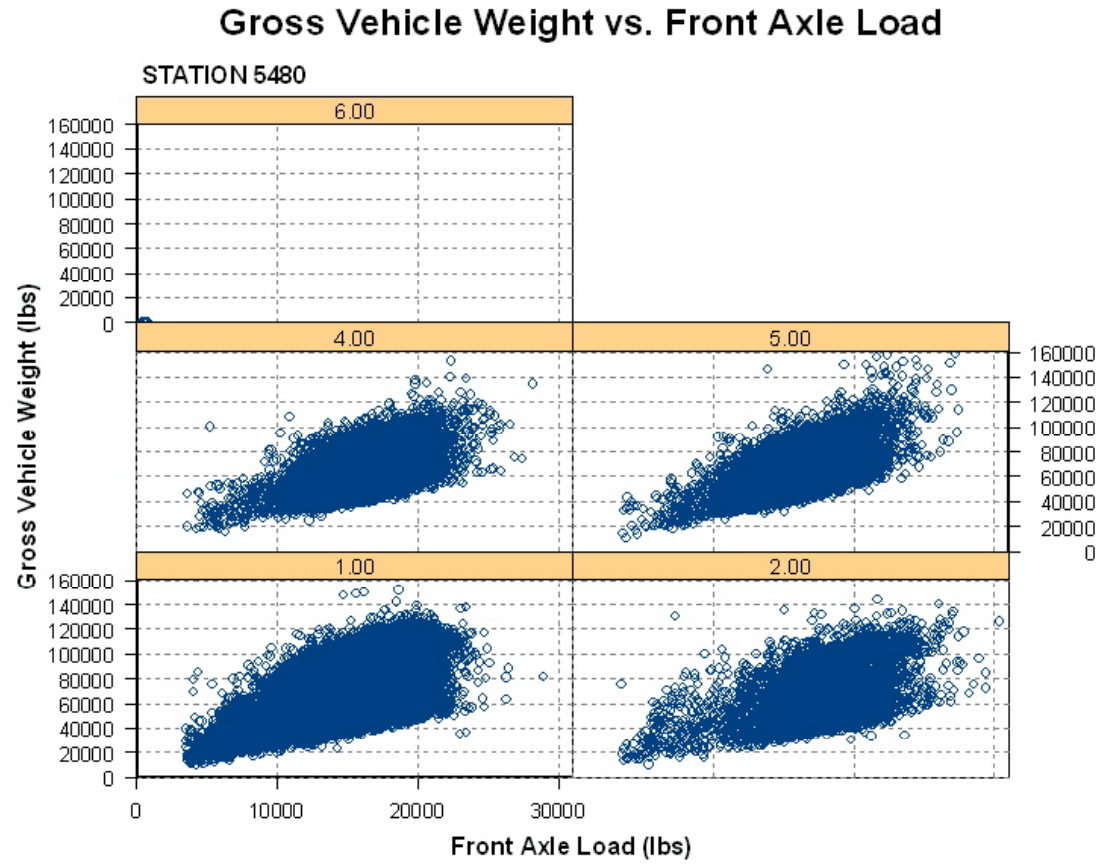

Figure F-44: Station 5480, Class 9 Vehicles - Gross Vehicle Weight vs. Front Axle 


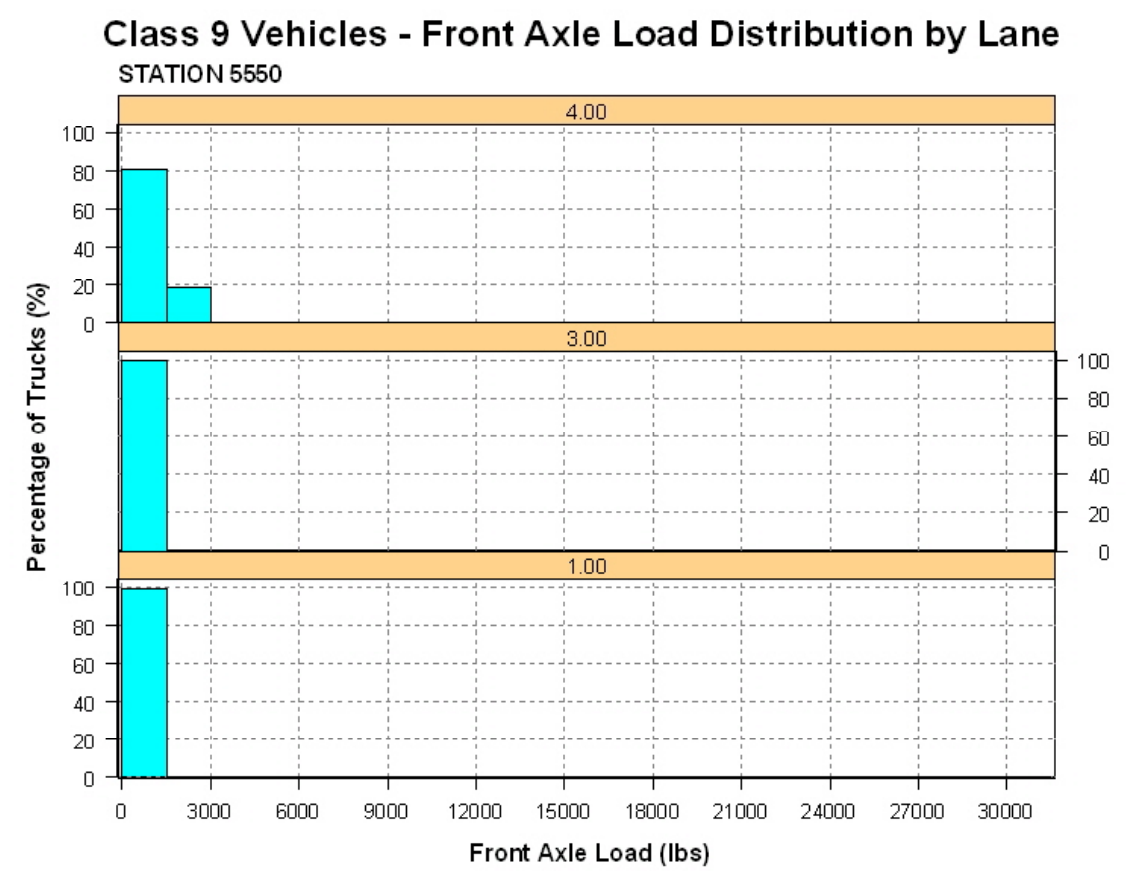

Figure F-45: Station 5550, Class 9 Vehicles - Front Axle Load Distribution

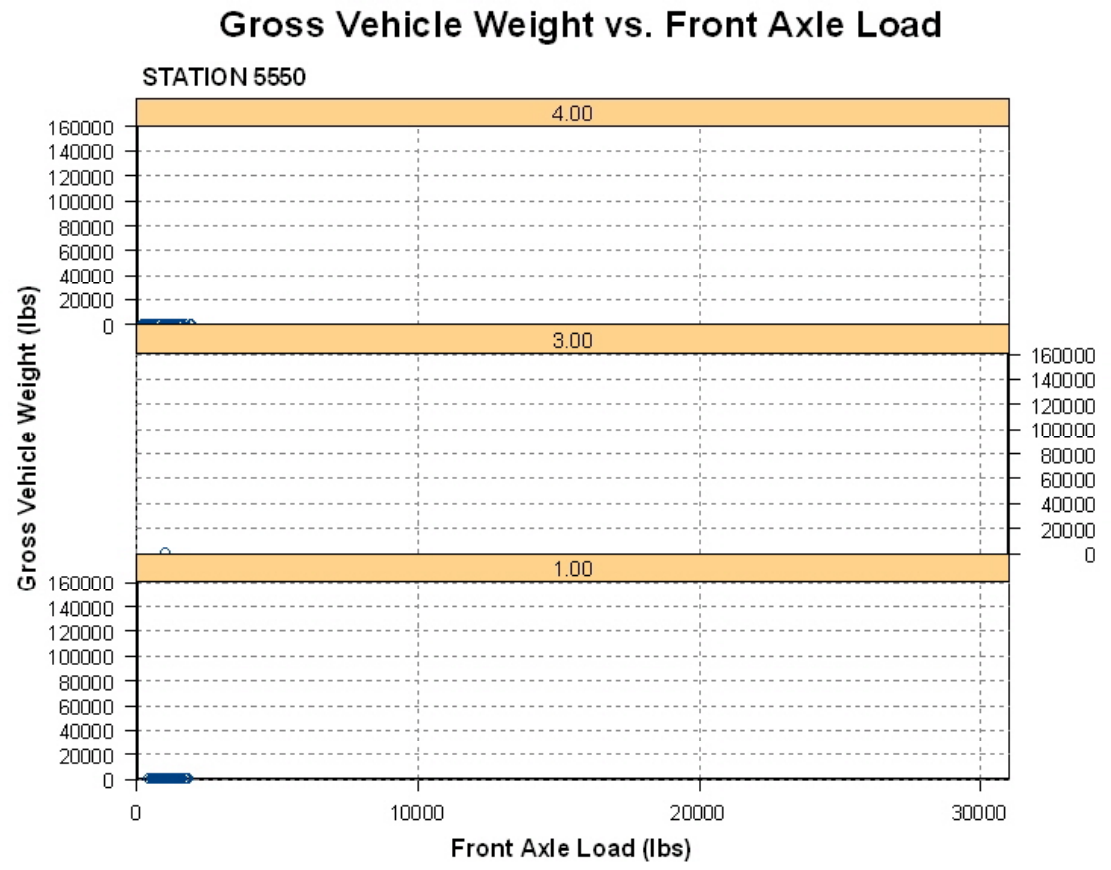

Figure F-46: Station 5550, Class 9 Vehicles - Gross Vehicle Weight vs. Front Axle 


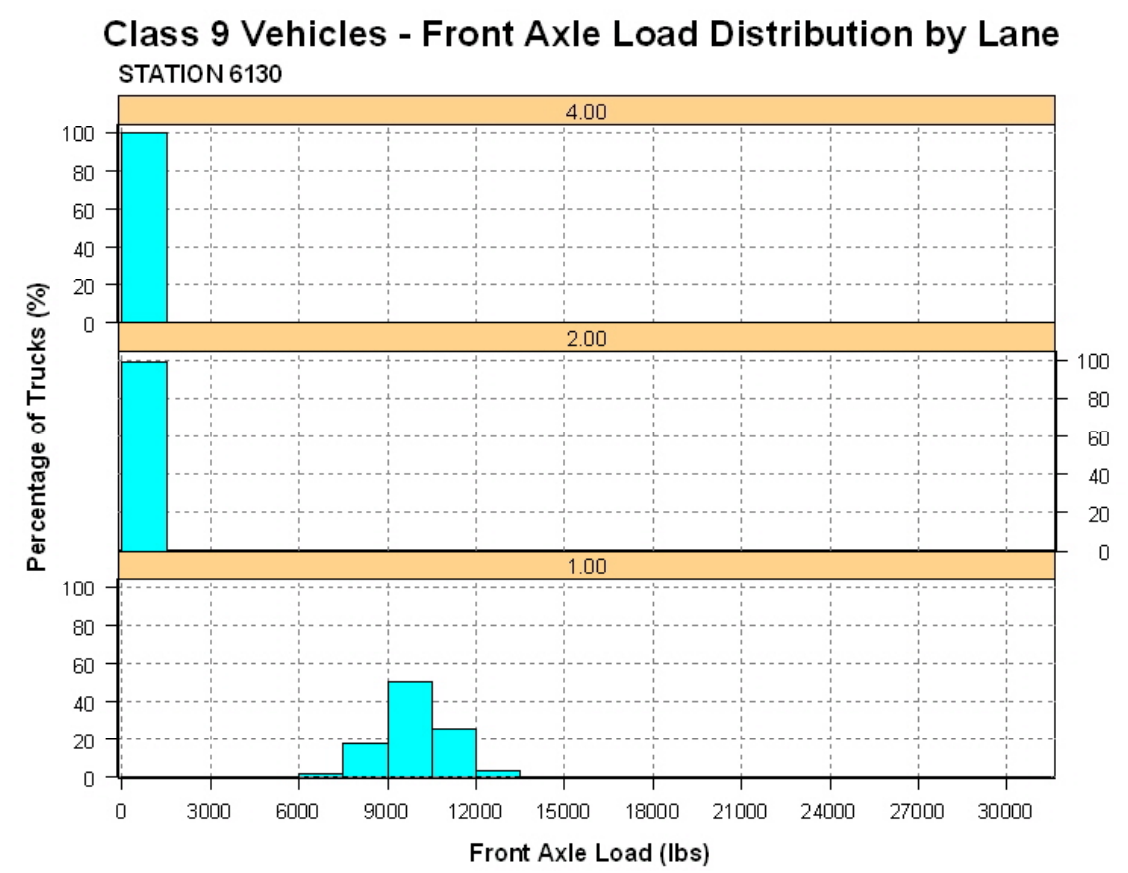

Figure F-47: Station 6130, Class 9 Vehicles - Front Axle Load Distribution

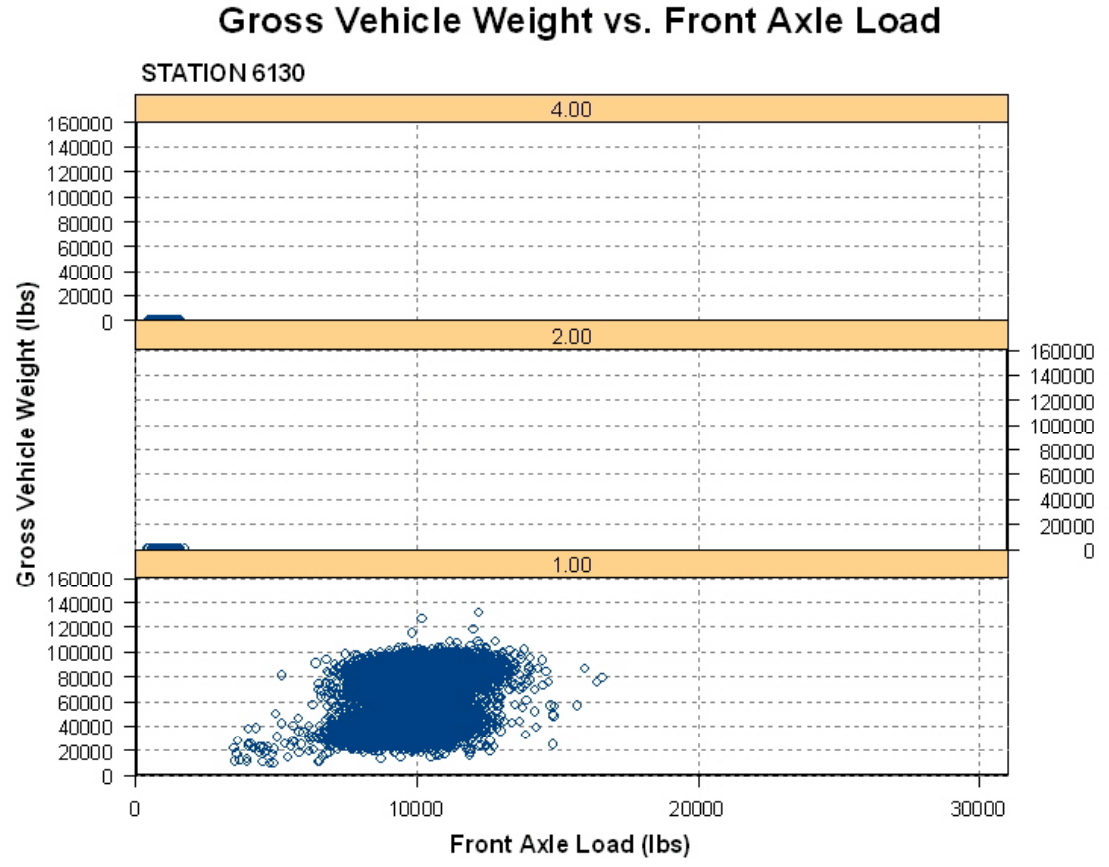

Figure F-48: Station 6130, Class 9 Vehicles - Gross Vehicle Weight vs. Front Axle 


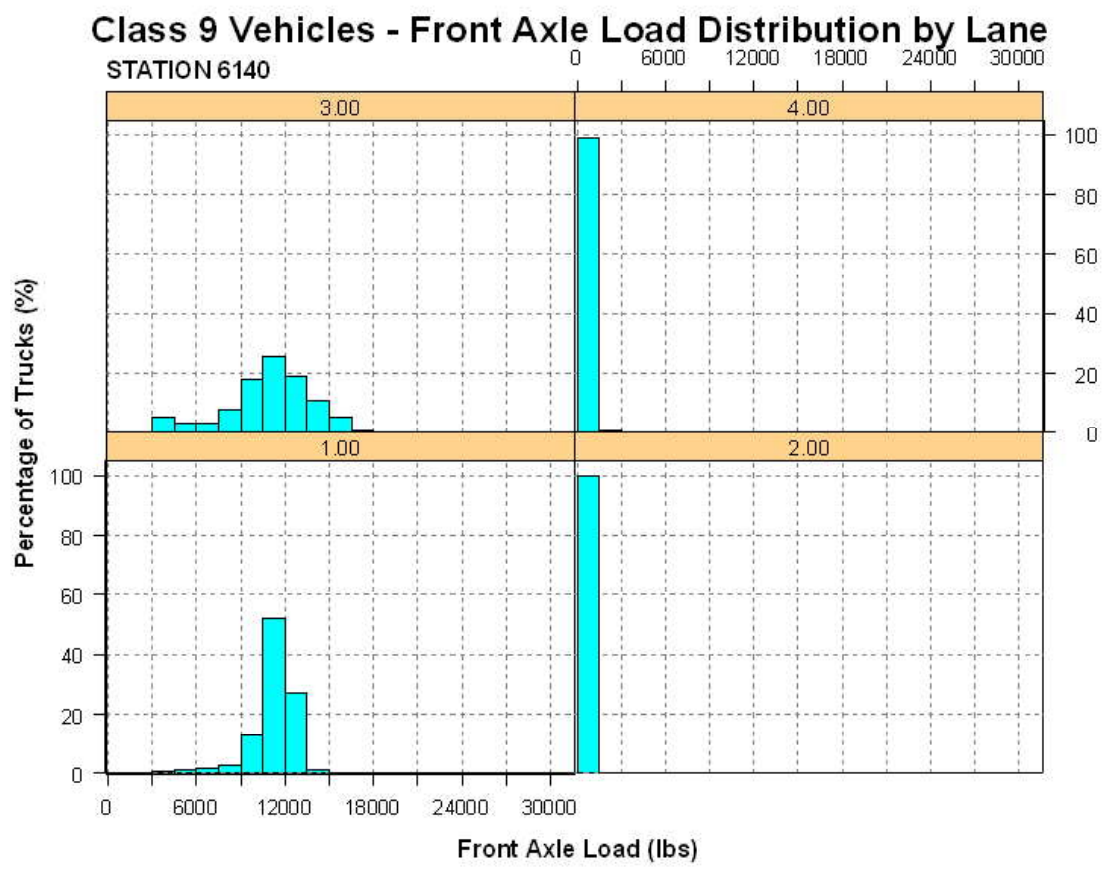

Figure F-49: Station 6140, Class 9 Vehicles - Front Axle Load Distribution

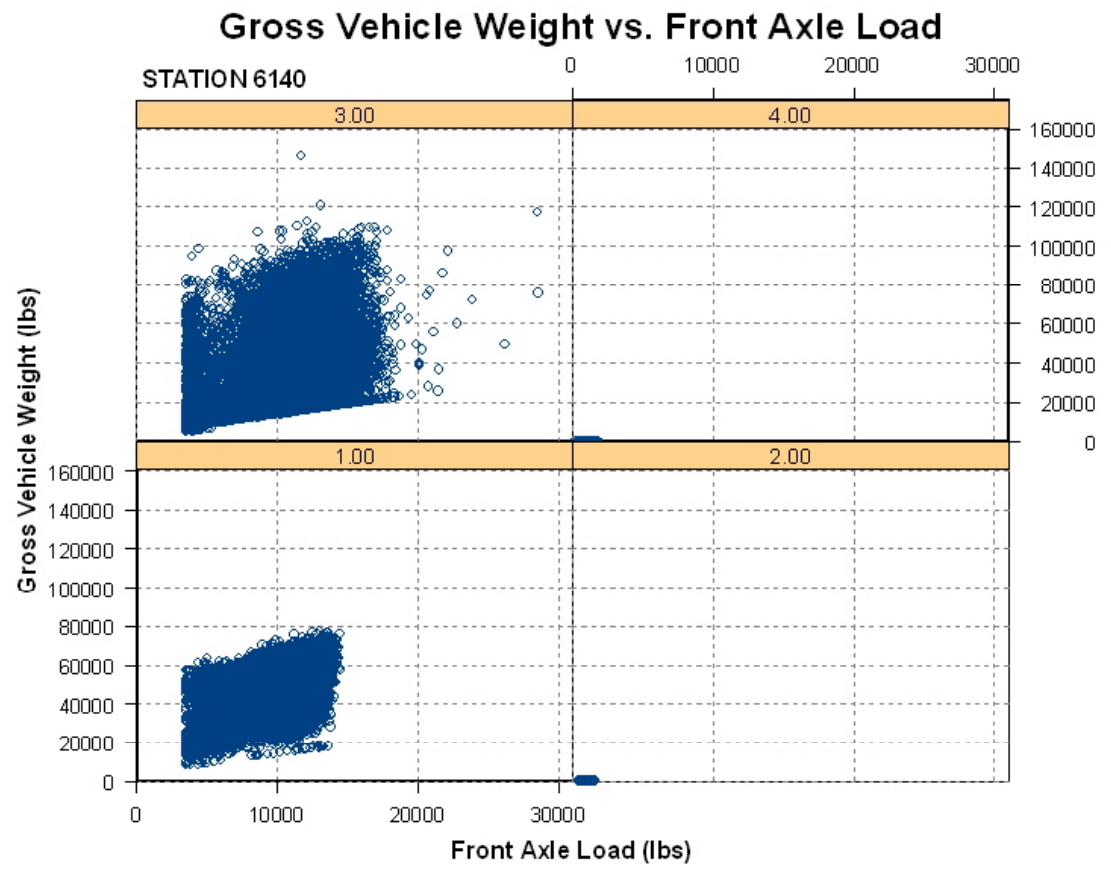

Figure F-50: Station 6140, Class 9 Vehicles - Gross Vehicle Weight vs. Front Axle 


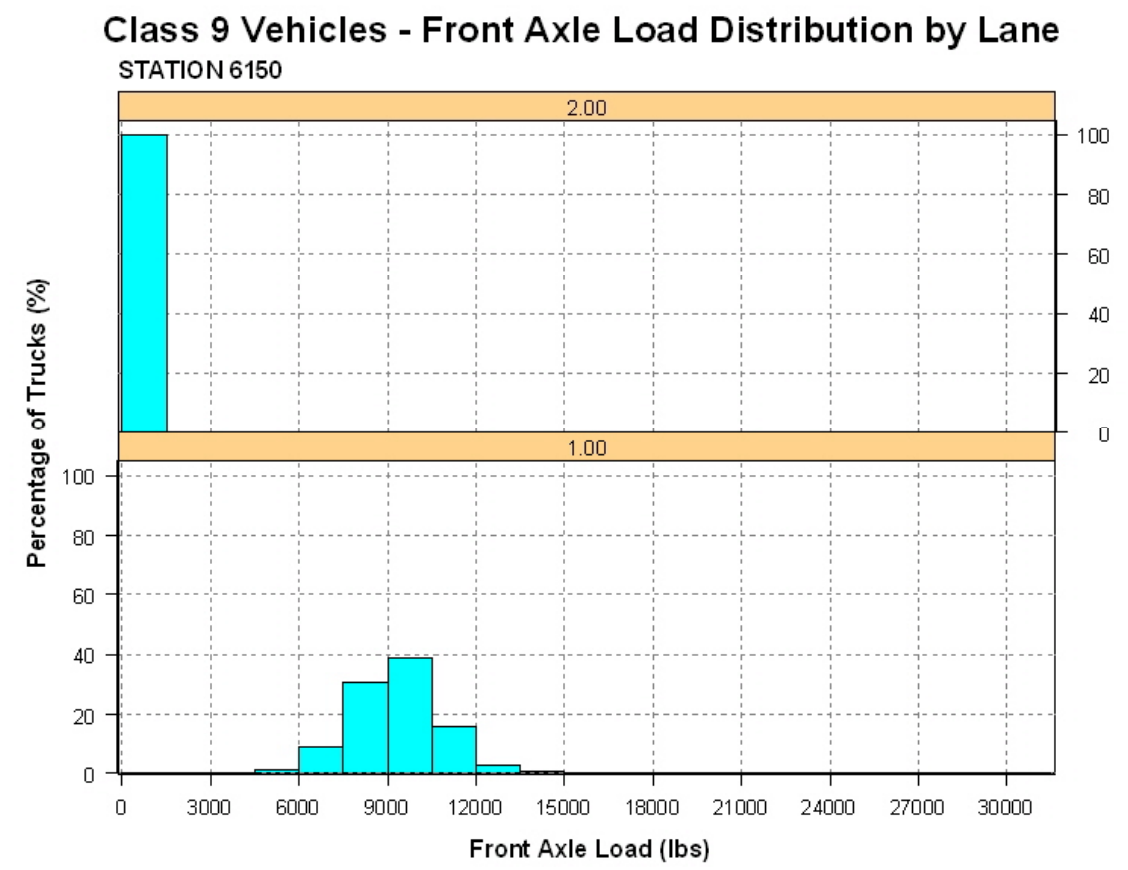

Figure F-51: Station 6150, Class 9 Vehicles - Front Axle Load Distribution

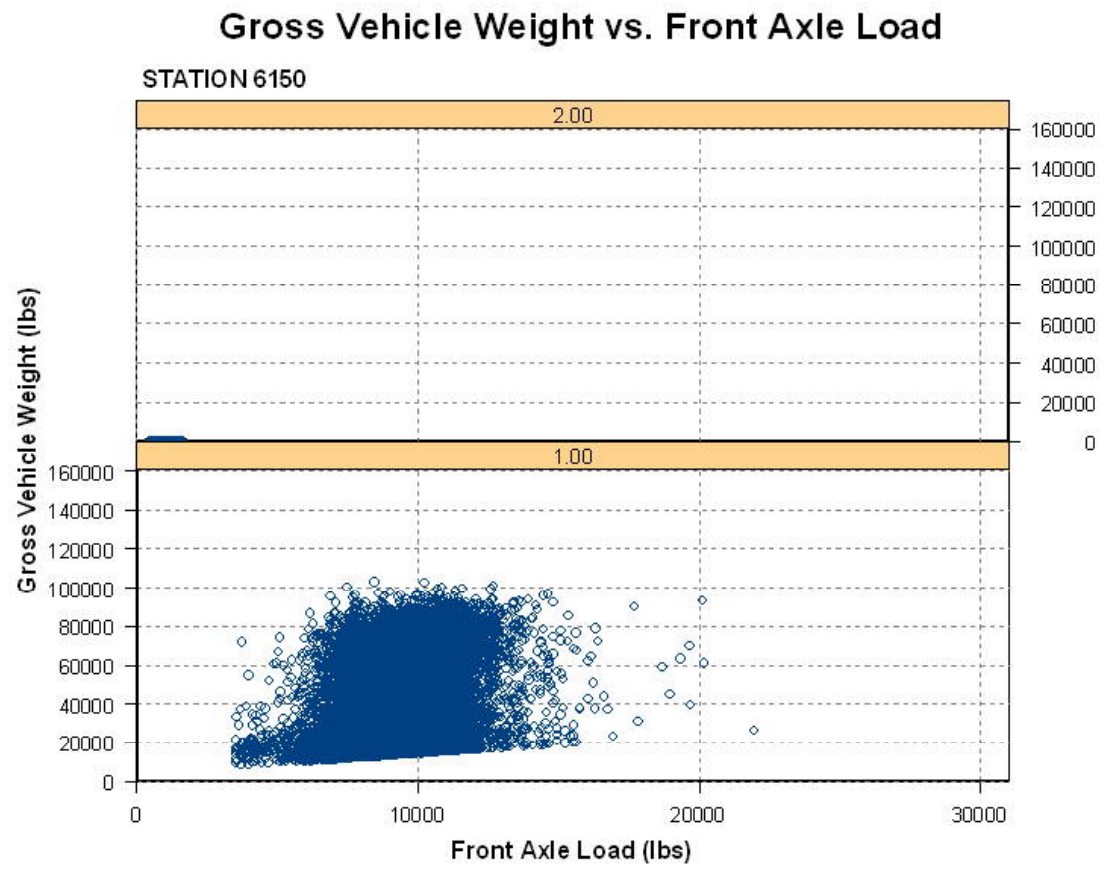

Figure F-52: Station 6150, Class 9 Vehicles - Gross Vehicle Weight vs. Front Axle 


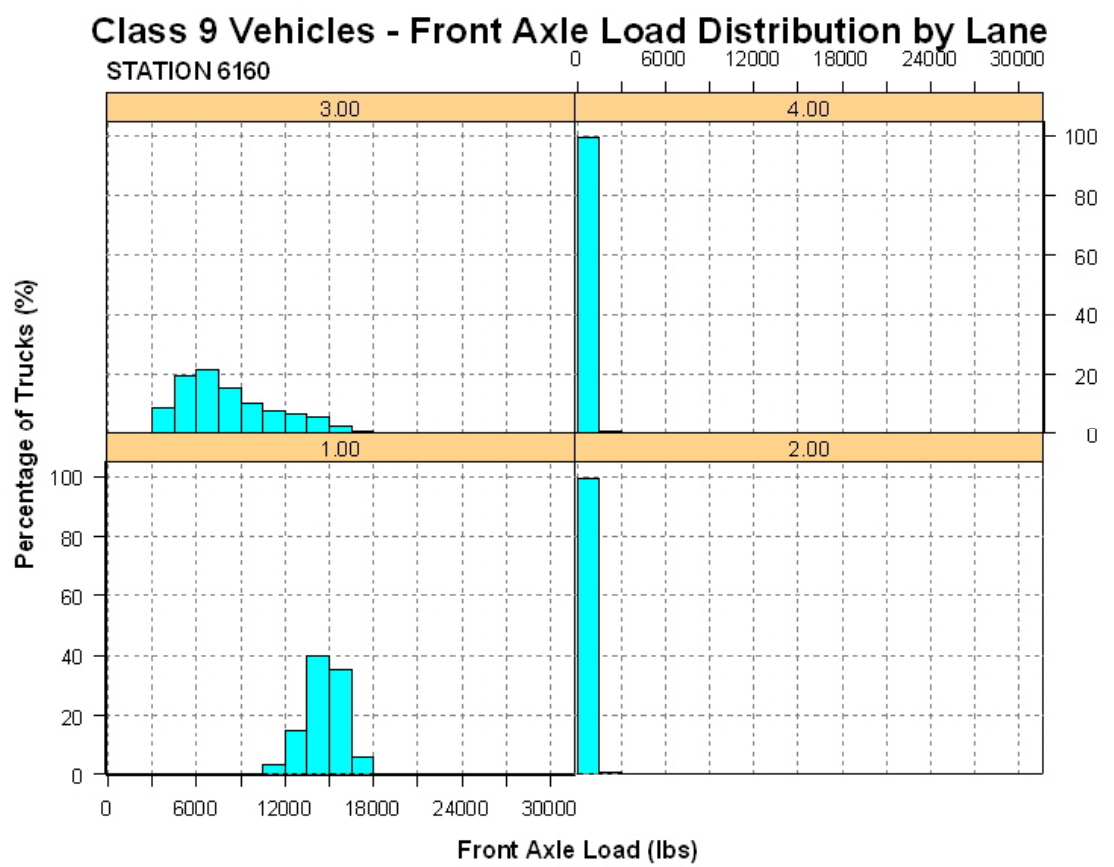

Figure F-53: Station 6160, Class 9 Vehicles - Front Axle Load Distribution

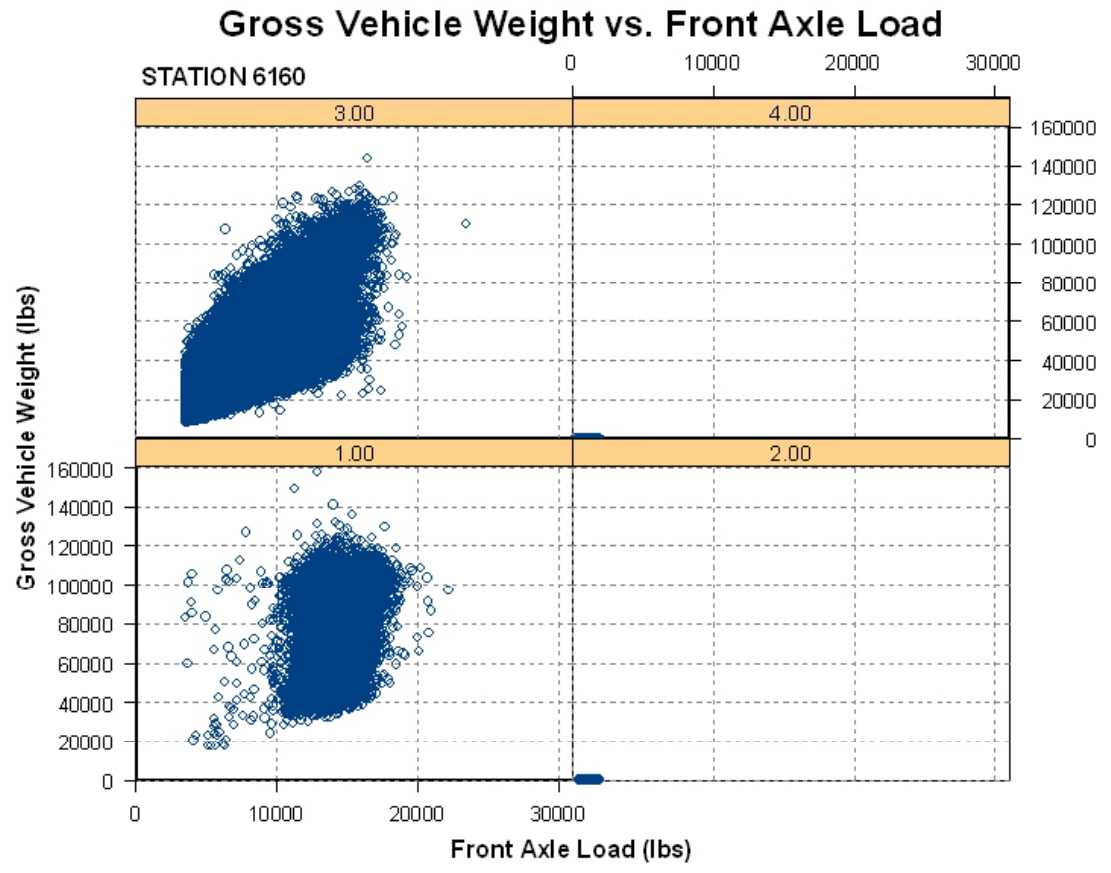

Figure F-54: Station 6160, Class 9 Vehicles - Gross Vehicle Weight vs. Front Axle 


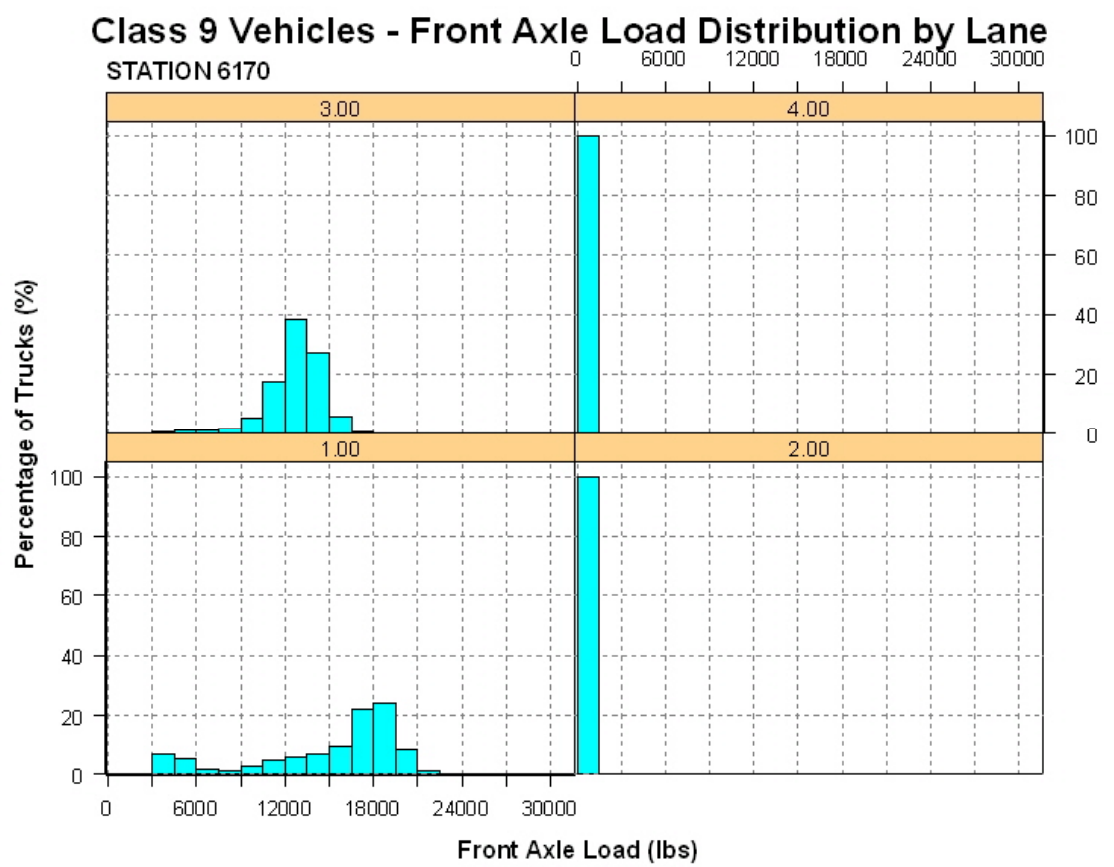

Figure F-55: Station 6170, Class 9 Vehicles - Front Axle Load Distribution

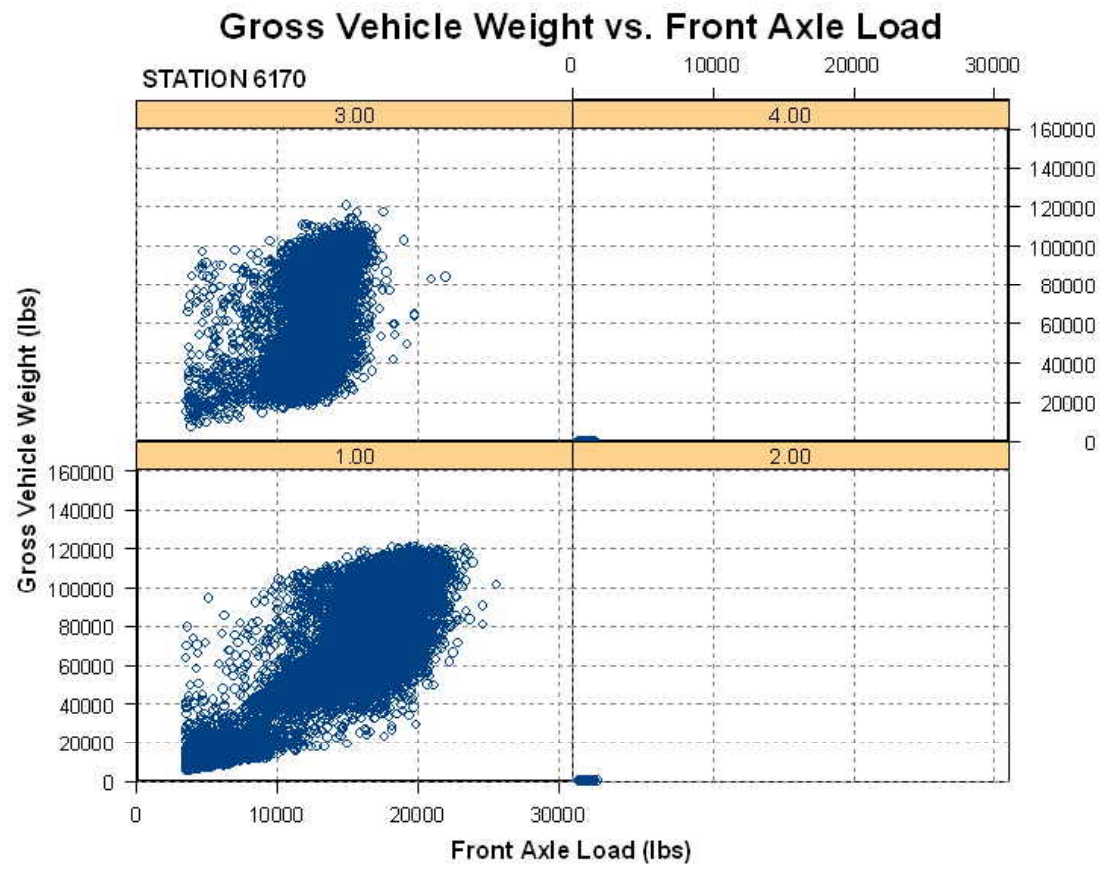

Figure F-56: Station 6170, Class 9 Vehicles - Gross Vehicle Weight vs. Front Axle 


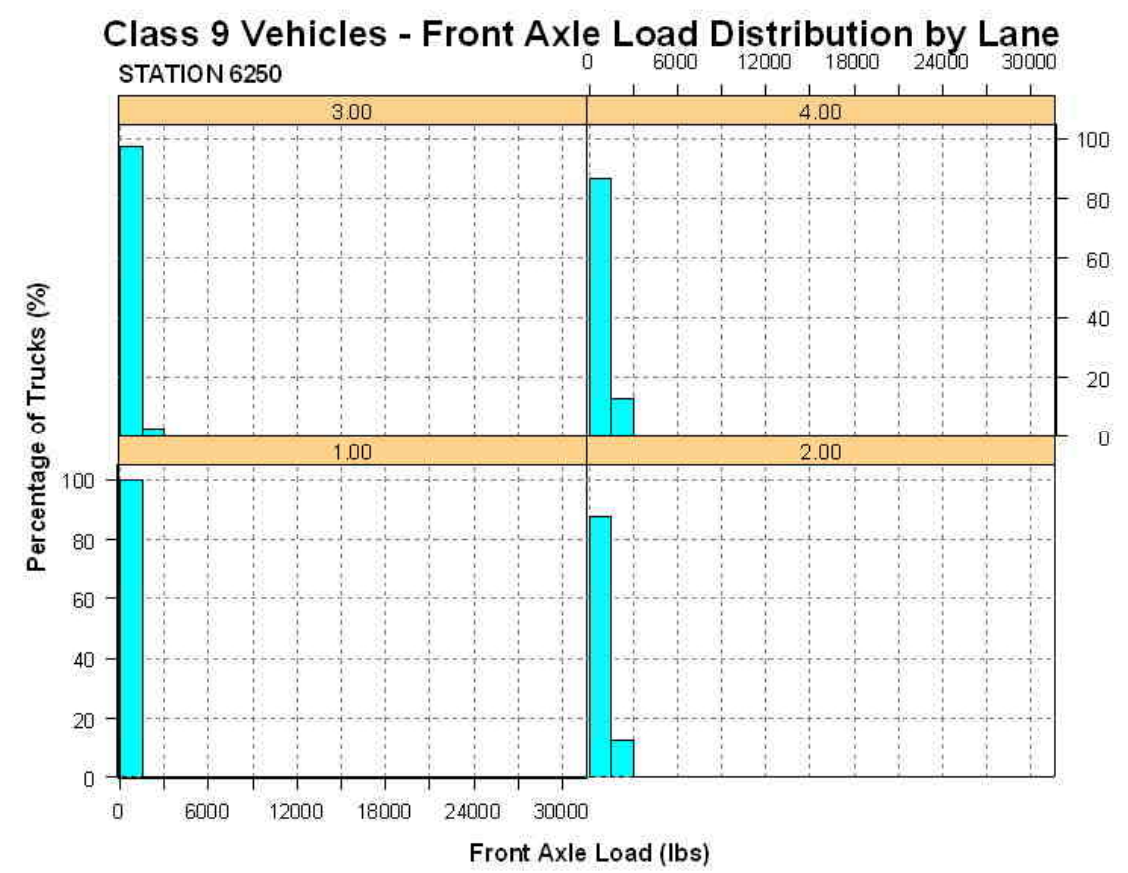

Figure F-57: Station 6250, Class 9 Vehicles - Front Axle Load Distribution

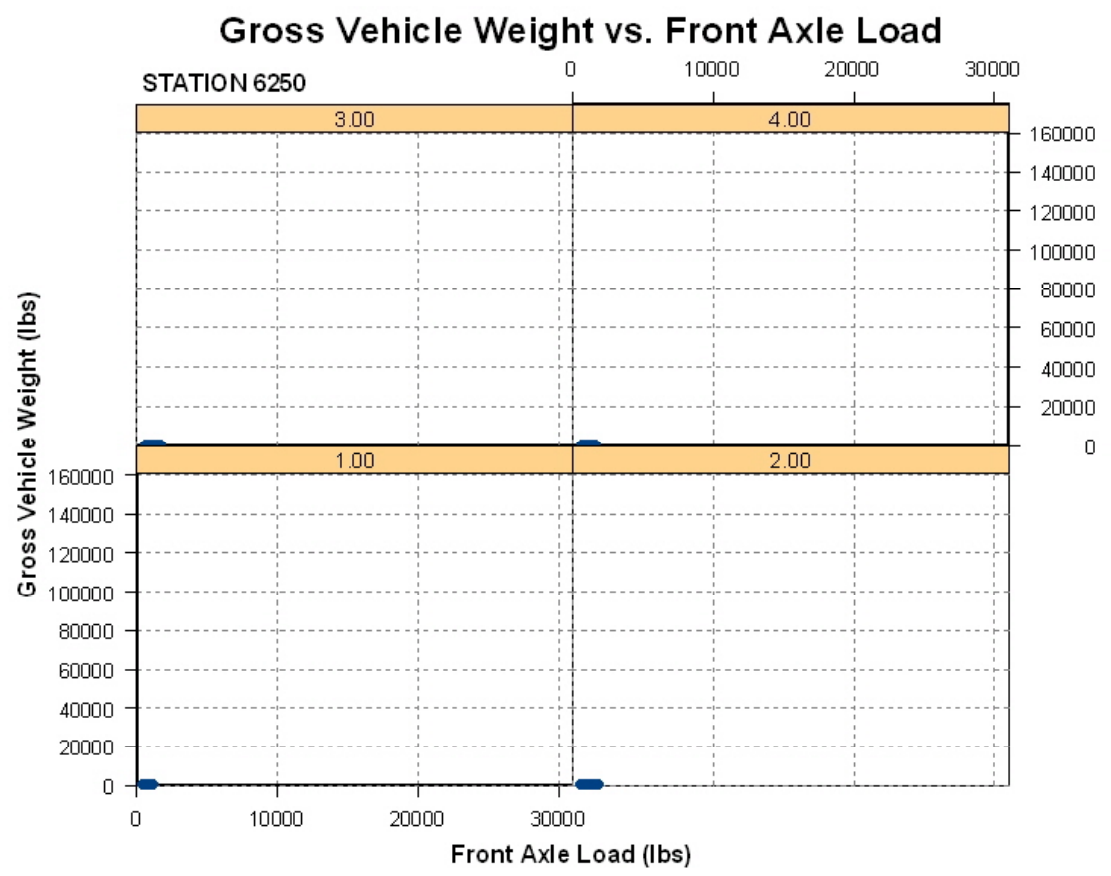

Figure F-58: Station 6250, Class 9 Vehicles - Gross Vehicle Weight vs. Front Axle 


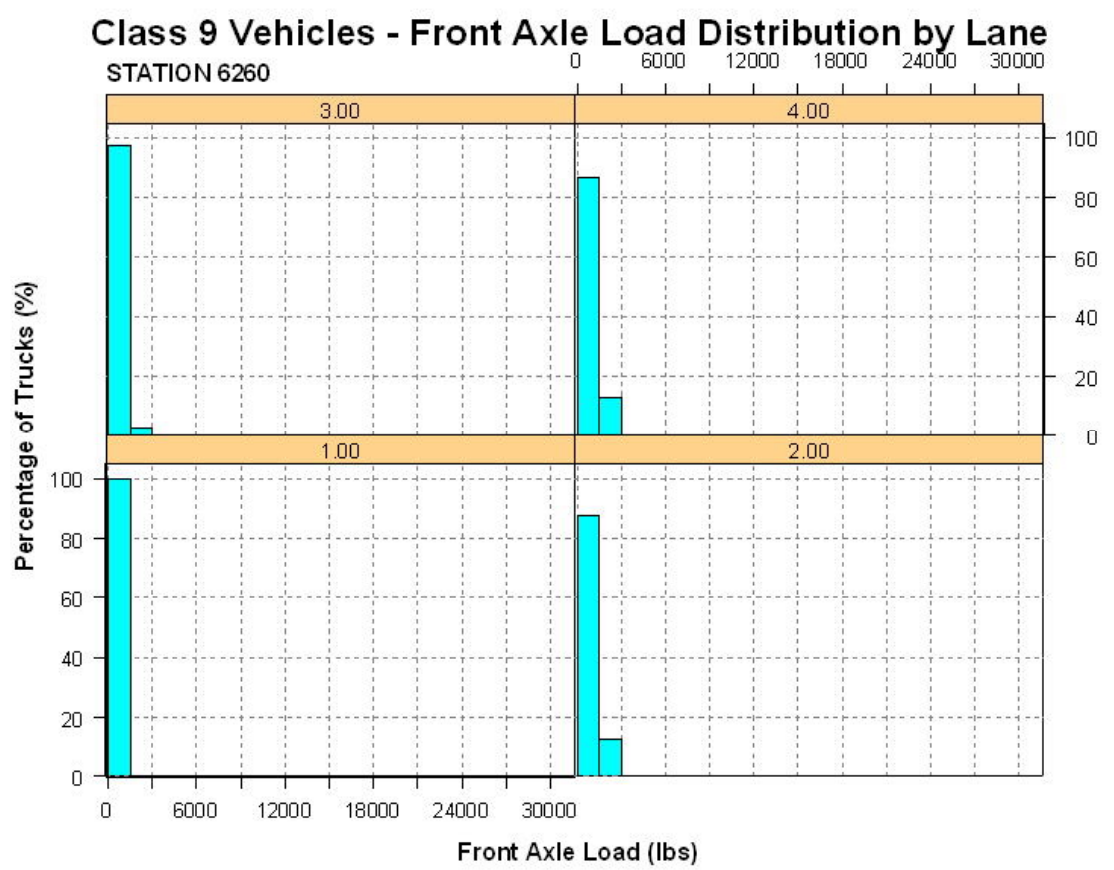

Figure F-59: Station 6260, Class 9 Vehicles - Front Axle Load Distribution

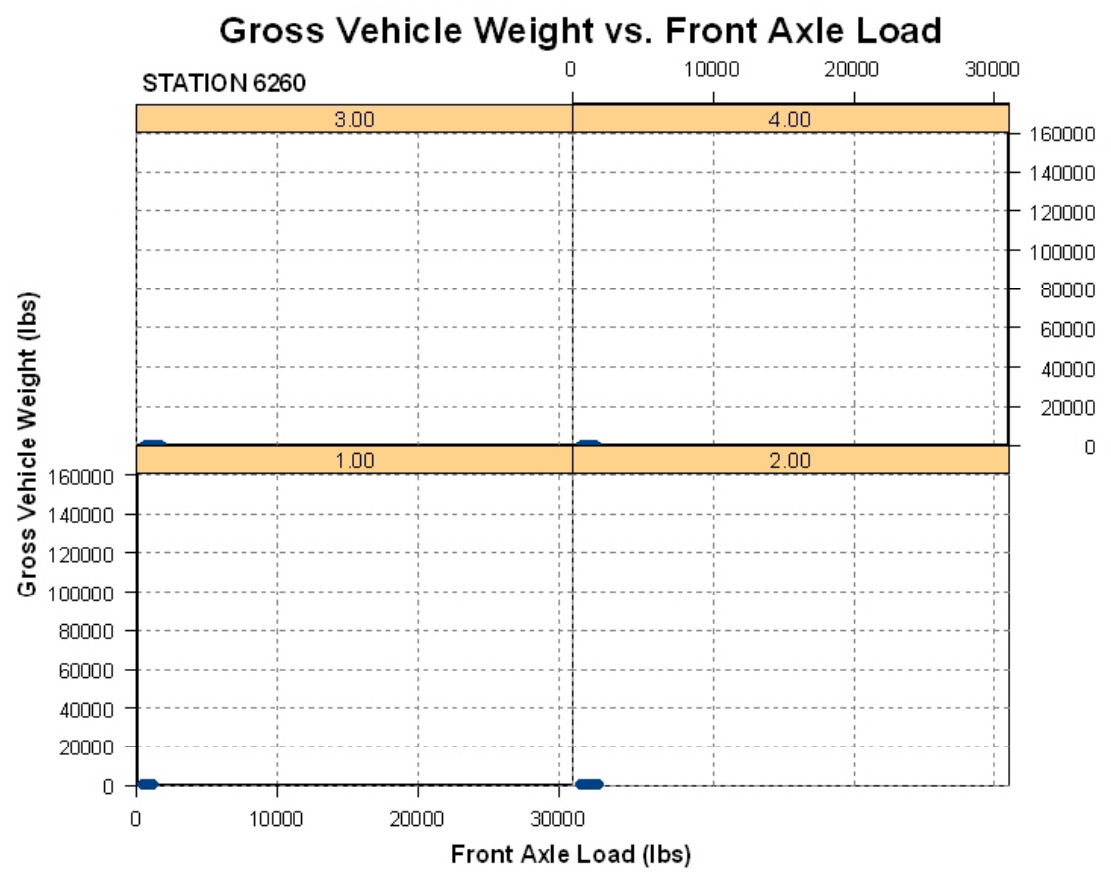

Figure F-60: Station 6260, Class 9 Vehicles - Gross Vehicle Weight vs. Front Axle 


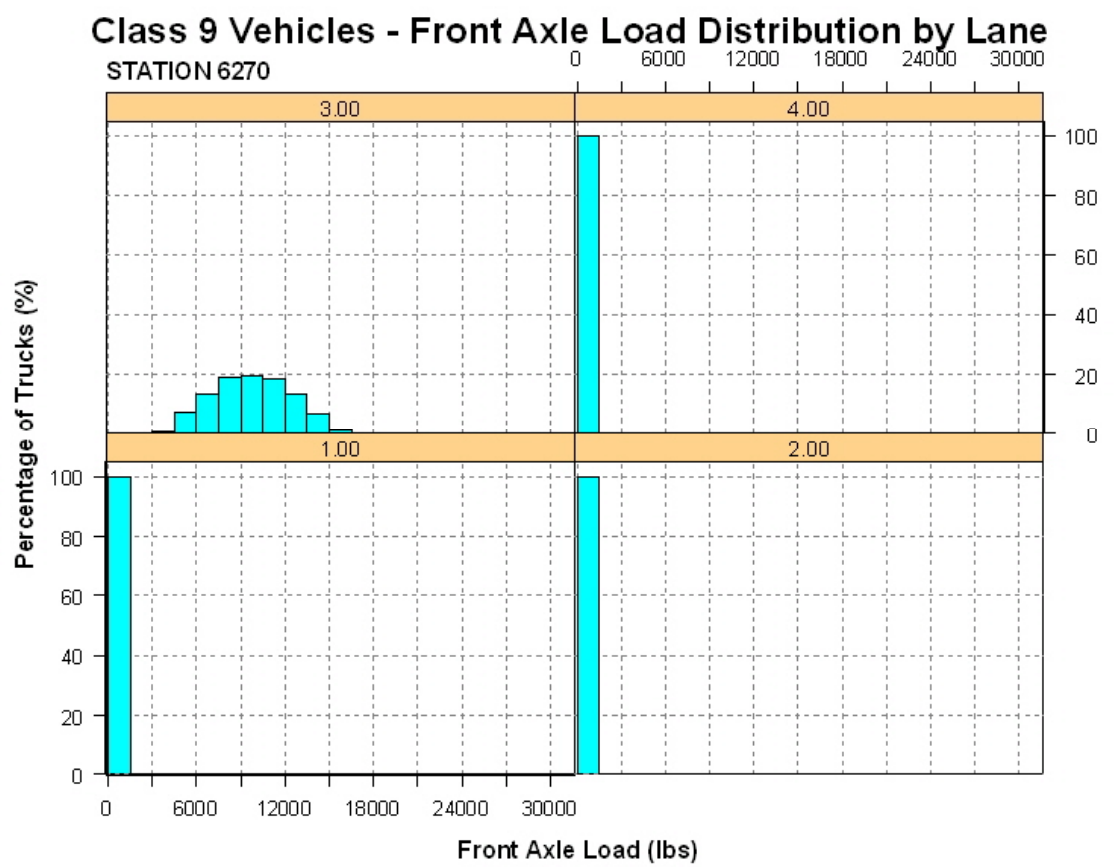

Figure F-61: Station 6270, Class 9 Vehicles - Front Axle Load Distribution

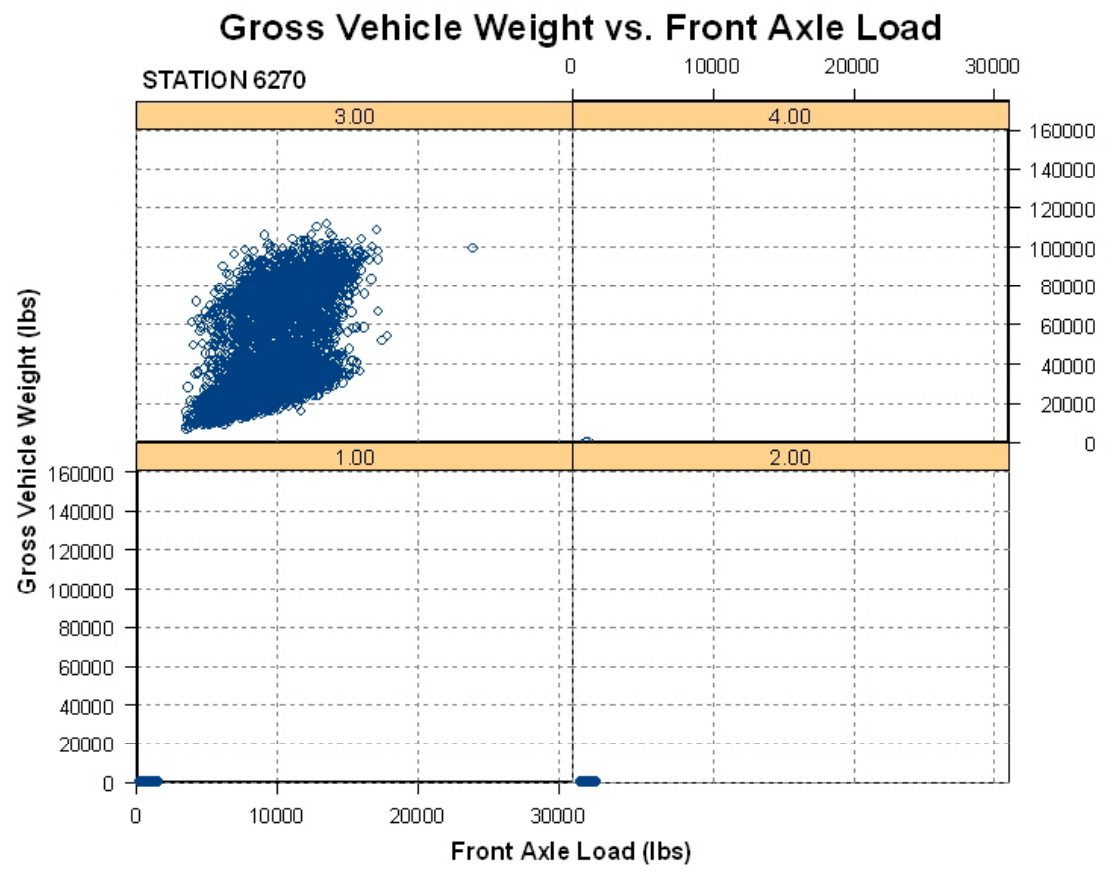

Figure F-62: Station 6270, Class 9 Vehicles - Gross Vehicle Weight vs. Front Axle 


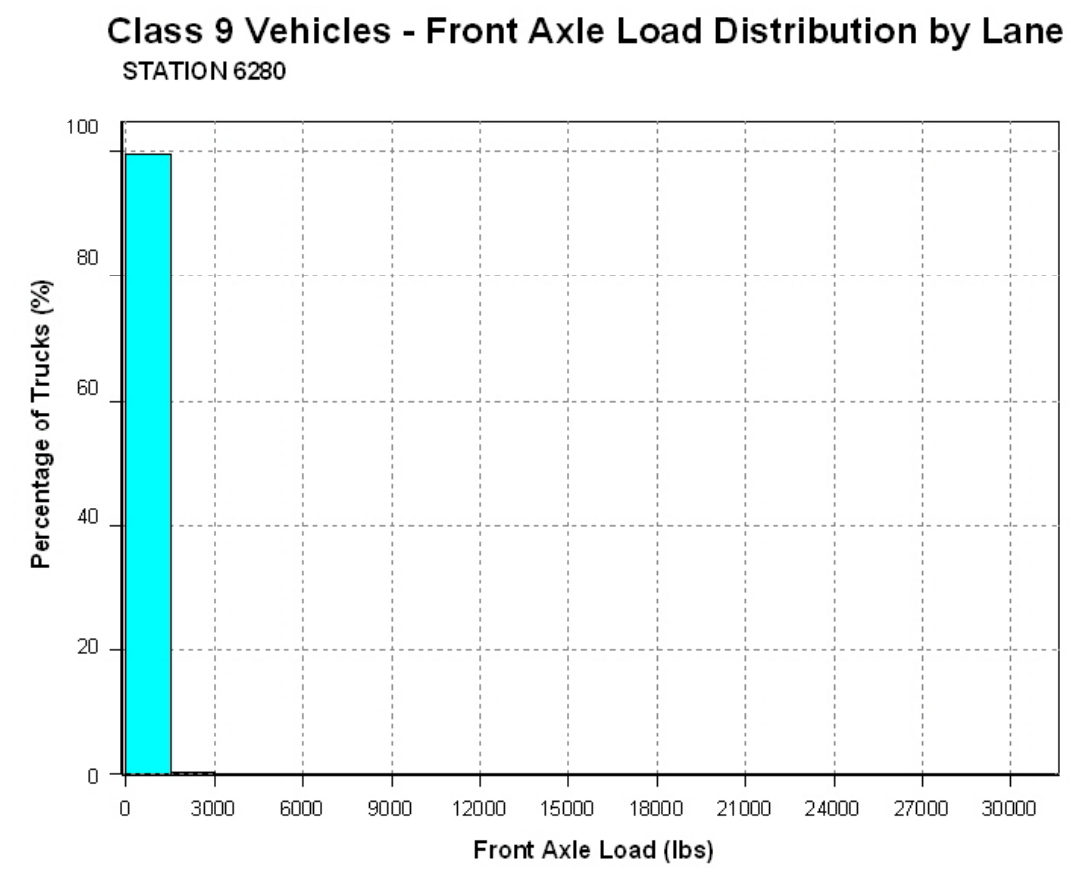

Figure F-63: Station 6280, Class 9 Vehicles - Front Axle Load Distribution

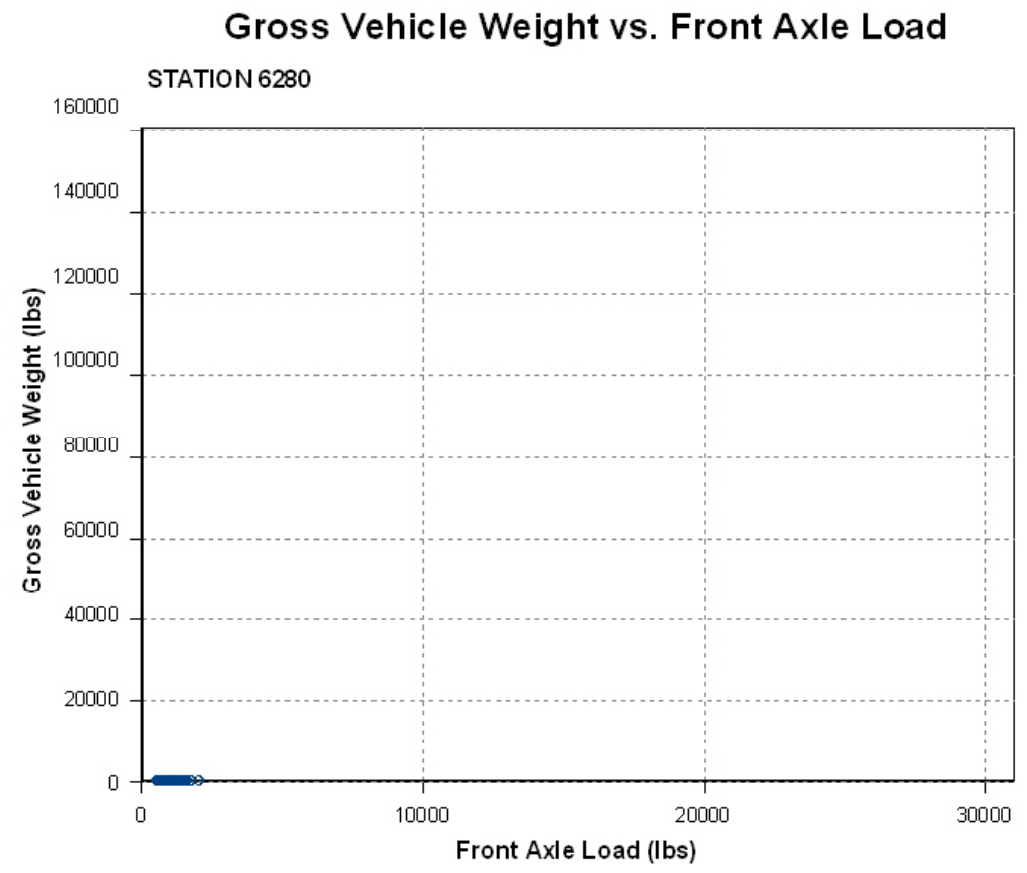

Figure F-64: Station 6280, Class 9 Vehicles - Gross Vehicle Weight vs. Front Axle 


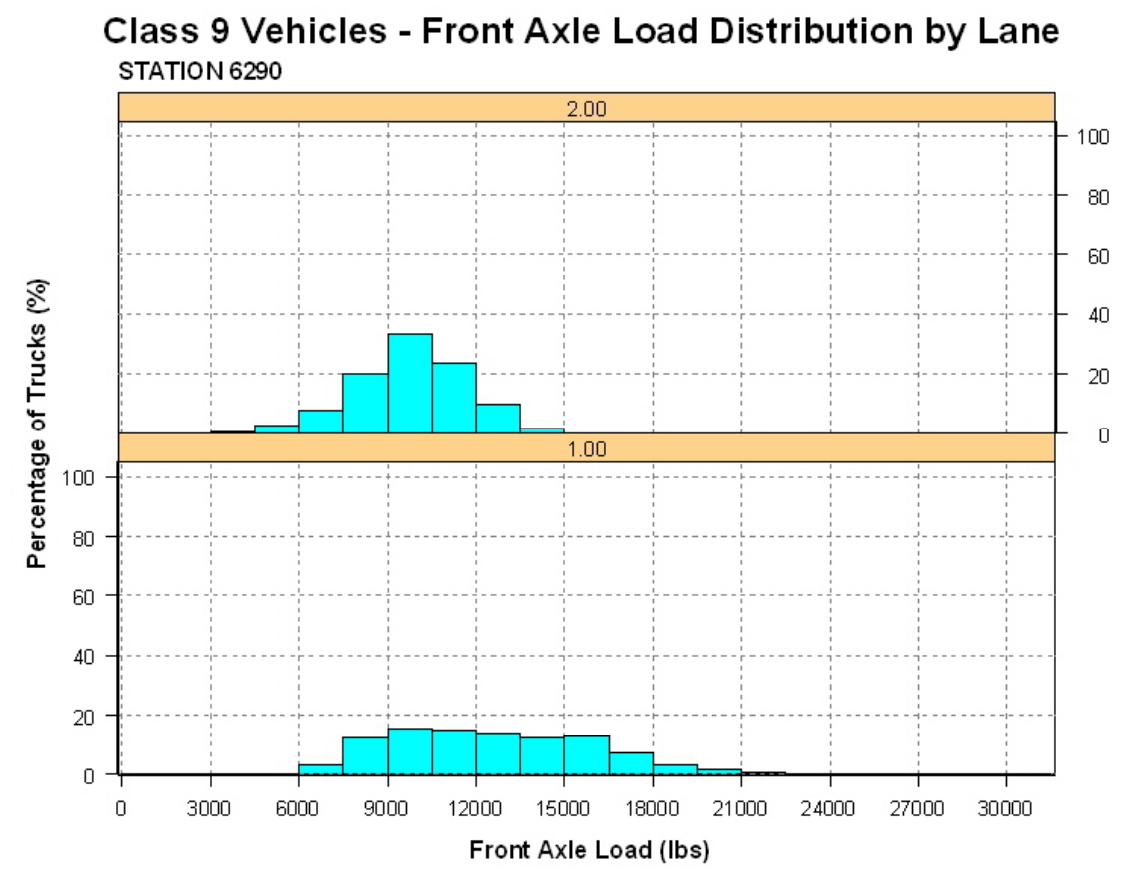

Figure F-65: Station 6290, Class 9 Vehicles - Front Axle Load Distribution

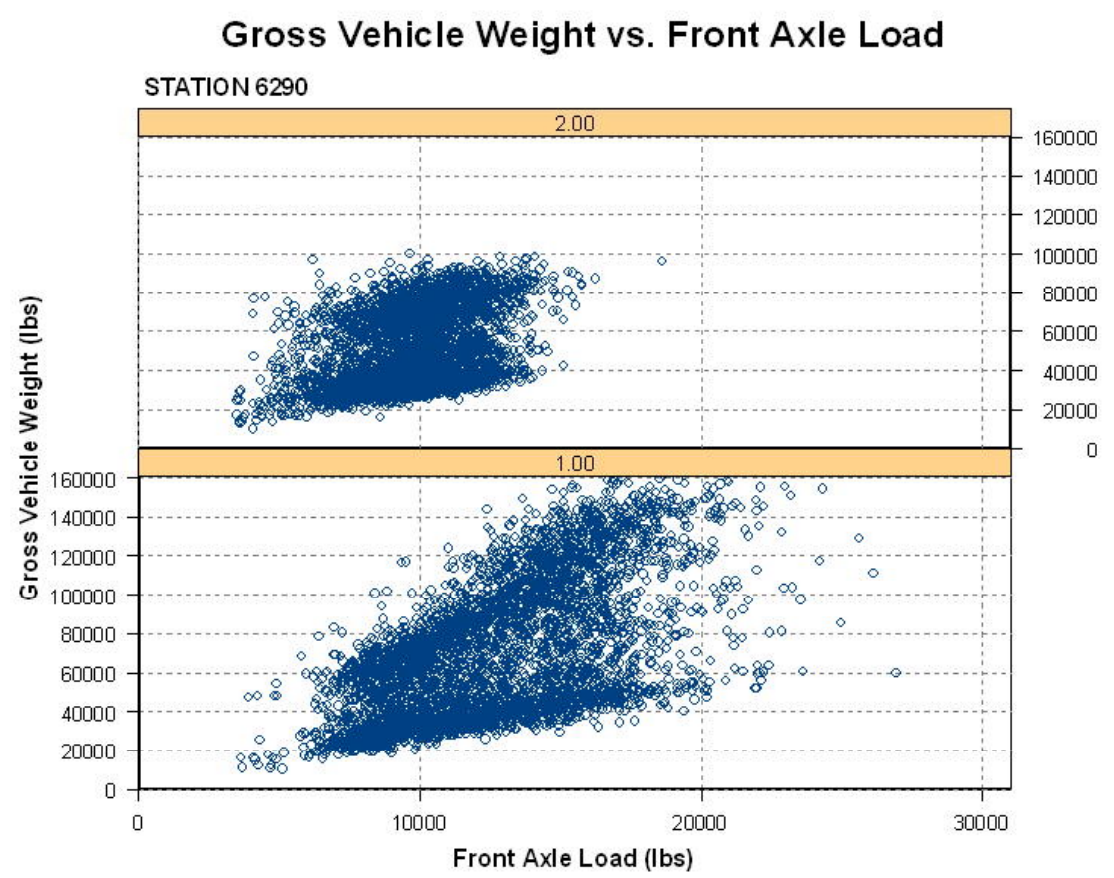

Figure F-66: Station 6290, Class 9 Vehicles - Gross Vehicle Weight vs. Front Axle 


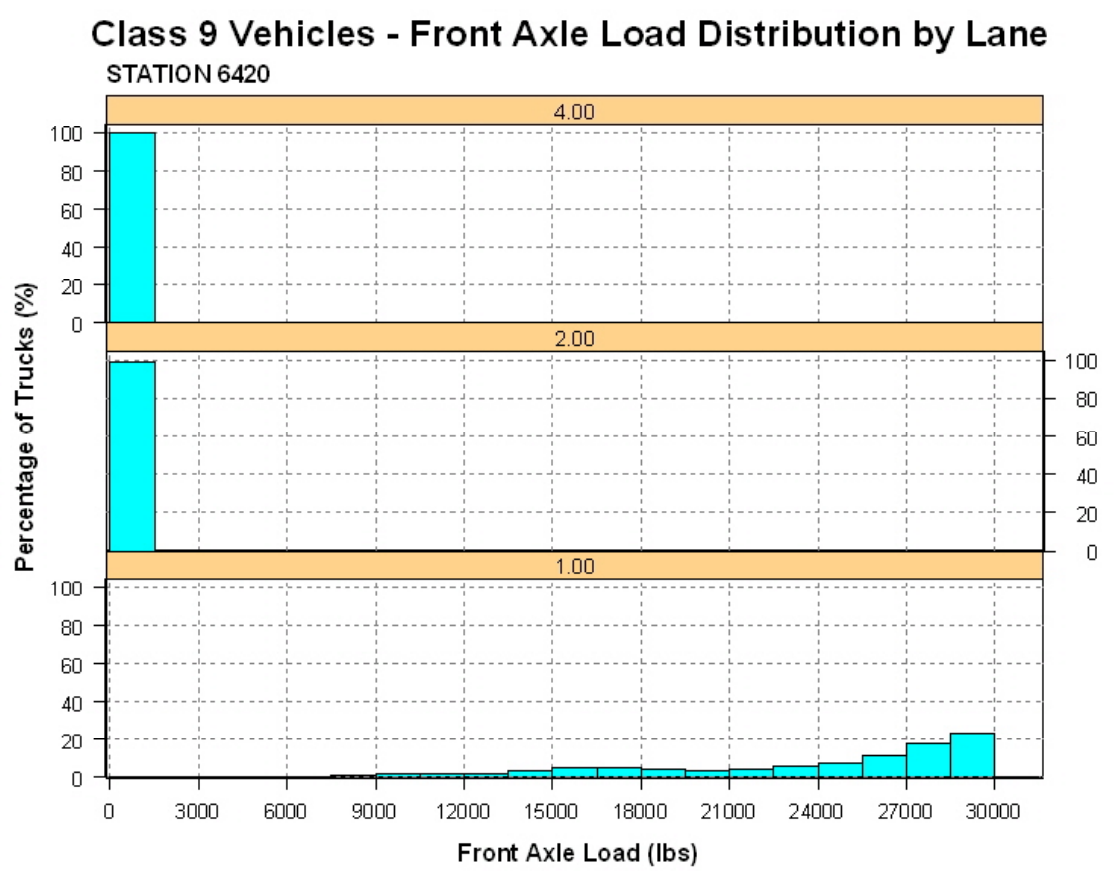

Figure F-67: Station 6420, Class 9 Vehicles - Front Axle Load Distribution

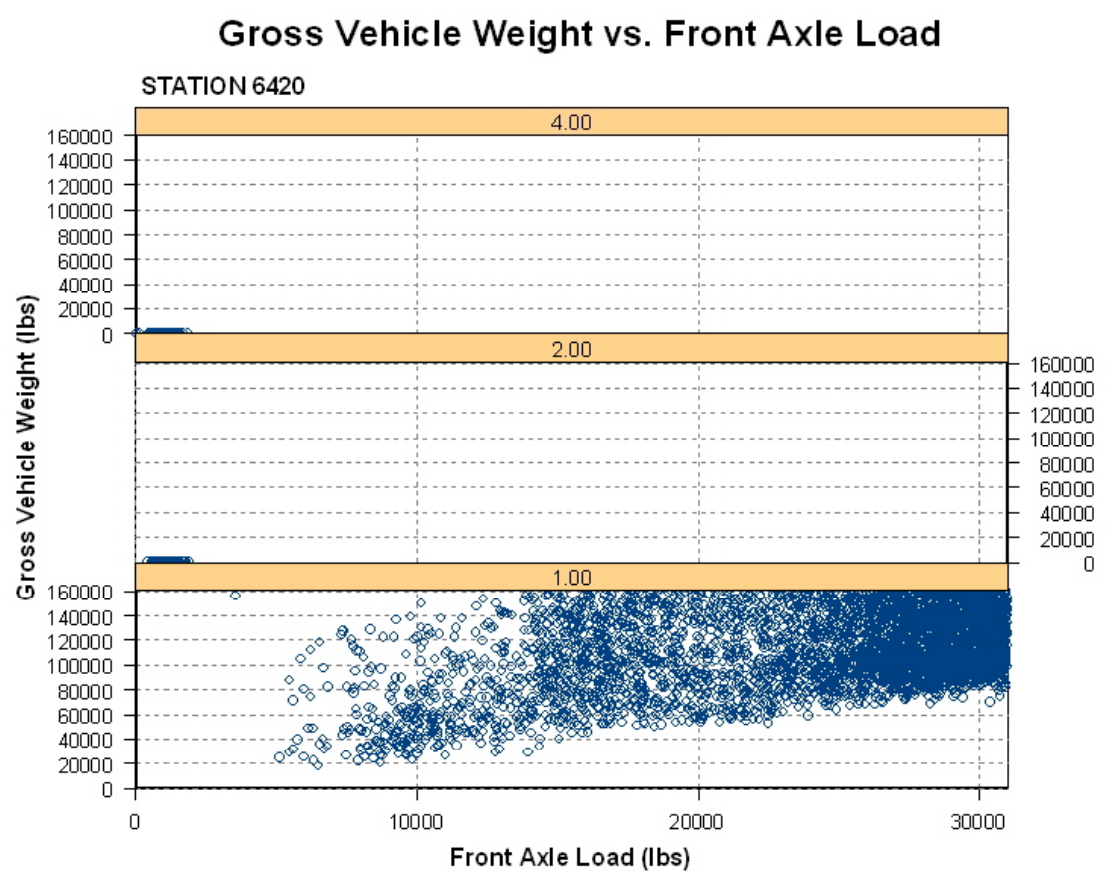

Figure F-68: Station 6420, Class 9 Vehicles - Gross Vehicle Weight vs. Front Axle 
Appendix G Merrillville WIM Test 3-23-01 


\begin{tabular}{|c|c|c|c|c|c|c|c|c|c|c|}
\hline $\begin{array}{l}3 / 23 / 01 \\
\text { Station \#441 } \\
\text { NB }\end{array}$ & & & & & & & & & & \\
\hline $\begin{array}{l}\text { Record } \\
8679\end{array}$ & $\begin{array}{c}\text { Time } \\
\text { 7:32 AM }\end{array}$ & $\begin{array}{c}\text { Lane } \\
2\end{array}$ & $\begin{array}{l}\text { WIM } \\
\text { Portable }\end{array}$ & $\begin{array}{r}\text { Axle } 1 \\
11.2 \\
11.6\end{array}$ & $\begin{array}{r}\text { Axle } 2 \\
14.4 \\
15.2\end{array}$ & $\begin{array}{r}\text { Axle } 3 \\
13.9 \\
14.8\end{array}$ & $\begin{array}{r}\text { Axle } 4 \\
16.5 \\
14.9\end{array}$ & $\begin{array}{r}\text { Axle } 5 \\
15.2 \\
16.0\end{array}$ & $\begin{array}{r}\text { GVW } \\
71.2 \\
72.5 \\
-1.3\end{array}$ & $\begin{array}{l}\% \text { Error } \\
-1.79 \%\end{array}$ \\
\hline 10093 & $8: 15$ AM & 1 & $\begin{array}{l}\text { WIM } \\
\text { Portable }\end{array}$ & $\begin{array}{l}11.8 \\
11.9\end{array}$ & $\begin{array}{l}16.4 \\
16.8\end{array}$ & $\begin{array}{l}16.8 \\
16.0\end{array}$ & $\begin{array}{l}15.5 \\
15.8\end{array}$ & $\begin{array}{l}14.9 \\
15.5\end{array}$ & $\begin{array}{l}75.4 \\
76.0 \\
-0.6\end{array}$ & $-0.79 \%$ \\
\hline 11130 & 8:46 AM & 1 & $\begin{array}{l}\text { WIM } \\
\text { Portable }\end{array}$ & $\begin{array}{l}11.1 \\
10.2\end{array}$ & $\begin{array}{l}16.8 \\
16.3\end{array}$ & $\begin{array}{l}16.9 \\
16.8\end{array}$ & $\begin{array}{l}16.6 \\
16.5\end{array}$ & $\begin{array}{l}19.4 \\
16.4\end{array}$ & $\begin{array}{r}80.8 \\
76.2 \\
4.6\end{array}$ & $6.04 \%$ \\
\hline 12132 & $9: 18$ AM & 1 & $\begin{array}{l}\text { WIM } \\
\text { Portable }\end{array}$ & $\begin{array}{l}12.5 \\
12.2\end{array}$ & $\begin{array}{l}16.6 \\
15.9\end{array}$ & $\begin{array}{l}16.5 \\
16.3\end{array}$ & $\begin{array}{l}15.5 \\
14.0\end{array}$ & $\begin{array}{l}16.7 \\
17.0\end{array}$ & $\begin{array}{r}77.8 \\
75.4 \\
2.4\end{array}$ & $3.18 \%$ \\
\hline 13522 & $10: 06$ AM & 1 & $\begin{array}{l}\text { WIM } \\
\text { Portable }\end{array}$ & $\begin{array}{l}12.5 \\
12.7\end{array}$ & $\begin{array}{l}15.4 \\
15.8\end{array}$ & $\begin{array}{l}15.7 \\
16.3\end{array}$ & $\begin{array}{l}15.3 \\
14.7\end{array}$ & $\begin{array}{l}20.3 \\
17.7\end{array}$ & $\begin{array}{r}79.2 \\
77.2 \\
2.0\end{array}$ & $2.59 \%$ \\
\hline 15038 & $10: 54 \mathrm{AM}$ & 3 & $\begin{array}{l}\text { WIM } \\
\text { Portable }\end{array}$ & $\begin{array}{l}12.6 \\
12.2\end{array}$ & $\begin{array}{l}17.3 \\
16.2\end{array}$ & $\begin{array}{l}16.2 \\
16.6\end{array}$ & $\begin{array}{l}16.7 \\
15.4\end{array}$ & $\begin{array}{l}16.7 \\
17.0\end{array}$ & $\begin{array}{r}79.6 \\
77.3 \\
2.3\end{array}$ & $3.04 \%$ \\
\hline 16548 & $11: 42$ AM & 1 & $\begin{array}{l}\text { WIM } \\
\text { Portable }\end{array}$ & $\begin{array}{l}10.4 \\
11.1\end{array}$ & $\begin{array}{l}17.8 \\
14.4\end{array}$ & $\begin{array}{l}17.2 \\
14.6\end{array}$ & $\begin{array}{l}19.5 \\
18.2\end{array}$ & $\begin{array}{l}19.2 \\
17.2\end{array}$ & $\begin{array}{r}84.0 \\
75.4 \\
8.7\end{array}$ & $11.48 \%$ \\
\hline 17419 & 12:08 PM & 2 & $\begin{array}{l}\text { WIM } \\
\text { Portable }\end{array}$ & $\begin{array}{l}11.1 \\
11.5\end{array}$ & $\begin{array}{l}15.5 \\
16.3\end{array}$ & $\begin{array}{l}15.6 \\
16.1\end{array}$ & $\begin{array}{l}16.7 \\
17.7\end{array}$ & $\begin{array}{l}16.7 \\
16.5\end{array}$ & $\begin{array}{l}75.7 \\
78.1 \\
-2.3\end{array}$ & $-3.01 \%$ \\
\hline 18261 & 12:33 PM & 1 & $\begin{array}{l}\text { WIM } \\
\text { Portable }\end{array}$ & $\begin{array}{l}9.2 \\
9.0\end{array}$ & $\begin{array}{l}23.9 \\
19.1\end{array}$ & $\begin{array}{l}22.5 \\
19.6\end{array}$ & $\begin{array}{l}22.1 \\
20.7\end{array}$ & $\begin{array}{l}19.5 \\
16.5\end{array}$ & $\begin{array}{l}97.2 \\
84.8 \\
12.5\end{array}$ & $14.69 \%$ \\
\hline
\end{tabular}

Table G-1: WIM \#4410 Comparison to Portable Scales Test Results, 3-23-01 


\section{Comparison to Portable Scales WIM \#4410}

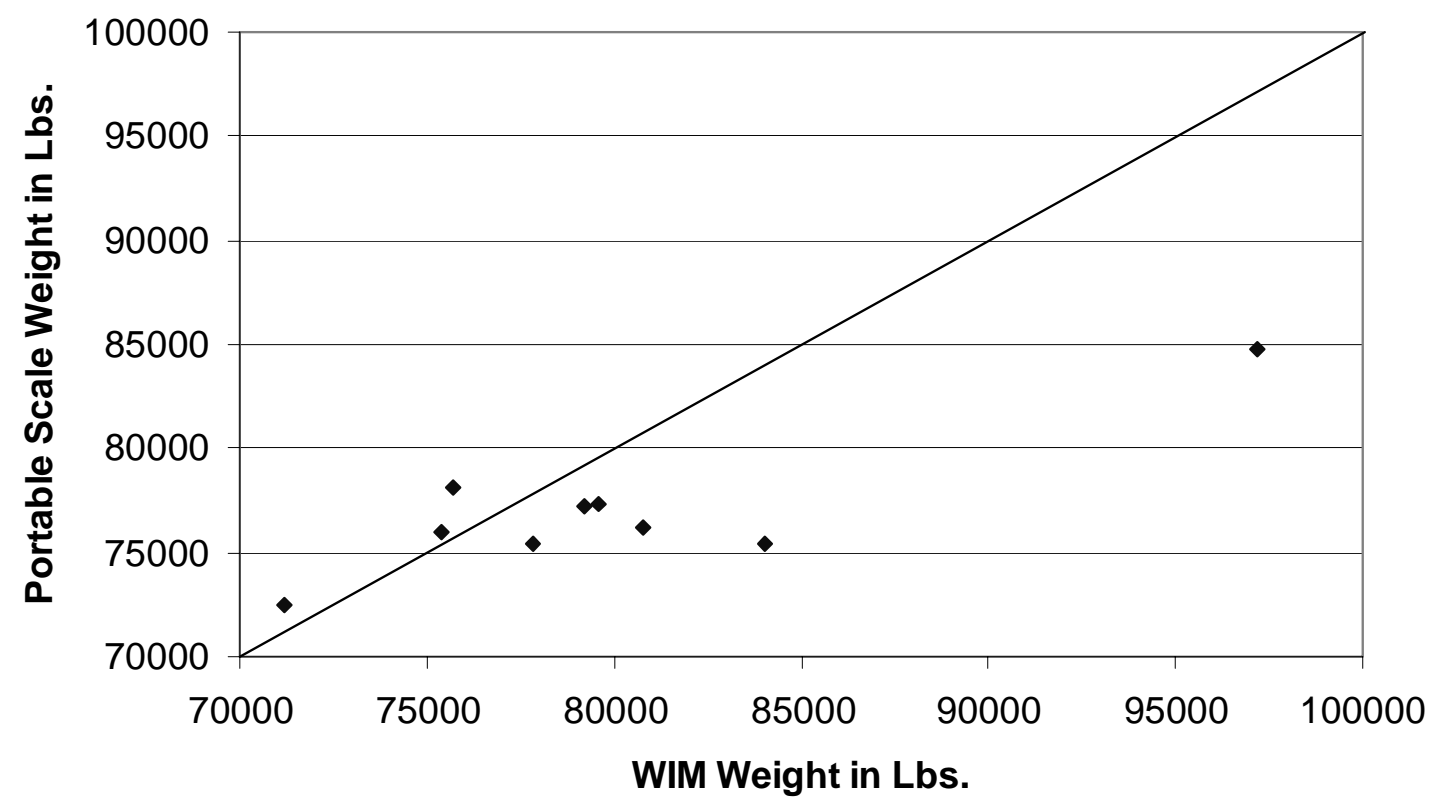

Figure G-1: WIM \#4410 Comparison to Portable Scales Test Results, 3-23-01 
Appendix H Assessment of WIM Accuracy and Precision 


\begin{tabular}{|c|c|c|c|c|c|c|c|c|c|}
\hline \multirow[b]{3}{*}{ STE } & \multirow[b]{3}{*}{ Lane } & \multicolumn{3}{|c|}{ Mer-01 } & \multicolumn{3}{|c|}{ Inم0 } & \multirow{3}{*}{$\begin{array}{c}\text { Front AxeLoed } \\
\text { 20002001 } \\
\text { \%change }\end{array}$} & \multirow{3}{*}{$\begin{array}{l}\text { VehideCant } \\
\text { \%dhenge }\end{array}$} \\
\hline & & \multicolumn{2}{|c|}{ Font Axe Loed(lbs) } & \multirow[b]{2}{*}{$\begin{array}{l}\text { Vehide } \\
\text { Count }\end{array}$} & \multicolumn{2}{|c|}{ Frant AdeLoed(lbs) } & \multirow[b]{2}{*}{$\begin{array}{l}\text { Vehide } \\
\text { Cant }\end{array}$} & & \\
\hline & & Meen & ScDev & & Mean & ScDev & & & \\
\hline 4110 & 3 & 33,689 & 5,256 & 15,359 & 37,733 & 5,803 & 63,524 & $-11 \%$ & $-76 \%$ \\
\hline 4260 & 1 & 16,702 & 5,759 & 20,048 & 697 & 126 & 20,599 & $2296 \%$ & $-3 \%$ \\
\hline 5480 & 2 & 16,004 & 3,641 & 4,581 & 17,618 & 3,742 & 5,100 & $-9 \%$ & $-10 \%$ \\
\hline 6140 & 3 & 14,710 & 2,672 & 34,753 & 10,943 & 2939 & 18,12 & $34 \%$ & $92 \%$ \\
\hline 4150 & 1 & 14,262 & 1,634 & 71,305 & 12,096 & 1,295 & 60,58 & $18 \%$ & $18 \%$ \\
\hline 6160 & 1 & 14,184 & 1,831 & 54,036 & 14,90 & $1,3 / 6$ & 23,01 & $-3 \%$ & $135 \%$ \\
\hline 5550 & 3 & 13,562 & 6,341 & 8,412 & 1,034 & & & $1211 \%$ & $841100 \%$ \\
\hline 5500 & 1 & 13,315 & $6,5 / 2$ & 8,252 & 1,059 & 188 & 6,95 & $115 \%$ & $19 \%$ \\
\hline 6270 & 3 & 13,132 & 2,040 & 9,069 & 9,765 & 2606 & 5,010 & $35 \%$ & $81 \%$ \\
\hline 5480 & 4 & 12739 & 4,050 & 5,639 & 15,507 & 2854 & $8,5 \pi$ & $-18 \%$ & $-34 \%$ \\
\hline 6290 & 1 & 12,648 & 3,636 & 8,602 & 12,626 & 3,452 & 4,510 & $0 \%$ & $91 \%$ \\
\hline 5440 & 3 & 12,179 & 2,063 & 95,105 & 10,550 & 1,450 & 79,34 & $15 \%$ & $20 \%$ \\
\hline 5120 & 2 & 12,002 & 1,702 & 9,353 & 12,816 & 1,496 & 14,418 & $-6 \%$ & $-35 \%$ \\
\hline 6280 & 1 & 11,677 & 1,711 & 8 & & & 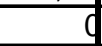 & & \\
\hline 4400 & 1 & 11,609 & 4,546 & 153,922 & & & & & \\
\hline 4150 & 2 & 11,350 & 1,462 & 6,574 & 10,174 & 1,968 & 5,88 & $12 \%$ & $12 \%$ \\
\hline 4130 & 3 & 11,241 & 4,423 & 227 & 15,436 & 4,399 & 22 & $-27 \%$ & $-1 \%$ \\
\hline 4400 & 2 & 11,135 & 5,714 & 62,392 & & & & & \\
\hline 5470 & 6 & 11,025 & 3,445 & 962 & $23,8 / 6$ & 6,098 & 1,08 & $-54 \%$ & $-12 \%$ \\
\hline 7340 & 4 & $10,9 / 5$ & 3,147 & 5,097 & & & & & \\
\hline 4400 & 5 & 10,928 & 2657 & 175,245 & & & & & \\
\hline 4250 & 3 & 10,915 & 1,261 & 3,863 & 10,867 & 1,186 & 3,73 & $0 \%$ & $4 \%$ \\
\hline 5450 & 3 & 10,869 & 2,612 & 116,942 & 13,189 & 3,095 & 104,500 & $-18 \%$ & $12 \%$ \\
\hline 4150 & 3 & 10,693 & 1,265 & 62,198 & 9,586 & 1,386 & 60,064 & $12 \%$ & $4 \%$ \\
\hline 4130 & 6 & 10,517 & 4,149 & 459 & 14,007 & 4,260 & 398 & $-25 \%$ & $16 \%$ \\
\hline 4150 & 4 & 10,498 & 1,377 & 7,211 & 10,659 & 1,623 & 6,286 & $-2 \%$ & $15 \%$ \\
\hline 4400 & 4 & 10,492 & 2621 & 164,704 & & & & & \\
\hline 4280 & 1 & 10,486 & 1,286 & 8,743 & 8,794 & 998 & 13,513 & $19 \%$ & $-35 \%$ \\
\hline 5120 & 4 & 10,461 & 1,474 & 9,799 & 10,850 & 6,234 & 149 & $-4 \%$ & $621 \%$ \\
\hline 5470 & 3 & 10,442 & 2,854 & 496 & 10,280 & 2,484 & 54 & $2 \%$ & $-9 \%$ \\
\hline 4270 & 1 & 10,419 & 1,749 & 11,799 & 8,540 & 1,430 & 9,424 & $22 \%$ & $25 \%$ \\
\hline 4130 & 2 & 10,401 & 1,016 & 10,640 & 10,305 & 964 & 41,09 & $1 \%$ & $-74 \%$ \\
\hline 7300 & 4 & 10,398 & 2,249 & 11,982 & & & & & \\
\hline
\end{tabular}

Table H-1: Average Class 9 Front Axle Weight for All WIM Lanes, Sorted by Front Axle Weight (33,689-10,398) 


\begin{tabular}{|c|c|c|c|c|c|c|c|c|c|}
\hline \multirow[b]{3}{*}{ SITE } & \multirow[b]{3}{*}{ Lane } & \multicolumn{3}{|c|}{ Mar-01 } & \multicolumn{3}{|c|}{ Jun-00 } & \multirow[b]{2}{*}{ Front Axle } & \multirow[b]{2}{*}{ Vehicle } \\
\hline & & \multicolumn{2}{|c|}{ Front Axle Load (Ibs) } & \multirow[b]{2}{*}{$\begin{array}{c}\text { Vehicle } \\
\text { Count }\end{array}$} & \multicolumn{2}{|c|}{ Front Axle Load } & \multirow[b]{2}{*}{$\begin{array}{c}\text { Vehicle } \\
\text { Count }\end{array}$} & & \\
\hline & & Mean & StdDev & & Mean & StdDev & & $\begin{array}{l}2000-2001 \\
\% \text { change }\end{array}$ & $\%$ change \\
\hline 5110 & 4 & 10,285 & 882 & 22,418 & 17,109 & 2,045 & 22,565 & $-40 \%$ & $-1 \%$ \\
\hline 7340 & 3 & 10,170 & 2,435 & 38,795 & & & & & \\
\hline 7300 & 3 & 10,139 & 1,915 & 108,307 & & & & & \\
\hline 7320 & 2 & 10,126 & 2,244 & 13,202 & & & & & \\
\hline 5140 & 3 & 10,108 & 1,967 & 29,827 & 11,307 & 1,867 & 130,393 & $-11 \%$ & $-77 \%$ \\
\hline 6150 & 1 & 10,047 & 5,609 & 19,801 & 9,315 & 1,519 & 19,216 & $8 \%$ & $3 \%$ \\
\hline 7320 & 3 & 10,030 & 2,844 & 98,022 & & & & & \\
\hline 7300 & 2 & 10,026 & 2,396 & 11,612 & & & & & \\
\hline 4400 & 6 & 10,023 & 2,563 & 963 & & & & & \\
\hline 7340 & 2 & 9,938 & 2,149 & 3,567 & & & & & \\
\hline 7300 & 1 & 9,909 & 4,169 & 96,923 & & & & & \\
\hline 7320 & 1 & 9,858 & 2,440 & 103,988 & & & & & \\
\hline 7340 & 1 & 9,846 & 2,446 & 43,214 & & & & & \\
\hline 5470 & 5 & 9,837 & 1,686 & 56,871 & 9,982 & 2,299 & 53,099 & $-2 \%$ & $7 \%$ \\
\hline 5240 & 1 & 9,826 & 1,716 & 18,437 & 13,143 & 2,191 & 16,875 & $-25 \%$ & $9 \%$ \\
\hline 5140 & 1 & 9,822 & 1,613 & 31,483 & 11,654 & 2,329 & 138,734 & $-16 \%$ & $-77 \%$ \\
\hline 5470 & 1 & 9,685 & 1,657 & 91,327 & 9,849 & 1,763 & 80,961 & $-2 \%$ & $13 \%$ \\
\hline 5470 & 4 & 9,651 & 2,746 & 89,824 & 6,720 & 2,012 & 78,858 & $44 \%$ & $14 \%$ \\
\hline 4130 & 1 & 9,626 & 1,127 & 2,859 & 9,958 & 2,049 & 89,487 & $-3 \%$ & $-97 \%$ \\
\hline 6170 & 1 & 9,561 & 3,894 & 38,425 & 15,031 & 4,905 & 29,667 & $-36 \%$ & $30 \%$ \\
\hline 4140 & 1 & 9,548 & 1,038 & 2 & 9,219 & 3,642 & 45,343 & $4 \%$ & $-100 \%$ \\
\hline 7320 & 4 & 9,539 & 5,497 & 11,569 & & & & & \\
\hline 5250 & 1 & 9,517 & 1,300 & 9,434 & 8,031 & 1,501 & 2,148 & $19 \%$ & $339 \%$ \\
\hline 5450 & 1 & 9,421 & 2,357 & 98,597 & 11,816 & 6,300 & 50,021 & $-20 \%$ & $97 \%$ \\
\hline 6160 & 3 & 9,419 & 3,508 & 45,576 & 8,265 & 3,221 & 25,878 & $14 \%$ & $76 \%$ \\
\hline 5550 & 2 & 9,213 & 4,440 & 763 & & & 0 & & \\
\hline 6170 & 3 & 9,022 & 1,572 & 26,349 & 12,663 & 2,002 & 8,889 & $-29 \%$ & $196 \%$ \\
\hline 5110 & 2 & 8,803 & 1,087 & 23,747 & 9,450 & 1,100 & 18,382 & $-7 \%$ & $29 \%$ \\
\hline 5110 & 3 & 8,771 & 931 & 116,346 & 10,599 & 1,102 & 130,871 & $-17 \%$ & $-11 \%$ \\
\hline 5550 & 4 & 8,716 & 5,373 & 200 & 967 & 527 & 53 & $801 \%$ & $277 \%$ \\
\hline 6290 & 2 & 8,700 & 4,067 & 6,604 & 9,809 & 1,891 & 4,190 & $-11 \%$ & $58 \%$ \\
\hline 5480 & 1 & 8,533 & 3,016 & 19,092 & 14,921 & 3,104 & 34,134 & $-43 \%$ & $-44 \%$ \\
\hline 5110 & 1 & 8,406 & 1,444 & 128,723 & 10,565 & 1,996 & 131,252 & $-20 \%$ & $-2 \%$ \\
\hline 4110 & 1 & 8,245 & 2,105 & 17,046 & 10,742 & 2,680 & 106,734 & $-40 \%$ & $-1 \%$ \\
\hline 4130 & 4 & 7,581 & 2,270 & 29,648 & 5,465 & 2,317 & 1,351 & & \\
\hline 5120 & 3 & 7,361 & 4,036 & 77,728 & 10,057 & 1,387 & 18,170 & & \\
\hline 6250 & 1 & 7,200 & 983 & 5,619 & 764 & 134 & 7,861 & & \\
\hline
\end{tabular}

Table H-2: Average Class 9 Front Axle Weight for All WIM Lanes, Sorted by Front Axle Weight $(\mathbf{1 0 , 2 8 5 - 7 , 2 0 0 )}$ 


\begin{tabular}{|c|c|c|c|c|c|c|c|c|c|}
\hline \multirow[b]{3}{*}{ SITE } & \multirow[b]{3}{*}{ Lane } & \multicolumn{3}{|c|}{ Mar-01 } & \multicolumn{3}{|c|}{ Jun-00 } & \multirow{3}{*}{$\begin{array}{c}\text { Front } \\
\text { Axle Load } \\
2000-2001 \\
\% \text { change }\end{array}$} & \multirow{3}{*}{$\begin{array}{c}\begin{array}{c}\text { Vehicle } \\
\text { Count }\end{array} \\
\% \text { change }\end{array}$} \\
\hline & & \multicolumn{2}{|c|}{ Front Axle Load (Ibs) } & \multirow[b]{2}{*}{$\begin{array}{c}\text { Vehicle } \\
\text { Count }\end{array}$} & \multicolumn{2}{|c|}{ Front Axle Load (Ibs) } & \multirow[b]{2}{*}{$\begin{array}{c}\text { Vehicle } \\
\text { Count }\end{array}$} & & \\
\hline & & Mean & StdDev & & Mean & StdDev & & & \\
\hline 4400 & 3 & 6,310 & 1,722 & 24 & & & & & \\
\hline 6140 & 1 & 5,783 & 1,774 & 51,296 & 11,184 & 1,564 & 43,679 & $-48 \%$ & $17 \%$ \\
\hline 5460 & 1 & 5,657 & 2,307 & 3 & 9,608 & 2,401 & 25,704 & $-41 \%$ & $-100 \%$ \\
\hline 5470 & 2 & 5,563 & 3,053 & 6 & 6,926 & 973 & 6 & $-20 \%$ & $0 \%$ \\
\hline 6250 & 4 & 1,272 & 211 & 508 & 1,272 & 206 & 654 & $0 \%$ & $-22 \%$ \\
\hline 6250 & 2 & 1,259 & 203 & 849 & 1,260 & 209 & 770 & $0 \%$ & $10 \%$ \\
\hline 4280 & 4 & 1,202 & 258 & 22 & 1,138 & 188 & 566 & $6 \%$ & $-96 \%$ \\
\hline 5120 & 1 & 1,200 & 208 & 10,203 & 1,086 & 185 & 58,264 & $11 \%$ & $-83 \%$ \\
\hline 6140 & 4 & 1,177 & 172 & 2,388 & 1,173 & 182 & 2,346 & $0 \%$ & $2 \%$ \\
\hline 6160 & 4 & 1,153 & 174 & 6,730 & 1,148 & 179 & 7,181 & $0 \%$ & $-6 \%$ \\
\hline 4280 & 2 & 1,147 & 191 & 941 & 1,139 & 183 & 789 & $1 \%$ & $19 \%$ \\
\hline 4260 & 4 & 1,138 & 227 & 968 & 1,138 & 211 & 1,217 & $0 \%$ & $-21 \%$ \\
\hline 5140 & 4 & 1,137 & 162 & 6,960 & 1,139 & 166 & 27,282 & $0 \%$ & $-75 \%$ \\
\hline 6160 & 2 & 1,134 & 168 & 5,587 & 1,139 & 170 & 5,517 & $0 \%$ & $1 \%$ \\
\hline 5140 & 2 & 1,132 & 160 & 3,642 & 1,137 & 156 & 20,005 & $0 \%$ & $-82 \%$ \\
\hline 4260 & 2 & 1,119 & 204 & 1,988 & 1,115 & 200 & 2,303 & $0 \%$ & $-14 \%$ \\
\hline 4140 & 4 & 1,112 & 162 & 8,320 & 1,263 & 180 & 4,482 & $-12 \%$ & $86 \%$ \\
\hline 6150 & 2 & 1,110 & 168 & 2,337 & 1,117 & 172 & 3,005 & $-1 \%$ & $-22 \%$ \\
\hline 5440 & 4 & 1,105 & 140 & 29,102 & 1,105 & 147 & 29,568 & $0 \%$ & $-2 \%$ \\
\hline 6250 & 3 & 1,102 & 244 & 5,709 & 1,136 & 198 & 7,359 & $-3 \%$ & $-22 \%$ \\
\hline 4250 & 4 & 1,094 & 218 & 164 & 980 & 330 & 199 & $12 \%$ & $-18 \%$ \\
\hline 6140 & 2 & 1,082 & 157 & 3,259 & 1,103 & 157 & 3,282 & $-2 \%$ & $-1 \%$ \\
\hline 5240 & 2 & 1,078 & 187 & 973 & 1,107 & 192 & 1,070 & $-3 \%$ & $-9 \%$ \\
\hline 4270 & 2 & 1,070 & 176 & 636 & 1,057 & 181 & 584 & $1 \%$ & $9 \%$ \\
\hline 5450 & 4 & 1,062 & 155 & 9 & & & 0 & & \\
\hline 4140 & 3 & 1,052 & 173 & 57,643 & 1,127 & 192 & 43,630 & $-7 \%$ & $32 \%$ \\
\hline 4270 & 4 & 1,049 & 186 & 192 & 1,064 & 187 & 460 & $-1 \%$ & $-58 \%$ \\
\hline 4250 & 2 & 1,044 & 211 & 305 & 1,030 & 198 & 269 & $1 \%$ & $13 \%$ \\
\hline 4270 & 3 & 1,038 & 176 & 8,382 & 1,045 & 182 & 8,356 & $-1 \%$ & $0 \%$ \\
\hline 4250 & 1 & 1,033 & 205 & 3,902 & 1,041 & 200 & 1,850 & $-1 \%$ & $111 \%$ \\
\hline 6130 & 4 & 1,025 & 159 & 1,064 & 1,073 & 169 & 2,187 & $-5 \%$ & $-51 \%$ \\
\hline 6130 & 2 & 1,003 & 157 & 650 & 1,106 & 187 & 1,517 & $-9 \%$ & $-57 \%$ \\
\hline 5250 & 2 & 1,001 & 179 & 1,229 & 985 & 181 & 1,573 & $2 \%$ & $-22 \%$ \\
\hline
\end{tabular}

Table H-3: Average Class 9 Axle Weight for All WIM Lanes, Sorted by Front Axle Weight (6,310-1,001) 


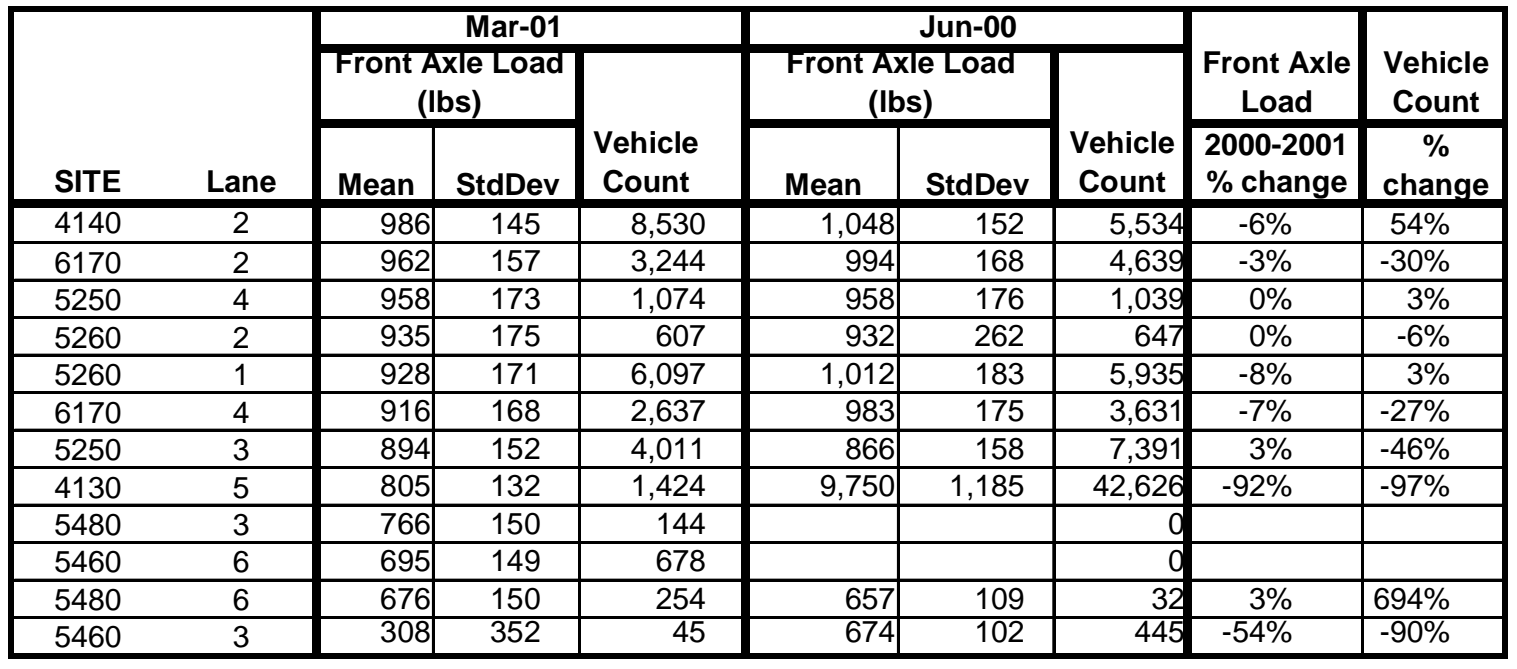

Table H-4: Average Class 9 Axle Weight for All WIM Lanes, Sorted by Front Axle Weight (986-308) 


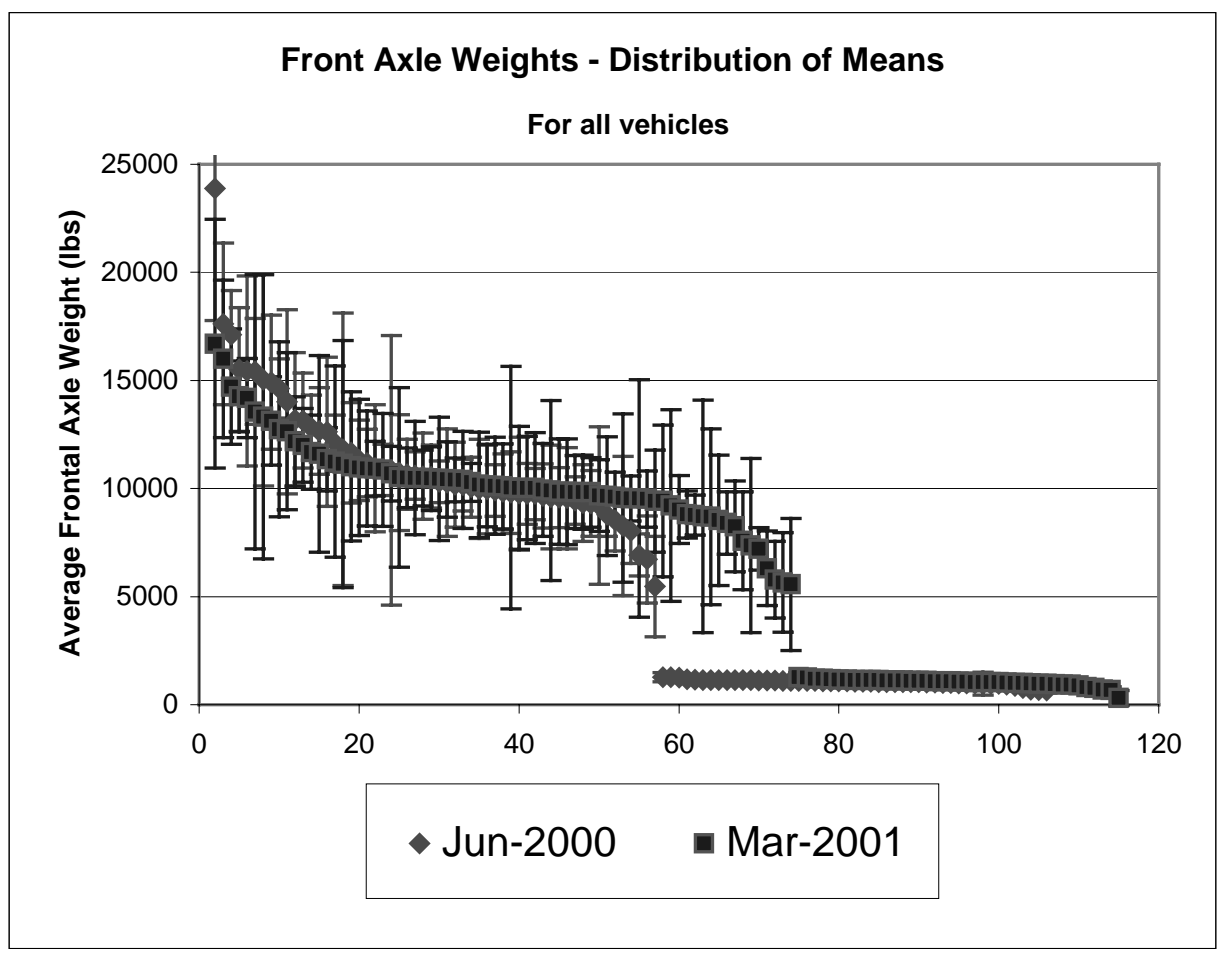

Figure H-1: Average Class 9 Front Axle Weight for All WIM Lanes 


\begin{tabular}{|c|c|c|c|c|c|c|c|c|c|}
\hline \multirow[b]{3}{*}{ SITE } & \multirow[b]{3}{*}{ Lane } & \multicolumn{3}{|c|}{ Mar-01 } & \multicolumn{3}{|c|}{ Jun-00 } & \multirow{3}{*}{\begin{tabular}{|c|}
$\begin{array}{c}\text { Front Axle } \\
\text { Load }\end{array}$ \\
$2000-2001$ \\
$\%$ change
\end{tabular}} & \multirow{3}{*}{$\begin{array}{c}\begin{array}{c}\text { Vehicle } \\
\text { Count }\end{array} \\
\% \text { change }\end{array}$} \\
\hline & & \multicolumn{2}{|c|}{$\begin{array}{l}\text { Front Axle Load } \\
\text { (Ibs) }\end{array}$} & \multirow[b]{2}{*}{$\begin{array}{l}\text { Vehicle } \\
\text { Count }\end{array}$} & \multicolumn{2}{|c|}{ Front Axle Load (Ibs) } & \multirow[b]{2}{*}{$\begin{array}{c}\text { Vehicle } \\
\text { Count }\end{array}$} & & \\
\hline & & Mean & StdDev & & Mean & StdDev & & & \\
\hline 4110 & 1 & 8,245 & 2,105 & 17,046 & 10,742 & 2,680 & 106,734 & $-23 \%$ & $-84 \%$ \\
\hline 4110 & 3 & 33,689 & 5,256 & 15,359 & 37,733 & 5,803 & 63,524 & $-11 \%$ & $-76 \%$ \\
\hline 4130 & 1 & 9,626 & 1,127 & 2,859 & 9,958 & 2,049 & 89,487 & $-3 \%$ & $-97 \%$ \\
\hline 4130 & 2 & 10,401 & 1,016 & 10,640 & 10,305 & 964 & 41,091 & $1 \%$ & $-74 \%$ \\
\hline 4130 & 3 & 11,241 & 4,423 & 227 & 15,436 & 4,399 & 229 & $-27 \%$ & $-1 \%$ \\
\hline 4130 & 4 & 7,581 & 2,270 & 29,648 & 5,465 & 2,317 & 1,351 & $39 \%$ & $2095 \%$ \\
\hline 4130 & 5 & 805 & 132 & 1,424 & 9,750 & 1,185 & 42,626 & $-92 \%$ & $-97 \%$ \\
\hline 4130 & 6 & 10,517 & 4,149 & 459 & 14,007 & 4,260 & 395 & $-25 \%$ & $16 \%$ \\
\hline 4140 & 1 & 9,548 & 1,038 & 2 & 9,219 & 3,642 & 45,343 & $4 \%$ & $-100 \%$ \\
\hline 4140 & 2 & 986 & 145 & 8,530 & 1,048 & 152 & 5,534 & $-6 \%$ & $54 \%$ \\
\hline 4140 & 3 & 1,052 & 173 & 57,643 & 1,127 & 192 & 43,630 & $-7 \%$ & $32 \%$ \\
\hline 4140 & 4 & 1,112 & 162 & 8,320 & 1,263 & 180 & 4,482 & $-12 \%$ & $86 \%$ \\
\hline 4150 & 1 & 14,262 & 1,634 & 71,305 & 12,096 & 1,295 & 60,581 & $18 \%$ & $18 \%$ \\
\hline 4150 & 2 & 11,350 & 1,462 & 6,574 & 10,174 & 1,968 & 5,881 & $12 \%$ & $12 \%$ \\
\hline 4150 & 3 & 10,693 & 1,265 & 62,198 & 9,586 & 1,386 & 60,064 & $12 \%$ & $4 \%$ \\
\hline 4150 & 4 & 10,498 & 1,377 & 7,211 & 10,659 & 1,623 & 6,286 & $-2 \%$ & $15 \%$ \\
\hline 4250 & 1 & 1,033 & 205 & 3,902 & 1,041 & 200 & 1,850 & $-1 \%$ & $111 \%$ \\
\hline 4250 & 2 & 1,044 & 211 & 305 & 1,030 & 198 & 269 & $1 \%$ & $13 \%$ \\
\hline 4250 & 3 & 10,915 & 1,261 & 3,863 & 10,867 & 1,186 & 3,733 & $0 \%$ & $4 \%$ \\
\hline 4250 & 4 & 1,094 & 218 & 164 & 980 & 330 & 199 & $12 \%$ & $-18 \%$ \\
\hline 4260 & 1 & 16,702 & 5,759 & 20,048 & 697 & 126 & 20,599 & $2296 \%$ & $-3 \%$ \\
\hline 4260 & 2 & 1,119 & 204 & 1,988 & 1,115 & 200 & 2,303 & $0 \%$ & $-14 \%$ \\
\hline 4260 & 4 & 1,138 & 227 & 968 & 1,138 & 211 & 1,217 & $0 \%$ & $-21 \%$ \\
\hline 4270 & 1 & 10,419 & 1,749 & 11,799 & 8,540 & 1,430 & 9,423 & $22 \%$ & $25 \%$ \\
\hline 4270 & 2 & 1,070 & 176 & 636 & 1,057 & 181 & 584 & $1 \%$ & $9 \%$ \\
\hline 4270 & 3 & 1,038 & 176 & 8,382 & 1,045 & 182 & 8,356 & $-1 \%$ & $0 \%$ \\
\hline 4270 & 4 & 1,049 & 186 & 192 & 1,064 & 187 & 460 & $-1 \%$ & $-58 \%$ \\
\hline 4280 & 1 & 10,486 & 1,286 & 8,743 & 8,794 & 998 & 13,513 & $19 \%$ & $-35 \%$ \\
\hline 4280 & 2 & 1,147 & 191 & 941 & 1,139 & 183 & 789 & $1 \%$ & $19 \%$ \\
\hline 4280 & 4 & 1,202 & 258 & 22 & 1,138 & 188 & 566 & $6 \%$ & $-96 \%$ \\
\hline
\end{tabular}

Table H-5: Average Class 9 Front Axle Weight for All WIM Lanes, Sorted by Number and Lane (4110-4280) 


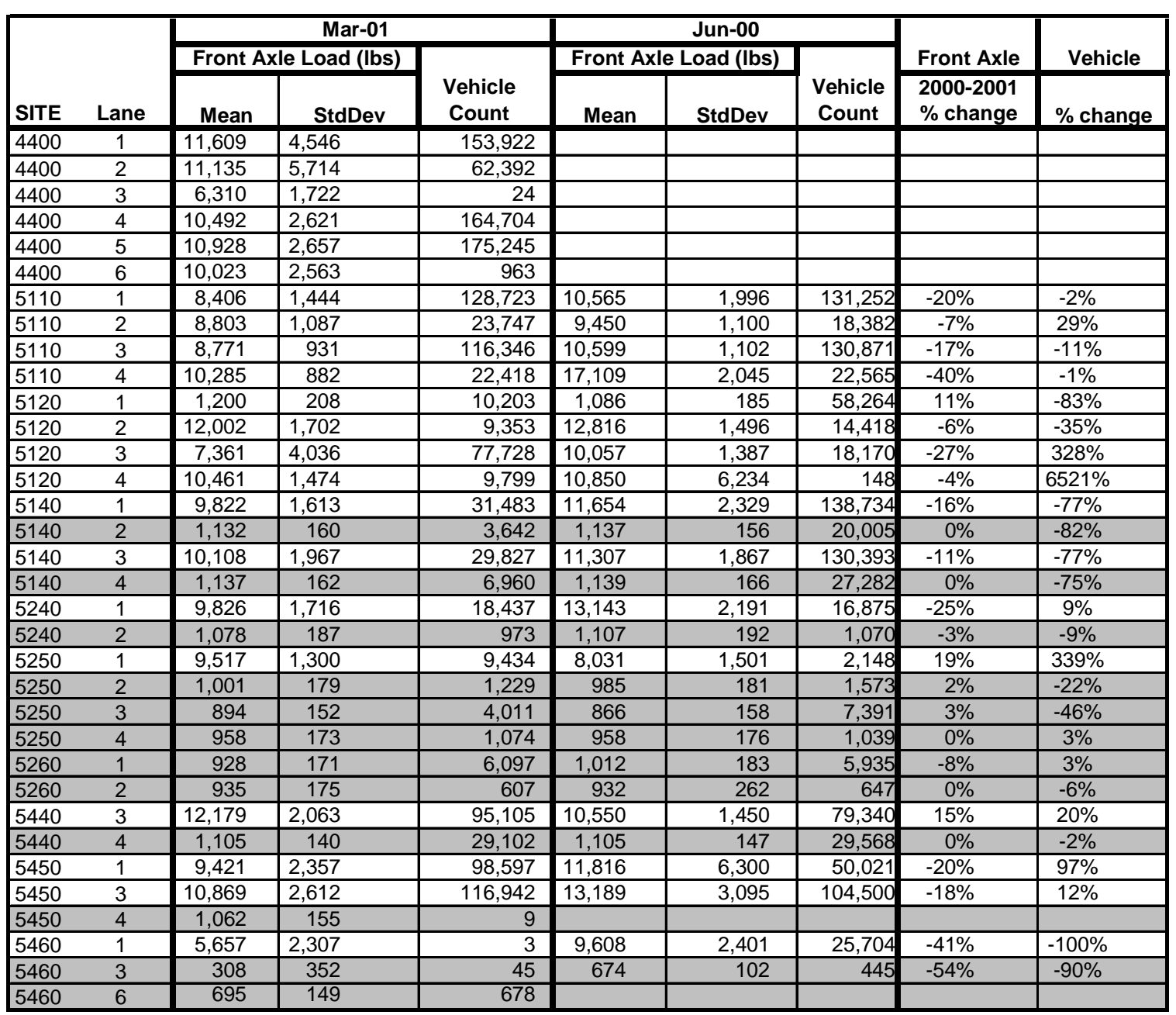

Table H-6: Average Class 9 Front Axle Weight for All WIM Lanes, Sorted by Number and Lane (4400-5460) 


\begin{tabular}{|c|c|c|c|c|c|c|c|c|c|}
\hline \multirow[b]{3}{*}{ SITE } & \multirow[b]{3}{*}{ Lane } & \multicolumn{3}{|c|}{ Mar-01 } & \multicolumn{3}{|c|}{ Jun-00 } & \multirow{3}{*}{\begin{tabular}{|c|}
$\begin{array}{c}\text { Front Axle } \\
\text { Load }\end{array}$ \\
$2000-2001$ \\
$\%$ change
\end{tabular}} & \multirow{3}{*}{$\begin{array}{c}\begin{array}{c}\text { Vehicle } \\
\text { Count }\end{array} \\
\% \text { change }\end{array}$} \\
\hline & & \multicolumn{2}{|c|}{ Front Axle Load (Ibs) } & \multirow[b]{2}{*}{$\begin{array}{c}\text { Vehicle } \\
\text { Count }\end{array}$} & \multicolumn{2}{|c|}{ Front Axle Load (Ibs) } & \multirow[b]{2}{*}{$\begin{array}{c}\text { Vehicle } \\
\text { Count }\end{array}$} & & \\
\hline & & Mean & StdDev & & Mean & StdDev & & & \\
\hline 5470 & 1 & 9,685 & 1,657 & 91,327 & 9,849 & 1,763 & 80,961 & $-2 \%$ & $13 \%$ \\
\hline 5470 & 2 & 5,563 & 3,053 & 6 & 6,926 & 973 & 6 & $-20 \%$ & $0 \%$ \\
\hline 5470 & 3 & 10,442 & 2,854 & 496 & 10,280 & 2,484 & 544 & $2 \%$ & $-9 \%$ \\
\hline 5470 & 4 & 9,651 & 2,746 & 89,824 & 6,720 & 2,012 & 78,858 & $44 \%$ & $14 \%$ \\
\hline 5470 & 5 & 9,837 & 1,686 & 56,871 & 9,982 & 2,299 & 53,099 & $-2 \%$ & $7 \%$ \\
\hline 5470 & 6 & 11,025 & 3,445 & 962 & 23,876 & 6,098 & 1,087 & $-54 \%$ & $-12 \%$ \\
\hline 5480 & 1 & 8,533 & 3,016 & 19,092 & 14,921 & 3,104 & 34,134 & $-43 \%$ & $-44 \%$ \\
\hline 5480 & 2 & 16,004 & 3,641 & 4,581 & 17,618 & 3,742 & 5,103 & $-9 \%$ & $-10 \%$ \\
\hline 5480 & 3 & 766 & 150 & 144 & & & & & \\
\hline 5480 & 4 & 12,739 & 4,050 & 5,639 & 15,507 & 2,854 & 8,570 & $-18 \%$ & $-34 \%$ \\
\hline 5480 & 6 & 676 & 150 & 254 & 657 & 109 & 32 & $3 \%$ & $694 \%$ \\
\hline 5550 & 1 & 13,315 & 6,572 & 8,252 & 1,059 & 188 & 6,951 & $1157 \%$ & $19 \%$ \\
\hline 5550 & 2 & 9,213 & 4,440 & 763 & & & & & \\
\hline 5550 & 3 & 13,552 & 6,341 & 8,412 & 1,034 & & 1 & $1211 \%$ & $841100 \%$ \\
\hline 5550 & 4 & 8,716 & 5,373 & 200 & 967 & 527 & 53 & $801 \%$ & $277 \%$ \\
\hline 6130 & 2 & 1,003 & 157 & 650 & 1,106 & 187 & 1,517 & $-9 \%$ & $-57 \%$ \\
\hline 6130 & 4 & 1,025 & 159 & 1,064 & 1,073 & 169 & 2,187 & $-5 \%$ & $-51 \%$ \\
\hline 6140 & 1 & 5,783 & 1,774 & 51,296 & 11,184 & 1,564 & 43,679 & $-48 \%$ & $17 \%$ \\
\hline 6140 & 2 & 1,082 & 157 & 3,259 & 1,103 & 157 & 3,282 & $-2 \%$ & $-1 \%$ \\
\hline 6140 & 3 & 14,710 & 2,672 & 34,753 & 10,943 & 2,939 & 18,125 & $34 \%$ & $92 \%$ \\
\hline 6140 & 4 & 1,177 & 172 & 2,388 & 1,173 & 182 & 2,346 & $0 \%$ & $2 \%$ \\
\hline 6150 & 1 & 10,047 & 5,609 & 19,801 & 9,315 & 1,519 & 19,216 & $8 \%$ & $3 \%$ \\
\hline 6150 & 2 & 1,110 & 168 & 2,337 & 1,117 & 172 & 3,005 & $-1 \%$ & $-22 \%$ \\
\hline 6160 & 1 & 14,184 & 1,831 & 54,036 & 14,630 & 1,376 & 23,011 & $-3 \%$ & $135 \%$ \\
\hline 6160 & 2 & 1,134 & 168 & 5,587 & 1,139 & 170 & 5,517 & $0 \%$ & $1 \%$ \\
\hline 6160 & 3 & 9,419 & 3,508 & 45,576 & 8,265 & 3,221 & 25,878 & $14 \%$ & $76 \%$ \\
\hline 6160 & 4 & 1,153 & 174 & 6,730 & 1,148 & 179 & 7,181 & $0 \%$ & $-6 \%$ \\
\hline 6170 & 1 & 9,561 & 3,894 & 38,425 & 15,031 & 4,905 & 29,667 & $-36 \%$ & $30 \%$ \\
\hline 6170 & 2 & 962 & 157 & 3,244 & 994 & 168 & 4,639 & $-3 \%$ & $-30 \%$ \\
\hline 6170 & 3 & 9,022 & 1,572 & 26,349 & 12,663 & 2,002 & 8,889 & $-29 \%$ & $196 \%$ \\
\hline 6170 & 4 & 916 & 168 & 2,637 & 983 & 175 & 3,631 & $-7 \%$ & $-27 \%$ \\
\hline 6250 & 1 & 7,200 & 983 & 5,619 & 764 & 134 & 7,861 & $842 \%$ & $-29 \%$ \\
\hline 6250 & 2 & 1,259 & 203 & 849 & 1,260 & 209 & 770 & $0 \%$ & $10 \%$ \\
\hline 6250 & 3 & 1,102 & 244 & 5,709 & 1,136 & 198 & 7,359 & $-3 \%$ & $-22 \%$ \\
\hline 6250 & 4 & 1,272 & 211 & 508 & 1,272 & 206 & 654 & $0 \%$ & $-22 \%$ \\
\hline
\end{tabular}

Table H-7: Average Class 9 Front Axle Weight for All WIM Lanes, Sorted by Number and Lane (5470-6250) 


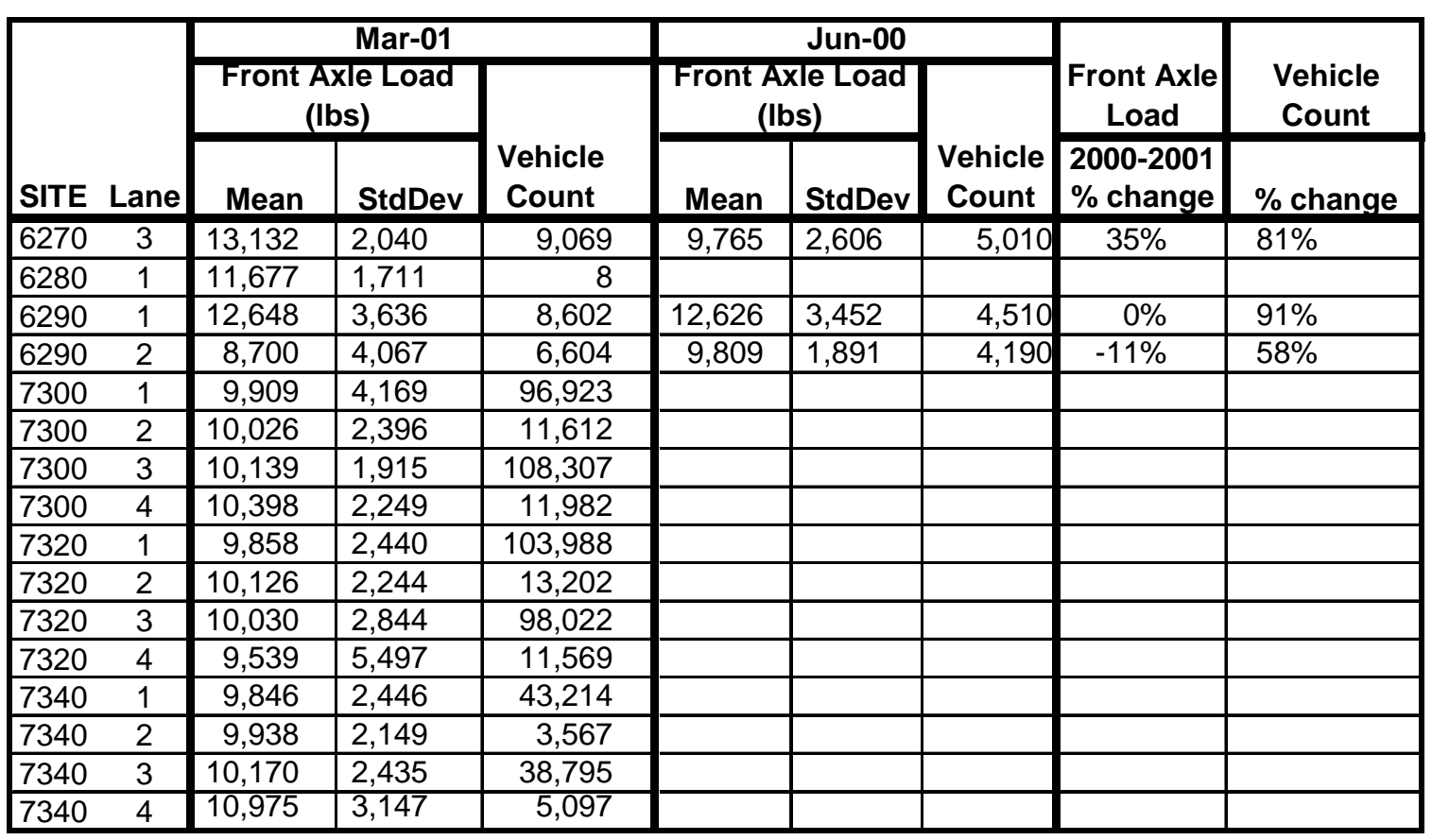

Table H-8: Average Class 9 Front Axle Weight for All WIM Lanes, Sorted by Number and Lane (6270-7340) 


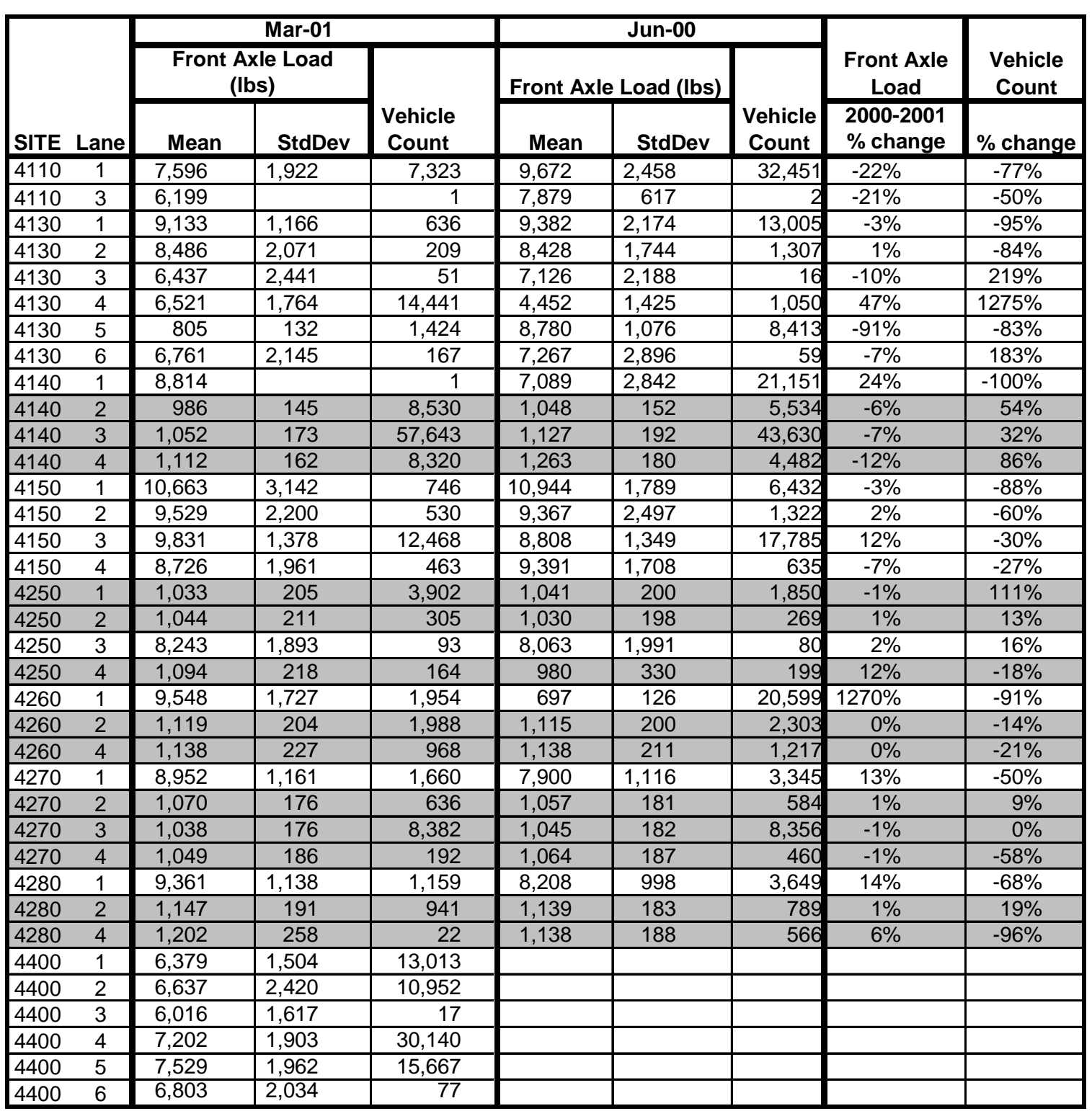

Table H-9: Average Class 9 Front Axle Weight for WIM lanes with GVW<32,000, Sorted by Site Number (4110-4400) 


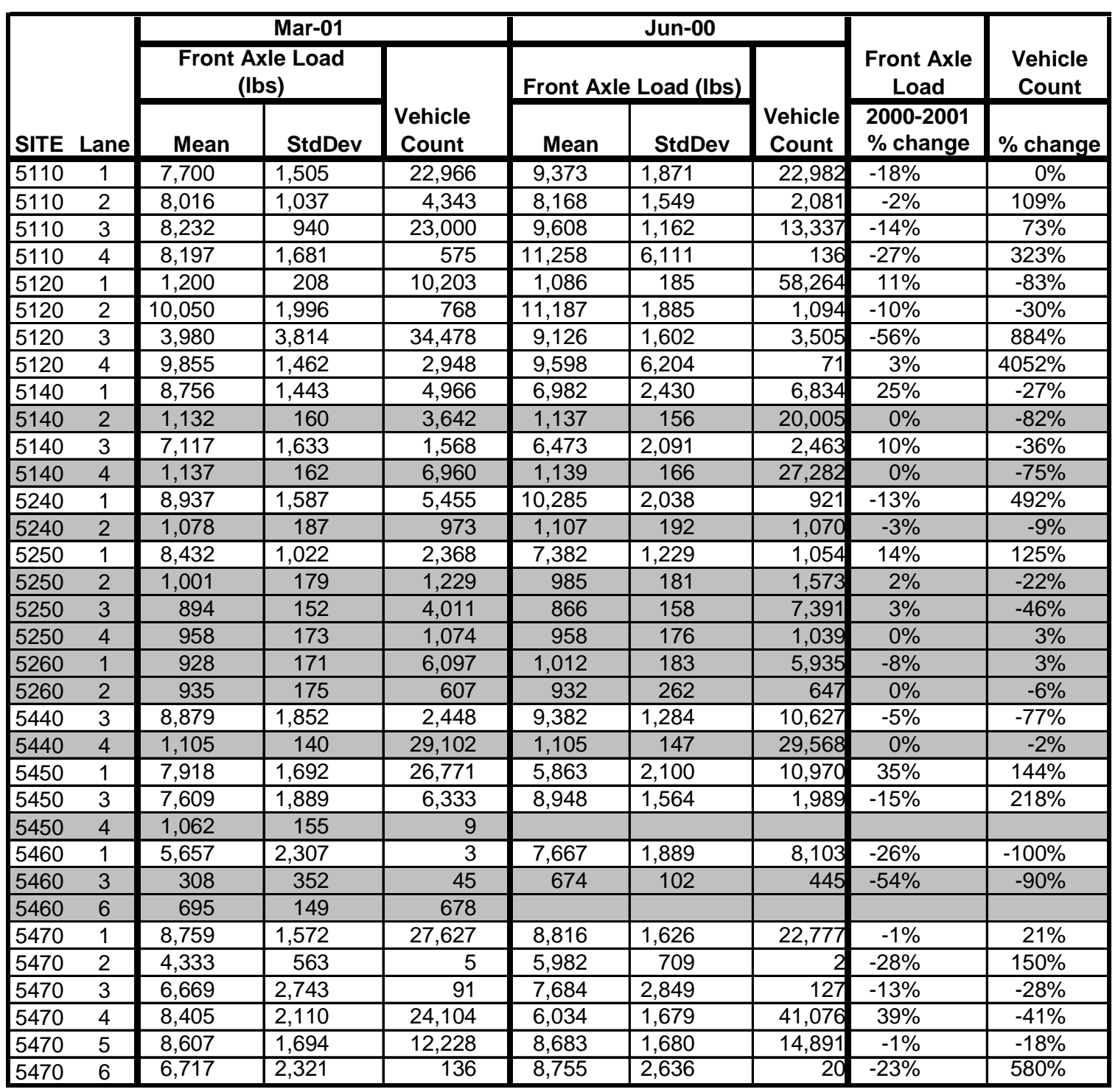

Table H-10: Average Class 9 Front Axle Weight for WIM lanes with GVW<32,000, Sorted by Site Number (5110-5470) 


\begin{tabular}{|c|c|c|c|c|c|c|c|c|c|}
\hline \multirow[b]{3}{*}{ SITE } & \multirow[b]{3}{*}{ Lane } & \multicolumn{3}{|c|}{ Mar-01 } & \multicolumn{3}{|c|}{ Jun-00 } & \multirow{3}{*}{$\begin{array}{c}\begin{array}{c}\text { Front Axle } \\
\text { Load }\end{array} \\
2000-2001 \\
\% \text { change }\end{array}$} & \multirow{3}{*}{$\begin{array}{c}\begin{array}{c}\text { Vehicle } \\
\text { Count }\end{array} \\
\% \text { change }\end{array}$} \\
\hline & & \multicolumn{2}{|c|}{$\begin{array}{l}\text { Front Axle Load } \\
\text { (Ibs) }\end{array}$} & \multirow[b]{2}{*}{$\begin{array}{l}\text { Vehicle } \\
\text { Count }\end{array}$} & \multicolumn{2}{|c|}{ Front Axle Load (Ibs) } & \multirow[b]{2}{*}{$\begin{array}{c}\text { Vehicle } \\
\text { Count }\end{array}$} & & \\
\hline & & Mean & StdDev & & Mean & StdDev & & & \\
\hline 5480 & 1 & 6,728 & 2,031 & 6,712 & 8,800 & 2,564 & 857 & $-24 \%$ & $683 \%$ \\
\hline 5480 & 2 & 10,349 & 3,801 & 352 & 9,510 & 3,707 & 163 & $9 \%$ & $116 \%$ \\
\hline 5480 & 3 & 766 & 150 & 144 & & & & & \\
\hline 5480 & 4 & 10,411 & 4,730 & 401 & 7,953 & 2,364 & 83 & $31 \%$ & $383 \%$ \\
\hline 5480 & 6 & 676 & 150 & 254 & 657 & 109 & 32 & $3 \%$ & $694 \%$ \\
\hline 5550 & 1 & 9,110 & 3,050 & 2,265 & 1,059 & 188 & 6,951 & $760 \%$ & $-67 \%$ \\
\hline 5550 & 2 & 7,180 & 1,856 & 405 & & & & & \\
\hline 5550 & 3 & 8,670 & 2,328 & 1,888 & 1,034 & & 1 & $739 \%$ & $188700 \%$ \\
\hline 5550 & 4 & 6,337 & 2,568 & 127 & 967 & 527 & 53 & $555 \%$ & $140 \%$ \\
\hline 6130 & 2 & 1,003 & 157 & 650 & 1,106 & 187 & 1,517 & $-9 \%$ & $-57 \%$ \\
\hline 6130 & 4 & 1,025 & 159 & 1,064 & 1,073 & 169 & 2,187 & $-5 \%$ & $-51 \%$ \\
\hline 6140 & 1 & 5,119 & 1,192 & 29,665 & 8,980 & 2,684 & 2,152 & $-43 \%$ & $1279 \%$ \\
\hline 6140 & 2 & 1,082 & 157 & 3,259 & 1,103 & 157 & 3,282 & $-2 \%$ & $-1 \%$ \\
\hline 6140 & 3 & 10,177 & 4,108 & 1,651 & 10,160 & 3,129 & 7,404 & $0 \%$ & $-78 \%$ \\
\hline 6140 & 4 & 1,177 & 172 & 2,388 & 1,173 & 182 & 2,346 & $0 \%$ & $2 \%$ \\
\hline 6150 & 1 & 6,725 & 2,641 & 5,196 & 8,879 & 1,452 & 9,461 & $-24 \%$ & $-45 \%$ \\
\hline 6150 & 2 & 1,110 & 168 & 2,337 & 1,117 & 172 & 3,005 & $-1 \%$ & $-22 \%$ \\
\hline 6160 & 1 & 9,347 & 2,703 & 183 & 7,173 & 2,492 & 25 & $30 \%$ & $632 \%$ \\
\hline 6160 & 2 & 1,134 & 168 & 5,587 & 1,139 & 170 & 5,517 & $0 \%$ & $1 \%$ \\
\hline 6160 & 3 & 6,783 & 2,060 & 13,769 & 6,030 & 1,886 & 8,736 & $13 \%$ & $58 \%$ \\
\hline 6160 & 4 & 1,153 & 174 & 6,730 & 1,148 & 179 & 7,181 & $0 \%$ & $-6 \%$ \\
\hline 6170 & 1 & 7,281 & 2,251 & 15,014 & 5,201 & 1,785 & 4,386 & $40 \%$ & $242 \%$ \\
\hline 6170 & 2 & 962 & 157 & 3,244 & 994 & 168 & 4,639 & $-3 \%$ & $-30 \%$ \\
\hline 6170 & 3 & 8,249 & 1,607 & 4,224 & 10,679 & 2,576 & 1,084 & $-23 \%$ & $290 \%$ \\
\hline 6170 & 4 & 916 & 168 & 2,637 & 983 & 175 & 3,631 & $-7 \%$ & $-27 \%$ \\
\hline 6250 & 1 & 6,856 & 858 & 3,370 & 764 & 134 & 7,861 & $797 \%$ & $-57 \%$ \\
\hline 6250 & 2 & 1,259 & 203 & 849 & 1,260 & 209 & 770 & $0 \%$ & $10 \%$ \\
\hline 6250 & 3 & 1,102 & 244 & 5,709 & 1,136 & 198 & 7,359 & $-3 \%$ & $-22 \%$ \\
\hline 6250 & 4 & 1,272 & 211 & 508 & 1,272 & 206 & 654 & $0 \%$ & $-22 \%$ \\
\hline
\end{tabular}

Table H-11: Average Class 9 Front Axle Weight for WIM lanes with GVW<32,000, Sorted by Site Number (5480-6250) 


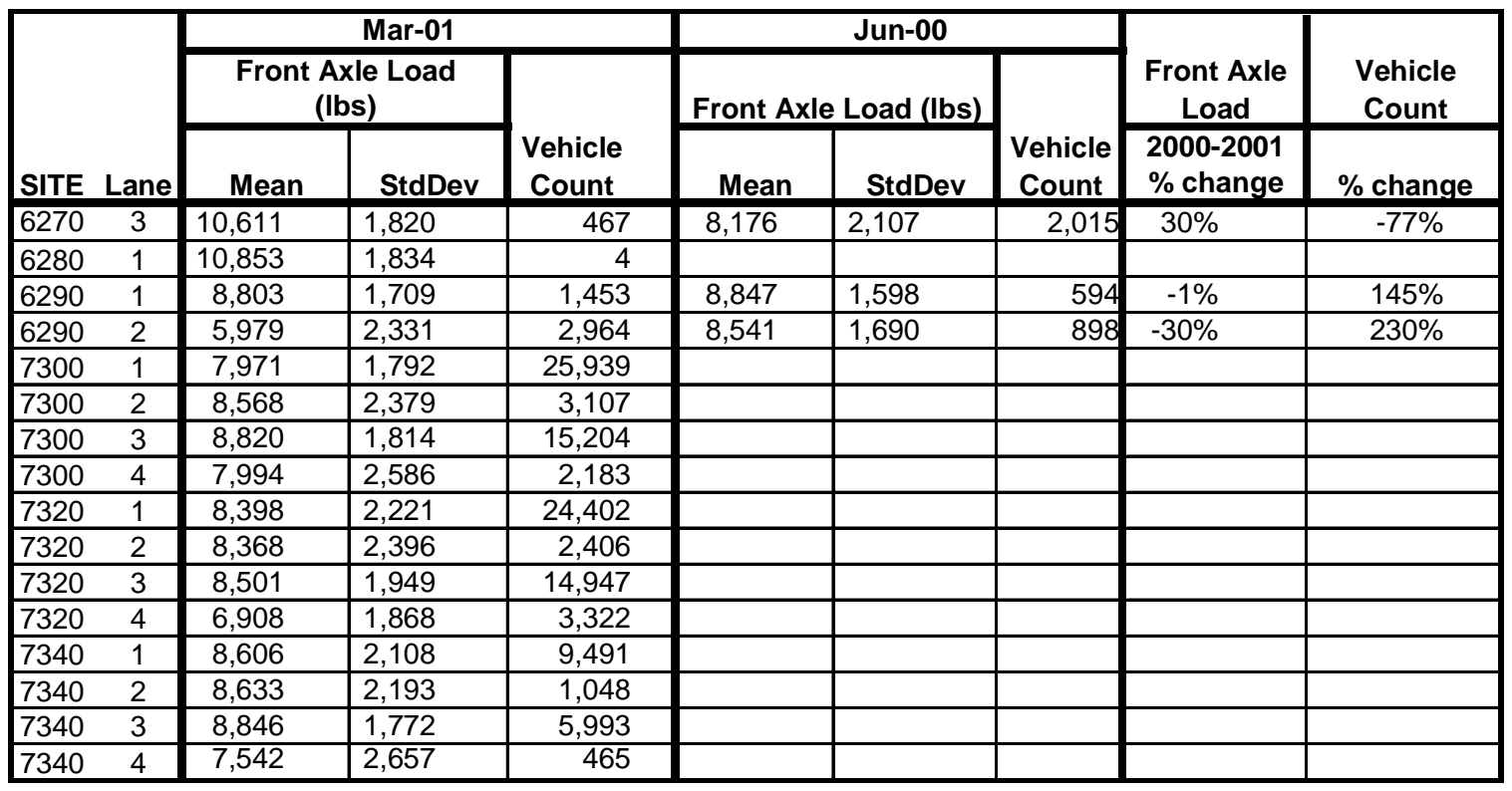

Table H-12: Average Class 9 Front Axle Weight for WIM lanes with GVW<32,000, Sorted by Site Number (6270-7340) 


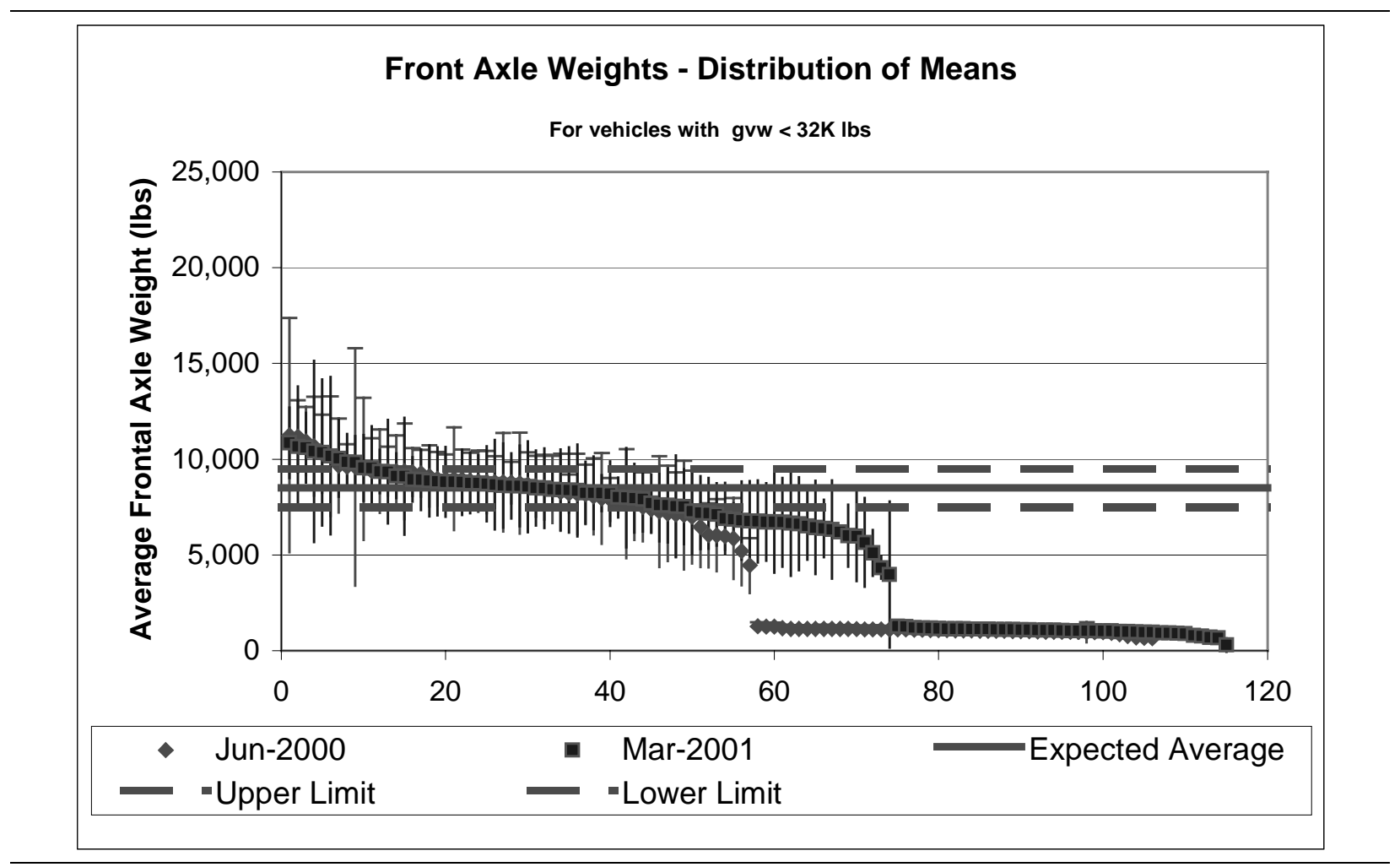

Figure H-2: Average Class 9 Front Axle Weight for WIM lanes with GVW $<32,000$ 


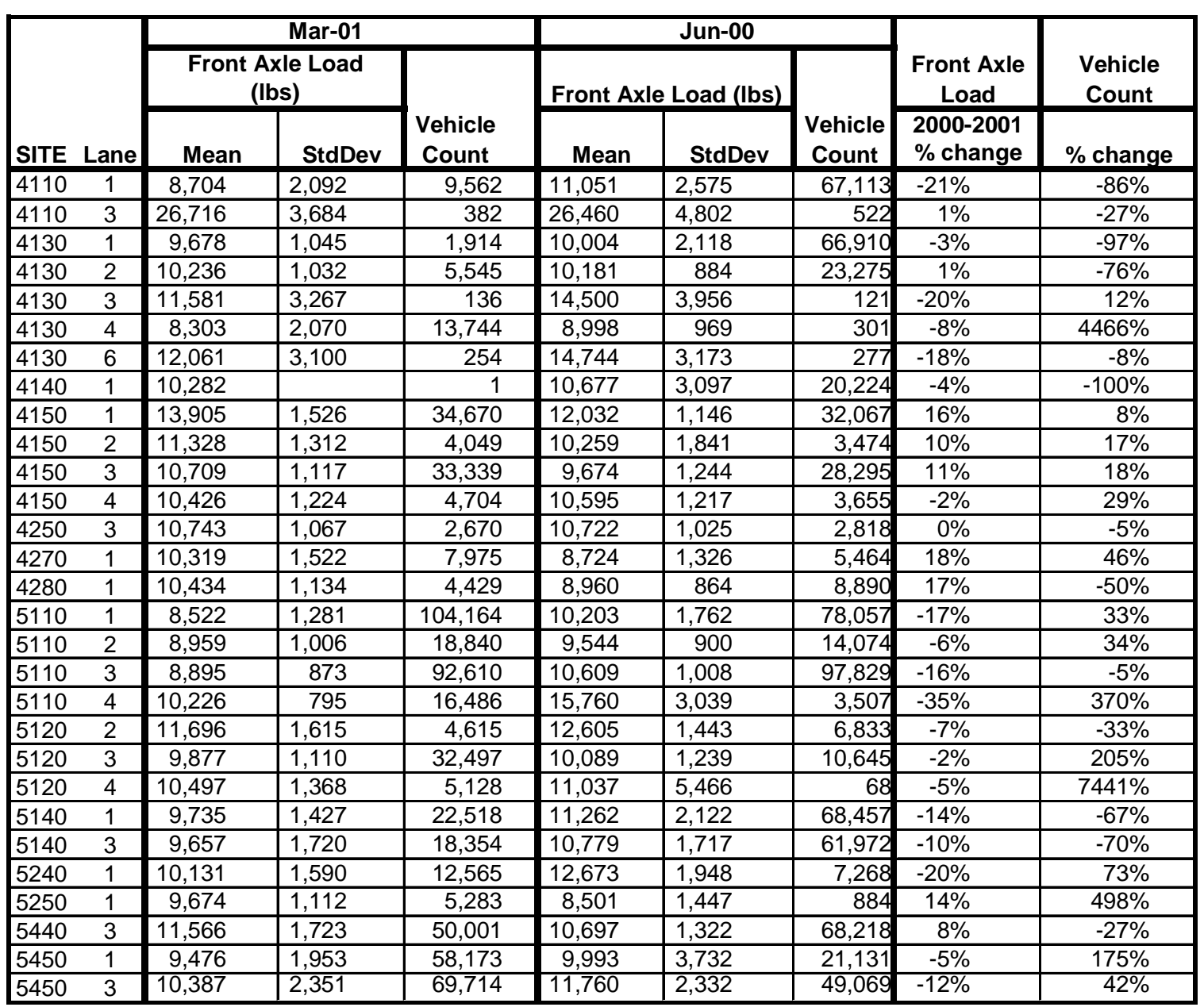

Table H-13: Average Class 9 Front Axle Weight for WIM lanes with 32,000<GVW<70,000, Sorted by Site Number (41105450) 


\begin{tabular}{|c|c|c|c|c|c|c|c|c|c|}
\hline \multirow[b]{3}{*}{ SITE } & \multirow[b]{3}{*}{ Lane } & \multicolumn{3}{|c|}{ Mar-01 } & \multicolumn{3}{|c|}{ Jun-00 } & \multirow{3}{*}{$\begin{array}{c}\begin{array}{c}\text { Front Axle } \\
\text { Load }\end{array} \\
2000-2001 \\
\% \text { change }\end{array}$} & \multirow{3}{*}{$\begin{array}{c}\begin{array}{c}\text { Vehicle } \\
\text { Count }\end{array} \\
\% \text { change }\end{array}$} \\
\hline & & \multicolumn{2}{|c|}{$\begin{array}{c}\text { Front Axle Load } \\
\text { (Ibs) }\end{array}$} & \multirow[b]{2}{*}{$\begin{array}{l}\text { Vehicle } \\
\text { Count }\end{array}$} & \multicolumn{2}{|c|}{ Front Axle Load (lbs) } & \multirow[b]{2}{*}{$\begin{array}{c}\text { Vehicle } \\
\text { Count }\end{array}$} & & \\
\hline & & Mean & StdDev & & Mean & StdDev & & & \\
\hline 5470 & 1 & 10,005 & 1,478 & 60,646 & 10,157 & 1,573 & 55,304 & $-2 \%$ & $10 \%$ \\
\hline 5470 & 2 & 11,709 & & 1 & 7,398 & 719 & 4 & $58 \%$ & $-75 \%$ \\
\hline 5470 & 3 & 10,945 & 2,138 & 285 & 10,908 & 1,710 & 352 & $0 \%$ & $-19 \%$ \\
\hline 5470 & 4 & 9,889 & 2,509 & 59,102 & 7,433 & 2,051 & 37,339 & $33 \%$ & $58 \%$ \\
\hline 5470 & 5 & 10,002 & 1,454 & 40,043 & 10,236 & 1,804 & 36,618 & $-2 \%$ & $9 \%$ \\
\hline 5470 & 6 & 11,116 & 2,685 & 595 & 16,403 & 4,862 & 146 & $-32 \%$ & $308 \%$ \\
\hline 5480 & 1 & 8,951 & 2,720 & 10,757 & 14,299 & 2,832 & 18,313 & $-37 \%$ & $-41 \%$ \\
\hline 5480 & 2 & 15,649 & 3,062 & 2,464 & 16,924 & 3,373 & 2,816 & $-8 \%$ & $-13 \%$ \\
\hline 5480 & 4 & 12,554 & 3,359 & 4,720 & 14,839 & 2,514 & 5,642 & $-15 \%$ & $-16 \%$ \\
\hline 6140 & 1 & 6,474 & 1,757 & 20,660 & 11,292 & 1,389 & 41,353 & $-43 \%$ & $-50 \%$ \\
\hline 6140 & 3 & 14,499 & 2,300 & 16,384 & 11,344 & 2,720 & 8,567 & $28 \%$ & $91 \%$ \\
\hline 6150 & 1 & 9,347 & 4,420 & 10,979 & 9,561 & 1,442 & 7,110 & $-2 \%$ & $54 \%$ \\
\hline 6160 & 1 & 13,582 & 1,733 & 25,082 & 14,112 & 1,308 & 8,412 & $-4 \%$ & $198 \%$ \\
\hline 6160 & 3 & 9,409 & 3,096 & 20,574 & 8,296 & 2,700 & 12,303 & $13 \%$ & $67 \%$ \\
\hline 6170 & 1 & 10,188 & 3,412 & 19,549 & 14,275 & 3,002 & 8,319 & $-29 \%$ & $135 \%$ \\
\hline 6170 & 3 & 8,910 & 1,510 & 16,104 & 12,497 & 1,780 & 3,805 & $-29 \%$ & $323 \%$ \\
\hline 6270 & 3 & 12,561 & 1,763 & 3,970 & 10,266 & 2,295 & 1,638 & $22 \%$ & $142 \%$ \\
\hline 6290 & 1 & 12,760 & 3,272 & 3,890 & 11,974 & 3,067 & 2,021 & $7 \%$ & $93 \%$ \\
\hline 6290 & 2 & 10,038 & 3,582 & 2,752 & 9,871 & 1,734 & 2,411 & $2 \%$ & $14 \%$ \\
\hline 7300 & 1 & 9,656 & 3,094 & 56,360 & & & & & \\
\hline 7300 & 2 & 10,332 & 2,098 & 7,069 & & & & & \\
\hline 7300 & 3 & 10,174 & 1,794 & 73,728 & & & & & \\
\hline 7300 & 4 & 10,728 & 1,733 & 8,081 & & & & & \\
\hline 7320 & 1 & 10,051 & 2,281 & 63,010 & & & & & \\
\hline 7320 & 2 & 10,252 & 1,961 & 7,894 & & & & & \\
\hline 7320 & 3 & 10,002 & 2,534 & 69,934 & & & & & \\
\hline 7320 & 4 & 8,793 & 2,724 & 6,690 & & & & & \\
\hline 7340 & 1 & 9,957 & 2,289 & 26,911 & & & & & \\
\hline 7340 & 2 & 10,316 & 1,767 & 2,286 & & & & & \\
\hline
\end{tabular}

Table H-14: Average Class 9 Front Axle Weight for WIM lanes with 32,000<GVW<70,000, Sorted by Site Number (54707340) 


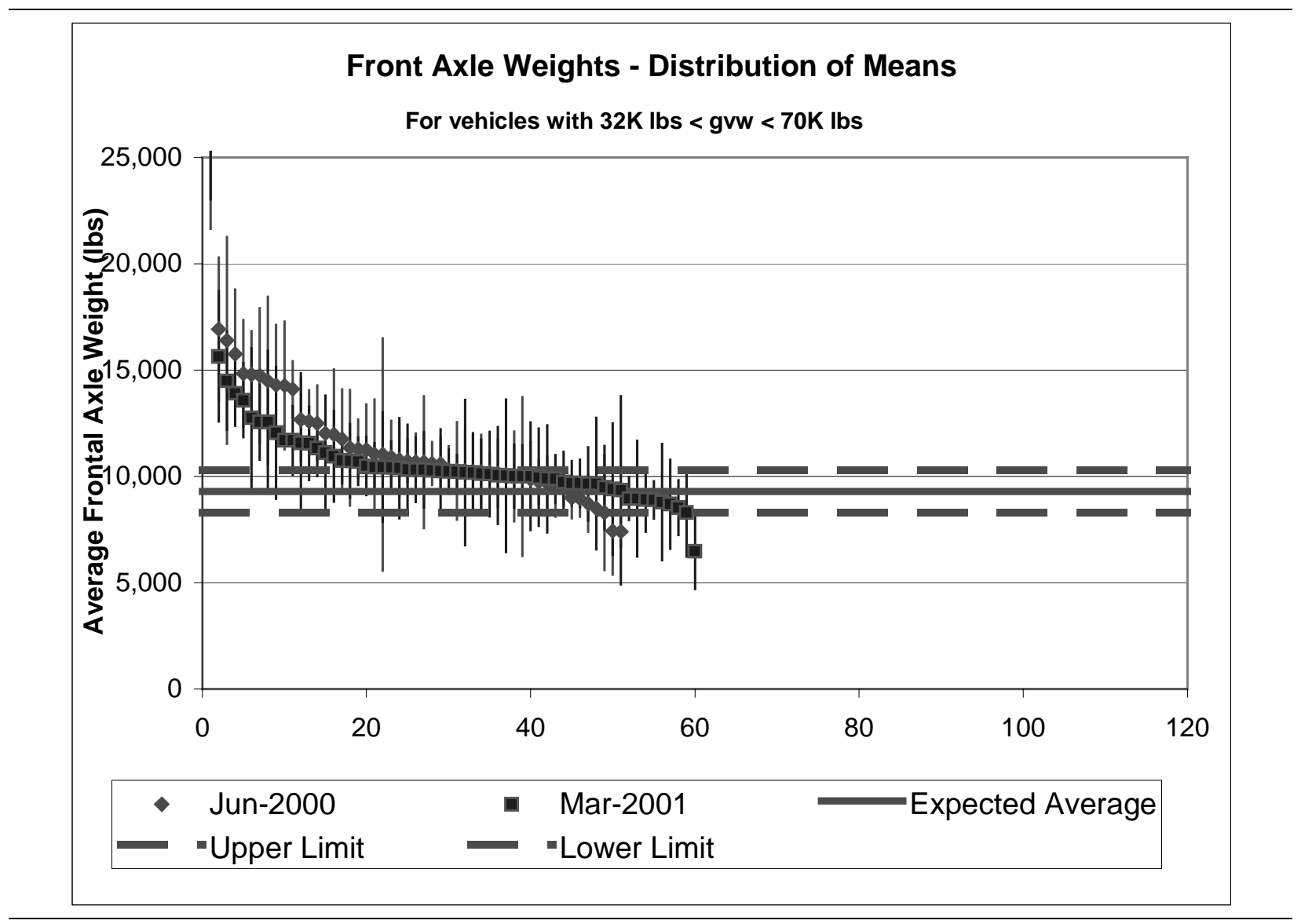

Figure H-3: Average Class 9 Front Axle Weight for WIM Lanes with 32,000 < GVW < 70,000 


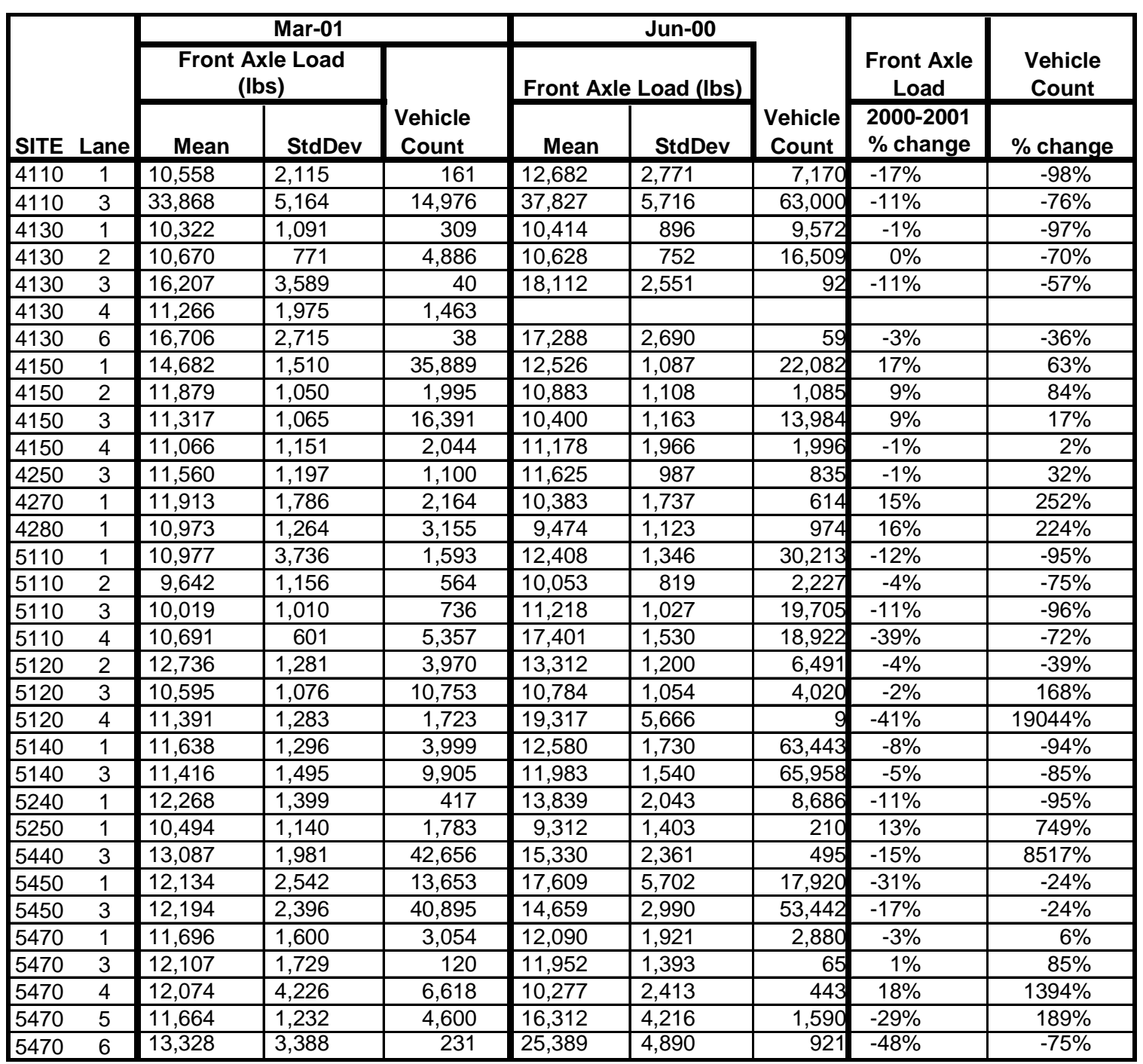

Table H-15: Average Class 9 Front Axle Weight for WIM lanes with GVW>70,000, Sorted by Site Number (4110-5470) 


\begin{tabular}{|c|c|c|c|c|c|c|c|c|c|}
\hline \multirow[b]{3}{*}{ SITE } & \multirow[b]{3}{*}{ Lane } & \multicolumn{3}{|c|}{ Mar-01 } & \multicolumn{2}{|r|}{ Jun-00 } & \multirow[b]{3}{*}{$\begin{array}{c}\text { Vehicle } \\
\text { Count }\end{array}$} & \multirow{3}{*}{$\begin{array}{c}\begin{array}{c}\text { Front Axle } \\
\text { Load }\end{array} \\
2000-2001 \\
\% \text { change }\end{array}$} & \multirow{3}{*}{$\begin{array}{c}\begin{array}{c}\text { Vehicle } \\
\text { Count }\end{array} \\
\% \text { change }\end{array}$} \\
\hline & & \multicolumn{2}{|c|}{$\begin{array}{l}\text { Front Axle Load } \\
\text { (Ibs) }\end{array}$} & \multirow[b]{2}{*}{$\begin{array}{c}\text { Vehicle } \\
\text { Count }\end{array}$} & \multicolumn{2}{|c|}{ Front Axle Load (Ibs) } & & & \\
\hline & & Mean & StdDev & & Mean & StdDev & & & \\
\hline 5480 & 1 & 13,225 & 2,071 & 1,623 & 16,032 & 2,817 & 14,964 & $-18 \%$ & $-89 \%$ \\
\hline 5480 & 2 & 17,628 & 3,043 & 1,765 & 19,161 & 3,073 & 2,124 & $-8 \%$ & $-17 \%$ \\
\hline 5480 & 4 & 16,226 & 6,472 & 518 & 17,052 & 2,630 & 2,845 & $-5 \%$ & $-82 \%$ \\
\hline 6140 & 1 & 11,349 & 1,636 & 971 & 12,851 & 913 & 174 & $-12 \%$ & $458 \%$ \\
\hline 6140 & 3 & 15,366 & 2,342 & 16,718 & 12,040 & 2,379 & 2,154 & $28 \%$ & $676 \%$ \\
\hline 6150 & 1 & 16,924 & 6,169 & 3,626 & 10,211 & 1,406 & 2,645 & $66 \%$ & $37 \%$ \\
\hline 6160 & 1 & 14,739 & 1,690 & 28,771 & 14,941 & 1,283 & 14,574 & $-1 \%$ & $97 \%$ \\
\hline 6160 & 3 & 12,670 & 2,844 & 11,233 & 12,222 & 2,418 & 4,839 & $4 \%$ & $132 \%$ \\
\hline 6170 & 1 & 15,253 & 4,204 & 3,862 & 17,943 & 1,760 & 16,962 & $-15 \%$ & $-77 \%$ \\
\hline 6170 & 3 & 9,866 & 1,319 & 6,021 & 13,358 & 1,586 & 4,000 & $-26 \%$ & $51 \%$ \\
\hline 6270 & 3 & 13,875 & 1,919 & 4,632 & 11,519 & 2,238 & 1,357 & $21 \%$ & $241 \%$ \\
\hline 6290 & 1 & 14,230 & 3,422 & 3,259 & 14,507 & 3,011 & 1,895 & $-2 \%$ & $72 \%$ \\
\hline 6290 & 2 & 13,633 & 3,246 & 888 & 10,932 & 1,722 & 881 & $25 \%$ & $1 \%$ \\
\hline 7300 & 1 & 14,319 & 6,799 & 14,624 & & & & & \\
\hline 7300 & 2 & 11,675 & 2,180 & 1,436 & & & & & \\
\hline 7300 & 3 & 11,042 & 1,867 & 19,375 & & & & & \\
\hline 7300 & 4 & 11,898 & 1,600 & 1,718 & & & & & \\
\hline 7320 & 1 & 11,274 & 2,245 & 16,576 & & & & & \\
\hline 7320 & 2 & 11,242 & 1,959 & 2,902 & & & & & \\
\hline 7320 & 3 & 11,918 & 3,955 & 13,141 & & & & & \\
\hline 7320 & 4 & 18,356 & 9,505 & 1,557 & & & & & \\
\hline 7340 & 1 & 11,132 & 2,688 & 6,812 & & & & & \\
\hline 7340 & 2 & 12,099 & 2,182 & 233 & & & & & \\
\hline 7340 & 3 & 11,515 & 3,527 & 7,006 & & & & & \\
\hline 7340 & 4 & 12,746 & 3,031 & 1,774 & & & & & \\
\hline
\end{tabular}

Table H-16: Average Class 9 Front Axle Weight for WIM lanes with GVW>70,000, Sorted by Site Number (5480-7340) 


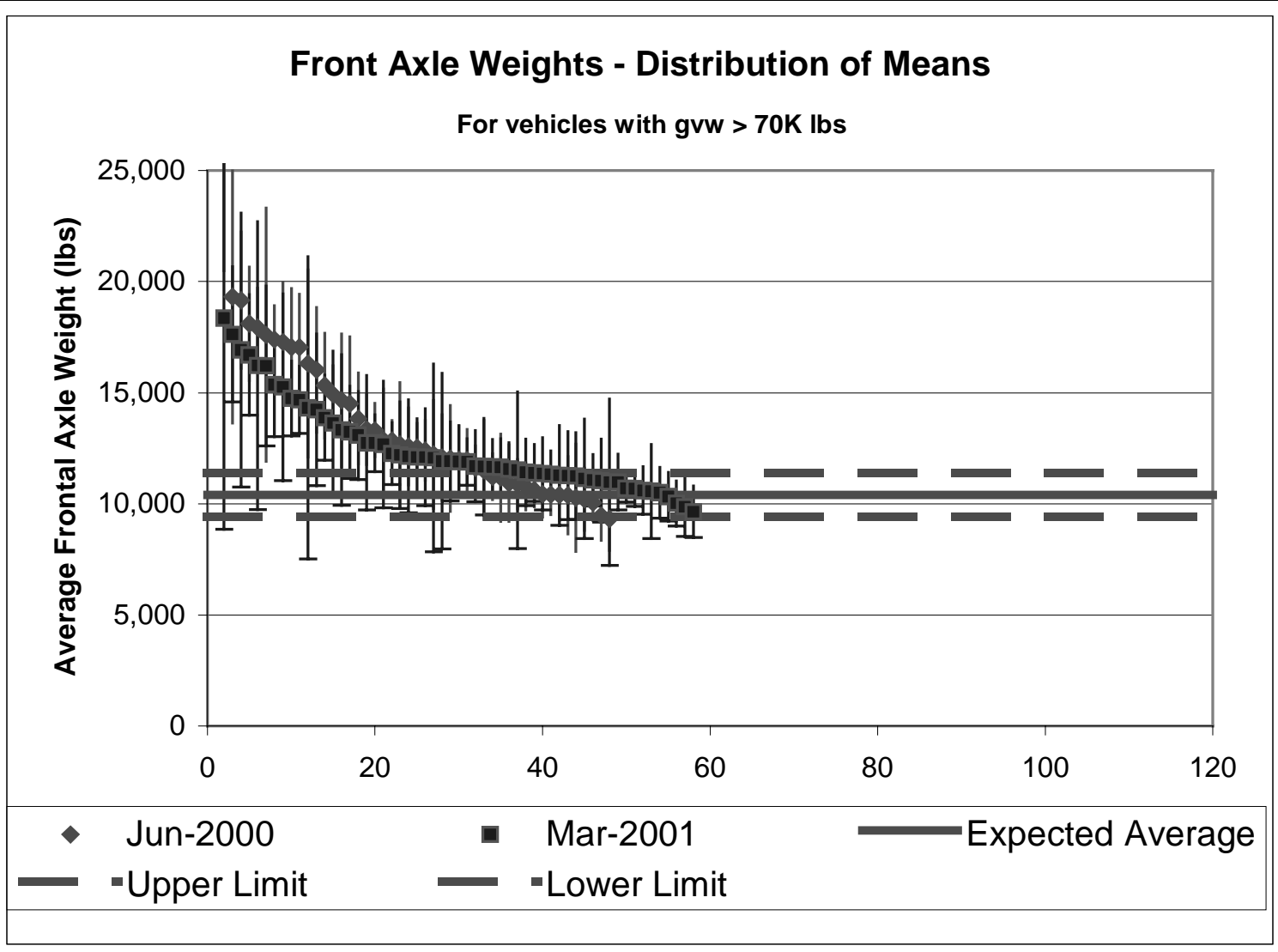

Figure H-4: Average Class 9 Front Axle Weight for WIM lanes with GVW > 70,000 


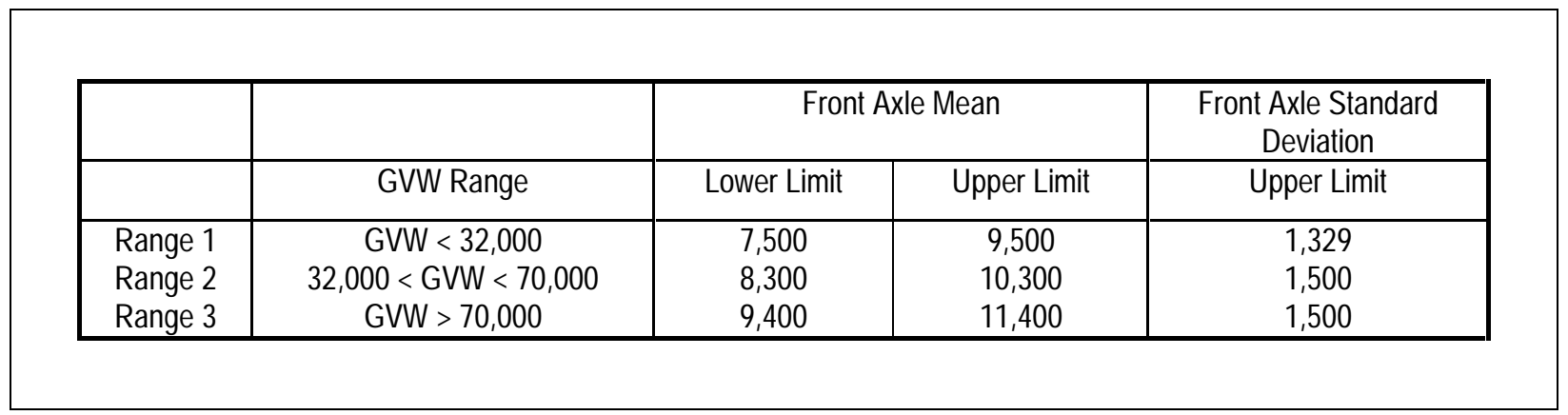

Table H-17: Acceptable Ranges for Front Axle Mean \& Standard Deviation for Table H-18 and Table H-19 


\begin{tabular}{|c|c|c|c|c|c|c|c|c|c|c|c|c|c|c|}
\hline \multirow[b]{3}{*}{ Site } & \multirow[b]{3}{*}{ Lane } & \multicolumn{6}{|c|}{ March, 2001} & \multicolumn{6}{|c|}{ June, 2000} & \multirow{3}{*}{$\begin{array}{l}\text { I.R.D. Sensor Report } \\
\text { for April 01, } 2001\end{array}$} \\
\hline & & \multicolumn{3}{|c|}{\begin{tabular}{|c|}
$\begin{array}{c}\text { Out-of-Range Front } \\
\text { Axle Mean }\end{array}$ \\
\end{tabular}} & \multicolumn{3}{|c|}{$\begin{array}{c}\text { Out-of-Range Front } \\
\text { Axle Standard }\end{array}$} & \multicolumn{3}{|c|}{\begin{tabular}{|c|} 
Out-of-Range Front \\
Axle Mean
\end{tabular}} & \multicolumn{3}{|c|}{$\begin{array}{c}\text { Out-of-Range Front } \\
\text { Axle Standard }\end{array}$} & \\
\hline & & 1 & 2 & 3 & 1 & 2 & 3 & 1 & 2 & 3 & 1 & 2 & 3 & \\
\hline 4110 & $\begin{array}{l}1 \\
3\end{array}$ & $\mathrm{x}$ & $\mathrm{x}$ & $\mathrm{x}$ & $\begin{array}{c}X \\
N D\end{array}$ & $\begin{array}{l}x \\
x\end{array}$ & $\begin{array}{l}x \\
x\end{array}$ & $\mathrm{x}$ & $\begin{array}{l}x \\
x\end{array}$ & $\begin{array}{l}x \\
x\end{array}$ & $\mathrm{x}$ & $\begin{array}{l}x \\
x\end{array}$ & $\begin{array}{l}x \\
x\end{array}$ & Piezo \#3 \& Dynax $1 \& 2$ need to be replaced \\
\hline 4130 & $\begin{array}{l}1 \\
2 \\
3 \\
4 \\
5 \\
6\end{array}$ & $\begin{array}{l}x \\
x \\
x \\
x\end{array}$ & $\begin{array}{l}N D \\
X\end{array}$ & $\begin{array}{c}X \\
N D \\
X\end{array}$ & $\begin{array}{l}x \\
x \\
x\end{array}$ & $\begin{array}{c}X \\
X \\
N D \\
X\end{array}$ & $\begin{array}{c}X \\
X \\
N D \\
X\end{array}$ & $\mathrm{x}$ & $\begin{array}{l}N D \\
X\end{array}$ & $\begin{array}{c}X \\
N D \\
N D \\
X\end{array}$ & $\begin{array}{l}x \\
x \\
x \\
x \\
x\end{array}$ & $\begin{array}{c}X \\
\text { ND } \\
X\end{array}$ & $\begin{array}{c}X \\
N D \\
N D \\
X\end{array}$ & SLC PM \& all Dynax Need to be replaced. \\
\hline 4140 & 1 & & & $\mathrm{ND}$ & $\mathrm{ND}$ & $\mathrm{ND}$ & $\mathrm{ND}$ & $\mathrm{x}$ & $\mathrm{x}$ & ND & $x$ & $\mathrm{x}$ & ND & All sensors ok. \\
\hline 4150 & $\begin{array}{l}1 \\
2 \\
3 \\
4 \\
\end{array}$ & $\begin{array}{l}X \\
x \\
x\end{array}$ & $\begin{array}{l}X \\
X \\
X \\
X\end{array}$ & $\begin{array}{l}x \\
x\end{array}$ & $\begin{array}{l}x \\
x \\
x \\
x\end{array}$ & & $\bar{x}$ & $\mathrm{x}$ & $\bar{x}$ & $\mathrm{x}$ & $\begin{array}{l}x \\
x \\
x \\
x\end{array}$ & $\mathrm{x}$ & $\mathrm{x}$ & SLC PM \& Dynax Need to be replaced. \\
\hline 4240 & $\begin{array}{l}1 \\
2 \\
3 \\
4\end{array}$ & $\begin{array}{l}\text { ND } \\
\text { ND } \\
\text { ND } \\
\text { ND }\end{array}$ & $\begin{array}{l}\text { ND } \\
\text { ND } \\
\text { ND } \\
\text { ND }\end{array}$ & $\begin{array}{l}\mathrm{ND} \\
\mathrm{ND} \\
\mathrm{ND} \\
\mathrm{ND}\end{array}$ & $\begin{array}{l}\mathrm{ND} \\
\mathrm{ND} \\
\mathrm{ND} \\
\mathrm{ND}\end{array}$ & $\begin{array}{l}\text { ND } \\
\text { ND } \\
\text { ND } \\
\text { ND }\end{array}$ & $\begin{array}{l}\mathrm{ND} \\
\mathrm{ND} \\
\mathrm{ND} \\
\mathrm{ND}\end{array}$ & $\begin{array}{l}\text { ND } \\
\text { ND } \\
\text { ND } \\
\text { ND }\end{array}$ & $\begin{array}{l}N D \\
N D \\
N D \\
N D\end{array}$ & $\begin{array}{l}\mathrm{ND} \\
\mathrm{ND} \\
\mathrm{ND} \\
\mathrm{ND}\end{array}$ & $\begin{array}{l}\text { ND } \\
\text { ND } \\
\text { ND } \\
\text { ND }\end{array}$ & $\begin{array}{l}\text { ND } \\
\text { ND } \\
\text { ND } \\
\text { ND }\end{array}$ & $\begin{array}{l}\text { ND } \\
\text { ND } \\
\text { ND } \\
\text { ND }\end{array}$ & NO DATA \\
\hline 4250 & 3 & & $\mathrm{x}$ & $x$ & $\mathrm{x}$ & & & & $\mathrm{x}$ & $x$ & $\mathrm{x}$ & & & Lane 3 Dynax needs to be replaced. \\
\hline 4260 & 1 & $\bar{x}$ & $\bar{x}$ & $\overline{N D}$ & $\mathrm{x}$ & $\mathrm{x}$ & ND & $\mathrm{X}$ & $\bar{x}$ & ND & & $\mathrm{X}$ & ND & All Dynax need to be replaced. \\
\hline 4270 & $\begin{array}{l}1 \\
2 \\
3 \\
4\end{array}$ & $\begin{array}{l}x \\
x \\
x\end{array}$ & $\begin{array}{c} \\
N D \\
N D \\
N D\end{array}$ & $\begin{array}{c}\mathrm{X} \\
\mathrm{ND} \\
\mathrm{ND} \\
\mathrm{ND}\end{array}$ & & $\begin{array}{c}X \\
N D \\
N D \\
N D\end{array}$ & $\begin{array}{c}X \\
N D \\
N D \\
N D\end{array}$ & $\begin{array}{l}x \\
x \\
x\end{array}$ & $\begin{array}{l}\text { ND } \\
\text { ND } \\
\text { ND }\end{array}$ & $\begin{array}{l}\text { ND } \\
\text { ND } \\
\text { ND }\end{array}$ & & $\begin{array}{l}\text { ND } \\
\text { ND } \\
\text { ND }\end{array}$ & $\begin{array}{c} \\
\text { ND } \\
\text { ND } \\
\text { ND }\end{array}$ & All Dynax need to be replaced. \\
\hline 4280 & 1 & & $\mathrm{X}$ & & & & & & & & & & & NB Dynax need to be replaced. \\
\hline 4400 & $\begin{array}{l}1 \\
2 \\
3 \\
4 \\
5 \\
6\end{array}$ & $\begin{array}{l}x \\
x \\
x \\
x\end{array}$ & $\begin{array}{l}\text { ND } \\
N D \\
N D \\
N D \\
N D \\
N D\end{array}$ & $\begin{array}{l}\mathrm{ND} \\
\mathrm{ND} \\
\mathrm{ND} \\
\mathrm{ND} \\
\mathrm{ND} \\
\mathrm{ND}\end{array}$ & $\begin{array}{l}x \\
x \\
x \\
x \\
x \\
x\end{array}$ & $\begin{array}{l}\text { ND } \\
\text { ND } \\
\text { ND } \\
\text { ND } \\
\text { ND } \\
\text { ND }\end{array}$ & $\begin{array}{l}\text { ND } \\
\text { ND } \\
\text { ND } \\
\text { ND } \\
\text { ND } \\
\text { ND }\end{array}$ & $\begin{array}{l}\text { ND } \\
\text { ND } \\
\text { ND } \\
\text { ND } \\
\text { ND } \\
\text { ND }\end{array}$ & $\begin{array}{l}\text { ND } \\
N D \\
N D \\
N D \\
N D \\
N D\end{array}$ & $\begin{array}{l}\text { ND } \\
\text { ND } \\
\text { ND } \\
\text { ND } \\
\text { ND } \\
\text { ND }\end{array}$ & $\begin{array}{l}\mathrm{ND} \\
\mathrm{ND} \\
\mathrm{ND} \\
\mathrm{ND} \\
\mathrm{ND} \\
\mathrm{ND}\end{array}$ & $\begin{array}{l}\text { ND } \\
\text { ND } \\
\text { ND } \\
\text { ND } \\
\text { ND } \\
\text { ND }\end{array}$ & $\begin{array}{l}\text { ND } \\
\text { ND } \\
\text { ND } \\
\text { ND } \\
\text { ND } \\
\text { ND }\end{array}$ & Piezo \#s 3, 6, 14 Need to be replaced. \\
\hline 5110 & $\begin{array}{l}1 \\
2 \\
3 \\
4\end{array}$ & & & & $\begin{array}{l}x \\
x\end{array}$ & & $x$ & $\begin{array}{l}x \\
x\end{array}$ & $\mathrm{x}$ & $x$ & $\begin{array}{l}x \\
x \\
x\end{array}$ & $x$ & $\mathrm{x}$ & SLC PM \\
\hline 5120 & $\begin{array}{l}1 \\
2 \\
3 \\
4\end{array}$ & $\begin{array}{l}X \\
x \\
x \\
x\end{array}$ & $\begin{array}{l}\mathrm{ND} \\
\mathrm{X}\end{array}$ & $\begin{array}{c}\mathrm{ND} \\
\mathrm{X}\end{array}$ & $\begin{array}{l}x \\
x \\
x\end{array}$ & $\begin{array}{l}\mathrm{ND} \\
\mathrm{X}\end{array}$ & ND & $\begin{array}{l}x \\
x\end{array}$ & $\begin{array}{c}\mathrm{ND} \\
\mathrm{X}\end{array}$ & $\begin{array}{c}\mathrm{ND} \\
\mathrm{X}\end{array}$ & $\begin{array}{l}x \\
x \\
x\end{array}$ & ND & ND & SLC PM \\
\hline 5130 & $\begin{array}{l}1 \\
2 \\
3 \\
4 \\
\end{array}$ & $\begin{array}{l}\text { ND } \\
N D \\
N D \\
N D \\
\end{array}$ & $\begin{array}{l}N D \\
N D \\
N D \\
N D \\
\end{array}$ & $\begin{array}{l}\mathrm{ND} \\
\mathrm{ND} \\
\mathrm{ND} \\
\mathrm{ND} \\
\end{array}$ & $\begin{array}{l}\mathrm{ND} \\
\mathrm{ND} \\
\mathrm{ND} \\
\mathrm{ND} \\
\end{array}$ & $\begin{array}{l}\mathrm{ND} \\
\mathrm{ND} \\
\mathrm{ND} \\
\mathrm{ND} \\
\end{array}$ & $\begin{array}{l}\mathrm{ND} \\
\mathrm{ND} \\
\mathrm{ND} \\
\mathrm{ND} \\
\end{array}$ & $\begin{array}{l}\text { ND } \\
\text { ND } \\
\text { ND } \\
\text { ND } \\
\end{array}$ & $\begin{array}{l}N D \\
N D \\
N D \\
N D \\
\end{array}$ & $\begin{array}{l}\mathrm{ND} \\
\mathrm{ND} \\
\mathrm{ND} \\
\mathrm{ND} \\
\end{array}$ & $\begin{array}{l}\mathrm{ND} \\
\mathrm{ND} \\
\mathrm{ND} \\
\mathrm{ND}\end{array}$ & $\begin{array}{l}\mathrm{ND} \\
\mathrm{ND} \\
\mathrm{ND} \\
\mathrm{ND} \\
\end{array}$ & $\begin{array}{l}\mathrm{ND} \\
\mathrm{ND} \\
\mathrm{ND} \\
\mathrm{ND} \\
\end{array}$ & NO DATA \\
\hline 5140 & $\begin{array}{l}1 \\
3\end{array}$ & $\mathrm{x}$ & & $\begin{array}{l}x \\
x\end{array}$ & $\begin{array}{l}x \\
x\end{array}$ & $\mathrm{x}$ & & $\begin{array}{l}x \\
x\end{array}$ & $\begin{array}{l}x \\
x\end{array}$ & $\begin{array}{l}x \\
x\end{array}$ & $\begin{array}{l}x \\
x\end{array}$ & $\begin{array}{l}x \\
x\end{array}$ & $\begin{array}{l}x \\
x\end{array}$ & Piezo \#3 needs to be replaced. \\
\hline 5240 & 1 & & & $\mathrm{x}$ & $\mathrm{x}$ & $\mathrm{x}$ & & $\mathrm{x}$ & $\mathrm{x}$ & $\mathrm{x}$ & $\mathrm{x}$ & $\mathrm{x}$ & $\mathrm{x}$ & Temp. Sensor to be replaced. \\
\hline
\end{tabular}

Table H-18: Evaluation of WIM Performance (Stations 4110-5240) 


\begin{tabular}{|c|c|c|c|c|c|c|c|c|c|c|c|c|c|c|}
\hline \multirow[b]{3}{*}{ Site } & \multirow[b]{3}{*}{ Lane } & \multicolumn{6}{|c|}{ March, 2001} & \multicolumn{6}{|c|}{ June, 2000} & \multirow{3}{*}{$\begin{array}{l}\text { I.R.D. Sensor Report } \\
\text { for April 01, } 2001\end{array}$} \\
\hline & & \multicolumn{3}{|c|}{$\begin{array}{c}\text { Out-of-Range Front } \\
\text { Axle Mean }\end{array}$} & \multicolumn{3}{|c|}{$\begin{array}{c}\text { Out-of-Range Front } \\
\text { Axle Standard }\end{array}$} & \multicolumn{3}{|c|}{$\begin{array}{c}\text { Out-of-Range Front } \\
\text { Axle Mean }\end{array}$} & \multicolumn{3}{|c|}{$\begin{array}{c}\text { Out-of-Range Front } \\
\text { Axle Standard }\end{array}$} & \\
\hline & & 1 & 2 & 3 & 1 & 2 & 3 & 1 & 2 & 3 & 1 & 2 & 3 & \\
\hline 5250 & 1 & & & & & & & $x$ & & $\mathrm{x}$ & & & & Site ok. \\
\hline 5270 & 1 & ND & ND & ND & ND & ND & ND & ND & ND & ND & ND & ND & ND & \\
\hline & 3 & ND & ND & ND & ND & ND & ND & ND & ND & ND & ND & ND & ND & Site ok. \\
\hline 5440 & $\begin{array}{l}1 \\
3 \\
\end{array}$ & ND & $\begin{array}{l}\text { ND } \\
\mathrm{X}\end{array}$ & $\begin{array}{c}\text { ND } \\
X\end{array}$ & $\begin{array}{l}\text { ND } \\
\mathrm{X}\end{array}$ & $\begin{array}{l}N D \\
X\end{array}$ & $\begin{array}{c}\text { ND } \\
X\end{array}$ & ND & $\begin{array}{l}\text { ND } \\
X\end{array}$ & $\begin{array}{c}\text { ND } \\
\mathrm{X}\end{array}$ & ND & ND & $\begin{array}{c}\text { ND } \\
X \\
\end{array}$ & $\begin{array}{l}\text { Upstream loop in lane } 1 \text { needs to be replaced. All Dynax need to be } \\
\text { replaced. All piezo sensors need to be checked. }\end{array}$ \\
\hline 5450 & $\begin{array}{l}1 \\
3\end{array}$ & & $\begin{array}{l}x \\
x\end{array}$ & $\begin{array}{l}x \\
X\end{array}$ & $\begin{array}{l}x \\
x\end{array}$ & $\begin{array}{l}x \\
X\end{array}$ & $\begin{array}{l}x \\
x\end{array}$ & $x$ & $\mathrm{X}$ & $\begin{array}{l}X \\
X\end{array}$ & $\begin{array}{l}x \\
x\end{array}$ & $\begin{array}{l}\mathrm{X} \\
\mathrm{X}\end{array}$ & $\begin{array}{l}X \\
X\end{array}$ & Site ok. \\
\hline 5460 & $\begin{array}{l}1 \\
2 \\
4 \\
5\end{array}$ & $\begin{array}{l}X \\
N D \\
N D \\
N D \\
\end{array}$ & $\begin{array}{l}\mathrm{ND} \\
\mathrm{ND} \\
\mathrm{ND} \\
\mathrm{ND}\end{array}$ & $\begin{array}{c}\mathrm{X} \\
\mathrm{ND} \\
\mathrm{ND} \\
\mathrm{ND} \\
\end{array}$ & $\begin{array}{c}X \\
\text { ND } \\
\text { ND } \\
\text { ND } \\
\end{array}$ & $\begin{array}{l}\mathrm{ND} \\
\mathrm{ND} \\
\mathrm{ND} \\
\mathrm{ND}\end{array}$ & $\begin{array}{c}\mathrm{X} \\
\mathrm{ND} \\
\mathrm{ND} \\
\mathrm{ND}\end{array}$ & $\begin{array}{l}\text { ND } \\
\text { ND } \\
\text { ND }\end{array}$ & $\begin{array}{l}\text { ND } \\
\text { ND } \\
\text { ND } \\
\text { ND }\end{array}$ & $\begin{array}{c}\mathrm{X} \\
\mathrm{ND} \\
\mathrm{ND} \\
\mathrm{ND}\end{array}$ & $\begin{array}{c}X \\
\text { ND } \\
\text { ND } \\
\text { ND }\end{array}$ & $\begin{array}{l}\text { ND } \\
\text { ND } \\
\text { ND } \\
\text { ND }\end{array}$ & $\begin{array}{c} \\
\text { ND } \\
\text { ND } \\
\text { ND }\end{array}$ & All piezo \& Dynax need to be replaced. \\
\hline 5470 & $\begin{array}{l}1 \\
2 \\
3 \\
4 \\
5 \\
6 \\
\end{array}$ & $\begin{array}{l}x \\
x\end{array}$ & $\begin{array}{l}x \\
x\end{array}$ & $\begin{array}{c}\mathrm{X} \\
\mathrm{ND} \\
\mathrm{X} \\
\mathrm{X} \\
\mathrm{X} \\
\mathrm{X} \\
\end{array}$ & $\begin{array}{l}\mathrm{X} \\
\mathrm{x} \\
\mathrm{x} \\
\mathrm{x}\end{array}$ & $\begin{array}{c}N D \\
x \\
X\end{array}$ & $\begin{array}{c}X \\
N D \\
X \\
X \\
X \\
\end{array}$ & $x$ & $\begin{array}{l}X \\
X \\
X\end{array}$ & $\begin{array}{c}\mathrm{X} \\
\mathrm{ND} \\
\\
\mathrm{X} \\
\mathrm{X} \\
\mathrm{X} \\
\end{array}$ & $\begin{array}{l}\mathrm{x} \\
\mathrm{x} \\
\mathrm{x} \\
\mathrm{x}\end{array}$ & $\begin{array}{l}x \\
x \\
x \\
x \\
x \\
\end{array}$ & $\begin{array}{c}\mathrm{X} \\
\mathrm{ND} \\
\mathrm{X} \\
\mathrm{X} \\
\mathrm{X} \\
\end{array}$ & Site ok. \\
\hline 5480 & $\begin{array}{l}1 \\
2 \\
4 \\
5\end{array}$ & $\begin{array}{c}X \\
X \\
X \\
N D\end{array}$ & $\begin{array}{c}X \\
X \\
N D\end{array}$ & \begin{tabular}{c|}
$X$ \\
$X$ \\
$X$ \\
$N D$ \\
\end{tabular} & $\begin{array}{c}X \\
X \\
X \\
N D\end{array}$ & $\begin{array}{c}X \\
X \\
X \\
N D\end{array}$ & $\begin{array}{c}X \\
X \\
X \\
N D \\
\end{array}$ & ND & $\begin{array}{c}X \\
X \\
X \\
N D\end{array}$ & $\begin{array}{c}X \\
X \\
X \\
N D \\
\end{array}$ & $\begin{array}{c}X \\
X \\
X \\
N D\end{array}$ & $\begin{array}{c}X \\
X \\
X \\
\text { ND }\end{array}$ & \begin{tabular}{c|}
$X$ \\
$X$ \\
$X$ \\
$N D$ \\
\end{tabular} & Site to be rebuilt. \\
\hline 5550 & $\begin{array}{l}1 \\
2 \\
3 \\
4 \\
\end{array}$ & $\mathrm{x}$ & $\begin{array}{l}\mathrm{X} \\
\mathrm{x} \\
\mathrm{x} \\
\mathrm{X} \\
\end{array}$ & $\begin{array}{l}\mathrm{ND} \\
\mathrm{ND} \\
\mathrm{ND} \\
\mathrm{ND} \\
\end{array}$ & $\begin{array}{l}\mathrm{X} \\
\mathrm{x} \\
\mathrm{x} \\
\mathrm{x}\end{array}$ & $\begin{array}{l}\mathrm{X} \\
\mathrm{x} \\
\mathrm{x} \\
\mathrm{X} \\
\end{array}$ & $\begin{array}{l}\text { ND } \\
\text { ND } \\
\text { ND } \\
\text { ND } \\
\end{array}$ & $\begin{array}{l}\mathrm{X} \\
\mathrm{ND} \\
\mathrm{X} \\
\mathrm{X}\end{array}$ & $\begin{array}{l}\mathrm{X} \\
\mathrm{X} \\
\mathrm{X} \\
\mathrm{X}\end{array}$ & $\begin{array}{l}\mathrm{ND} \\
\mathrm{ND} \\
\mathrm{ND} \\
\mathrm{ND} \\
\end{array}$ & $\begin{array}{l}\text { ND } \\
\text { ND }\end{array}$ & $\begin{array}{l}\mathrm{X} \\
\mathrm{x} \\
\mathrm{x} \\
\mathrm{x}\end{array}$ & $\begin{array}{l}\text { ND } \\
\text { ND } \\
\text { ND } \\
\text { ND } \\
\end{array}$ & $\begin{array}{l}\text { Site ok. Loops need to be re-sealed (topped off) \& piezo \#7 needs to } \\
\text { be replaced. }\end{array}$ \\
\hline 6130 & $\begin{array}{l}1 \\
3\end{array}$ & ND & $\begin{array}{l}\mathrm{ND} \\
\mathrm{ND}\end{array}$ & $\begin{array}{l}N D \\
N D\end{array}$ & ND & ND & ND & ND & ND & $\begin{array}{l}N D \\
N D\end{array}$ & ND & ND & ND & $\begin{array}{l}\text { Conduit under road is blocked. } \\
\text { BP \& Dynax need to be replaced. }\end{array}$ \\
\hline 6140 & $\begin{array}{l}1 \\
3 \\
\end{array}$ & $\begin{array}{l}\mathrm{X} \\
\mathrm{x}\end{array}$ & $\begin{array}{l}\mathrm{x} \\
\mathrm{x}\end{array}$ & $\mathrm{x}$ & $\mathrm{x}$ & $\begin{array}{l}\mathrm{X} \\
\mathrm{X} \\
\end{array}$ & $\begin{array}{l}\mathrm{X} \\
\mathrm{x}\end{array}$ & $\mathrm{x}$ & $\begin{array}{l}\mathrm{X} \\
\mathrm{X}\end{array}$ & $\begin{array}{l}\mathrm{X} \\
\mathrm{x}\end{array}$ & $\begin{array}{l}\mathrm{x} \\
\mathrm{x}\end{array}$ & $\mathrm{x}$ & $\mathrm{x}$ & $\begin{array}{l}\text { Site ok. } \\
\text { NB Vault needs to be ground down. }\end{array}$ \\
\hline 6150 & 1 & $x$ & & $x$ & $x$ & $x$ & $x$ & & & & $x$ & & & Site ok. \\
\hline 6160 & $\begin{array}{l}1 \\
3 \\
\end{array}$ & $\mathrm{x}$ & $\mathrm{x}$ & $\begin{array}{l}X \\
X \\
\end{array}$ & $\begin{array}{l}\mathrm{X} \\
\mathrm{x} \\
\end{array}$ & $\begin{array}{l}\mathrm{X} \\
\mathrm{X} \\
\end{array}$ & $\begin{array}{l}X \\
x \\
\end{array}$ & $\begin{array}{l}X \\
x \\
\end{array}$ & $\begin{array}{l}X \\
X \\
\end{array}$ & $\begin{array}{l}\mathrm{X} \\
\mathrm{x} \\
\end{array}$ & $\begin{array}{l}\mathrm{x} \\
\mathrm{x} \\
\end{array}$ & $x$ & $\mathrm{X}$ & Dynax needs to be replaced. \\
\hline 6170 & $\begin{array}{l}1 \\
3 \\
\end{array}$ & $\mathrm{x}$ & & $x$ & $\begin{array}{l}X \\
X \\
\end{array}$ & $\begin{array}{l}X \\
X \\
\end{array}$ & $x$ & $\begin{array}{l}X \\
X \\
\end{array}$ & $\begin{array}{l}X \\
X \\
\end{array}$ & $\begin{array}{l}X \\
X \\
\end{array}$ & $\begin{array}{l}X \\
X \\
\end{array}$ & $\begin{array}{l}X \\
X \\
\end{array}$ & $\begin{array}{l}X \\
X \\
\end{array}$ & Site ok. \\
\hline 6250 & 1 & $\mathrm{x}$ & ND & ND & & ND & ND & $\mathrm{x}$ & ND & ND & & ND & ND & $\begin{array}{l}\text { Dynax need to be replaced. } \\
\text { BP needs to be checked. }\end{array}$ \\
\hline 6260 & 1 & ND & ND & ND & ND & $\mathrm{ND}$ & ND & ND & ND & ND & ND & ND & ND & NO DATA \\
\hline 6270 & 3 & $\mathrm{X}$ & $\mathrm{x}$ & $\mathrm{x}$ & $\mathrm{x}$ & $\mathrm{X}$ & $\mathrm{X}$ & $\mathrm{x}$ & & $\mathrm{X}$ & $\mathrm{x}$ & $\mathrm{x}$ & $\mathrm{X}$ & Dynax need to be replaced. \\
\hline 6280 & 1 & $\mathrm{X}$ & $\mathrm{x}$ & ND & $\mathrm{x}$ & $x$ & ND & ND & $x$ & ND & ND & $\mathrm{x}$ & ND & Site to be rebuilt. \\
\hline 6290 & $\begin{array}{l}1 \\
2 \\
\end{array}$ & $\mathrm{x}$ & $x$ & $\begin{array}{l}\mathrm{X} \\
\mathrm{X} \\
\end{array}$ & $\begin{array}{l}X \\
X \\
\end{array}$ & $\begin{array}{l}X \\
X \\
\end{array}$ & $\begin{array}{l}X \\
X \\
\end{array}$ & $\begin{array}{l}X \\
X \\
\end{array}$ & $x$ & $x$ & $\begin{array}{l}x \\
x \\
\end{array}$ & $\begin{array}{l}X \\
X \\
\end{array}$ & $\begin{array}{l}X \\
X \\
\end{array}$ & Site ok. \\
\hline 7300 & $\begin{array}{l}1 \\
2 \\
3 \\
4\end{array}$ & & $\mathrm{x}$ & $\begin{array}{l}\mathrm{X} \\
\mathrm{X} \\
\mathrm{x}\end{array}$ & $\begin{array}{l}x \\
x \\
x \\
x\end{array}$ & $\begin{array}{l}X \\
X \\
X \\
X \\
\end{array}$ & $\begin{array}{l}x \\
x \\
x \\
x \\
\end{array}$ & $\begin{array}{l}\text { ND } \\
\text { ND } \\
\text { ND } \\
\text { ND }\end{array}$ & $\begin{array}{l}\text { ND } \\
\text { ND } \\
\text { ND } \\
\text { ND } \\
\end{array}$ & $\begin{array}{l}\mathrm{ND} \\
\mathrm{ND} \\
\mathrm{ND} \\
\mathrm{ND}\end{array}$ & $\begin{array}{l}\text { ND } \\
\text { ND } \\
\text { ND } \\
\text { ND }\end{array}$ & $\begin{array}{l}\text { ND } \\
\text { ND } \\
\text { ND } \\
\text { ND }\end{array}$ & $\begin{array}{l}\mathrm{ND} \\
\mathrm{ND} \\
\mathrm{ND} \\
\mathrm{ND}\end{array}$ & Site ok. \\
\hline 7320 & $\begin{array}{l}1 \\
2 \\
3 \\
4 \\
\end{array}$ & $\mathrm{x}$ & & $\begin{array}{l}x \\
x \\
\end{array}$ & $\begin{array}{l}X \\
x \\
x \\
x \\
\end{array}$ & $\begin{array}{l}X \\
X \\
X \\
X \\
\end{array}$ & $\begin{array}{l}x \\
x \\
x \\
x \\
\end{array}$ & $\begin{array}{l}\text { ND } \\
\text { ND } \\
\text { ND } \\
\text { ND }\end{array}$ & $\begin{array}{l}\text { ND } \\
\text { ND } \\
\text { ND } \\
\text { ND } \\
\end{array}$ & $\begin{array}{l}\mathrm{ND} \\
\mathrm{ND} \\
\mathrm{ND} \\
\mathrm{ND}\end{array}$ & $\begin{array}{l}\text { ND } \\
\text { ND } \\
\text { ND } \\
\text { ND }\end{array}$ & $\begin{array}{l}\text { ND } \\
\text { ND } \\
\text { ND } \\
\text { ND }\end{array}$ & $\begin{array}{l}\mathrm{ND} \\
\mathrm{ND} \\
\mathrm{ND} \\
\mathrm{ND}\end{array}$ & Piezo \#7 needs to be replaced. \\
\hline 7340 & $\begin{array}{l}1 \\
2 \\
3 \\
4 \\
\end{array}$ & & $\begin{array}{l}x \\
x \\
\end{array}$ & $\begin{array}{l}x \\
x \\
x \\
\end{array}$ & $\begin{array}{l}X \\
X \\
X \\
X \\
\end{array}$ & $\begin{array}{l}x \\
x \\
x \\
x\end{array}$ & $\begin{array}{l}x \\
x \\
x \\
x \\
\end{array}$ & $\begin{array}{l}\text { ND } \\
\text { ND } \\
\text { ND } \\
\text { ND }\end{array}$ & $\begin{array}{l}\text { ND } \\
\text { ND } \\
\text { ND } \\
\text { ND } \\
\end{array}$ & $\begin{array}{l}\mathrm{ND} \\
\mathrm{ND} \\
\mathrm{ND} \\
\mathrm{ND}\end{array}$ & $\begin{array}{l}\text { ND } \\
\text { ND } \\
\text { ND } \\
\text { ND }\end{array}$ & $\begin{array}{l}\text { ND } \\
\text { ND } \\
\text { ND } \\
\text { ND }\end{array}$ & $\begin{array}{l}\mathrm{ND} \\
\mathrm{ND} \\
\mathrm{ND} \\
\mathrm{ND}\end{array}$ & Piezos need to be patched. \\
\hline
\end{tabular}

Table H-19: Evaluation of WIM Performance (Stations 5250-7340) 
Appendix I Summary of Merrillville Enforcement Detail 


\begin{tabular}{|c|c|c|c|c|c|c|c|c|c|}
\hline \multicolumn{10}{|c|}{$\begin{array}{l}\text { John Green } \\
\text { Officer Deb Burkhart } \\
\text { Officer Scott Fleming } \\
\text { Officer Brian Nagle }\end{array}$} \\
\hline Description & $\begin{array}{c}\text { Axle } 1 \\
\text { WIM }\end{array}$ & $\begin{array}{l}\text { Axle } 1 \\
\text { Scale }\end{array}$ & $\begin{array}{c}\text { Tandem } \\
\text { WIM }\end{array}$ & $\begin{array}{c}\text { Tandem } 1 \\
\text { Scale }\end{array}$ & $\begin{array}{c}\text { Tandem } 2 \\
\text { WIM }\end{array}$ & $\begin{array}{c}\text { Tandem } 2 \\
\text { Scale }\end{array}$ & $\begin{array}{l}\text { GVW } \\
\text { WIM }\end{array}$ & $\begin{array}{l}\text { GVW } \\
\text { Scale }\end{array}$ & Action Taken \\
\hline CL9/L2 & 11,200 & 11,600 & 28,300 & 30,000 & 31,700 & 30,900 & 71,200 & 72,500 & None \\
\hline CL9/L1 & 11,800 & 11,900 & 33,200 & 32,800 & 30,400 & 31,300 & 75,400 & 76,000 & None \\
\hline CL9/L1 & 11,100 & 10,200 & 33,700 & 33,100 & 36,000 & 32,900 & 80,800 & 76,200 & None \\
\hline CL9/L1 & 12,500 & 12,200 & 33,100 & 32,200 & 32,200 & 31,000 & 77,800 & 75,400 & None \\
\hline CL9/L1 & 12,500 & 12,700 & 31,100 & 32,100 & 35,600 & 32,400 & 79,200 & 77,200 & None \\
\hline CL9/L3 & 12,600 & 12,200 & 33,500 & 32,800 & 33,400 & 32,400 & 79,600 & 77,300 & None \\
\hline CL9/L1 & 10,400 & 11,100 & 35,000 & 29,000 & 38,700 & 35,400 & 84,000 & 75,400 & $\begin{array}{c}\text { Tandem warning } \\
(34,000 \text { legal })\end{array}$ \\
\hline CL9/L2 & 11,100 & 11,500 & 31,100 & 32,400 & 33,400 & 34,200 & 75,700 & 78,100 & $\begin{array}{c}\text { Tandem warning } \\
(34,000 \text { legal })\end{array}$ \\
\hline CL9/L1 & 9,200 & 9,000 & 46,400 & 38,700 & 41,600 & 37,200 & 97,200 & 84,800 & $\begin{array}{c}\text { GVW ticket } \\
(80,000 \text { legal) \& } \\
\text { tandem ticket } \\
(34,000 \text { legal }) \\
\text { issued }\end{array}$ \\
\hline
\end{tabular}

Table I-1: March 29, 2001 - Merrillville Scale Detail (WIM 4410) - WIM v. Static

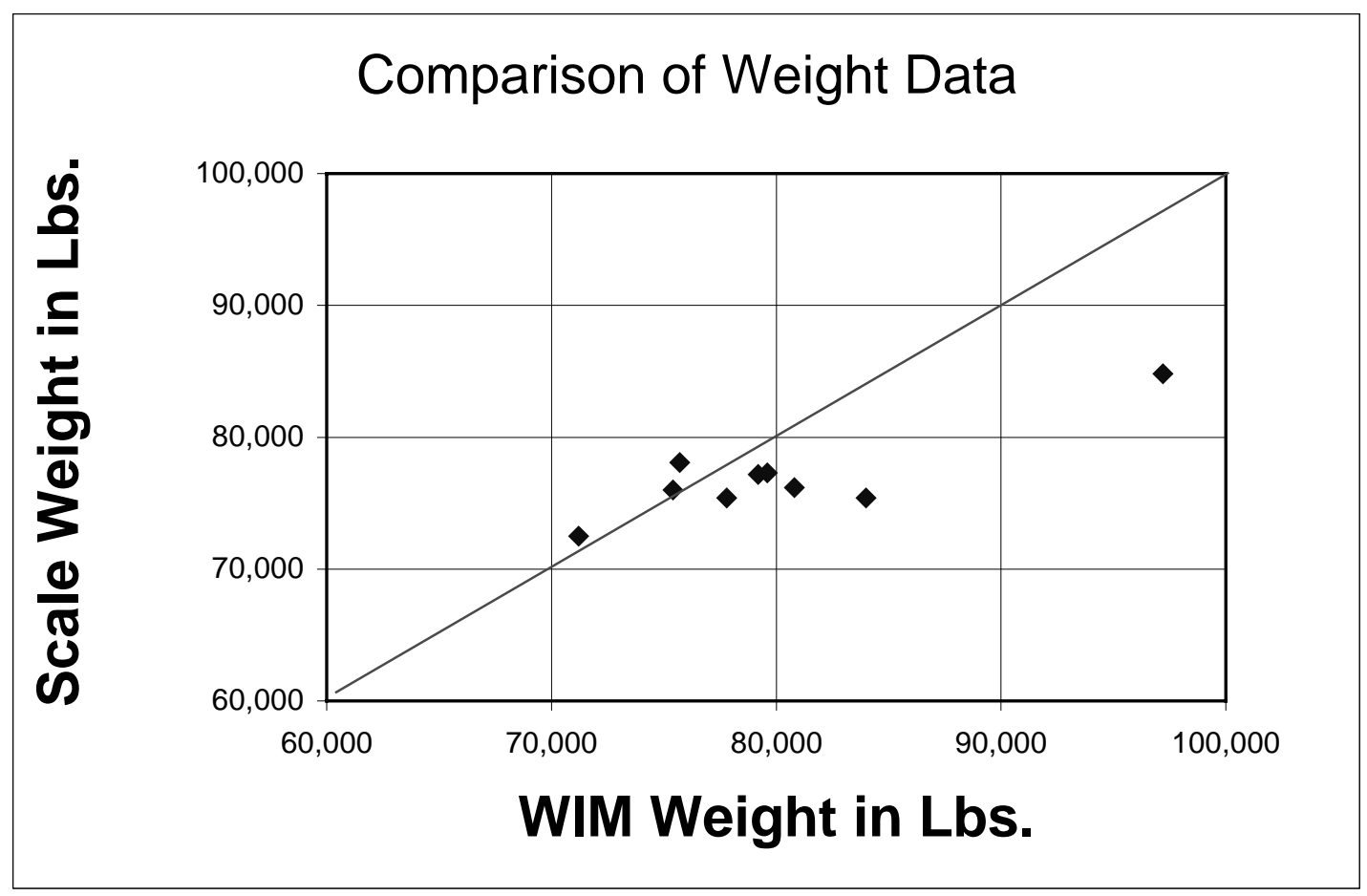

Figure I-1: March 29, 2001 - Merrillville Scale Detail (WIM 4410) - WIM v. Static graph 


\begin{tabular}{|c|c|c|c|c|c|c|c|c|c|}
\hline \multicolumn{10}{|c|}{$\begin{array}{c}\text { Ed Allen } \\
\text { John Green } \\
\text { Officer Henry Davis } \\
\text { Officer Gerald Young }\end{array}$} \\
\hline Description & $\begin{array}{c}\text { Axle } 1 \\
\text { WIM }\end{array}$ & $\begin{array}{l}\text { Axle 1 } \\
\text { Scale }\end{array}$ & $\begin{array}{c}\text { Tandem } 1 \\
\text { WIM }\end{array}$ & $\begin{array}{c}\text { Tandem } 1 \\
\text { Scale }\end{array}$ & $\begin{array}{c}\text { Tandem } \\
2 \text { WIM }\end{array}$ & $\begin{array}{c}\text { Tandem } 2 \\
\text { Scale }\end{array}$ & $\begin{array}{l}\text { GVW } \\
\text { WIM }\end{array}$ & $\begin{array}{l}\text { GVW } \\
\text { Scale }\end{array}$ & Action Taken \\
\hline $\begin{array}{c}\text { CL9/L1 } \\
\text { Freight Box }\end{array}$ & 11,500 & 11,750 & 33,500 & 32,400 & 35,500 & 32,800 & 82,600 & 76,950 & none \\
\hline $\begin{array}{c}\text { CL9/L1 } \\
\text { Freight Box }\end{array}$ & 10,800 & 10,700 & 34,100 & 35,300 & 36,900 & 32,800 & 81,800 & 78,800 & none \\
\hline $\begin{array}{c}\text { CL9/L2 } \\
\text { Grain }\end{array}$ & 11,600 & 12,700 & 34,400 & 39,800 & 37,400 & 41,300 & 83,400 & 93,800 & $\begin{array}{c}\text { GVW ticket } \\
(80,000 \text { legal }) \\
\text { issued, } \\
\text { tandem warning } \\
(34,000 \text { legal })\end{array}$ \\
\hline $\begin{array}{c}\text { CL9/L1 } \\
\text { Steel Coil }\end{array}$ & 10,900 & 11,400 & 44,300 & 32,500 & 29,200 & 32,400 & 84,500 & 76,300 & none \\
\hline $\begin{array}{c}\text { CL9/L1 } \\
\text { Container }\end{array}$ & 11,000 & 11,400 & 34,100 & 34,900 & 33,700 & 32,800 & 78,800 & 79,100 & $\begin{array}{c}\text { Tandem warning } \\
(34,000 \text { legal) }\end{array}$ \\
\hline $\begin{array}{c}\mathrm{CL9} / \mathrm{L} 1 \\
\text { Freight Box }\end{array}$ & 11,600 & 12,500 & 32,700 & 35,200 & 33,000 & 31,700 & 77,300 & 79,400 & $\begin{array}{l}\text { Tandem warning } \\
(34,000 \text { legal) }\end{array}$ \\
\hline
\end{tabular}

Table I-2: May 8, 2001 - Merrillville Scale Detail (WIM 4410) - WIM v. Static

\section{Comparison of Weight Data}

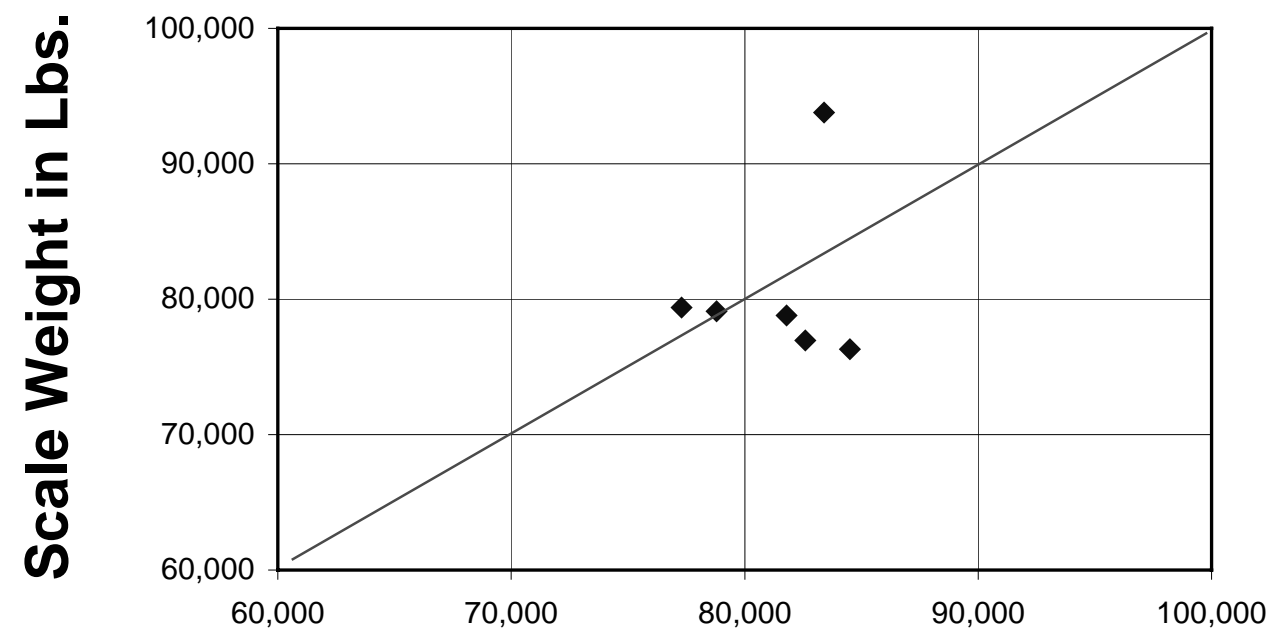

WIM Weight in Lbs.

Figure I-2: May 8, 2001 - Merrillville Scale Detail (WIM 4410) - WIM v. Static graph 


\begin{tabular}{|c|c|c|c|c|c|c|c|c|c|}
\hline $\begin{array}{c}\text { Ed Allen } \\
\text { John Green } \\
\text { Officer Gerald Young }\end{array}$ & ${ }^{*}=$ tridem \\
\hline Description & $\begin{array}{c}\text { Axle 1 } \\
\text { WIM }\end{array}$ & $\begin{array}{c}\text { Axle 1 } \\
\text { Scale }\end{array}$ & $\begin{array}{c}\text { Tandem } \\
1 \text { WIM }\end{array}$ & $\begin{array}{c}\text { Tandem 1 } \\
\text { Scale }\end{array}$ & $\begin{array}{c}\text { Tandem 2 } \\
\text { WIM }\end{array}$ & $\begin{array}{c}\text { Tandem 2 } \\
\text { Scale }\end{array}$ & $\begin{array}{c}\text { GVW } \\
\text { WIM }\end{array}$ & $\begin{array}{c}\text { GVW } \\
\text { Scale }\end{array}$ & Action Taken \\
\hline $\begin{array}{c}\text { CL7/L1 } \\
\text { 4-Axle Dump }\end{array}$ & 19,100 & 19,100 & $75,500^{*}$ & $50,100^{*}$ & 0 & 0 & 93,400 & 69,200 & $\begin{array}{c}\text { GVW ticket } \\
\text { (68,000 legal) } \\
\text { issued }\end{array}$ \\
\hline $\begin{array}{c}\text { CL9/L1 } \\
\text { Short Dump }\end{array}$ & 9,400 & 10,200 & 36,300 & 27,900 & 45,500 & 35,100 & 91,200 & 73,200 & $\begin{array}{c}\text { Tandem } \\
\text { warning (34,000 } \\
\text { legal) }\end{array}$ \\
\hline $\begin{array}{c}\text { CL9/L1 } \\
\text { Short Dump }\end{array}$ & 9,400 & 10,400 & 33,000 & 31,100 & 43,300 & 39,300 & 85,700 & 80,800 & $\begin{array}{c}\text { Tandem ticket } \\
\text { (34,000 legal), } \\
\text { GVW warning } \\
\text { (73,280 legal) }\end{array}$ \\
\hline
\end{tabular}

Table I-3: May 15, 2001 - Merrillville Scale Detail (WIM 4410) - WIM v. Static

\section{Comparison of Weight Data}

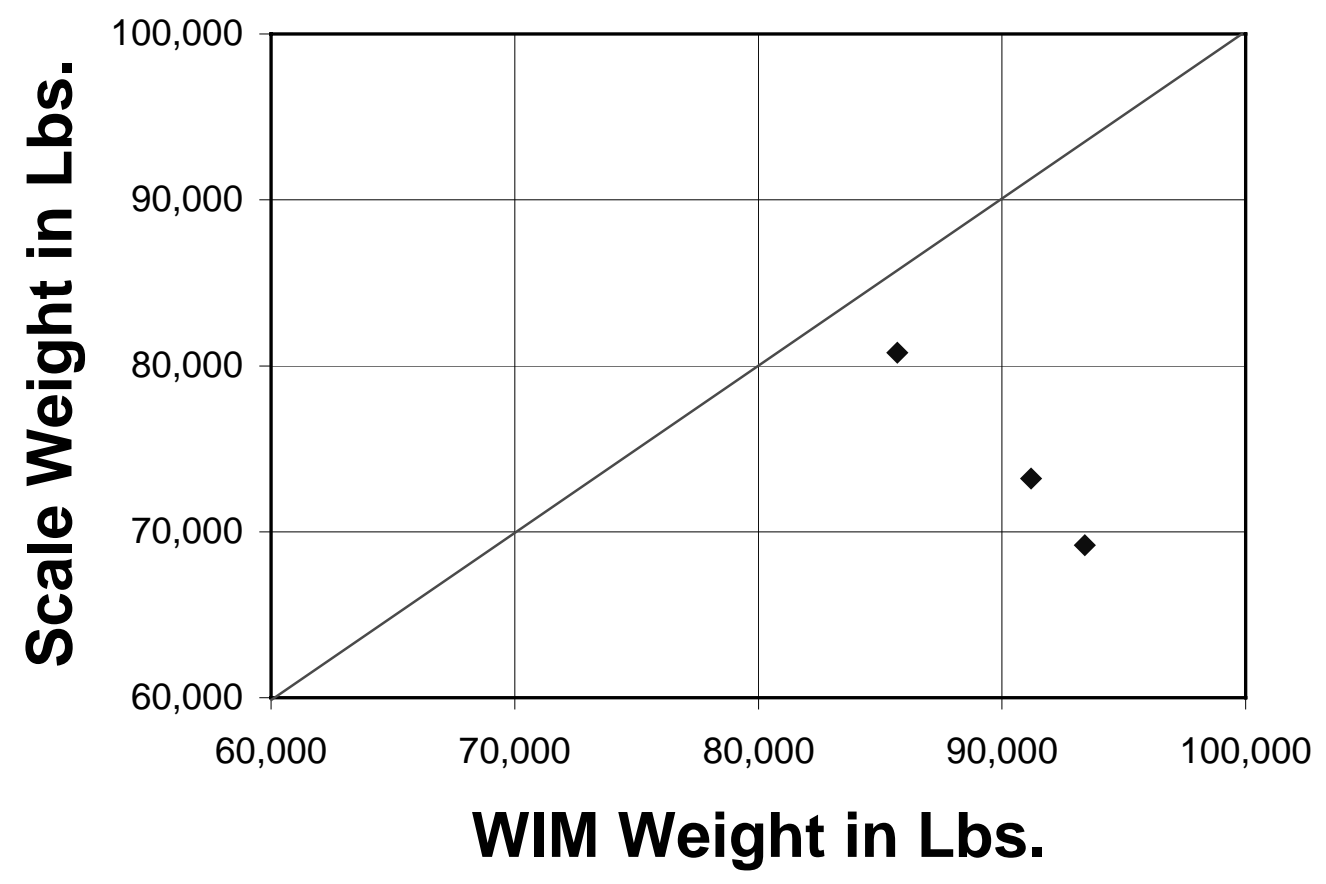

Figure I-3: May 15, 2001 - Merrillville Scale Detail (WIM 4410) - WIM v. Static graph 


\begin{tabular}{|c|c|c|c|c|c|c|c|c|c|}
\hline \multicolumn{10}{|c|}{$\begin{array}{l}\text { John Green } \\
\text { Officer Henry }\end{array}$} \\
\hline Description & $\begin{array}{c}\text { Axle } 1 \\
\text { WIM }\end{array}$ & $\begin{array}{c}\text { Axle } 1 \\
\text { Scale }\end{array}$ & Tandem 1 WIM & $\begin{array}{c}\text { Tandem } \\
1 \text { Scale } \\
\end{array}$ & $\begin{array}{c}\text { Tandem } 2 \\
\text { WIM }\end{array}$ & $\begin{array}{c}\text { Tandem } 2 \\
\text { Scale }\end{array}$ & $\begin{array}{l}\text { GVW } \\
\text { WIM }\end{array}$ & $\begin{array}{l}\text { GVW } \\
\text { Scale }\end{array}$ & Action Taken \\
\hline $\begin{array}{c}\text { CL9/L2 } \\
\text { Spread Axle }\end{array}$ & 9,800 & 10,900 & 32,500 & 37,700 & 48,000 & 50,100 & 90,400 & 98,700 & \begin{tabular}{|c} 
Vehicle \\
Impounded, GVW \\
$(80,000$ legal) \& \\
Tandem $\left(40,000^{\star}\right)$ \\
Ticket \\
\end{tabular} \\
\hline $\begin{array}{c}\text { CL9/L2 } \\
\text { Spread Axle }\end{array}$ & 10,900 & 11,800 & 34,400 & 38,600 & 46,300 & 50,200 & 91,500 & 100,600 & \begin{tabular}{|c|} 
Vehicle \\
Impounded, GVW \\
$(80,000$ legal) \& \\
Tandem $\left(40,000^{*}\right)$ \\
Ticket \\
\end{tabular} \\
\hline $\begin{array}{c}\text { CL9/L1 } \\
\text { Freight Box }\end{array}$ & 11,100 & 12,200 & 37,300 & 35,300 & 35,200 & 33,100 & 83,600 & 80,600 & $\begin{array}{l}\text { Tandem ticket } \\
\text { (34,000 legal), } \\
\text { GVW warning } \\
\text { (80,000 legal) }\end{array}$ \\
\hline $\begin{array}{c}\text { CL9/L1 } \\
\text { Freight Box }\end{array}$ & 9,700 & 11,200 & 37,900 & 36,600 & 36,100 & 31,300 & 83,700 & 79,100 & $\begin{array}{l}\text { Tandem ticket } \\
(34,000 \text { legal) }\end{array}$ \\
\hline
\end{tabular}

Table I-4: May 18, 2001 - Merrillville Scale Detail (WIM 4410) - WIM v. Static

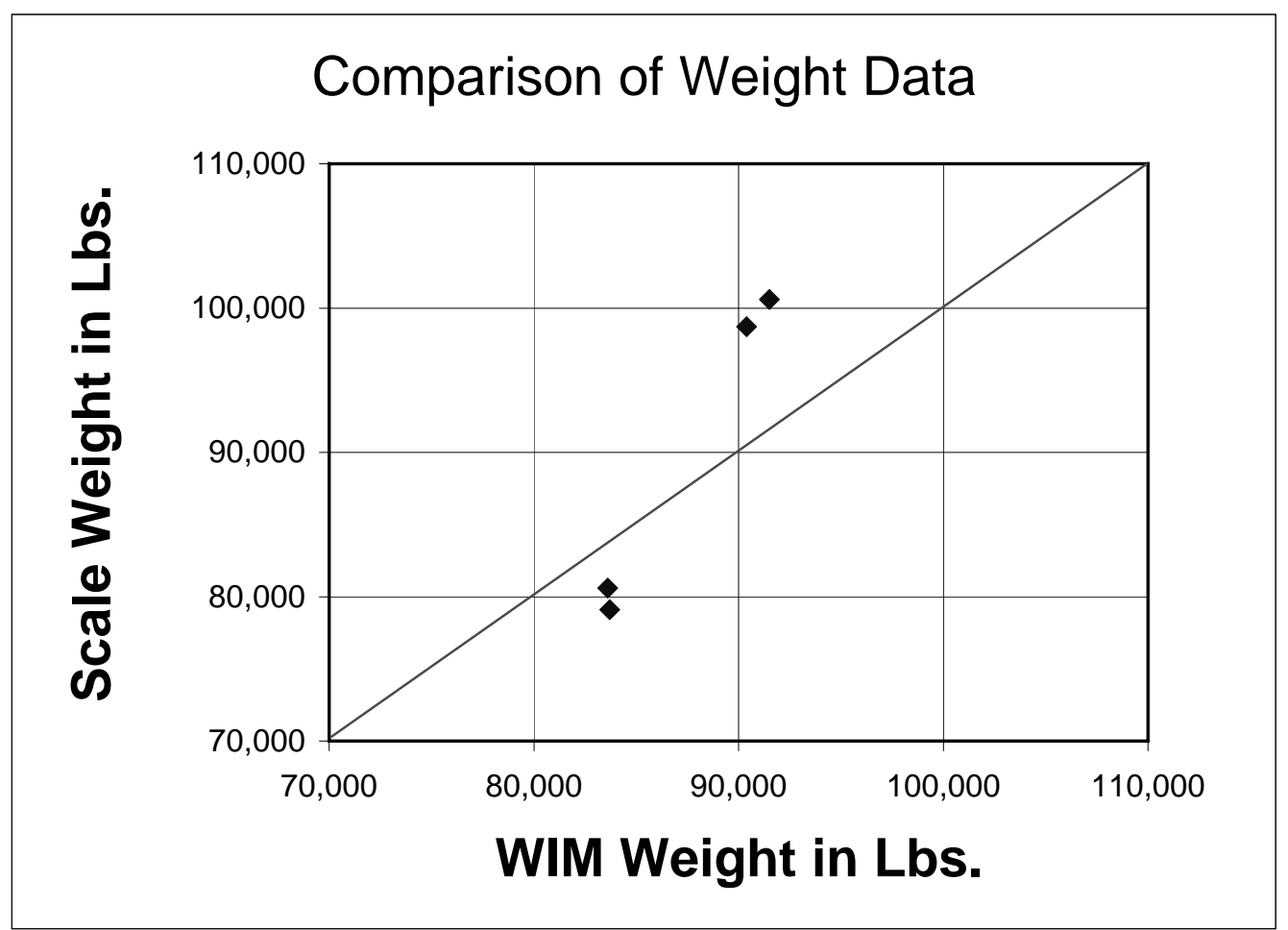

Figure I-4: May 18, 2001 - Merrillville Scale Detail (WIM 4410) - WIM v. Static graph 


\begin{tabular}{|c|c|c|c|c|c|c|c|c|c|}
\hline \multicolumn{10}{|c|}{$\begin{array}{l}\text { Ed Allen } \\
\text { John Green } \\
\text { Officer Deb Burkhart }\end{array}$} \\
\hline Description & $\begin{array}{c}\text { Axle } 1 \\
\text { WIM }\end{array}$ & $\begin{array}{l}\text { Axle } 1 \\
\text { Scale }\end{array}$ & $\begin{array}{c}\text { Tandem } 1 \\
\text { WIM }\end{array}$ & $\begin{array}{c}\text { Tandem } 1 \\
\text { Scale }\end{array}$ & $\begin{array}{c}\text { Tandem } 2 \\
\text { WIM }\end{array}$ & $\begin{array}{c}\text { Tandem } 2 \\
\text { Scale }\end{array}$ & $\begin{array}{l}\text { GVW } \\
W I M\end{array}$ & $\begin{array}{l}\text { GVW } \\
\text { Scale }\end{array}$ & Action Taken \\
\hline $\begin{array}{c}\text { CL7/L1 } \\
\text { 4-Axle Dump }\end{array}$ & 11,100 & 13,650 & 60,700 & $50,100^{\star}$ & 0 & 0 & 71,900 & 63,750 & $\begin{array}{l}\text { Verbal Tridem } \\
(50,000) \text { Warning }\end{array}$ \\
\hline $\begin{array}{c}\text { CL9/L1 } \\
\text { Short Dump }\end{array}$ & 8,800 & 9,650 & 31,000 & 25,800 & 35,400 & 32,450 & 75,300 & 67,900 & None \\
\hline $\begin{array}{c}\text { CL9/L1 } \\
\text { Short Dump }\end{array}$ & 8,600 & 9,950 & 31,800 & 27,350 & 39,000 & 31,600 & 79,400 & 68,900 & None \\
\hline $\begin{array}{c}\text { CL9/L1 } \\
\text { Grain Hauler }\end{array}$ & 9,300 & 10,650 & 38,000 & 40,200 & 38,300 & 38,750 & 85,500 & 89,600 & $\begin{array}{c}\text { Tandem ticket } \\
\text { (34,000 legal), } \\
\text { GVW ticket } \\
(80,000 \text { legal) }\end{array}$ \\
\hline $\begin{array}{c}\text { CL9/L1 } \\
\text { Steel Hauler }\end{array}$ & 8,300 & 8,450 & 33,500 & 33,250 & 38,900 & 34,000 & 80,800 & 75,700 & None \\
\hline
\end{tabular}

Table I-5: May 21, 2001 - Merrillville Scale Detail (WIM 4410) - WIM v. Static

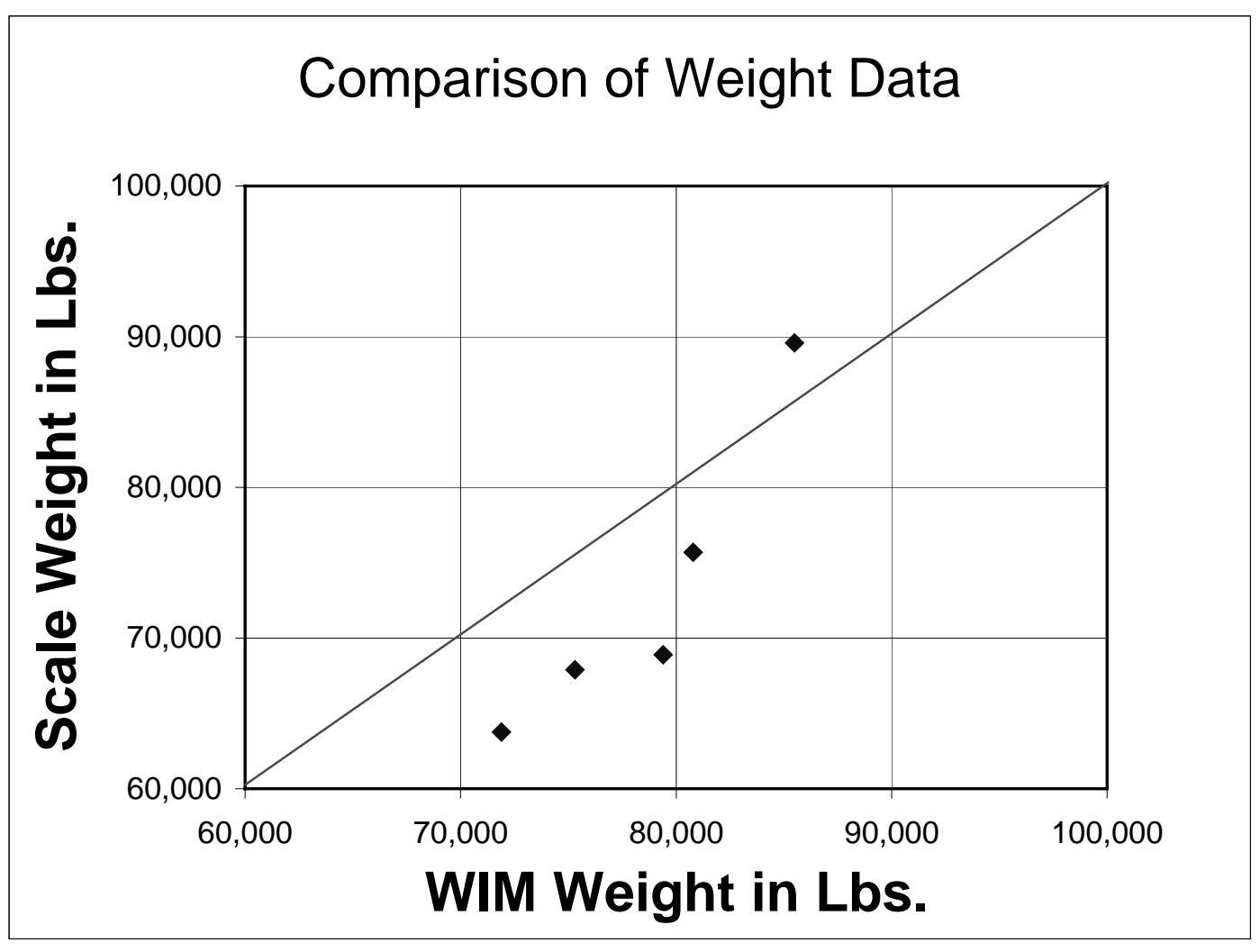

Figure I-5: May 21, 2001 - Merrillville Scale Detail (WIM 4410) - WIM v. Static graph 


\begin{tabular}{|c|c|c|c|c|c|c|c|c|c|}
\hline \multicolumn{10}{|c|}{$\begin{array}{l}\text { John Green } \\
\text { Officer Deb Burkhart }\end{array}$} \\
\hline Description & $\begin{array}{c}\text { Axle } 1 \\
\text { WIM }\end{array}$ & $\begin{array}{l}\text { Axle } 1 \\
\text { Scale }\end{array}$ & $\begin{array}{c}\text { Tandem } 1 \\
\text { WIM }\end{array}$ & $\begin{array}{c}\text { Tandem } 1 \\
\text { Scale }\end{array}$ & $\begin{array}{c}\text { Tandem } 2 \\
\text { WIM }\end{array}$ & $\begin{array}{c}\text { Tandem } 2 \\
\text { Scale }\end{array}$ & $\begin{array}{l}\text { GVW } \\
\text { WIM }\end{array}$ & $\begin{array}{l}\text { GVW } \\
\text { Scale }\end{array}$ & $\begin{array}{l}\text { Action } \\
\text { Taken }\end{array}$ \\
\hline $\begin{array}{l}\text { CL9/L1 } \\
\text { Tanker }\end{array}$ & 11,000 & 11,750 & 34,300 & 31,900 & 35,500 & 33,100 & 80,700 & 76,750 & None \\
\hline
\end{tabular}

Table I-6: May 23, 2001 - Merrillville Scale Detail (WIM 4410) - WIM v. Static

\section{Comparison of Weight Data}

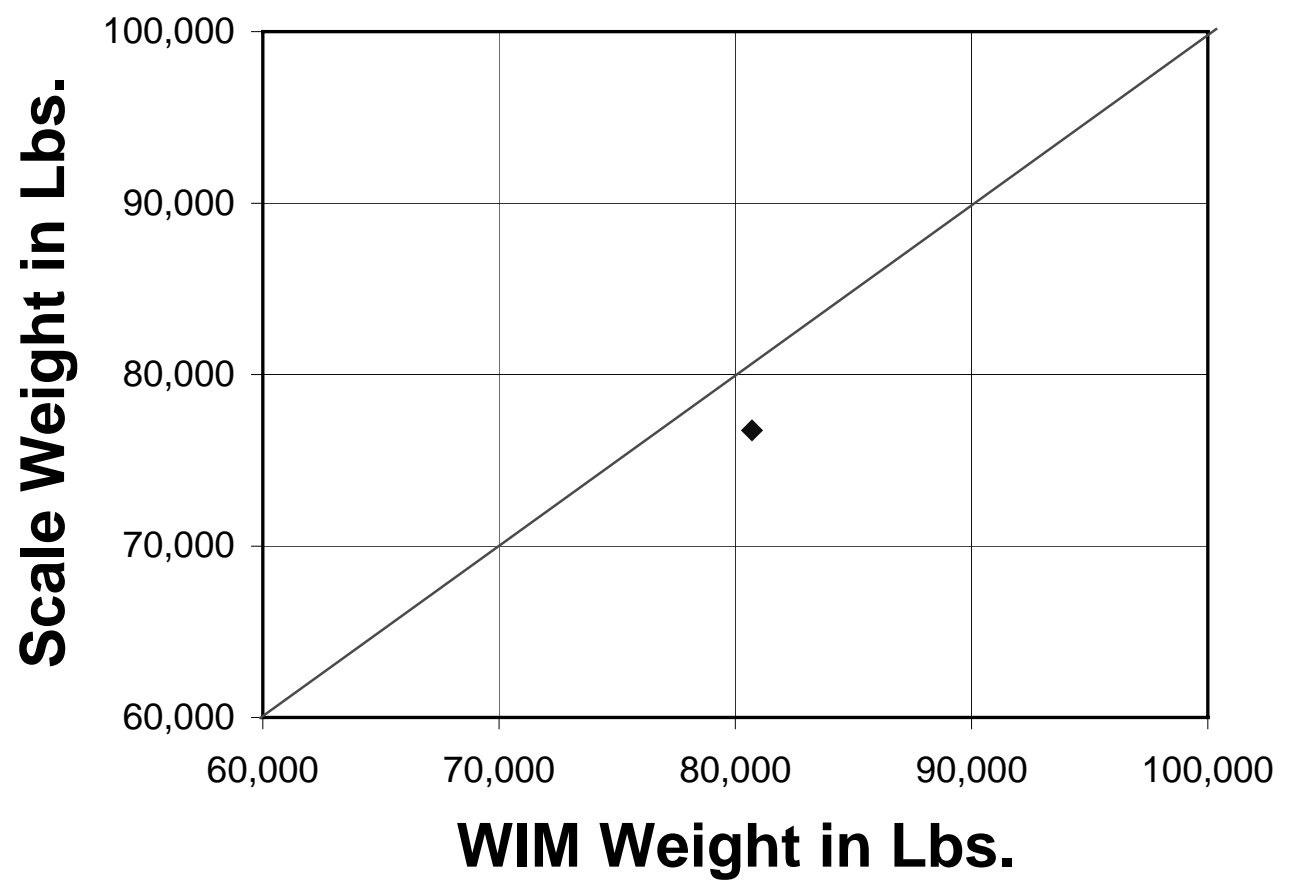

Figure I-6: May 23, 2001 - Merrillville Scale Detail (WIM 4410) - WIM v. Static graph 


\begin{tabular}{|c|c|c|c|c|c|c|c|c|c|}
\hline \multicolumn{10}{|c|}{$\begin{array}{c}\text { Ed Allen } \\
\text { John Green } \\
\text { Officer Henry Davis }\end{array}$} \\
\hline Description & $\begin{array}{c}\text { Axle } 1 \\
\text { WIM }\end{array}$ & \begin{tabular}{|c|} 
Axle 1 \\
Scale
\end{tabular} & $\begin{array}{c}\text { Tandem } 1 \\
\text { WIM }\end{array}$ & Tandem 1 Scale & $\begin{array}{c}\text { Tandem } 2 \\
\text { WIM }\end{array}$ & $\begin{array}{c}\text { Tandem } 2 \\
\text { Scale }\end{array}$ & $\begin{array}{l}\text { GVW } \\
\text { WIM }\end{array}$ & $\begin{array}{l}\text { GVW } \\
\text { Scale }\end{array}$ & Action Taken \\
\hline $\begin{array}{c}\text { CL9/L1 } \\
\text { Steel Hauler }\end{array}$ & 10,500 & 9,700 & 38,000 & 36,600 & 32,700 & 37,100 & 81,200 & 83,400 & $\begin{array}{c}\text { Vehicle } \\
\text { Impounded, } \\
\text { GVW and } \\
\text { Tandem ticket }\end{array}$ \\
\hline $\begin{array}{c}\text { CL9/L1 } \\
\text { Timber Hauler }\end{array}$ & 12,500 & 11,800 & 36,800 & 40,700 & 36,700 & 34,100 & 86,200 & 86,600 & $\begin{array}{c}\text { Vehicle } \\
\text { Impounded, } \\
\text { GVW and } \\
\text { Tandem ticket }\end{array}$ \\
\hline $\begin{array}{c}\text { CL9/L1 } \\
\text { Steel Hauler }\end{array}$ & 13,800 & 12,700 & 47,700 & 54,600 & 51,600 & 59,200 & 113,200 & 126,500 & $\begin{array}{c}\text { Vehicle } \\
\text { Impounded, } \\
\text { GVW and } \\
\text { Tandem ticket }\end{array}$ \\
\hline
\end{tabular}

Table I-7: May 31, 2001 - Merrillville Scale Detail (WIM 4410) - WIM v. Static

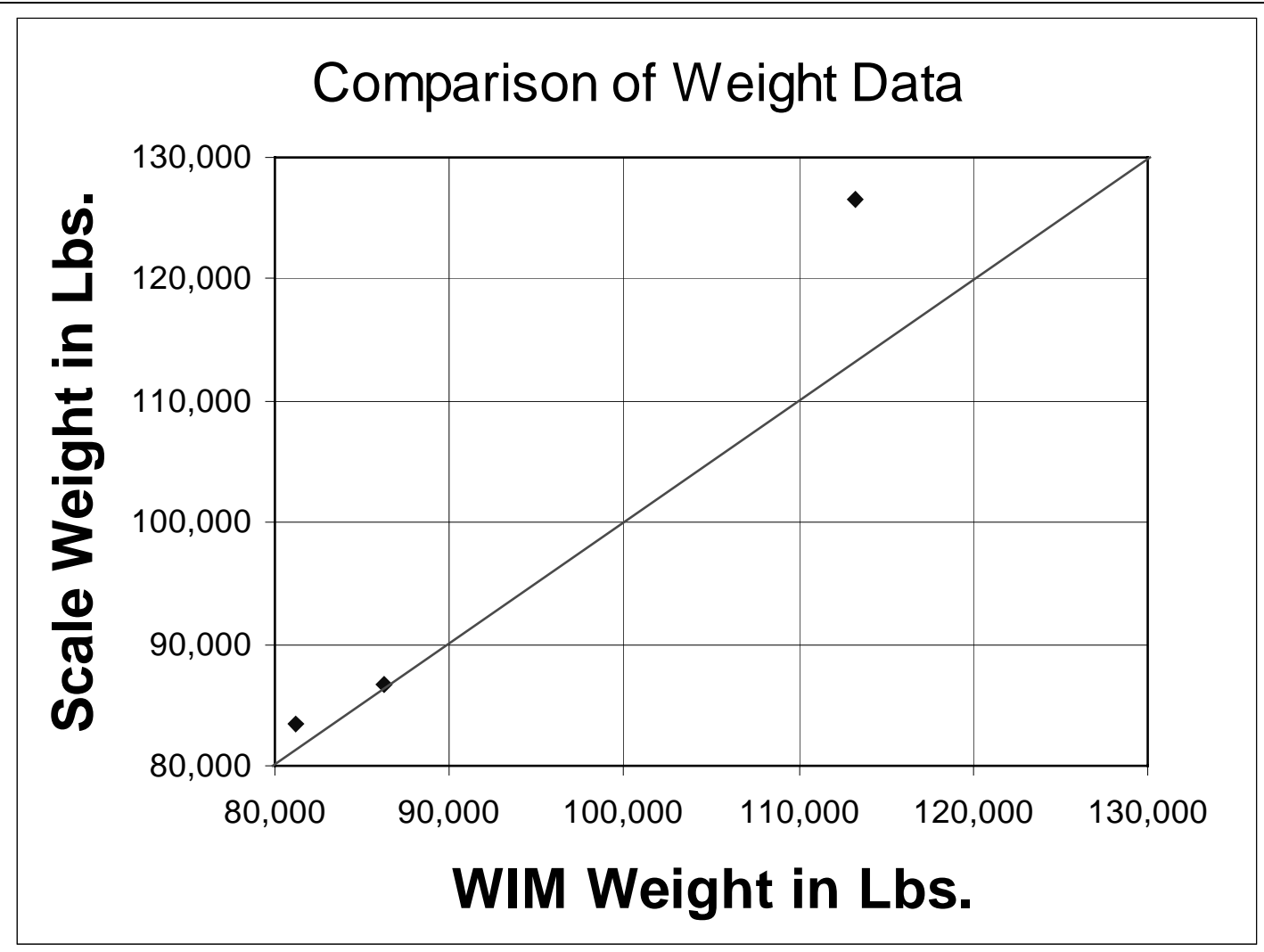

Figure I-7: May 31, 2001 - Merrillville Scale Detail (WIM 4410) - WIM v. Static graph 
Appendix J AutoCad Drawings 


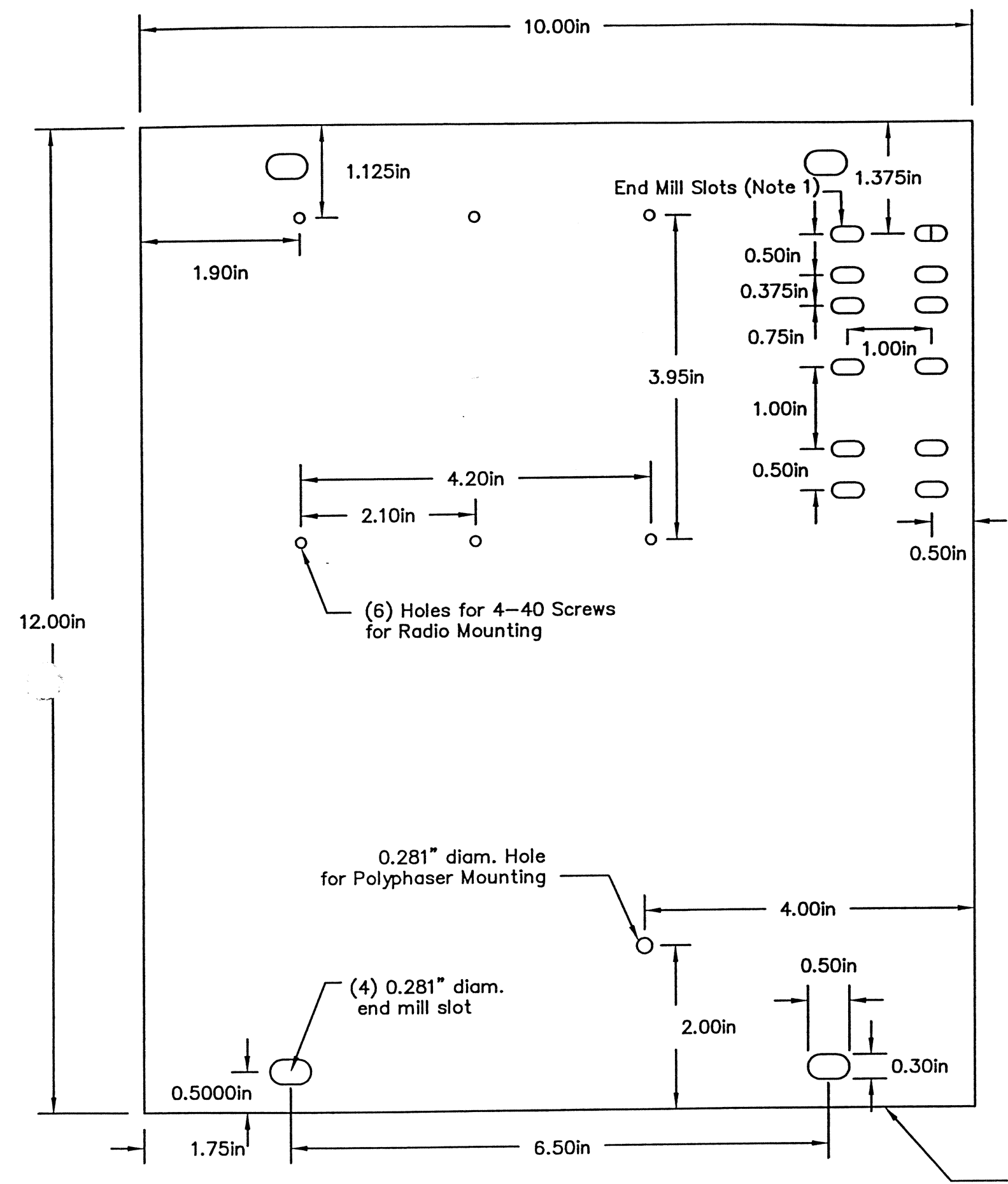

\begin{tabular}{|c|c|l|}
\hline Qty. & Part No. & Description \\
\hline 4 & Spring Loaded Toggle Nuts & Nuts with Springs to Mount in Traffic Box \\
\hline 4 & $1 / 4^{\prime \prime}$ Bolts & Bolts for Traffic Box Brackets \\
\hline 6 & $4-40$ Screws $3 / 8^{\prime \prime}$ LG & Brass Screws for Radio Mounting \\
\hline 1 & $1 / 4^{\prime \prime}$ Stroight Head Bolt & Screw to Mount Polyphaser \\
\hline 1 & $1 / 4^{\prime \prime}$ Nut & Nut for Polyphaser Bolt \\
\hline 1 & $1 / 4^{\prime \prime}$ Washer & Washer for Polyphoser Bolt \\
\hline & & \\
\hline & & \\
\hline
\end{tabular}

Note 1) End Mill Slots are

nominally $3 / 16$ " $\times 3 / 8$ "

\begin{tabular}{|c|c|c|c|}
\hline $\begin{array}{l}\text { Remote Rodio } \\
\text { Mounting Plate }\end{array}$ & $\begin{array}{c}\text { PURDUE } \\
\text { UNIVERSITY }\end{array}$ & 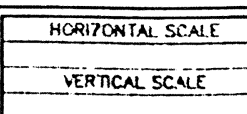 & 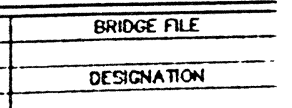 \\
\hline 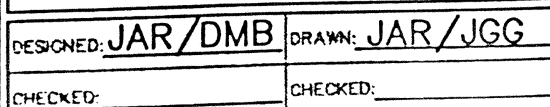 & & 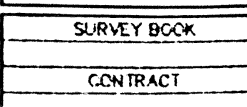 & 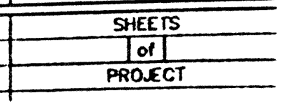 \\
\hline
\end{tabular}




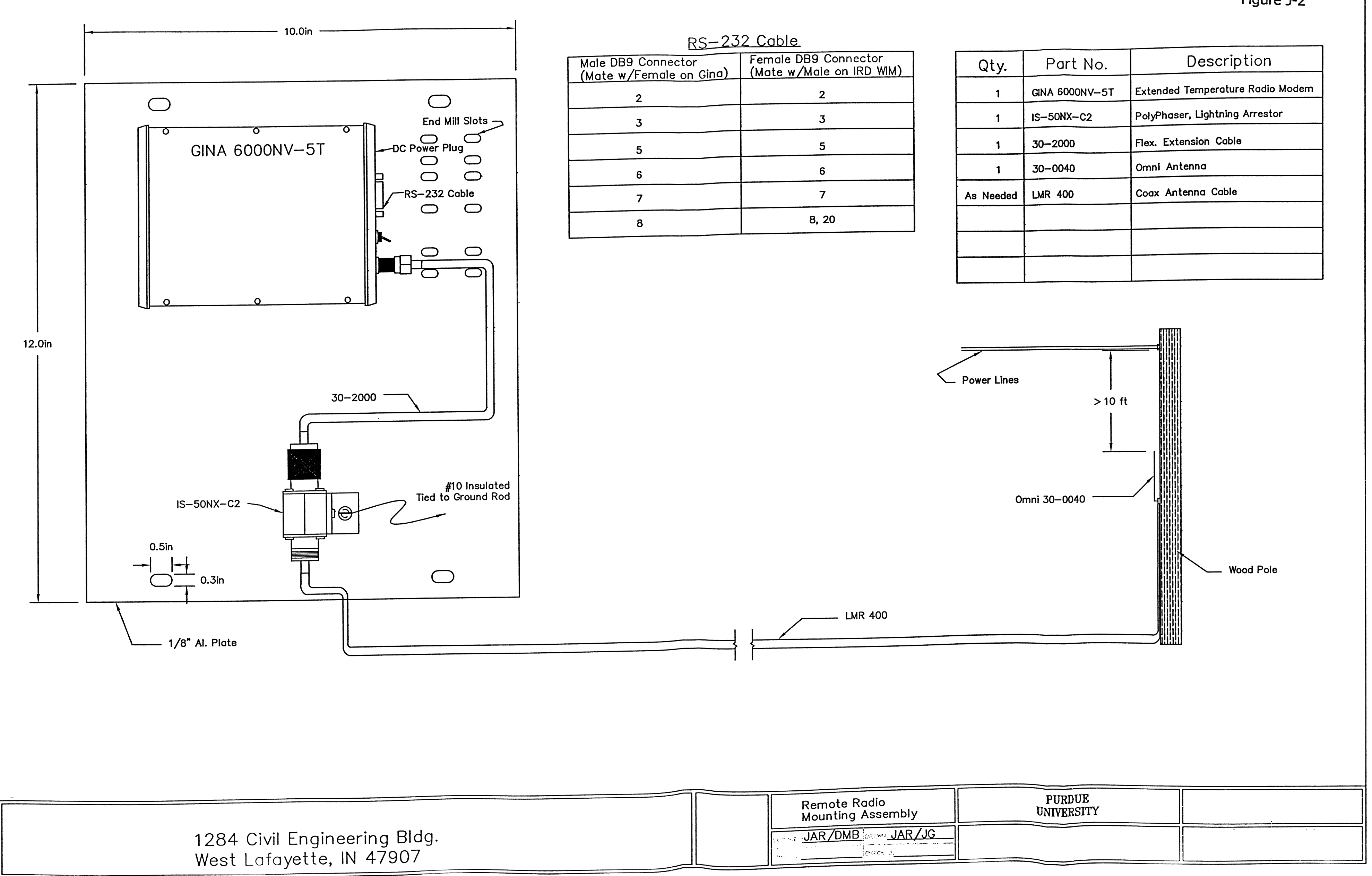


Appendix K Summary of SR 1 Data (March - May 2001) Memo 
To: $\quad$ Mark Newland, Guy Boruff

From: $\quad$ Darcy Bullock, Jose Thomaz

Date: $\quad$ June 25, 2001

Subject: $\quad$ Summary of SR 1 Weigh In Motion Data from March 18 to May 30, 2001.

As you are aware, you requested that we tabulate the data obtained from the SR 1 . The raw data files for this analysis were downloaded from the SR 1 site by Steve Rowlands of Mettler-Toledo. Steve emailed us the data he downloaded during April, May and June approximately every 20 days. Those data files covered the period March 18 to May 30, 2001 and were parsed for Class 9 trucks. Based upon the data we extracted, I offer the following comments:

- $\quad$ The Class 9 truck traffic is approximately evenly split, with slightly more Northbound Class 9 trucks. Tables 1 and 2 report the total Southbound Class 9 traffic during the period was 9455 and the total Northbound Class 9 traffic was 10,059.

- In our June 12, 2001 memo, we reported that during that period, the WIM recorded $2.8 \%$ of the Southbound traffic had GVW's exceeding $80,000 \mathrm{lbs}$ and $0.1 \%$ of the Northbound traffic had GVW's exceeding $80,000 \mathrm{lbs}$. At the request of Guy Boruff we went back and examined the data for over axle and over tandem. That data is now also tabulated in Tables 1 and 2. Somewhat surprisingly, it shows that $11 \%$ of the Southbound Class 9 vehicles have overweight tandems. This is more the 5 times the number of Northbound Class 9 vehicles that were measured overweight on their tandem.

- Figure 1 shows the distribution of Southbound Class 9 volume with Wednesday generally having the highest number and Saturday the lowest.

- Figure 2 shows the number of Southbound Class 9 vehicles with GVW's exceeding 80,000 lbs for each day during the study period.

- $\quad$ Figure 3 shows the same general distribution of Northbound Class 9 vehicles.

- $\quad$ Figure 4 shows much fewer Northbound overweight vehicles then shown in Figure 2.

- Figures 5 and 6 shows the average hourly distribution of all Southbound Class 9 vehicles and those Class 9 vehicles with GVW's exceeding 80,000 lbs. Figure 7 and 8 show similar graphs for the Northbound traffic.

- Since there appears to be substantially more Southbound vehicles with GVW's exceeding 80,000 lbs, we examined the Front axle statistics. Figure 9 shows virtual identical histograms for both the Northbound and Southbound lanes. Table 3 shows very similar average front axle weights. In fact, the average Northbound front axle weight is slightly higher then the average Southbound front axle so there does not appear to be any evidence that the Northbound Class 9 vehicles are weighing light (or Southbound weighing heavy). However, in order to verify this, several Class 9 trucks should be stopped and their static weight compared to the WIM.

- We examined the distribution of GVWs for both the Northbound and Southbound directions. Figure 10 shows the histogram from 0 to $100,000 \mathrm{lbs}$, Figure 11 shows the same data with the histogram zoomed in on the just the tail near $80,000 \mathrm{lbs}$. From these histograms, one can see that the Northbound Class 9 traffic is skewed such that there is a substantial number of vehicles with GVW's just under $80,000 \mathrm{lbs}$, but very few exceeding $80,000 \mathrm{lbs}$ (Table 2). In contrast, the Southbound Class 9 traffic is more evenly distributed, but approximately 258 (Table 1) Class 9 vehicles during the period exceed $80,000 \mathrm{lbs}$.

- From inspecting the raw data, 5 Southbound Class 9 vehicles exceeded $90,000 \mathrm{lbs}$ during this period. Those GVW's were 94900, 92020, 90820, 90480, 90380 and occurred on May 30, May 11, May 6, April 10, and March 20' respectively. Although the heaviest GVW's are the most recent, Figure 2 does not appear to show any evidence that the number of Class 9 vehicles with GVW's exceeding $80,000 \mathrm{lbs}$ is increasing.

- Figures 12 and 13 show the histograms for axle and tandem weights during this period. 
- Figure 14 shows the histograms by the time of day the overweight tandems were observed at the South bound station. In comparison to over GVW South bound vehicles shown in Figure 6, it appears that a detail targeting over tandem trucks might be reasonably successful since there are several hours where on average more then 1 truck per hour per day is overweight on their tandem.

Table 1: SR 1 WIM Station, Southbound.

\begin{tabular}{|c|c|c|c|c|}
\hline & $\begin{array}{c}\text { March 18-31, } \\
2001\end{array}$ & $\begin{array}{c}\text { April 1-30, } \\
2001\end{array}$ & $\begin{array}{c}\text { May 1-30, } \\
2001\end{array}$ & Total \\
\hline Total Class 9 Vehicles & 1776 & 3649 & 3772 & 9197 \\
\hline $\begin{array}{c}\text { Class 9 Vehicles with } \\
\text { GVW>80k }\end{array}$ & 68 & 117 & 73 & 258 \\
\hline $\begin{array}{c}\text { Class 9 Vehicles with an } \\
\text { Axle > 20k }\end{array}$ & 12 & 21 & 17 & 50 \\
\hline $\begin{array}{c}\text { Class 9 Vehicles with a } \\
\text { Tandem > 34k }\end{array}$ & 232 & 416 & 441 & 1089 \\
\hline$\%$ Overweight GVW & $3.8 \%$ & $3.2 \%$ & $1.9 \%$ & $2.8 \%$ \\
\hline \% Over Axle & $0.7 \%$ & $0.6 \%$ & $0.4 \%$ & $0.5 \%$ \\
\hline$\%$ Over Tandem & $13.1 \%$ & $11.4 \%$ & $11.7 \%$ & $11.8 \%$ \\
\hline
\end{tabular}

Table 2: SR 1 WIM Station, Northbound.

\begin{tabular}{|c|c|c|c|c|}
\hline & $\begin{array}{c}\text { March 18-31, } \\
2001\end{array}$ & $\begin{array}{c}\text { April 1-30, } \\
2001\end{array}$ & $\begin{array}{c}\text { May 1-30, } \\
2001\end{array}$ & Total \\
\hline Total Class 9 Vehicles & 2018 & 4066 & 3971 & 10,045 \\
\hline $\begin{array}{c}\text { Class 9 Vehicles with } \\
\text { GVW>80k }\end{array}$ & 1 & 7 & 6 & 14 \\
\hline $\begin{array}{c}\text { Class 9 Vehicles with an } \\
\text { Axle > 20k }\end{array}$ & 1 & 4 & 1 & 6 \\
\hline $\begin{array}{c}\text { Class 9 Vehicles with a } \\
\text { Tandem > 34k }\end{array}$ & 39 & 91 & 72 & 202 \\
\hline $\begin{array}{c}\% \text { Overweight GVW } \\
\% \text { Over Axle }\end{array}$ & $0.0 \%$ & $0.2 \%$ & $0.2 \%$ & $0.1 \%$ \\
\hline$\%$ Over Tandem & $0.0 \%$ & $0.1 \%$ & $0.0 \%$ & $0.1 \%$ \\
\hline
\end{tabular}

Table 3: Average Front Axle and GVW Weights.

\begin{tabular}{|c|c|c|c|c|}
\hline Lane & $\begin{array}{c}\text { Average Front Axle } \\
\text { Load (lbs) }\end{array}$ & $\begin{array}{c}\text { St.Dev. Front } \\
\text { Axle Load } \\
\text { (lbs) }\end{array}$ & $\begin{array}{c}\text { Average GVW } \\
\text { (lbs) }\end{array}$ & $\begin{array}{c}\text { St.Dev. GVW } \\
\text { (lbs) }\end{array}$ \\
\hline Southbound & 10,190 & 1,259 & 57,822 & 15,340 \\
\hline Northbound & 10,508 & 1,159 & 55,886 & 15,271 \\
\hline
\end{tabular}




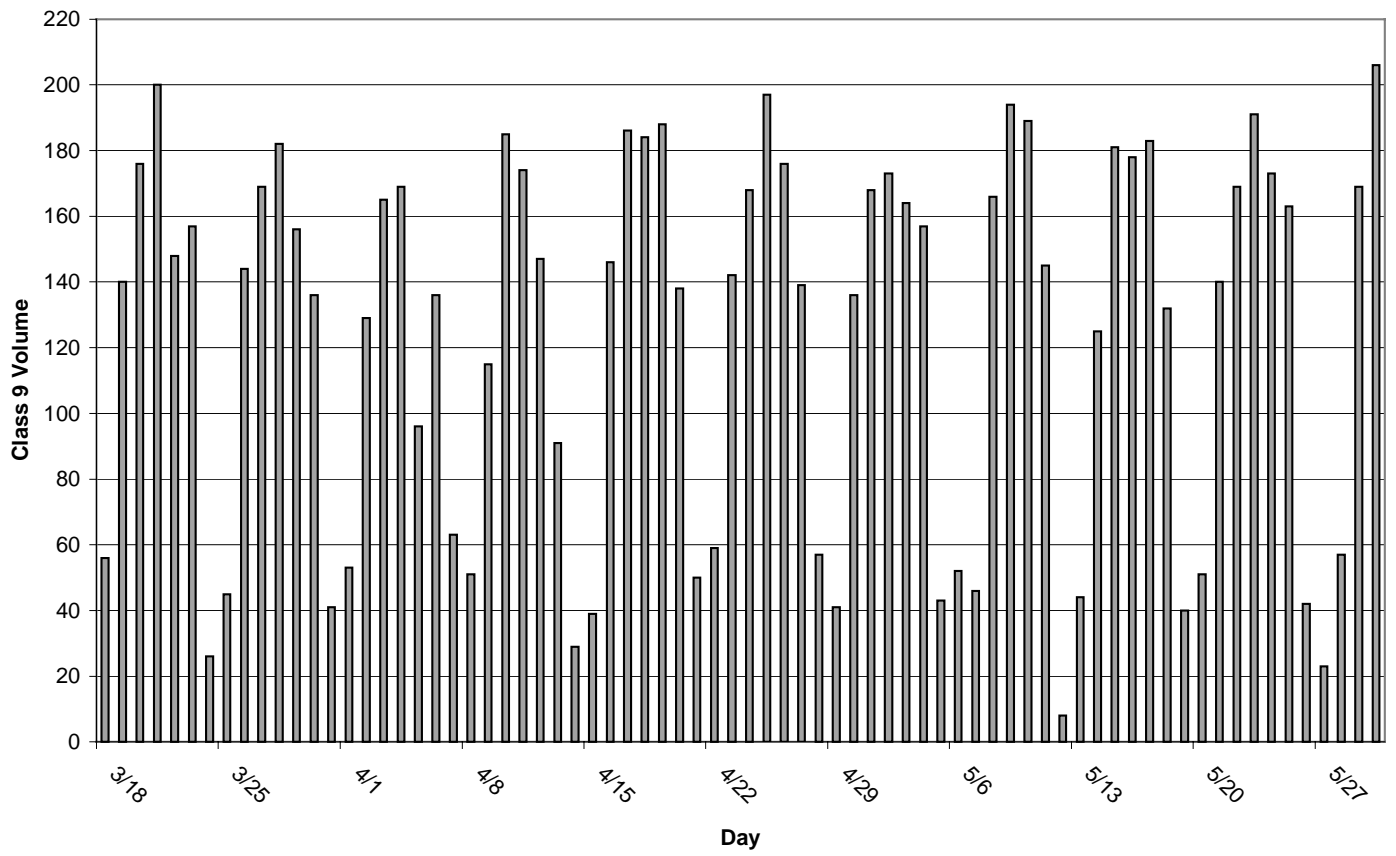

Figure 1: Southbound Class 9 Volume on SR 1 for March 18 to May 30, 2001

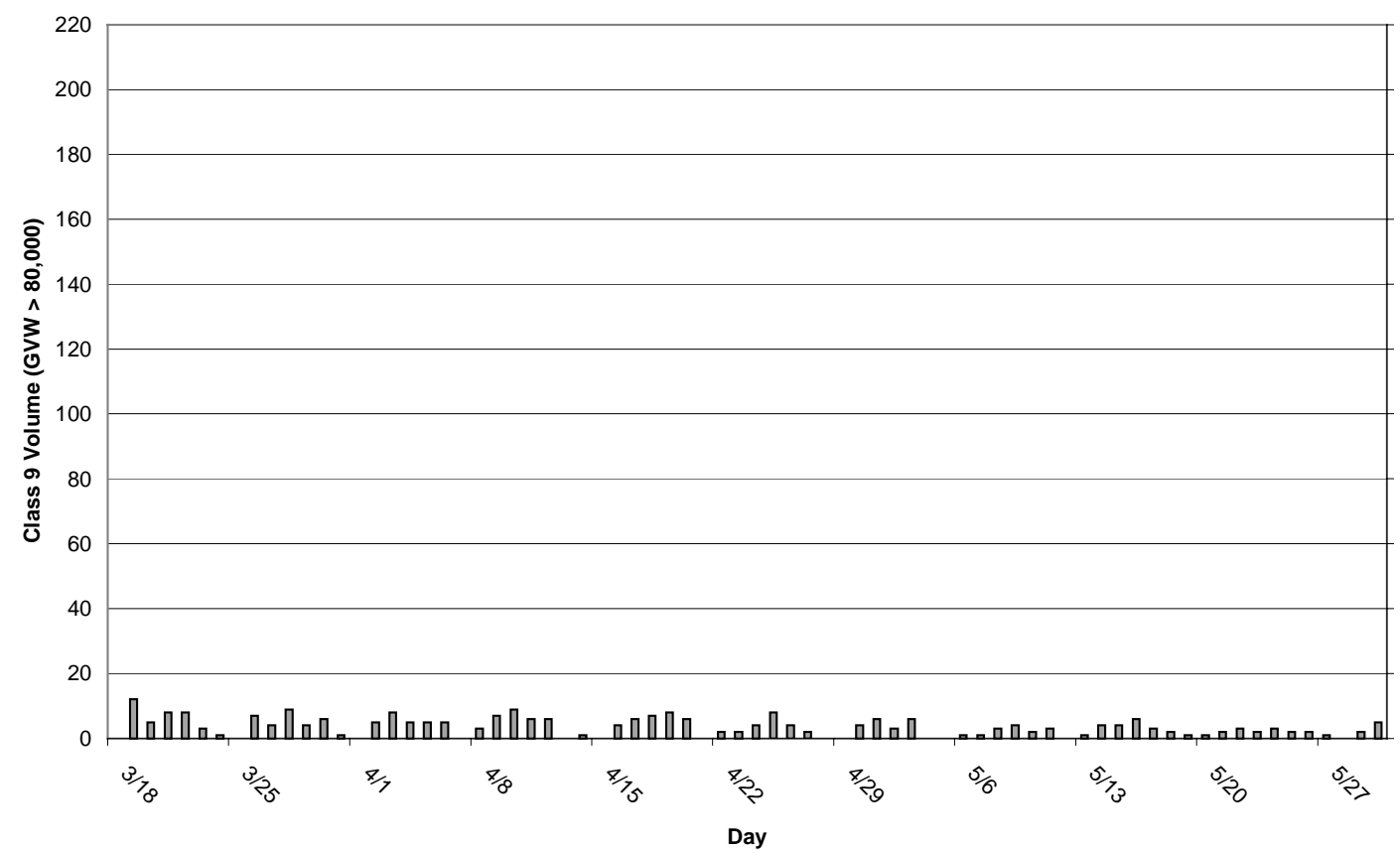

Figure 2: Southbound Class 9 Volume on SR 1 with GVW>80,000lbs for March 18 to May 30, 2001 


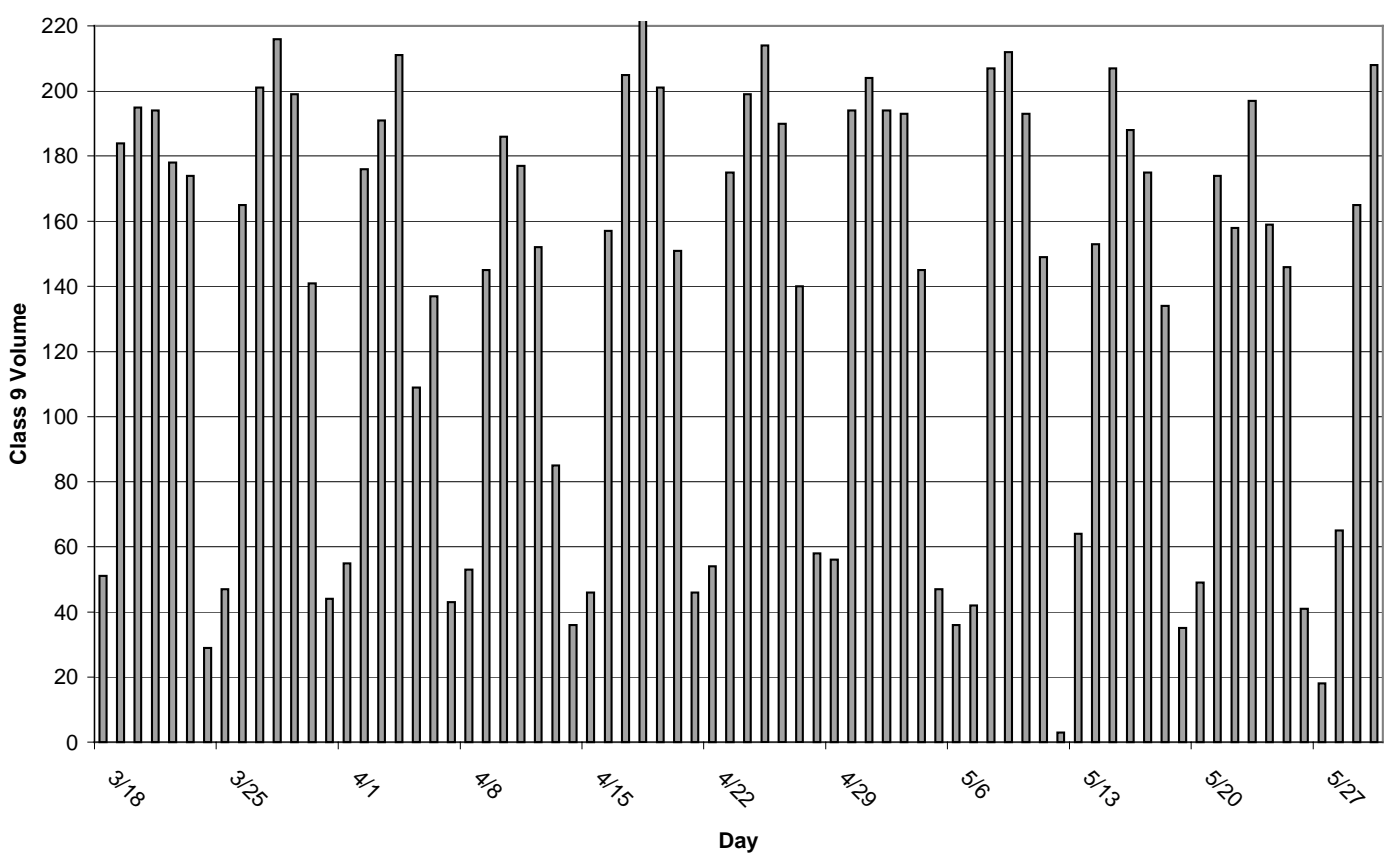

Figure 3: Northbound Class 9 Volume on SR 1 for March 18 to May 30, 2001

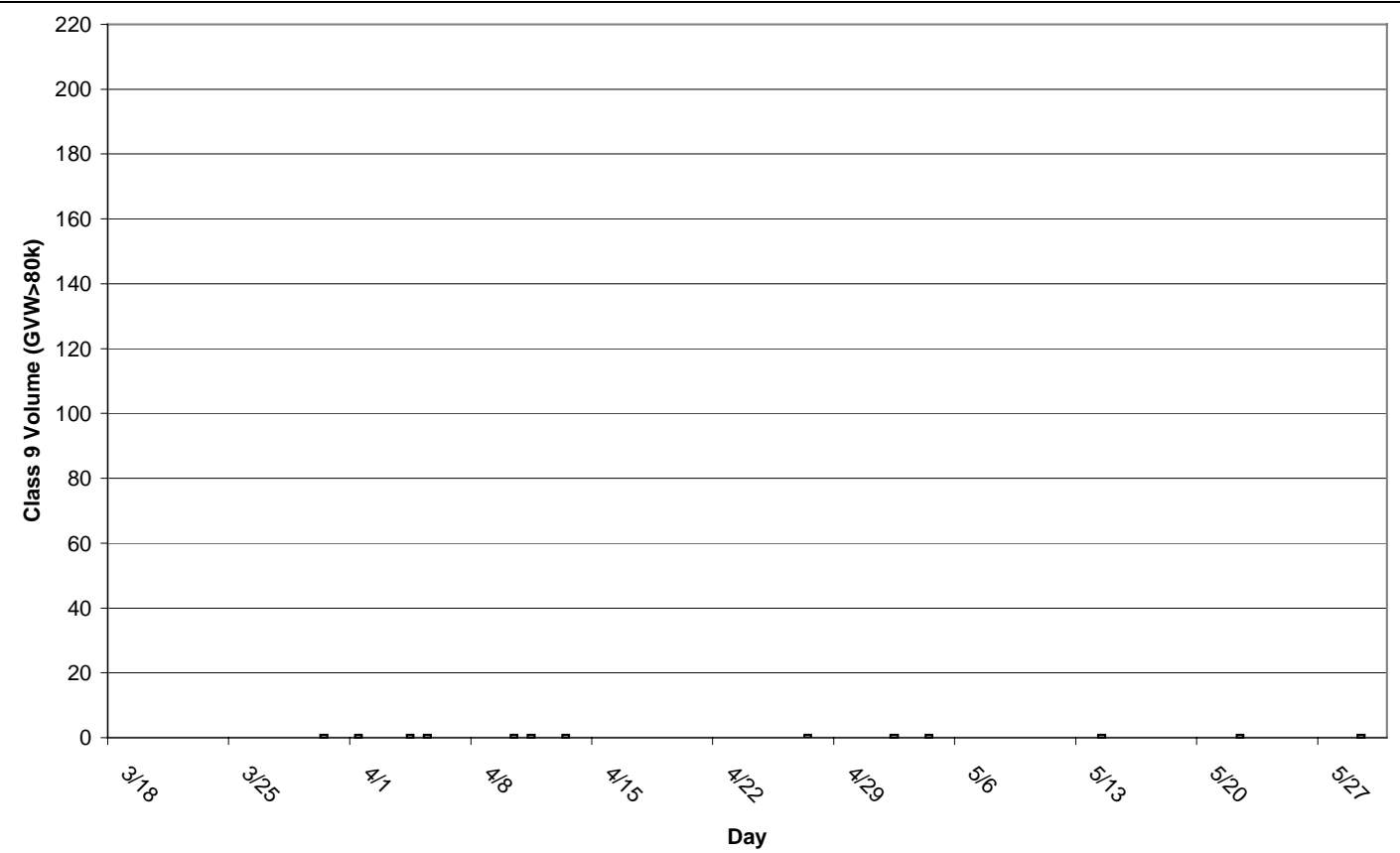

Figure 4: Northbound Class 9 Volume on SR 1 with GVW>80,000lbs for March 18 to May 30, 2001 


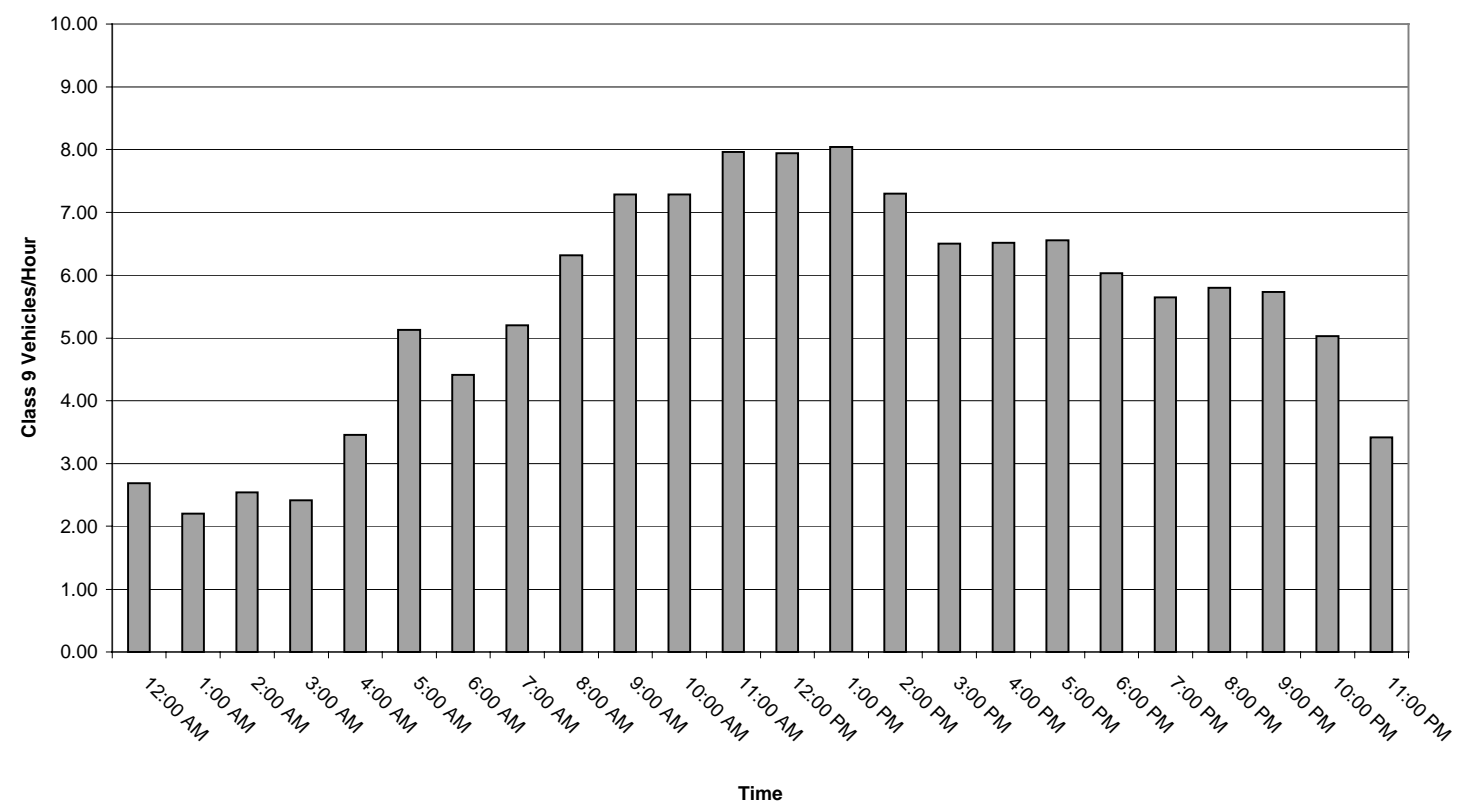

Figure 5: Average Hourly Southbound Class 9 Volume on SR 1 for March-May, 2001

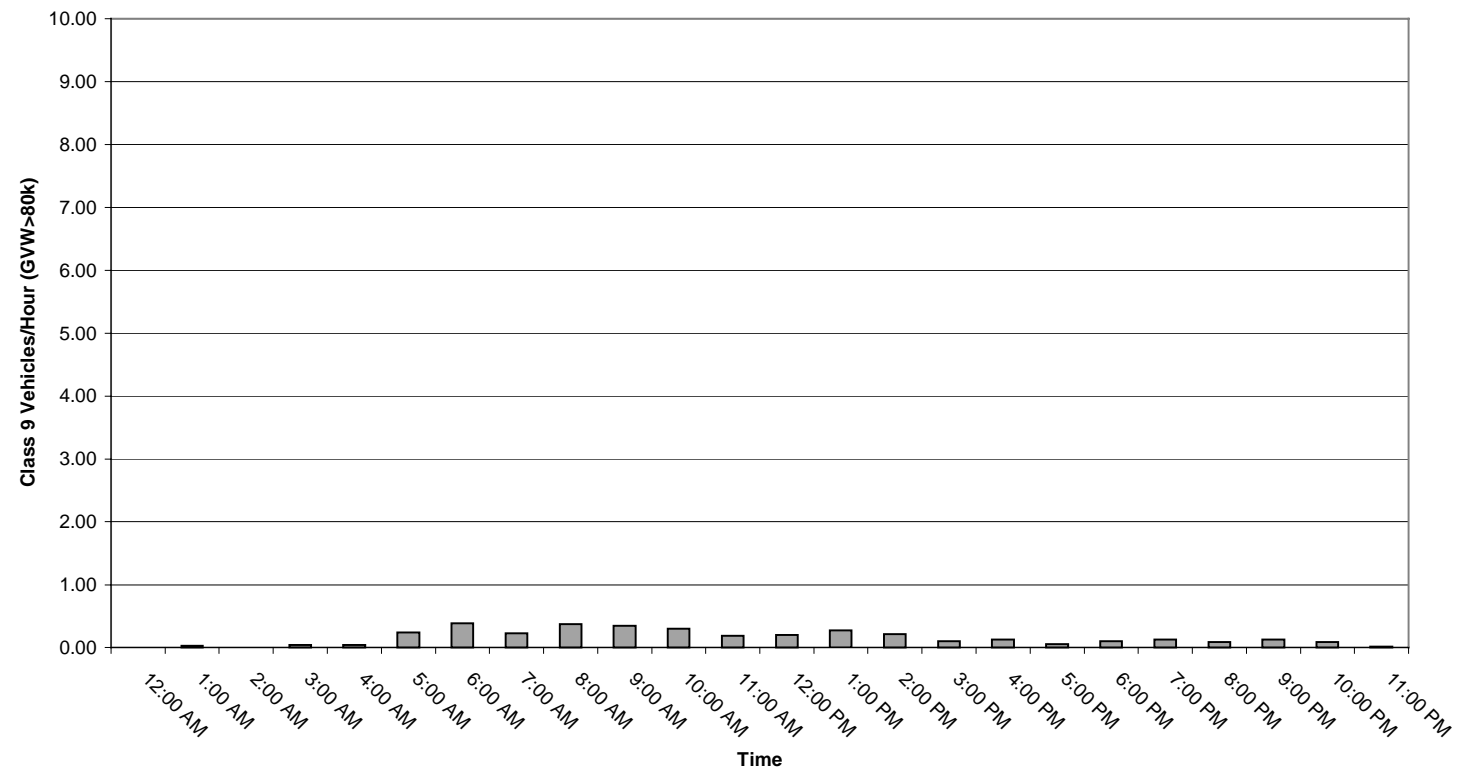

Figure 6: Average Hourly Southbound Class 9 Volume with GVW>80,000 on SR 1 for March-May, 2001 


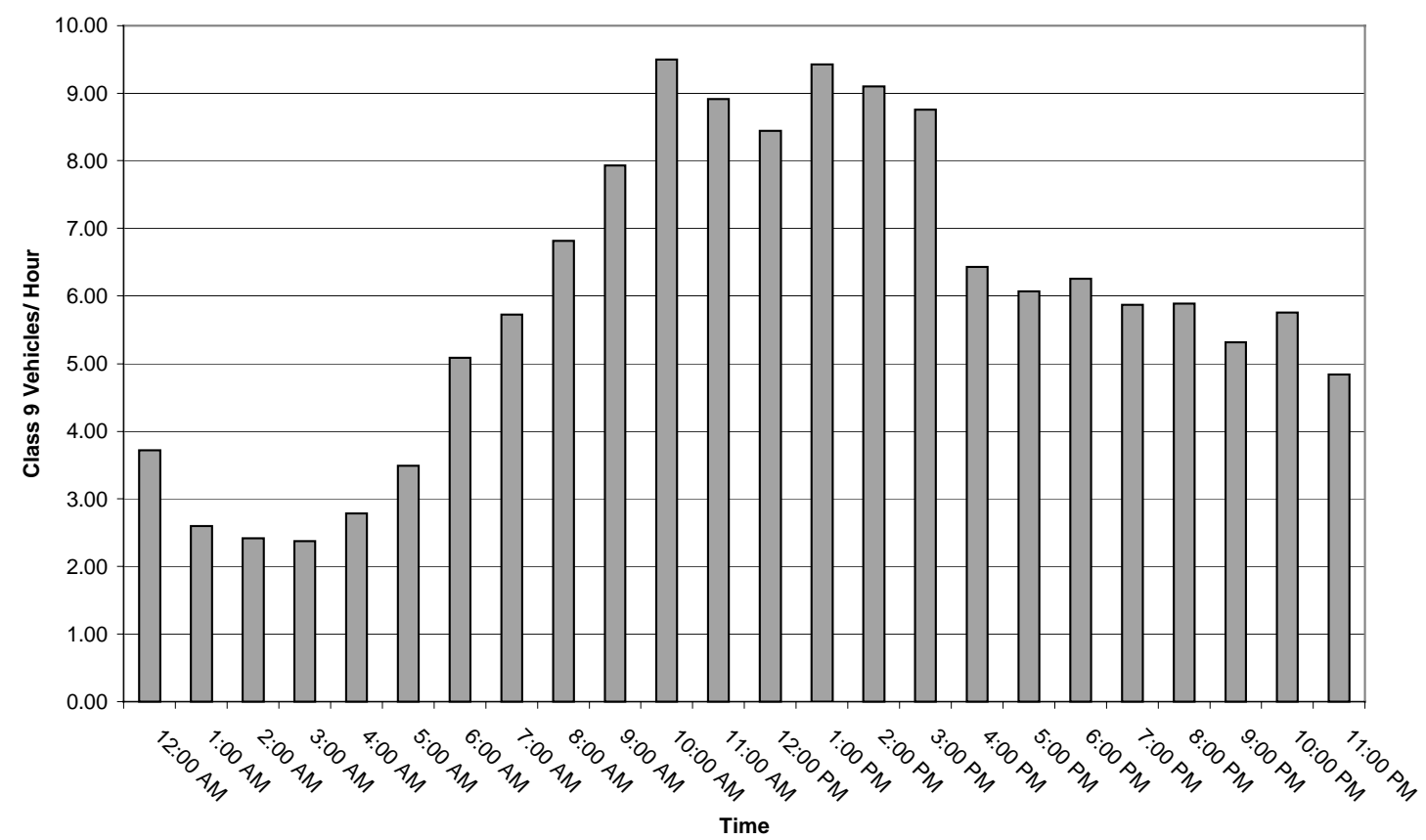

Figure 7: Average Hourly Northbound Class 9 Volume on SR 1 for March-May, 2001

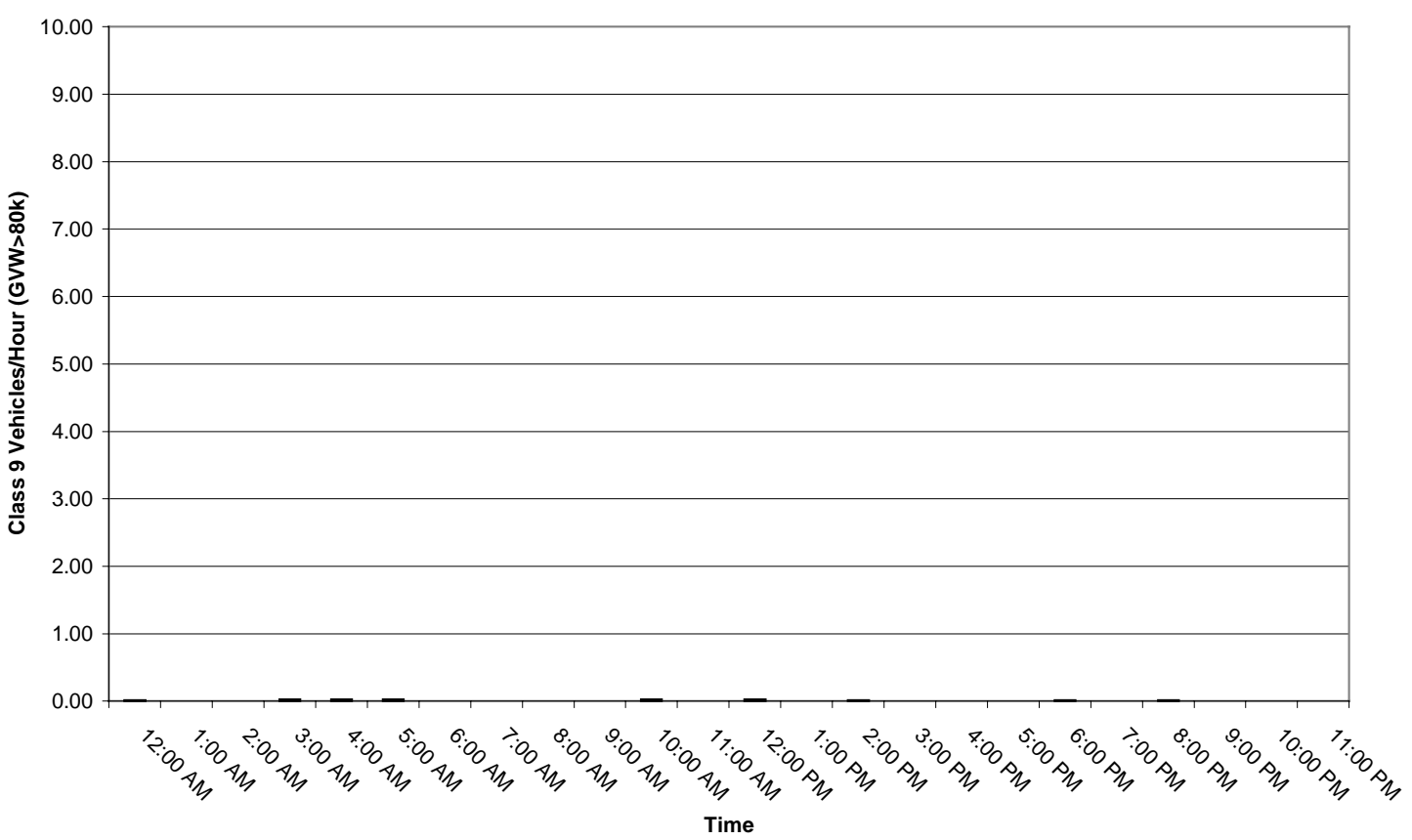

Figure 8: Average Hourly Northbound Class 9 Volume with GVW>80,000 on SR 1 for March-May, 2001 


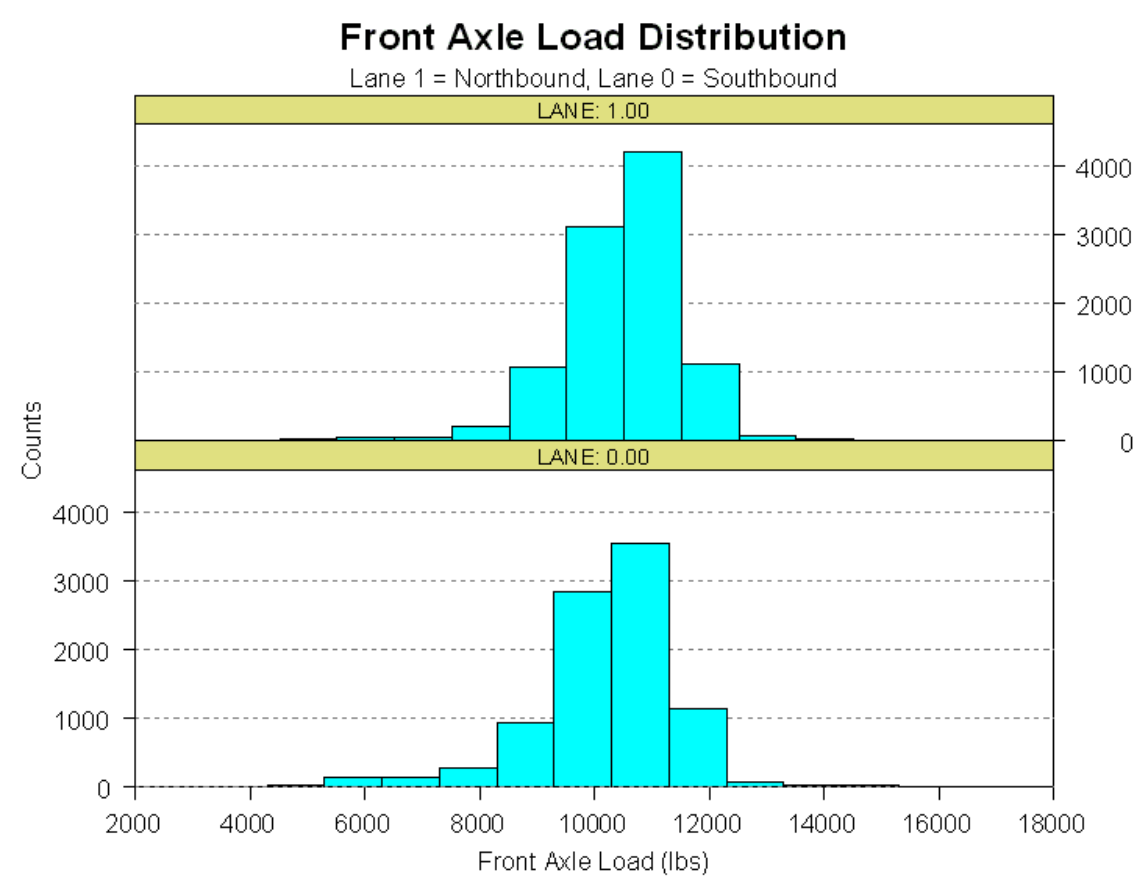

Figure 9: Average Class 9 Front Axle Weight Distribution on SR 1 for March-May, 2001

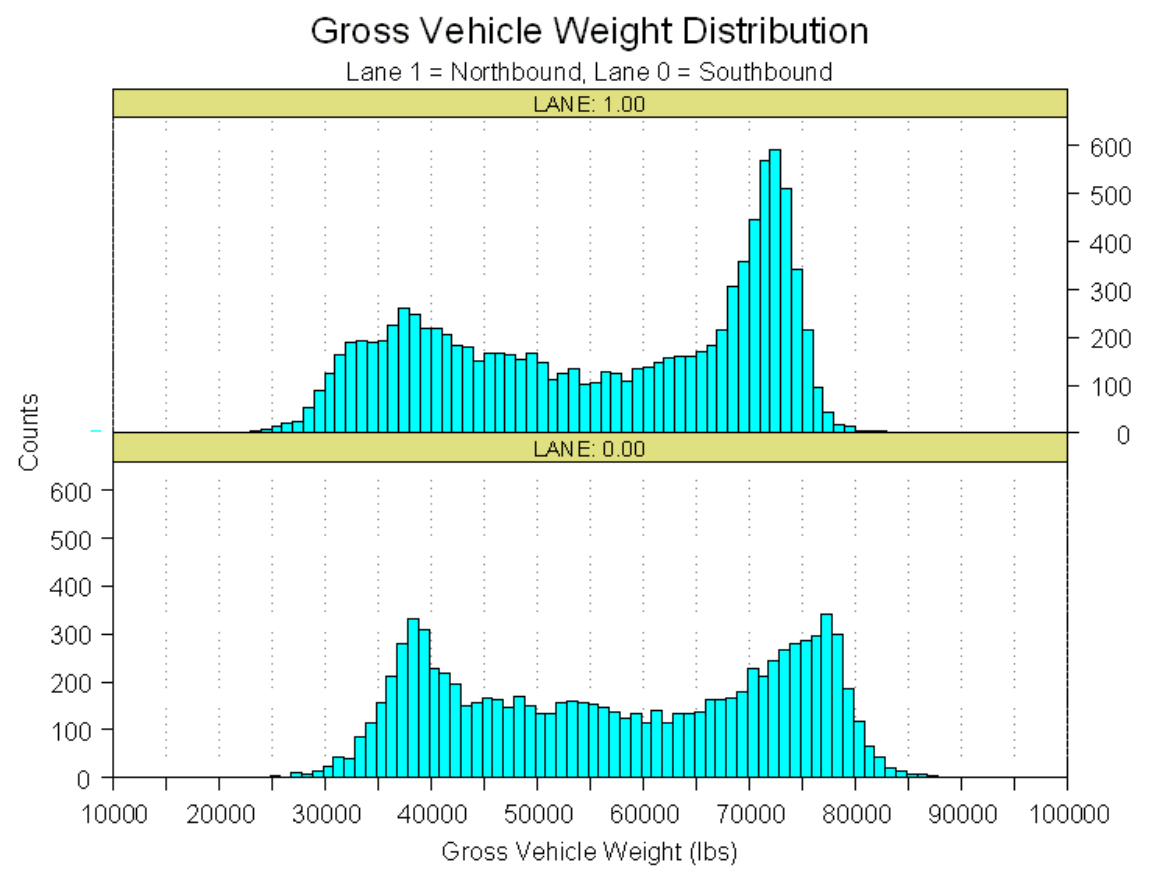

Figure 10: Distribution of Class 9 GVW, March 18-May 30, 2001. 


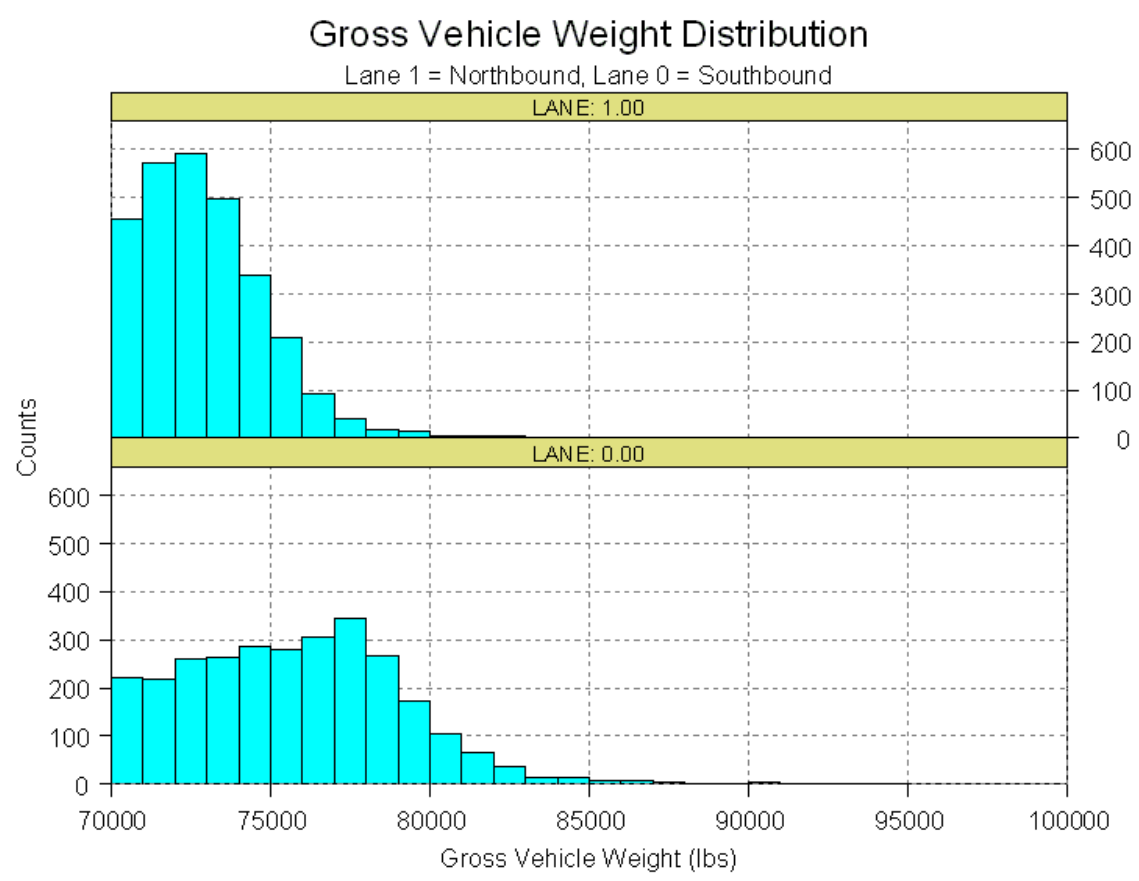

Figure 11: Distribution of Class 9 GVW, Zoomed in graph of same data shown in Figure 10.

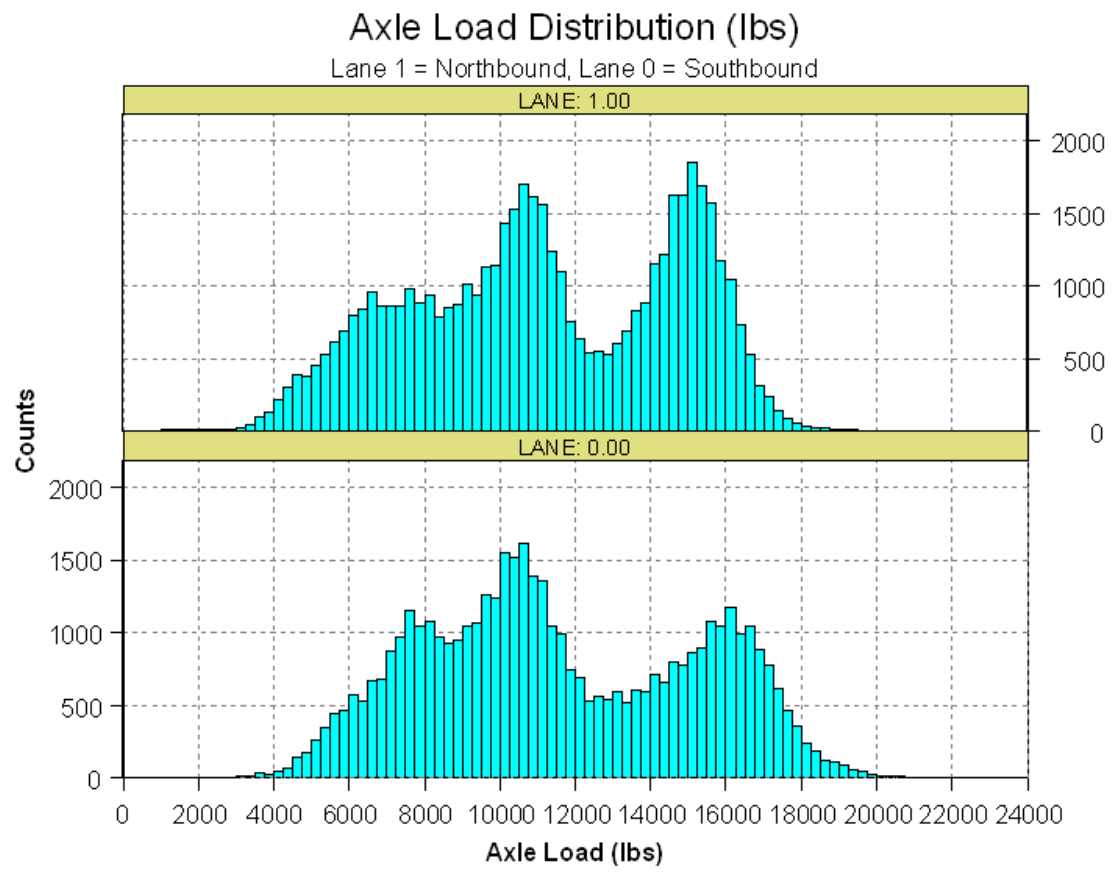

Figure 12: Distribution of Class 9 Axle Weight, March 18-May 30, 2001. 


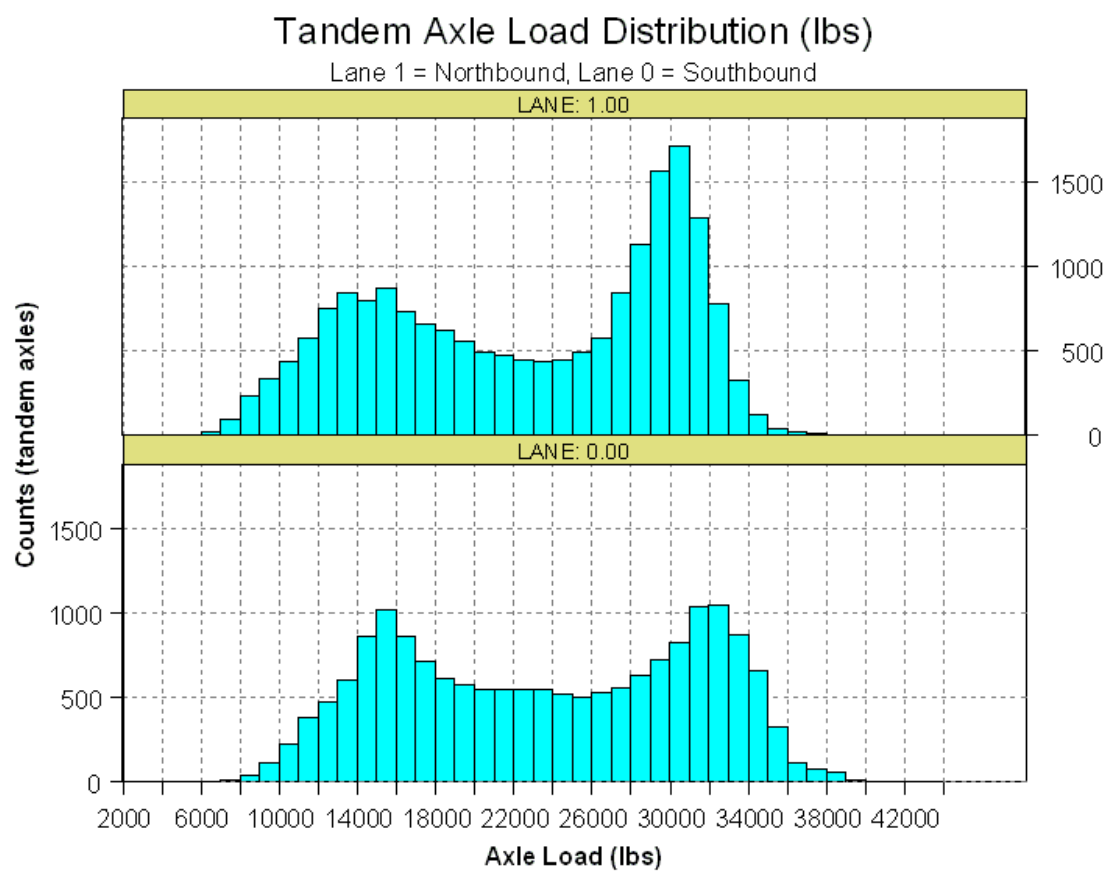

Figure 13: Distribution of Class 9 Tandem Weight, March 18-May 30, 2001. 
Overweight Tandems by Hour

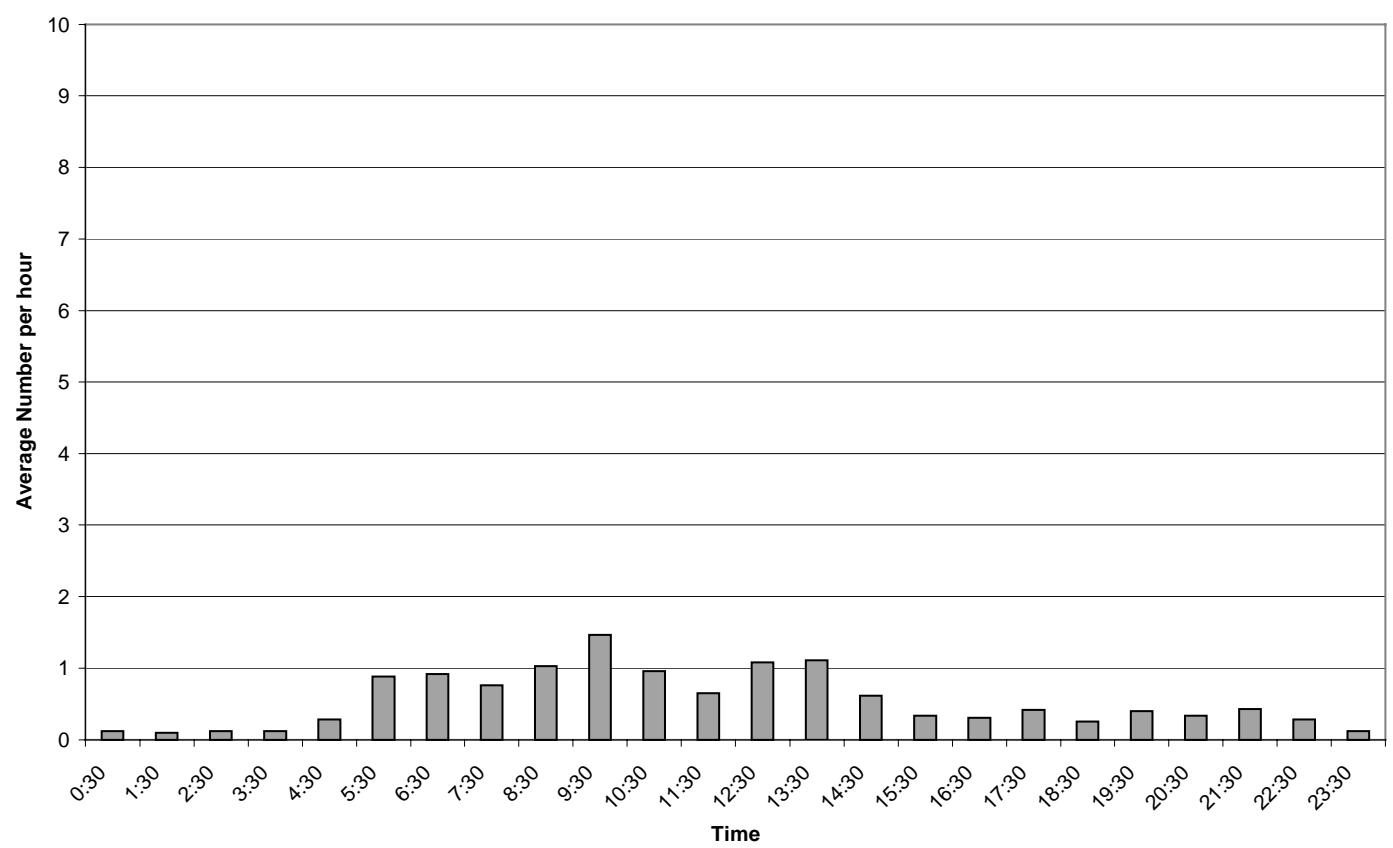

Figure 14: Distribution of Southbound Class 9 Tandem Over weights by hour, March-May, 2001. 
Appendix L Summary of SR 1 Data (March - July 2001) Memo 
To: $\quad$ Mark Newland, Guy Boruff

From: $\quad$ Darcy Bullock, Jose Thomaz, Andrew Nichols

Date: $\quad$ September 12, 2001

Subject: $\quad$ Summary of SR 1 Weigh In Motion Data

\section{March 18- May 2001}

As you are aware, you requested that we tabulate the data obtained from the SR 1 . The raw data files for this analysis were downloaded from the SR 1 site by Steve Rowlands of Mettler-Toledo. Steve emailed us the data he downloaded during April, May and June approximately every 20 days. Those data files covered the period March 18 to May 30, 2001 and were parsed for Class 9 trucks. Based upon the data we extracted, I offer the following comments:

- The Class 9 truck traffic is approximately evenly split, with slightly more Northbound Class 9 trucks. Table 1 and Table 2, columns 1, 2, and 3 report the total Southbound Class 9 traffic during the period was 9455 and the total Northbound Class 9 traffic was 10,059.

- In our June 12, 2001 memo, we reported that during that period, the WIM recorded $2.8 \%$ of the Southbound traffic had GVW's exceeding $80,000 \mathrm{lbs}$ and $0.1 \%$ of the Northbound traffic had GVW's exceeding $80,000 \mathrm{lbs}$. At the request of Guy Boruff we went back and examined the data for over axle and over tandem. That data is now also tabulated in Table 1 and Table 2, columns 1,2 , and 3 . Somewhat surprisingly, it shows that $11 \%$ of the Southbound Class 9 vehicles have overweight tandems. This is more the 5 times the number of Northbound Class 9 vehicles that were measured overweight on their tandem.

- Figure 1 shows the distribution of Southbound Class 9 volume with Wednesday generally having the highest number and Saturday the lowest.

- Figure 2 shows the number of Southbound Class 9 vehicles with GVW's exceeding 80,000 lbs for each day during the study period.

- $\quad$ Figure 3 shows the same general distribution of Northbound Class 9 vehicles.

- Figure 4 shows much fewer Northbound overweight vehicles then shown in Figure 2.

- Figure 5 and Figure 6 shows the average hourly distribution of all Southbound Class 9 vehicles and those Class 9 vehicles with GVW's exceeding 80,000 lbs. Figure 7 and Figure 8 show similar graphs for the Northbound traffic.

- Since there appears to be substantially more Southbound vehicles with GVW's exceeding 80,000 Ibs, we examined the Front axle statistics. Figure 9 shows virtual identical histograms for both the Northbound and Southbound lanes. Table 3 shows very similar average front axle weights. In fact, the average Northbound front axle weight is slightly higher then the average Southbound front axle so there does not appear to be any evidence that the Northbound Class 9 vehicles are weighing light (or Southbound weighing heavy). However, in order to verify this, several Class 9 trucks should be stopped and their static weight compared to the WIM.

- We examined the distribution of GVWs for both the Northbound and Southbound directions. Figure 10 shows the histogram from 0 to $100,000 \mathrm{lbs}$, Figure 11 shows the same data with the histogram zoomed in on the just the tail near $80,000 \mathrm{lbs}$. From these histograms, one can see that the Northbound Class 9 traffic is skewed such that there are a substantial number of vehicles with GVW's just fewer than 80,000 lbs, but very few exceeding 80,000 lbs (Table 2). In contrast, the Southbound Class 9 traffic is more evenly distributed, but approximately 258 (Table 1) Class 9 vehicles during the period exceed 80,000 lbs.

- From inspecting the raw data, 5 Southbound Class 9 vehicles exceeded $90,000 \mathrm{lbs}$ during this period. Those GVW's were 94900, 92020, 90820, 90480, 90380 and occurred on May 30, May 11 , May 6, April 10, and March 20' respectively. Although the heaviest GVW's are the most recent, Figure 2 does not appear to show any evidence that the number of Class 9 vehicles with GVW's exceeding 80,000 lbs is increasing. 
- Figure 12 and Figure 13 show the histograms for axle and tandem weights during this period.

- Figure 14 shows the histograms by the time of day the overweight tandems were observed at the South bound station. In comparison to over GVW South bound vehicles shown in Figure 6, it appears that a detail targeting over tandem trucks might be reasonably successful since there are several hours where on average more then 1 truck per hour per day is overweight on their tandem.

June-July 2001

- The overall volume of Class 9 vehicles in both directions was approximately the same with 7,035 Southbound and 7,587 Northbound during June and July.

- The monthly volumes decreased by nearly 300 vehicles between June and July in both directions, as detailed in Table 1 and Table 2. In the Northbound direction, the volumes decreased monthly over the period from April to July.

- The number of Class 9 vehicles with gross vehicle weights greater than $80,000 \mathrm{lbs}$ during the June-July period was 9 in the Northbound direction, but was 103 in the Southbound direction.

- In the Southbound direction, the number of GVW overweights continued to decrease over the period of analysis from 117 in April to 36 in July, as shown in Table 1.

- In the Southbound direction, the percentage of overweight GVW, axle, and tandems has steadily decreased from April to July, as shown in Table 1.

- In June and July the number of overweight tandems is still more frequent than the overweight axles and GVW in both directions, with the Southbound direction having the higher rate of overweights overall.

- The maximum GVW in the Southbound direction was 95,560 lbs and the max in the Northbound direction was $92,320 \mathrm{lbs}$ (Table 4).

- The average front axle and GVW between the April-May period (Table 3) and the June-July period (Table 4) remained consistent for each direction.

- The time of day with the highest average number of Southbound overweight tandems is 9:00 9:59 AM for both March-May (Figure 14) and June-July (Figure 27).

- The following data were missing for this period:

- GVW > 80k 6/4,6/21,6/29,7/4,7/21,7/29

- Axle > 20k 6/4, 6/5, 6/9, 6/15, 6/18, 6/19, 6/21, 6/22, 6/24, 6/29, 7/4, 7/5, 7/9, 7/15, 7/18, 7/19, $7 / 21,7 / 22,7 / 24,7 / 29,7 / 31$ 
Table 1: SR 1 WIM Station, Southbound.

\begin{tabular}{|c|c|c|c|c|c|c|}
\hline & $\begin{array}{c}\text { March 18- } \\
31, \\
2001\end{array}$ & April 2001 & May 2001 & $\begin{array}{c}\text { June } \\
2001\end{array}$ & July 2001 & Total \\
\hline Total Class 9 Vehicles & 1776 & 3649 & 3772 & 3659 & 3376 & 16232 \\
\hline $\begin{array}{c}\text { Class 9 Vehicles with } \\
\text { GVW>80k }\end{array}$ & 68 & 117 & 73 & 67 & 36 & 361 \\
\hline $\begin{array}{c}\text { Class 9 Vehicles with } \\
\text { an Axle > 20k }\end{array}$ & 12 & 21 & 17 & 16 & 9 & 75 \\
\hline $\begin{array}{c}\text { Class 9 Vehicles with a } \\
\text { Tandem > 34k }\end{array}$ & 232 & 416 & 441 & 379 & 283 & 1751 \\
\hline$\%$ Overweight GVW & $3.8 \%$ & $3.2 \%$ & $1.9 \%$ & $1.8 \%$ & $1.1 \%$ & $2.2 \%$ \\
\hline$\%$ Over Axle & $0.7 \%$ & $0.6 \%$ & $0.4 \%$ & $0.4 \%$ & $0.3 \%$ & $0.5 \%$ \\
\hline$\%$ Over Tandem & $13.1 \%$ & $11.4 \%$ & $11.7 \%$ & $10.4 \%$ & $8.4 \%$ & $10.8 \%$ \\
\hline
\end{tabular}

Table 2: SR 1 WIM Station, Northbound.

\begin{tabular}{|c|c|c|c|c|c|c|}
\hline & $\begin{array}{c}\text { March } \\
18-31, \\
2001\end{array}$ & $\begin{array}{c}\text { April } \\
2001\end{array}$ & May 2001 & $\begin{array}{c}\text { June } \\
2001\end{array}$ & July 2001 & Total \\
\hline Total Class 9 Vehicles & 2018 & 4066 & 3971 & 3970 & 3617 & 17642 \\
\hline $\begin{array}{c}\text { Class 9 Vehicles with } \\
\text { GVW>80k }\end{array}$ & 1 & 7 & 6 & 7 & 2 & 23 \\
\hline $\begin{array}{c}\text { Class 9 Vehicles with } \\
\text { an Axle > 20k }\end{array}$ & 1 & 4 & 1 & 2 & 4 & 12 \\
\hline $\begin{array}{c}\text { Class 9 Vehicles with a } \\
\text { Tandem > 34k }\end{array}$ & 39 & 91 & 72 & 65 & 48 & 315 \\
\hline$\%$ Overweight GVW & $0.0 \%$ & $0.2 \%$ & $0.2 \%$ & $0.2 \%$ & $0.0 \%$ & $0.1 \%$ \\
\hline \% Over Axle & $0.0 \%$ & $0.1 \%$ & $0.0 \%$ & $0.0 \%$ & $0.1 \%$ & $0.1 \%$ \\
\hline$\%$ Over Tandem & $1.9 \%$ & $2.2 \%$ & $1.8 \%$ & $1.6 \%$ & $1.3 \%$ & $1.8 \%$ \\
\hline
\end{tabular}


Table 3: Average Front Axle and GVW Weights March 18-May 2001

\begin{tabular}{|c|c|c|c|c|}
\hline Lane & $\begin{array}{c}\text { Average Front Axle } \\
\text { Load (Ibs) }\end{array}$ & $\begin{array}{c}\text { St.Dev. Front } \\
\text { Axle Load } \\
\text { (lbs) }\end{array}$ & $\begin{array}{c}\text { Average GVW } \\
\text { (lbs) }\end{array}$ & $\begin{array}{c}\text { St.Dev. GVW } \\
\text { (lbs) }\end{array}$ \\
\hline Southbound & 10,190 & 1,259 & 57,822 & 15,340 \\
\hline Northbound & 10,508 & 1,159 & 55,886 & 15,271 \\
\hline
\end{tabular}

Table 4: Average Front Axle and GVW Weights June-July 2001

\begin{tabular}{|c|c|c|c|c|c|c|}
\hline Lane & $\begin{array}{c}\text { Average Front } \\
\text { Axle Load } \\
\text { (lbs) }\end{array}$ & $\begin{array}{c}\text { St.Dev. } \\
\text { Front Axle } \\
\text { Load (lbs) }\end{array}$ & $\begin{array}{c}\text { Max Front } \\
\text { Axle Load } \\
\text { (lbs) }\end{array}$ & $\begin{array}{c}\text { Average } \\
\text { GVW (lbs) }\end{array}$ & $\begin{array}{c}\text { St.Dev. } \\
\text { GVW } \\
\text { (lbs) }\end{array}$ & $\begin{array}{c}\text { Max } \\
\text { GVW } \\
\text { (lbs) }\end{array}$ \\
\hline Southbound & 10,020 & 1,213 & 15560 & 56,703 & 15,019 & 95560 \\
\hline Northbound & 10,530 & 1,164 & 19460 & 55,512 & 15,091 & 92320 \\
\hline
\end{tabular}




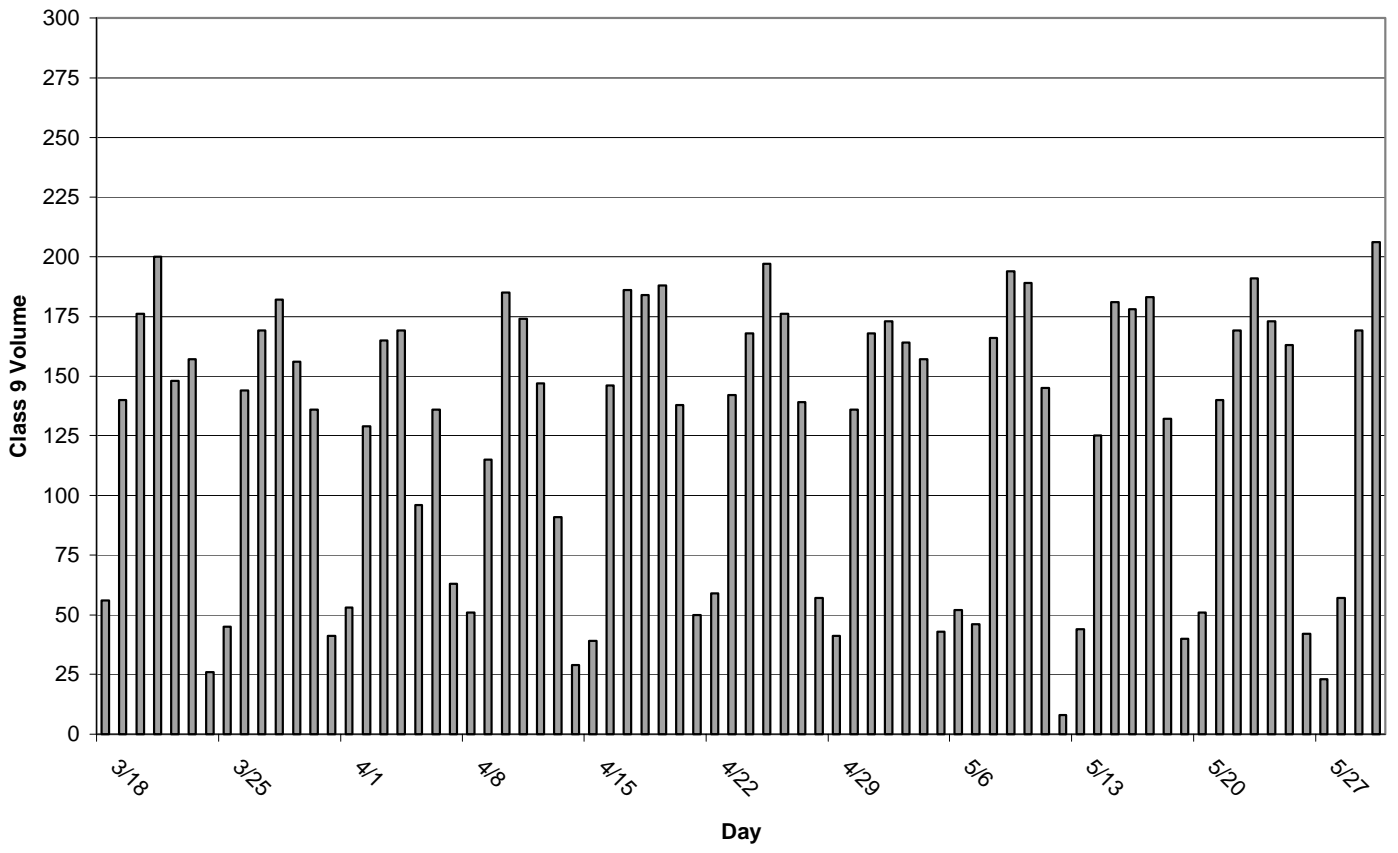

Figure 1: Southbound Class 9 Volume on SR 1 for March 18 to May 2001

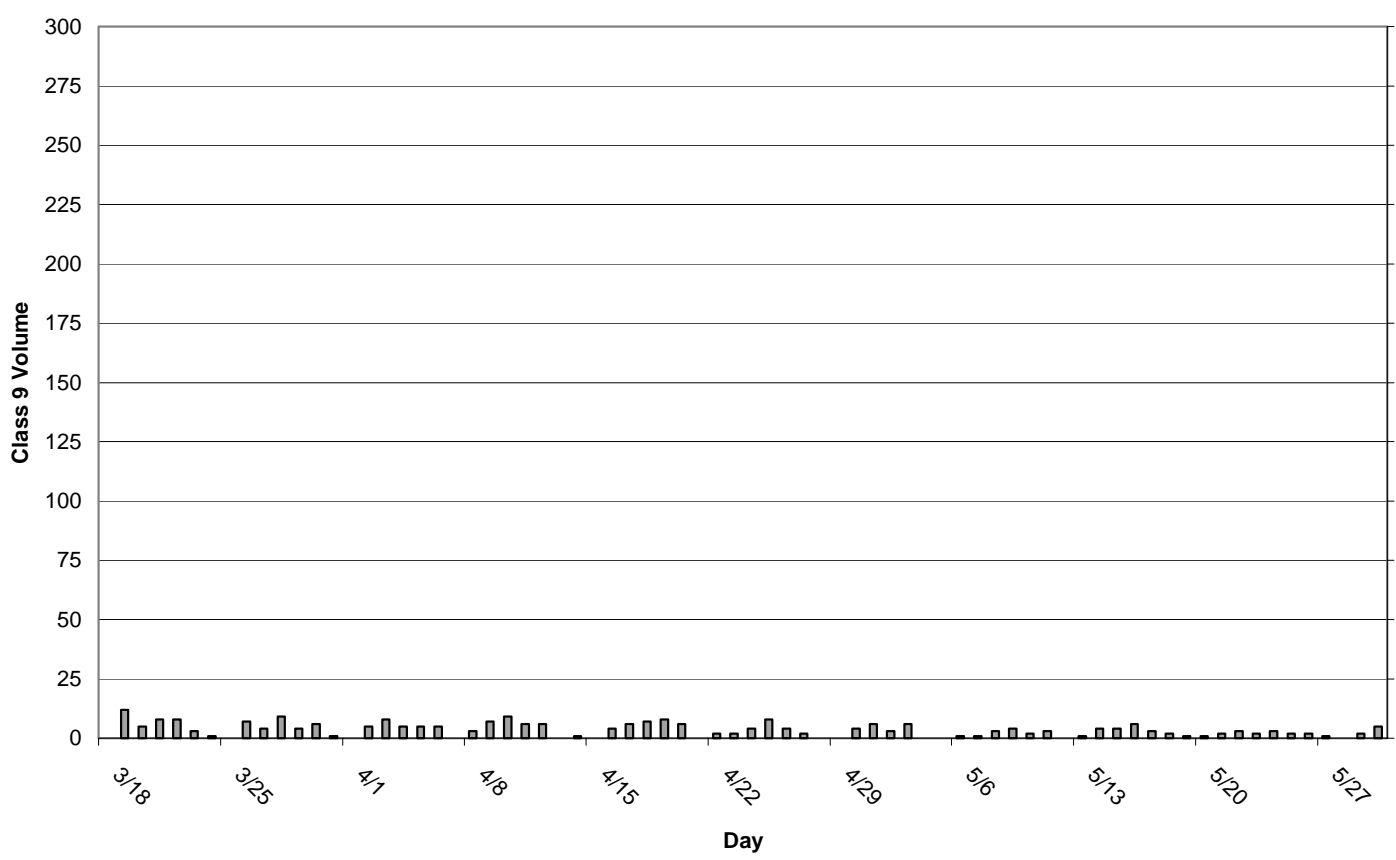

Figure 2: Southbound Class 9 Volume on SR 1 with GVW>80,000 for March 18 to May 2001 


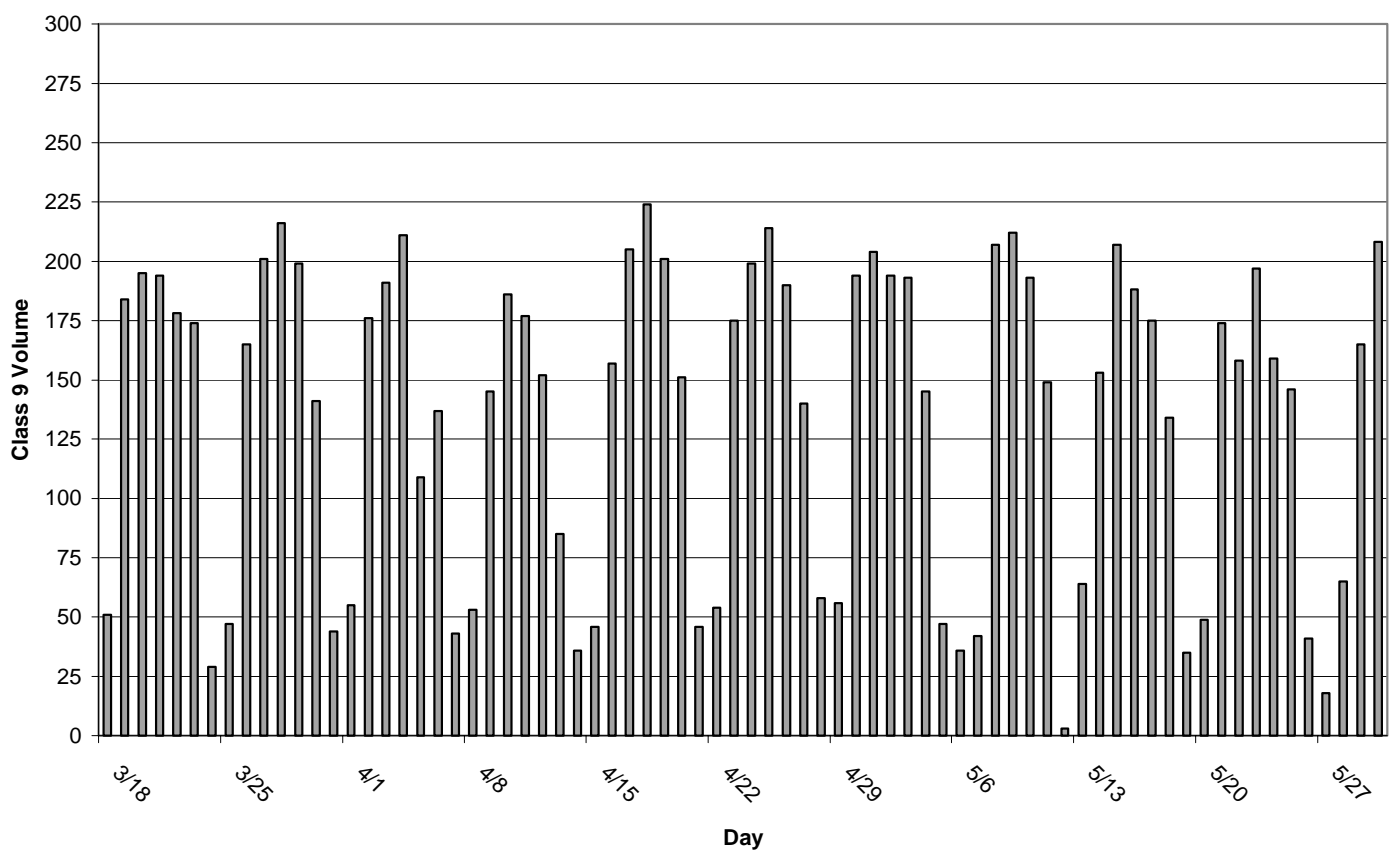

Figure 3: Northbound Class 9 Volume on SR 1 for March 18 to May 2001

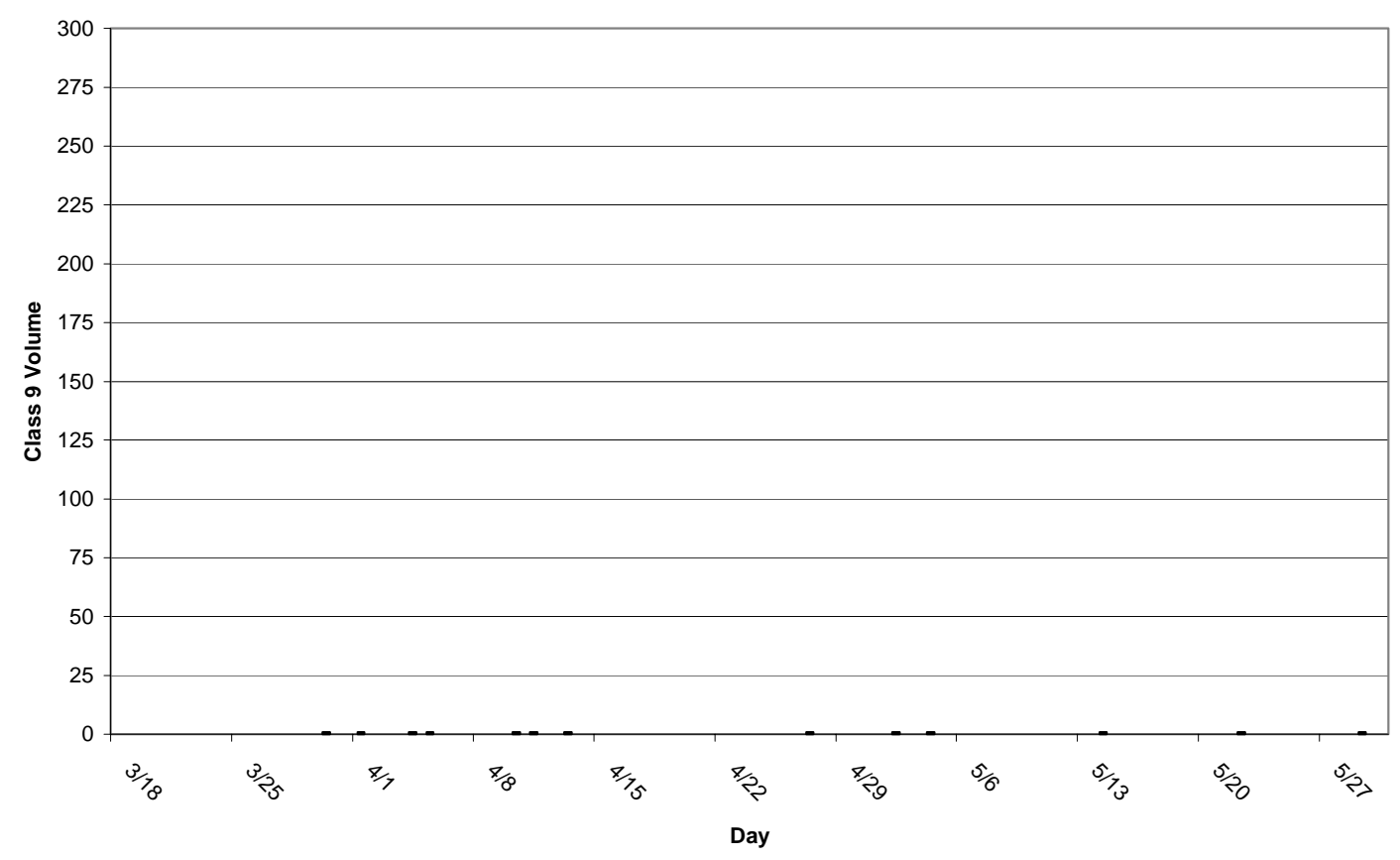




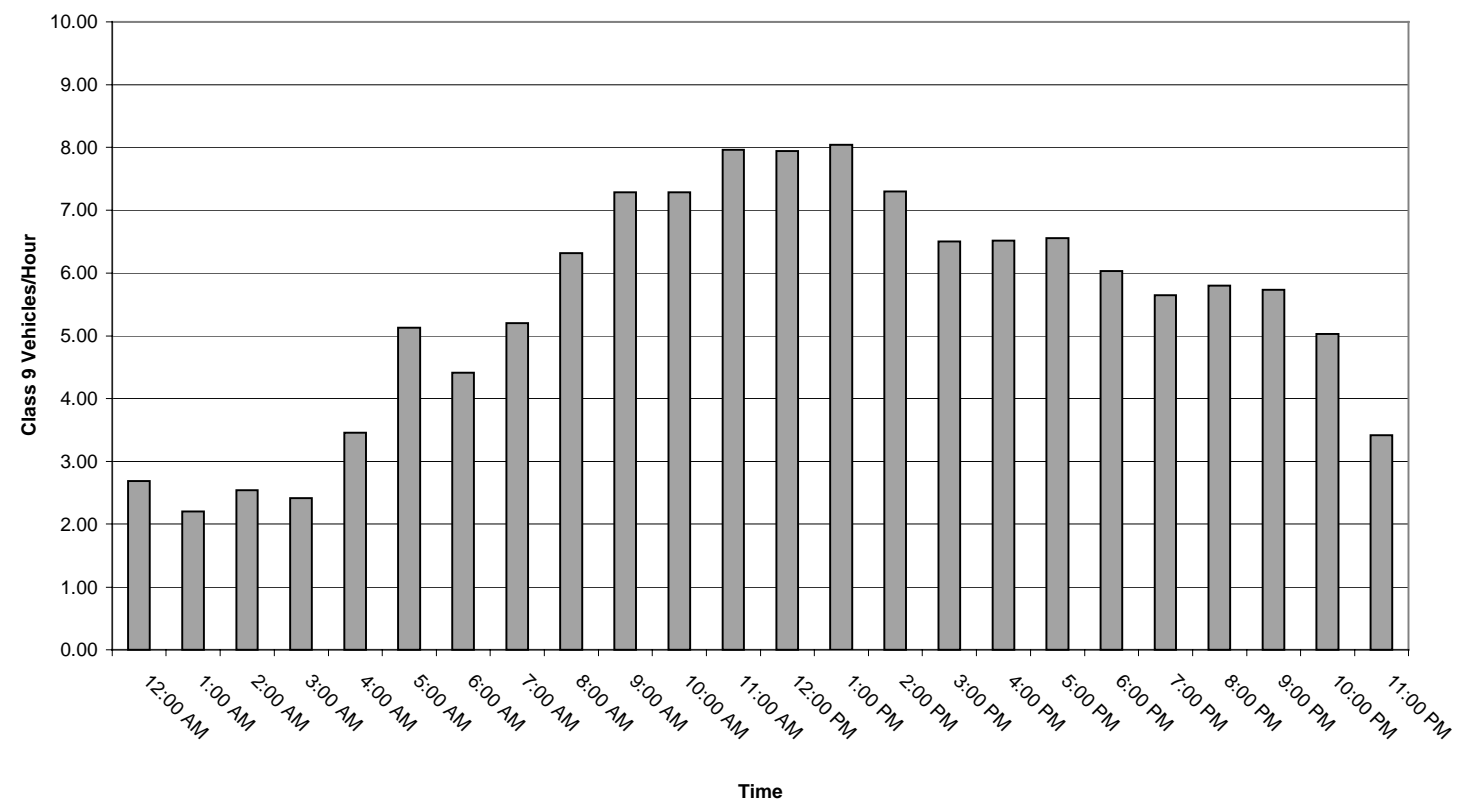

Figure 5: Average Hourly Southbound Class 9 Volume on SR 1 for March 18 to May 2001

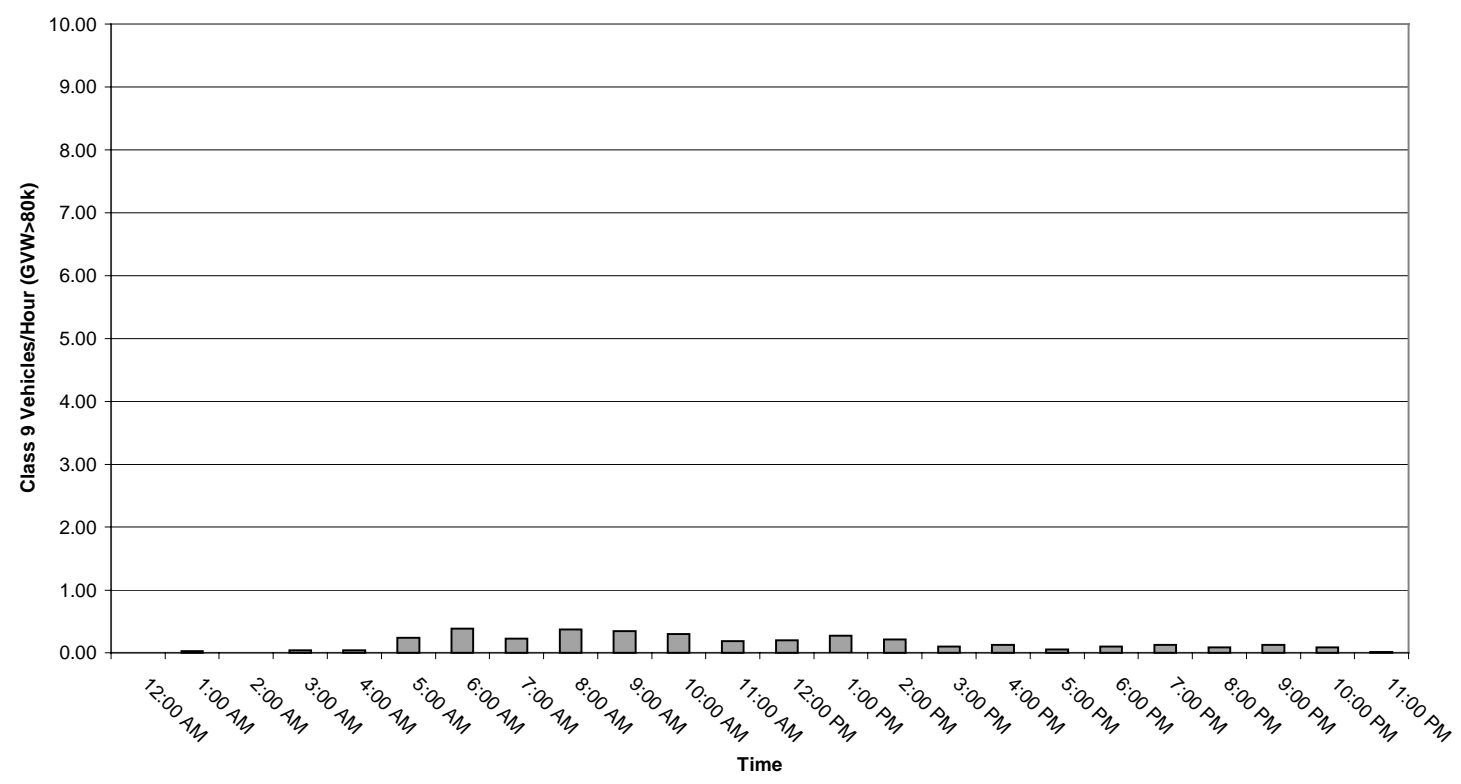

Figure 6: Average Hourly Southbound Class 9 Volume with GVW>80,000 on SR 1 for March 18 to May 2001 


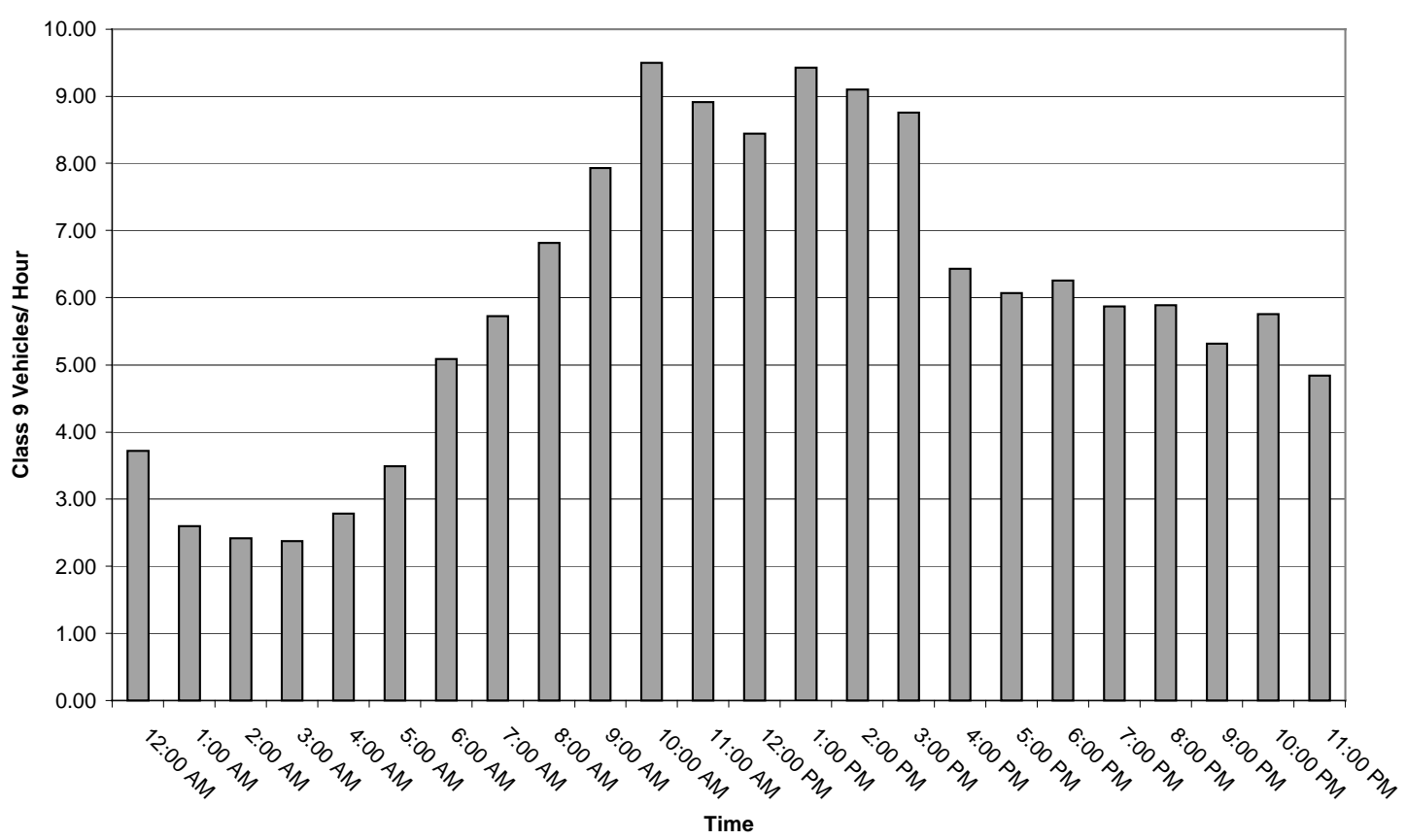

Figure 7: Average Hourly Northbound Class 9 Volume on SR 1 for March18 to May 2001

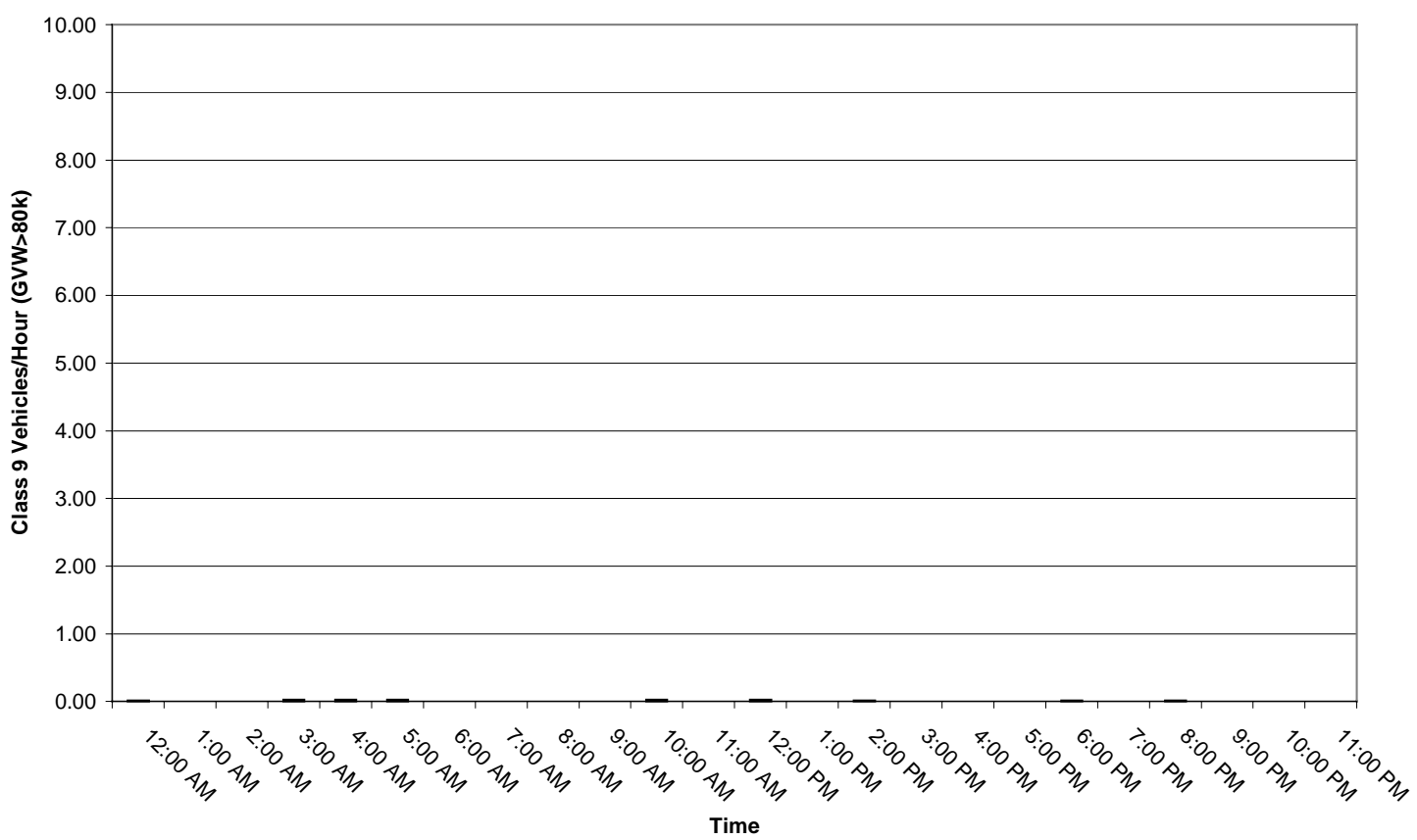

Figure 8: Average Hourly Northbound Class 9 Volume with GVW>80,000 on SR 1 for March 18 to May 2001 


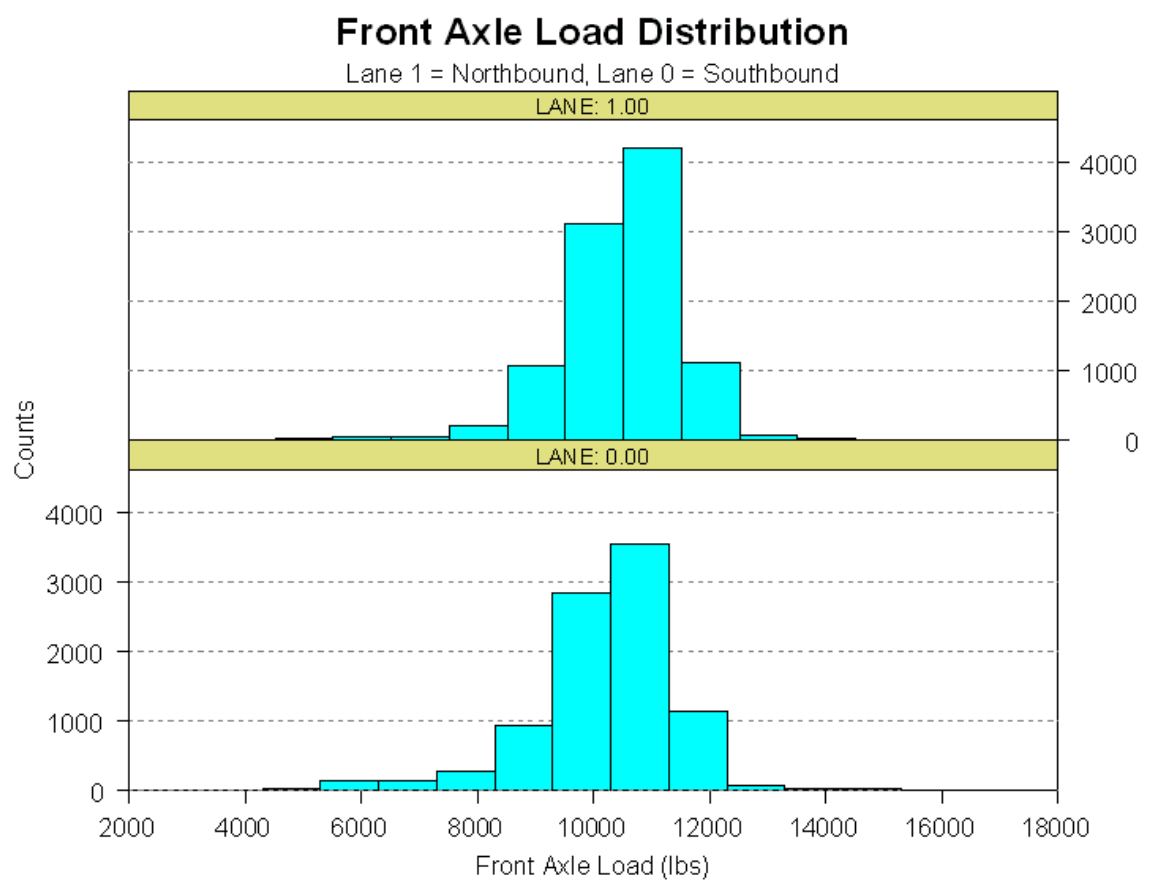

Figure 9: Average Class 9 Front Axle Weight Distribution on SR 1 for March 18 to May 2001

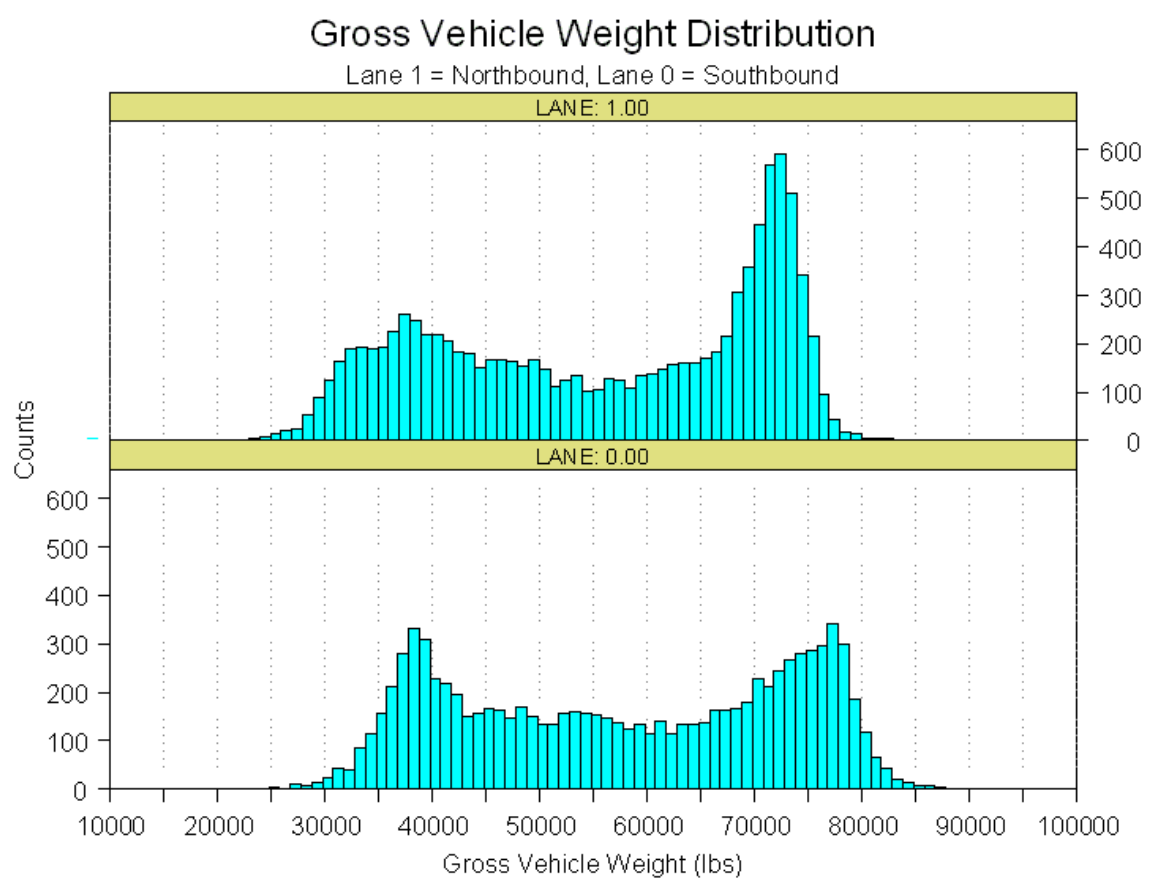

Figure 10: Distribution of Class 9 GVW, March 18 to May 2001 


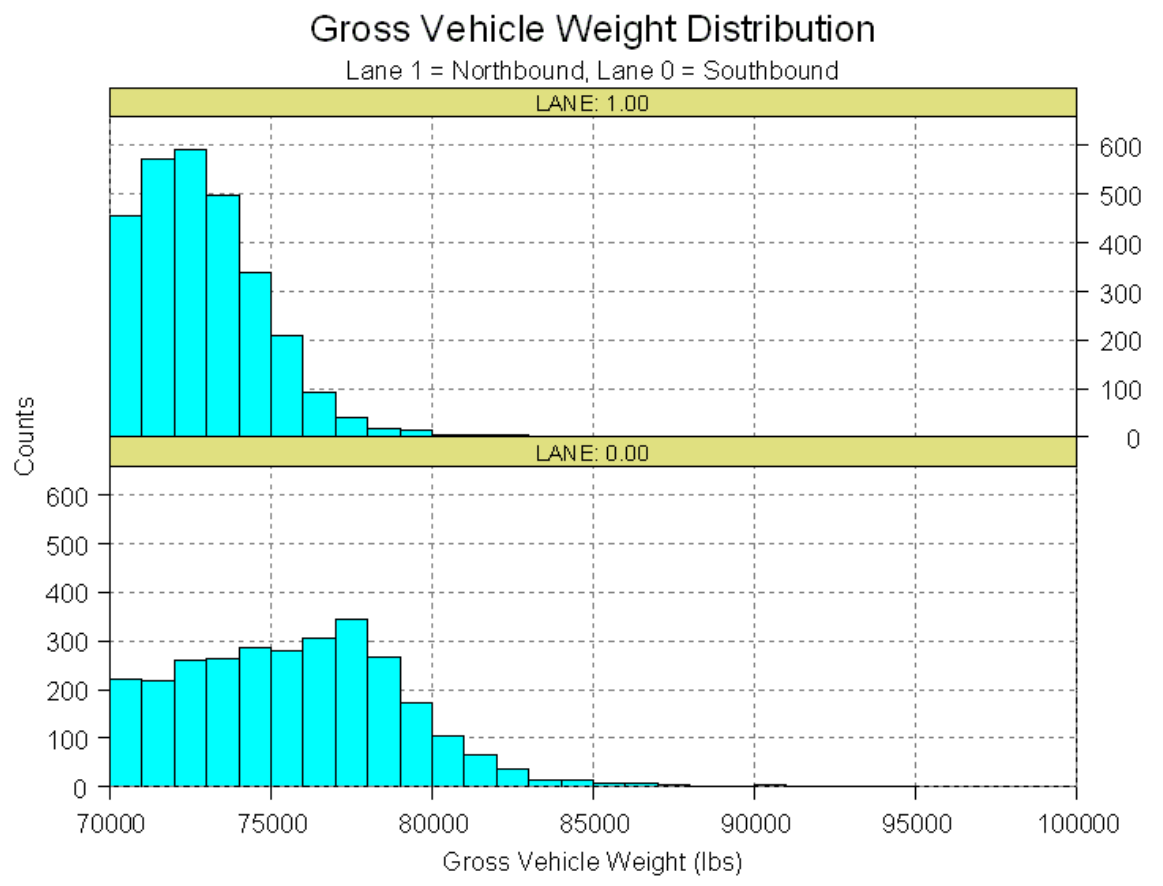

Figure 11: Distribution of Class 9 GVW, Zoomed in graph of same data shown in Figure 10 Figure 


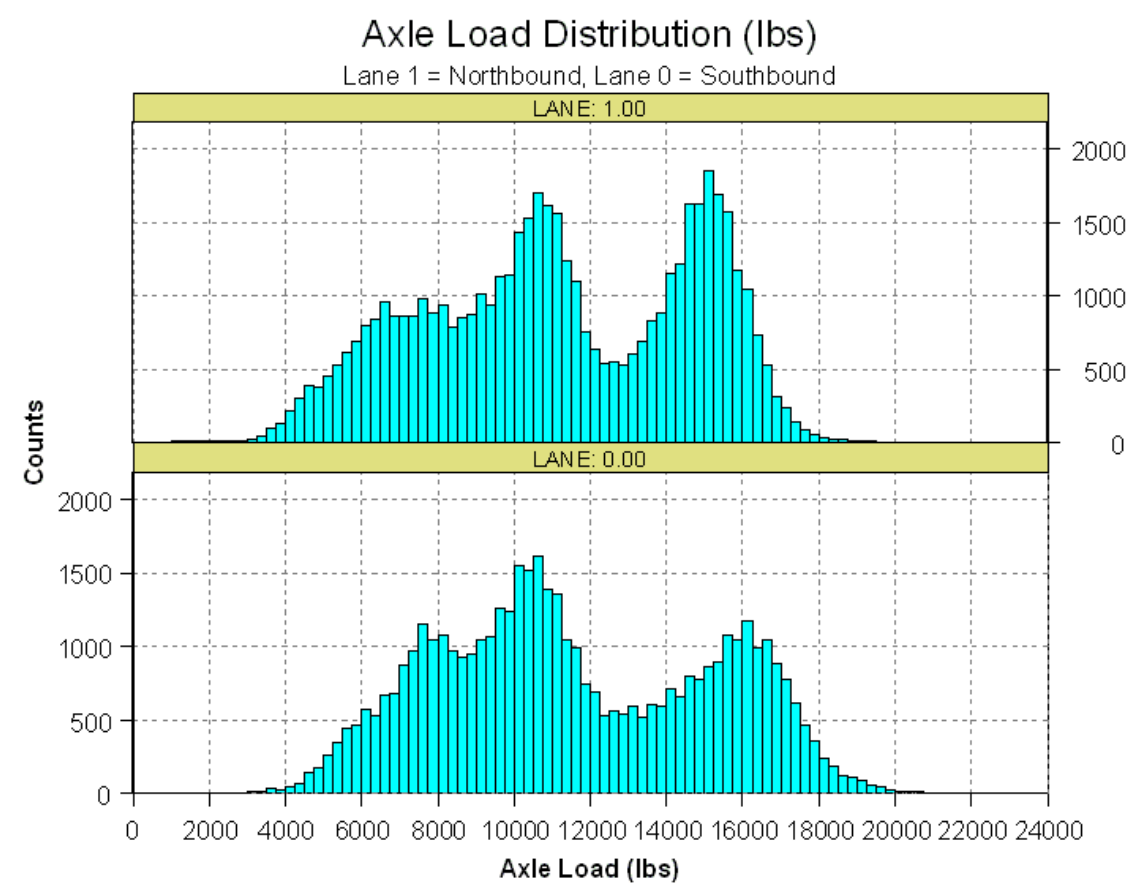

Figure 12: Distribution of Class 9 Axle Weight, March 18 to May 2001

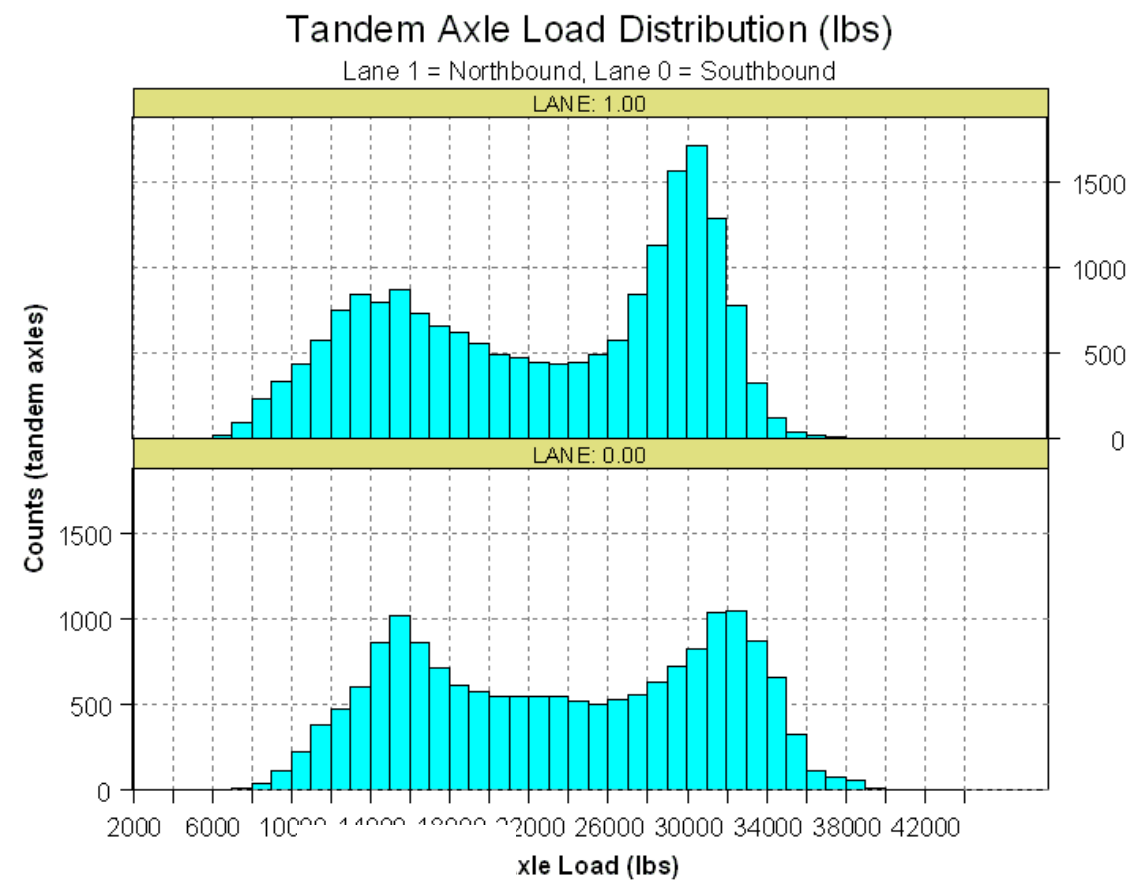

Figure 13: Distribution of Class 9 Tandem Weight, March 18 to May 2001 


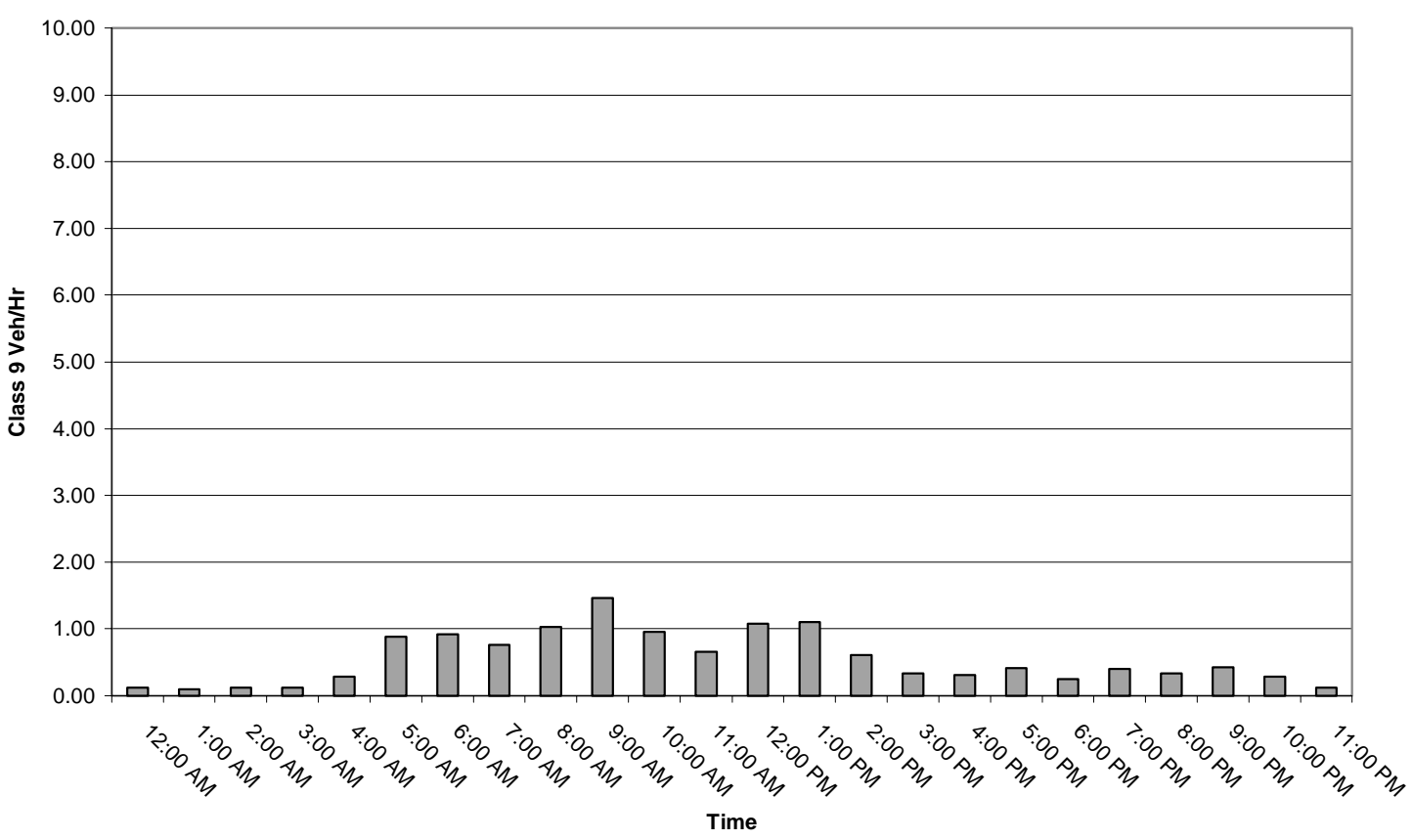

Figure 14: Average Hourly Southbound Class 9 Volume with Tandem>34,000 on SR1 for March 18 to May 2001

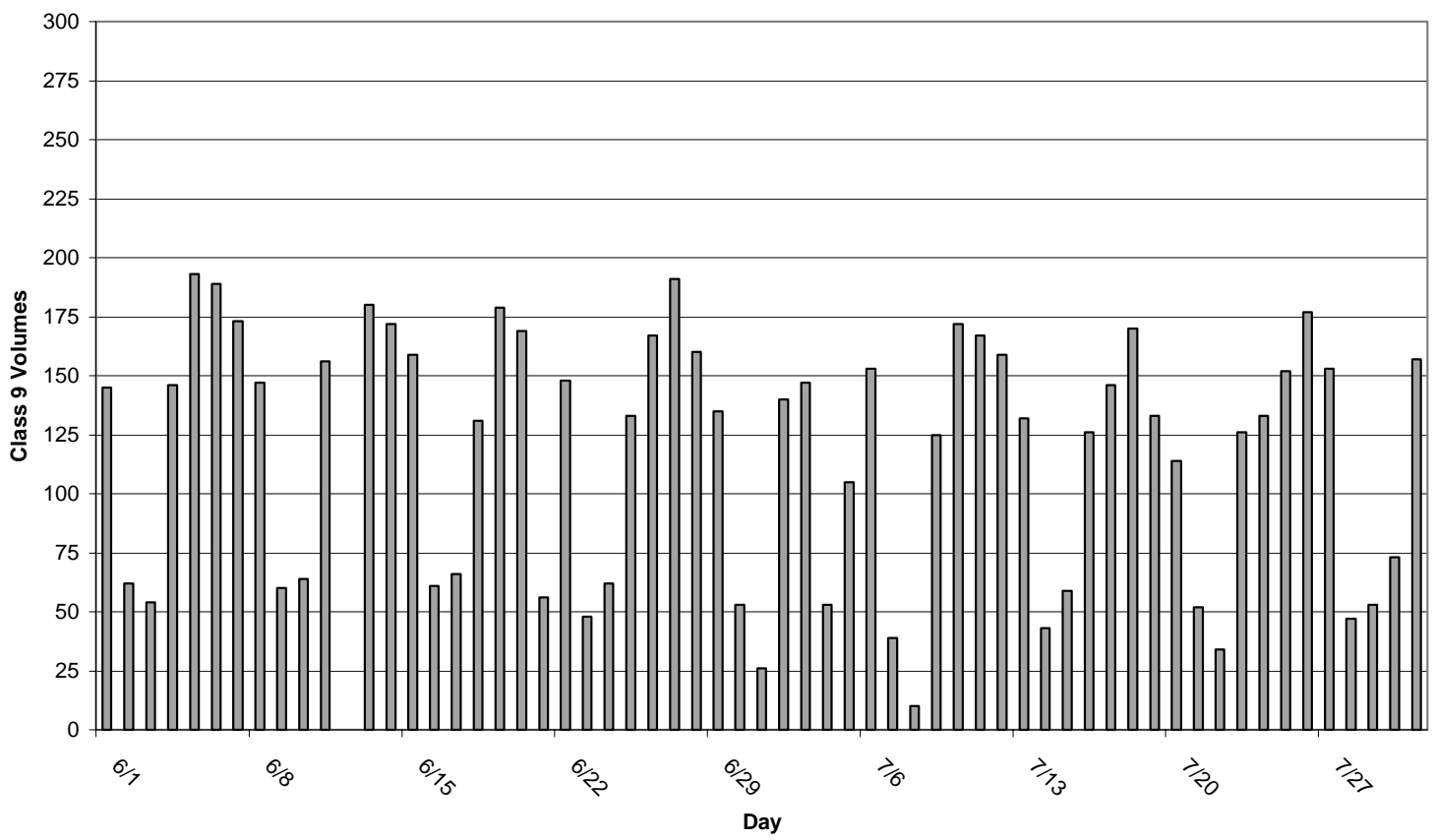

Figure 15: Southbound Class 9 Volume on SR 1 for June-July 2001 


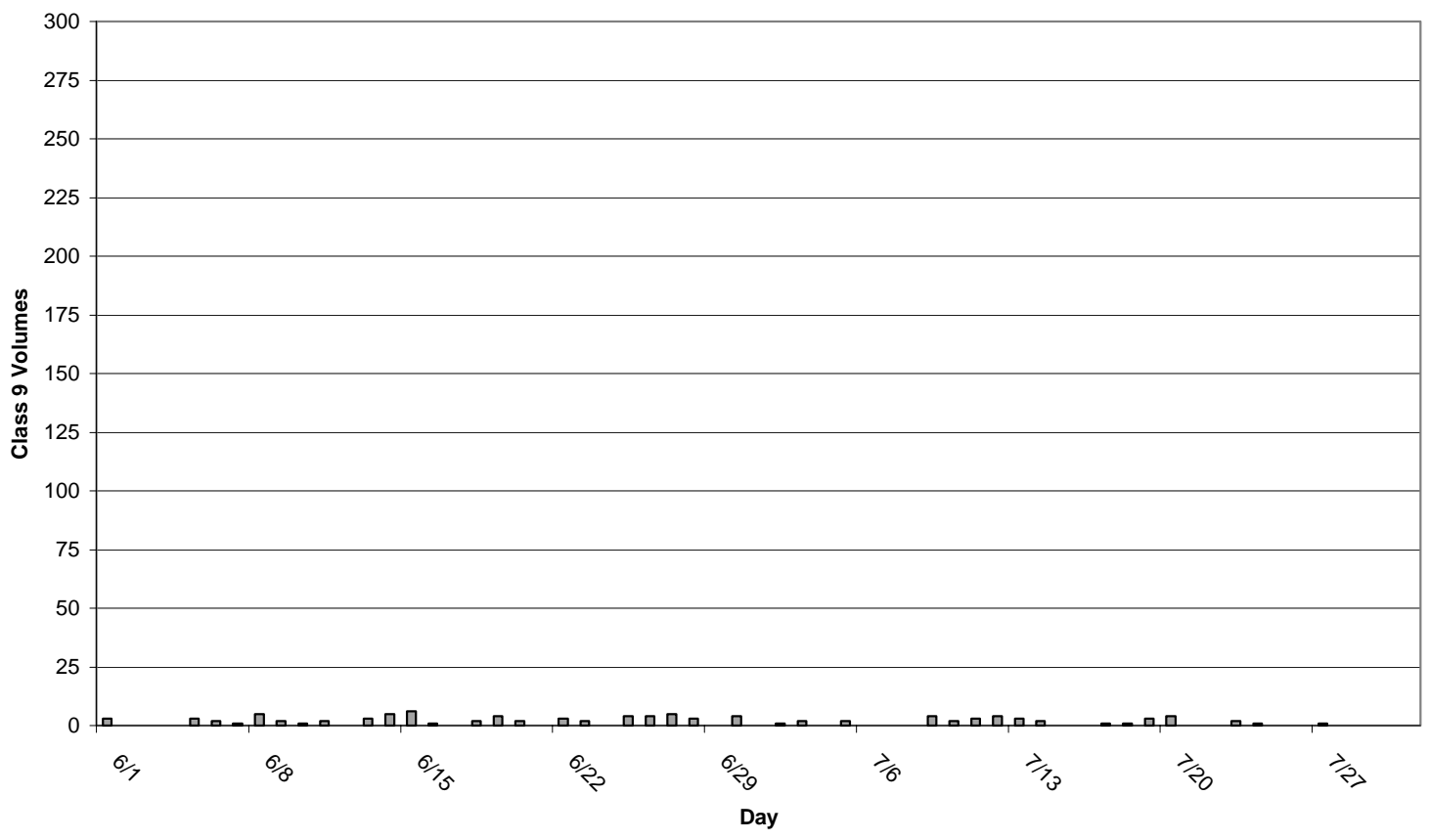

Figure 16: Southbound Class 9 Volume on SR 1 with GVW>80,000 for June-July 2001

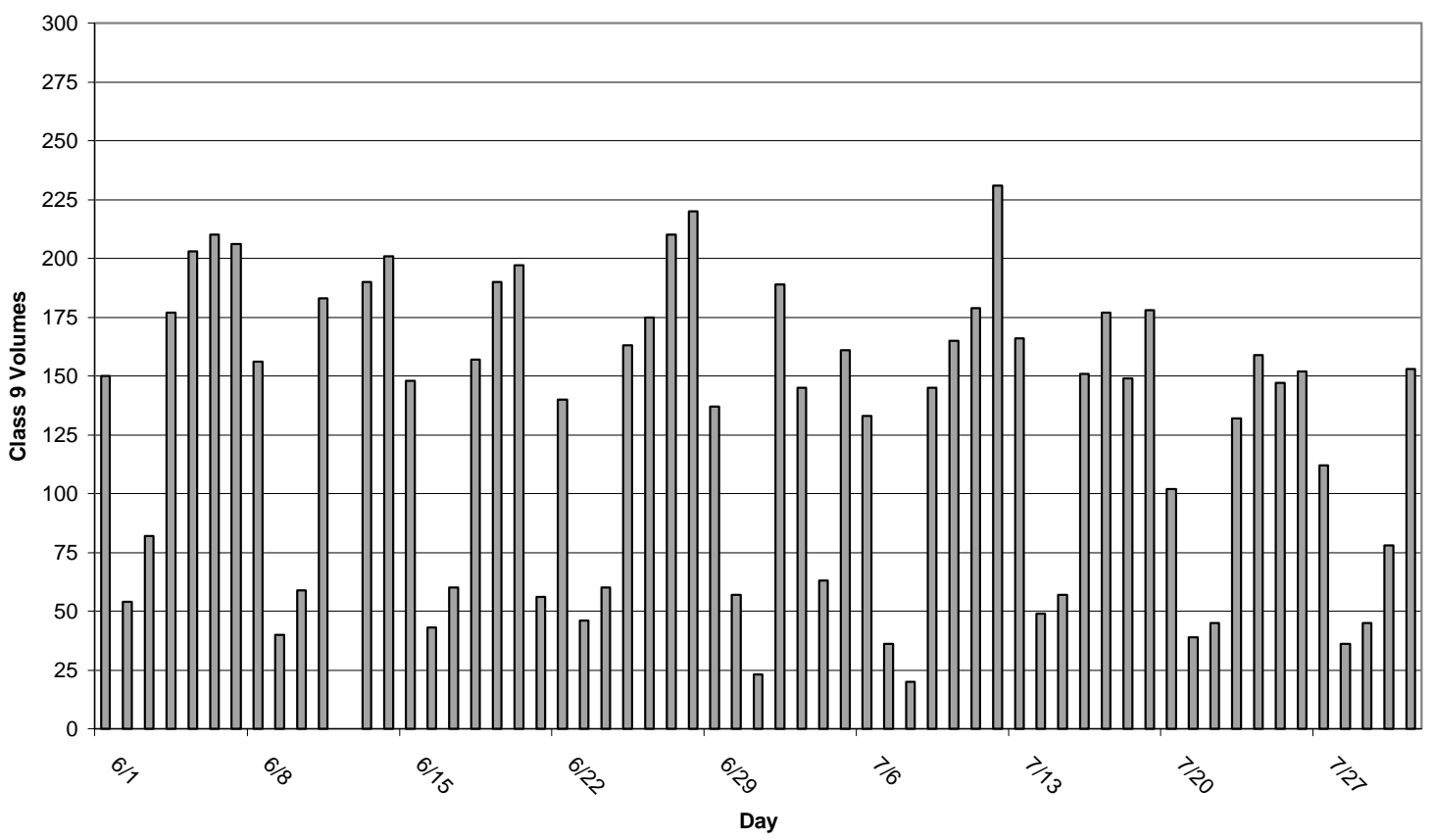




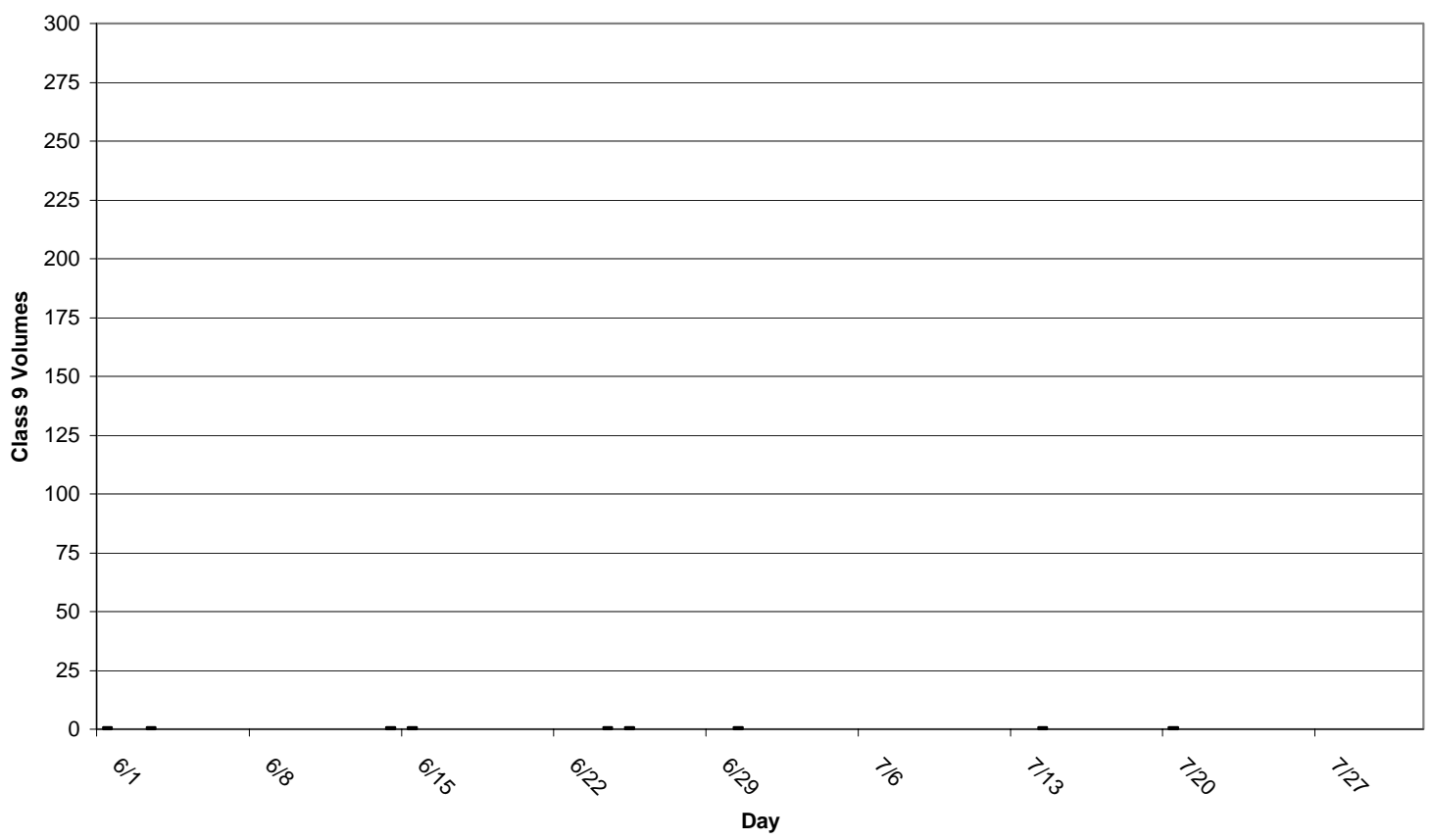

Figure 18: Northbound Class 9 Volume on SR 1 with GVW>80,000 for June-July 2001

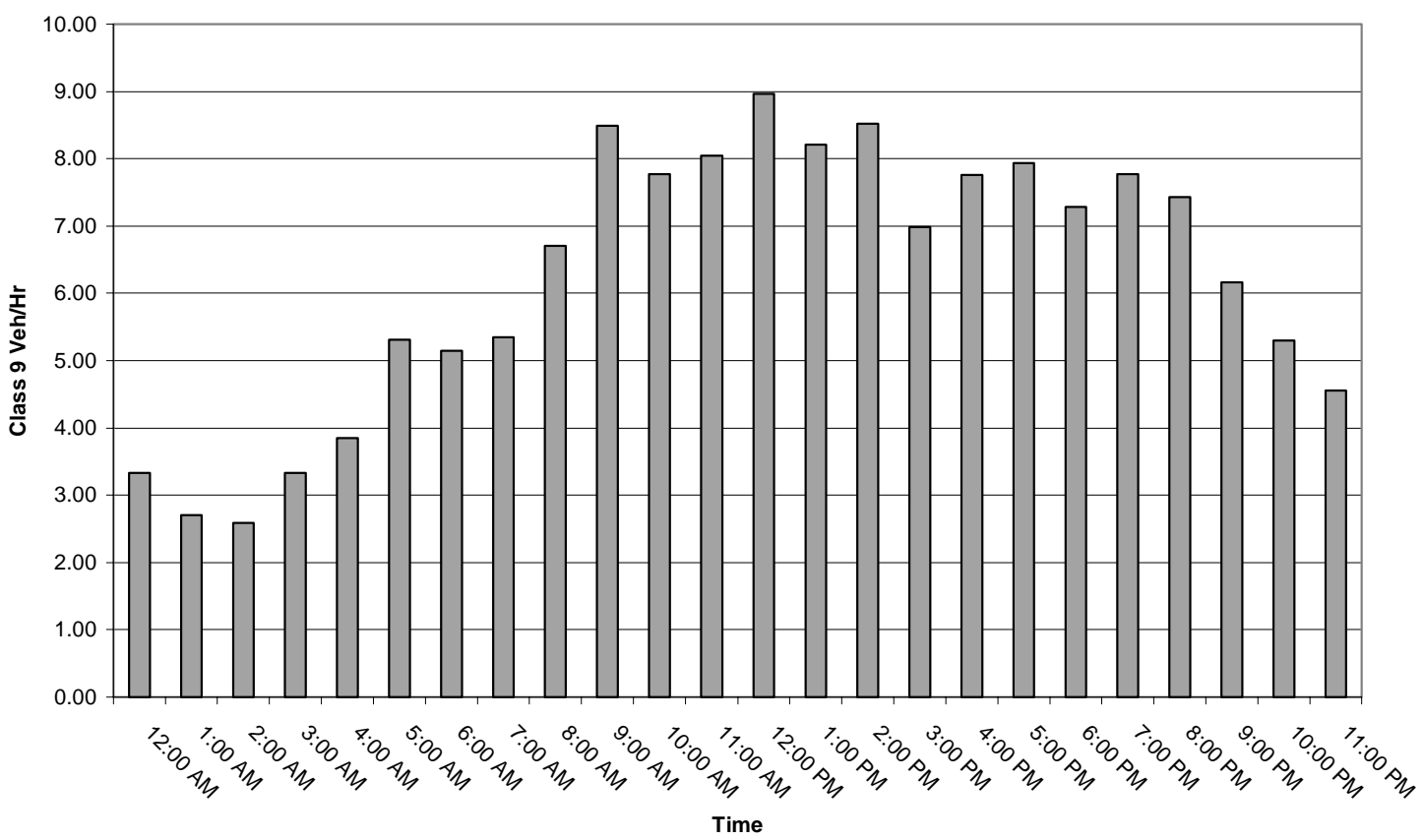




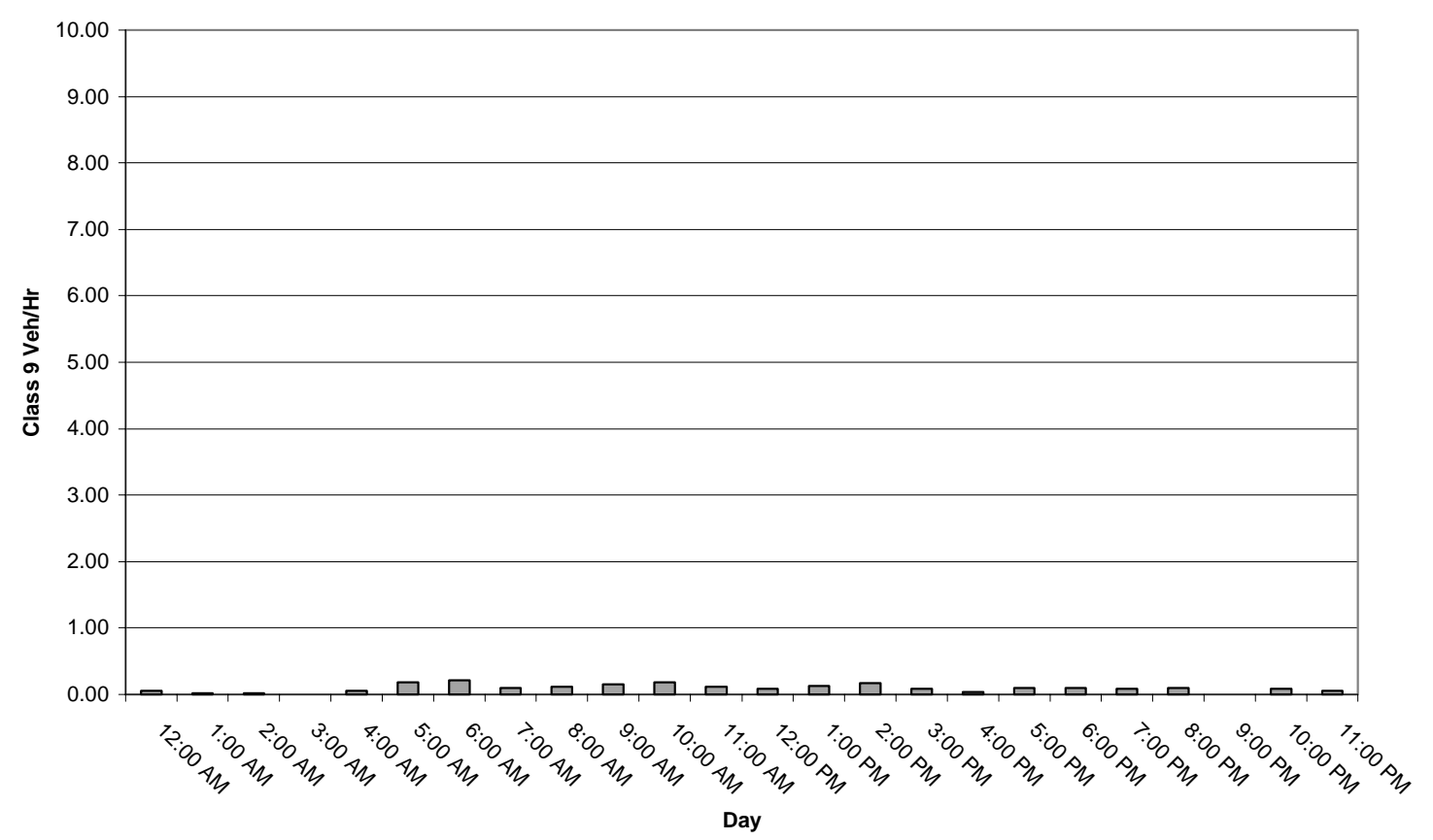

Figure 20: Average Hourly Southbound Class 9 Volume with GVW>80,000 on SR 1 for June-July 2001

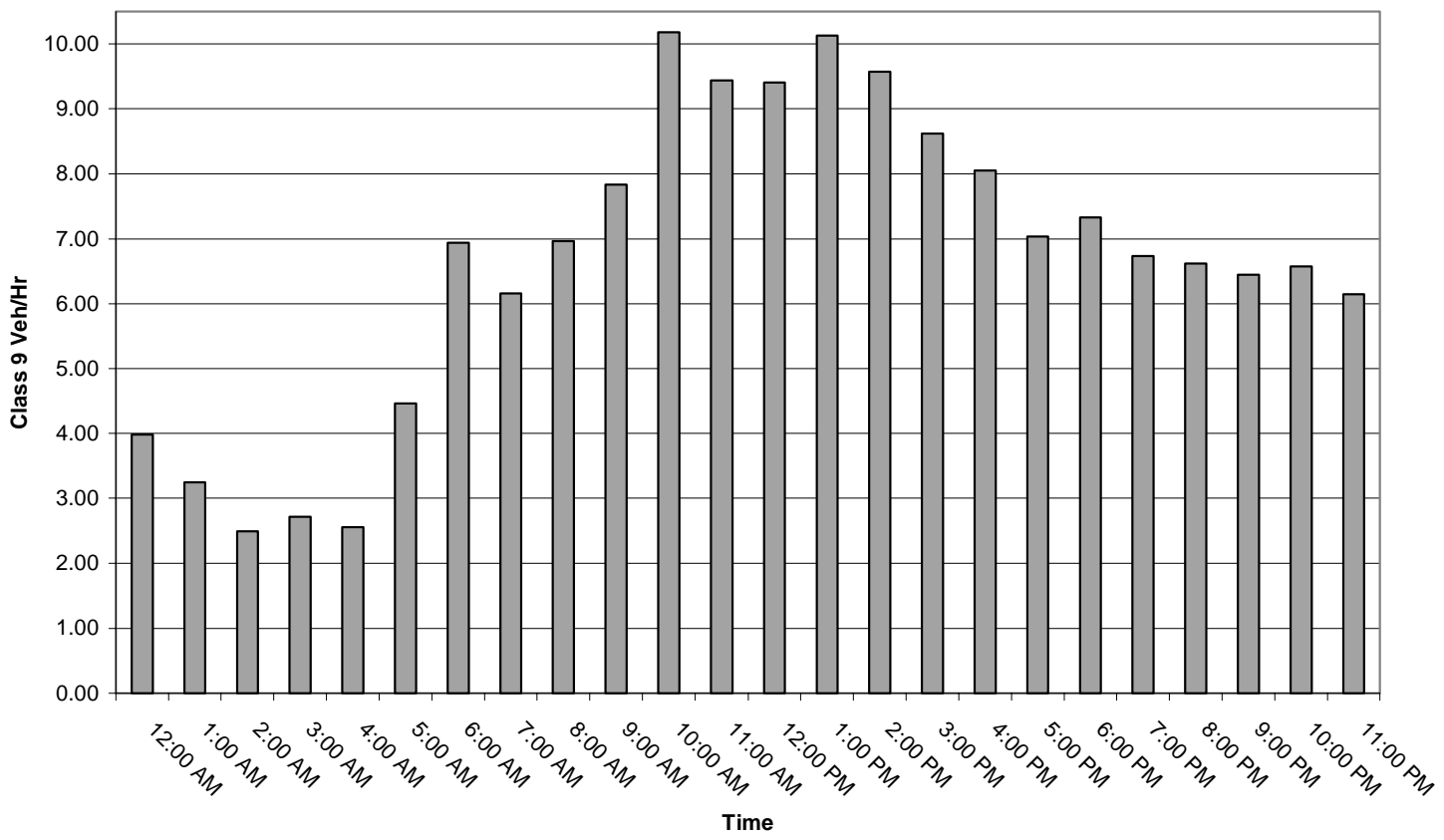




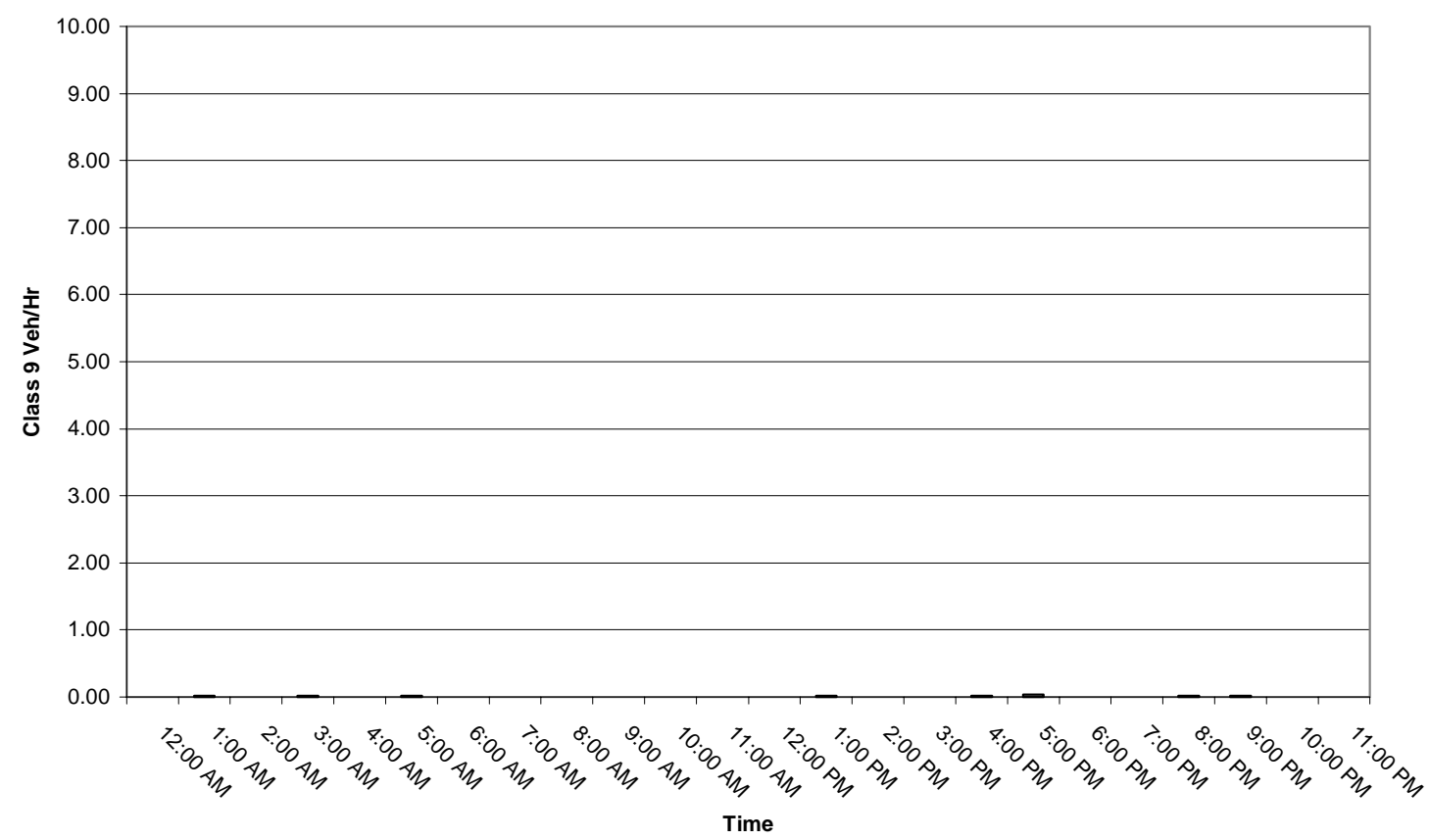

Figure 22: Average Hourly Northbound Class 9 Volume with GVW>80,000 on SR 1 for June-July 2001

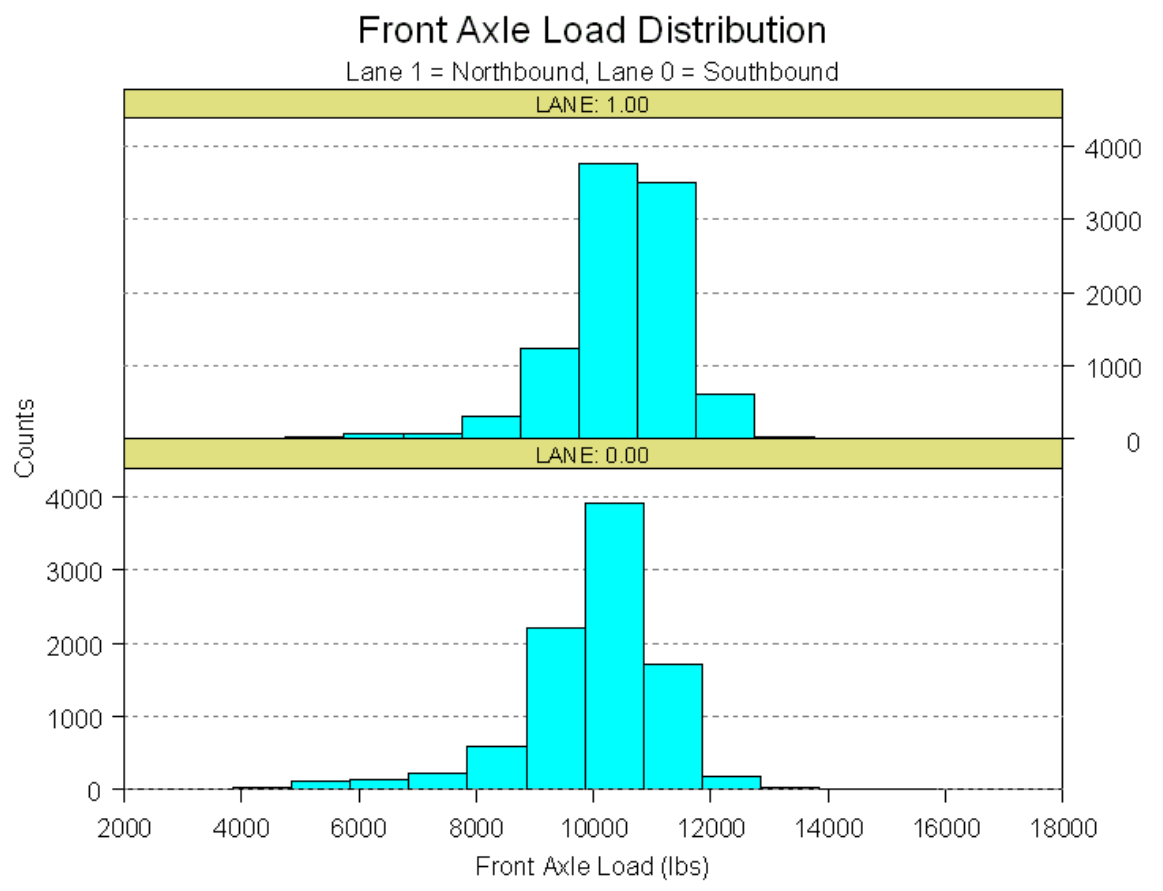

Figure 23: Average Class 9 Front Axle Weight Distribution on SR 1 for June-July 2001 


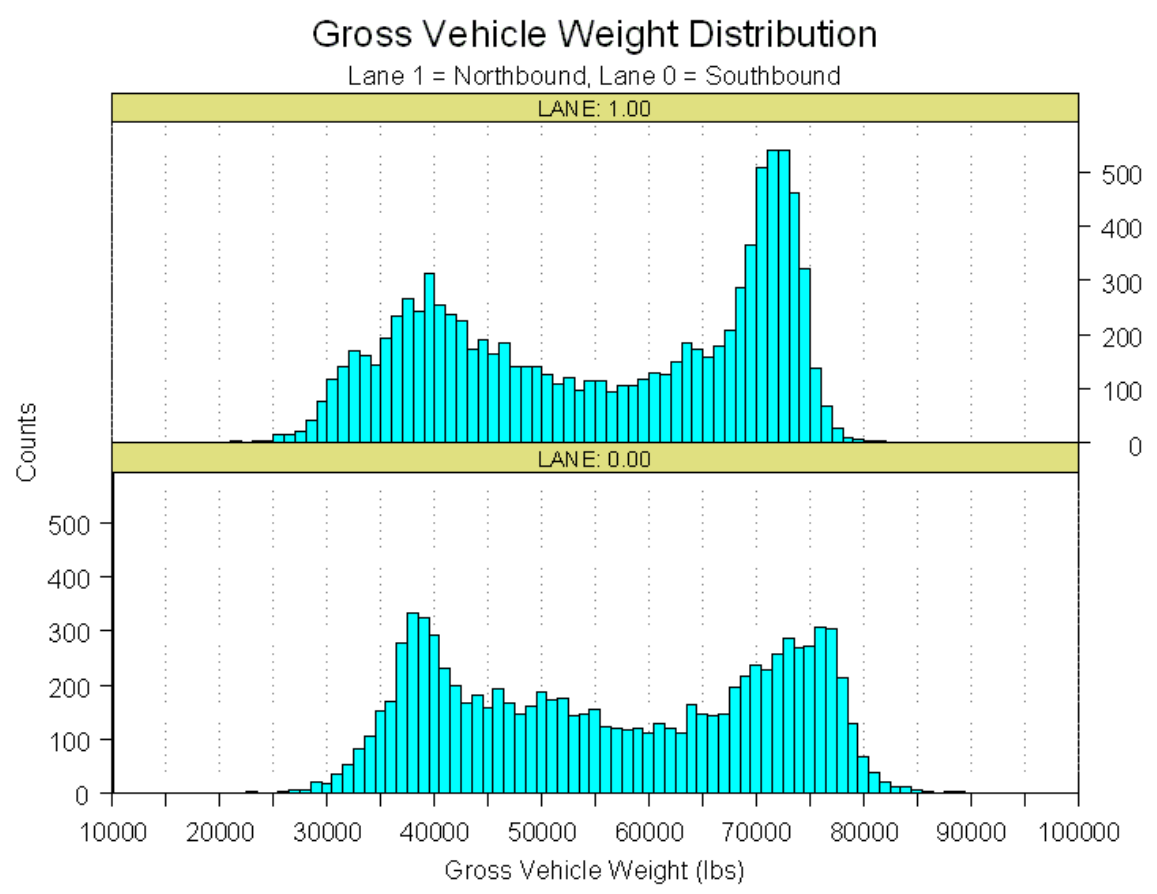

Figure 24: Distribution of Class 9 GVW, June-July 2001

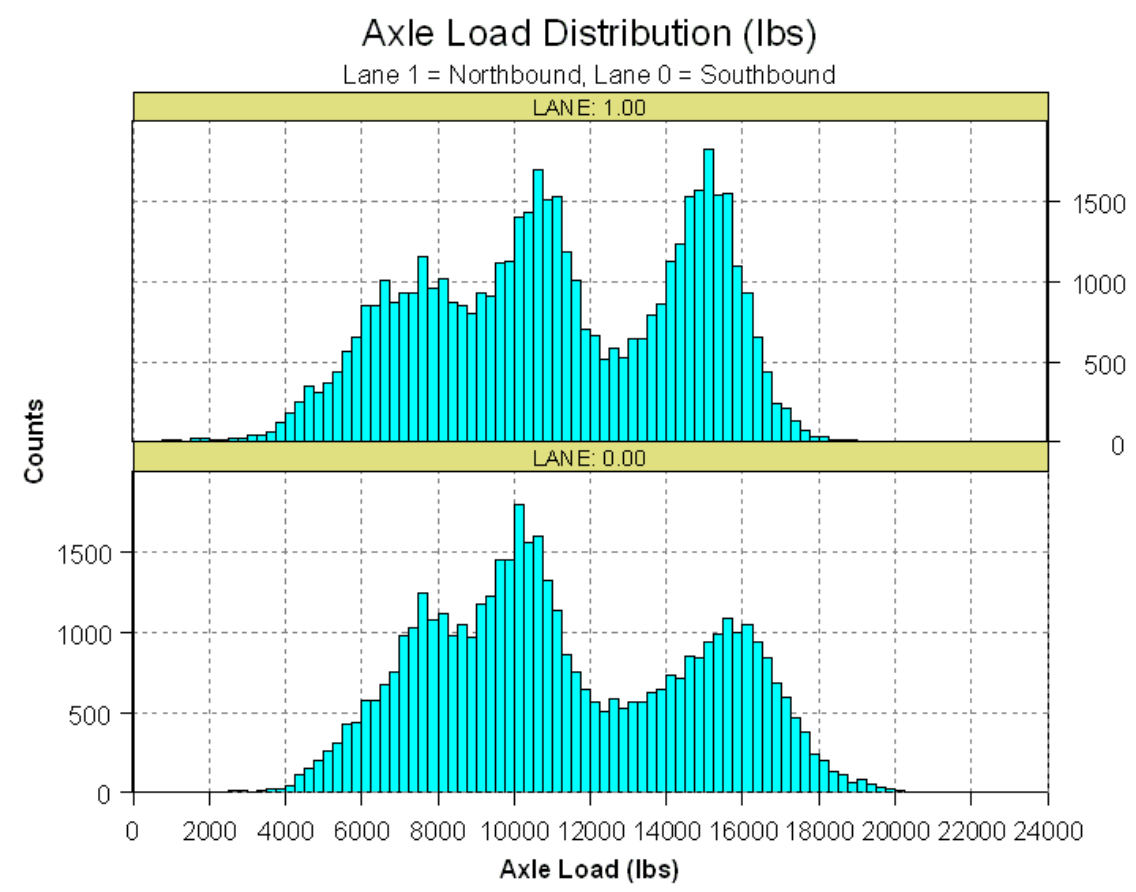

Figure 25: Distribution of Class 9 Axle Weight, June-July 2001 


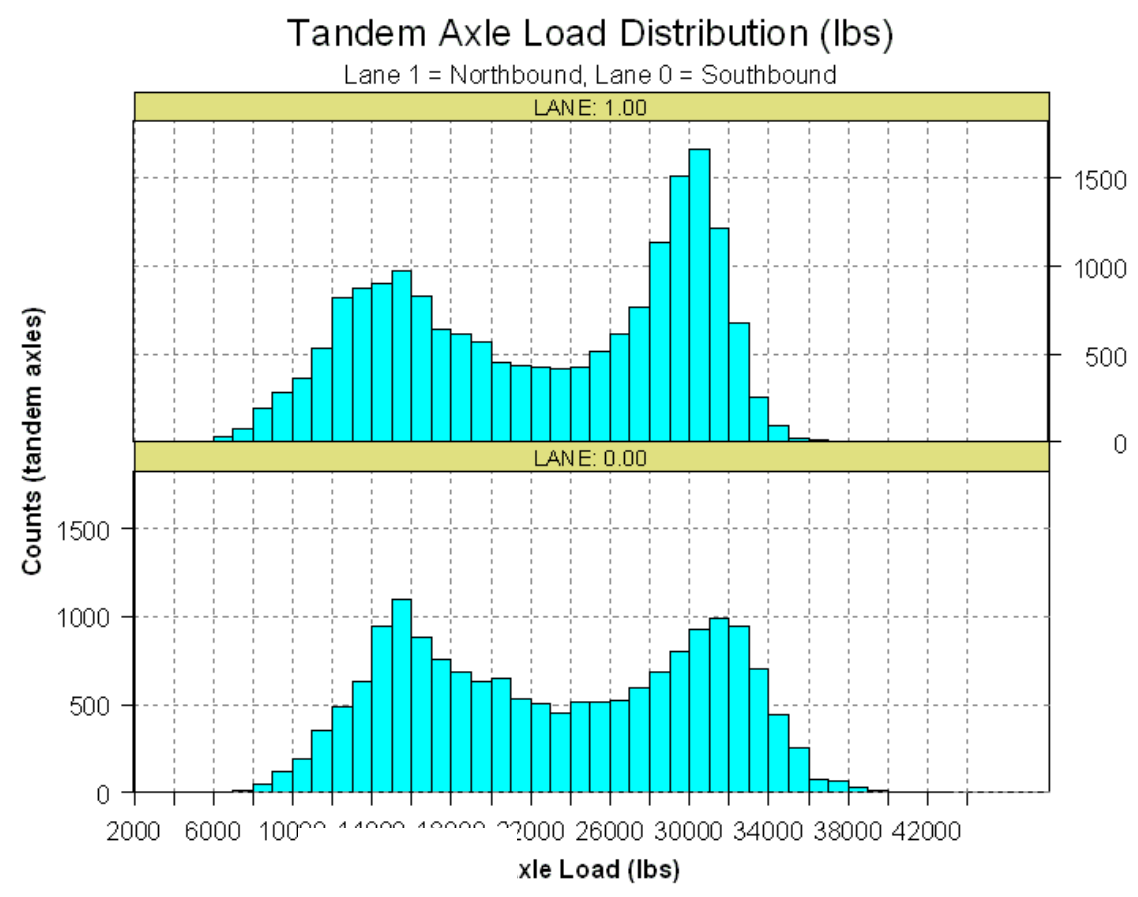

Figure 26: Distribution of Class 9 Tandem Weight, June-July 2001

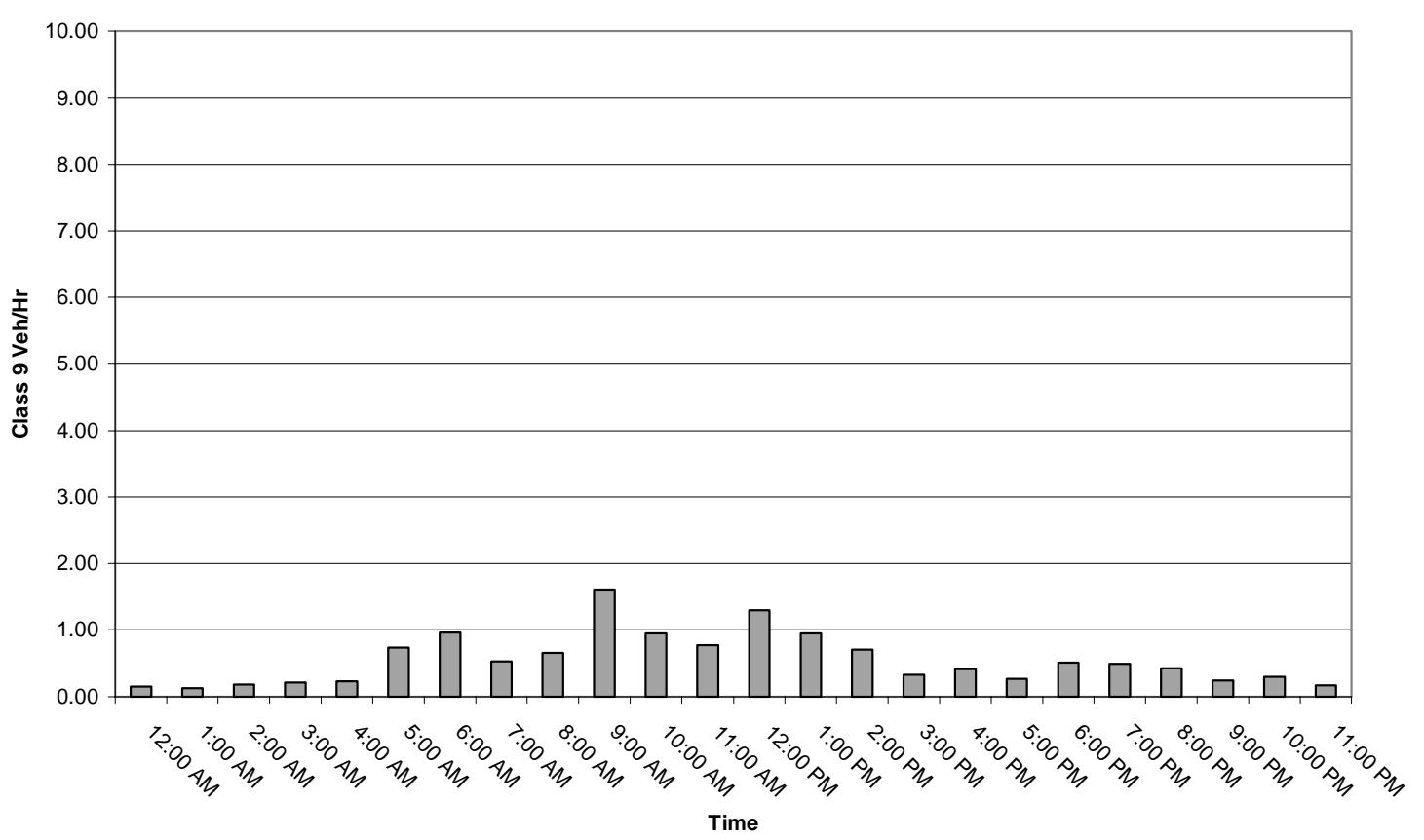

Figure 27: Average Hourly Volume of Southbound Class 9 Tandem > 34,000 on SR1 for June-July 2001 
Appendix M Specifications for SR 1 Photo WIM Memo 
To: $\quad$ Mark Newland

From: $\quad$ Darcy Bullock and Andrew Nichols

Date: $\quad$ September 17, 2001

Subject: $\quad$ Draft Scope of Work for SR 1 Video Capture Installation on SR 1 south of I-74.

Background: Due to the high volume of trucks traveling on SR1, a weigh-in-motion site was recently installed in the northbound and southbound lanes. Tables 1 and 2 summarize data recently collected at this site. This site serves as a test site for Indiana State Police Commercial Vehicle Enforcement activities. The information from the weigh-in-motion station will be used by the ISP/CVE to determine which trucks may be overweight so they can stop them to statically weigh them.

Table 1: SR 1 WIM Station, Southbound.

\begin{tabular}{|c|c|c|c|c|}
\hline & $\begin{array}{c}\text { March 18-31, } \\
2001\end{array}$ & $\begin{array}{c}\text { April 1-30, } \\
2001\end{array}$ & $\begin{array}{c}\text { May 1-30, } \\
2001\end{array}$ & Total \\
\hline Total Class 9 Vehicles & 1776 & 3649 & 3772 & 9197 \\
\hline $\begin{array}{c}\text { Class 9 Vehicles with } \\
\text { GVW>80k }\end{array}$ & 68 & 117 & 73 & 258 \\
\hline $\begin{array}{c}\text { Class 9 Vehicles with an } \\
\text { Axle > 20k }\end{array}$ & 12 & 21 & 17 & 50 \\
\hline $\begin{array}{c}\text { Class 9 Vehicles with a } \\
\text { Tandem > 34k }\end{array}$ & 232 & 416 & 441 & 1089 \\
\hline$\%$ Overweight GVW & $3.8 \%$ & $3.2 \%$ & $1.9 \%$ & $2.8 \%$ \\
\hline \% Over Axle & $0.7 \%$ & $0.6 \%$ & $0.4 \%$ & $0.5 \%$ \\
\hline$\%$ Over Tandem & $13.1 \%$ & $11.4 \%$ & $11.7 \%$ & $11.8 \%$ \\
\hline
\end{tabular}

Table 2: SR 1 WIM Station, Northbound.

\begin{tabular}{|c|c|c|c|c|}
\hline & $\begin{array}{c}\text { March 18-31, } \\
2001\end{array}$ & $\begin{array}{c}\text { April 1-30, } \\
2001\end{array}$ & $\begin{array}{c}\text { May 1-30, } \\
2001\end{array}$ & Total \\
\hline Total Class 9 Vehicles & 2018 & 4066 & 3971 & 10,045 \\
\hline $\begin{array}{c}\text { Class 9 Vehicles with } \\
\text { GVW>80k }\end{array}$ & 1 & 7 & 6 & 14 \\
\hline $\begin{array}{c}\text { Class 9 Vehicles with an } \\
\text { Axle > 20k }\end{array}$ & 1 & 4 & 1 & 6 \\
\hline $\begin{array}{c}\text { Class 9 Vehicles with a } \\
\text { Tandem > 34k }\end{array}$ & 39 & 91 & 72 & 202 \\
\hline$\%$ Overweight GVW & $0.0 \%$ & $0.2 \%$ & $0.2 \%$ & $0.1 \%$ \\
\hline \% Over Axle & $0.0 \%$ & $0.1 \%$ & $0.0 \%$ & $0.1 \%$ \\
\hline$\%$ Over Tandem & $1.9 \%$ & $2.2 \%$ & $1.8 \%$ & $2.0 \%$ \\
\hline
\end{tabular}


Concept: It has been decided that the most beneficial information that the weigh-in-motion site could provide to the ISP/CVE officer is a picture of the truck along with the weight information of that truck. In order to collect the data at the site, two cameras need to be installed to capture the image of each southbound truck. One camera shall be used to capture the entire truck cab and part of the trailer. The second camera shall be used to capture a zoomed image of the side of trucks to provide information specifically identifying the truck. The southbound direction has approximately $12 \%$ of the Class 9 trucks traveling in that direction were observed to have overweight tandems. It would be desirable to determine if a significant number of these trucks were run by the same trucking company and/or hauling the same commodity.

The wood utility pole on which the cameras will be mounted will be supplied by INDOT. The equipment described in this document will be purchased by Purdue University and transferred to INDOT.

\section{Specifications:}

1. Camera Installation

Two cameras shall be installed on a wood utility pole located within the INDOT right-of-way. The installation shall conform to the following specifications:

- The pole shall be on the west side of SR1 and will be approximately 20' above ground level. The vendor will determine the specific height at which the cameras will be mounted. The pole shall be installed within the INDOT right of way. The exact pole location and height will be determined by a field inspection with members of INDOT, Purdue University, and the vendor present.

- Lightning protection and environmental specifications for both cameras shall be provided. Shop drawings showing proposed lighting arrestor equipment and installation details shall be submitted to Purdue University for approval by Purdue and INDOT 10 days before proceeding with installation.

- Power/data/video connections shall be supplied to the cameras via an underground conduit from the cabinet.

- Appropriate cables shall be selected to prevent electrical noise from adversely impacting the data/video signals.

- Cameras shall be installed within weatherproof housings.

- The cameras and cables shall be installed in a manner that will discourage theft and vandalism. Ideally cameras will be installed in a "dome" type enclosure.

2. Computer System

The data will exist on the computer in the existing cabinet and shall conform to the following specifications:

- The computer shall run the Windows 2000 operating system.

- The computer shall be capable of storing up to 200,000 images.

- A single dial up modem will be used to access all functions remotely such as:

- To configure which images will be logged by vehicle class and violation.

- To set overweight threshold for logging images.

- To download images with WIM superimposed on image.

- To download standard WIM data similar to that currently available for remote download on existing DOS based system.

- The logged image filename shall have the precise time encoded such that one can directly associate an image with the detailed WIM record. For example, 140607.020.jpg would correspond to the WIM record obtained at time 14:06:07 and 20 milliseconds shown in Figure 1.

- The logged images shall be stored in folders corresponding to the date (MM_DD_YYYY).

- The system shall be configurable to log data for all vehicles. 
- The system shall be configurable to log annotated pictures for the user-defined vehicle classes.

- The system shall be configurable to log annotated pictures for the following user-defined violations:

- Check for GVW violations on selected classes and annotate captured picture accordingly.

- Check for Tandem violations on selected classes and annotate captured picture accordingly.

- Check for Axle violations on selected classes and annotate captured picture accordingly.

- Check for Bridge violations on selected classes and annotate captured picture accordingly.

- Check for Speed violations on selected classes and annotate captured picture accordingly.

- For testing purposes, it shall be configurable to log images (with WIM data overlaid) of all vehicles.

3. Logged Image

The information required on the image stored in the database is shown in Figure 1. The actual layout of the information on the screen may be changed subject to INDOTs approval. Descriptions for each field are listed below.

1. Traveling direction of vehicle - NB or SB

2. Vehicle Class

3. Vehicle Speed in miles per hour

4. Gross Vehicle Weight in pounds

5. Axle Weight in pounds

6. Axle Spacing in inches

7a. Check box for speed violation (threshold set by user)

7b. Check box for GVW violation (threshold set by user)

7c. Check box for axle violation on Axle 1 (threshold set by user)

7d. Check box for axle violation on Axle 2 (threshold set by user)

7e. Check box for axle violation on Axle 3 (threshold set by user)

7f. Check box for axle violation on Axle 4 (threshold set by user)

7g. Check box for axle violation on Axle 5 (threshold set by user)

8. Date (MM/DD/YY) and Time (HH:MM:SS) (this information shall be obtained from the actual WIM system so that records will be synchronized 


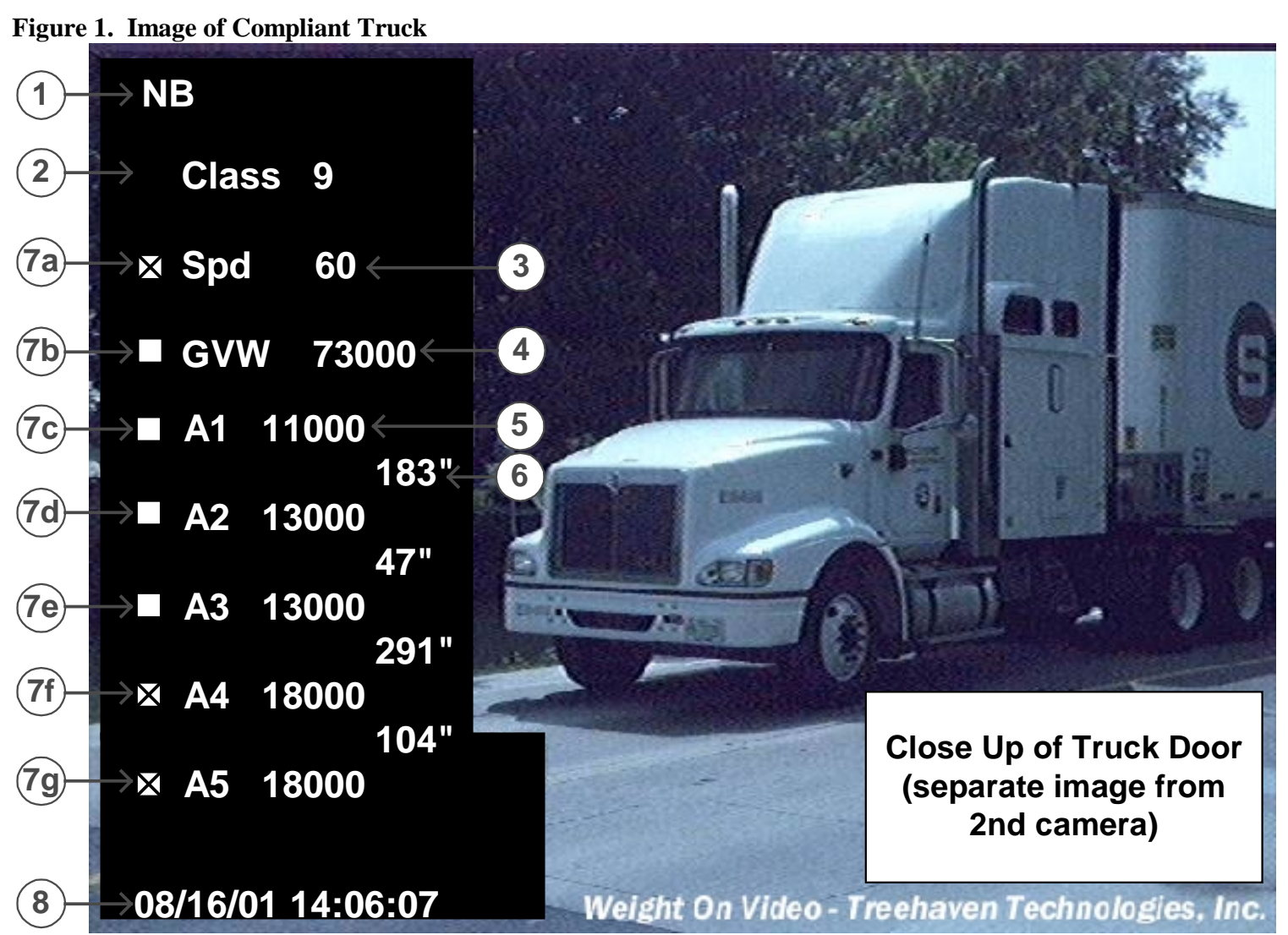

Violations will be indicated on the image in the following manner:

- $\quad$ Speed violations will be denoted with an ' $X$ ' in box 7a.

- $\quad$ GVW violations will be denoted with an ' $X$ ' in box 7b.

- Single axle violations will be denoted with an ' $X$ ' in the corresponding box(es) 7c, 7d, 7e, $7 f, 7 g$.

- Tandem axle violations will be denoted with an ' $X$ ' in the corresponding box(es) $7 \mathrm{~d} \& 7 \mathrm{e}$, $7 f \& 7 g$.

- Bridge violations will be denoted with an ' $X$ ' in boxes $7 d, 7 e, 7 f, 7 g$.

4. Documentation

- Manuals for all installed equipment shall be furnished to INDOT.

- As built plans shall be furnished to INDOT including (but not limited to) utility pole location, utility pole height, camera height, aerial wire paths, conduit paths, camera vendor and part numbers, cable vendor(s) and part number, connector vendor(s) and part numbers, and weatherproofing accessories for cameras and electrical connectors.

5. Acceptance Terms

All parts of the above specifications must be observed to be operational for 30 continuous days. If specifications are not met during the 30 day test period, the test period must be restarted. The invoicing shall be as follows:

- $30 \%$ due net 45 days from shipment.

- $30 \%$ due net 45 days from installation of equipment

- $15 \%$ due net 45 days from set-up/training

- $25 \%$ due net 45 days from completion of above described test 
Appendix N Summary of US 24 Detail Memo 
To: $\quad$ Mark Newland, Guy Boruff

From: $\quad$ Darcy Bullock, Andrew Nichols

Subject: $\quad$ US 24 Detail on September 18, 2001

Date: $\quad$ September 26, 2001

On September $18^{\text {th }}, 2001$ Officer Monty Buffum arranged a detail at the US 24 WIM sight (designated WIM site 2400 by INDOT) East of Fort Wayne to test the wireless communication link, laptop software, and WIM accuracy. Andrew Nichols from Purdue accompanied Officer Buffum. The following table summarizes the six samples that were obtained.

Table 1. Summary of Vehicles Weighed

\begin{tabular}{|c|c|c|c|c|c|c|}
\hline Record \# & Direction & Speed & GVW WIM & GVW Scale & Error & $\%$ Error \\
\hline 3090 & EB & 45 & 84,100 & 78,850 & 5,250 & $7 \%$ \\
\hline 3269 & EB & 52 & 88,300 & 79,300 & 9,000 & $11 \%$ \\
\hline 3316 & EB & 52 & 83,600 & 80,640 & 2,960 & $4 \%$ \\
\hline 3530 & WB & 46 & 83,200 & 85,800 & $-2,600$ & $-3 \%$ \\
\hline 3876 & WB & 55 & 73,200 & 76,150 & $-2,950$ & $-4 \%$ \\
\hline 3996 & WB & 46 & 82,000 & 81,050 & 950 & $1 \%$ \\
\hline
\end{tabular}

The following actions were taken on the six vehicles selected for weighing statically.

- 3090 Released

- 3269 Released

- 3316 Released

- 3530 Overweight ticket and placed out of service because of fuel leak

- 3876 Released

- 3996 Released 


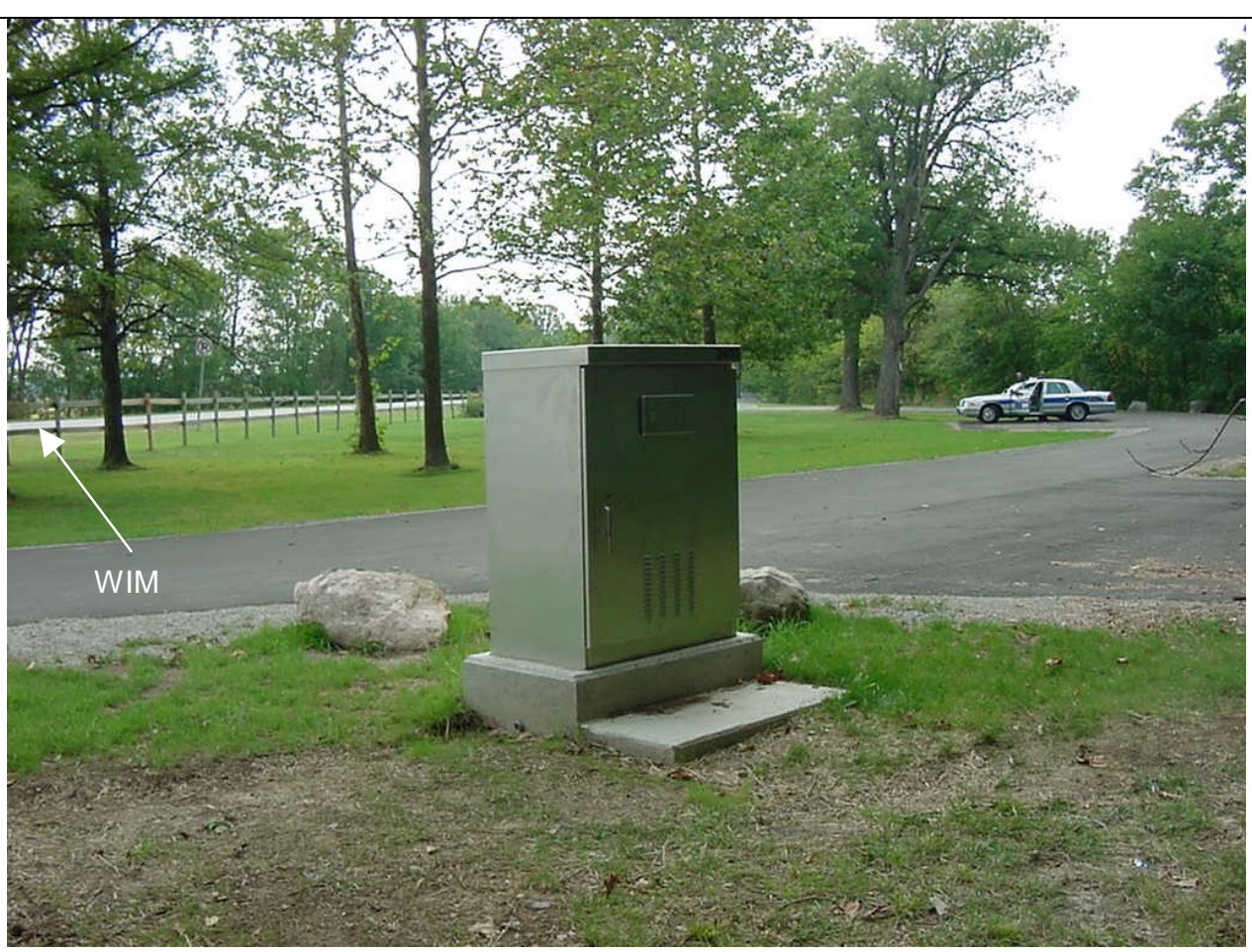

Figure 1: WIM monitoring site.

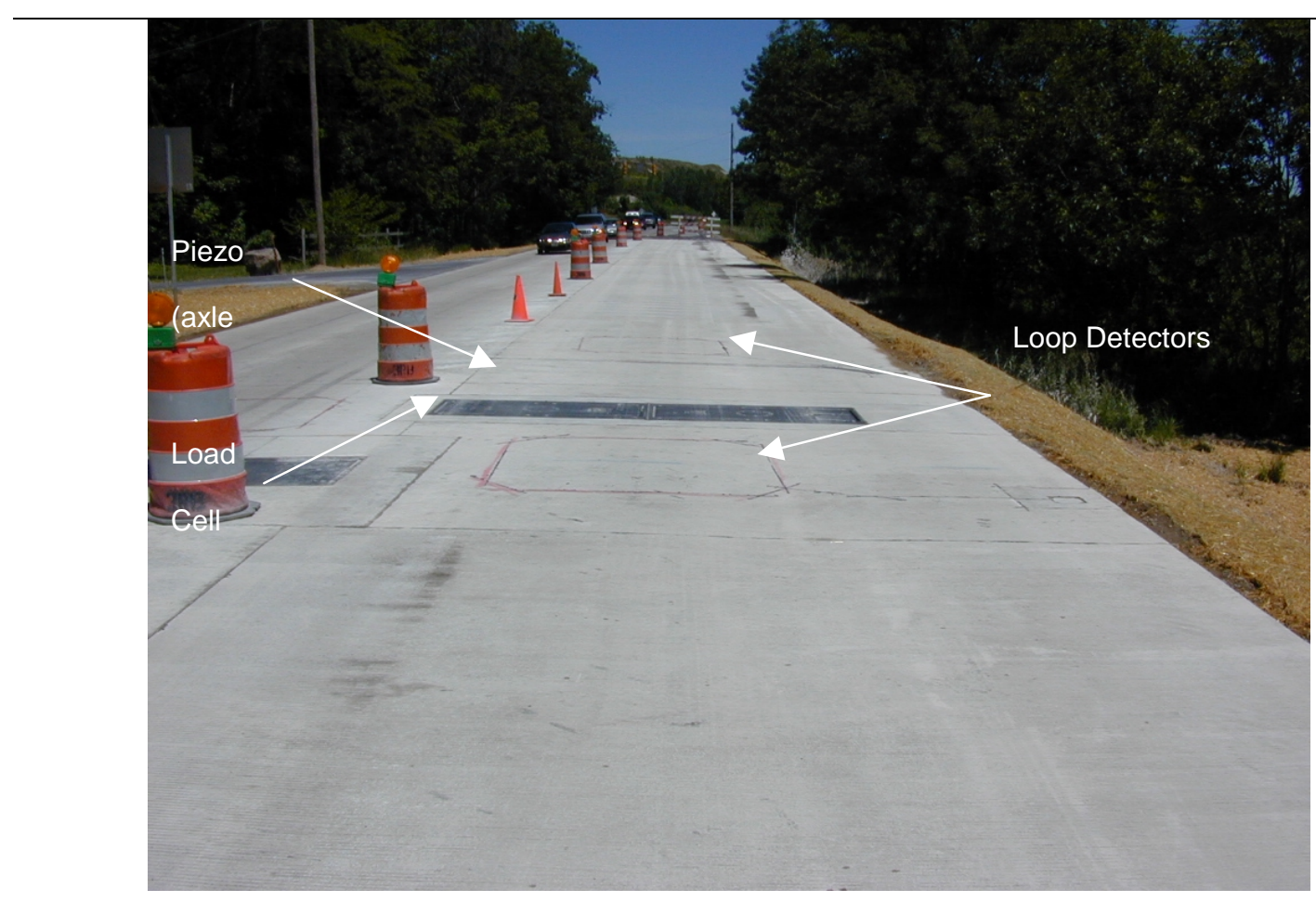

Figure 2: WIM scales (during construction July 2001). 


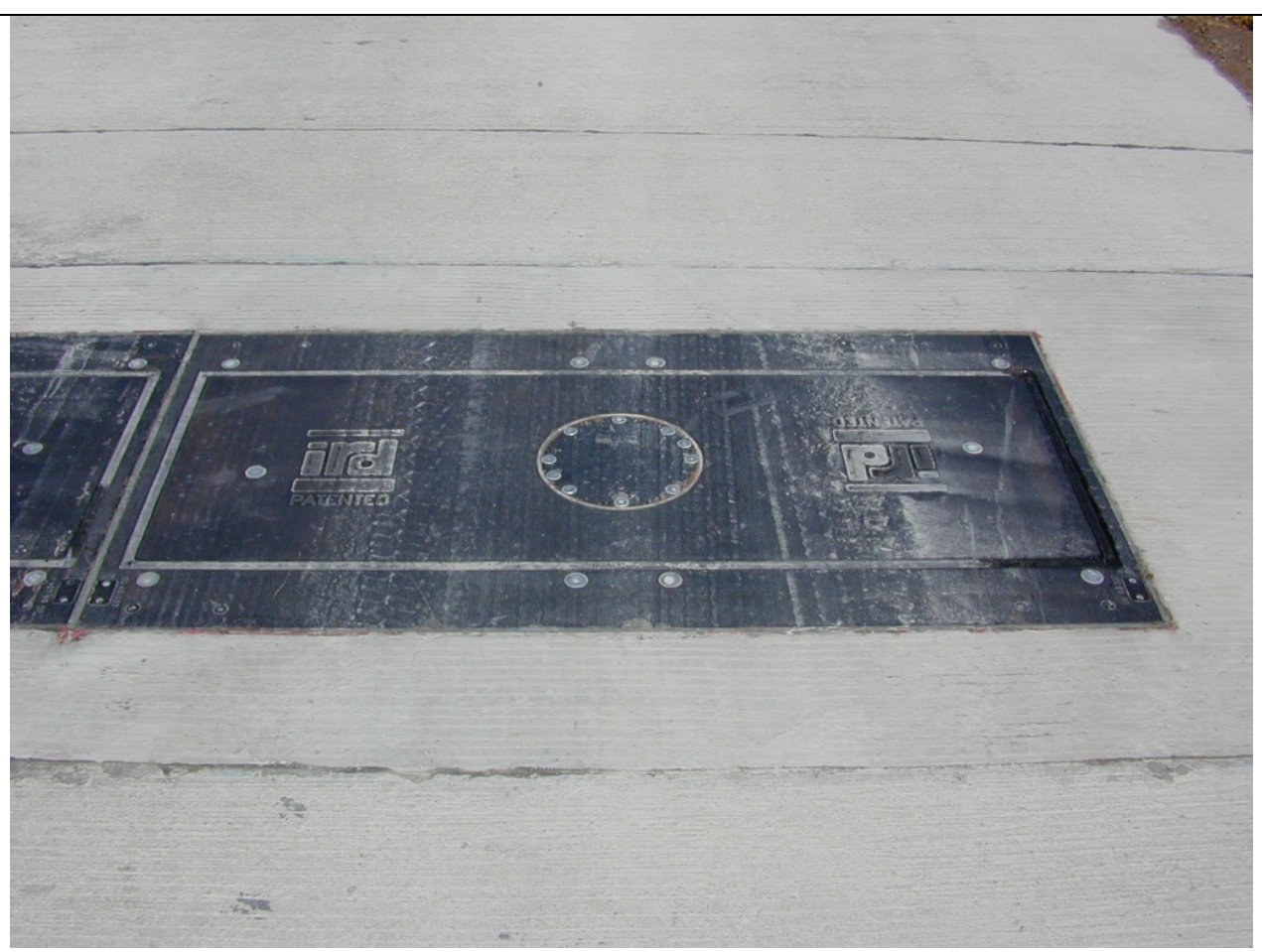

Figure 3: WIM load cell.

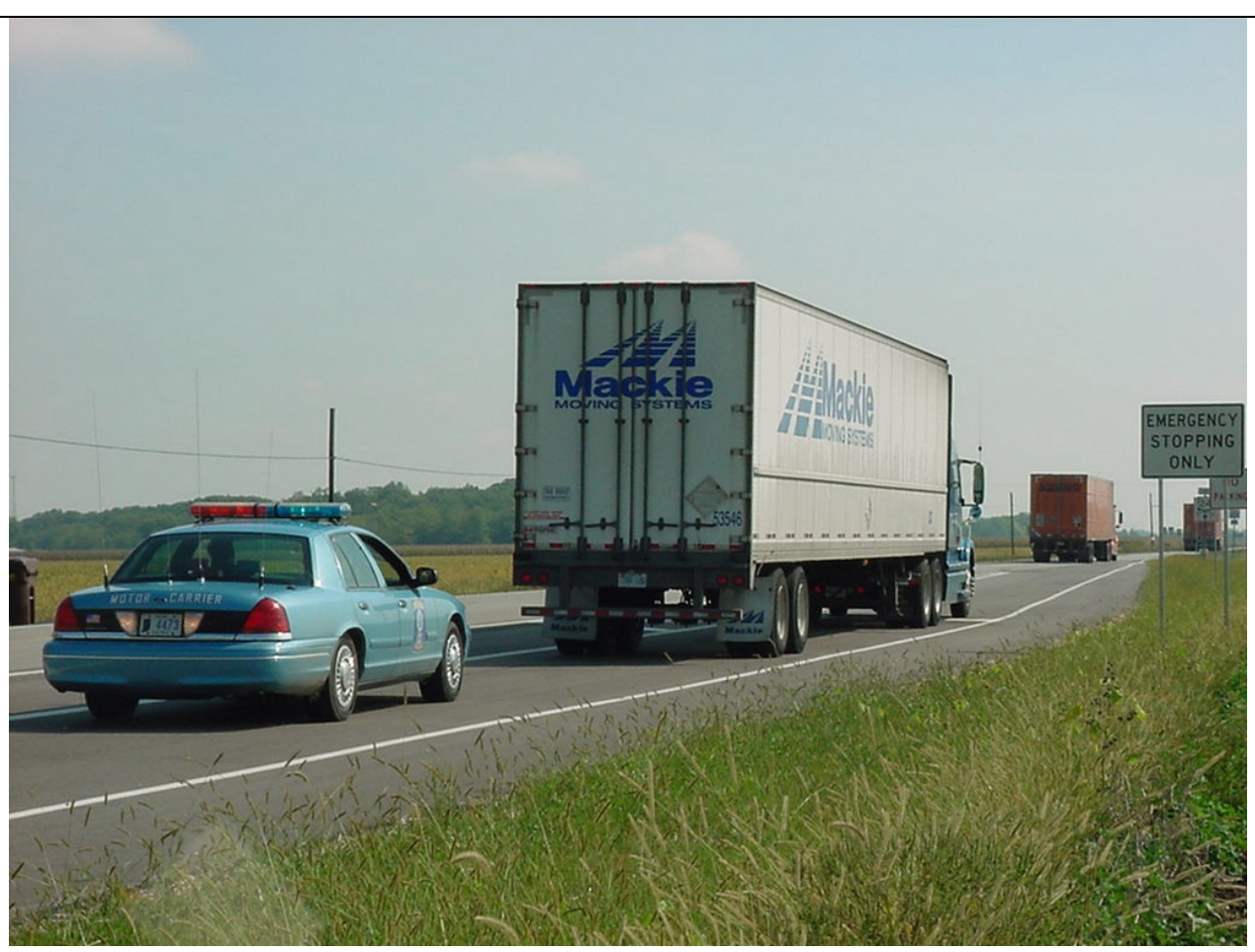

Figure 4: Truck inspection site. 


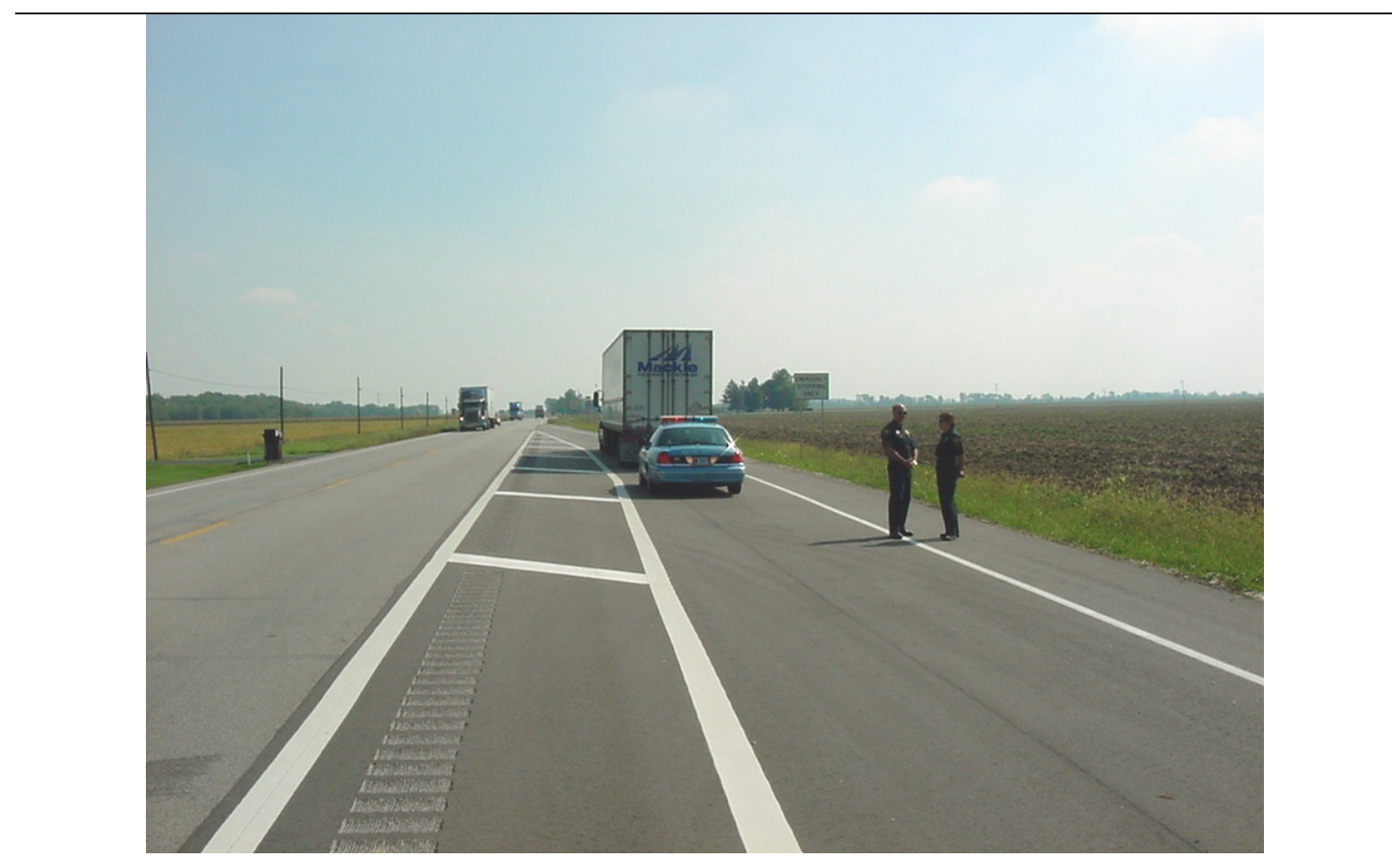

Figure 5: Truck inspection site. 
Appendix O US 24 Calibration Adjustment Memo 
To: $\quad$ Fred Keisig

From: Darcy Bullock, Andrew Nichols

Date: $\quad$ April 10, 2002

Subject: $\quad$ US 24 Virtual Weigh Station Enforcement Data Analysis

\section{February 2002}

The data below was collected at the US 24 WIM (station 2400) during February 2002 by ISP Commercial Vehicle Enforcement officers. The trucks' weights were observed as they crossed the scales using the virtual weigh station equipment and software. The trucks that were reported overweight by the scales were pulled over by the officer and weighed using portable scales. The officer recorded the gross vehicle weight reported by the WIM and the by portable scales. The graphs below show the data recorded by the officer in each direction, as well as a proposed percentage adjustment to the weights.

Based on this data, it is proposed that the EB lane be adjusted $-7.7 \%$ and the WB lane be adjusted $+3.9 \%$.

Table 1: Westbound US 24 WIM Station Data Collected

\begin{tabular}{|c|c|c|c|c|c|}
\hline Date & Time & WIM & Adjusted & Portable & Violation \\
\hline $02 / 05 / 2002$ & $8: 53$ AM & 81,600 & 84,763 & 79,150 & None \\
\hline $02 / 18 / 2002$ & $5: 45$ PM & 89,900 & 93,384 & 91,100 & Over GVW/Over Axle \\
\hline $02 / 21 / 2002$ & $2: 06$ PM & 83,200 & 86,425 & 90,200 & Over GVW/Over Tandem \\
\hline $02 / 21 / 2002$ & $2: 06$ PM & 80,500 & 83,620 & 90,900 & Over GVW/Over Tandem \\
\hline $02 / 22 / 2002$ & $11: 24$ AM & 80,200 & 83,309 & 80,800 & Warning Over GVW \\
\hline
\end{tabular}

Table 2: Eastbound US 24 WIM Station Data Collected

\begin{tabular}{|c|c|c|c|c|c|}
\hline Date & Time & WIM & Adjusted & Portable & Violation \\
\hline $02 / 05 / 2002$ & $10: 50$ AM & 87,000 & 80,262 & 76,200 & None \\
\hline $02 / 20 / 2002$ & $4: 20 \mathrm{PM}$ & 88,500 & 81,646 & 78,900 & Over Tandem \\
\hline $02 / 22 / 2002$ & $10: 50 \mathrm{AM}$ & 82,000 & 75,650 & 79,800 & Warning Over Axle \\
\hline $02 / 22 / 2002$ & $12: 20 \mathrm{PM}$ & 81,000 & 74,727 & 80,980 & Warning Over GVW \\
\hline $02 / 22 / 2002$ & $12: 51 \mathrm{PM}$ & 85,000 & 78,417 & 77,180 & None \\
\hline
\end{tabular}




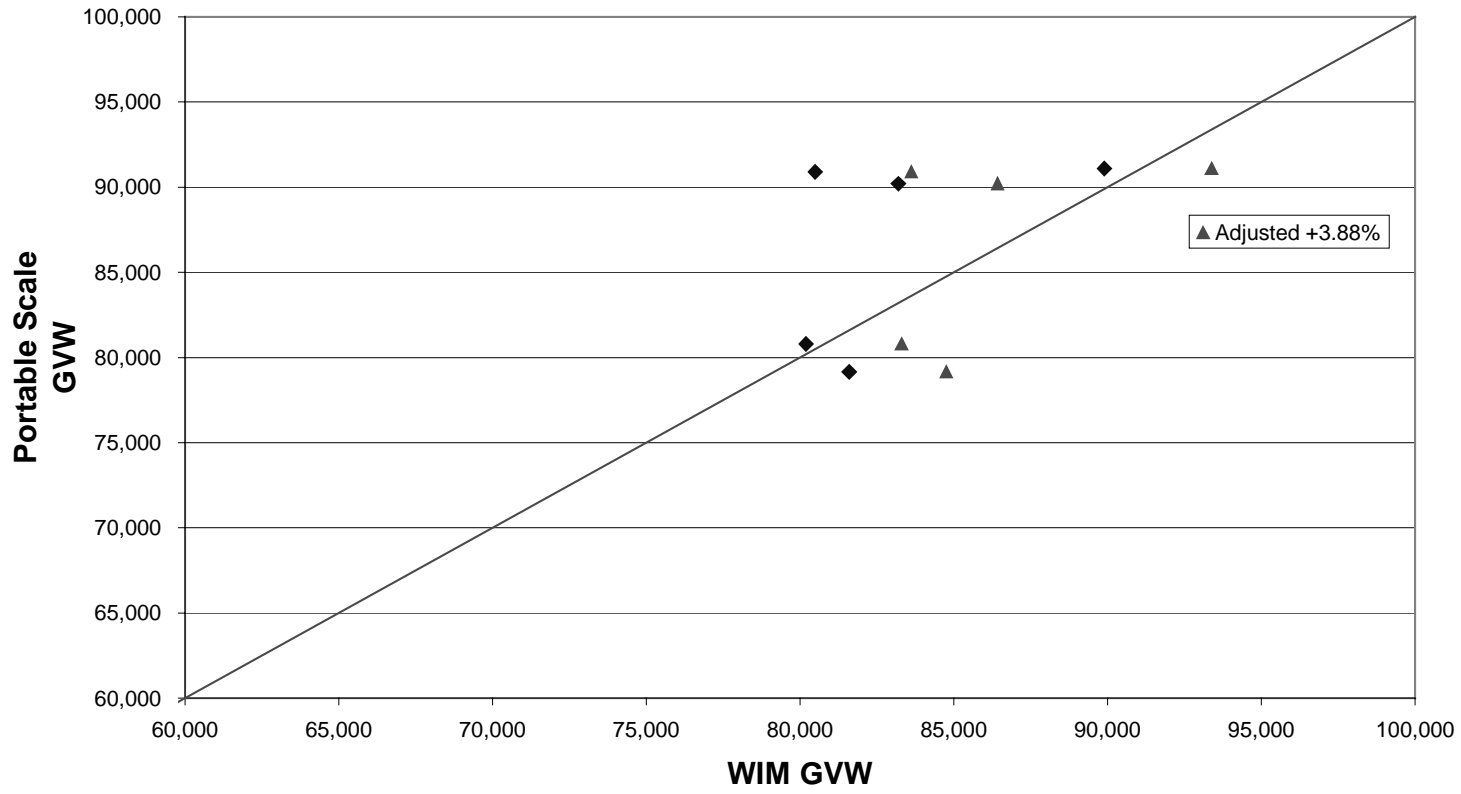

Figure 1: Westbound US 24 WIM Station Data Accuracy Plot \& Calibration Adjustment

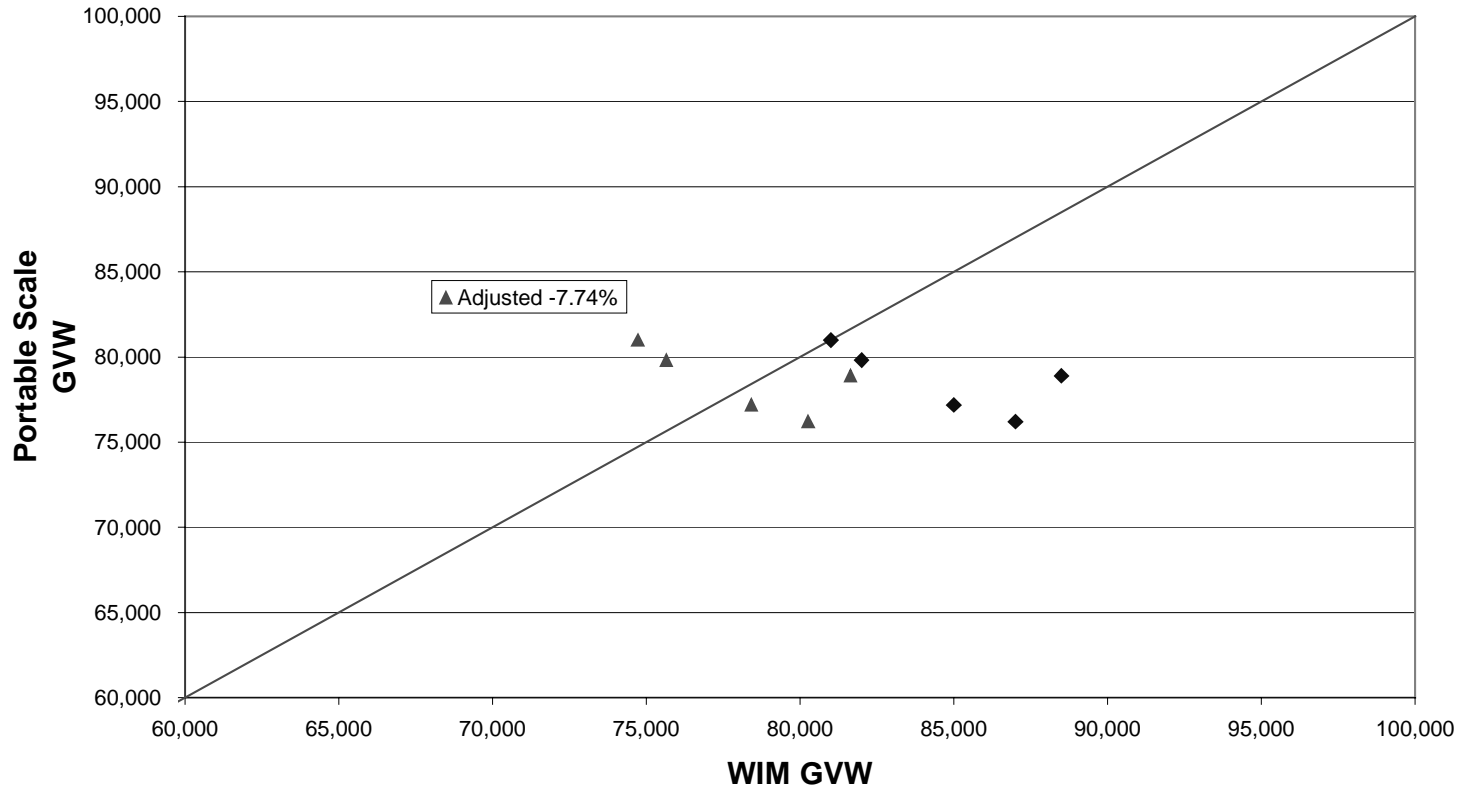

Figure 2: Eastbound US 24 WIM Station Data Accuracy Plot \& Calibration Adjustment 
Appendix P Summary of US 24 Data (March 2002) Memo 
To:

Guy Boruff

From: $\quad$ Darcy Bullock, Andrew Nichols

Date: $\quad$ April 11, 2002

Subject: $\quad$ US 24 March 2002 Data Analysis

This document contains an analysis of the weigh-in-motion data from March 2002 at USR 24 near Fort Wayne. Figure 1shows the average Class 9 volume with Gross Vehicle Weight exceeding 80,000 lbs by hour of the day. Figure 2 shows the average Class 9 volume with GVW exceeding 80,000 lbs by day of the week. Figure 3 shows the total Class 9 volume with GVW exceeding $80,000 \mathrm{lbs}$ for each day of the month.

IRD will have the scales recalibrated by Saturday, April 13. The recalibration is based on the data collected during the February enforcement details. The EB values reported in these graphs account for the adjustment factor of $-7.8 \%$ (WIM weighing heavy). The WB values were not adjusted in these graphs, but will be recalibrated by $+3.9 \%$ (WIM weighting light).

In general, the WB direction has a higher volume of overweight trucks. According to Figure 1, the time periods with the highest number of overweight trucks is 8:00am - 10:00am, 11:00am-12:00pm. According to Figure 2, the day with the highest number of overweight trucks is Wednesday.

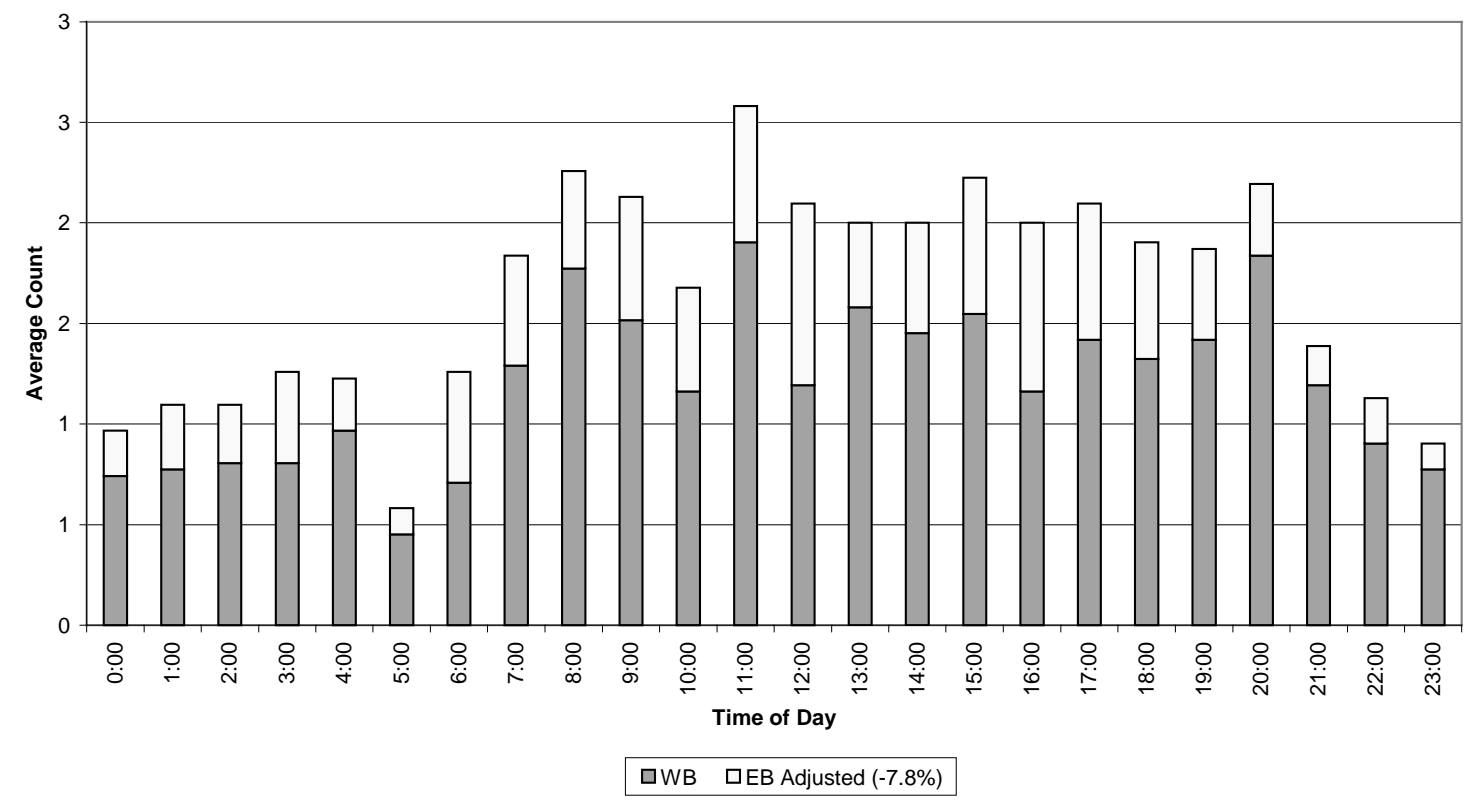

Figure 1: Average Hourly Class 9 Volume on US 24 with GVW Exceeding 80,000 lb (adjusted) 


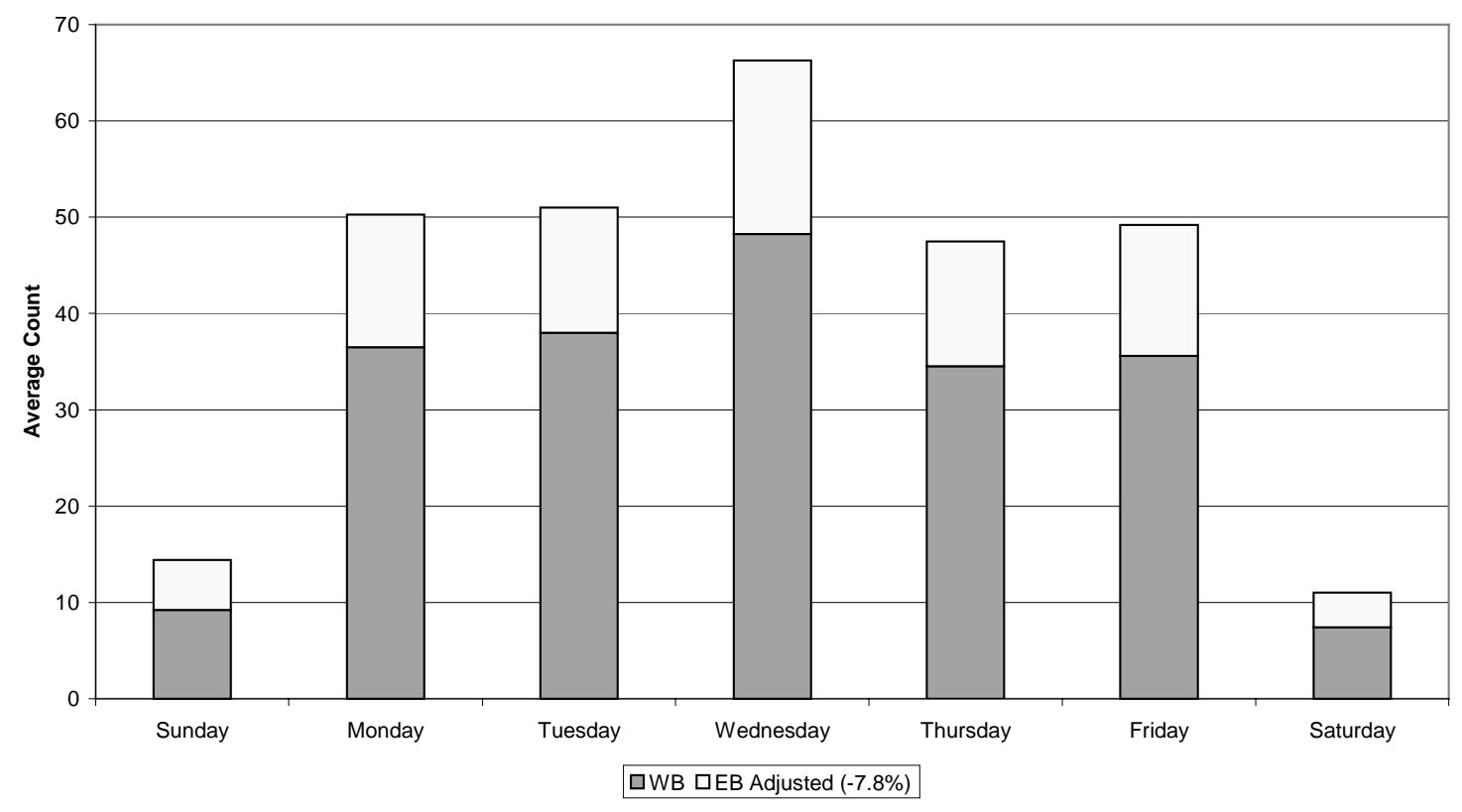

Figure 2: Average Daily Class 9 Volume on US 24 with GVW Exceeding 80,000 lb (adjusted)

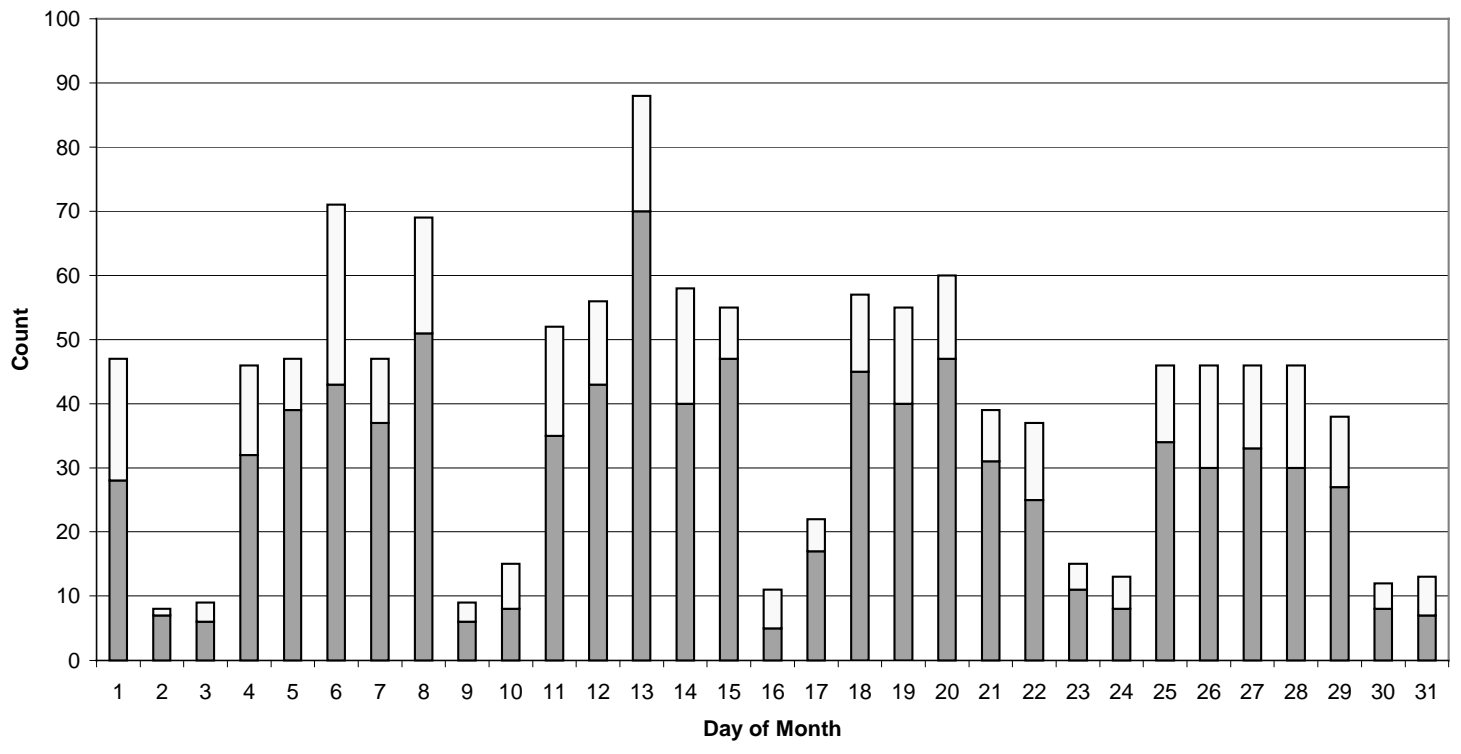

$\square$ WB 口EB Adjusted (-7.8\%)

Figure 3: Daily Class 9 Volume on US 24 with GVW Exceeding 80,000 lb (adjusted) 
Appendix Q Summary of I-65 Enforcement Detail Memo 
To: $\quad$ Guy Boruff

From: Darcy Bullock, Andrew Nichols

Date: $\quad$ April 25, 2002

Subject: $\quad$ I-65 Merrillville WIM Enforcement Details

\section{April 12, 2002}

An enforcement detail was conducted at the I-65 Northbound WIM station in Merrillville on April 12, 2002 by ISP Commercial Vehicle Enforcement Officers Williams, Young, Nagle, Kunstek, and Fleming. The detail was conducted between 7:00AM and 10:00AM. The trucks' weights were observed by Officer Young as they crossed the WIM scales using the virtual weigh station equipment and software. The trucks that were reported overweight by the WIM scales were pulled over on Exit 255 ( $61^{\text {st }}$ Avenue) and weighed using certified portable scales in an unused parking lot. The graph and table below show the truck weights and violations.

Table 1. Northbound I-65 WIM Station Data Collected April 12, 2002

\begin{tabular}{|c|c|c|c|c|}
\hline Time & Lane & WIM & Portable & Violation \\
\hline $7: 47$ AM & 2 & $80,400 \mathrm{lb}$ & $77,800 \mathrm{lb}$ & $\begin{array}{c}\text { Warning Overweight Tandem 400lb, No Seatbelt, Log } \\
\text { Book Not Current, Out-of-Service }\end{array}$ \\
\hline 8:01 AM & 2 & $81,400 \mathrm{lb}$ & $88,200 \mathrm{lb}$ & Overweight GVW, Out-of-Service \\
\hline 8:09 AM & 1 & $82,900 \mathrm{lb}$ & $87,400 \mathrm{lb}$ & Overweight GVW Fine: $\$ 529.50$ \\
\hline
\end{tabular}

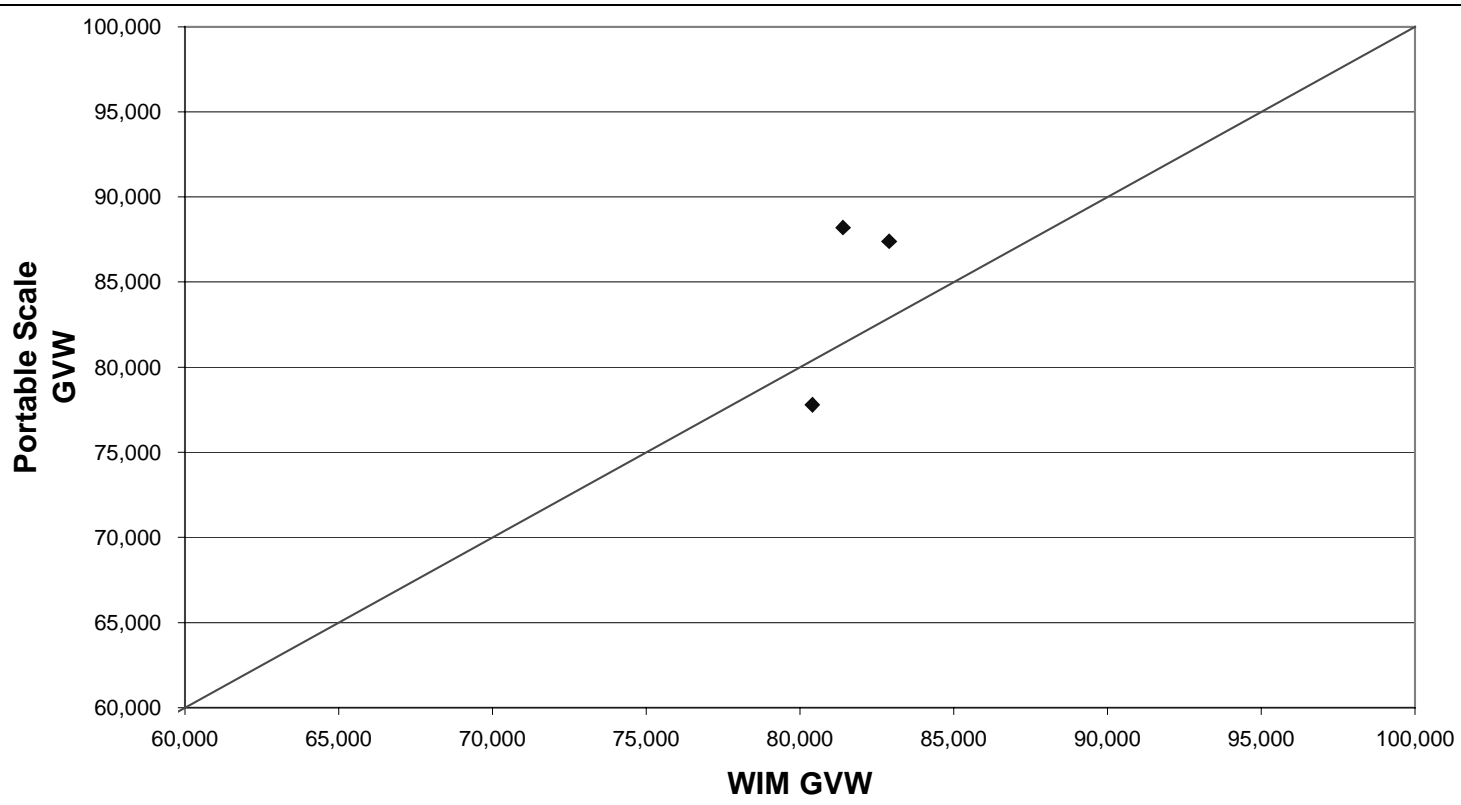

Figure 1: Northbound I-65 WIM Station Data Accuracy Plot 
Appendix R Effects of Enforcement on SR 1 Memo 
To: $\quad$ Barry Partridge

From: Darcy Bullock

CC: $\quad$ Kumares Sinha

Date: $\quad$ May 14, 2002

Subject: $\quad$ State Route 1 WIM Data

As requested by Commissioner Nicol today, I have reviewed our memo from September 12, 2001 (attached) summarizing the data from April, May, June, and July 2001 at the SR 1 weigh-inmotion (WIM) sight. The WIM system became active in early March and we began receiving data on March $18^{\text {th }}$. Table 1 below summarizes the percent reduction between April 2001 and July 2001, specific vehicle counts are contained in the attached September 12, 2001 memo.

One word of caution, these are raw counts and could reflect seasonal variation in truck traffic. I will plan on tabulating a comparison between 2001 and 2002 data after July 2002 (when we will have 4 consecutive months a year later) and transmit that information to you.

\begin{tabular}{|c|c|c|}
\hline & $\begin{array}{c}\text { \% Reduction in } \\
\text { South bound }\end{array}$ & $\begin{array}{c}\text { \% Reduction in } \\
\text { North bound }\end{array}$ \\
\hline Total Class 9 Vehicles & $7 \%$ & $11 \%$ \\
\hline $\begin{array}{c}\text { Class 9 Vehicles with } \\
\text { GVW >80k }\end{array}$ & $69 \%$ & $71 \%$ \\
\hline $\begin{array}{c}\text { Class 9 Vehicles with } \\
\text { an Axle > 20k }\end{array}$ & $57 \%$ & $47 \%$ \\
\hline $\begin{array}{c}\text { Class 9 Vehicles with a } \\
\text { Tandem > 34k }\end{array}$ & $32 \%$ & $68 \%$ \\
\hline$\%$ Overweight GVW & $66 \%$ & $0 \%$ \\
\hline$\%$ Over Axle & $50 \%$ & $41 \%$ \\
\hline$\%$ Over Tandem & $26 \%$ & \\
\hline
\end{tabular}

Table 1: Comparison of April 2001 with July 2001 Data. 
Appendix S Summary of Borman Data (January-March 2002) Memo 
To: $\quad$ Guy Boruff

From: $\quad$ Darcy Bullock, Andrew Nichols

Date: $\quad$ May 31, 2002

Subject: $\quad$ Borman WIM Data Summary January 16-March 31, 2002

\section{January 16 - March 31, 2002}

The tables and figures below summarize the data collected by the WIM sites on I-80/I-94 in Gary. According to the data in Table 1, there are a higher number of overweight class 9 trucks in the eastbound direction than there are in the westbound direction, even though the truck volumes are similar. As shown in Table 2, the average front axle weights for both WIMs are very close with relatively small standard deviations. This provides some indication that the WIMs are operating well. The highest rate of overweight trucks in both directions occurs between noon and 4pm shown in Figure 1 and Figure 2. Tuesdays and Wednesdays also see the highest rate of overweight activity shown in Figure 3 and Figure 4. Figure 5 and Figure 6 show the actual number of overweight trucks for each day in the time period between January 16 and March 31.

Table 1: Summary of Class 9 Vehicle Data January 16 - March 31, 2002

\begin{tabular}{|c|c|c|c|c|}
\cline { 2 - 5 } \multicolumn{1}{c|}{} & \multicolumn{2}{c|}{ EB $(4000)$} & \multicolumn{2}{c|}{ WB $(4010)$} \\
\cline { 2 - 5 } \multicolumn{1}{c|}{ Total } & $\%$ of Total & Total & $\%$ of Total \\
\hline Class 9 Vehicles & $1,101,434$ & -- & $1,082,450$ & -- \\
\hline GVW $>80 \mathrm{k}$ & 58,419 & $5.30 \%$ & 15,509 & $1.43 \%$ \\
\hline GVW $>90 \mathrm{k}$ & 1,673 & $0.15 \%$ & 1,001 & $0.09 \%$ \\
\hline GVW $>100 \mathrm{k}$ & 326 & $0.03 \%$ & 210 & $0.02 \%$ \\
\hline Axle $>20 \mathrm{k}$ & 22,392 & $2.03 \%$ & 8,922 & $0.82 \%$ \\
\hline Axle $>30 \mathrm{k}$ & 109 & $0.01 \%$ & 44 & $0.00 \%$ \\
\hline Tandem $>34 \mathrm{k}$ & 186,809 & $16.96 \%$ & 102,664 & $9.48 \%$ \\
\hline Tandem $>50 \mathrm{k}$ & 297 & $0.03 \%$ & 244 & $0.02 \%$ \\
\hline
\end{tabular}

Table 2: Summary of Class 9 Vehicle Data January 16 - March 31, 2002

\begin{tabular}{|c|c|c|}
\cline { 2 - 3 } \multicolumn{1}{c|}{} & EB & WB \\
\hline Avg Front Axle & 10,579 & 10,446 \\
\hline Std Dev Front Axle & 1,027 & 930 \\
\hline Max Front Axle & 32,300 & 20,200 \\
\hline Avg GVW & 56,428 & 54,491 \\
\hline Std Dev GVW & 18,433 & 17,386 \\
\hline Max GVW & 140,500 & 128,899 \\
\hline Max Tandem & 70,600 & 65,400 \\
\hline
\end{tabular}




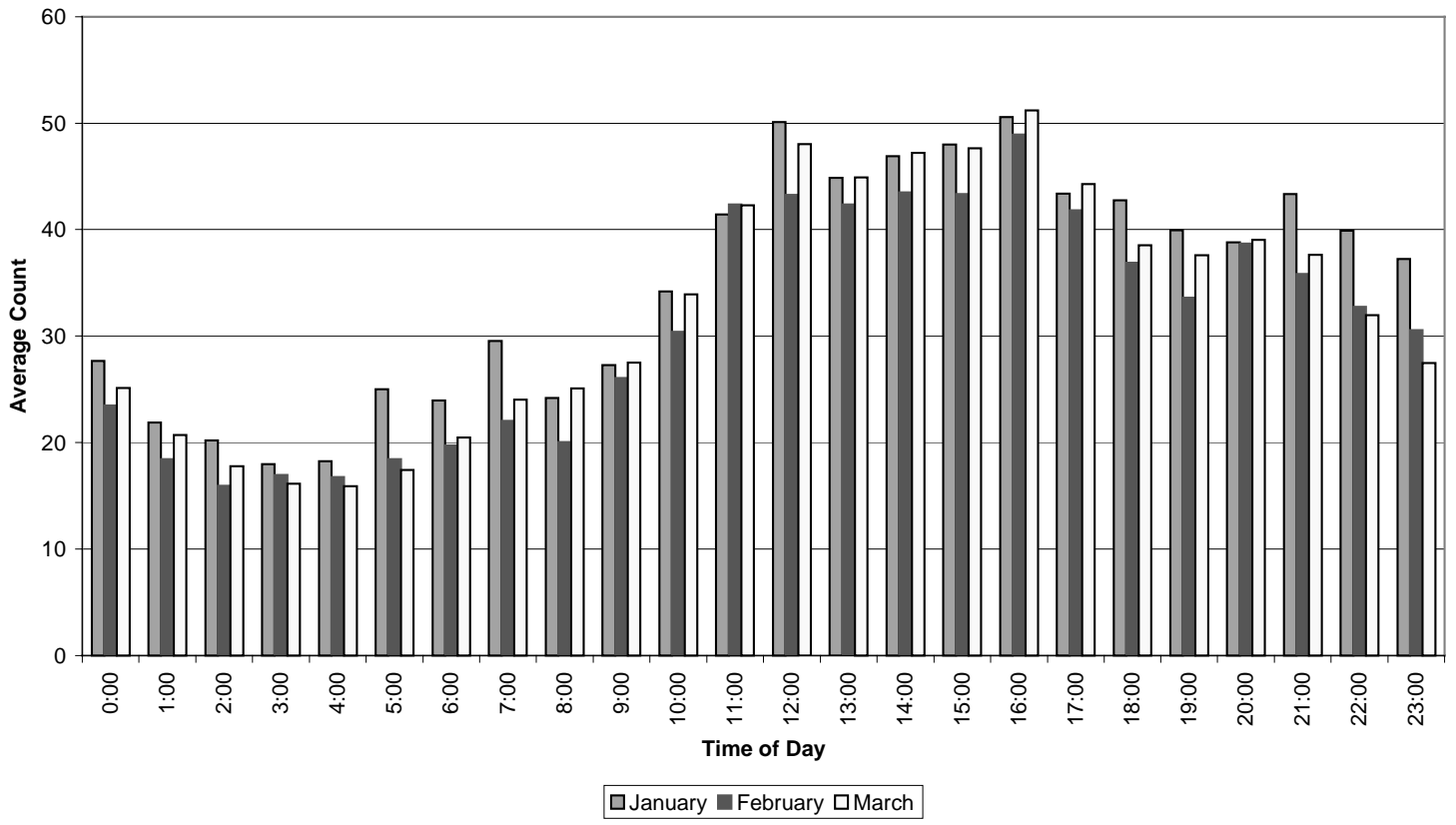

Figure 1: Eastbound Average GVW Violations by Hour

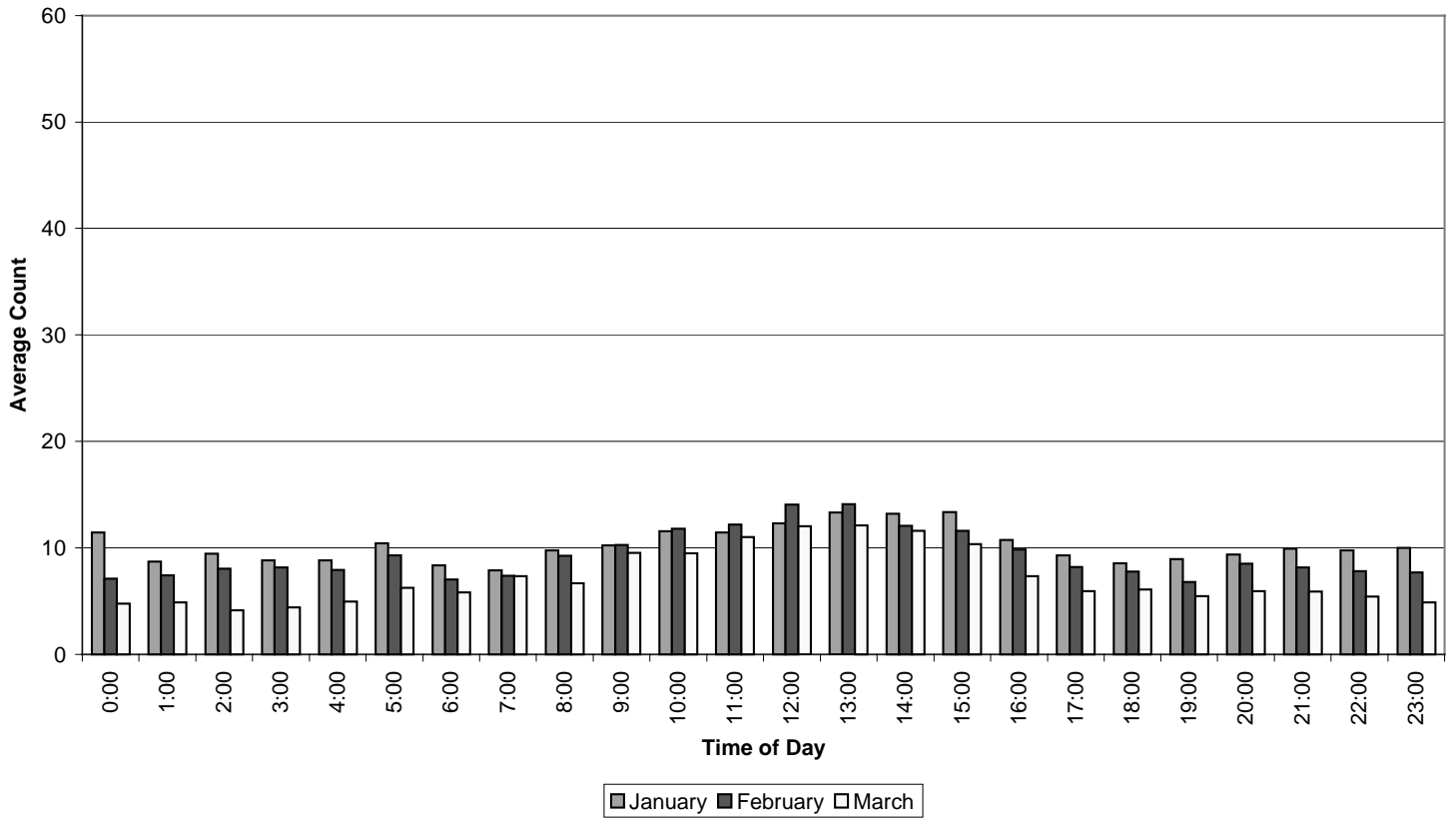

Figure 2: Westbound Average GVW Violations by Hour 


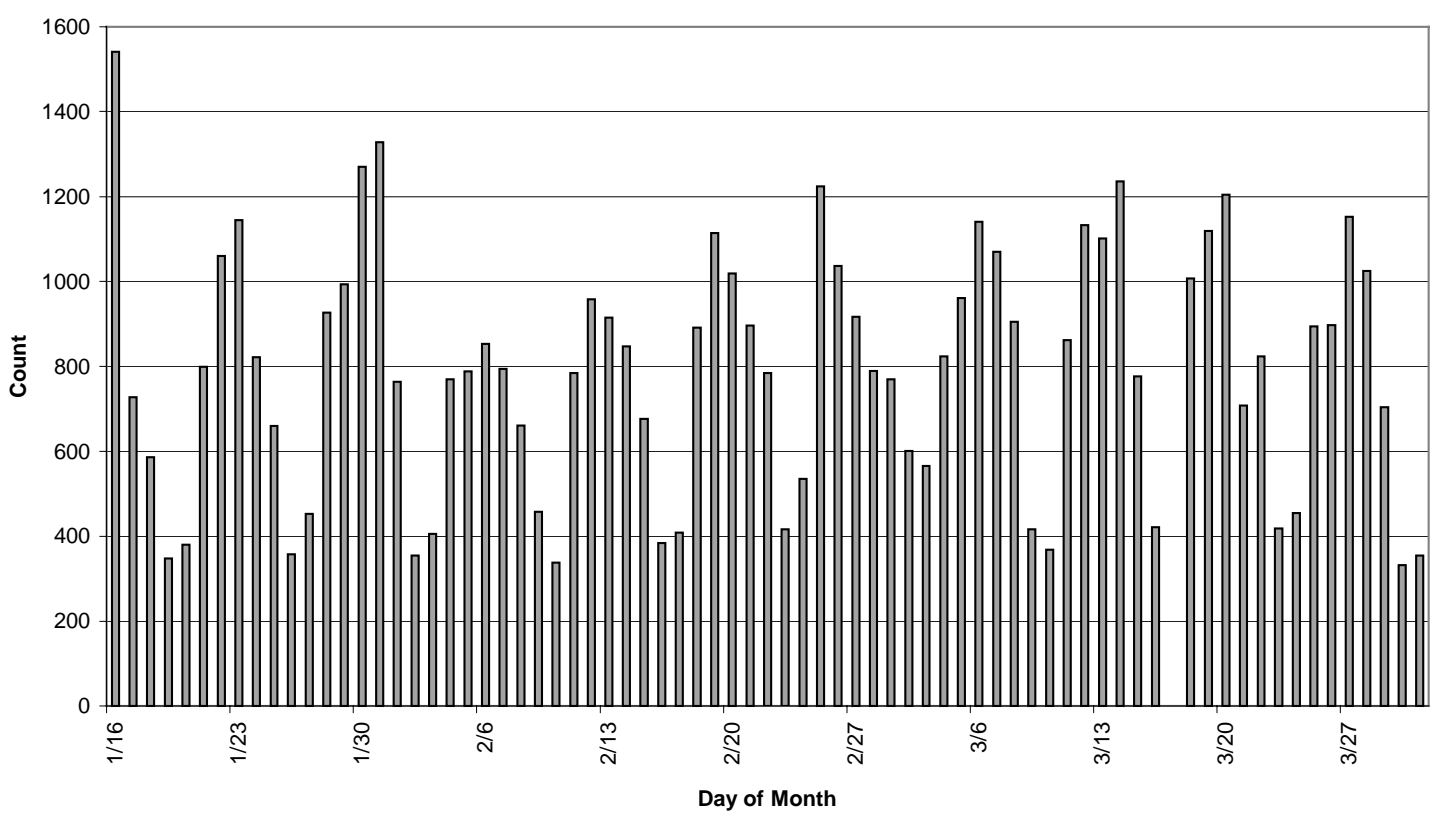

Figure 3: Eastbound GVW Violations by Day of the Month

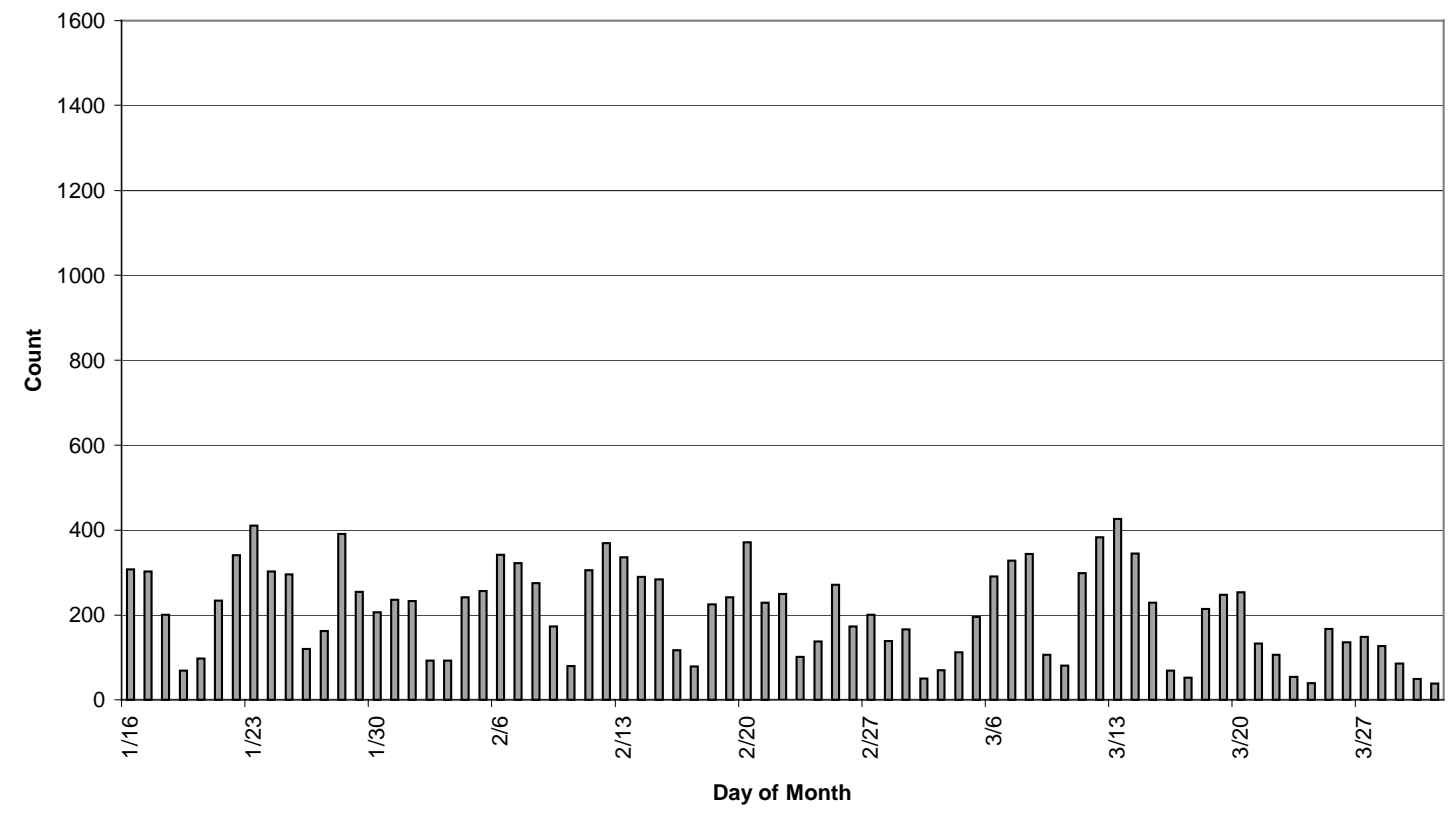

Figure 4: Westbound GVW Violations by Day of the Month 


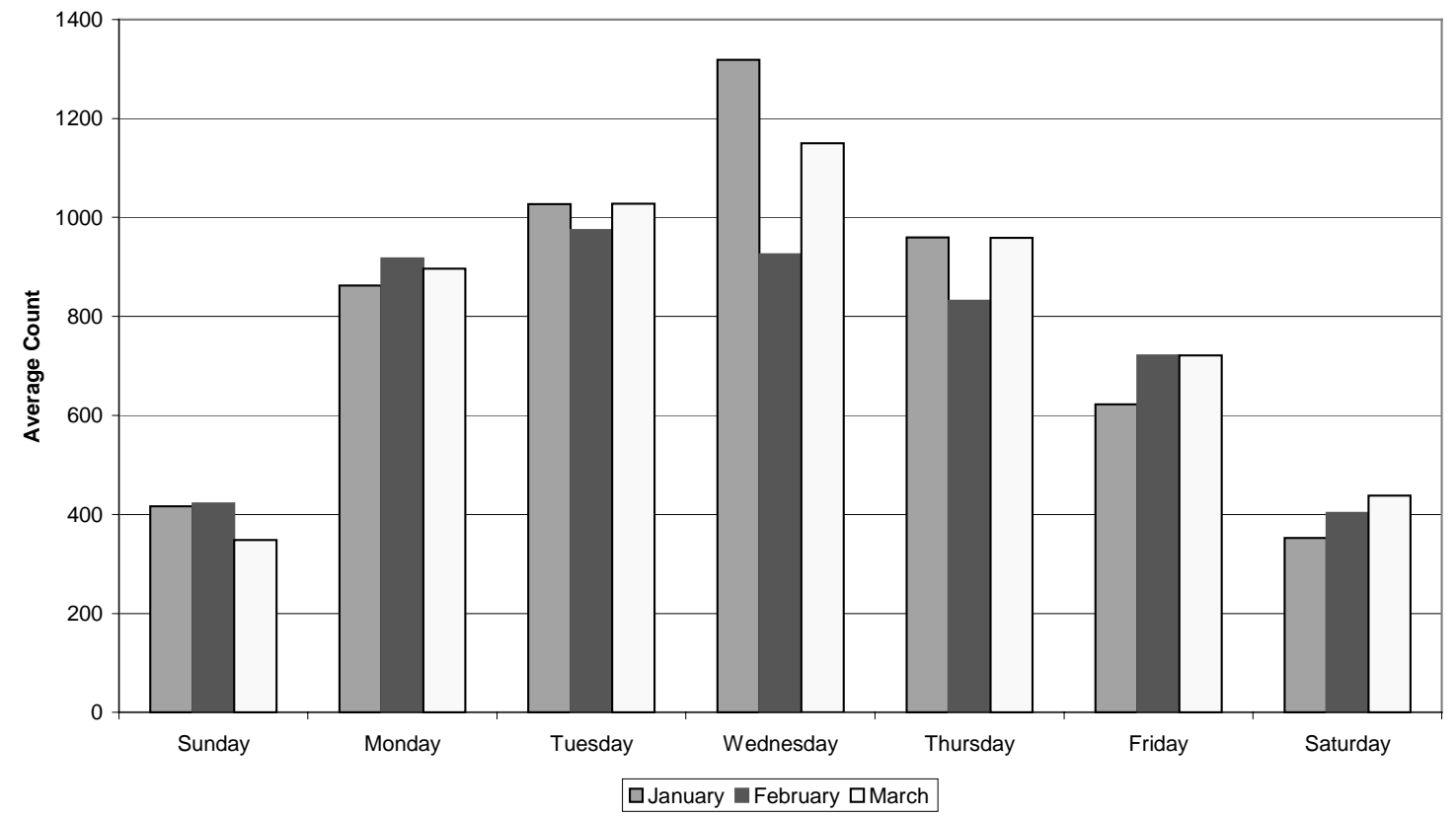

Figure 5: Eastbound Average GVW Violations by Day of the Week

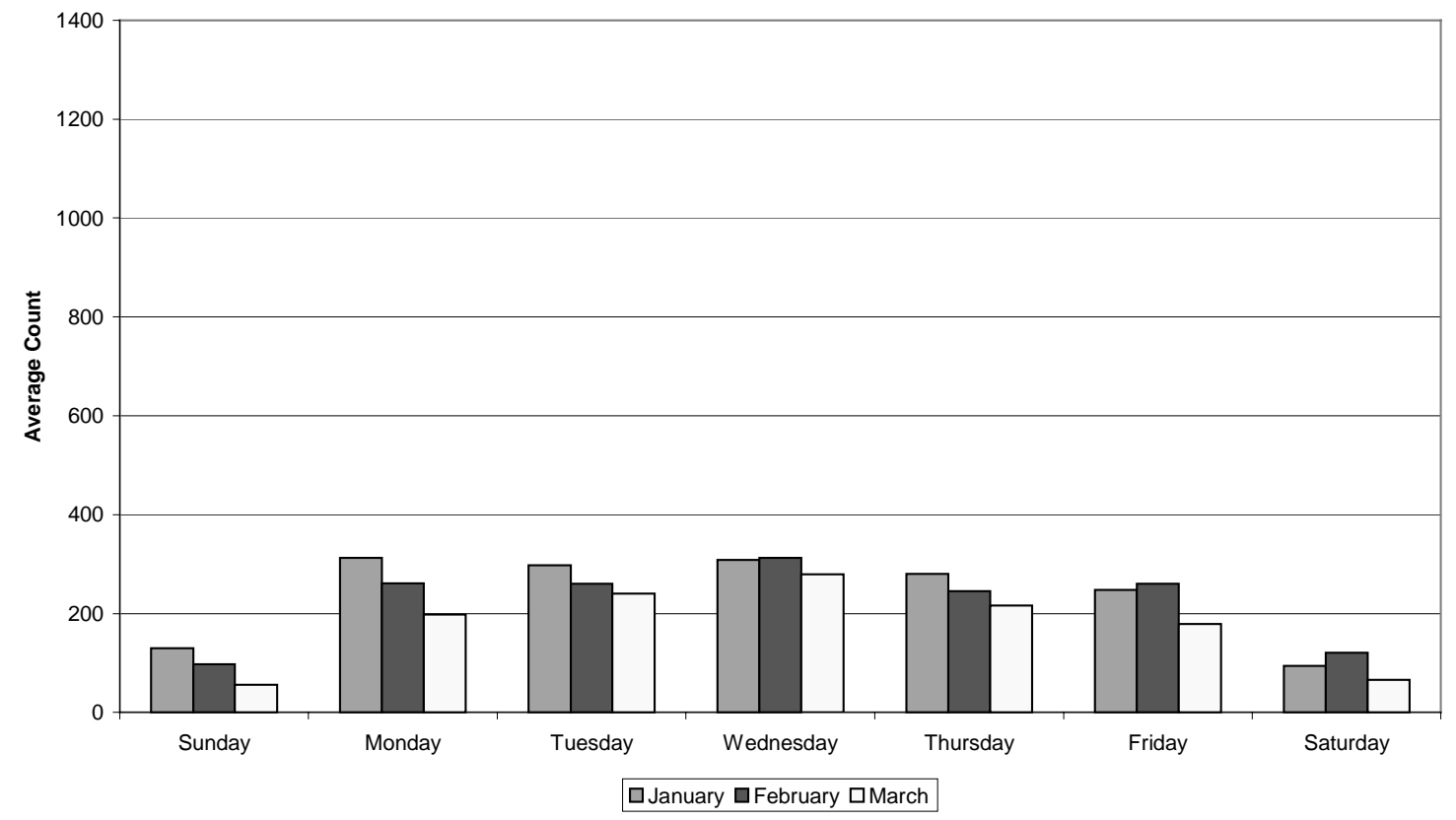

Figure 6: Westbound Average GVW Violations by Day of the Week 


\section{Appendix T Bibliography}

Access Indiana. 2000. http://www.state.in.us/legislative/ic/2000/title9/ar20/ch4.html

Alavi, Papagiannakis, et al. Performance Evaluation of Piezoelectric Weigh-In-Motion Sensors Under Controlled Field Loading Conditions. Washington, DC: Transportation Research Board, January 2001.

Bergan, Berthelot, and Taylor. Effect of Weigh-In-Motion Accuracy on Weight Enforcement Efficiency. Saskatoon, SK, Canada: International Road Dynamics, March 1997.

Bergen, Lindgren, et al. Preserving Highway Infrastructure Using Weigh-In-Motion. Saskatoon, SK, Canada: International Road Dynamics, November, 1998.

Bushman and Pratt. Weigh-In-Motion Technology - Economics and Performance. Charlotte, North Carolina: NATMEC, 1998.

Dahlin, Curtis. A Proposed Method for Calibration Weigh-In-Motion Systems and for Monitoring that Calibration Over Time. Washington, DC: Transportation Research Board, January 1992.

Eubanks and Broadwell. Safety Records of Weight Violating Motor Carriers. Salem, Oregon: Oregon Department of Transportation Motor Carrier Transportation Branch, September 30, 1997.

FHWA \& Ohio State Highway Patrol. Size and Weight Workshop Meeting Summary. Truck Size and Weight Workshop. Columbus, Ohio, October 2000.

Garber and Hoel. Traffic and Highway Engineering. St. Paul, Minnesota: West Publishing Company, 1998.

Huang, Yang. Pavement Analysis and Design. Englewood Cliffs, New Jersey: Prentice Hall, 1993.

Illinois Department of Transportation. Truck Size and Weight Report. Springfield, Illinois: June, 1998.

Ott, Weston, and Papagiannakis, A. WIM Data QA Based on 3-S2 Steering Axle Load Analysis. Washington DC: Transportation Research Board, January 1996.

Taylor, Bergan and Lindgren. A Summary of Vehicle Overloading, Safety, and Non-Compliance. Saskatoon, SK, Canada: International Road Dynamics, September, 1999. 
Taylor, Bergan, et al. "Heavyweight Safety." Traffic Technology International. Annual Review 2000, January 2000. 234-237.

“Keeping Overweight Trucks from Getting A-Weigh.” Texas Transportation Researcher. Volume 35, Number 3 (1999). 